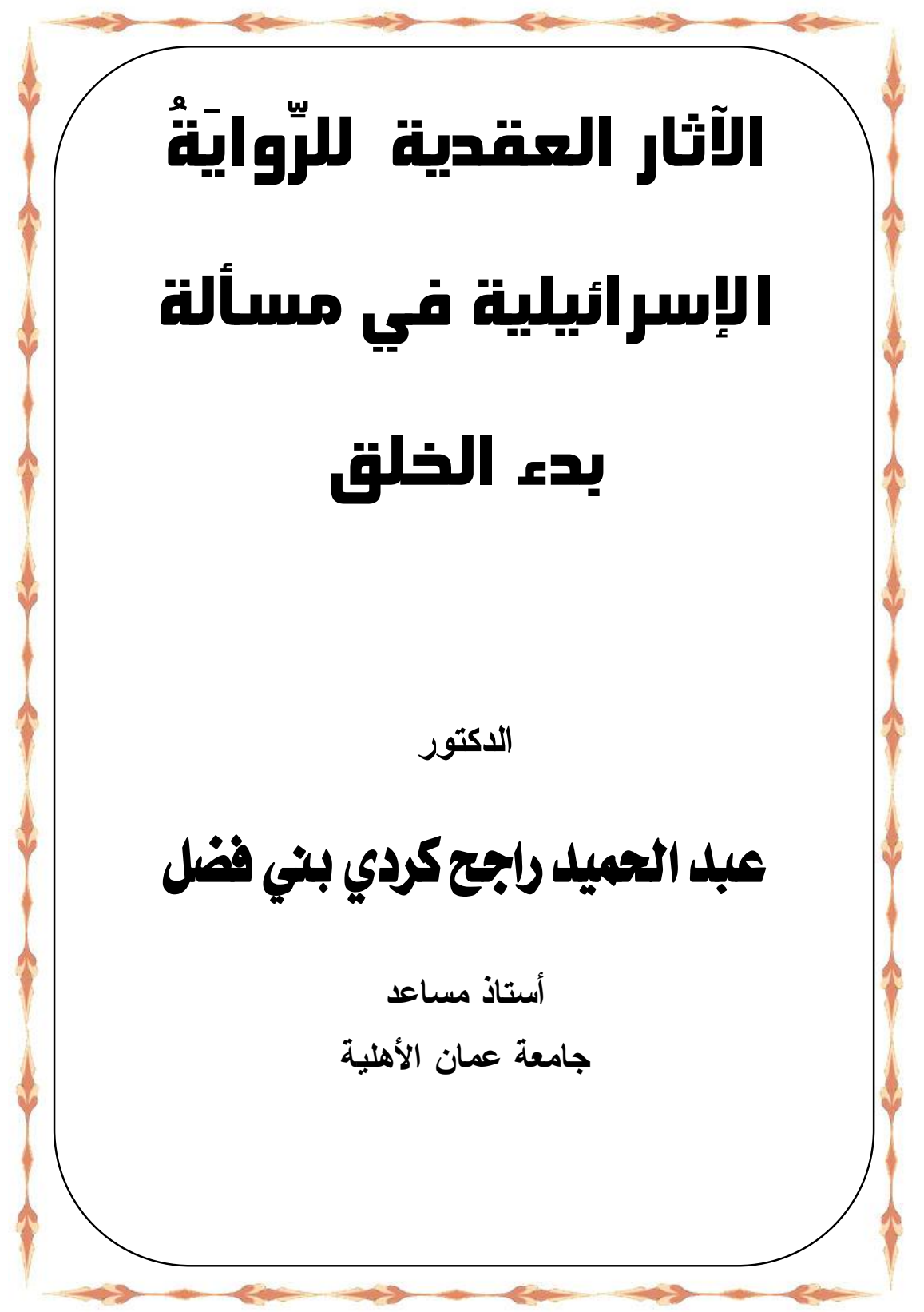




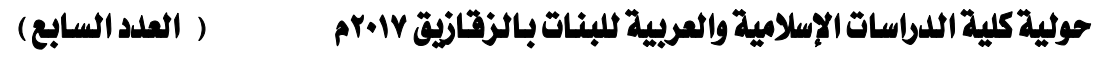

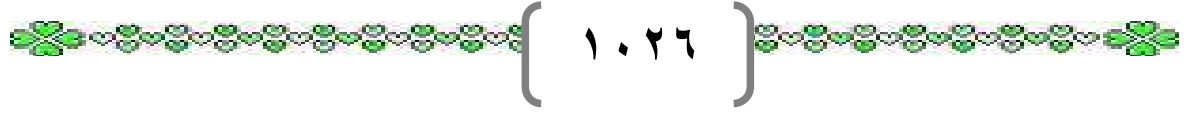




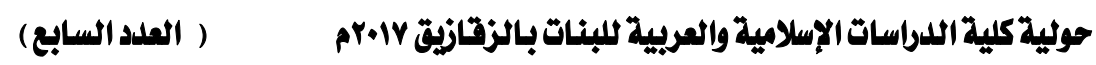

\section{ملخص اليحث}

مسألة الرواية الإسرائيلية انتشرت في كتب التفسير بالمأثور وبعضا من

كتب التقسير بالرأي وأخذت أهمية كبيرة؛ باعتبارها أحد مصادر فهم النص القرآني، ونظراً لأن هذه الرواية تعددت موضوعاتها في القصص القرآنـي فيما يتعلق بالعقائد، وفي شرح تفاصيل بـــــ الخليقـــة وخلــق الســموات والأرض كان لا بـ أن تبين هذه المسألة بتَتبهُع هذه الرواية وبيان أثرها في الاعتقاد. وحتى لا يطول البحث فقد رأى الباحث أن يـــرس القضــية فـي مسألة بداية الخلق كنموذج لأثرها في العقائد، وذلك ببيان ماهيــة الروايـــة الإسر ائيلية وسببها وأقسامها وحكمها، ومن ثم الرواية الإسر ائيلية في بلء الخلق، ثم الآثار العقدية لهذه الروايات.

الكلمات المفتاحية: العقيدة، الرواية، الإسر ائيليات، الرواية الإسرائيلية 


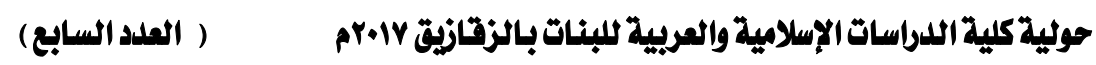

$$
\text { بسم الله الرحمن الرحيم }
$$

\section{أهمية اليحث ومسوغاته:}

أخذت قضية الرواية الإسر ائيلية في كتب التفسير بالمــأثور خصوصــاً

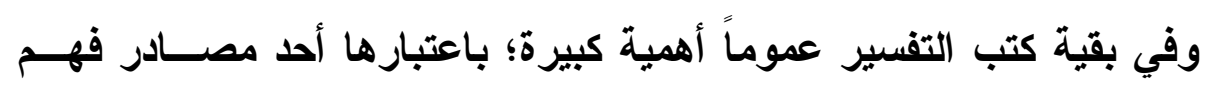
النص القرآني، وق عُرفت هذه الرواية بالإسر ائيليات.

ونظراً لأن هذه الرواية تعددت موضوعاتها في القصص القرآني فيمــا

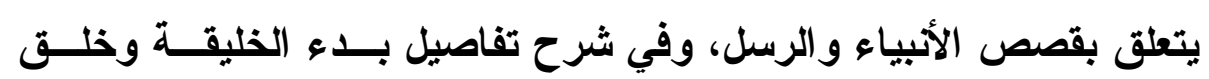

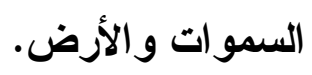

ونظراً لتأثير هذه الرواية على قضايا الايمان؛ فقد رأى الباحث أن يُجلّي هذه القضية بتَبَّع هذه الرواية وبيان أثرها في الاعتقاد. وحتــى لا يطــول البحث فقد رأى الباحث أن يارس القضية في مسألة بداية الخلق نموذجاً.

\section{مشكالة الدراستة:}

تجيب هذه الار اسة على الأسئلة الآتية:

$$
\text { ا ـ ما المقصود بالرواية الإسرائيلية؟ }
$$

r . ما سب دخولها إلى التفسير باعتباره مصدر فهم العقيدة؟ r. ما أقسام هذه الرواية وحكم روايتها والأخذ بها؟ ء. ما الإسر ائيليات المتعلقة ببدء الخلق عموماً؟

ه. ما الآثار المترتبة على هذه الإســر ائيليات فـي الخلــق علـى الاعتقاد 


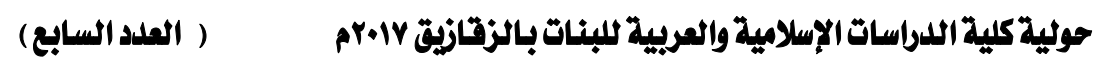

أهماف اليحث:

ا - بيان مفهوم الرواية الإسر ائيلية وحكمها.

r - تحليل خطرة الرواية الإسر ائيلية عموماً وخطورتها على العقيدة.

ب- جمعٌ ودر اسةٌ وتحليلّ للرواية الإسر ائيلية فيما يتعلق ببدء الخلق

ع - مناقشة الآثار العقدية المترتبة على الرواية الإسر ائيلية فيما يتعلق

ببدء الخلق

منهج الياحث:

1 - المنهج التاريخي ومنهج النقا الحديثي من حيث تتبـع الروايـات

الإسر ائيلية جمعاً و استقر اءً وحكماً.

r - المنهج التحليلي والاستتباطي.

خطة اليحث:

مقدمة

المطلب الأول: الرواية الإسرائيلية: تعريفها وسببها وأقسامها وحكمها. المطلب الثاني: الرواية الإسرائيلية في بلاء الخلق. المطلب الثالث: الآثار العقدية لهذه الروايات الخاتمة: وفيها أهم نتائج البحث وتوصيات الباحث. 


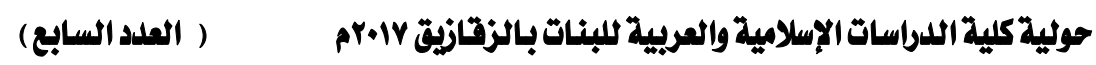

\section{المطلب الأول}

\section{الرواية الإسرائيلية: تعريفها وسيبها وأقسامها}

\section{وحكمها}

أولاً: تعربف الرواية الإسرائبية:

الروايةة: ما جاء منقولاً أي بطريق نقلي بسند عن أمسـر غيــر مشـــاهد للمنقول له أو من غير سماع مباشر من المنقول له، فهي طريق" ســماعي

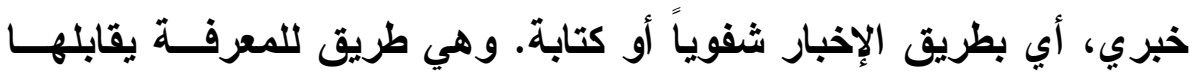
الطريق العقلي أو التفكير أو الرأي.

والإسر ائيلية: نسبة إلى بني إسرائيل، وهم القوم الممتدون من نبي الله ورسوله يعقوب عليه السلام أو إسرائيل ابن أبي الأبياء ابـــــاهيم علــيهم جمبعاً الصلاة و السلام.

والروابة الإسر ائيلية: هي ما عرف في علم التفسير بالإسر ائيليات، جمع إسر ائيلية - وهي ”قصة أو حادثة تروي عن مصدر إسرائيلي،“(1). وهـــا

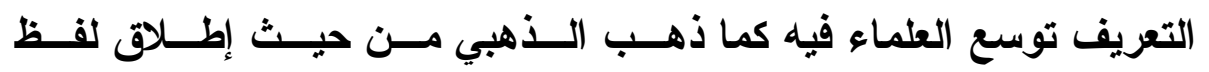
الإسرائيليات، من باب التظليب أي أن أغلب هذه الروايات عن بني إسرائيل وأنها لا تقتصر تلك الروايات في مصدرها عن المصادر اليهودية، بل تطلق أيضاً على ما روي من المصادر النصر انية، فالنصر انية أيضاً دين إلى بنـي

(1) نعناعة، رمزي، الإسرائيليات وأثرها في كتب التفسير، طا، دار القلم دمشق ودار

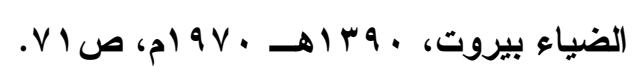

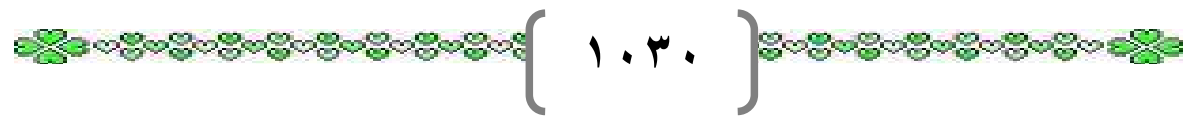




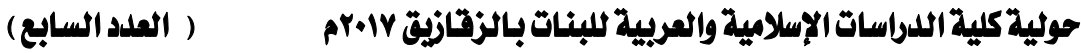

إسرائيل لكن الثقافة اليهودية تعتمد على التوراة وكُثب بني إسرائيل. وأكثر

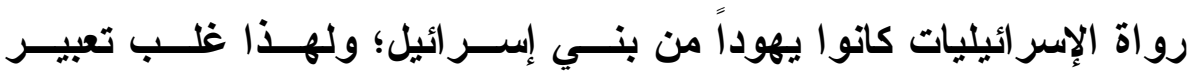
الإسرائيليات على تلك المرويات عن أهل الكتاب، كما كان أثهر الناقلين لها

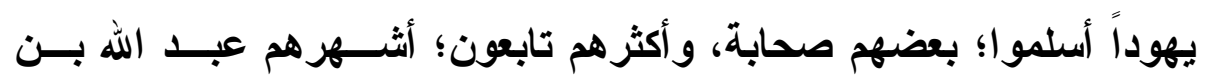

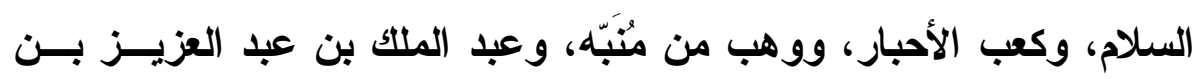

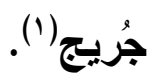
ومصطلح الإسرائيات مصطلح متأخر عن عهد الصــحابة والتـابعين

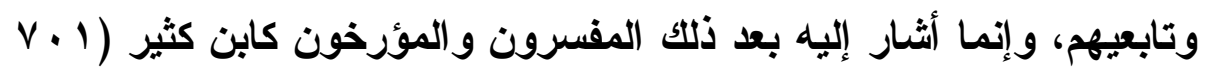

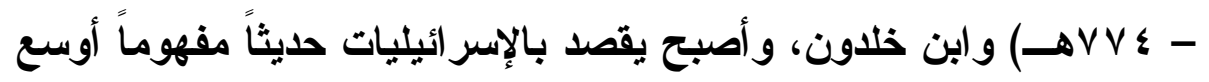
لتشمل الاخيل في التفسير والموضوعات. وذهبت دائرة المعارف الإسلامية إلى اعتبار المرويات المتصلة بمرويات التفسـير النقاتــي مـن المصــادر اليهودية في جميع أعصارها مع مزيج من الأديــان الأخــرى، والثقافــات الأخرى إسر ائيليات أو سمتّها بالإسر ائيليات(؟).

(1) انظر الذهبي، محمد حين، التفسير والمفسرون، طץ، دار الكتب الحديثة، القاهرة

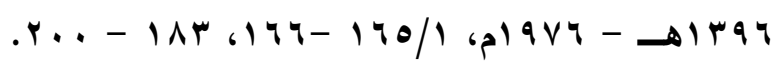

(r) انظر نعناعة، الإسرائيات، صه V، ودائرة المعارف الإسلامية معجم أمين الخولي، مادة تفسير، ص اهـr. 
وهناك من نظر إلى الطريق الناقل للأخبار والمرويات بغضّ النظر عـن كونها من مصادر يهودية أو من أديان أخرى ولكن نظر إلى نَقَتَتِهــا؛ فـــإن كاتوا إسر ائيلين سميت إسر ائيليات ('). وعلى العموم فإن تسبب تسمية تلك المرويّات جميعاً بالإسر ائيليات لأن أوائل من نقلها ورواها هم من بني إسرائيل، وإن توسعت مصادرها، وذلك

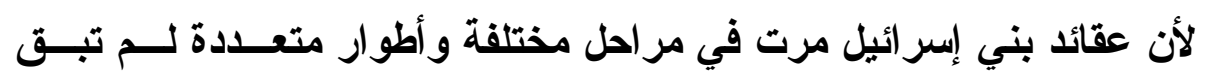
صافية كما تأثرت بالترجمة من لغة إلى أخرى حتى ترجمت إلــى التــور اة، و إنما حرّقها أحبار هم وتأثرت بالظروف البيئية زماتياً ومكاتياً في شـروحها

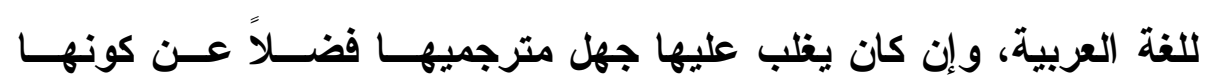
معتقدات وقصصاً للعامة منهم، فضلاً عن كونها محرفة اصلاً في مصادرها التي ترجمت عنها. وق ذكر ابن حجر أن هذه الإسر ائيليات هي من ترجمــة أهل الكتاب للمسلمين؛ فمن حديث أبي هريرة قال: "كان أهل الكتاب يقرأون التور اة بالعبر انية ويفسرونها بالعربية لأهل السلام..،(؟).

(1) (1) انظر نعناعة، المرجع السابق.

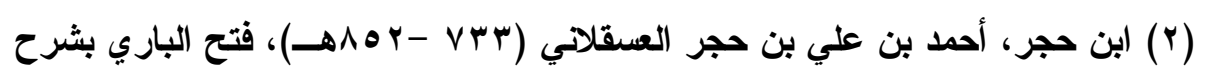
صحيح الإمام أبي عبدالله محمد بن إسماعيل البخاري، المطبعة السلقية ومكتبتها،

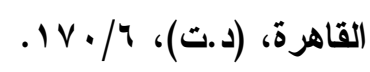

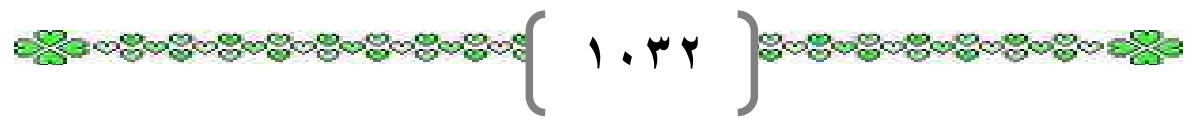




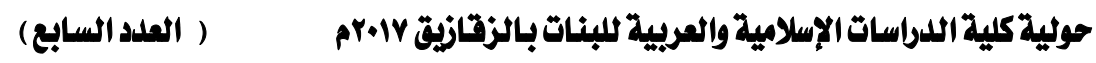

\section{ثانياً : سيب دخول الرواية الإسرائيلية في كتب التفسير:}

ذكر العلماء أسباباً لاخول الإسرائيليات في كتب التفسير أهمها:

ا ـ يعزو ابن خلاون سبب تسرب الإسر ائيليات إلى الثقافــة الإســلامية

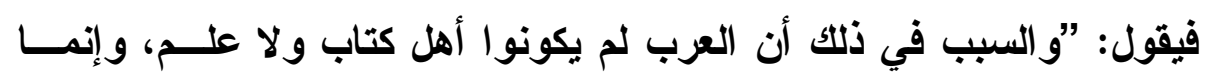

غلبت عليهم البداوة والأميّة، وإذا تشوفوا إلى معرفة شيء لما تتشوف لـــهـ

النفوس البشرية في أسباب المكونات وبدء الخليقة وأسرار الوجود، فإنمــا

يسألون عنه أهل الكتاب من قبلهم، ويستفيدونه منهم، وهم أهل التوراة من اليهود ومن تبع دينهم من النصارى. وأهل التوراة الذين بين العرب يومئــذٍ بادية مثلهم، ولا يعرفون منه إلا ما تعرفه العامة من أهل الكتاب. ومعظمهم من حِيْر الأين أخذوا بدين اليهودية، فلما أسلموا بقوا على ما كان عندهم

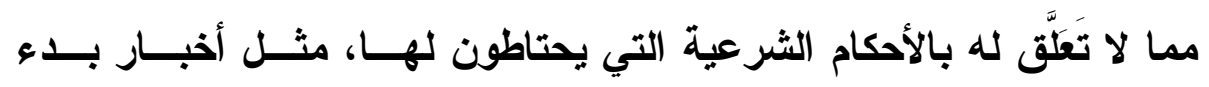
الخليقة، وما يرجع إلى الحََثَان و الملاحم وأمثال ذلتك (...) وأصلها - كمــا قلنا - عن أهل التوراة الأين يسكنون البادية ولا تحقيق عندهم بمعرفة مـــا ينقلونه من ذلك؛ إلا أنه بَعُد صيتهم وعظمت أقدارهم لما كانوا عليـهـه مـنـ المقامات في الدين و الملة، فتلقيت بالقبول،“(1).

وقد عبرت آمال ربيع عن هذا السبب من غلبة البداوية والأميّــة علــى العرب وحب الفضول للاستفادة من أهل الكتاب عن أخبار الماضي والـــي هـي عبّر عنه ابن خلاون بتشوف النفس البشرية لأخبار الماضي ومدته وأسرار

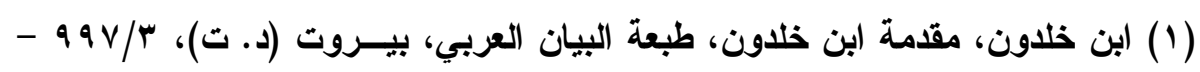

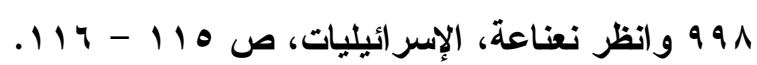

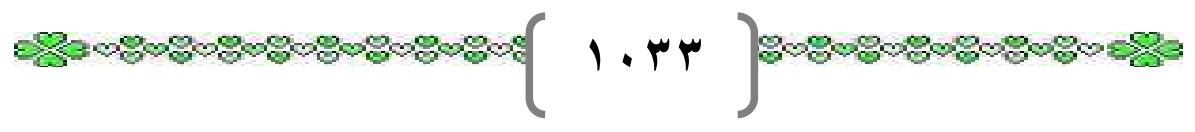


الوجود بالسبب الاجتماعي والايني فقالت: "وقد أرجع ابن خلدون أسـبـاب

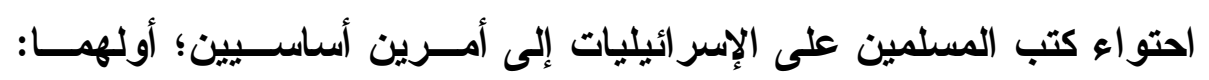

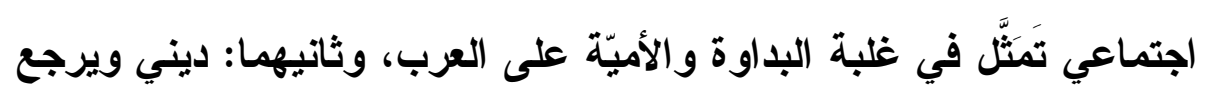

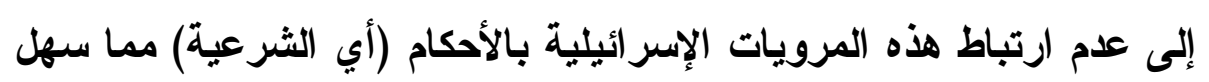
وسوّغ رو ايتها وتلقيها،، (1).

r - ويفصل الذهبي في مبدأ دخول الإسر ائيليات في التفسير وتطــوره؛

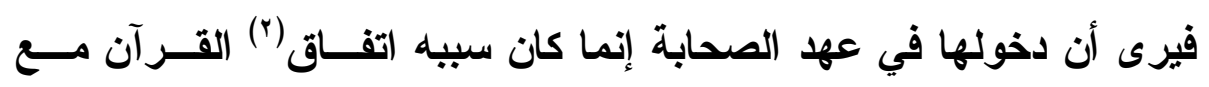

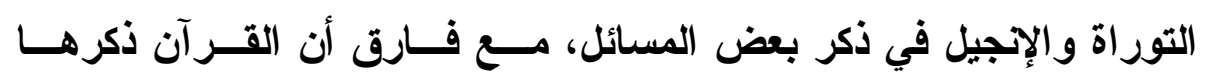

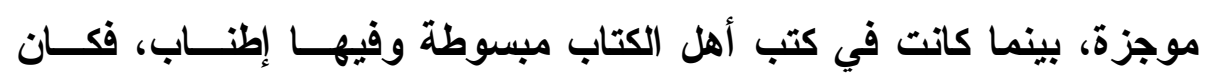

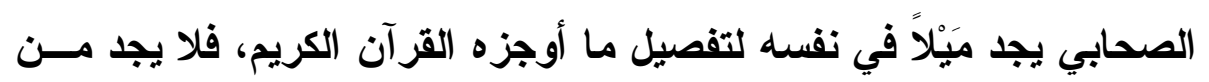

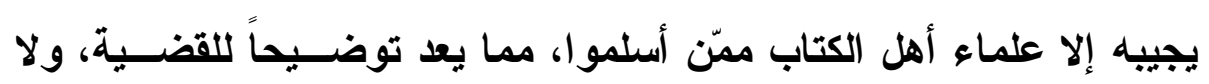

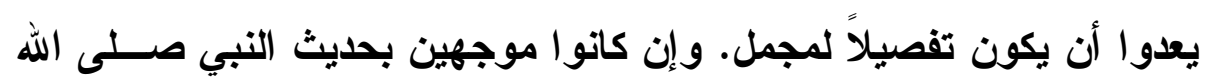

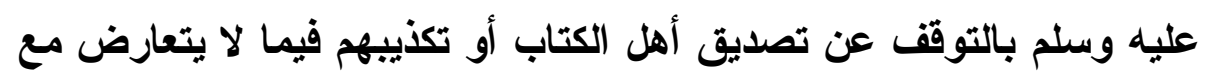

(1) ربيع، آمال محمد عبد الرحمن، الإسرائيليات في تفسير الطبري - دراسة في اللغة

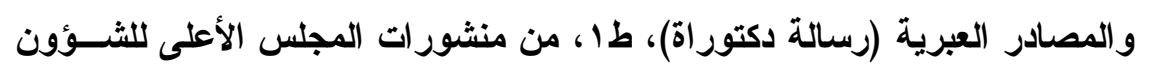

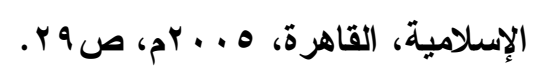

$$
\text { (Y) انظر الذهبي، التفسير والمفسرون (YVV- 179/1) }
$$

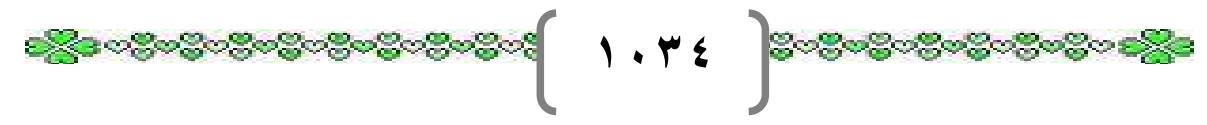


دينهم، وذلك في توجيهه صلى الله عليه وسلم لهم بقوله: "لا تصدقوا أهـلـ الكتاب ولا تكذبوهم، وقولوا: آمنا بما أنزل...،؛(1). وشرح ابن حجر هذا الحديث معلِّلًا الحكم فيه بعدم تصديقهم ولا تكذيبهم مع ذكر الضابط في ذلك المروي فقال: "أي إذا كـــان مـــا يخبـرونكم بــهـ

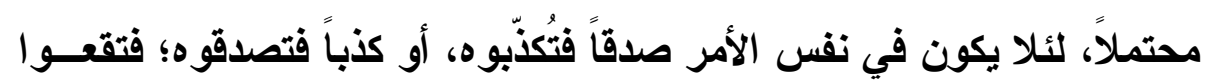
في الحرج. ولم يرد النهي عن تكذيبهم فيما ورد شرعنا بخلافـها، ولا عـن تصديقهم في ما ورد شرعنا بوفاقه. نبّه على ذلــــ الشــافعي رحمــهـ الله. ويؤخذ من هذا الحديث التوقف عن الخوض فيما يقع فيه الظن. وعلى هـــا نحمل ما جاء عن السلف من ذلك؛“(؟). r. ويستكمل الذهبي حديثه عن مبدأ ظهور الإسرائيليات عند الصحابة؛ فيرى أن الصحابة كانوا لا يتكلفون في سؤال أهل الكتاب فيما هو متكــف

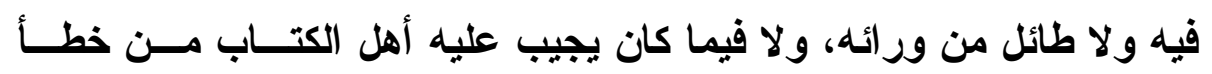
واضتح يتعارض مع ما جاء في الاسلام.

وبهذا فان الصحابة في منهجهم لم يخرجوا عن دائــرة الجــواز التــي

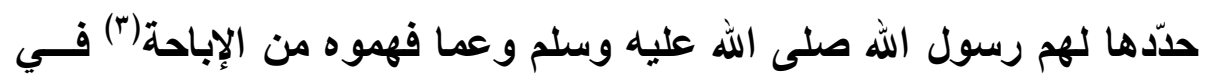

(1) صحيح البخاري بشرح فتح الباري، الطبعة السلفية، هو كتاب التفسير، حديث رقم

$$
\begin{aligned}
& .1 v \cdot / \Lambda ،(\leqslant \leqslant \wedge \theta)
\end{aligned}
$$

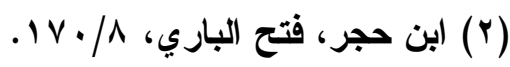

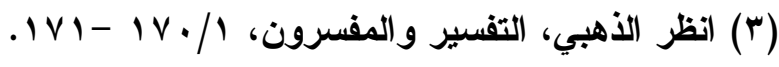


قوله عليه الصلاة والسلام: ”بلّغوا عني ولو آية، وحلثوا عن بني إسرائيل ولا حرج، ومن كذب عليّ متعداً فليتبوأ مقعده من النار ،؛(1). ـ. ويعلل ابن حجر التوسع في التحديث عنهم بعد التوقف في الحــديث السابق فيقول: "وكان النبي منع قبل استقرار الأحكام الإسلامية والقواعـــ الاينية خشية الفتنة. ثم لما زال المحظور وقع الإذن في ذلك؛ لما في سماع الأخبار التي كاتت في زمانهم من الاعتبار،“(؟). ه. ويرى الذهبي أيضاً أن التابعين توسيّعوا في الأخذ بالإسر ائيليات من

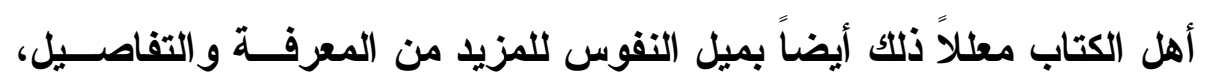
ولسدّ ثغرات بالقصص والخرافات المتناقضة والمخالفــة لــبعض القضـــايا الهامة في حياة الأنبياء، ومما يسيء إلى عصمتهم وإلى بعـض القضــايا

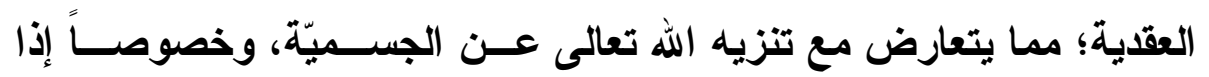

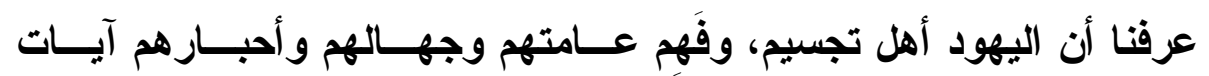

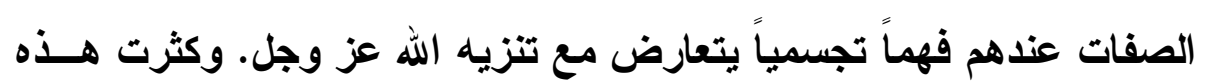
الروايات فيما نسب من روايات عن أبي هريرة معنعنــة، أو صــيغت لهـــا الأسانيد المكذوبة، وكذلك عن ابن عباس، فضلاً عما نسب إلــى الصـــابي عبد الله بن سلام من مسلمة أهل الكتاب، وفيما جاء فــي المنســوب مـن النـ

(1) البخاري، بشرح فتح الباري، الطبعة السلفية، كتاب أحاديث الأبياء، باب ما ذــــر

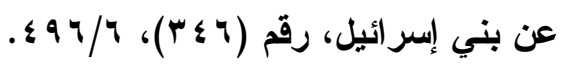

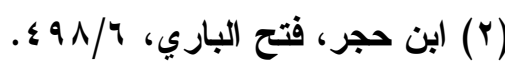

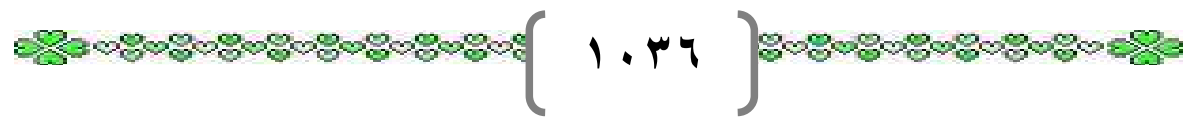


روايات في تفسير مقاتل بن سليمان (ت ه ـ اهـ)(') ومما نسب إلى كبـار

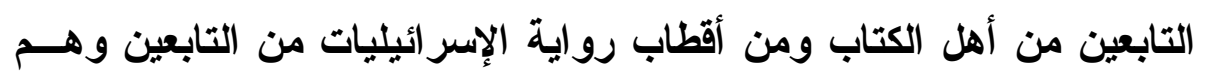
كعب الأحبار، ووهب بن منبَّه، وعبد الملكك بن عبد العزيز بن جريج، وكانوا و اسعي الاطلاع على ما عند اليهود من قصص نبوي وأخبار بلدء الخليةـــة

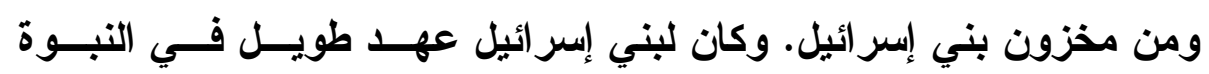
و الأبياء و الكتب السماوية.

7. مرحلة حين حذفت أسانيد تلك الروايات الإسر ائيلية، وأخذت تنقل وتــروى وتكتب في كتب التقسير بدون أسانيدها مما لا يمكن معه تمحيص أسانيدها ويحيل الحكم عليها بصحة أو ضعف أو وضع من جهة الصنعة الحديثية في علم الأسانيد. وكان حذف الأسـاتيد للروايات بزعم الاختصار، وهـــ زعــم باطل ومدمرّ، وسيع من الناحية العلمية، ومن ناحية منهجيــة التفكيــر؛ إذ إذ كثر فيه وضع الروايات والكذب فيها، مما جعـل الروايــة الإســر ائيلية الإسر ائيليات - عثرة كبيرة من عثرات كتب التفسـير بالمــأثور؛ كتقســير

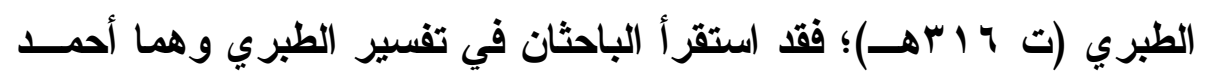
نجيب بن عبدالله في رسالته للاكتوراة بعنوان "الروايات الإســرائيلية فـي

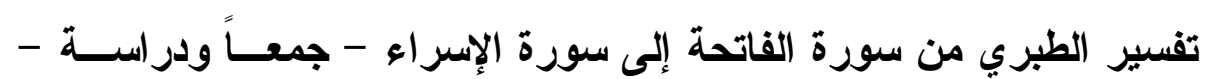

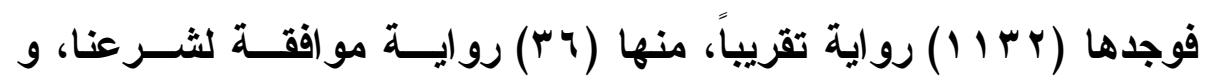




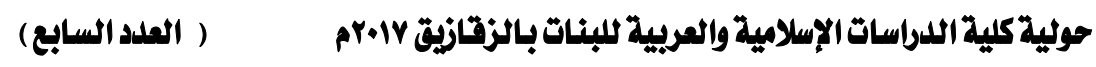

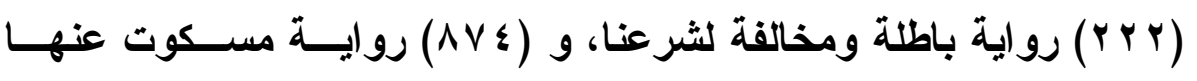

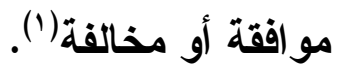

وأما الار اسة الأخرى فهي للباحثة آمال محمد عبد الرحمن ربيــع فـي رسالتها للاكتور اة / كلية دار العلوم بالقاهرة بعنوان: "الإســرائيليات فـي تفسير الطبري - دراسة في اللفة والمصادر العبرية"، فقد اســتقرأت عــد الروايات الإسر ائيلية في الطبري فوجدتها ( . . ه ץ) رواية(؟).

وقد ذكر ابن كثير (ت \& \&VVـ) في تفسيره باعتباره تفسيراً بالمـأثور

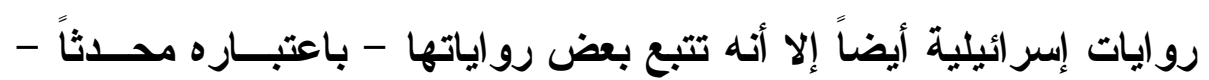
ونقدها ونبّه عليها، حيث يُعدّ المرجع الأول عند المفسـرين الـــين عُـــوا بالتفسير النقلي بعد شهرة تفسير ابن جرير الطبري، باعتباره أول مراجـع التفسير بالمأثور بما فيه من إسرائيليات من الناحية الزمنية والقنيّــة فـي بـي صناعة التأليف من التفسير، وبما نقله من أقوال السلف بأسانيدها وبيــان رأيه في آيات الكتاب، وكان له آراء في الإسناد، وكان يأتي فــي روايتــهـ للإسر ائيليات بأساتيد تنتهي إلى كعب الأحبار ووهب بن مُنبِّهُ وابن جـريج

(1) (ابن عبدالله، أحمد نجيب الماليزي، الروايات الإسرائيلية في تفسير الطبري - جمعاً

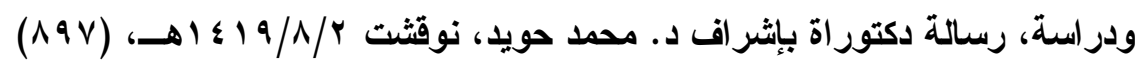
صفحة الملخص و الخاتمة رابط: http://www.iu.edu.sa/arabic/daleel/r.../doctor/26.htm. (r) انظرها مطبوعة من منشورات وزارة الأوقاف، المجلس الأعلى للشؤون الإسلامية،

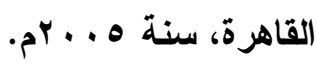

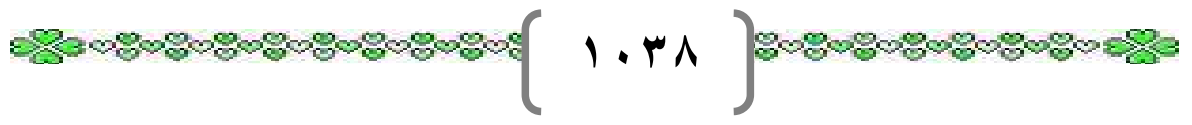


و الستُّدي("). وكان له نقد لبعض تلك الأساتيد، ولكنه أكثر من الإســر ائيليات باعتبار احترام أمانة النقل، وأنه يروي كل ما وصل إليه، إذ لا يخفي شـيئًاً مما علمه رواية، والعهدة على غيره ممّن يسمع أو يقرأ، فليبحث بعد ذلك،

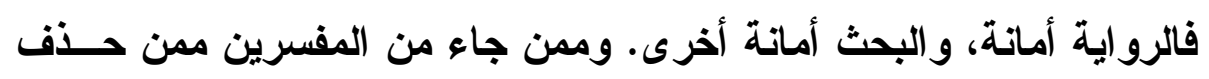
الأسانيد الثعلبي أبو اسحاق أحمد بن إبراهيم النيسابوري (ت V V هــ) في تفسيره، الكشفُ والبيان عن تفسير القرآن، والبغوي أبو محمد الحسين بن مسعود الفرَّاء (ت 17 (ه هـ) في تفسيره، معالم التززيل، وهو مختصر من

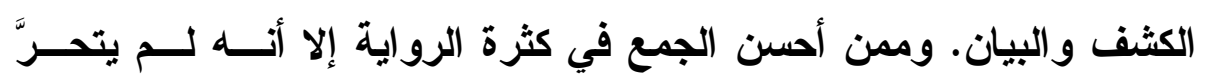
الصحة في الجمع فخلط بين الصحيح والعليل السيوطي، الحافظ جلا الدين

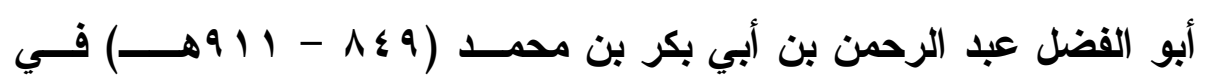

$$
\text { تفسيره الجلالين (r). }
$$

ثم جاء من المفسرين من نقل عن السابقين الروايات الإســـرائيلية دون ذكر الأساتيا ودون تمحيص صحيحها من سقيمها، كما فعل الخازن، عـلاء الدين أبو الحسن علي بن محمد بن إبراهيم بن عمر بــن خليـلـ الشــيحي

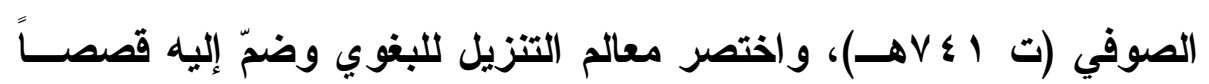
محذوفة الأسانيا - تجنبّاً حد التطويل والإسهاب ولحسن الترتيب والتأليف.

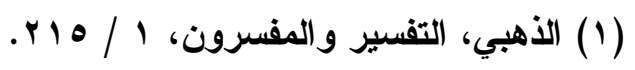

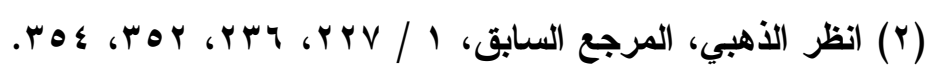

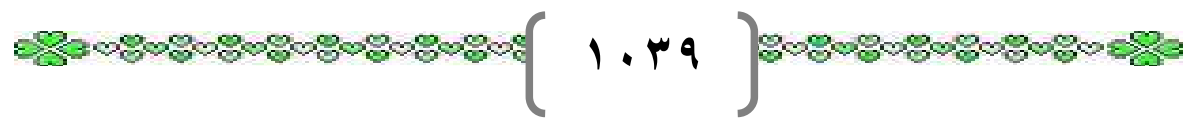




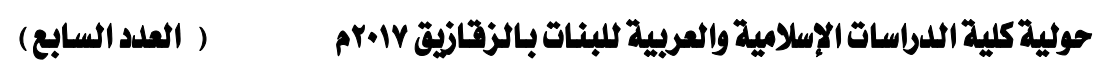

ولكنه للأسف لم يكن يعقب في بعض المواضع على القصــص الإســر ائيلي

وما فيه من خطورة (1).

وعلى هذا فلا يكاد يخلو كتاب من كتب التفسير إلا نادراً مــن الروايــة

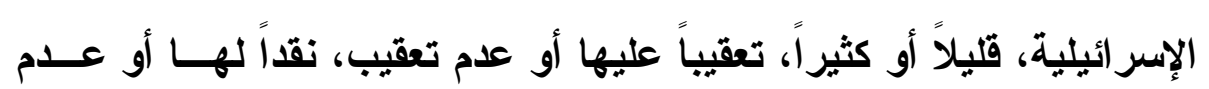
نقد، ذكراً لإسناد ها أو تركاً للإسناد.

ثالثاً : أقسام الرواية الإسرائيلية:

ثمة اعتبارات متعددة لتقسيم الرواية الإسر ائيلية؛ فهناك من قسمها من حيث:

1) كونها مرويات فهي: إما صحيحة من حيث سندها ومتنها أو ضعيفة

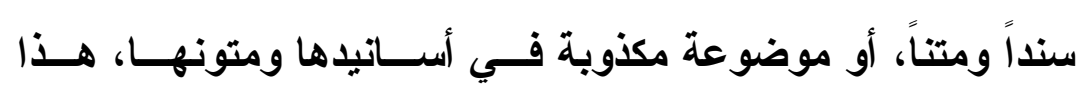

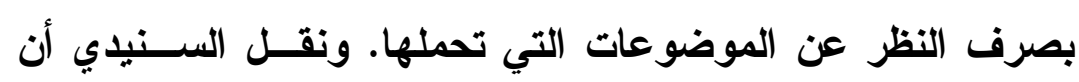
العلماء قسموا الإسر ائيليات إلى ثلاثة أقسام:" الأول: صحيح مقبول، وهو ما يشهر له القرآن أو السنة الصحيحة. الثاني: كذب مرفوض، وهو ما يخالف الكتاب والسنة. الثالث: مسكوت عنه لا مــن هــذا القبيل ولا من ذالك القبيل .فأما الصحيح المقبول فيروى عـنهم ولا 


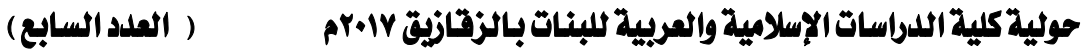

حرج فيه، وأما المردود فلا تجوز روايته، وأما المسكوت عنه فهذا

نحكيه عنهم دون جزم بصحة أو كذب "(1).

r ) وهناك من قَّمَها من حيث موضوعاتها التي تحملها بصرف النظــر عن درجة الحديث فيها صحة أو ضعفاً أو وضعاً؛ فهي قد تكون في مي

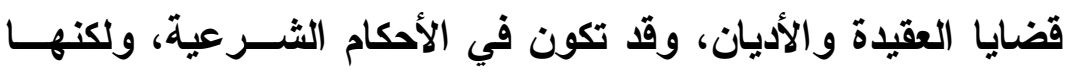
قليلة جداً، وقد تكون في القصص والأبــــاء والإخبــار ات الغيبيــة الماضية، مثل بدء الخليقة، أو القادمة مثل أحداث الانيا أو أحــداث الآخرة، وهي ذات طابع عقدي، وقد تكون في المواعظ والاعتبارات

$$
\text { وهي كثيرة جذاً. }
$$

r) وثمة تقسيم لها باعتبار ما ورد فيها؛ هل هو موافق لشريعتنا ومسـا ورد في دينتا، أم هو مخالف لشريعتنا أو دينتا، أم هو مسكوت عنه في شريعتنا ودينتا فليس مو افقاً ولا مخالفاً ولكنه لم يرد في دينتا. على ضوء هذه التقسيمات يكون الحكم في رواية الإســـر ائيليات وحكــــ الأخذ بها والتعامل معها من حيث كونها؛ مقبولة يؤخذ بها أو مردودة غيــر مقبولة، أو متوققاً في حكمها قبولاً أو رداً

(1)(السنياي، فه بن عبد العزيز بن عبد الله، حوار الحضارات (دراسة عقدية في ضوء الكتاب و السنة)،رسالة ماجستير،تخصص العقيدة،كلية التربية،جامعة الملك

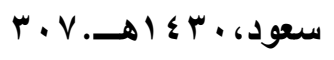




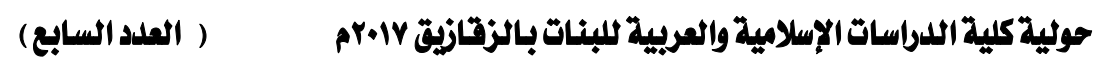

ولكثرة هذه الروايات في كتب التفسير والتاريخ بالمأثور وورود بعضها

في كتب السنة، فإن الأمثلة عليها بحسب تقسيماتها باعتبار اتهـــا المتعــددة

يصعب حصره في بحثنا هذا بأهدافه(')

رايعاً: حكم الرواية الإسراثيلية:

وأجمل فيما يأتي حكم رواية الإسرائيليات عند أثثر علماء الأمة:

يعتمد حكم رواية الإسر ائيليات والتعامل معها من الناحية الشرعية على

أحاديث تناولت الموقف، أهمها:

1 - الحديث الأول: أخرجه الإمام أحمد والبزار، - واللفظ لــه - عـن

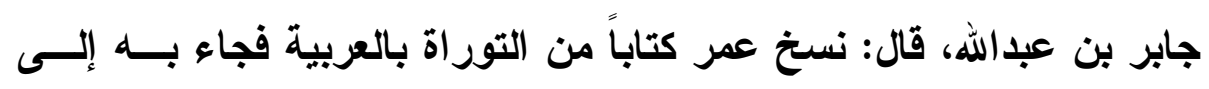
النبي صلى الله عليه وسلم فجعل يقرأ، ووجه رسول الله صــلى الله عليــه وسلم يتغير، فقال له رجل من الأصصار : ويحك يا ابن الخطاب! ألا ترى وجه رسول الله صلى الله عليه وسلم؟ فقال رسول الله صلى الله عليه وسلم: ”لا

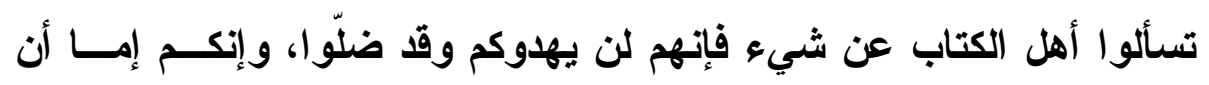
تكذّبوا بحق أو تصدقو ا بياطل. والله لو كان موسى حيّاً بين أظهركم ما حل

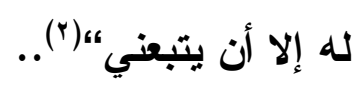

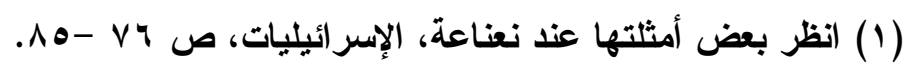

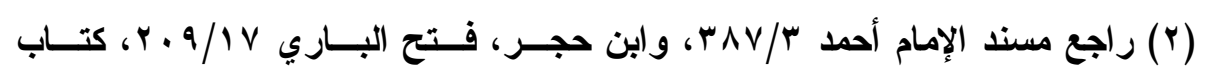

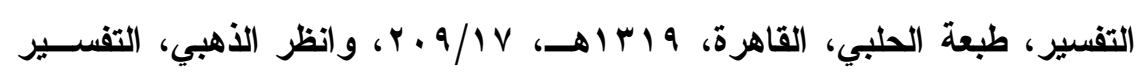

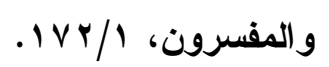

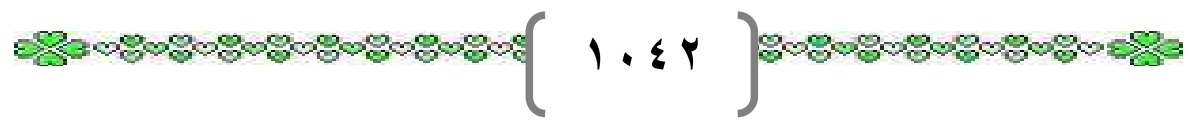


وهنالك حديث عن آخر عن جابر: "أن عمر بن الخطاب أتى النبي صلى

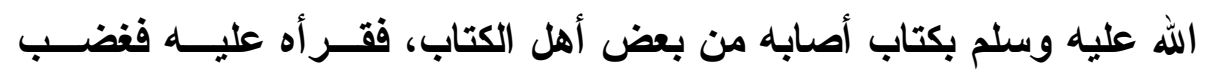
فقال: أمتهوكون (بمعنى متحيّرون) فيها يا ابن الخطاب؟ والأي نفسي بيـــه جئتكم بها بيضاء نقية، لا تسألوهم عن شيء فيخبروكم بحق فتكذبوا به، أو

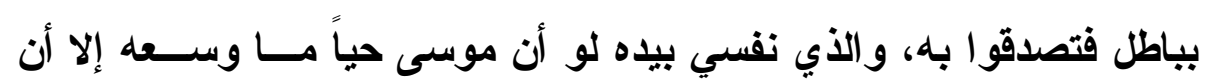
يتبعني، (1) (1)

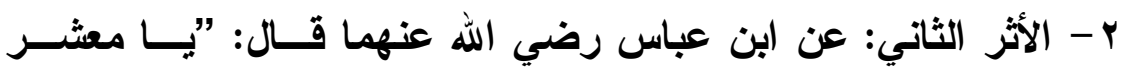

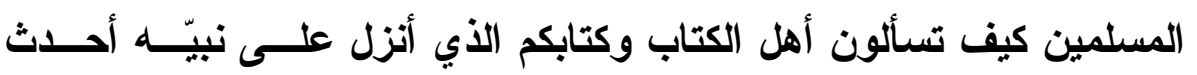
الأخبار تقر أونه لم يُشَبْ، وقد حدثم الله أن أهل الكتاب بدّلوا ما كتـب الله وغيّروا بأيديهم الكتاب فقالوا: \}هو من عند الله ليشتروا به ثمناً قليلاً. أفلا ينهاكم ما جاءكم من العلم مُساء كتبهم؟ والله ما رأينا منهم رجلاً قط يسأكم عن الأي أنزل عليكم،“(؟).

r- الحديث الثالث: عن عبد الله بن عمرو بن العاص رضي الله عنهما أن النبي صلى الله عليه وسلم قال: ”بلغوا عني ولو آية، وحدّثوا عن بنـي

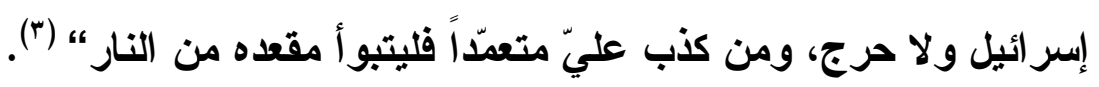

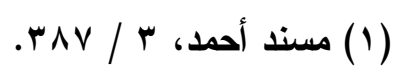

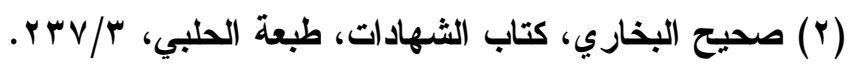

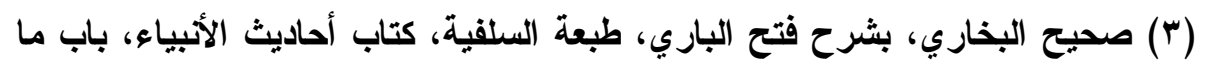

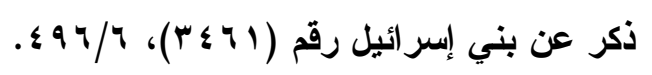

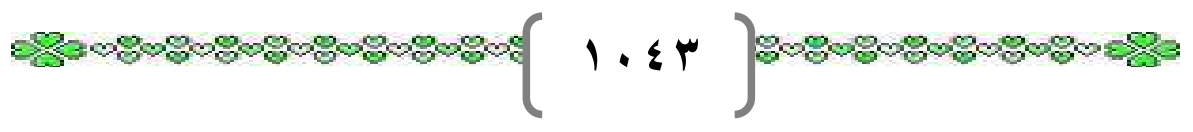


צ - الحديث الرابع: عن أبي هريرة رضي الله عنه قال: كان أهل الكتاب يقرأون التوراة بالعبرانية، ويفسرونها بالعربية لأهل الاسلام، فقال رســول الله صلى الله عليه وسلم: "ولا تصدقوا أهل الكتاب ولا تكــذبوهم وقولـــوا: \} فالأحاديث بعضها يجيز التحدث عنهم دون تحرج، وبعضها الآخر يمنــع التحديث عنهم فيما يروونه من أخبار إسرائيلياتهم، وبعضها فيــه توقــف الرواية عنهم والتوقف في تصديقهم أو تكذيبهم (ץ). وخير ما وجدت في التوفيق بين هذه الأحاديث ما قاله ابن حجــر فـي الفتح وعزا بعض الأقو ال للإمام الثـافعي حيث قال: "قولــه (أي صــلـى الله عليه وسلم): وحلثوا عن بني إسرائيل ولا حرج؛ أي لا ضيق علـيكم فـي

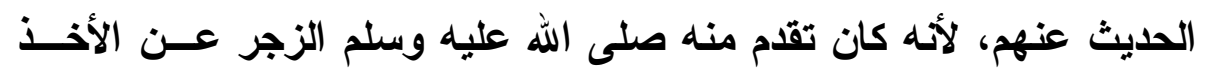
عنهم والنظر في كتبهم، ثم حصل التوسع في ذلك. وكأن النهي وقــع قبـلـ

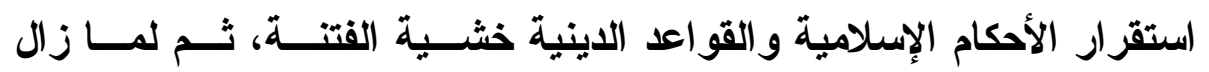
المحظور وقع الإذن في ذلك لما في سماع الأخبار التي كاتت في زماتهم من الاعتبار، وقيل: معنى لا حرج؛ لا تضيق صدوركم بما تسمعونه عنهم مسن

(1) سبق تخريجه، صحيح البخاري بشرح فتح الباري، كتاب التفسير، طبعة الســلفية، رقم (vی)

(r) الاستدلالات بهذه الأحاديث بين المجيزين والماتعين، انظر نعناعـة، الإســر ائيليات

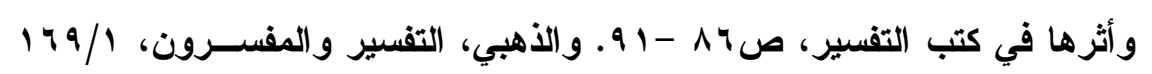
وما بعدها. 
الأعاجيب؛ فإن ذلك وقع لهم كثيراً. وقيل: لا حرج في أن لا تحدثوا عــهم؛ لأن قوله أولاً: حلّثوا صيغة أمر تقتضي الوجوب، فأثار إلى عدم الوجوب، وأن الأمر فيه للإباحة بقوله ولا حرج؛ أي في ترك التحديث عنهم. وقيـلـل: وقع الحرج عن حاكي لمِا في أخبارهم من الألفاظ الثــنيعة نحــو قـــلهم: (اذهب أنت وربك فقاتلا) وقولهم (اجعل لنا إلهاً).

وقال مـالك: جواز التحديث عنهم بمـا كان من أمر حسن، أمـا مـــا علــم كذبه فلا. وقيل: حدثوا عنهم بما ورد في القرآن والحديث الصــيح (...)، وقال الشافعي: من المعلوم أن النبي صلى الله عليه وسلم لا يجيز التحـدث بالكذب فالمعنى: حلثوا عن بني إسر ائيل بما لا تعلمون كذبه، وأما تجوزّونه

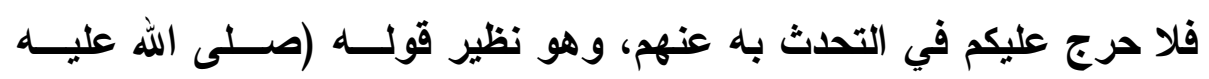
وسلم): إذا حدثم أهل الكتاب فلا تصدقونهم ولا تكذبونهم، ولم يــرد الإذن ولا المنع من التحدث بما يُقطع بصدقه،“(1). وأما الأثر عن ابن عباس فهو ليس حديثاً مرفوعاً إلى النبي صــلى الله

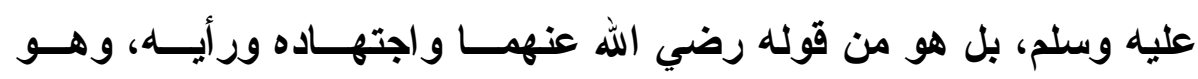

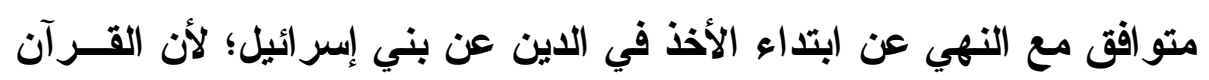

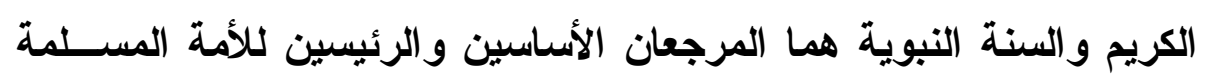
في معرفة دينها. وهذا أيضاً متوافق مع نهي النبي صلى الله عليــه وســلم لعمر بن الخطاب عن قراعة التوراة، وذلك في مرحلة التأسيس لفهم الإسلام من مصدره الحقيقي وهو القرآن الكريم، المهيمن علــى الكتـب الســابقة. 
والنبي صلى الله عليه وسلم وهو خاتم الأبيــاء والمرسـلين. ولا يجــوز إطلاقًا في مرحلة البناء لفهم التربية والحضانة المبكرة والأولى أن يشوبها في مصادر التربية أي مصدر خارج عن الكتاب والسنة؛ إذ لا يصح التخليط أو التهجين في مصادر التربية في مرحلة بناء فهم الإسلام. وواقع الأمر أن ابن عباس نفسه بعد استقرار الاحكام الشرعية من الكتاب والسنة، ونضـــج المسلمين في فهمهم للاين و إتمام النعمة بكمال نزول الوحي، كــان يســـع كلام أهل الكتاب، بل نقلت عنه روايات من قصصهم وأخبارهم. ولذلك وجه ابن حجر لكلام ابن عباس أن المراد بالنهي عنده "إنما هو سؤال من لم يؤمن منهم،" (')، وأن التهي هنا ربما كان للتنزيه لا للتحــريم، وأن الجواز بالتحديث عنهم إنما هو لمن هو مُتَّكن وراستخ في العلم، أمسـا غير المتمكن فهو منهيٌ عن ذلك، وأن الجواز إنما هو لضرورة الردّ علـى المخالفين ومعرفة آرائهم ومعتقداتهم لمناقشتهم فيها و الحوار معهم. (ץ). وهناك توجيهات تفصيلية للنهي والجواز، وبحسب موضوعات الروايات من حيث كونها موافقة لشرعنا أو مخالقة له عند عدد من العلمــاء كـابن تيمية و ابن كثير (r).

(1) انظر نعناعة، الإسرائيليات 1 / ب 9 وكلام ابن حجر في الفتح كتاب التوحيد، طبعة

$$
\text { الحلبي، V/ / . 1. }
$$

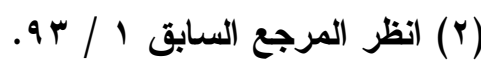

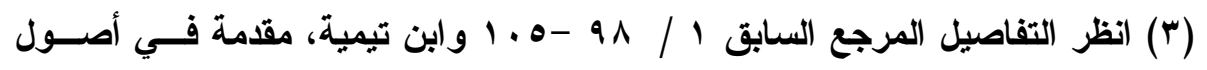

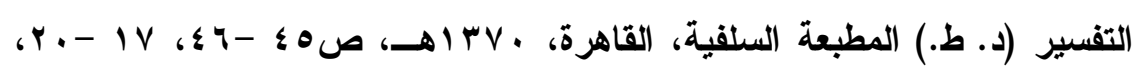


وعلق الأهبي بعد استعر اضه لمواقف العلماء في حكم الرواية عن بنـي

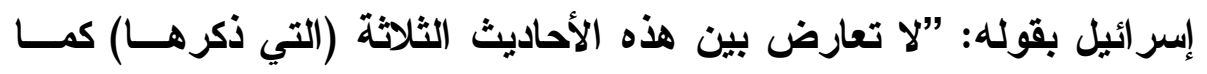
يتبين لنا المقدار الأي أباحه الثارع من الرواية من أهل الكتاب،، (1).

\section{خامساً : الإسرائيليات وما يتعلق يالعقائد:}

العقائد هي أهم موضوع يمكن أن يكــــن للروايــة الإســـرائيلية أثـــر

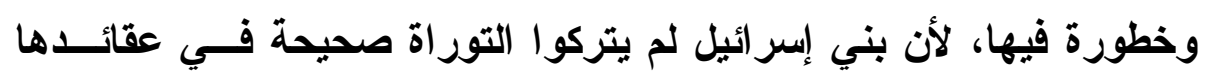
على ما عليه عند نزولها على موسى عليه السلام. ولم تُكتب في زمن موسى، وإنما جرى عليها من التــأليف والتحريــف و الفهم البشري في صياغتها وترجمتها، وتـــوالي عصــورها، وعلاقاتهـــا وتأثراتها بالبيئات المختلفة والمتعددة، والأطوار والأعصار في حيــاة بنـي إسر ائيل. والعقائد لا تتحمل مثل هذا التغيير والتحريف البشري، والتأويـلـل البشري والتأثر بالعقائد الوثنية و الثعبية في البيئات المختلفة. ومن ثم كان لعبارات أهل الكتاب في العقائد وقصص الأببياء وقصص الماضي من بــــ لــاء الخليقة وخلق السماوات والأرض والإنسان وما كان؛ فالقليل بل النادر منه كان يوافق الإسلام، ولكن التفاصيل زائدة جداً عما ورد في القرآن والسنة، فضلاً عن أن كثيراً منها مُشوَّش؛ وفيه تفصيلات مُمِلّة ولا داعي لهــا، ولا

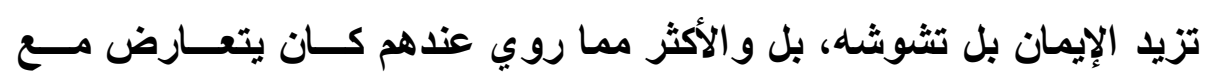

و ابن كثير، البداية و النهاية، طا، مطبعة كردستان العلميـة، وطبعـة ال، مطبعـة

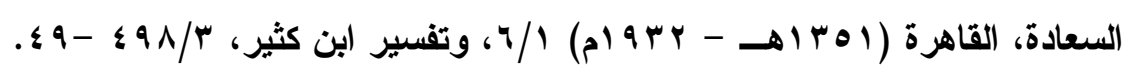

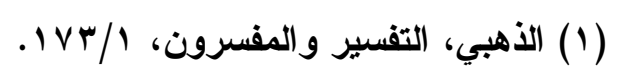

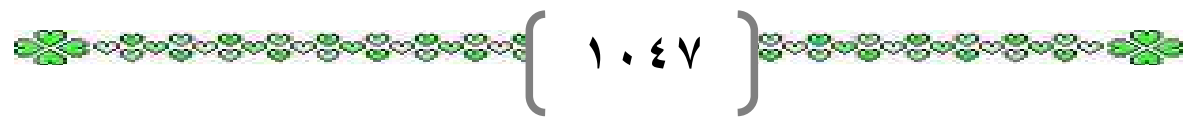




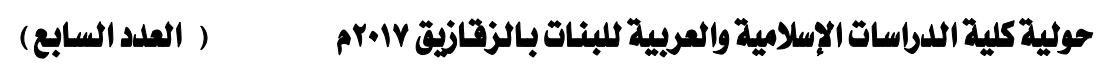

تنزيه الله سبحانه. وغالب قصص الأببياء في الرواية الإســرائيلية مُخلّــة بعصمة الأبياء والرسل، وتتهمهم في أخلاقهم وسلوكهم بما يتعارض مــع مبدأ إرسالهم وبعثهم ليكونوا قدوة لأتباعهم المؤمنين برسالاتهم. وما سلَّمَ نبي ولا رسول من هذه الروايــة الإســر ائيلية المسـيئة فـي الاعتقاد وفي تنزيه الله، وفي العصمة ونحن نقتصر في هذا البحــث علـى الرواية الإسرائيلية وأثرها في الاعتقاد فيما ورد في آدم عليه السلام الــذي كان أبا البشرية جميعاً، والنبي الرسول الأول، نموذجاً للبحث والار اسة. 


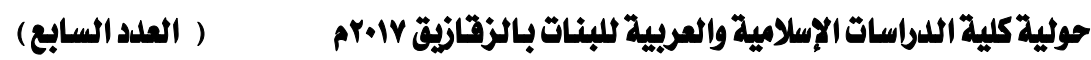

\section{المطلب الثاتي}

\section{الرواية الإسرائيلية في بحء الخلق}

تذكر الروايات الإسرائيلية تفاصيل في خلق الله تعالى للسموات والأرض وبدء الخلق. وما جاء في القرآن لا يثير التفاصيل و إنما يقرر بلدء الخلــق، ويشير ضمن أهدافه في تعريف الناس بعظمة الخالق سبحانه، وأنـــه خلــق السموات والأرض في ستة ايام. بينما يورد المفسرون من أهـلـ المــأثور روايات إسرائيلية لبيان مزيد من المعلومات والتفاصيل؛ وهي لا تخلو مسن تحريف بني إسر ائيل بما يخدم تفكيرهم واستغلال تحريف النصوص لصالح عقائدهم، مسيئين لله سبحانه، وغير مُعَظمين له، ولا منزهين، ومن ذلـــــ تذور الرواية الإسرائيلية حول تفسـير آيــات الغلــق للســموات والأرض الواردة في القرآن الكريم في قوله تعالى:

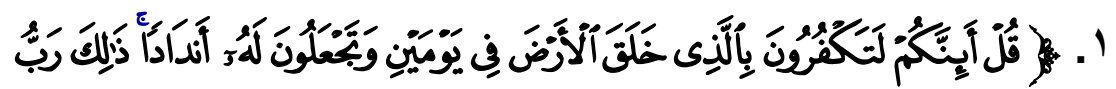

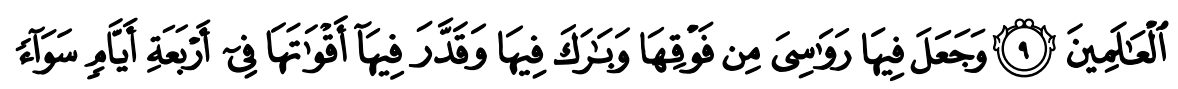

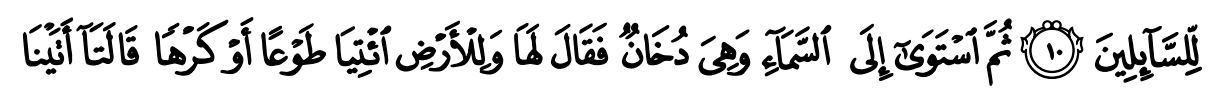

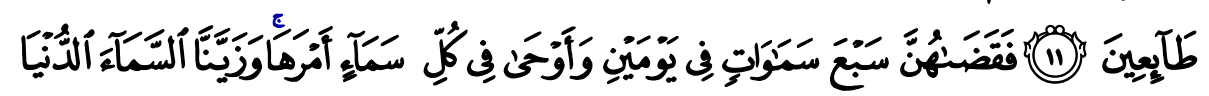

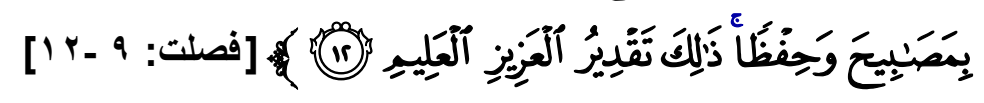

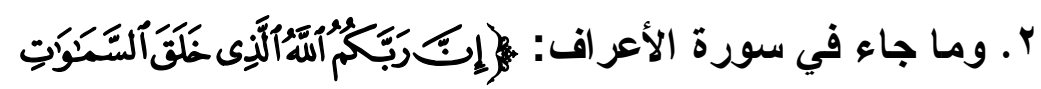

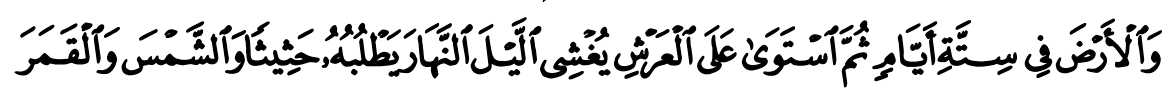

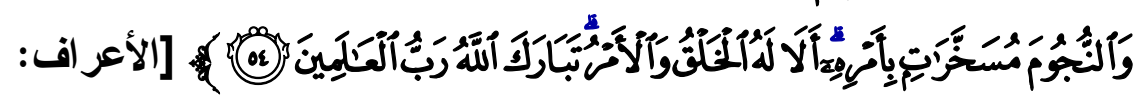
. [0 


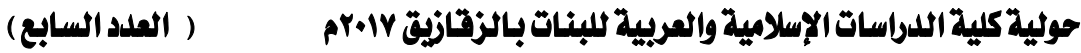

أ. فصّل الطبري بذكر الأيام وما خلق الله في كل يــوم معتمـــاً علــى

روايات عن تابعين غير مرفوعة إلى رسول الله صلى الله عليه وسلم، ممـــا يؤكد أنها بطبيعتها ليست اجتهاداً فهي علوم غيبية، وقد صرح بأنه فسرها بناء على روايات فقال: ".. في ستة أيام وذلك يوم الأحد والإثنين والثلاثاء و الأربعاء والخميس والجمعة كما حدثني المثني قال: بلـ الخلــق العـرش

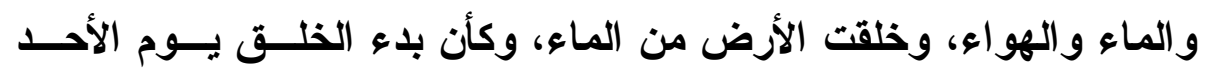

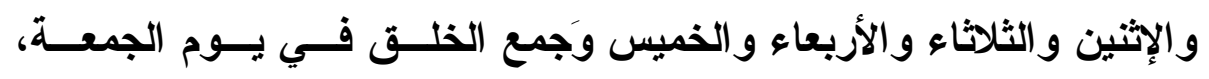
وتهوَّدت اليهود يوم السبت. ويوم من الستة الأيام كالف سنة مما تعـدون. ثم استوى على العرش“، (1). ب. وقد وافق ابن كثير الطبري في هذا التفصيل بذكر الستة أيام: الأحد و الإثنين و الثلاثاء والأربعاء والخميس والجمعة وأضاف عن يــوم الجمعــة

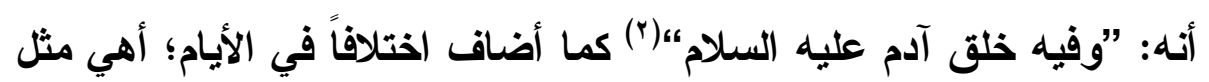
أيامنا اليوم وهي المتبادرة للأه؟ أو أنها ألف سنة كما نص عليها مجاهد فيما ذكره الطبري. كما أضاف فقال: "أمسا يوم السبت فلم يقع فيه خلق لأنه اليوم السابع ومنه سمي السبت وهو القطع،" (ॅ).

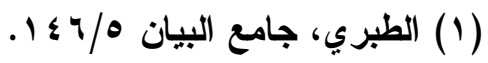

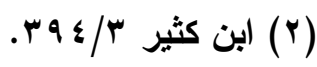

$$
\begin{aligned}
& \text { (r) المرجع السابق. }
\end{aligned}
$$


ت. وقد جاء الطبري بتفصيل أكثر في تفسيره آيات سورة فصلت في ما خلق الله في كل يوم من الأيام وأسباب تسمية هذه الأيام بأســمائها وهــــه

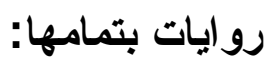

وقوله: الأحد ويوم الإثنين. بذلك جاءت الأخبار عن رسول الله صلى الله عليه وسلم وقالته العلماء. حدثنا هناد بن السري قال: ثنا أبو بكر بن عياش عن أبسي سعيد البقال عن عكرمة عن ابن عباس، قال هناد: قرأت سائرَ الحديث على أبي بكر أن اليهود أتت التبي صلى الله عليه وســلم فســألته عـن خلــق السموات والأرض. قال: خلق الله الأرض يوم الأحد والإثنين وخلق الجبــال يوم الثالاثاء وما فيهنّ من منافع، وخلق يــوم الأربعــاء الثـــر والمـــاء و المدائن و العمر ان والخراب فهذه أربعة، ثم قال أئنكم لتكفرون بالذي خلــق مأق

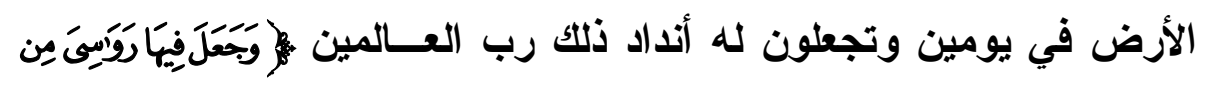

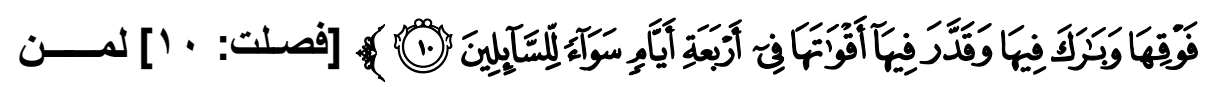

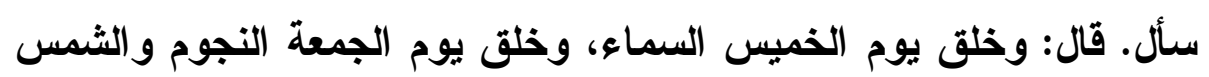
و القمر والملايكة إلى ثلاث ساعات بقيت منه، فخلق في أول ساعة من هذه الثلاثة الآجال حين يموت من مات، وفي الثانية ألقى الآفة على كل شــيء مما ينتفع به الناس، وفي الثالثة آ دم، وأسكنه الجنة، وأمر إبليس بالسجود لله، وأخرجه منها في آخر ساعة، قالت اليهود: ثم مـاذا يا محمد؟ قال: ثــــ استوى على العرش. قالوا: قد أصبت وأتممت. قالوا ثم اســتراح. فغضــب

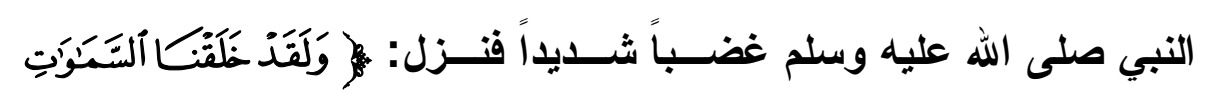




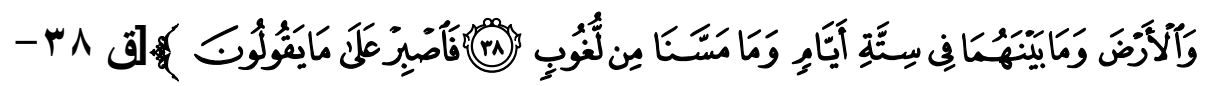

حاثثا تميم بن المنتصر قال: أخبرنـا إسحاق عن شريك عن غالــب بـنـ غلاب عن عطاء بن أبي رباح عن ابن عباس قال: إن الله خلق يوماً واحداً

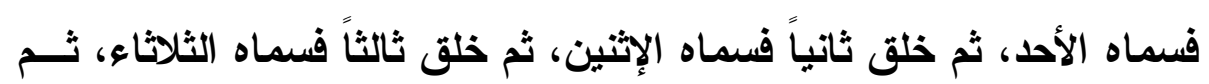

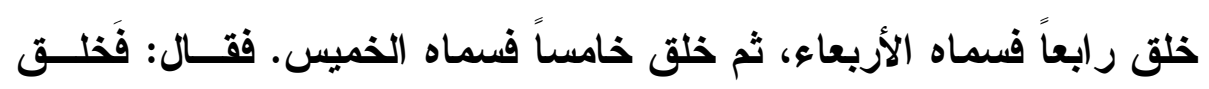

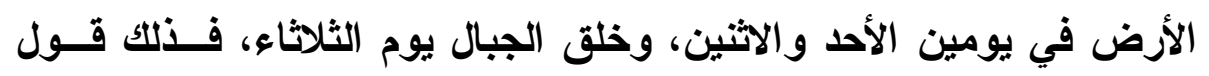

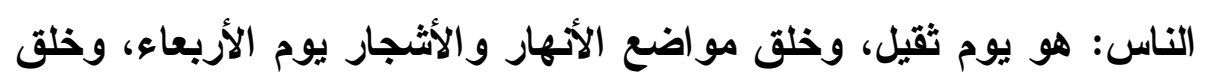

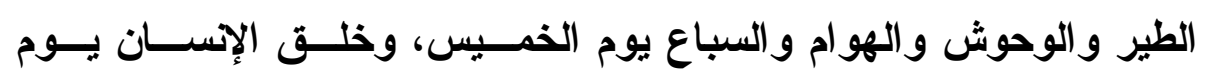
الجمعة، فقرغ من خلق كل شيء يوم الجمعة. حدثنا موسى قال: ثنا عمرو قال: ثنا أسباط عن السدّي خلق الأرض في

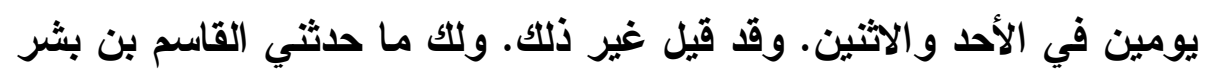

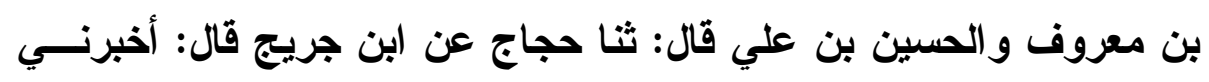

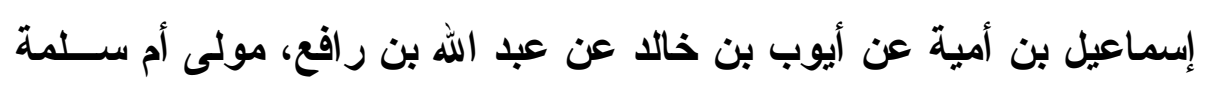

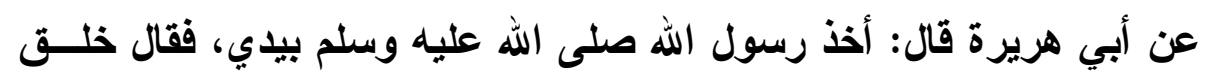

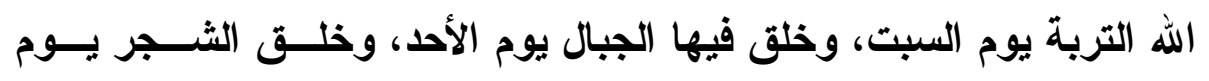

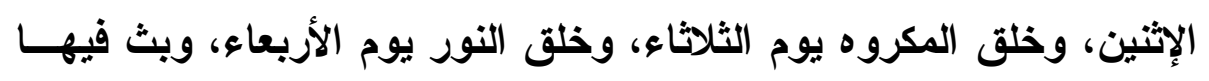


الدواب يوم الخميس، وخلق آدم بعد العصر يوم الجمعة، آخر خلق في آخر ساعة من ساعات الجمعة فيما بين العصر إلى الليل، (1). ث. وجاء ابن كثير في تفسير آيات السجدة بتفصيل الأيام الستة أيضـــاً،

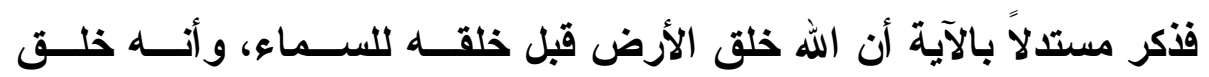

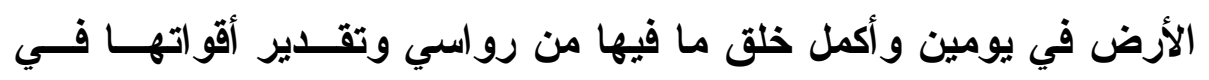
يومين آخرين فتم خلقها في أربعة أيام، وأنه استوى إلى السماء، فسـوّاهُن سبع سموات في يومين، وأوحى في كل سماء أمرها. وهكذا يكـون خلـق إنق الأرض في أربعة أيام، وخلق السموات في يومين، ومجموع ذلك ستة أيام. وهذا لا شيء فيه فهو تفسير للآيات، ويتوافق مع آيات أخرى في تفاصــيل

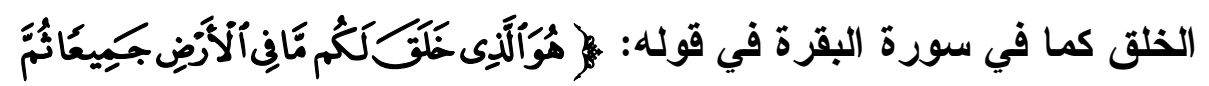

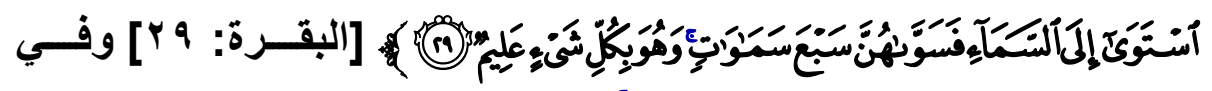

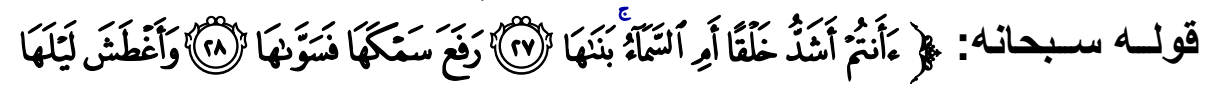

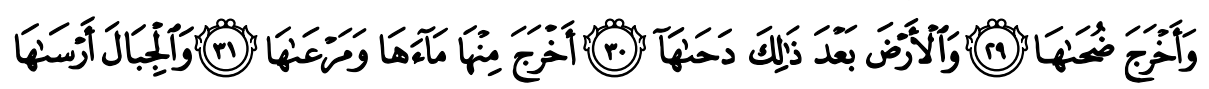

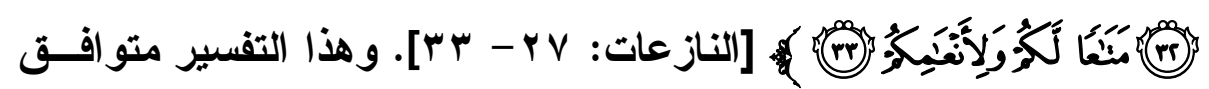

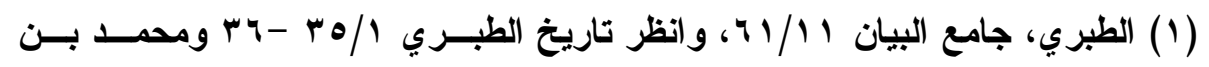

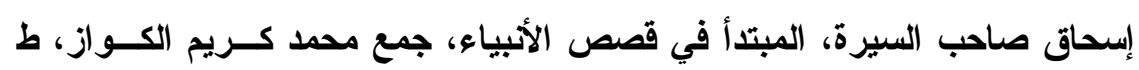

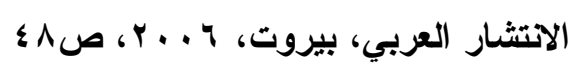

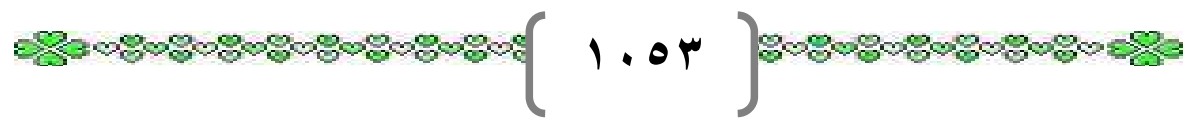


تماماً مع رواية الإمـام البخاري التي علّقها البخاري('). نفسه ثـــ وصـــها

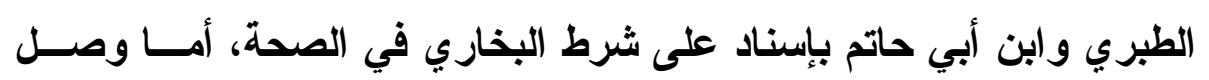

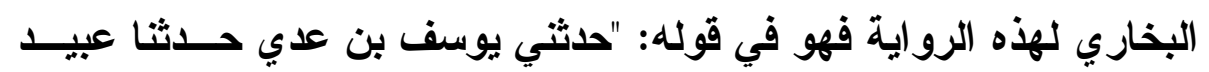
الله بن عمرو عن زيد بن أبي أنيسة عن المنهال بهذا،ه(؟). وعلل ابن كثير خلق الأرض قبل السموات، ولذلك ذكر الله خلق الأرض قبل خلق السموات، "لأنها الأساس، والأصل فقال: أن يبدأ بالأسـاس ثم بعده (السقف، (").

وأورد ابن كثير رواية هناد بسندها عن ابن عباس، التي ذكرهــا (بـن جريز، وفيها تفاصيل الأيام وما خلق في كل يوم فيها، وأن خلق آدم كــان في الساعة الثالثة، وأنه أخرجه في تلك الساعة. وأنه سبحانه استوى على ألى العرش فقال: اليهود قد أجبت يا محمد لو أتممت. قالوا: ثم استراح: ففضب

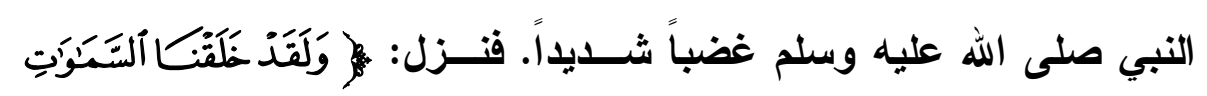

(1) الحديث بطوله في البخاري، انظره في البخاري يشرح فتح الباري، الطبعة السلفية،

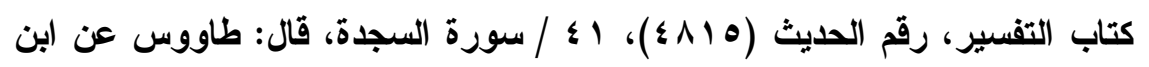

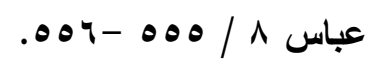
(ץ) البخاري، شرح فتح الباري، الطبعة السلفية، 1 / 1004، و وانظر كلام ابن حجر عن

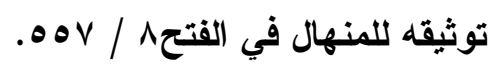

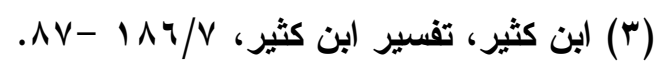

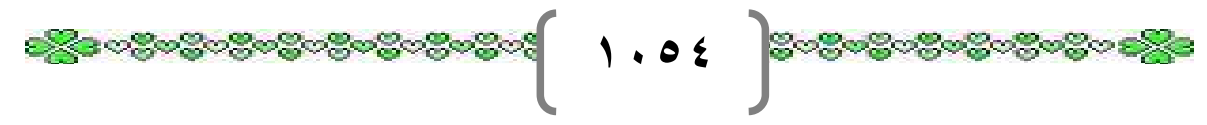




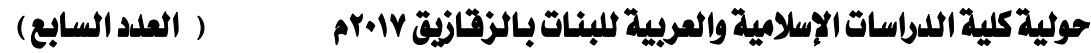

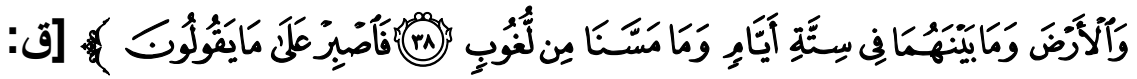

(') $[\mathrm{r} \Lambda$

ج. وهناك رواية في صحيح مسلم من حديث (بن جريج عن إسماعيل بـن أمية عن أيوب بن خالد، عن عبدالله بن رافع عن أبي هريرة رضي الله عنــه، عن رسول الله صلى الله عليه وسلم، تخالف تلك الروايات السابقة مــن حيــث أنها تجعل الخلق في الأيام السبعة، وتجعل البداية في الخلق من يوم الســبت، وكأنها تخالف ما يراه اليهود من أن السبت كان يوم الاستراحة للرب (حاثاه)، وذلك ليتوافق مع معتقداتهم في يوم السبت وأنه عيد لا يعملون فيه شيئًا، كمــا ويتوافق مع الروايات الأخرى بأن يوم الجمعة خلــق الله فيـــه آدم فــي آخـــر ساعات ذلك اليوم من العصر إلى الليل. و الرواية بتمامها هي:

"عن أبي هريرة رضي الله عنه قال: أخذ رســول الله صــلى الله عليــهـ وسلم بيدي، فقال: خلق الله التربة يوم السبت، وخلق فيهــا الجبــال يــوم الأحد، وخلق الشجر يوم الإثنين، وخلق المكروه يوم الثالاثاء، وخلق النــور يوم الأربعاء، وبث فيها الدواب يوم الخميس، وخلق آدم بعد العصر من يوم الجمعة في آخر الخلق في آخر سـاعة من ساعات الجمعة فيما بين العصــر

$$
\text { إلى الليل“، (r). }
$$

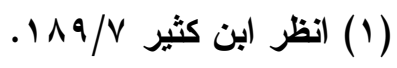

(Y) مسلم، صحيح مسلم، كتاب صفة القيامة، باب ابتـــاء الخـــق وخلــق آدم، رقــم

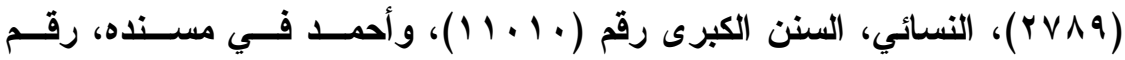


وقد علل البخاري هذا الحديث من التاريخ الكبير فقال: رواه بعضهم عن

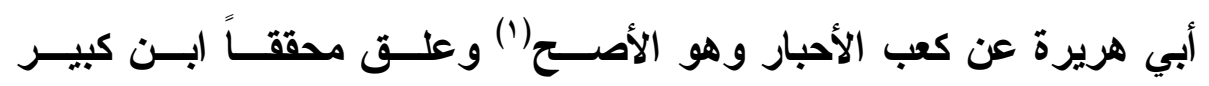
الأرناؤوط والحسن بأن الحديث معلول من جهة الإسناد، فقيه أيوب بن خالا وقد ليّنه ابن حجر في التقريب، ومن جهة المتن فقيه عزابة شديدة إذ ليس فيه خلق السموات، وفيه خلق الأرض وما فيها في سبعة أيام، وهذا خلاف القرآن إذ أن فيه أن الله خلق الأرض في أربعة أيام وخلق السموات السبع في يومين(r)

وقد علق صاحب المنار على هذه الروايات والأخبار بما فيهـــا روايــة مسلم بقوله: "وقد ورد في الأخبار والآثار (...) وفي حديث أخرجه أحمـــ في مسنده، ومسلم في صحيحه عن أبي هريرة (... وذكر الحــديث) وهـــا ظاهر في أن الخلق كان جزافاً ودفعة واحدة لكل نوع في يوم من أيامنا هذه القصيرة. والجواب: ان كل ما روي في هذه المسألة من الأخبــار والآثـــار مأخوذة من الإسرائيليات لم يصح فيها حديث مرفوع. وحديث أبي هريــرة هذا- وهو أقواها- مردود بمخالفة متنه لنص كتاب الله. وأما ســـده؛ فــلا يغرنك رواية مسلم له به؛ فهو قـ رواه كغيره عن حجاج بن محمد الأعــور المصيص عن ابن جُريج، وهو قد تغير في آخر عمره، وثبث أنه حدّث بعد اختلاط عقله، كما في تهذيب التهذيب وغيره (...) وفيه اسـتيعاب الأيــام

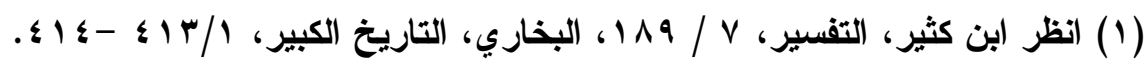

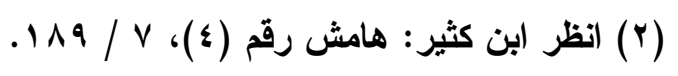

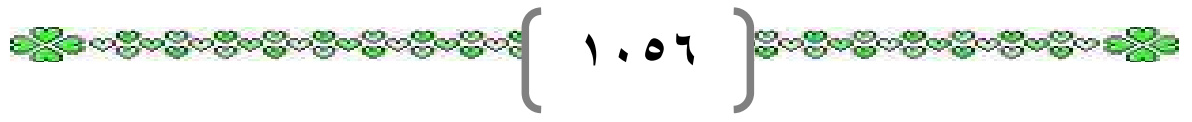




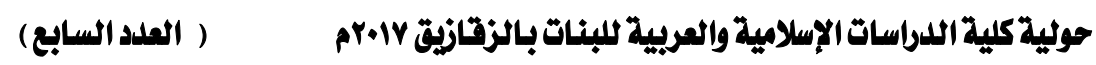

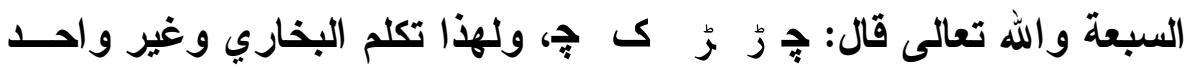
من الحفاظ في هذا الحديث وجعلوه من رواية أبي هريرة عن كعب الأحبـار

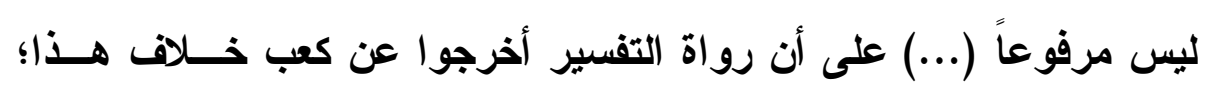
كرواية ابن أبي شيبة عنه وأنه قال: بدأ الله بخلق السموات والأرض يــوم الأحد والإثنين والثلاثاء والأربعاء و الخميس و الجمعة، وجعل كل يوم ألــف

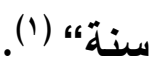

(1) رضا، محمد رشيد، تفسير المناز، طبعة الهيئة المصرية العامة للكتاب، القــاهرة،

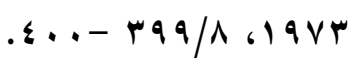

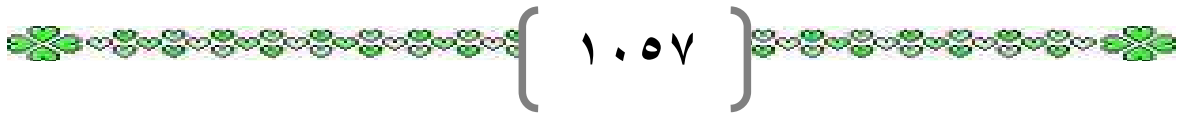




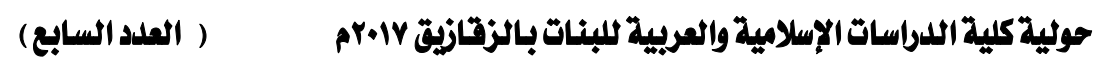

\section{المطالب الثالث:}

\section{الآثار العقدية المترتية على هخه الروايات:}

وبعد استعر اض تلك الروايات يمكننا تسجيل الملاحظات الآتية عليها بما قد يكون له علاقة بالاعتقاد، ولما لا تضر معلوماته بالاعتقاد مما لا يخالف العقيدة ولا النصوص القرآنية، ولكنه تفصيل لا يحتاج إليه، وهو يقع ممــا يروى عن بني إسرائيل مما لا نُصدقه ولا نكذبه. 1. هناك رواية للبخاري وان كانت معلقة ثم وصلها البخــاري نفســه ووصلها الطبري في تفسير خلق الأرض قبل السموات، وأن الله تعالى خلق الأرض وقرّ فيها أقواتها في أربعة أيام، فسّواهن سبع سموات في يــومين فتكون الأيام ستة كما في القرآن الكريم، وهو تفسير لمجموعة من الآيــات كما ورد في التفسير. فمثل هذا لا غبار عليه وليس فيه آثار من روايات الإسر ائيليات. r. وأمـا روايات ذكر الأيام وأسمائها وترتيبها وخلق الله في كـلـل يــوم شيئًا أو أشياء محددة فهو مزيل من التفصيل: الله أعلم به، لا نصــدقه ولا نكذبه طالما ليس يخالف القرآن، وليس فيه مما يضر الاعتقاد في الله وفي أسمائه وصفاته، ولا بسائر أركان الإيمان.

r. وأما ما يتعلق بما يريد أن يصل اليهود إليه من الروايات التي تذكر

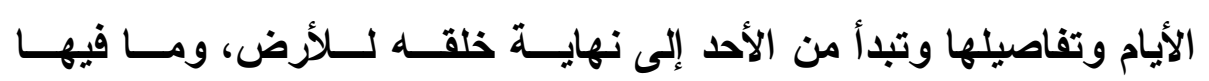
وللسموات ومـا فيها، فهو مما يسيء لربنا سبحانه وتعالى؛ لأنها تتسب لـــه

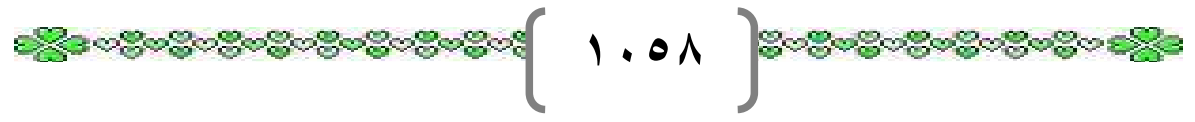


سبحانه التعب والإعياء والإرهاق والحاجة إلى الراحة في اليوم السابع وهو

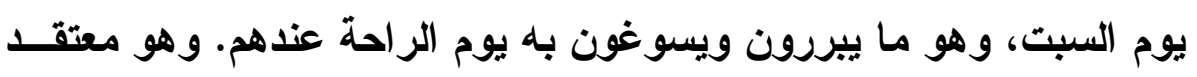
أخذوه عن غيرهم من الثعوب والأديان والنبوة ووضعوه في التوراة. ـ. وجميع الروايات الإسرائيلية التي تتحدث عن تفاصيل الأيام الســتة وتشميتها وما خلق الله في كل يوم هي روايات موافقه لســفر التكــوين (') حيث جاء في الإصحاح الأول: أن الله خلق السموات والأرض في ستة أيام،

(1) وهو السفر الأول من أسفار العهد القديم -التوراة كما يزعم اليهود - وهو السفر الذي يتحدث عن نثأة الكون ونثأة الإسان وخلق آدم إلى وفاة يعقوب ويوسـف

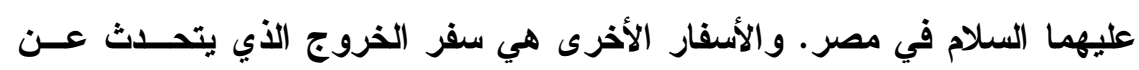
اضطهاد بني إسرائيل في مصر وخروجهم مع موسى إلى الأرض المقسة. وسفر

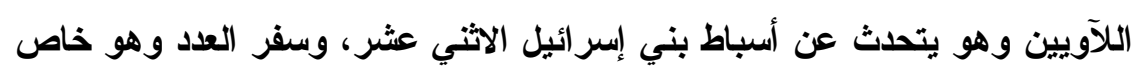

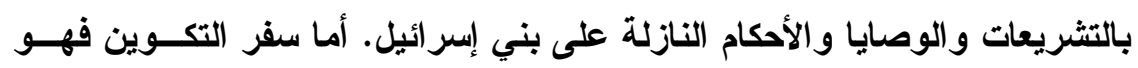
مؤلف من خمسين إصحاحاً أي فصلاً، وكل إصحاح مكوَّن من فقرة أو جملة صغيرة أو فقرات ولها رقم خاص. وهو يقوم - بعد تدخل الأحبار في كتابته - لأجله على هن فكرة عنصرية إسرائيلية استعلائية لشعب الله المختار، الذي يجري كل شيء فــي

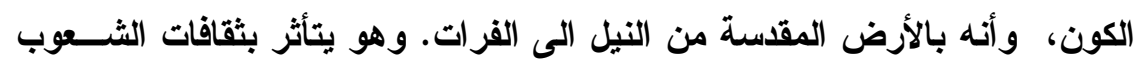

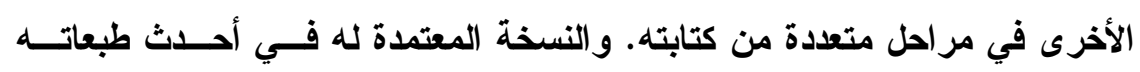

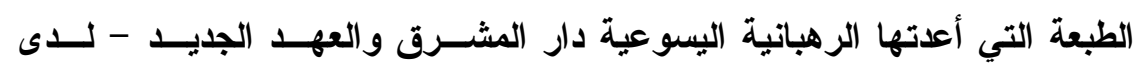

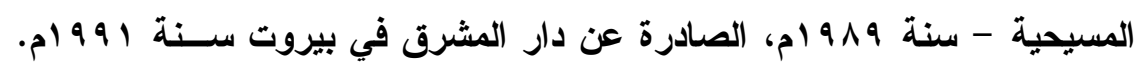
انظر التعريف بهذا السفر، الخالدي، صلاح عبد الفتاح، سفر التكوين فــي ميـزان

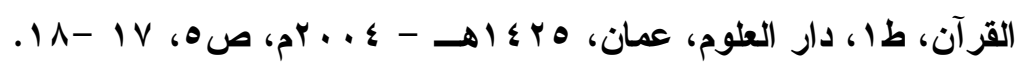

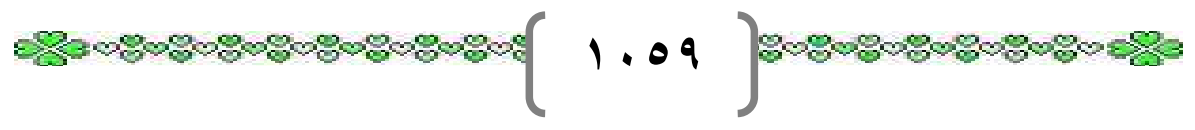


وفي يوم الأحد خلق الليل والنهار، والظلمات والنور، وفي يوم الإنثين خلق الله السماء التي هي جَلَّ فوقها ماء وتحتها ماء، وفي يوم الثلاثاء خلق الله الأرض بما فيها من بحار وأثجار وزروع وثثمار، وفي يوم الأربعاء خلــق الله الشمس والقمر والكواكب، وفي يوم الخميس خلق الله الطيور، وفي يوم الجمعة خلق الله الحيوان والإنسان (1). وفي هذا التقسيم والترتيب خلاف واضح مع القرآن الكريم الأي جعـل خلق الأرض وما فيها في أربعة أيام، وخلق الســموات فــي يــومين، دون الاشارة إلى تسمية الأيام وتفصيل الخلق فيها. كما أن تسمية هذه الأيام وأيام الأسبوع المعروفة لا يمكن الجزم بــه؛ لأن اليوم عند الله له أكثر من معنى، فأيام الله فيها ما يقدر بألف سنة مما يُعَدّ مسن أيامنا وسنواتنا، ويوم من أيامه كخمسين ألف سنة. وكأن الذي كان يشخل اليهود في روايات أهل الكتاب- الإسر ائيليات- أن يثبتوا أن خلق الله للسموات والأرض ومخلوقاته في ستة أيام محددة بأيــام الأسبوع المعروفة من الأحد إلى الجمعة، وأن اليوم السابع هو يوم السبت، وقد استراح فيه الخالق - حاثـاه - من الارهاق والعناء والتعب، ليسوغوا

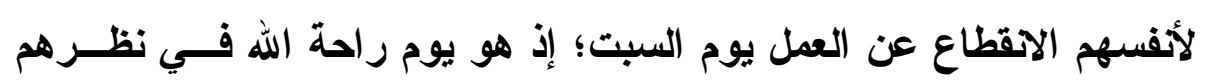

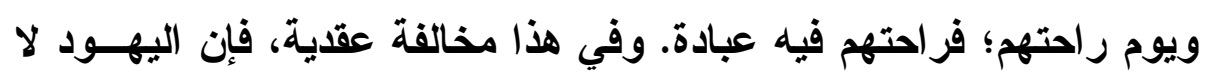
يقدرون الله حق قدره، ولا يعظمونه، ويجعلون من أفعاله ما يرضي شــعبه

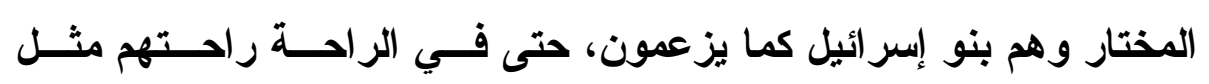

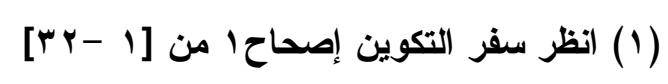




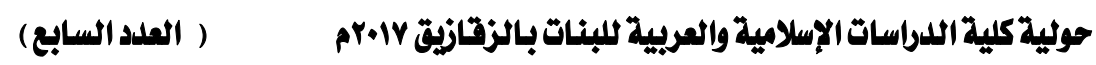

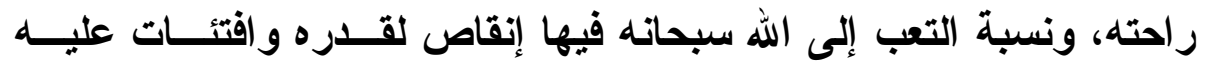
وسوء أدب معه وكفر به.

إذ لا مانـع أن تكون الأيام الستة للخلق لا علاقة لها بأيـام الأسبوع، بـلـل هي مر احل زمنيّة، الله أعلم بمدتها.

ه. ولعل روايات أهل الكتاب الإسر ائيلية عن اليوم السابع وهو الســبث

أو يوم الر احة هي ما أر ادث الرواية الإسر ائيلية أن تمهّد لـهه فـي تفسـير استواء الله على العرش بعد خلقه الأرض والسموات في ستة أيسام. ولهـــاذ فيما أورده ابن كثير (1) من رواية ابن عباس، وفيمــا ذكرهــا (بـن جريـر الطبري التي قال فيها اليهود: قد أصبت بـا محمد لو أتمدــث. قــالوا: ثــم استر اح. فغضب النبي صلى الله عليه وسلم غضباً شديداً فنزل قولـه تعالى:

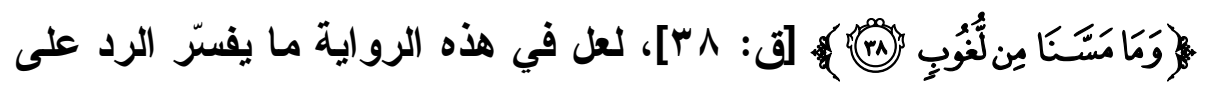
اليهود في ادعائهم أن يوم السبث هو الراحة لله بعد الخلق في الأيسام الستة السابقة.

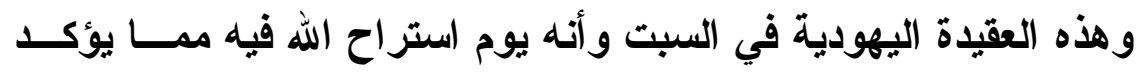
الروايات الإسرائيلية في كتب التفسير موجودة في العهد القديم فـي سـفر التكوين في الإصحاح الثاني منه: \}وهذا أُكملت السموات والأرض وجميـع أقواتها (...) وانتهى الله في اليوم السابع من عمله الذي عمله، واســتراح في اليوم السابع من كل عمله الأي عمله، وبارت الله اليوم السابع وقــره؛

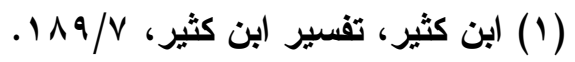

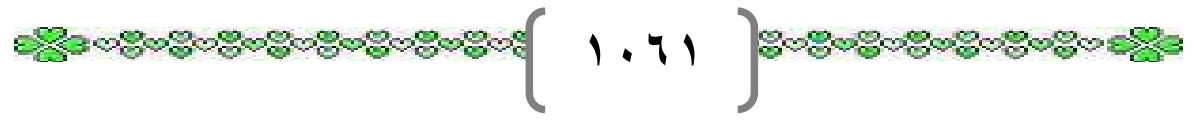


لأله استراح من كل عمله الذي عمله خالقاً|(1). وفي سفر الخروج أيضــاً: |ذكر يوم السبت لتقدسه في ستة أيام تعمل وتصنع أعمالك كلها، واليـوم السابع سبتُ للرب إلهك، فلا تصنع فيه عملاً (...) لأن الرب في ستة أيــام خلق السموات والأرض والبحر وكل ما فيها، وفي اليوم الســابع اســتراح. ولذلك بارك الرب يوم السبث وقسده|r) و \}قل لهم: احفظوا سبوتي خاصة؛ لأنها علامة تفصل تلك النفس من وسط شعبها (...) فليحفظ بنو إبــر ائيل السبت (...) فهو بيني وبين بني إسرائيل علامة أبديه؛ لأنه في ستة أيــام

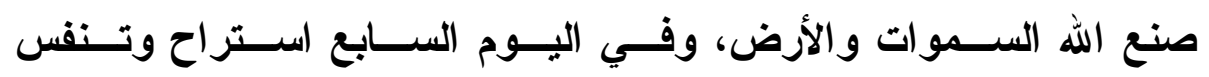
(الصعداع)

وقد أكد ابن حجر رواية عن الطبري من طريق قتادة، وهي: "أكذب الله جلا وعلا اليهود في زعمهم أنه اسـتراح في اليوم السابع فقال سـبـانه:

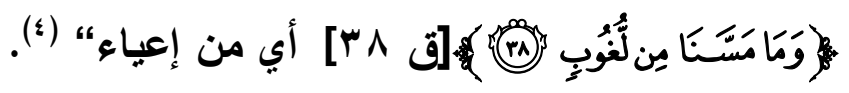

$$
\begin{aligned}
& \text { (1) التكوين ץ: [ [1 - (1)]. }
\end{aligned}
$$

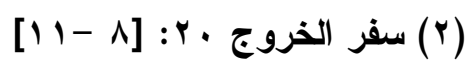

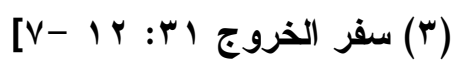

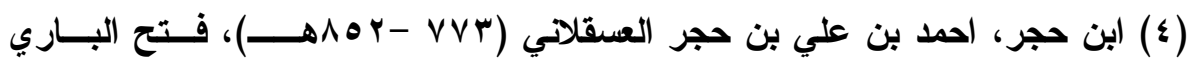
بشروح صحيح البخاري، ترقيم محمد فؤاد عبد الباقي، اخراج محب الدين الخطيب

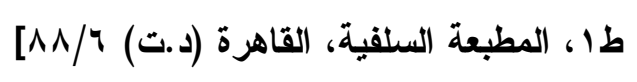


وذكر الصنعاني في تفسيره رواية فيها أنه ".. فرغ من الخلــق يـوم

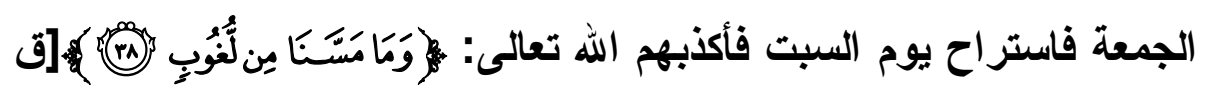
(') $[\mathrm{r} \Lambda$

7 ـ ولعمل في رواية مسلم وفيها أن الله بدأ خلق بعض الأثـــياء يــوم

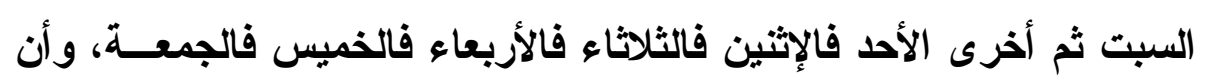
في آخر سـاعة في الجمعة كان خلق آدم عليه السلام، ما كان يُر اد به دفــع مفهوم الأيام الستة التي يتبعها اليوم السابع وهو يوم السبت للراحة. حيث تثبت هذه الرواية أن الله خلق يوم السبت أشياء، وفي ذلك ردّ اليهود اللأين يزعمون أنه تعب في الأيام الستة، واستراح يوم السبت - حاثـاه تعالى -. وهذه الرواية لم تشر إلى الأيام الستة المعروفة في القرآن، والتي فصّل فيها أن خلق الأرض وما فيها وما لها من خصائص كان في أربعـة أيسـام، وأن خلق السموات كان في يومين، وأنه استوى على العرش؛ لأن الإثـــارة إلى استوائه على العرش لا في يوم محدد وليس في اليوم السابع و إنما هذه الرواية - رواية مسلم - أثبتث أن الله خلق أثياء متعددة دون الالتزام بما هو في الأرض أو السماء في سبعة أيام ابتداء من يوم السبت إلــى آخــر ساعة في الجمعة. والرواية بهذا الفهم فيها ردّ على روايات بني إسرائيل التي تدّعي راحة يوم السبت لله سبحانه - حاثـاه - وفيها أيضاً إثبات لخلقه في جميع الأيام

(1) انظر الصنعاني، عبد الرزاق بن همام، تفسير عبد الرزاق بن همام الصنعاني، طا،

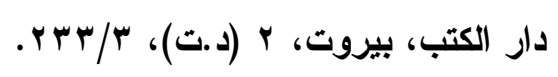




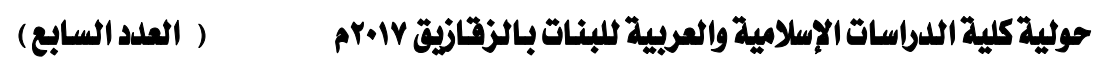

السبعة دون استراحة. وتفاصيل مـا فيها من الخلق لا يتعارض مـــع الأيــام الستة في القرآن التي خلق فيها الأرض وتوابعها في أربعــة أيسـام منهــا، وخلق السموات السبع في يومين، وأنه استوى على العرش دون الاشــارة إلى يوم سابع. وبهذا تتجو هذه الرواية - رواية مسلم - بهـــا الفهــم مــن نقــدها، ويكفيها من الإسناد - والله تعالى أعلم - أنها ثابتة بتصحيح الإمام مُســلم، وهو مَن هو في دقته في الحكم على الصحيح. 


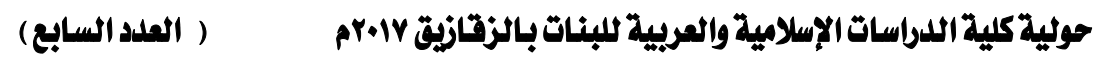

\section{الذاتمة}

توصل الباحث إلى النتائج الآتية:

ا ـ وجود الرواية الإسرائيلية واقع في كتب التفسير بالمأثور ولا بـ من

معالجته و إبعاد آثاره السلبية عن العقيدة.

r. لا بـ من تأكيد حكم التعاطي مع الرواية الإسر ائيلية بجدية واضحة،

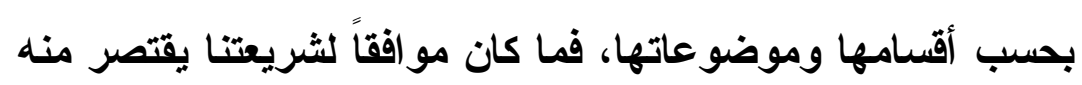
على ما يؤكد الحق الأي عندنا للعظة والاعتبار فحسب دون الاخول في التفاصيل، وما كان مخالفاً لشرعنا لا بـ من رفضه،، ومـــا جـــاء

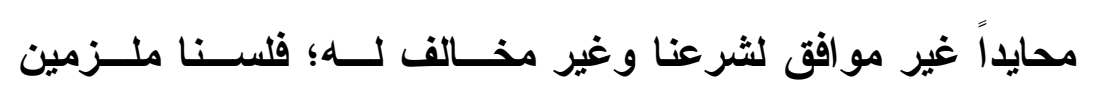
بروايته، كما أننا لسنا ملزمين بتصديقه أو تكذيبه.

r. لا يصح الاعتماد على شيء من الرواية الإسر ائيلية في مرحلة بناء التصور الإسلامي والتربية الإسلامية في محاضن التربية الأولى. ء. يقتصر في التعامل مع الرواية الإسرائيلية على العلماء مــن بـاب

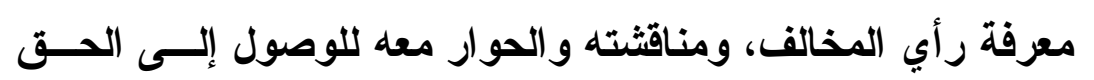

$$
\text { الأي جاء به دينتا. }
$$

ه. كثرت الروايات الإسر ائيلية في تفسير آيات خلق السموات والأرض وما فيهما مما كان له أثر سيء في عقيدة تنزيه الله فـي أســمائه (الحسنى وصفاته. 


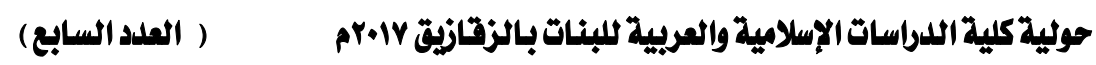

\section{التوصيات}

$$
\text { يوصي الباحث: }
$$

ا ـ بكتابة أبحاث ودراسات في الآثار العقدية للرواية الإسرائيلية بصفة

$$
\text { عامة في تفسير القرآن الكريم. }
$$

r ـ وبعمل بحوث ودراسات في قصص كل نبي من الأبياء والرسل بما

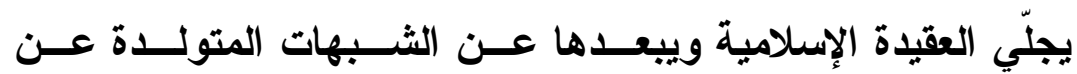
الإسر ائيليات في كتب التفسير.

r. وتنقية مر اجعنا الإسلامية من الرواية الإسر ائيلية حتى يتوقف إهدار الوقت والجها في قراعة الإســرائيليات وحتــى تصــفو مراجعنــا ومصادرنا في تفسير القرآن الكريم منها. والله تعالى الموفق وهو الهادي إلى سواء السبيل، وصــلى الله علـى سيدنا محمد النبي الأميّ وعلى آله وصحبه وسلم. 


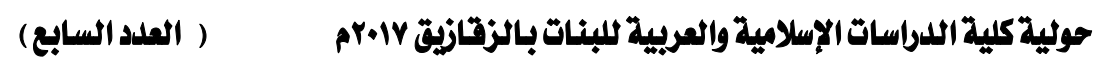

\section{قائمة المراجع}

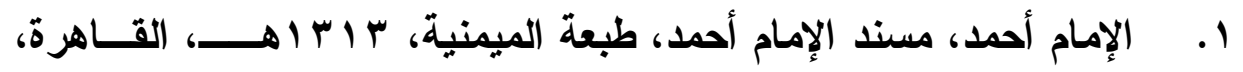

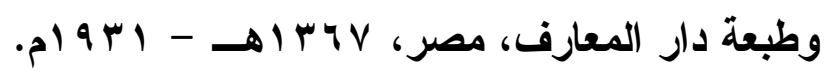

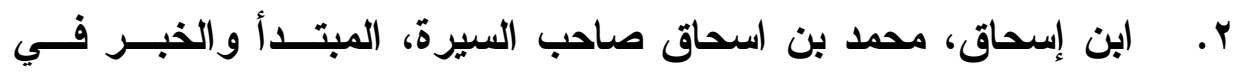
قصص الأبياء، جمع وتوثيق محمـــ كـريم الكــواز، طا، مؤسســـة

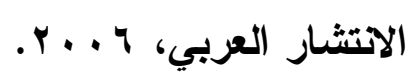

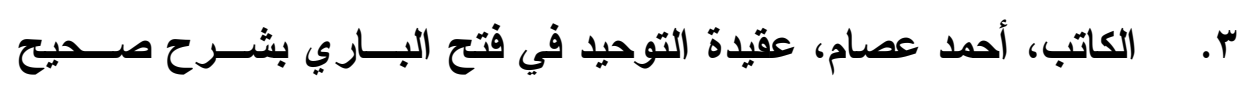

البخاري لابن العسقلاني، (د.ط) دار الآفاق الجديدة، بيروت، (د.ت).

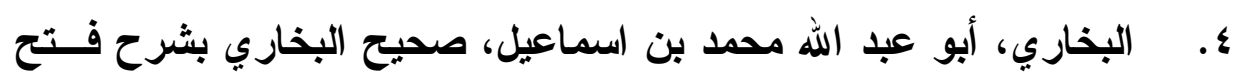

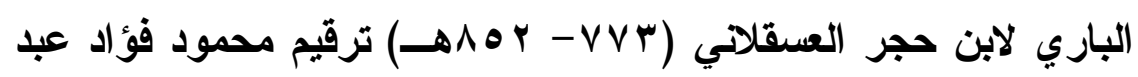

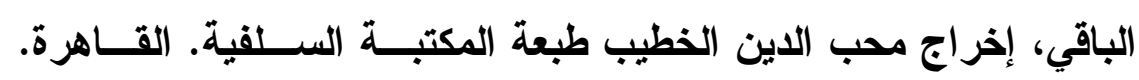
(ت.د)

ه. البيقهي، أبو بكر أحمد بن الحسين بـن علــي بــن موســى البيهزة

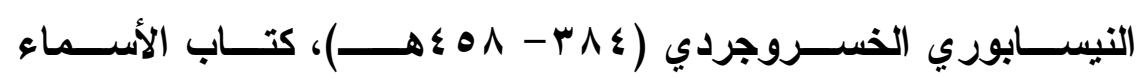

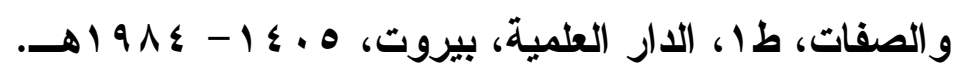
7. ابن تيمية، مقدمة في أصول التفسير. (د.ط) المطبعة السلفية، القاهرة، . V. ابن حجر: فتح الباري بشرح صحيح البخاري، إخــراج محسب الــدين الخطيب، الطبعة السلقية، القاهرة، (د.ت).

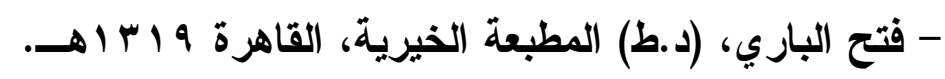

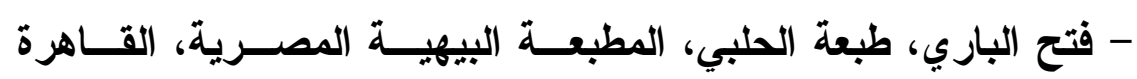
. $) ~ 9 \mu v$ 


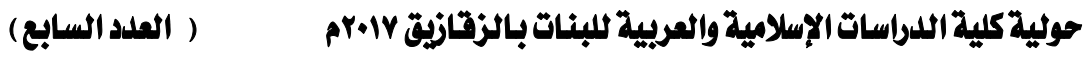

^. الخالدي، صلاح عبد القتاح، سفر التكوين في ميزان القــرآن، طا، دار

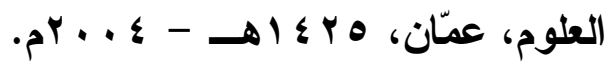

9 ـ ابن خلاون، مقدمة ابن خلــدون. (د.ط) دار البيــان العربــي، بيـروت

$$
\text { (د.د) }
$$

• 1 . الأهبي، محمد حسين، التفسير والمفسرون، طץ، مطبعة السعادة، القاهرة،

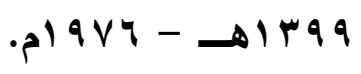

11. الرازي: الفخر الرازي، التفسير الكبير أو مفاتيح العنب، طا المطبعـة

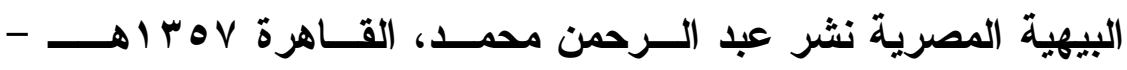

$$
\text { . }
$$

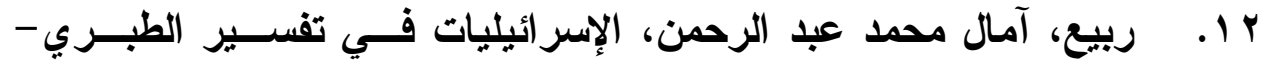

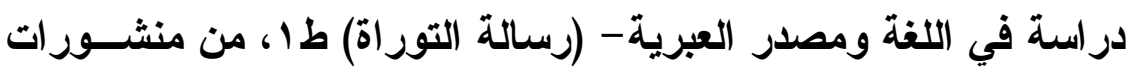
وزارة الأوقاف، المجلس الأعلى للشؤون الإسلامية، القاهرة، ه . . بم. r ا. رضا، محمد رشيد رضا، تفسير المنار، (د.ط) طبعة الهئـــة المصــرية الإسية

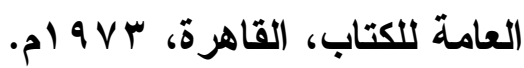

ـ 1 ـ الصنعاني، عبد الرزاق بن همام، تفسـير عبـــ الــرزاق بــن هـــام

$$
\text { الصنعاني، ط ال، دار الكتاب، بيروت (د.ت). }
$$

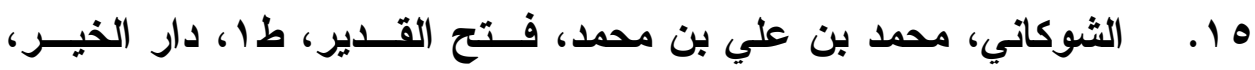

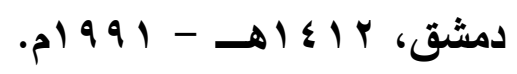

17 . ضيف الله، محمد الخضر بن الناجي، عصمة الأببياء، توزيــع رئاســة

$$
\text { المحاكم الثرعية، قطر، } 999 \text { ام. }
$$

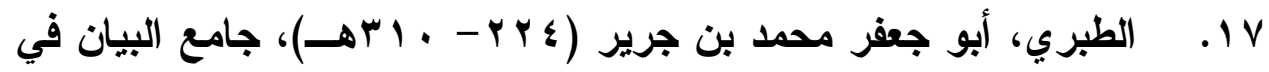
تفسير القرآن، تفسير الطبري - طب، طبعة معادة بالأوفست، عن الطبعة 


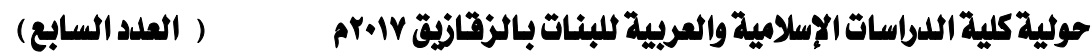

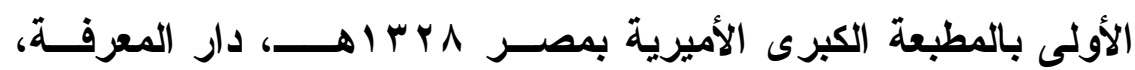

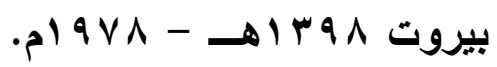

11. ابن عبد الله، أحمد نجيب الماليزي، الرواية الإســرائيلية فــي تفسـير

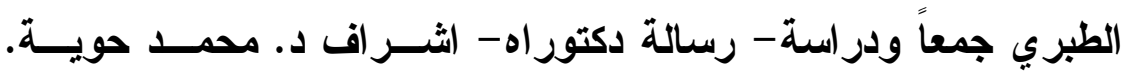

$$
\text { نوقشت }
$$

http://www.iu.edu.sa/arabic/daleel/r.../doctor/26.htm.

9 1. الطبري، تفسير الطبري، تحقيق محمود شاكر وأحمد شاكر، طبعـة دار

$$
\text { المعارف، مصر، (د.ت). }
$$

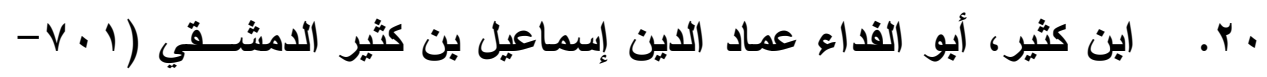

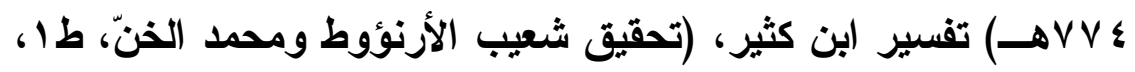

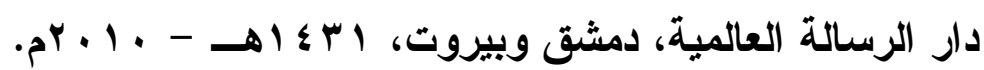
اYr. ابن كثير، قصص الأبياء، تحقيق سعيد اللحام، طبعة جديدة، دار مكتبة

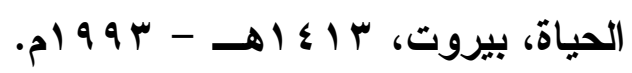

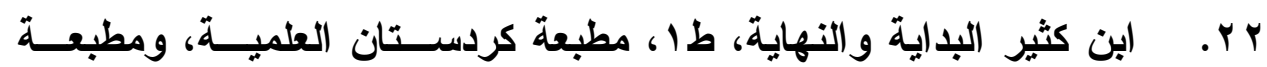

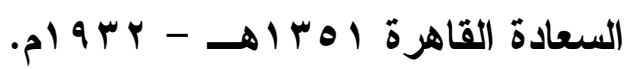

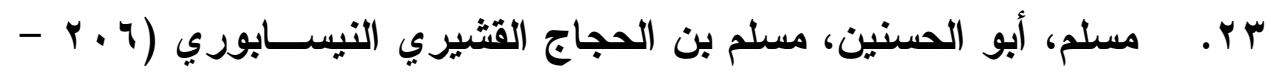
ا YY Pـ) صحيح مسلم، طا، دار (بن حزم، بيـروت، دار (الصــميعي،

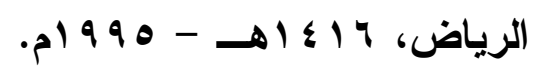

ع r. نعناعة، رمزي، الإسر ائيليات وأثرها في كتب التفسير، طا، دار العلـــم

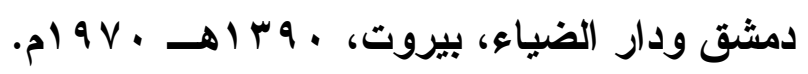




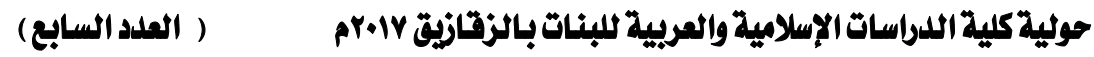

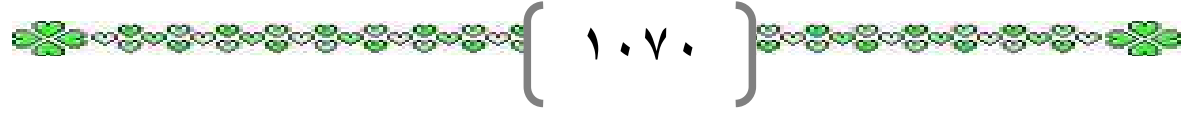




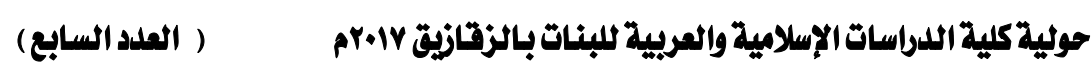

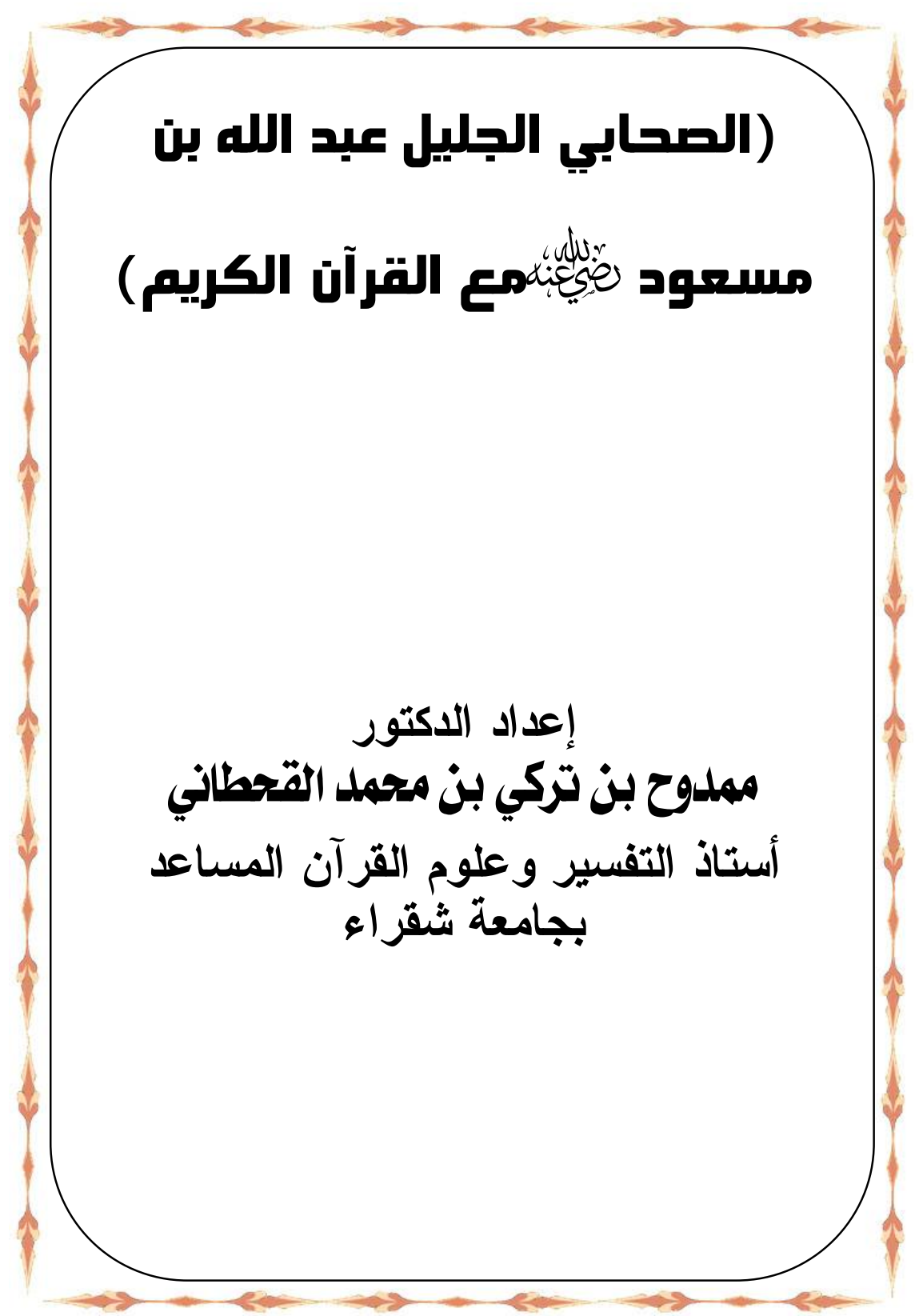




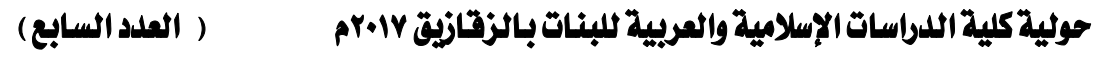

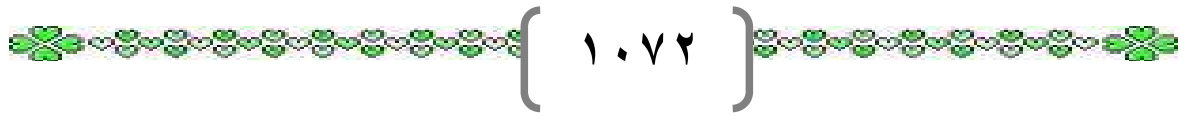




\section{مقلمة}

الحمد الله الذي نوَّر قلوب أهلِ القرآن بنورِ معرفته تتوير ا، وكسا وجوهَهَمَ من

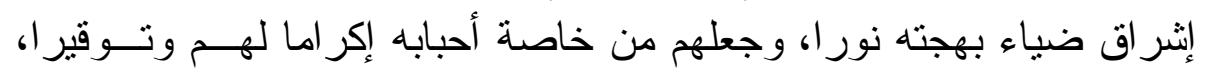

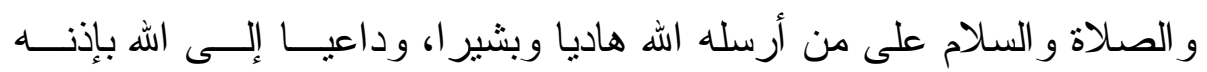

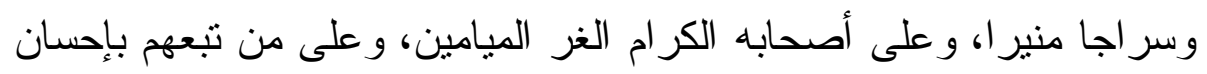
إلى يوم الجز اء و الدين.

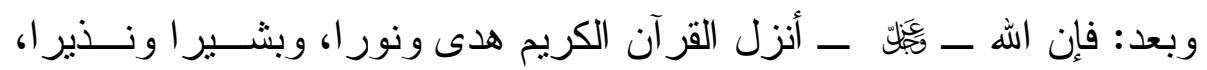
وسر اجا منير ا، وجعله أعظم كتبه المنزلة، وتولى حفظه وحماية من التحريف

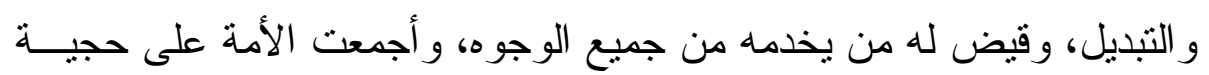

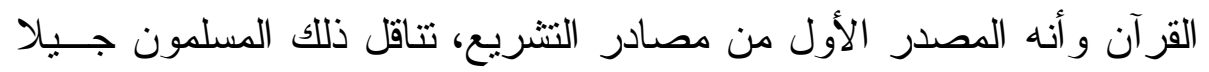
بعد جيل، ور عيلا بعد رعيل.

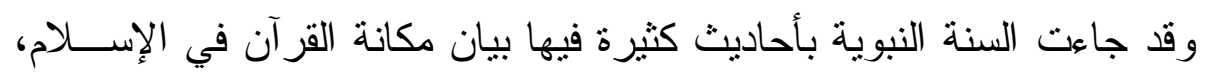

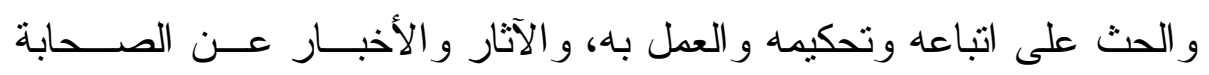

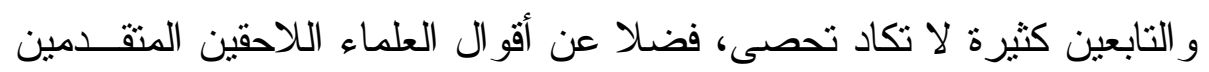
و المتأخرين.

و لأن المروي عن السلف الصالح كثثر صالح أحبيت أن يكون هـــا البحــث محصور ا في الحديث عن حبر من أحبار الأمة وعالم من علماء الصــــابة،

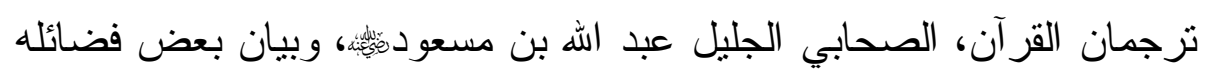

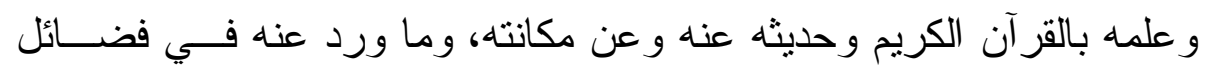

$$
\text { هاف البحث: آلن الكريم و أجر تناوته و اتباعه. }
$$

ا ـ إير از مكانة الصحابة رضي الله عنهم و علمهم بالقر آن الكريم. r. أهمية در اسة مناهج الصحابة في تعاملهم مع القر آن الكريم. r. معرفة حال ابن مسعود رضي الله عنه و علمه بالقر آن الكريم.

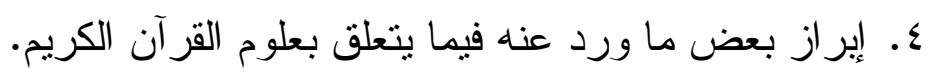




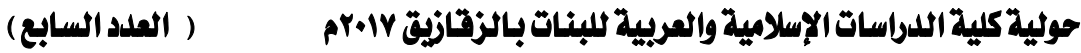

و أدرت الحديث في هذا البحث على مقدمة وثلاثة مباحث وخاتمة:

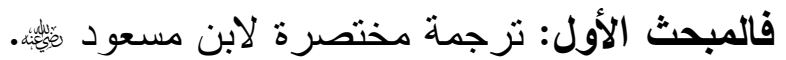

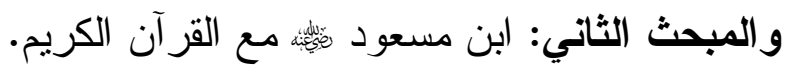

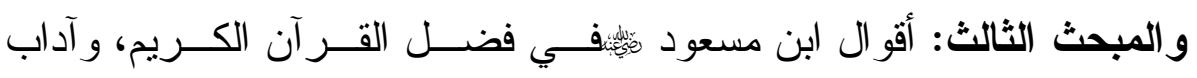
تلاوتنه.

الخاتمة وفيها النتائج و التوصيات.

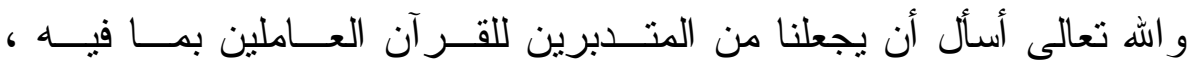

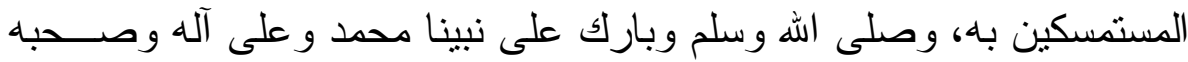

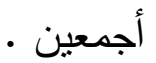




\section{الميصت الأول \\ ترجمة ايu مسمود}

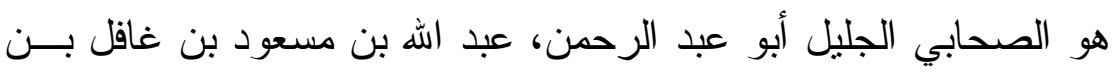

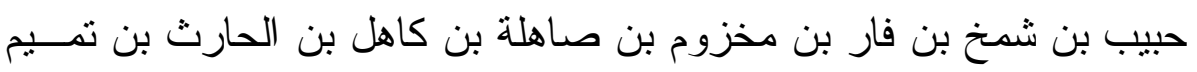

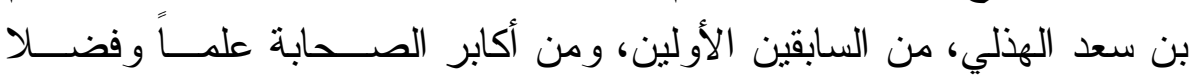

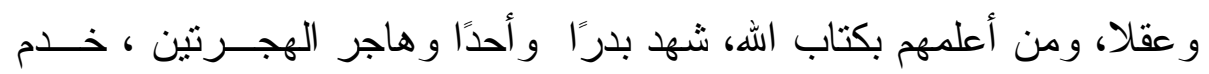

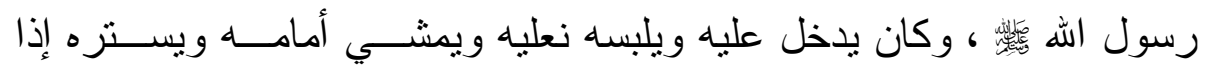

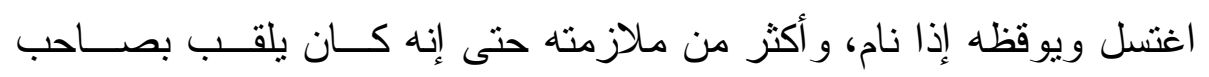

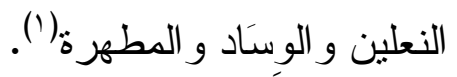

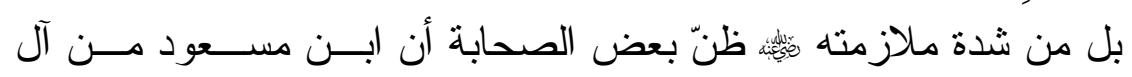

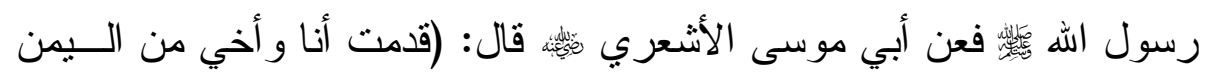

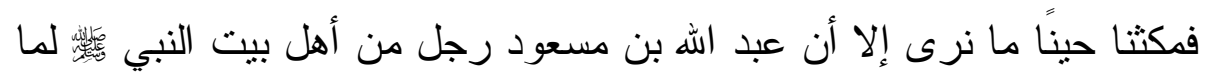

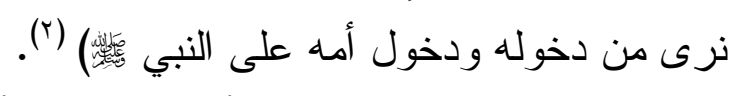
وذكر ابن مسعود عن نفسه أنه سادس من أسلم (r)، و وأمه هي: أم أم عبد بنت

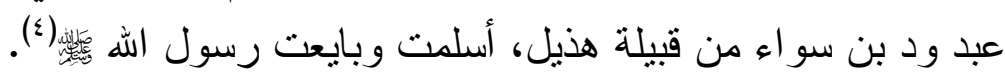

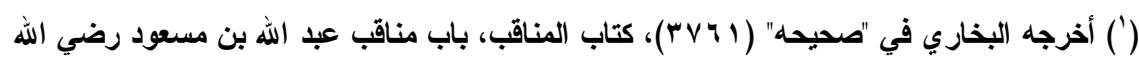

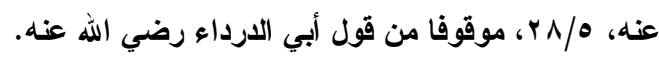

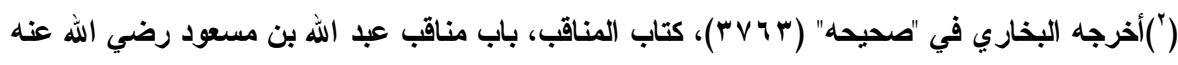

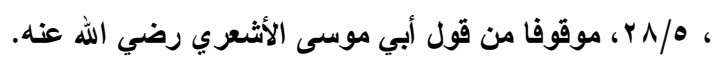

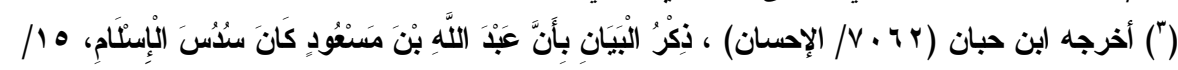

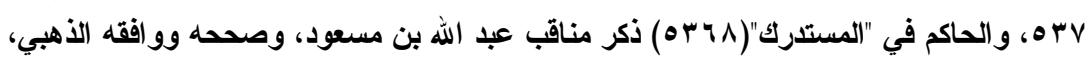

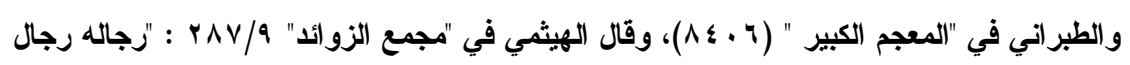

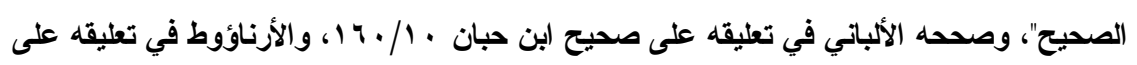

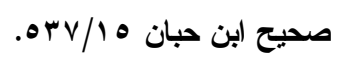

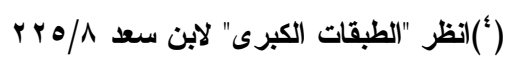

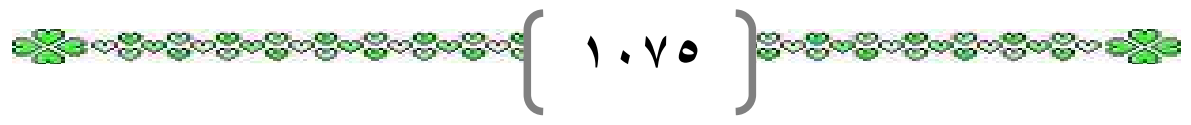


أرسله عمر بن الخطاب نِّئه: إلى الكوفة، فكان قاضيا متوليا لبيت المال فيهــا و معلما.

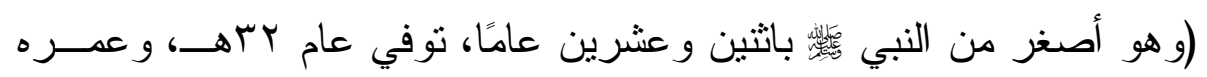

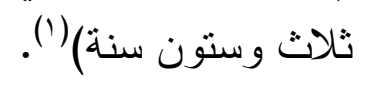

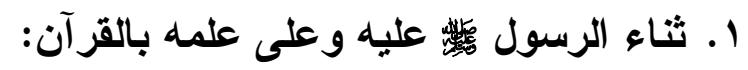

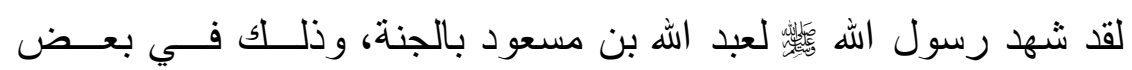
روايات حديث العشرة المبشرين بالجنة(؟).

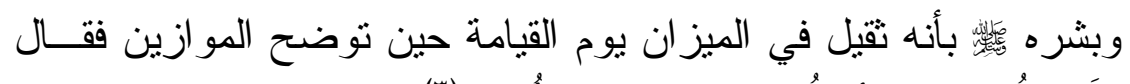

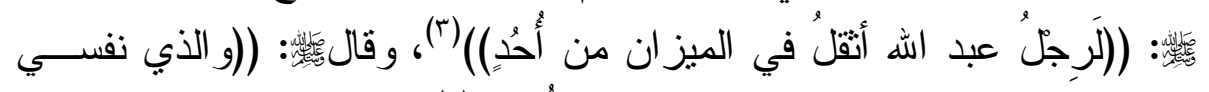

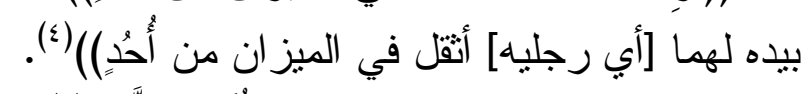

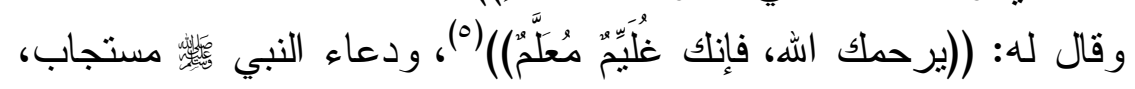
ومن رحمه الله أدخله الجنة، فهو من أهل الجنة استتباطا من هــــاء الحــديث فضلا عن غيره من الأحاديث.

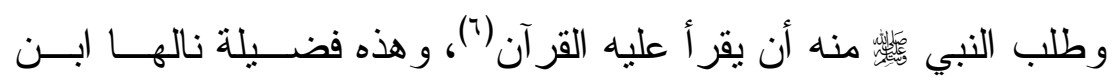

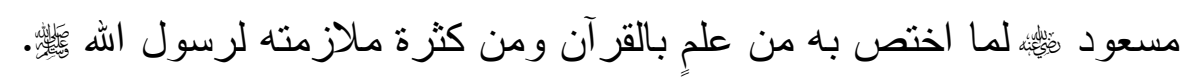

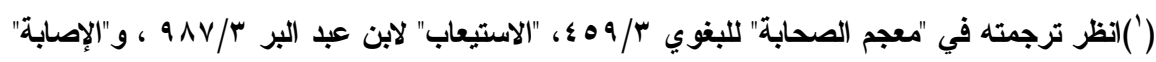

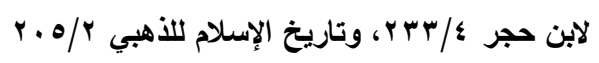

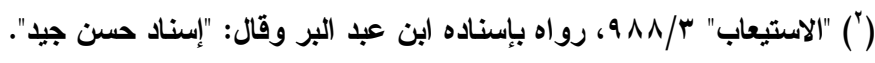

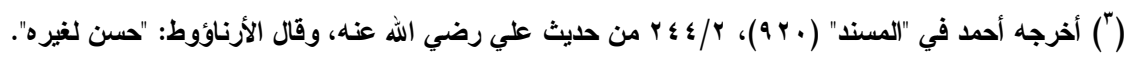

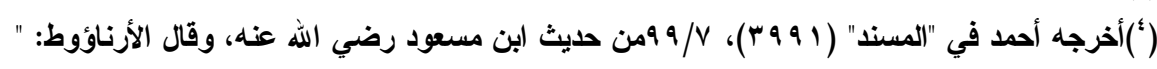
صحيح لغيره".

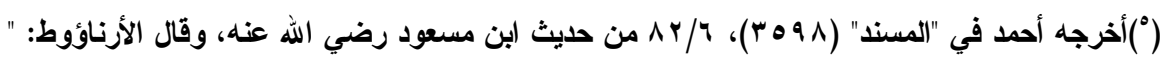
إسناده حسن".

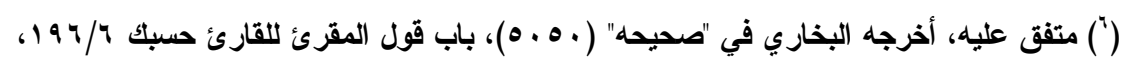

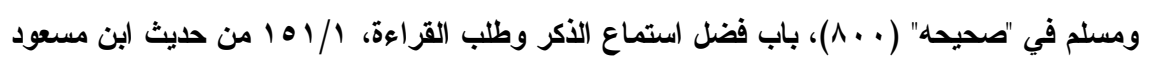
رضي الله عنه.

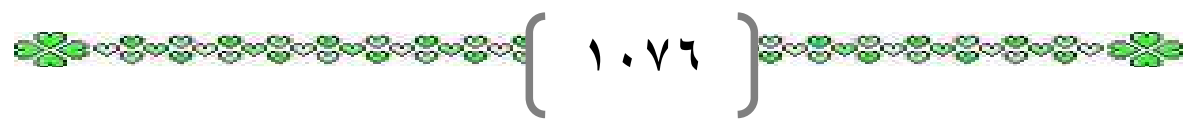


وقال)

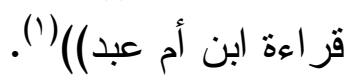

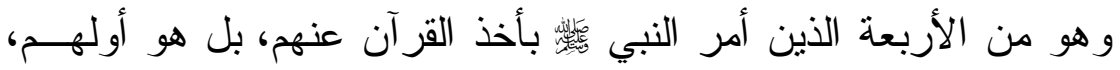

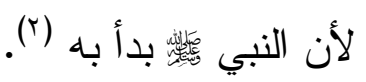

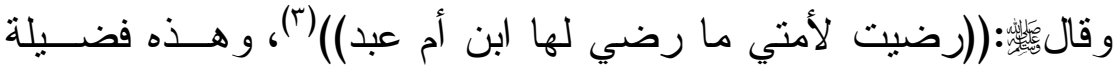

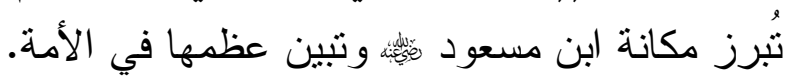

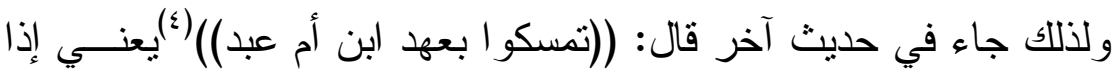

$$
\text { عهد إليكم عهدا. }
$$

وزكاه النبي صلى الله عليه وسلم بصدق حديثه فقــال صــلـى الله عليــه

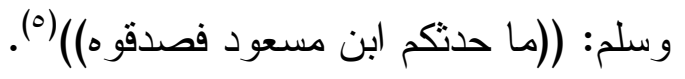

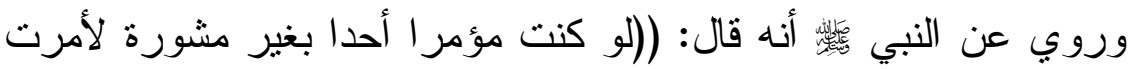

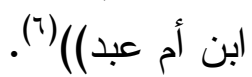

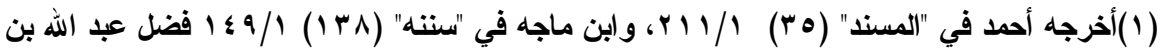

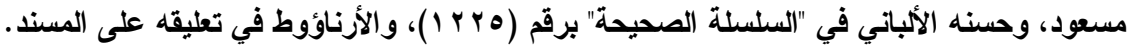

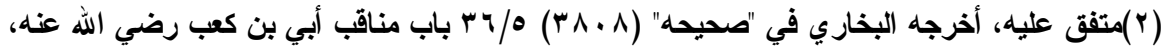

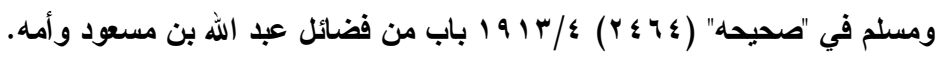

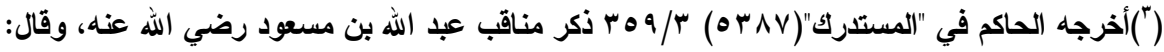

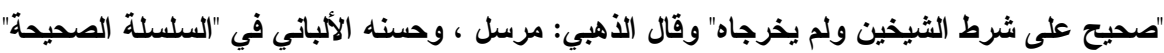

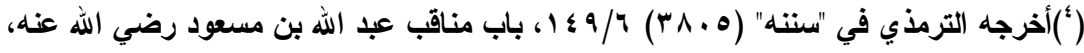

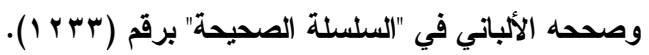

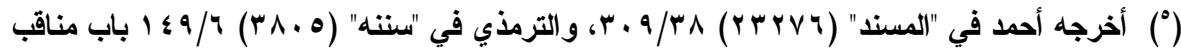

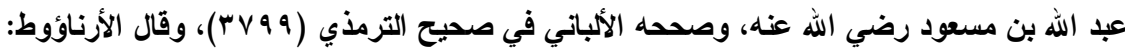
"حسن بطرقه وشو اهده"

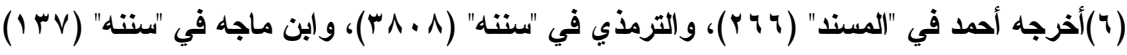

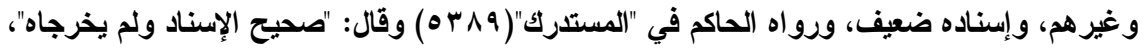
وفيه عاصم بن ضمرة، قال الذهبي في تلخيصه: "ضعيف"، ولكن وثقه ابن العديني والعجلي، انظر "تهذيب

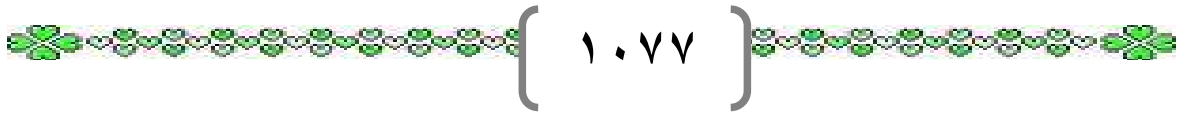




\section{r أثاء الصحابة عليه:}

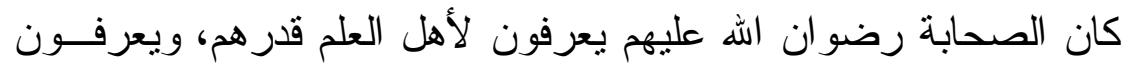

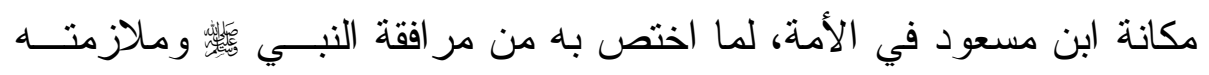

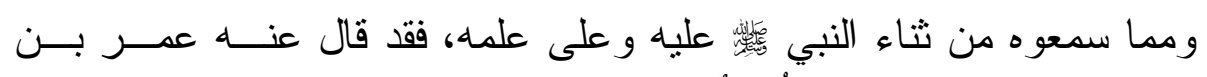

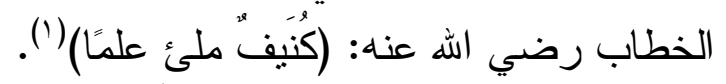

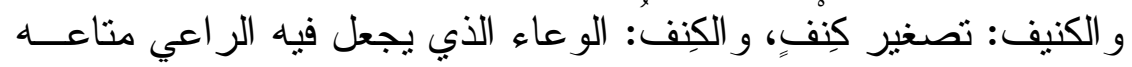

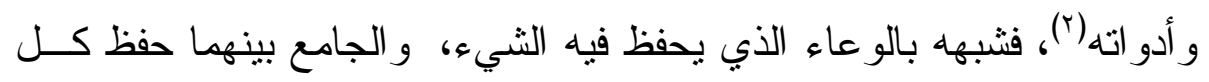

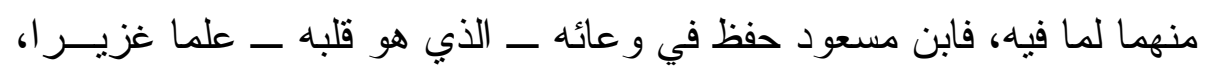

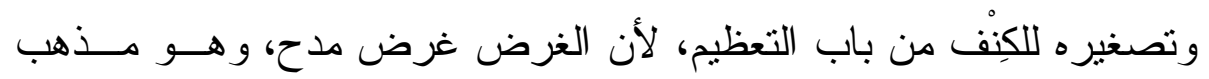

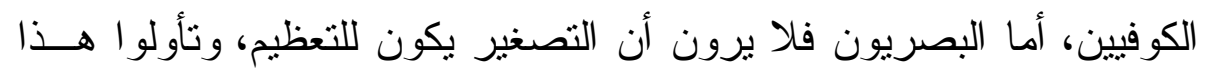

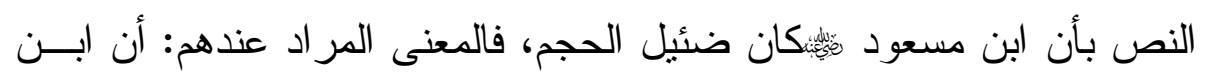

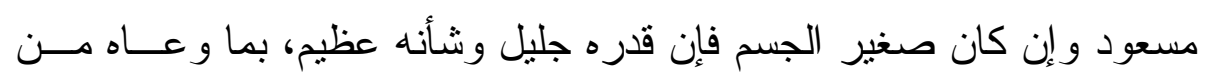
علمٍ للكتاب و السنة (َ).

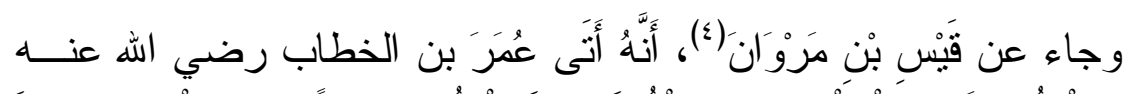

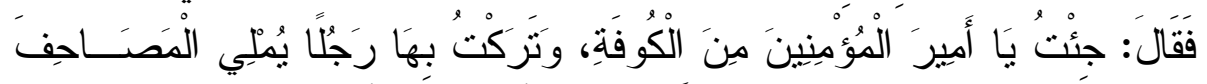

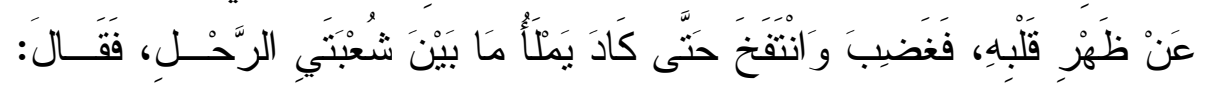

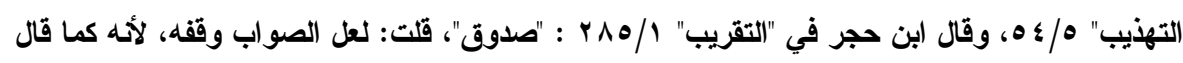

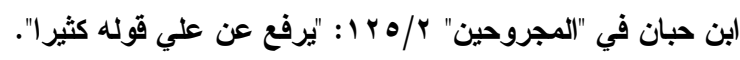

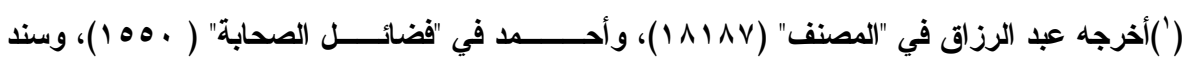

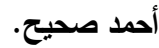

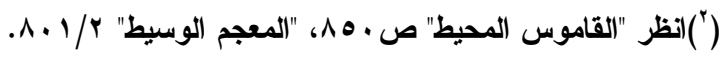

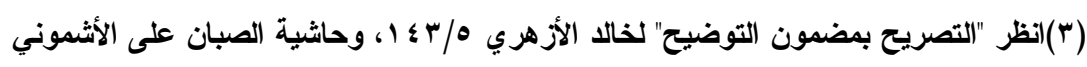
$17 r \wedge / \varepsilon$

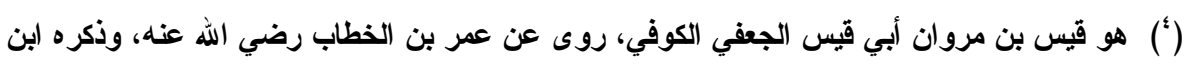

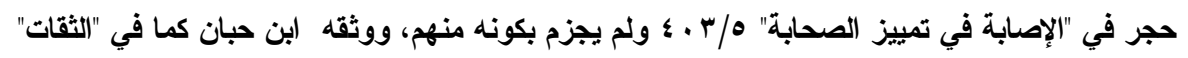

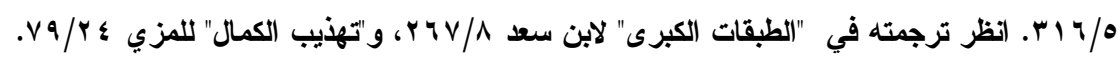

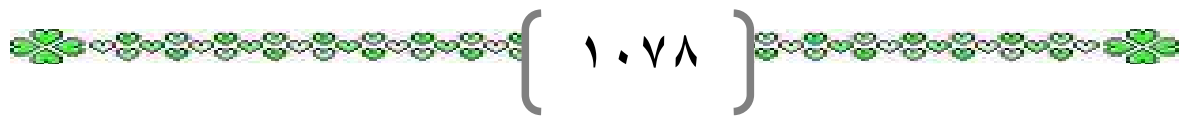




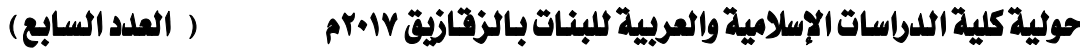

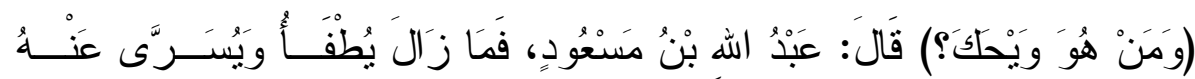

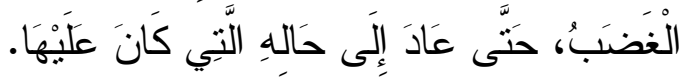

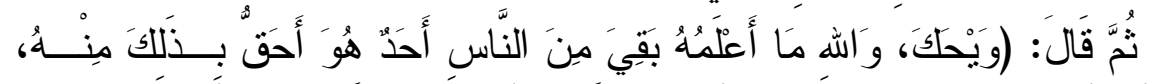

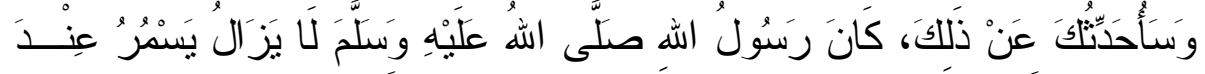

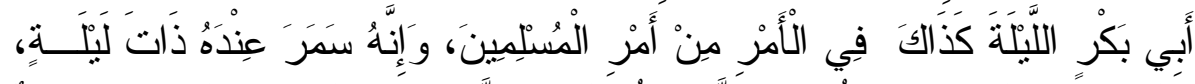

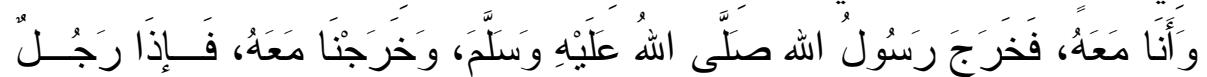

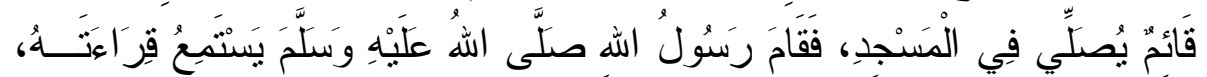

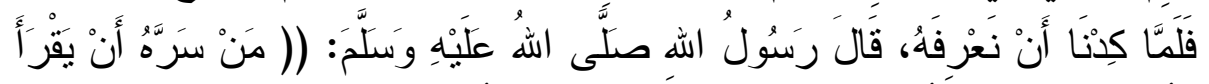

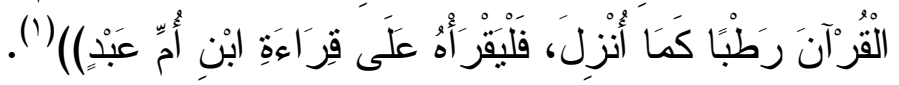
وهذه الرواية تفيا عدة أمور:

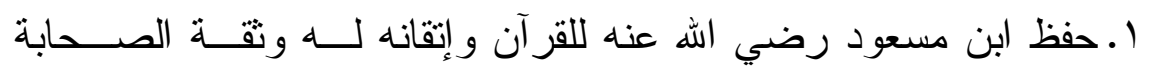
و التابعين بحفظه ورو ايته.

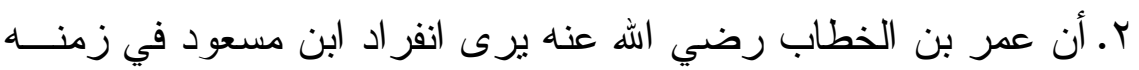

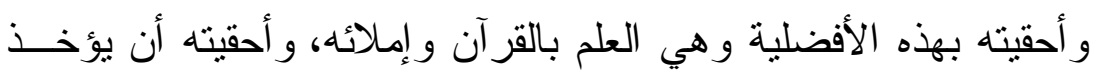
عنه هذا العلم.

r. استماع النبي صلى الله عليه وسلم لقر اعة ابن مسعود وثثاؤه عليه أمسام الصحابة رضي الله عنه.

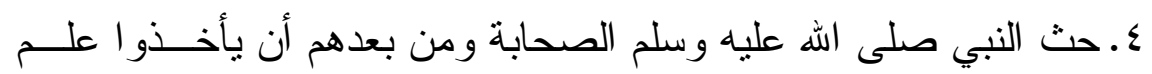
القر آن عن ابن مسعود، ونز كيته لقر اعته.

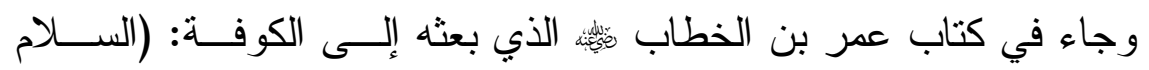

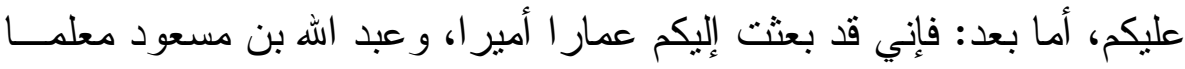

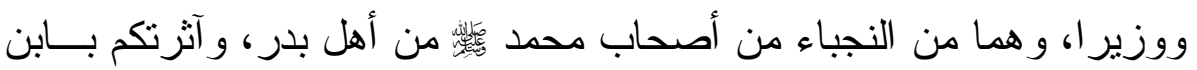

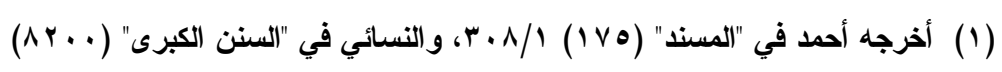

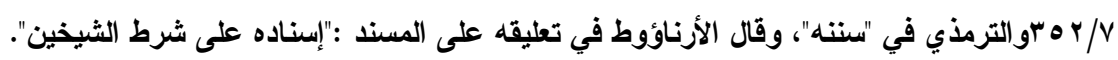

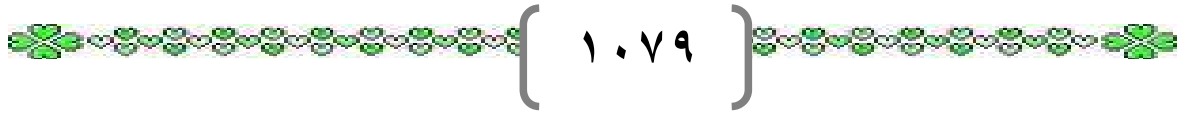


أم عبد على نفسي وجعلته على بيت مالكم)(")، وثتاء عمر على ابن مســود كثير مروي في الكتب الجو امع و المسانيد و المعاجم.

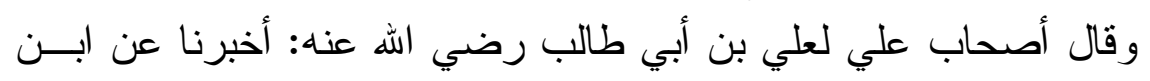

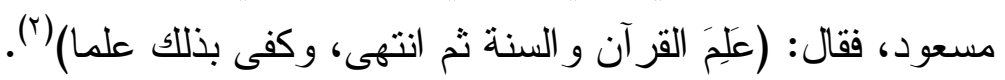

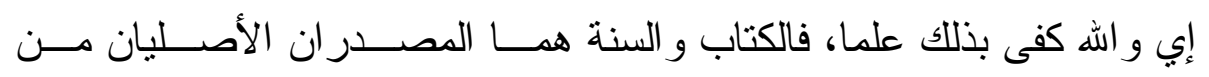

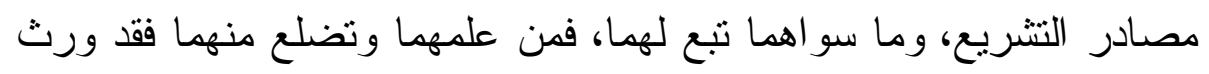

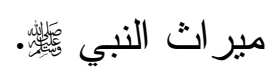

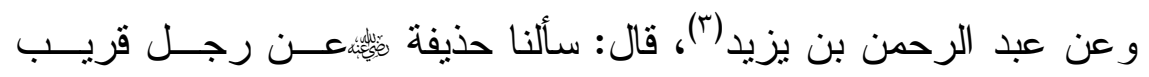

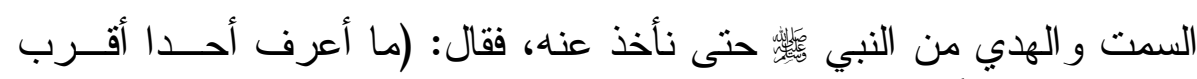

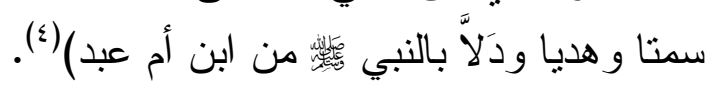
وقال حذيفة بن اليمان رضي الله عنه: (كان أقرب الناس هديا ودلَّا وسمتا

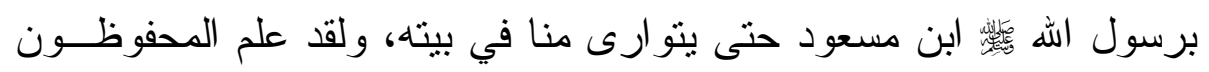

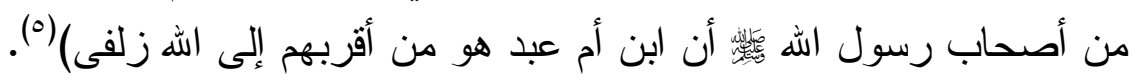

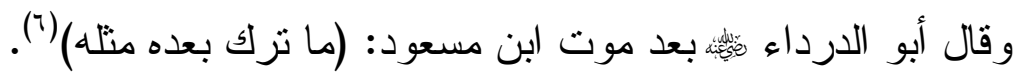

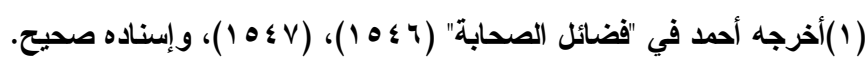

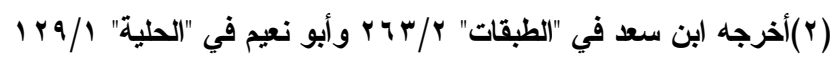

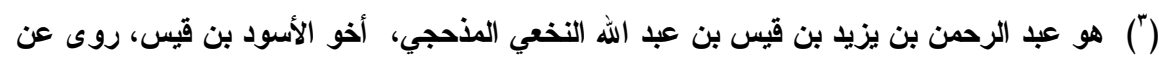

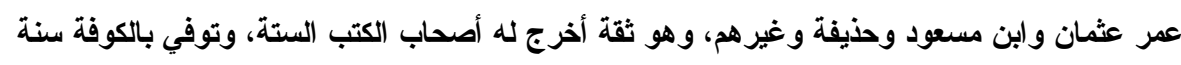

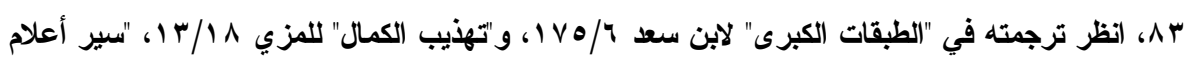

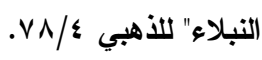

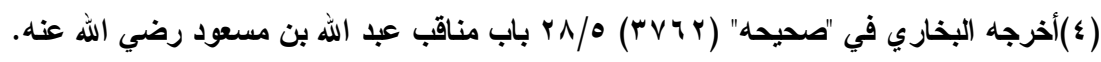

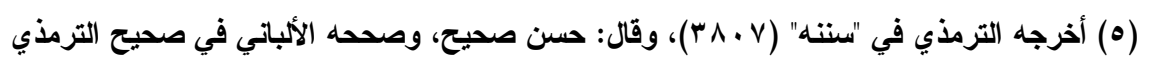
( $($ ( $) \cdot v)$

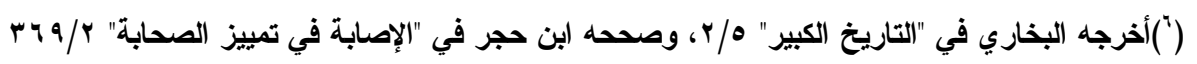

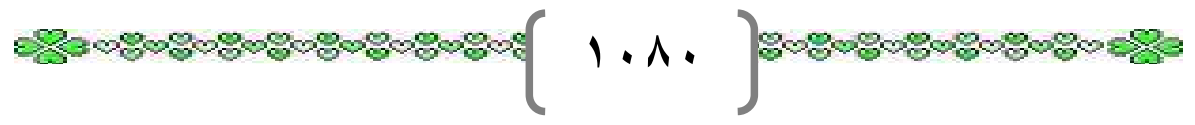


و عن أبي مسعود عقبة بن عمرو هِئم:قال : (ما أرى رجلا أعلم بما أنــزل الله

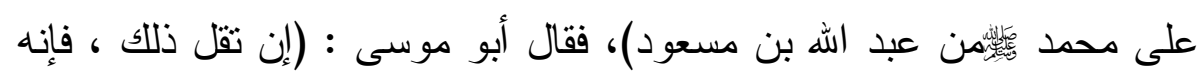
كان يسمع حين لا نسمع ويدخل حين لا ندخل) (').

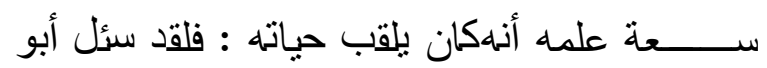

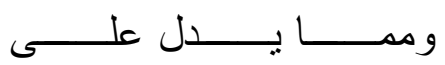

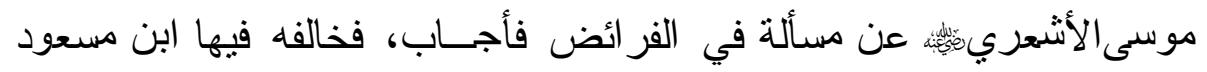
فقال أبو موسى: (لاتسألو احد مادام هذا البطل فيكم) (؟).

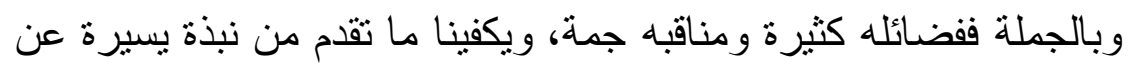

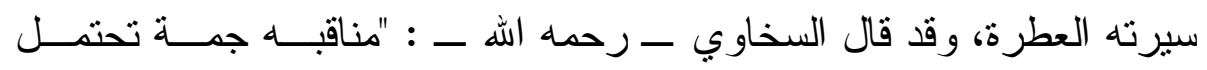

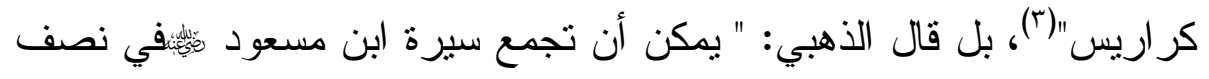
مجلد"(๕).

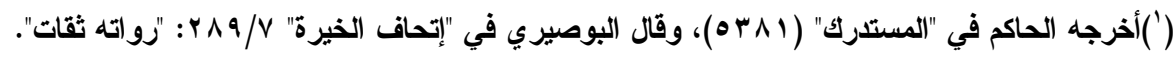

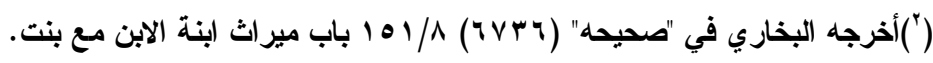

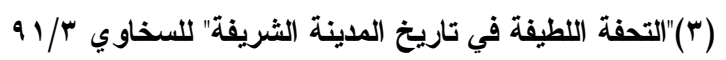

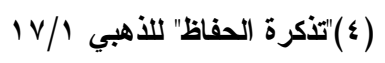




\section{المبصت الثاتي

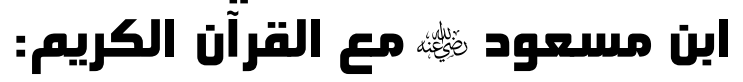

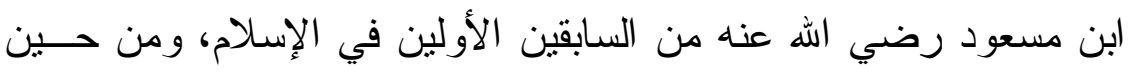

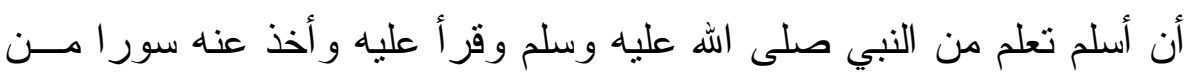

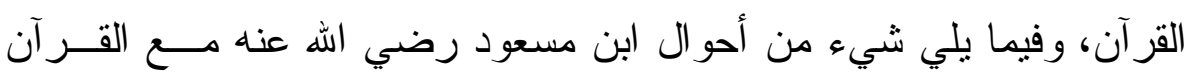
الكريم:

ا ـ قراعته وأخذه للقرآن من النبي

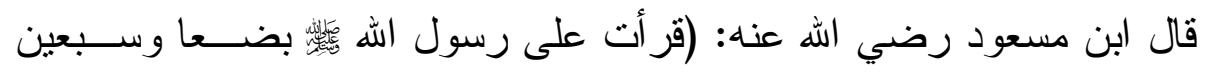

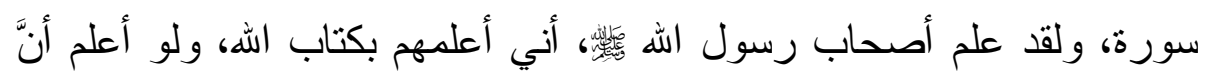
أحدا أعلم مني لرحلت ولمد إليه).

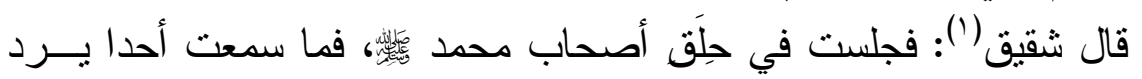
ذلك عليه، و لا يعيبه(؟)، وهذا إجماع سكوتي من أصحاب النبــي صـــلـى الله عليه وسلم. و إنما أثنبت لنفسه هذه السور من فم النبي

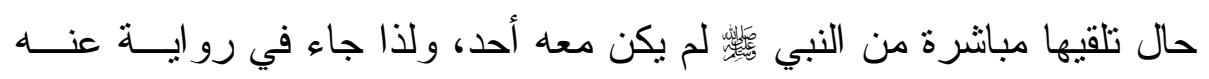

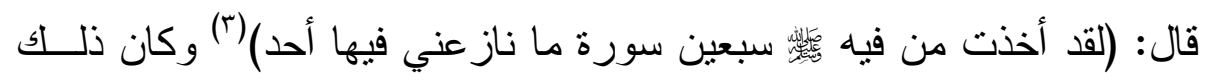

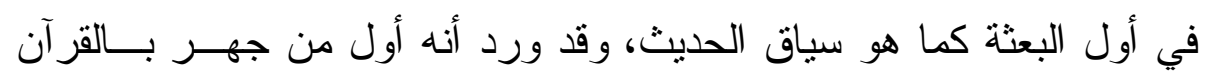

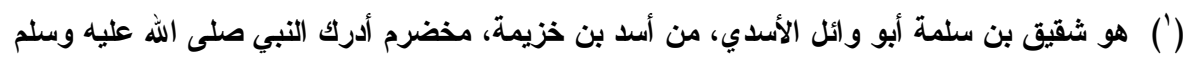

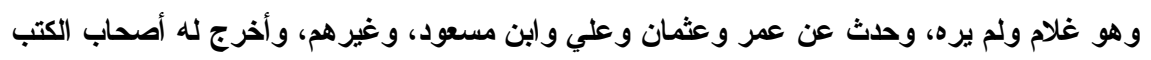

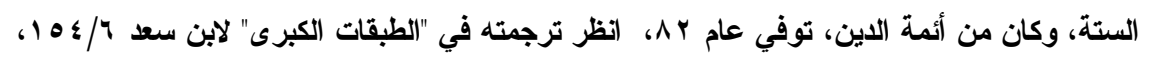

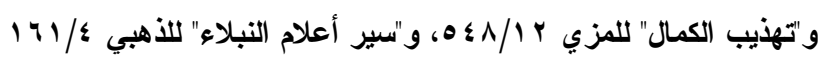

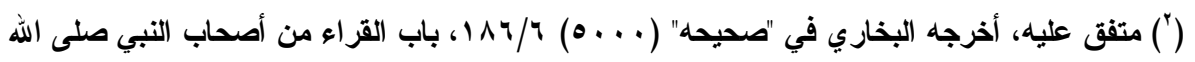

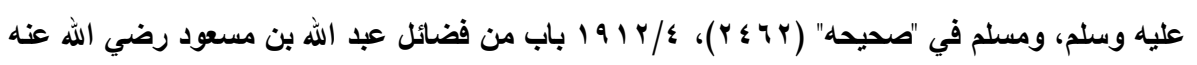
وأمه.

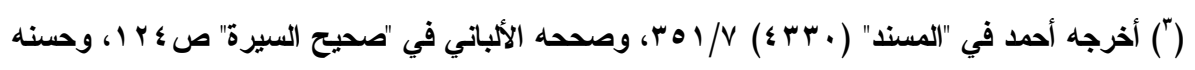
الأرناؤوط.

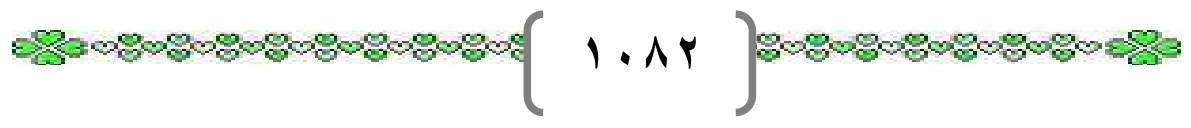




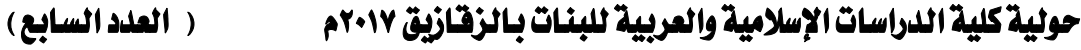

بمكة وأسمع المشركين القرآن مجاهر ا به، فناله منهم أذى(')، وهذا لا يعنـي تفرده بتلقي هذه السور عن النبي صلى الله عليه وسلم.

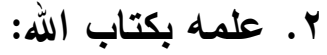

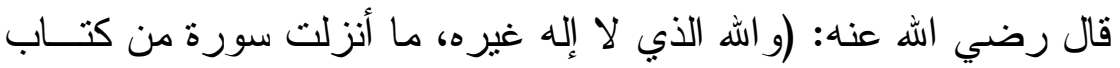

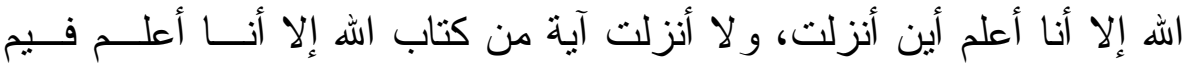
أنزلت، ولو أعلم أحدا أعلم مني بكتاب الله، تبلغه الإبل لركبت إلبه) (؟).

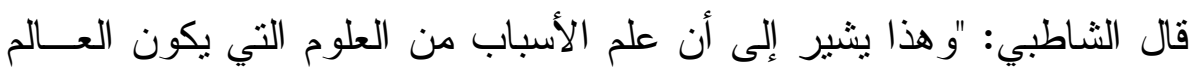

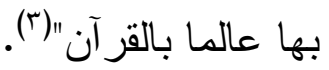

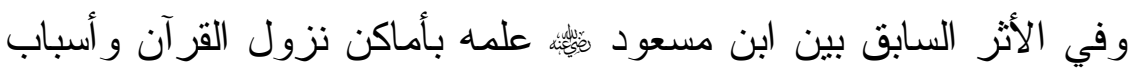
نزوله، وهو الذي ذكر الضابط الأغلبي المشهور في تمييز المكي من المدني

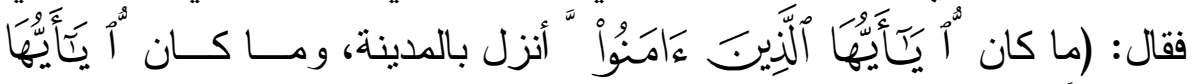

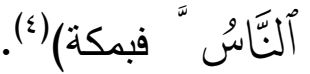
وكان من قوة علمه وثقته وتأكده من معر فته بالناسخ و المنسو خ و المتقــدم

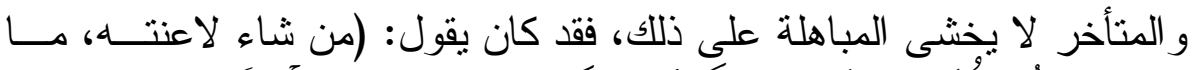

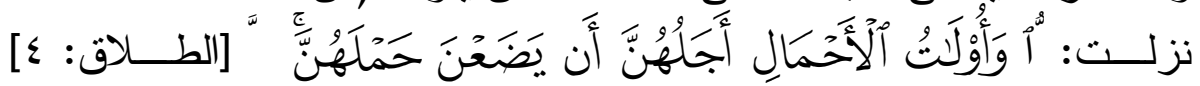

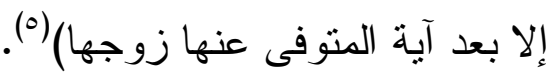

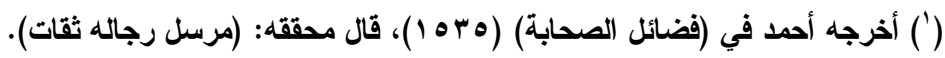

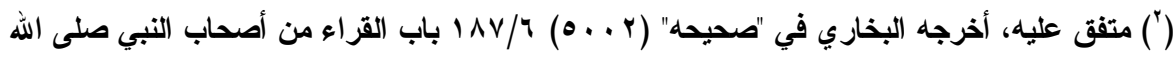

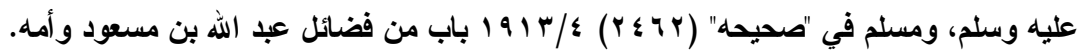

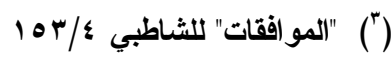

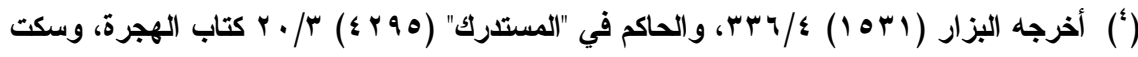

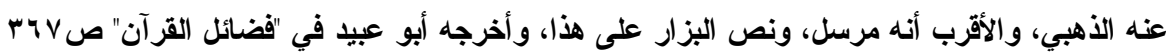
عن علقمة مرسلا.

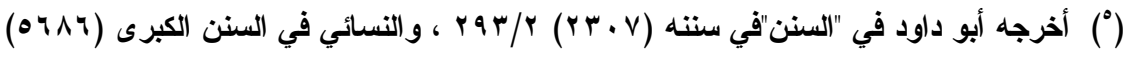

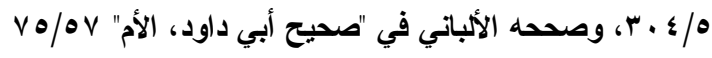

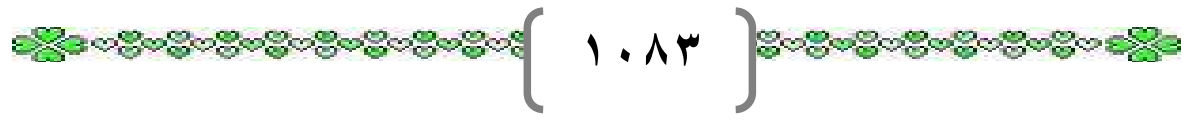


وكان يعلم السور القرائن التي كان رسول الله صلى الله عليه وسلم يقرن

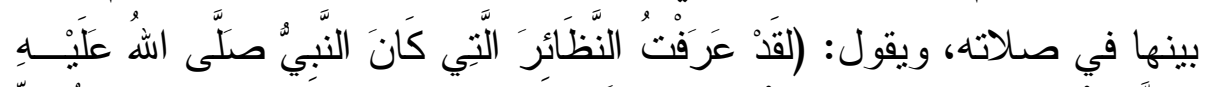

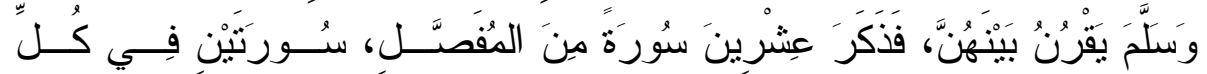

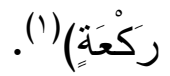

أما علمه بالتفسير فقد شهد لله بذلك الصحابة و التابعون، وقد قــال أحــد

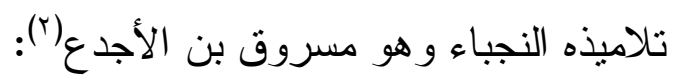

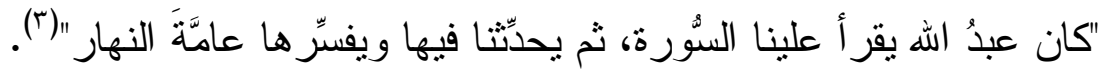

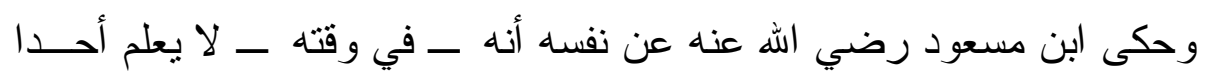

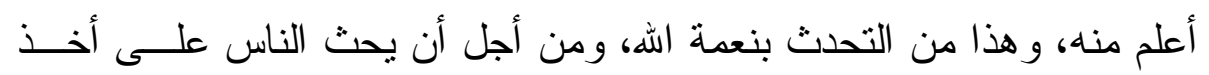

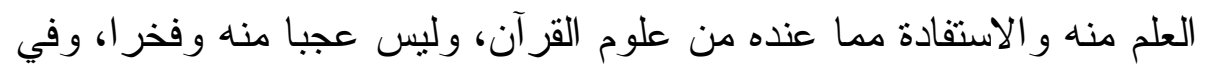

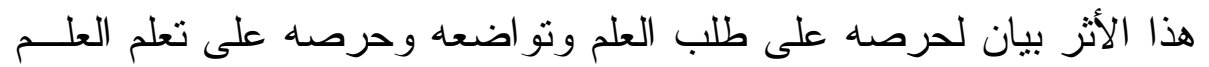
الذي ليس عنده ولو لقي في ذلك مشقة وعناء.

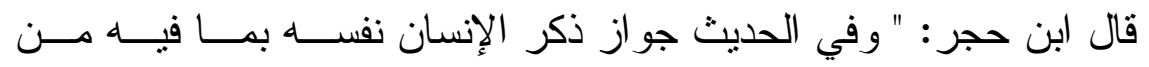
الفضيلة بقدر الحاجة ويحمل ما ورد من ذم ذللك على من وقع ذللك منه فخر الإنس

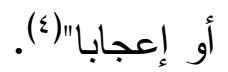
وقال: (إذا حدثتكم بحديث أنبأتكم بتصديقه من كتاب اله) (')، و هــذا بــدل

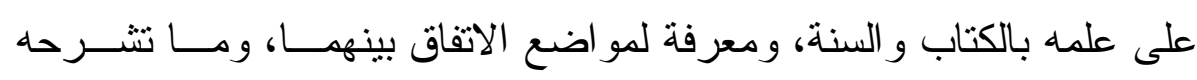

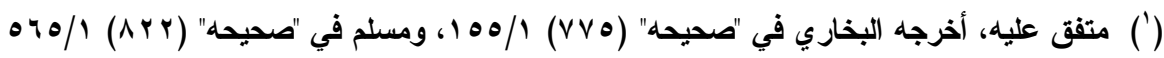

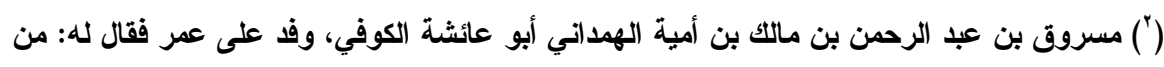

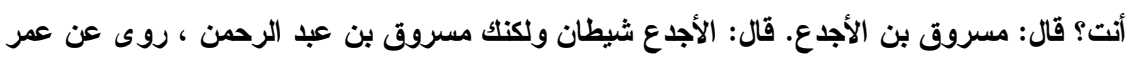

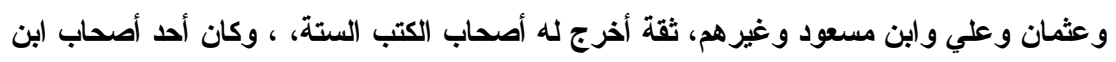

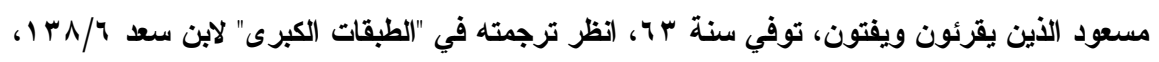

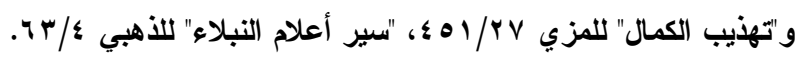

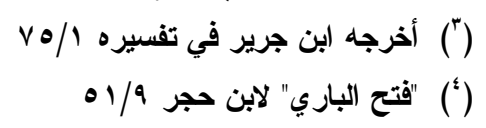

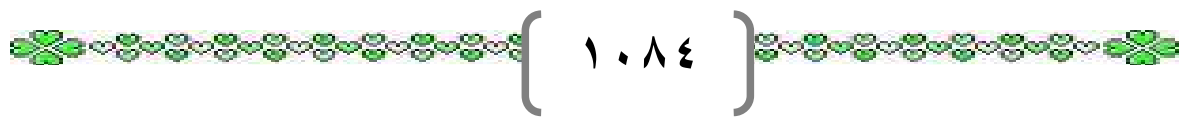


السنة من ألفاظ القرآن الكريم، و إنما قال ذلك لأن القرآن فيه بيان لجميع مــا

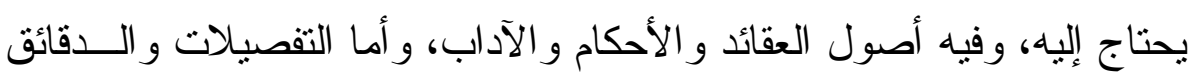

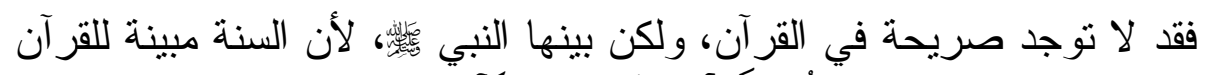

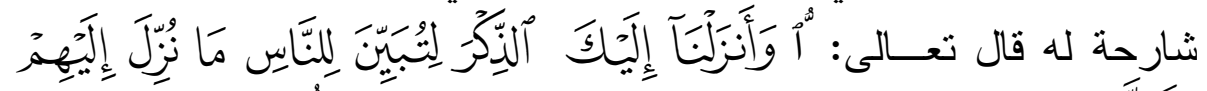

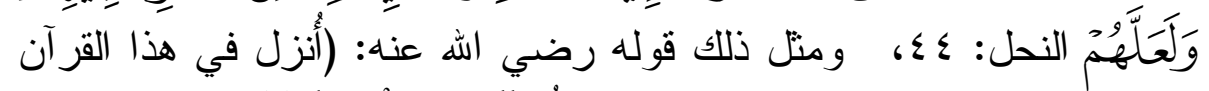

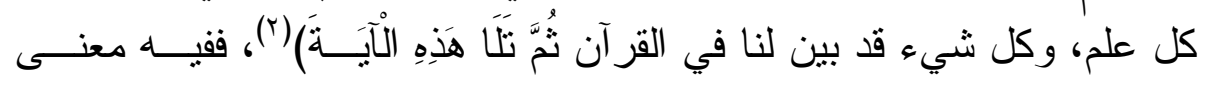
الرو اية السابقة.

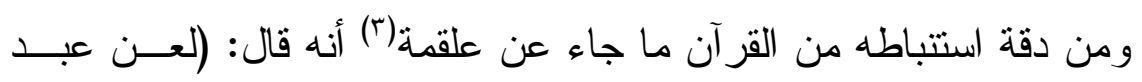

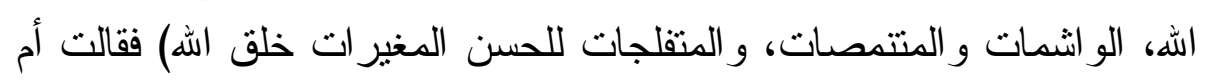
يعقوب(§): ما هذا؟ قال عبد الله: (وما لي لا ألعن من لعن رسول الله، وفـي

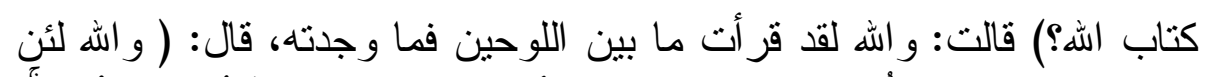

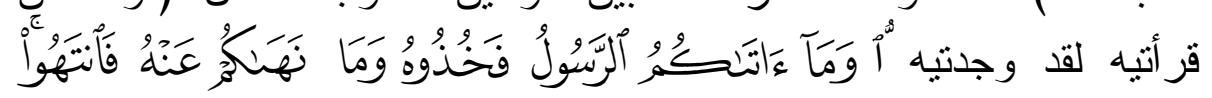

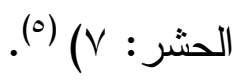

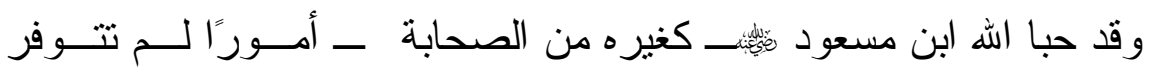

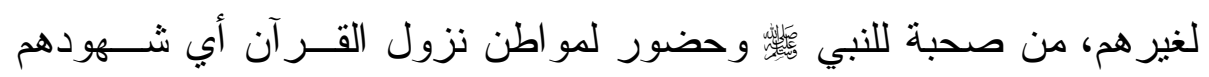
(') أخرجه الطبراني في "المعجم الكبير"(0 ؛ 19)، وقال الهيثمي في "مجمع الزوائد" ب/ ؛ ه: "إسناده

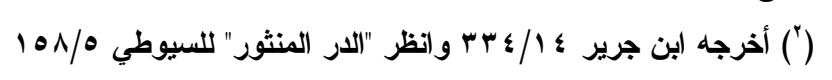

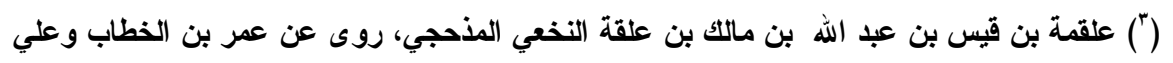

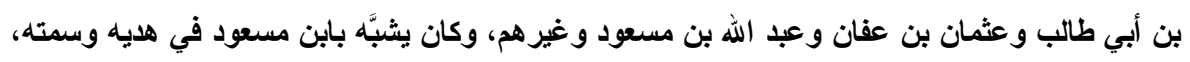

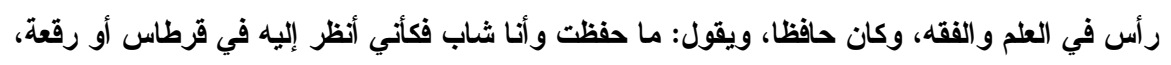

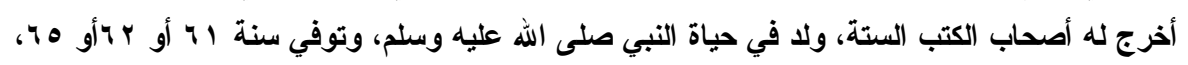

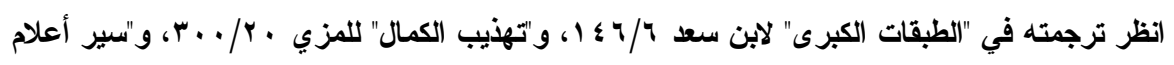

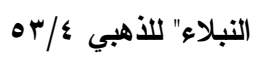

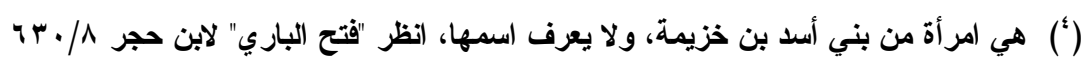

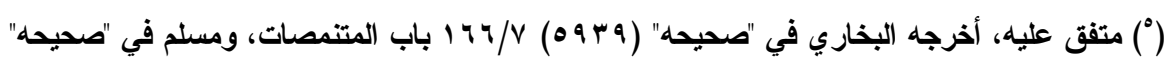

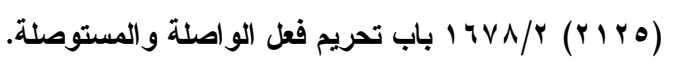

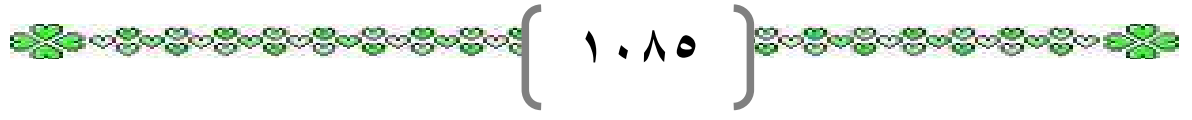


لوقت نزول الآيات؛ وهذا يعين كثير ا على فهم معنى الآيات، وكذللك معرفتهم

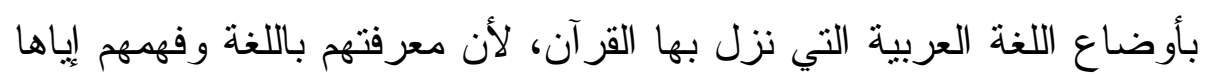

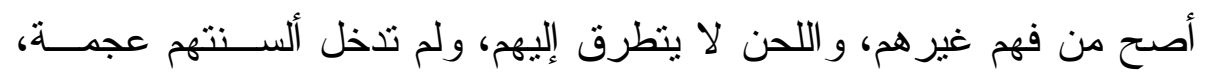

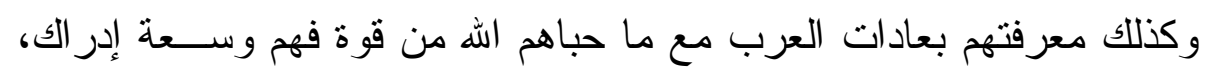

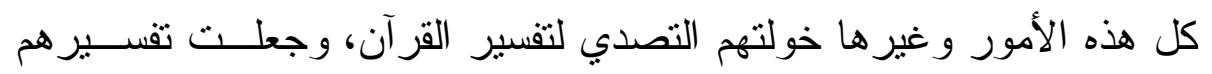

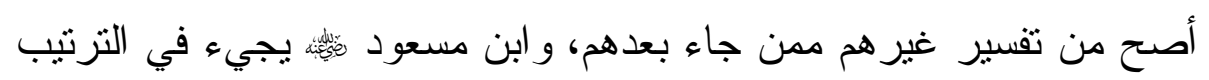

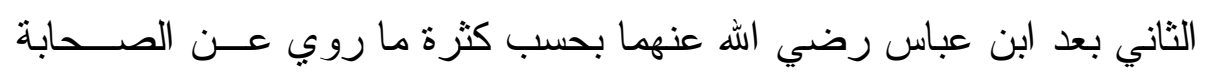

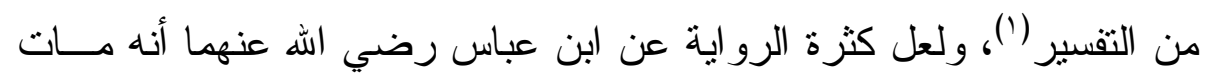

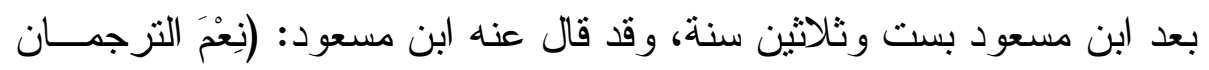
للقر آن ابن عباس)(؟) "فما ظنك بما كسبه من العلوم بعد ابن مسعود؟؟"(r).

$$
\text { r. موقفه من الإسر ائيليات: }
$$

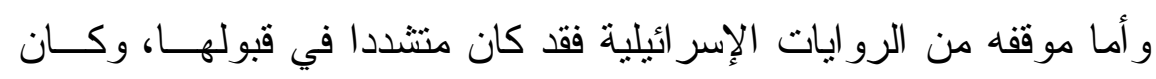

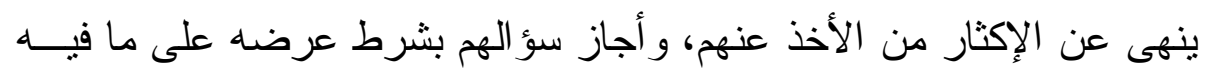

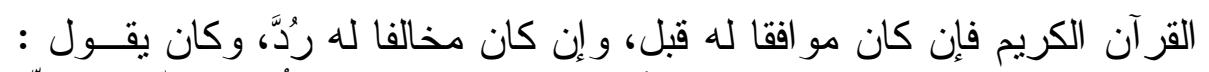

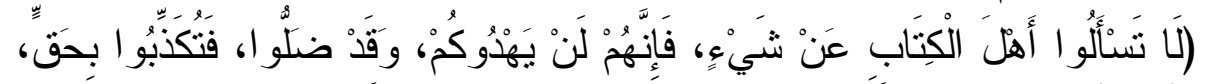

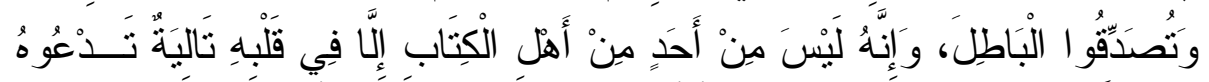

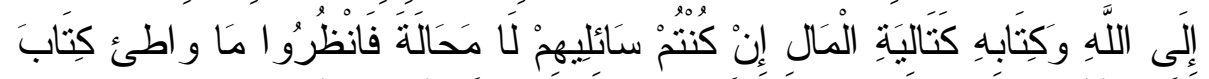

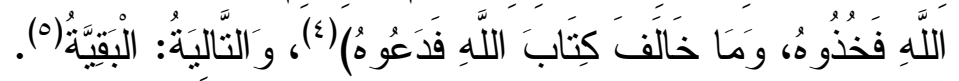

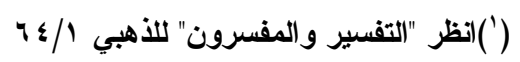

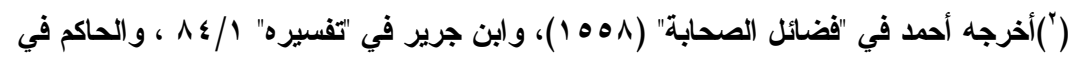

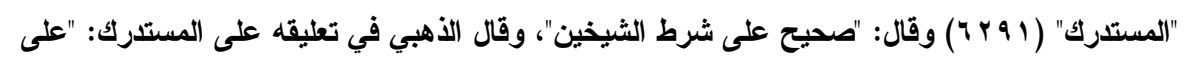
شرط البخاري ومسلم".

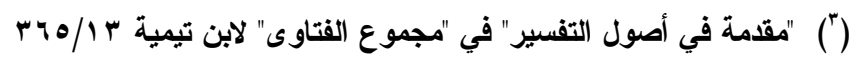

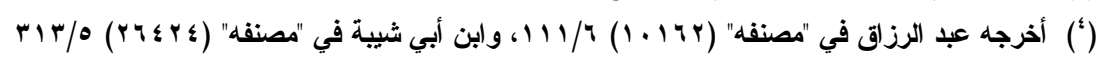
(") جاء هذا التفسير في الرواية نفسها.

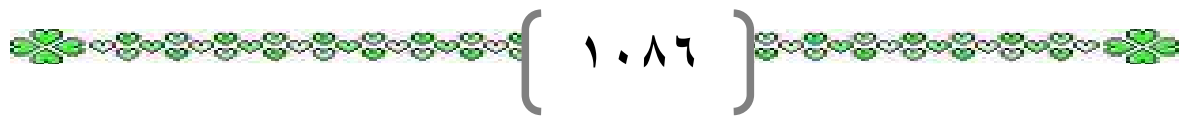




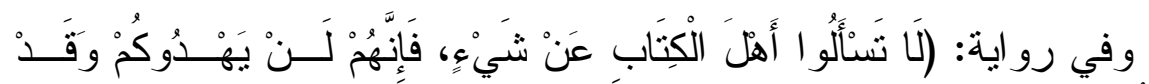

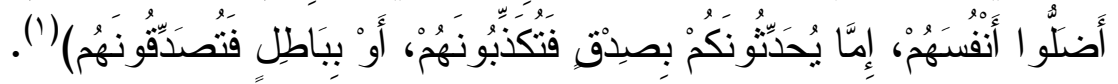

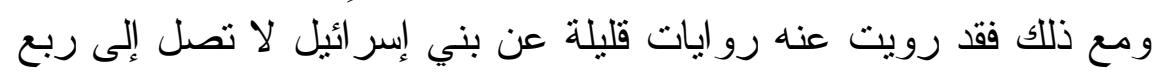

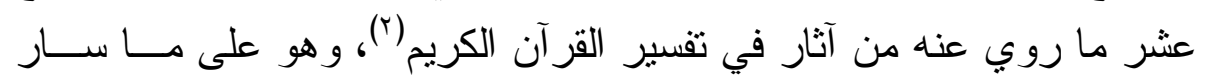

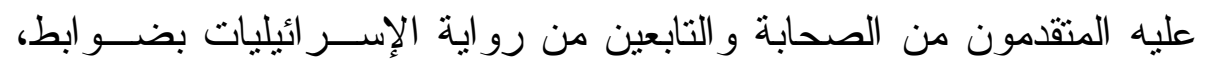
و عدم ردها كلية ولا قبولها مطلقابهان. ـ. إثارته إلى علم المناسبات:

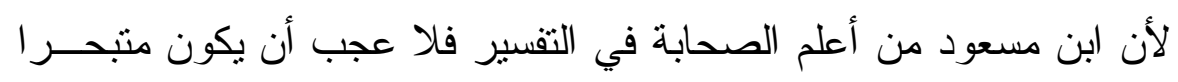

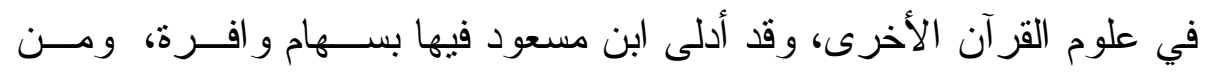

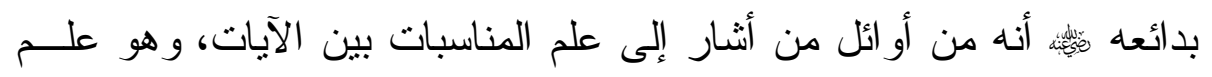

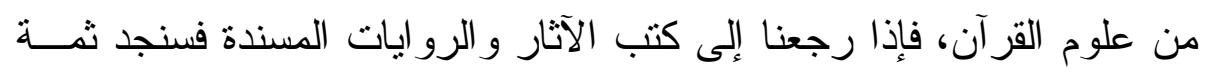

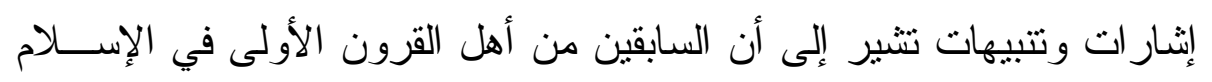

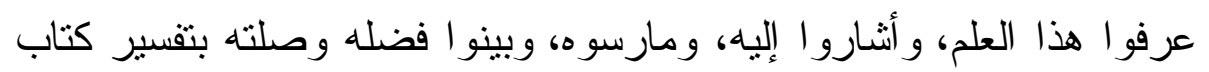

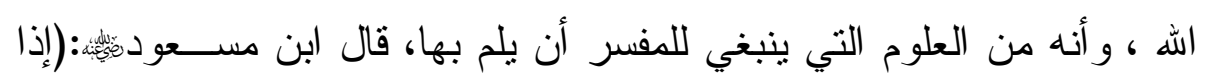

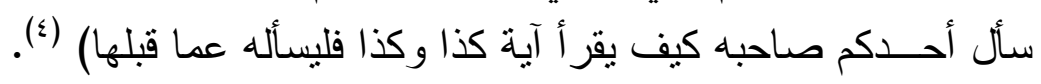

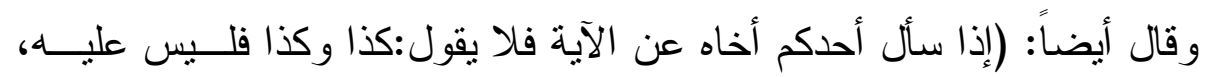

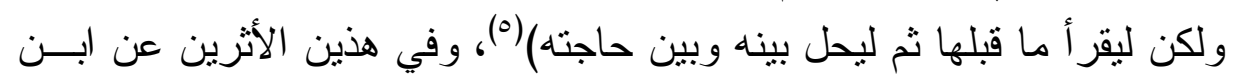

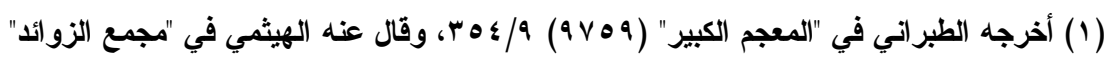

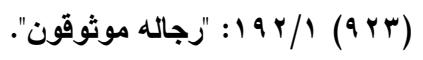

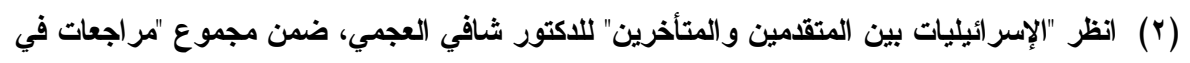

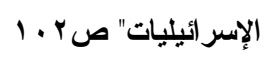

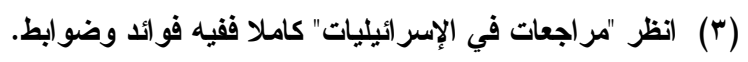

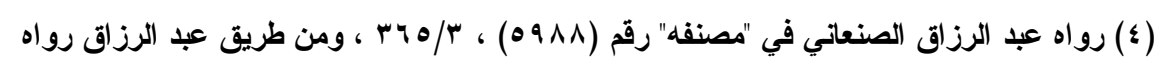

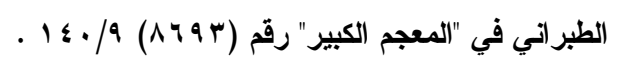

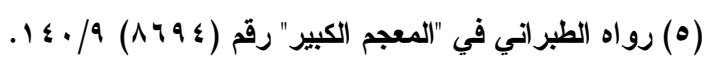

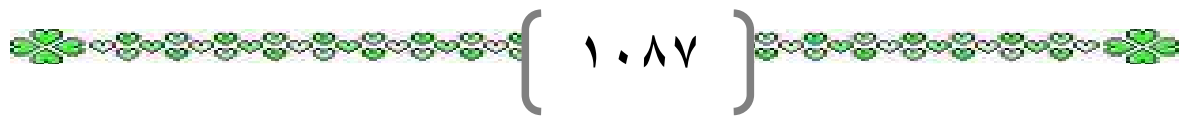


مسعود نِيّنَ: إثشارة و اضحة إلى أن معرفة معنى الآية وطريقة قر اعتها له ارتباط بالآيات التي قبلها.

هـ أقوال العلماء في علمه بالقرآن الكريم:

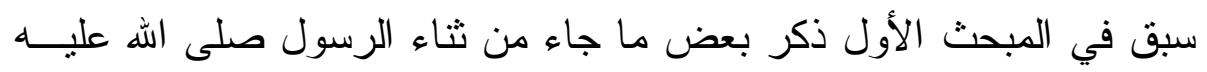

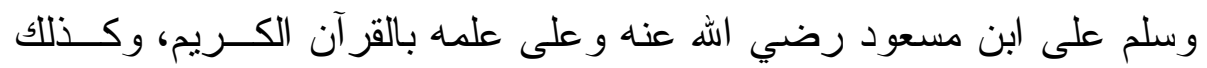

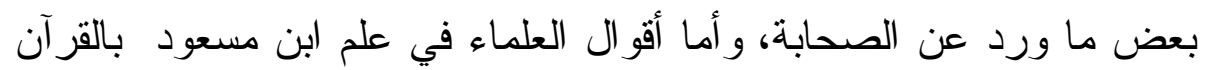

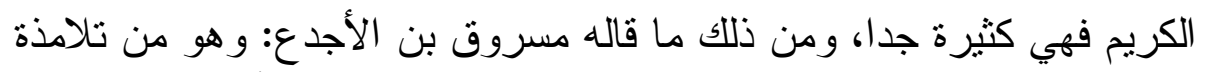

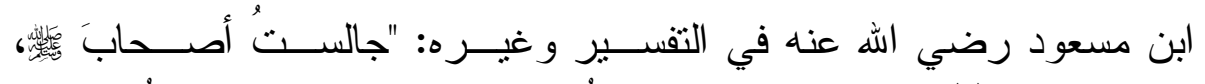

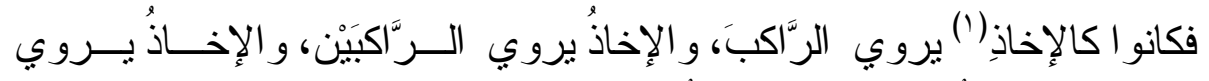

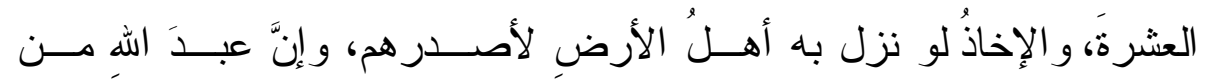

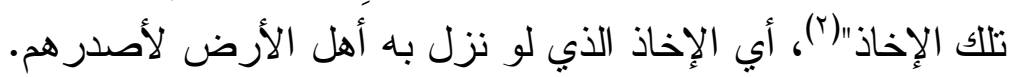

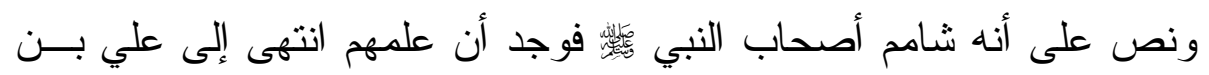

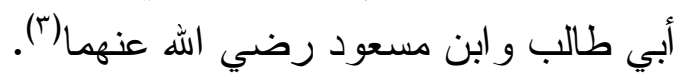

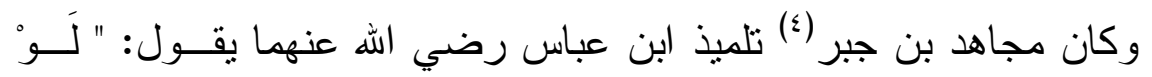

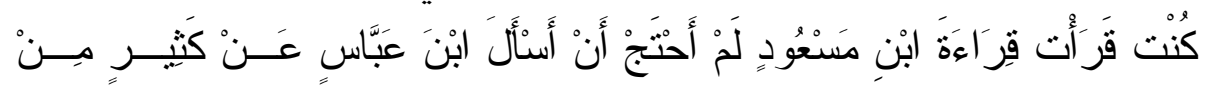

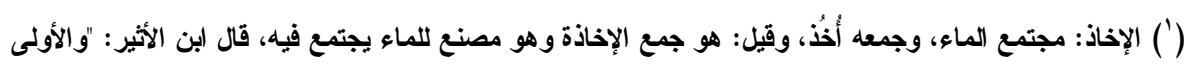

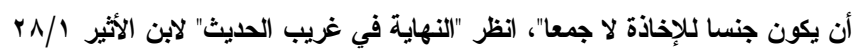

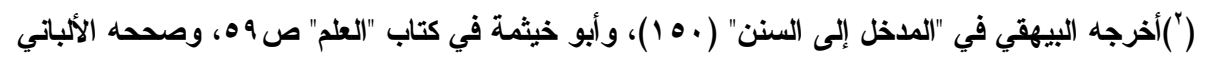

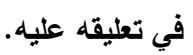

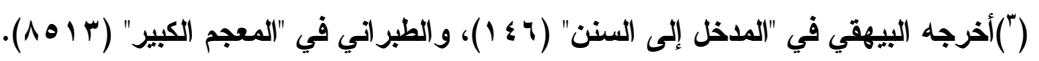

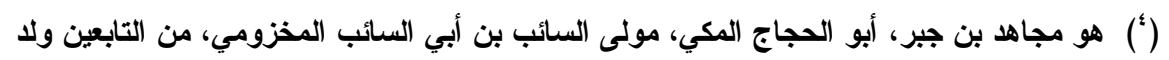

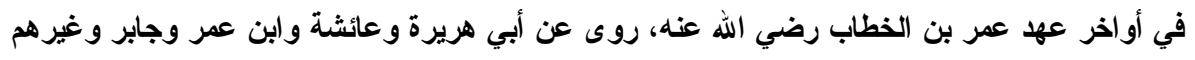

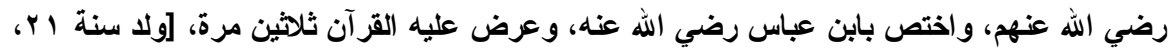

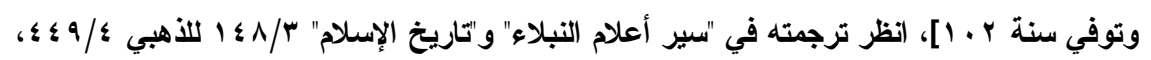

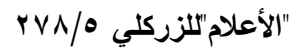

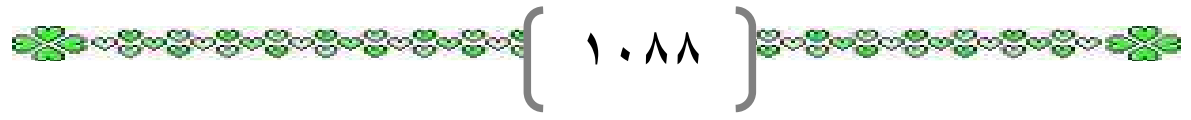


الْقُرْآن مِمَّا سَأَلْت"(')، و هذا يدل على سعة علم ابن مسعود بــالقر آن الكــريم مقارنة بعلم ابن عباس رضي الله عنهما.

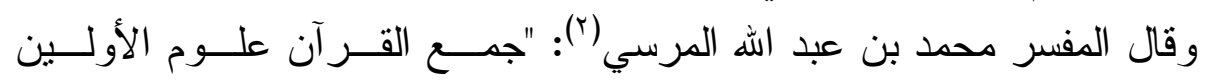

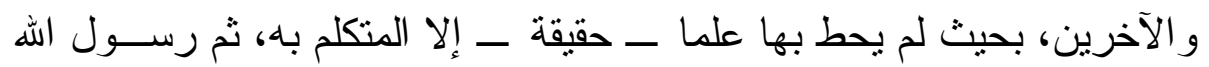

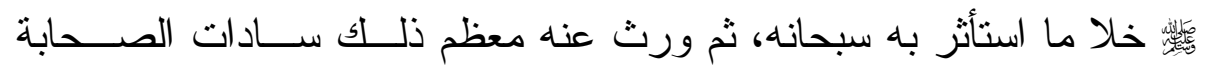

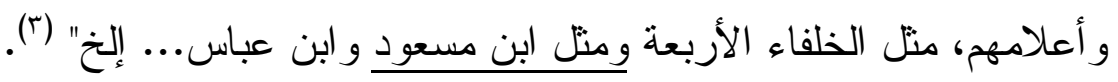

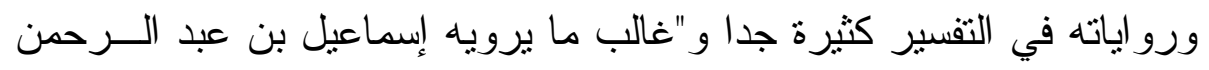

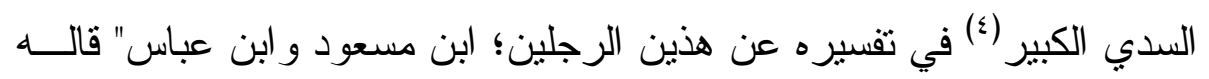
ابن تيمية(0).

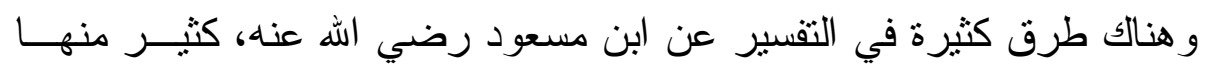

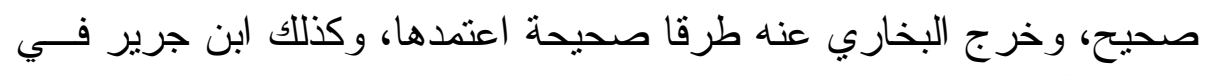

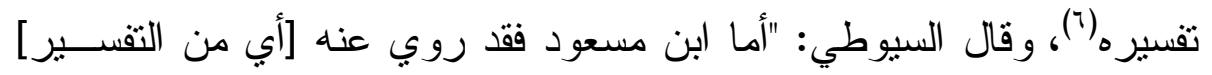
أكثر مما روي عن علي رضي الله عنهما"(V)

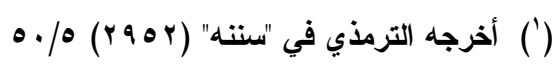

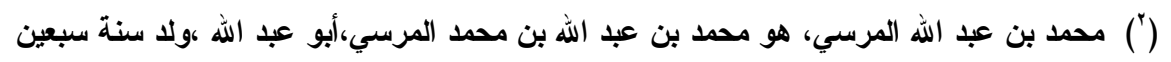

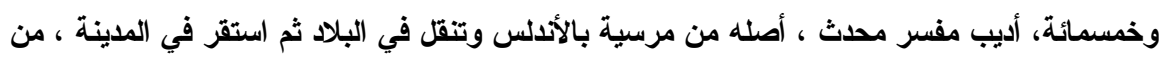

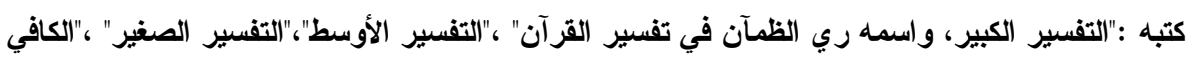

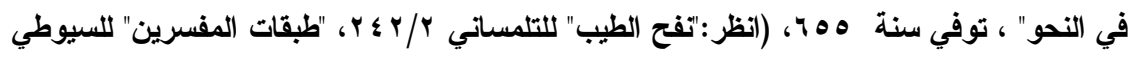

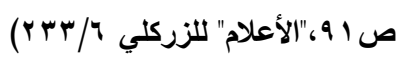

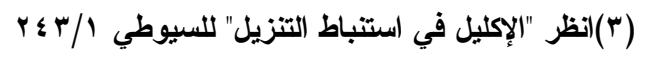

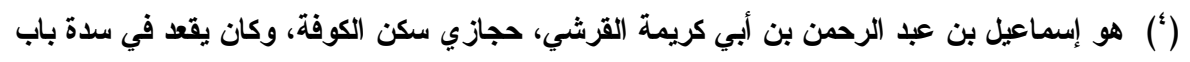

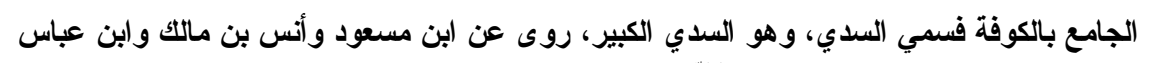

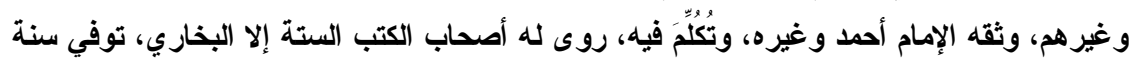

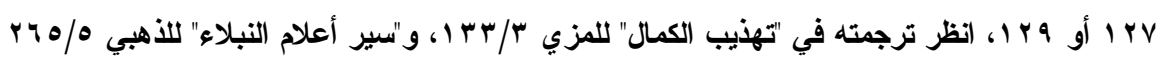

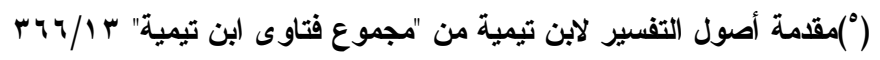

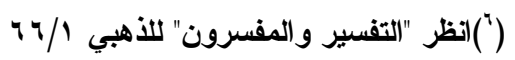

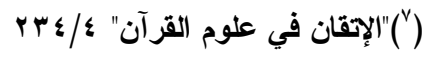




\section{צ. شهوده العرضة الأخيرة:}

وسميت بالعرضة الأخيرة لأنها آخر معارضة بالقرة آندان وقعت بين النبي صلى

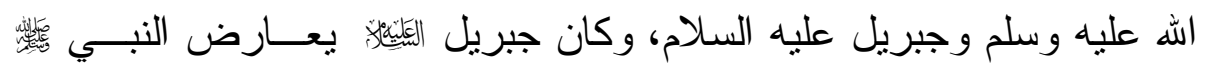

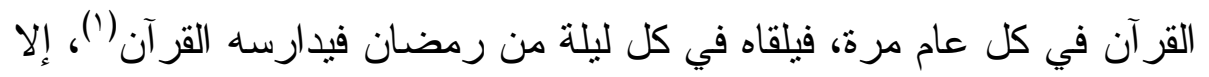

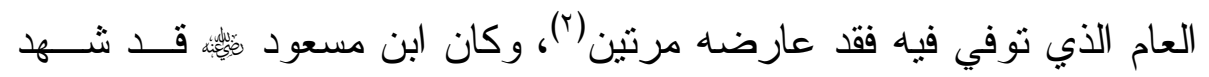

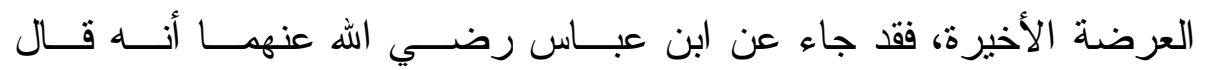
لأصحابه:(أيَّ القر اعتين تعدون أول؟) قالو ا: قر اءة عبد الله، قال: (لا، بل هي

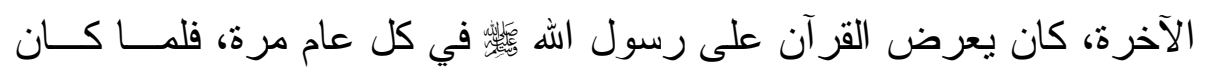

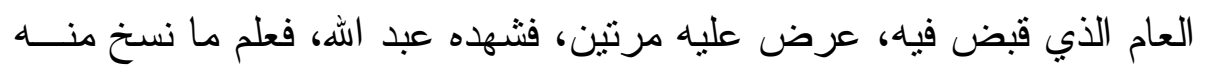

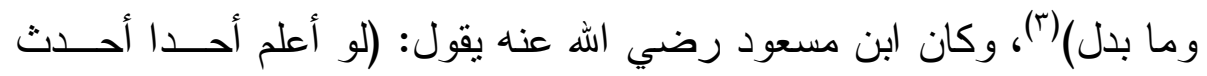
بالعرضة الأخيرة مني لرحلت إليه)( أ).

كان عبد الله بن مسعود رضي الله عنه يقل الصوم، فيُقال له في ذللك، فيقول:

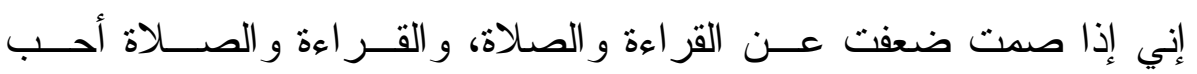
إلي (०).

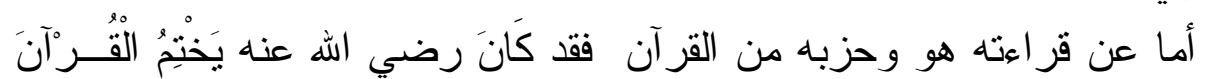

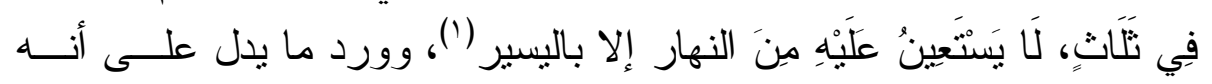

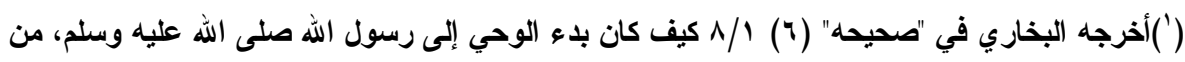
حلثيث ابن عباس رضي الله عنهما.

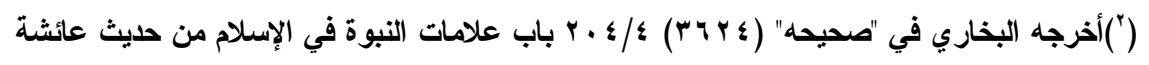
رضي الله عنها.

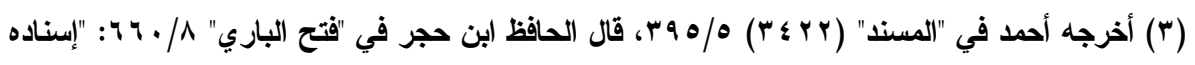

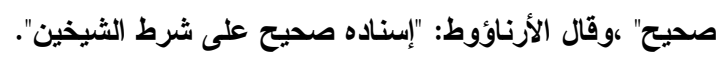

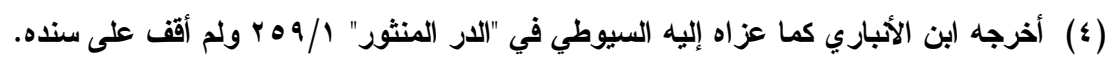

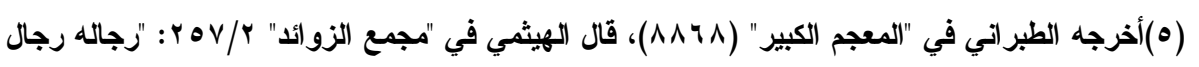
الصحيح".

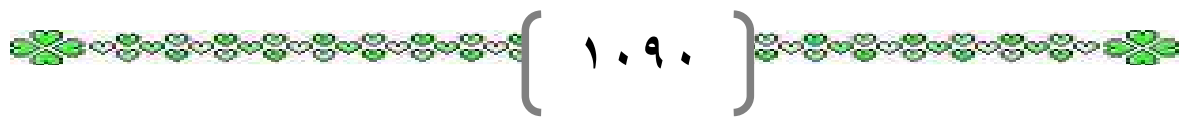




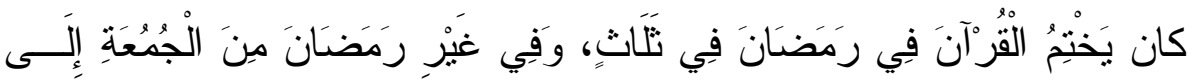

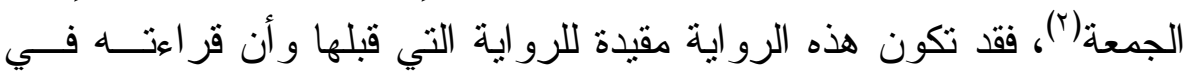

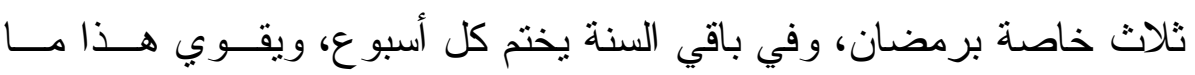

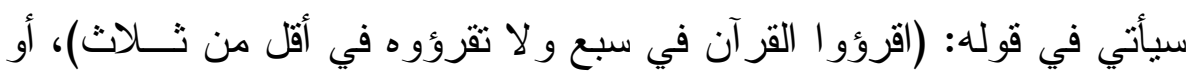
أنه كان يفعل هذا وهذي فوله:

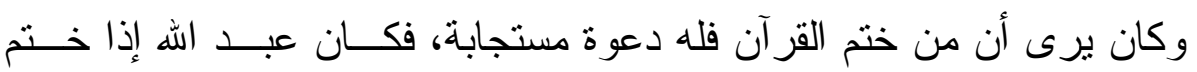

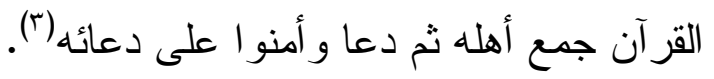

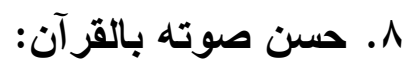

وكان ابن مسعود حسن الصوت بالقر آن، جيد الترتيل، فعن أبي عثــــان

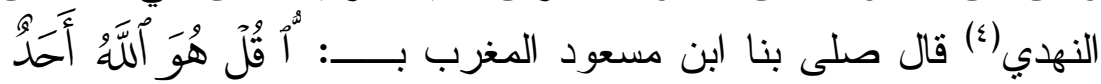

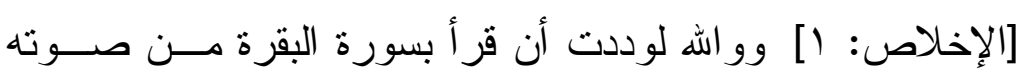

وثرنيله (ن).

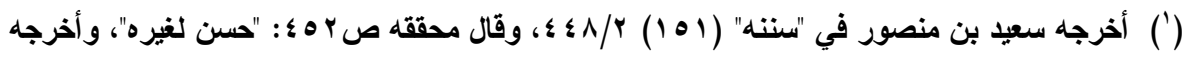

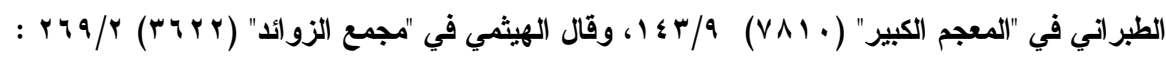

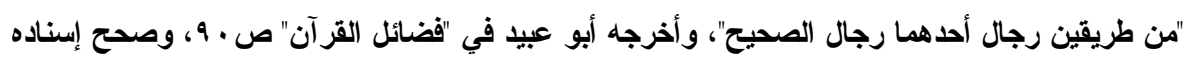

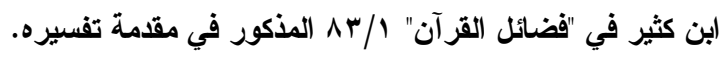

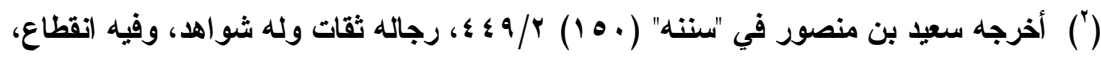

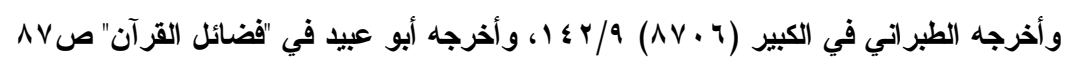

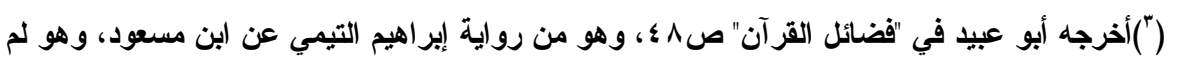
يدركه، ففي السند انقطاع. (") هو عبد الرحمن بن مل بن عمرو النهاي القضاعي، مخضرم، ولد في الجاهلية، وأسلم على عهد

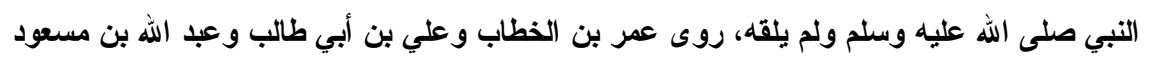

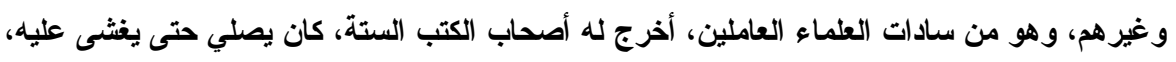

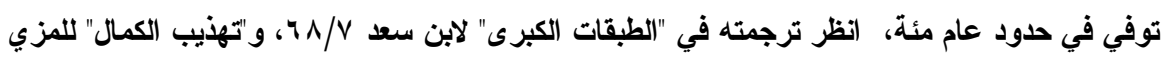

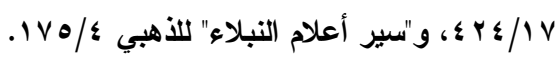

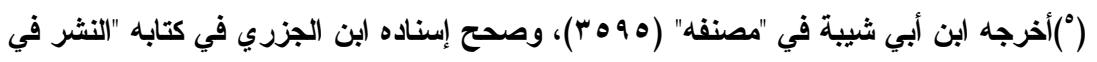

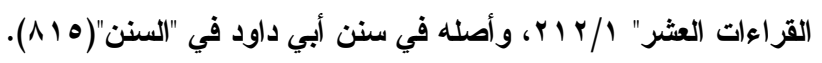

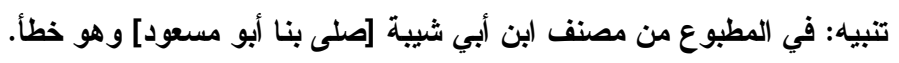

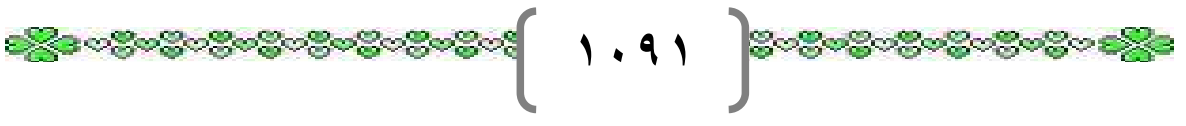


9 .طريقة تعلمه القرآن وتعليمه:

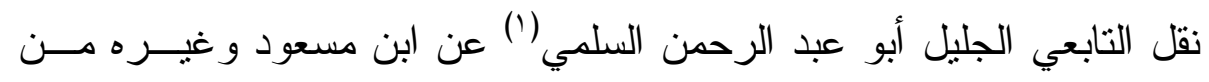

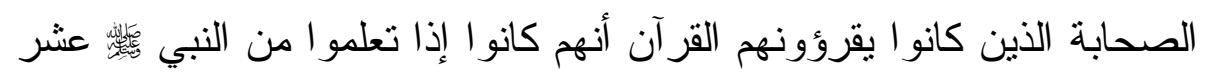

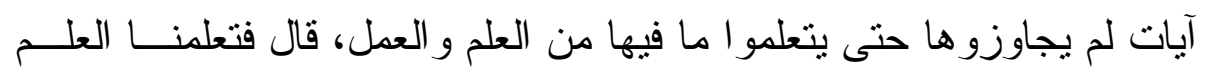

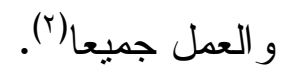
و هذه سمة بارزة من سمات السلف في تعلمهم للقر آن، نقلها أبو عبد الــرحمن

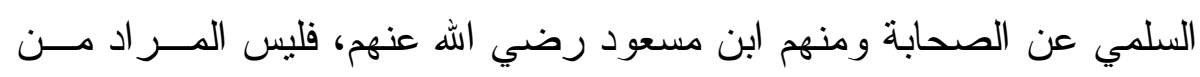

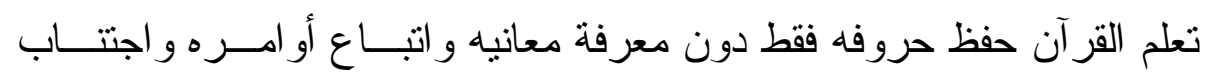
نو اهيه.

وفي هذا الأثر دلالة على أهمية التدرج في التربية و التعليم و التلازم بين تعلم القر آن و النزبية على تطبيق أحكامه و آدابه.

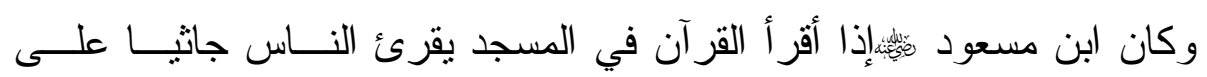

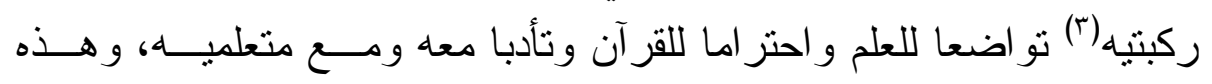

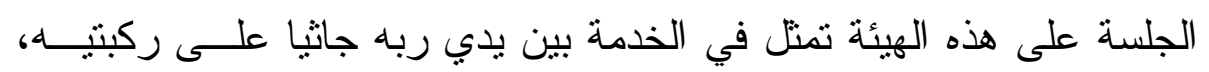

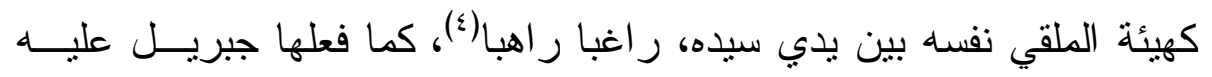
السلام لما جلس بين بدي النبي صلى الله عليه وسلم (॰).

(') أبو عبد الرحمن السلمي، عبد الله بن حبيب بن ربيعة السلمي الكوفي، روى عن عمر بن الخطاب

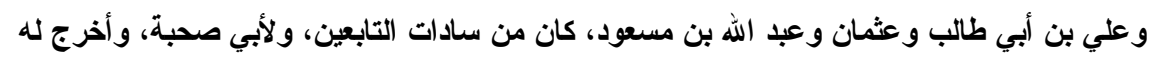

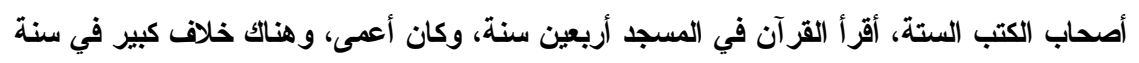

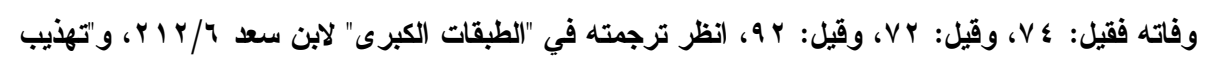

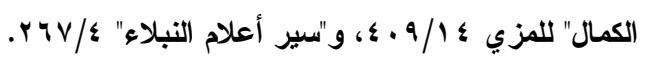

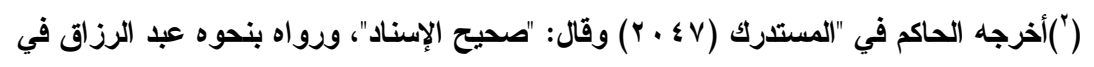

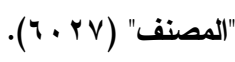
(") ("آ) عزاه النووي في "التبيان في آداب حملة القرآن" ص ؛ ؛ ؛ إلى ابن أبي داود بسنده.

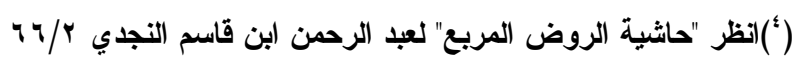

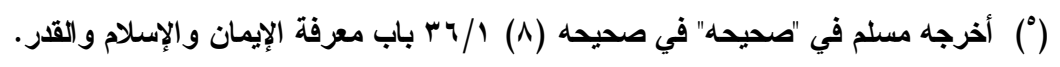

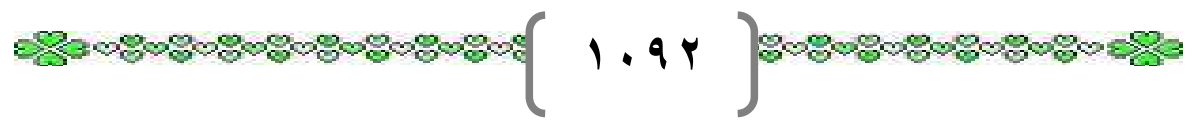




\section{الميحث الثالث}

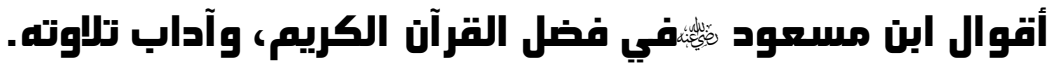

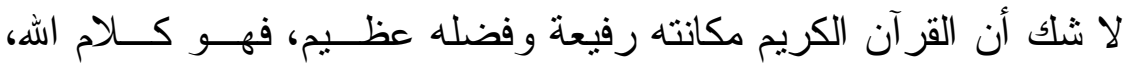

و أثرف الكلام، و أفصحه و أعجزه، وقد تحدى الله جميع التقلين الإنس و الجن

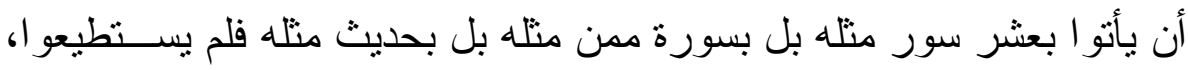

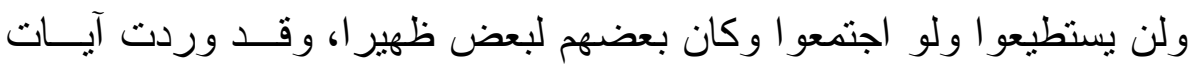

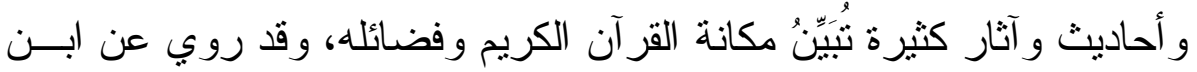
مسعود رضي الله عنه جملة صالحة، وحسبي أن أختار بعضا من هذه وفئه الآثار

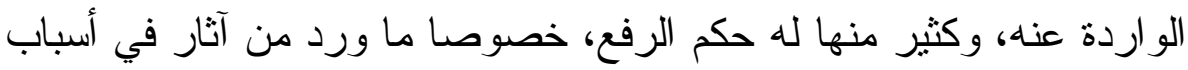
النزول، لأن الصحابي إذا أخبر عن آية أنها نزلت في كذا كان مسندا، وكذلك ما يقولونه في تفسير القر آن مما لا مجال للر أي فيه كتفسير أمر مــن أمسـور

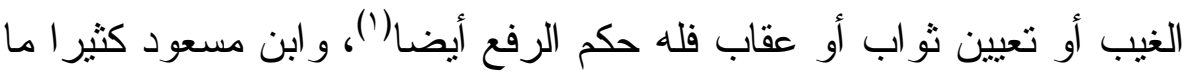

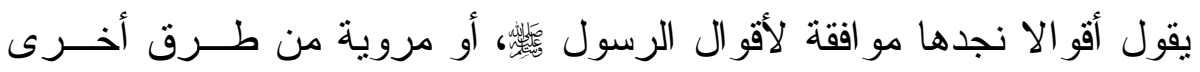
مرفو عة.

ا ـ أقو اله في فضل القرآن وتعلمه وتعليمه و التمسك به:

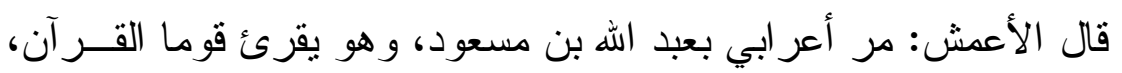

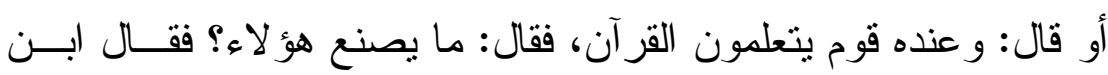

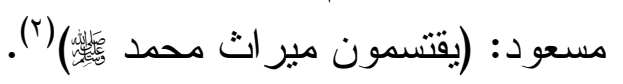

وقال ابن مسعود رضي الله عنه: (من أر اد العلم فعليه بالقر آن، فإن فيه خبر

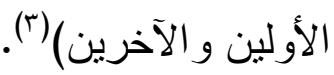

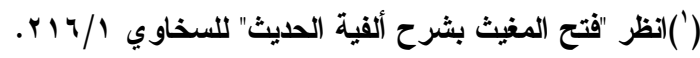

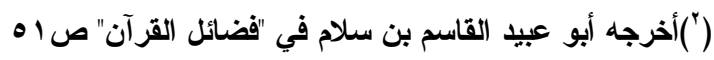

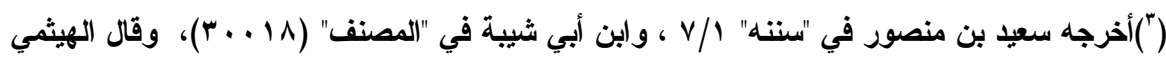

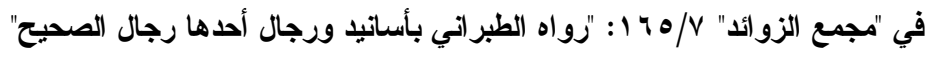

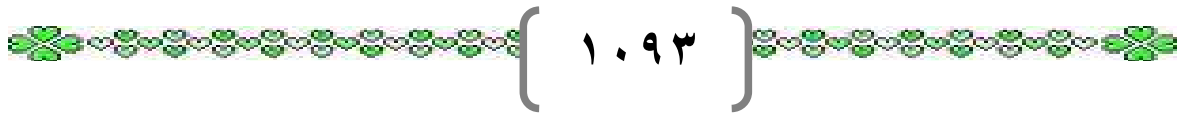


وقال رضي الله عنه: (هذا الصر اط فاتبعوه، و الصر اط المستقيم: كتــاب الله،

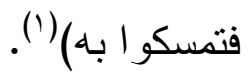

وقال: (إذا أردنم العلم؛ فأثثرو القرآن، فإن فيه علم الأولين و الآخرين).

وفي لفظ: (من أر اد العلم فليثور القرآن فإن فيه علم الأولين والآخرين) (r).

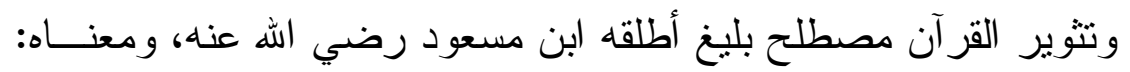

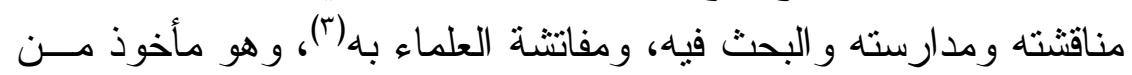

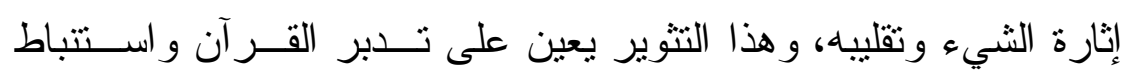
الأحكام و الفو ائد منه.

وقال ابن مسعود رضي الله عنه: (عليكم بالثفاعين: القر آن و العسل)(اء).

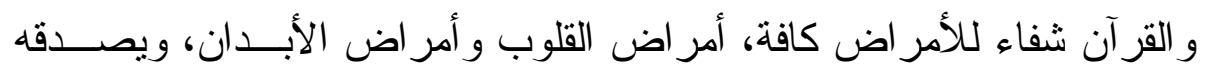

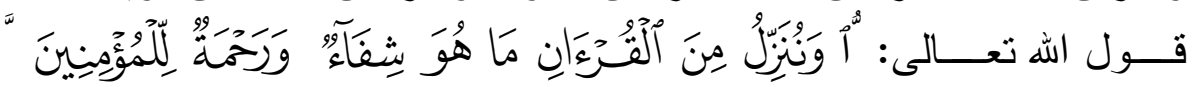

$$
\text { الإسر اء: المون }
$$

وقال رضي الله عنه: (إن القرآن شافع ومشفع، وماحلِّ مصدَّق، فمن جعلـــهـ أمامه قاده إلى الجنة، ومن جعله خلفه ساقه إلى النار )(॰).

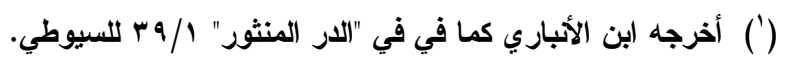

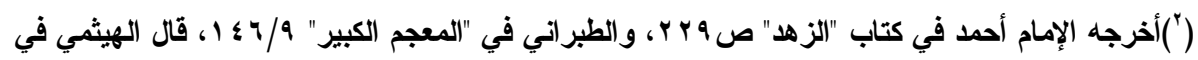

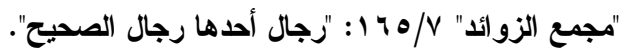

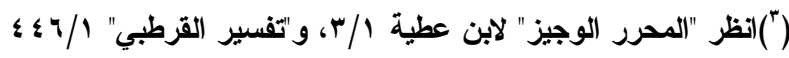

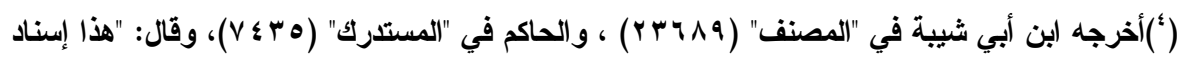

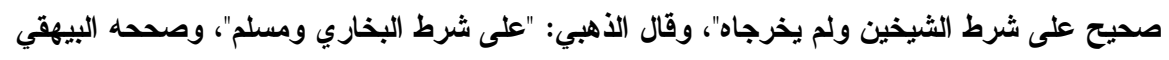

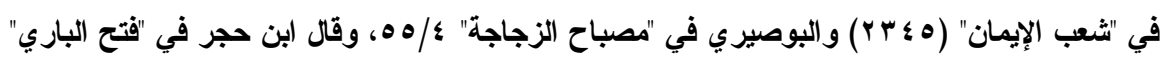

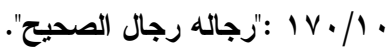

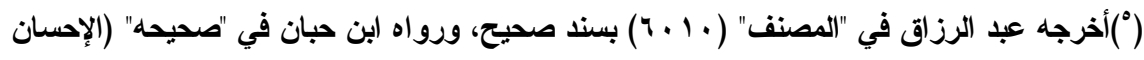

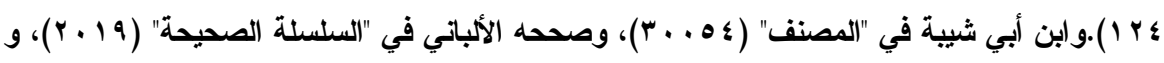

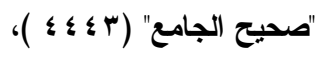

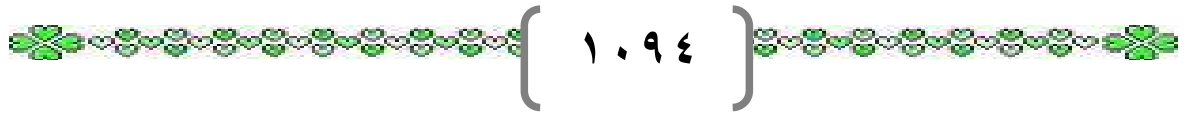


ومعنى قوله: (مَاحلِ مصدق) أي خصم مجادل مصــدق، وقيــل: ســــاعٍ

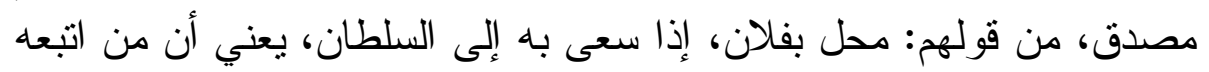

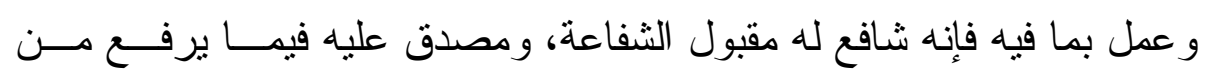

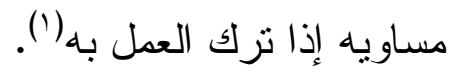

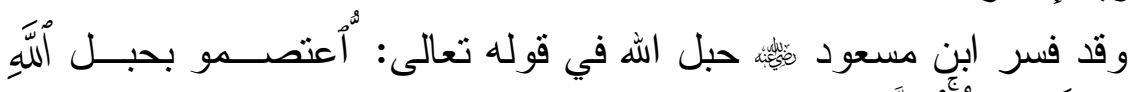

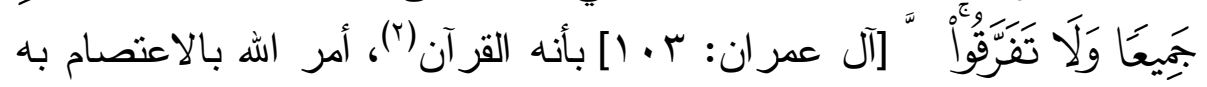
من كل ما يصيم.

وقال ابن مسعود رضي الله عنه: (إن للقرآن منار ا كمنار الطريق، فمـــــا

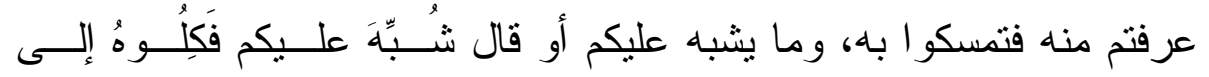

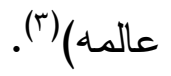

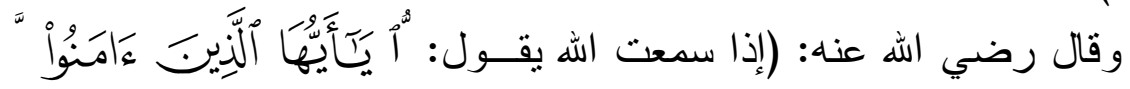
فأر عها سمعك، فإنه خير يؤمر به، أو شر ينهى عنه)(أ).

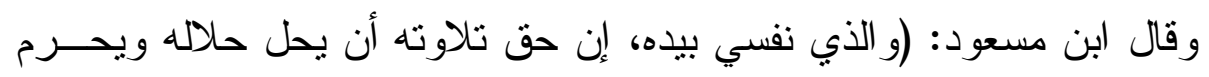

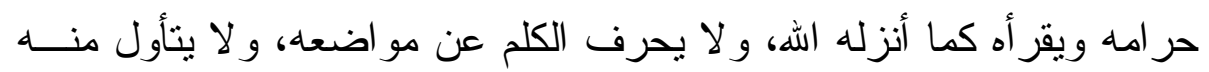
شيئا على غير تأويله)('). r. أقواله في حب القرآن الكريم: فأله

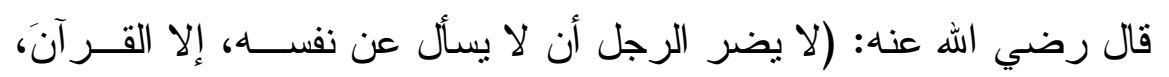

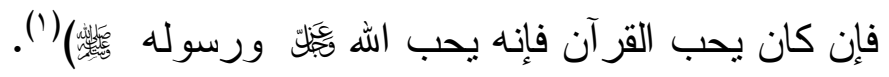

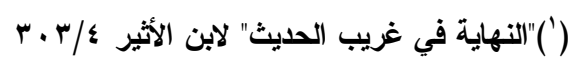

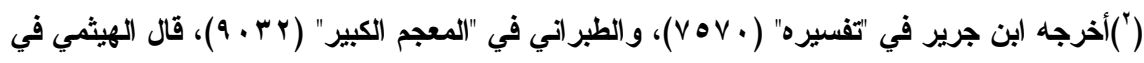

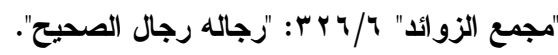

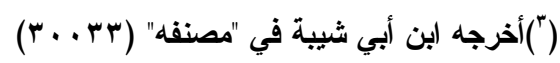

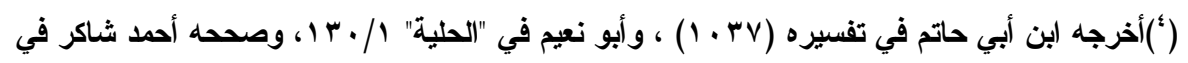

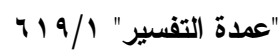

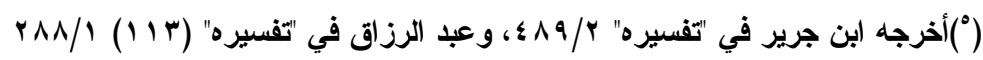

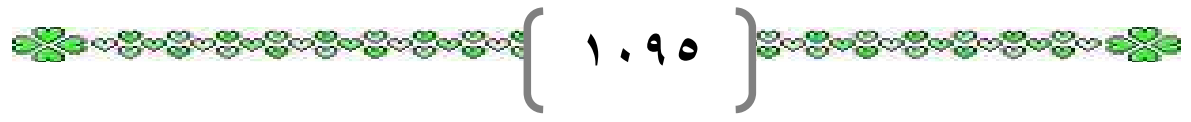


ومعنى هذا أن من كان يحب أن يعلم أنه يحب الله فليعرض نفسه على القرآن فمن أحب القرآن فهو يحب الله فإنما القرآن كلام الله.

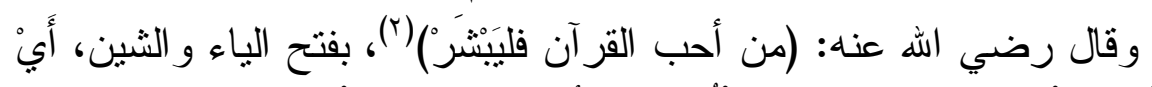

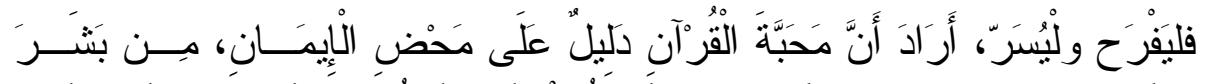

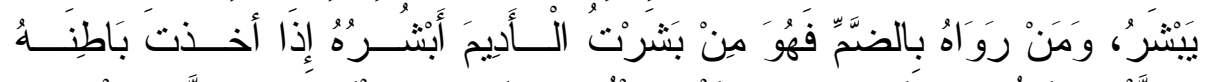

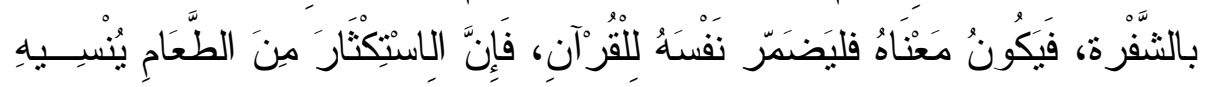

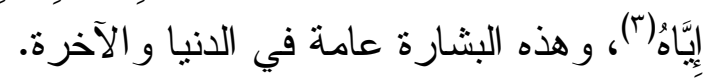

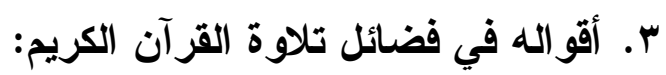

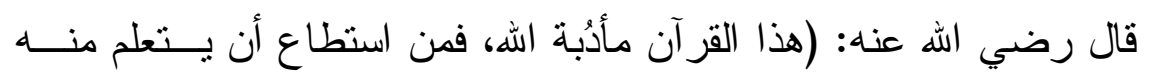

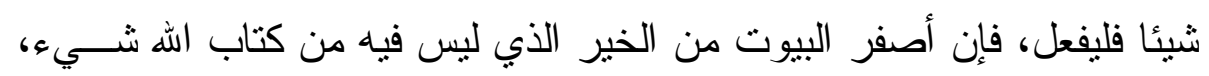

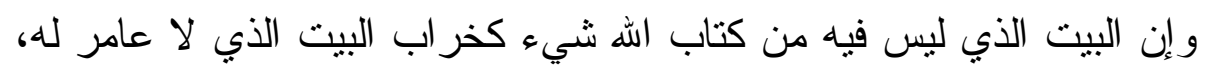

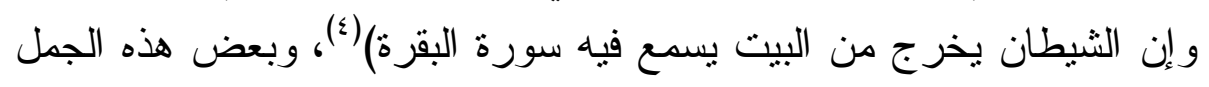
مرفو عة إلى النبي كئل ومعنى قوله: (أصنفرَ البيوت) أي أخلاها من الخير ، يقال صَفِرَ الإنــاء إذا خلا، و أصفرته إذا أخليته (ه).

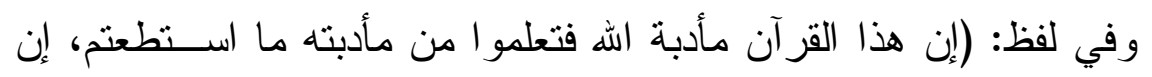

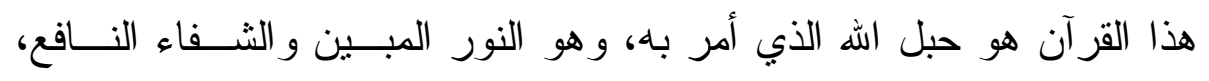

(') أخرجه سعيد بن منصور في سننه / / ـ ا،وقال الهيثمي في "مجمع الزوائد" / 17 / : "رجاله ثقات"،

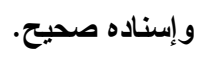

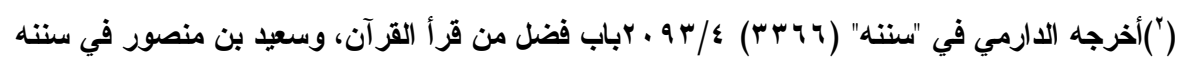

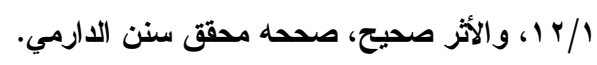

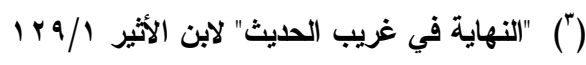

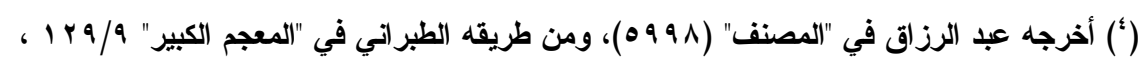

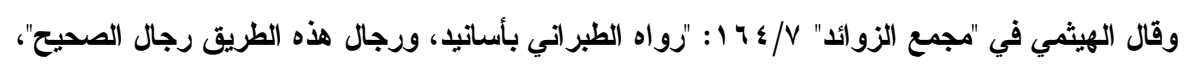

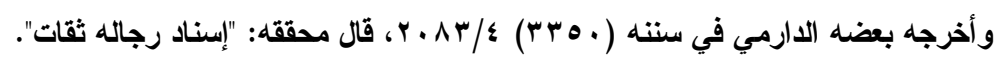

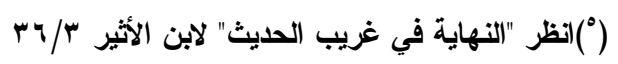

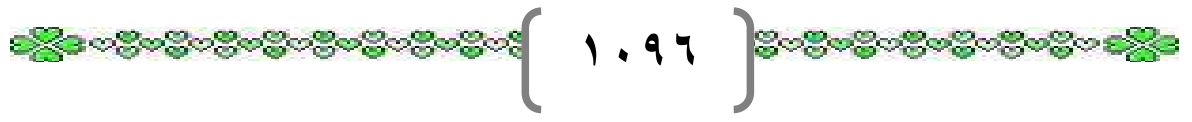




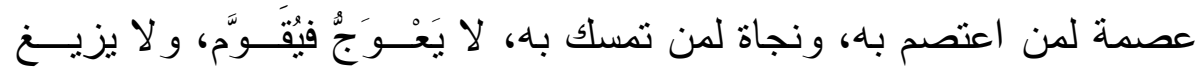

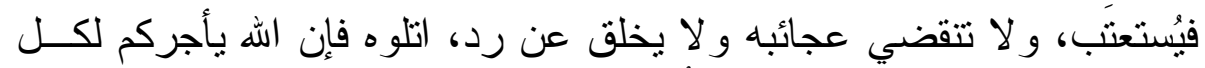

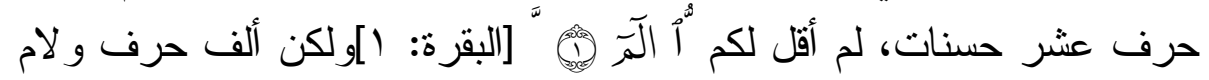
حرف وميم حرف) (').

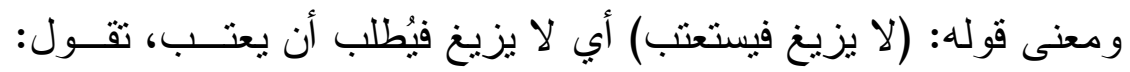

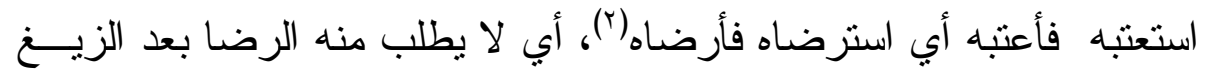
لأنه لا يزيغ.

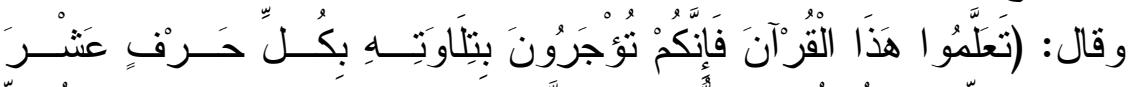

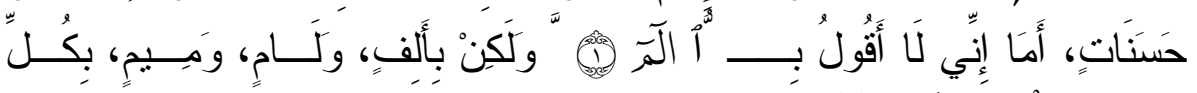

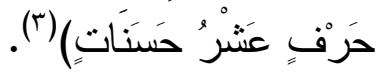

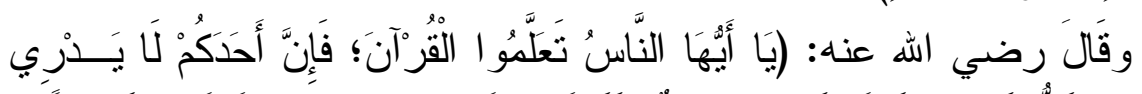

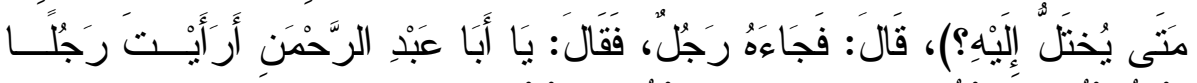

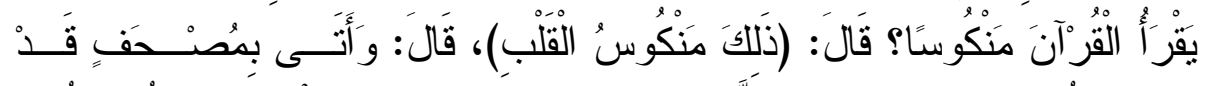

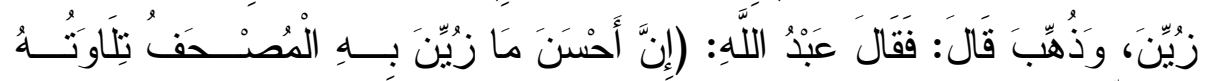

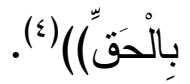

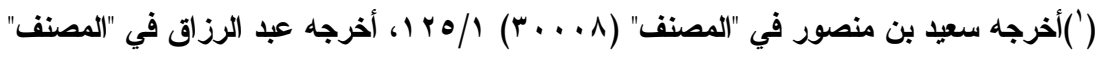

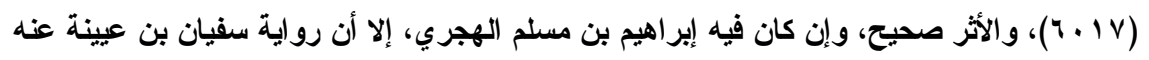

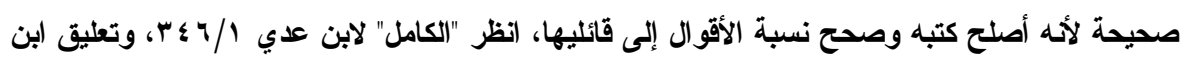

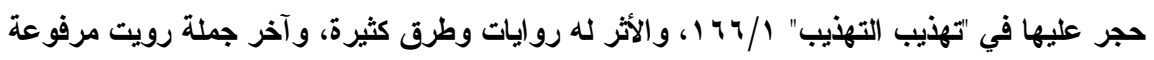

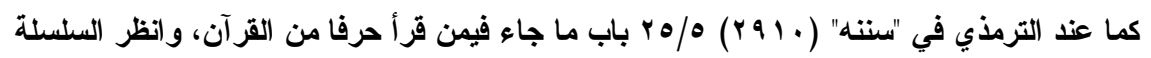

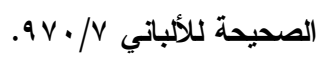

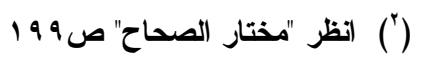

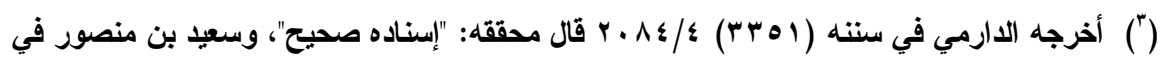

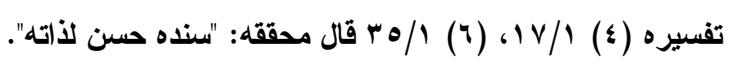

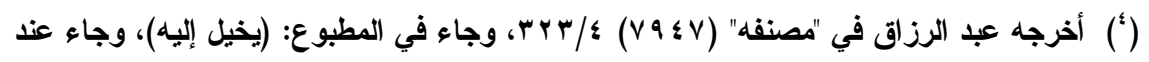

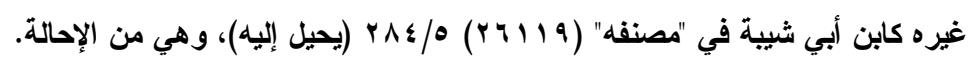

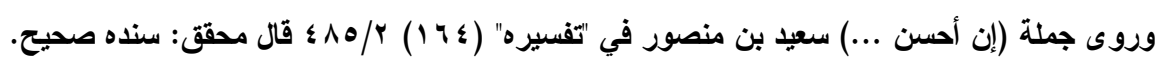

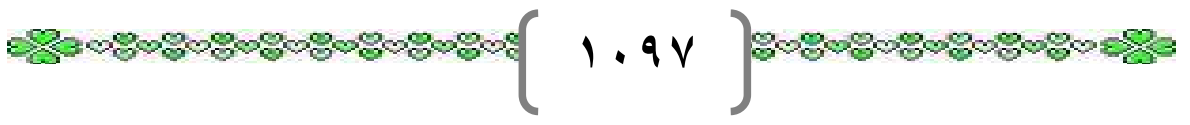




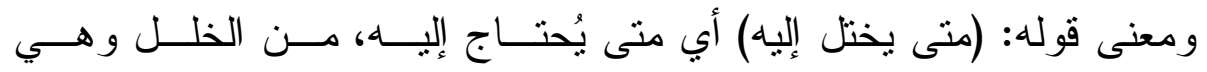

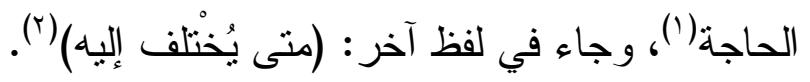

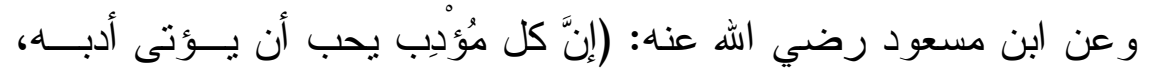

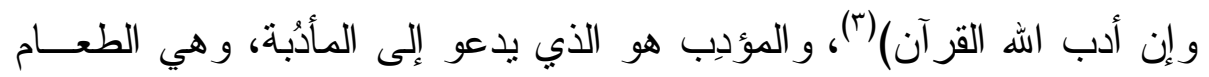

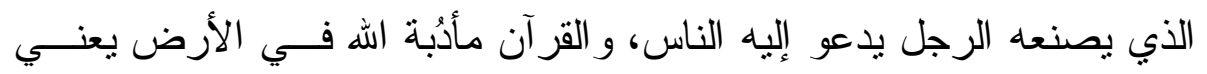
مدعاته، شبه القر آن بصنيع صنعه الله للناس لهم فيه خير ومنافع (ء).

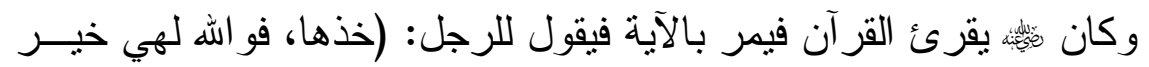

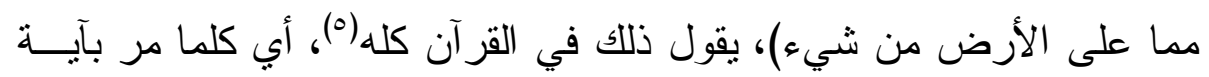

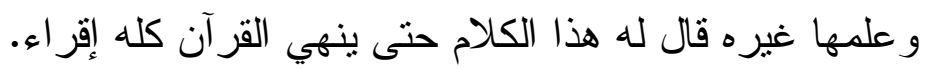

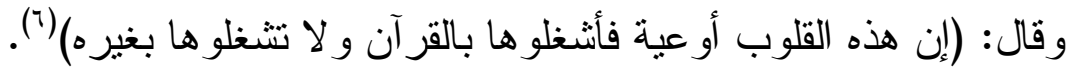

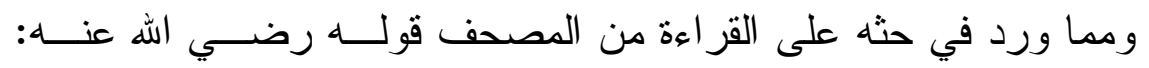

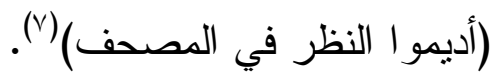
وقد ورد عن ابن مسعود رضي الله عنه مرويات كثيرة في فضائل سور

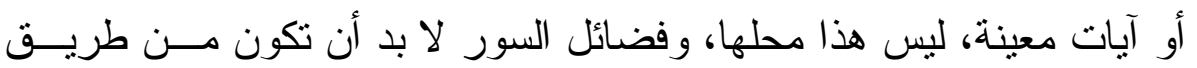
الوحي، وهذه الرو ايات الموقوفة عليه إن صحت فلها لهاب حكم الرفع. وله أقو ال لا تأخذ حكم الرفع منل قوله رضي رضي الله عنه: (من قر أ سورة آل آل

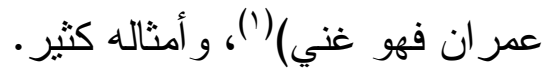

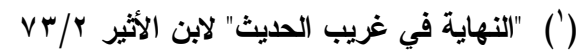

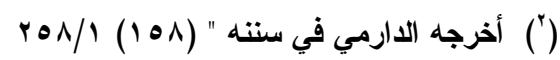

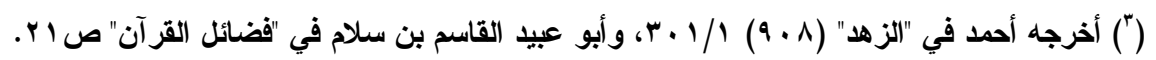

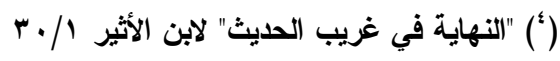

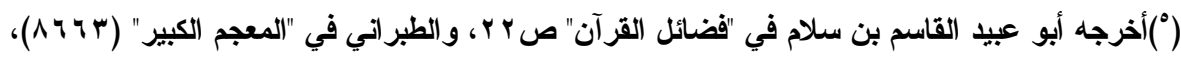

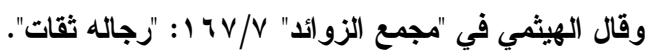

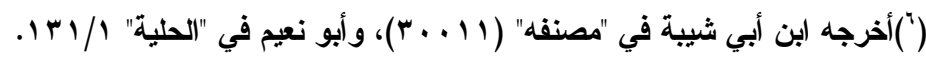

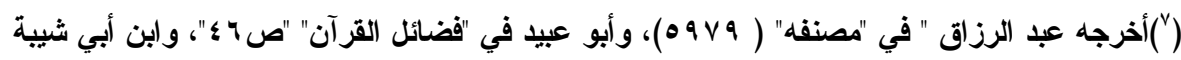

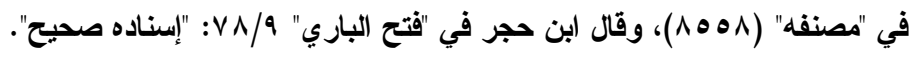

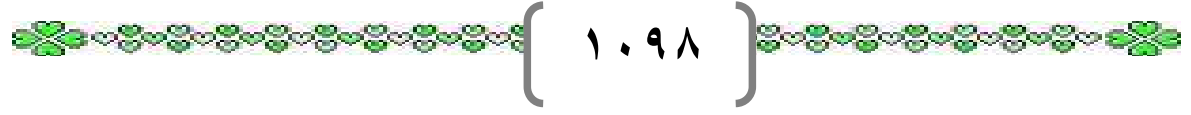




\section{ع. ـ أقو اله في آداب تلاوته:}

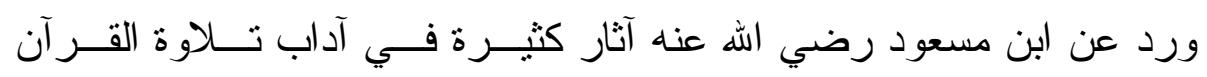

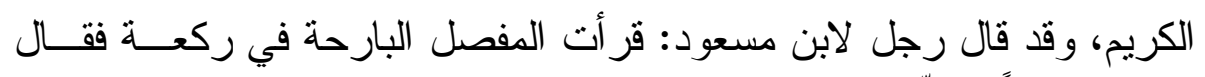

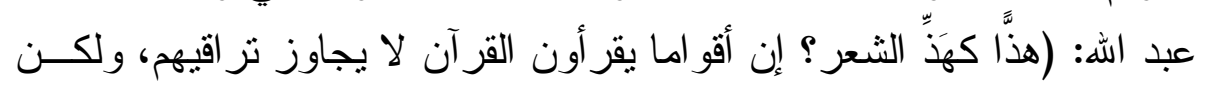

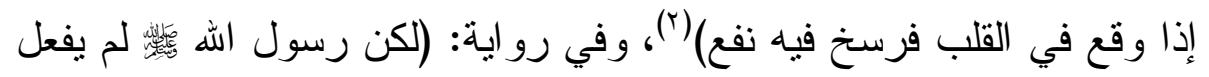
كما فعلت)(

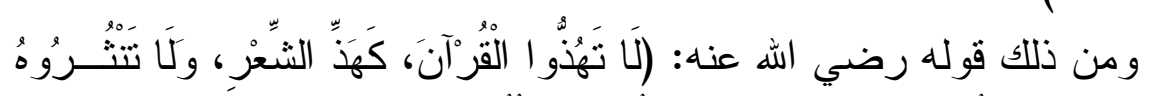

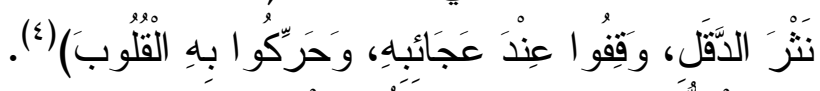

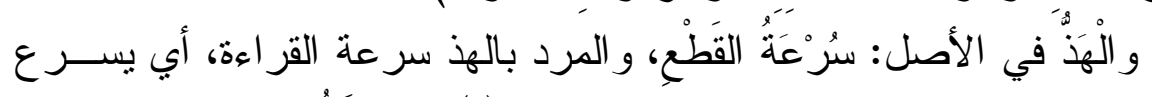

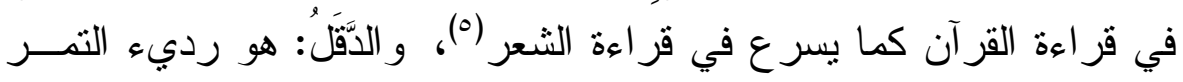

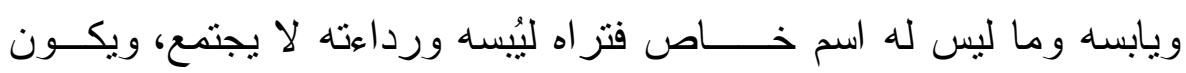

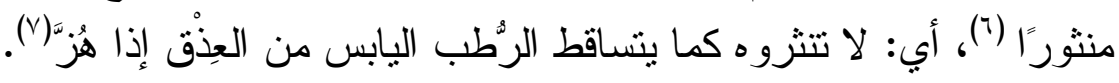

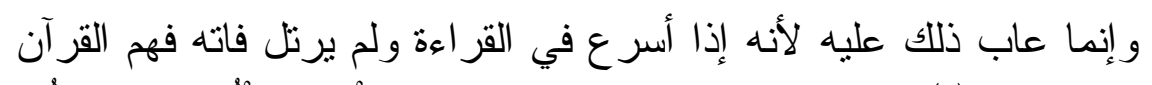

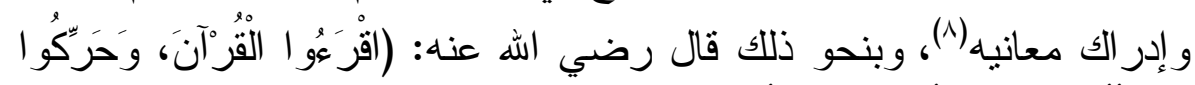

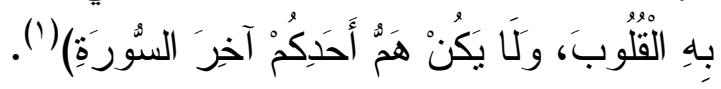

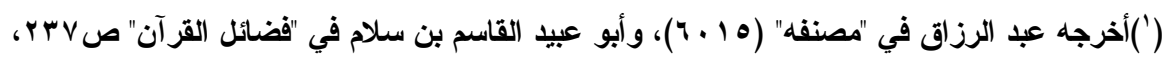

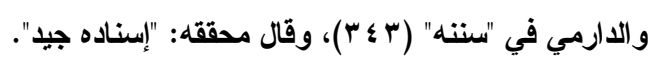

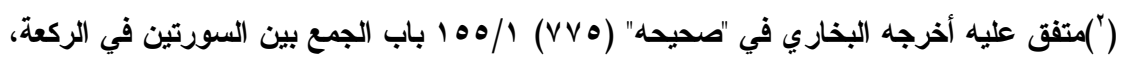

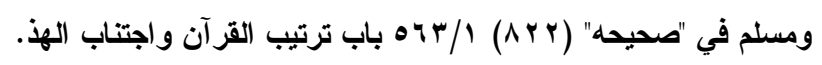

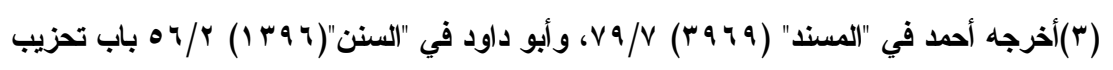
القرآن، وقال الأرناؤوط: "إسناده صحيح".

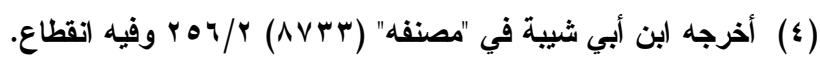

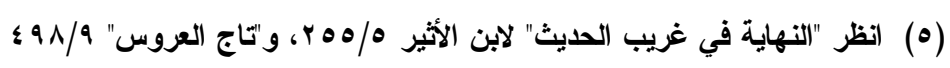

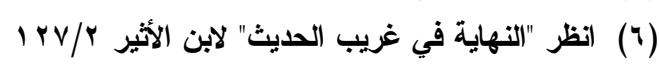
10/0 انظر المرجع السابق (V)

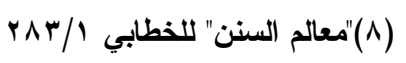




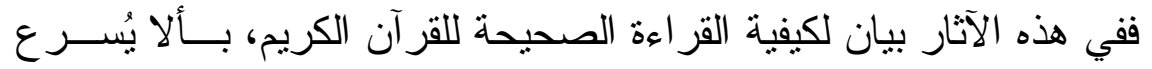

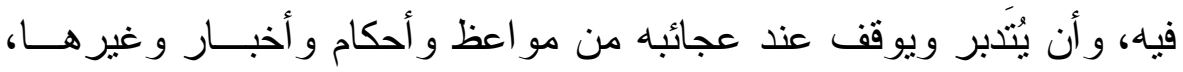

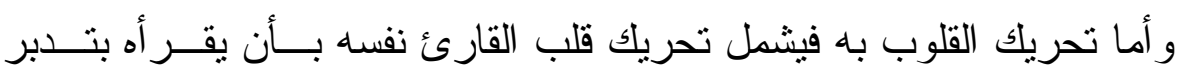
وكذلك أن يحرك به قلب غيره إذا تلا سو اء في الصلاة أو خارجها.

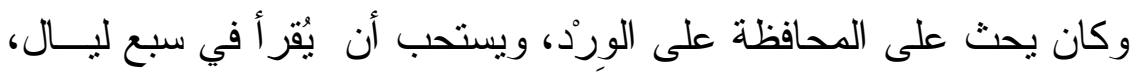

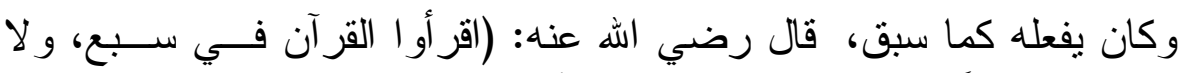

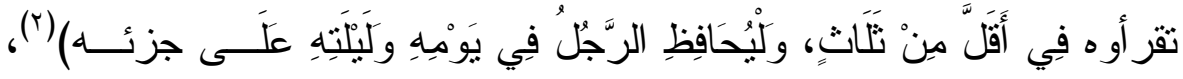
وقال: (من قر أ القر آن في أقل من ثناتث فهو راجز)(َ).

\section{هـ أقو الله في آداب حملته:}

قال رضي الله عنه: (بنبغي لحامل القرآن أن يعرف بليله إذا الناس نــائمون،

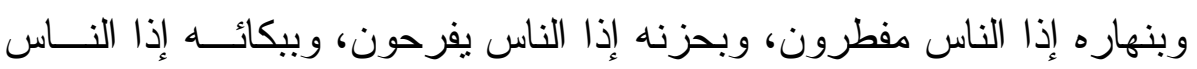

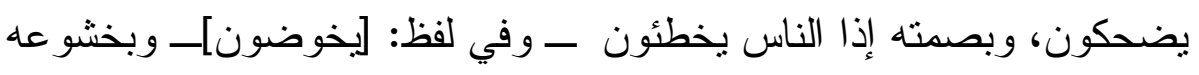

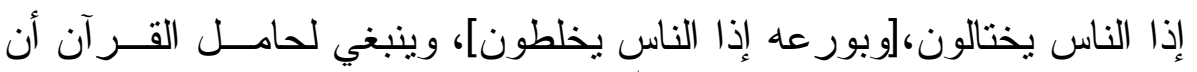

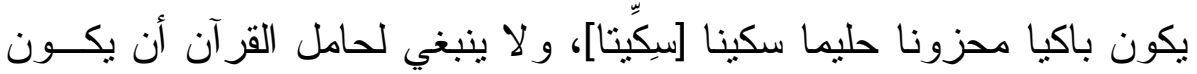

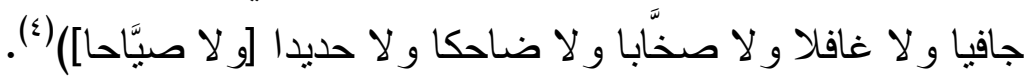

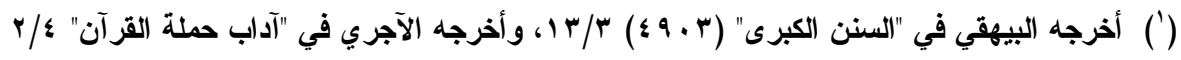

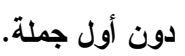

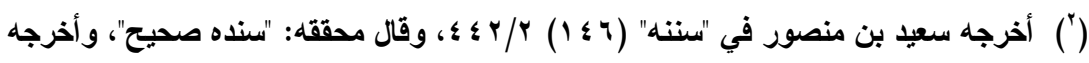

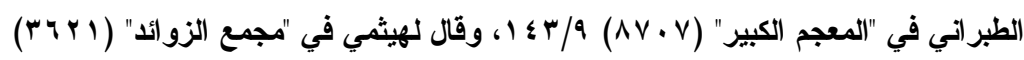

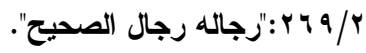

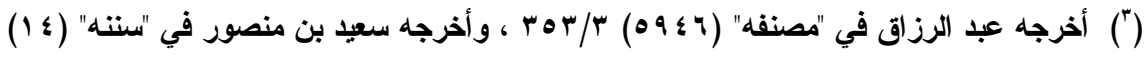

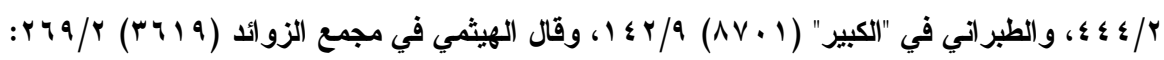

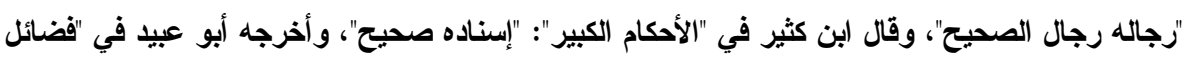

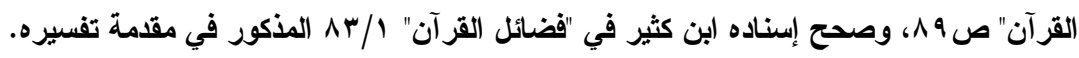

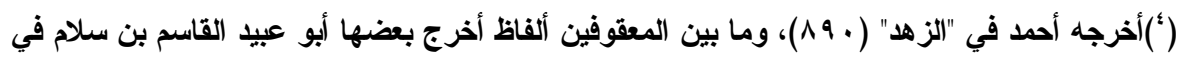

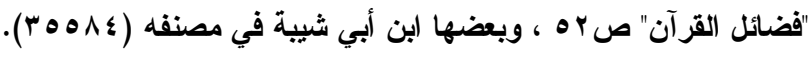

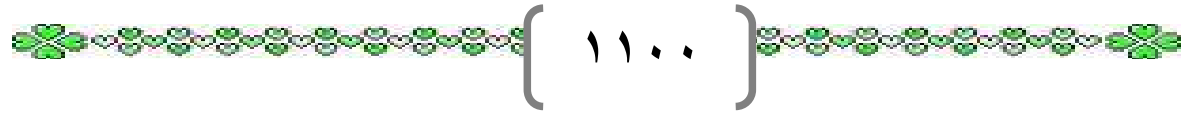




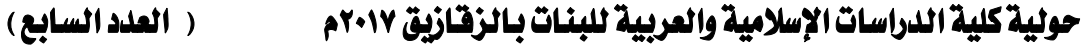

وكان رضي الله عنه يأمر بالاتباع وينهى عن الاختلاف في القرآن والتتازع

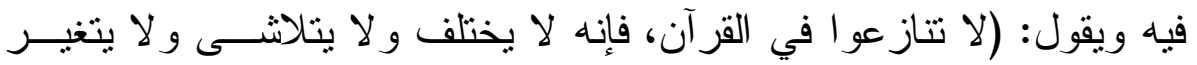

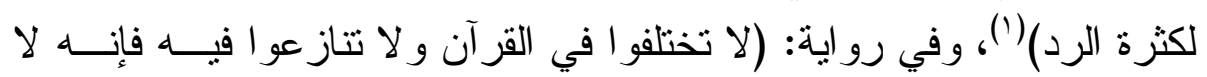

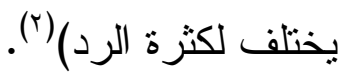

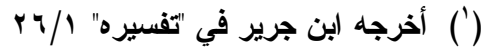

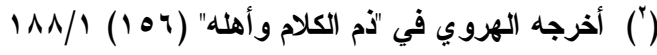




\section{خاتمة}

الحمد لله الذي بنعمته تتم الصالحات، وفي ختام هذا البحث المختصر أحب أن أثنير إلى بعض النتائج و التوصيات التي خلصت إليها، فأما النتائج فمنها:

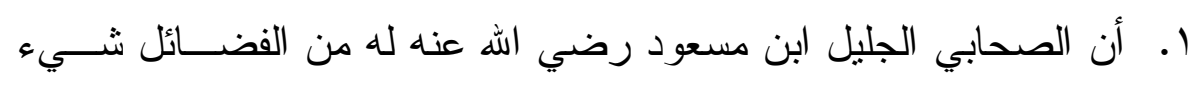
كثير، أثنى عليه النبي صلى الله عليه وسلم وكذا الصحابة ومن بعدهم.

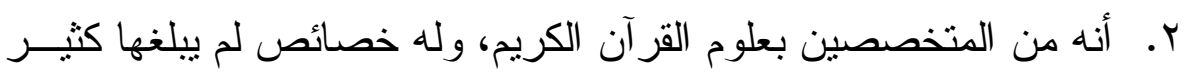
من الصحابة رضي الله عنهم.

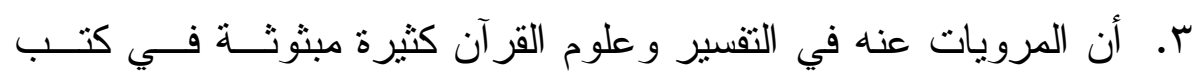
التقسير و السنة و الآثار ، وهو من الصحابة المكثرين من الرو اية. ـ. وجوب الرجوع إلى تفسير السلف، وخصوصا صحابة النبي صـــلى الله

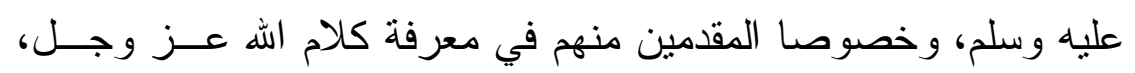
وأن معرفة تفسير هم للقر آن أصل أصيل من أصول علم التفسير وأما التوصيات فأوصي بالآتي:

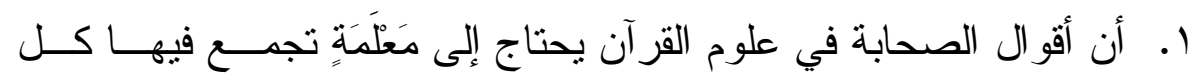

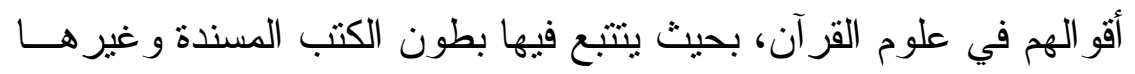

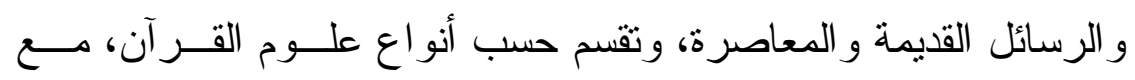

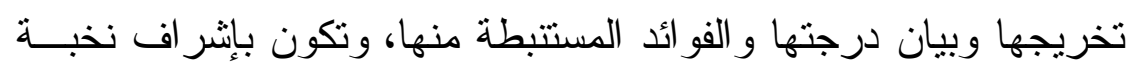
من العلماء و الباحثين المتخصصين تحت مظلة مؤسسة علمية ولهية.

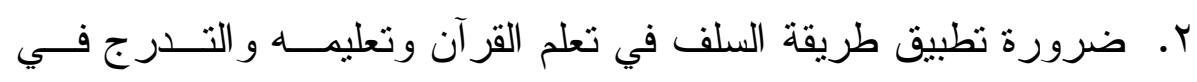

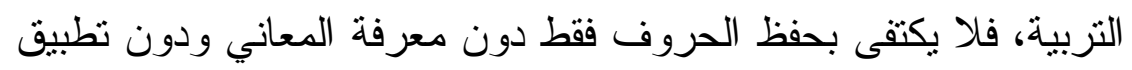

$$
\text { ما ورد في الآيات من أحكام و آداب. }
$$

r. إيجاد مقرر ات در اسية خاصة بعلوم القرآن تدرس في المرحلة الجامعية بحيث تكون مستقاة مما ورد عن النبي صلى الله عليه وسلم و الصــــابة فئل و التابعين، و لا تخلط بأقو ال غير هم إلا على سبيل الثر حن و البيان. 


\section{قائمة المصاص}

ا. إتحاف الخيرة المهرة بزو ائد المسانيد العشرة، تأليف: أحمد بن أبــي العياه بكر البوصيري، تحقيق: أبي تميم ياسر بــن إبــر اهيم، دار الــوطن

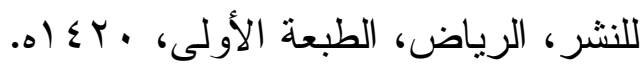

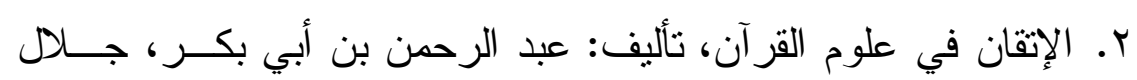

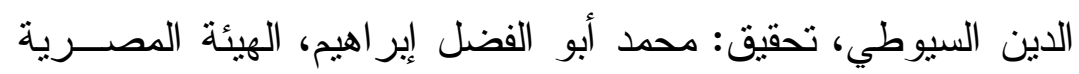

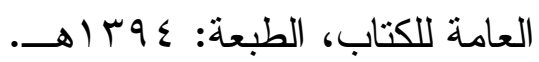

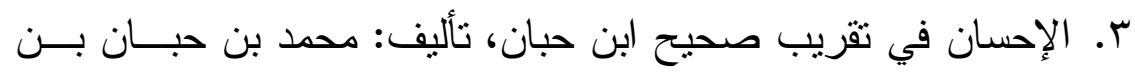

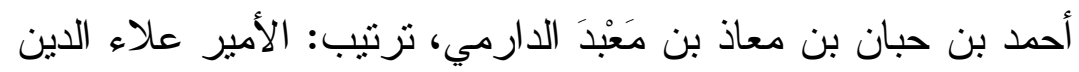

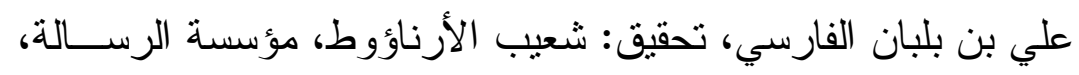

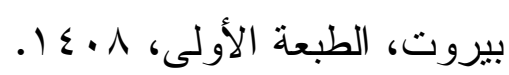

ع. الاستيعاب في معرفة الأصحاب، تأليف: يوسف بن عبد الله ابن عبد الأب

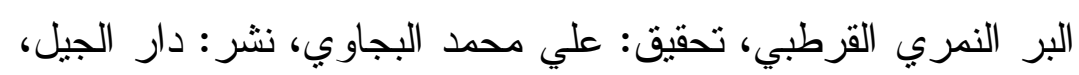

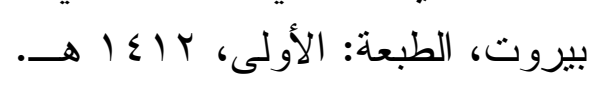

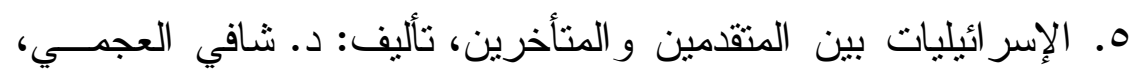

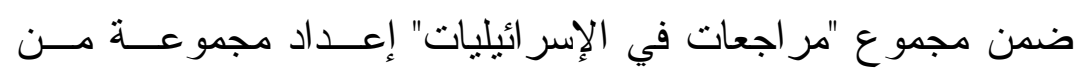

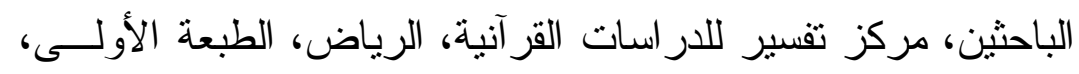

$$
.01 \leqslant 4
$$

7. الإصابة في تمييز الصحابة، تأليف: أحمد بن علي بن محمد بن أحمد بن

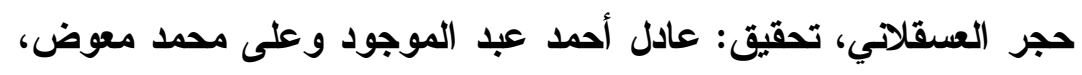

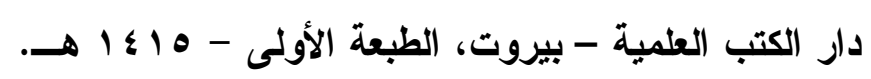

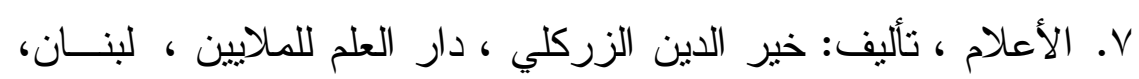

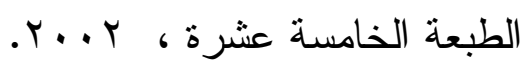


^. تاريخ الإسلام ووفيات مشـاهير الأعلام ، تأليف: محمـــــــن أحمـــ

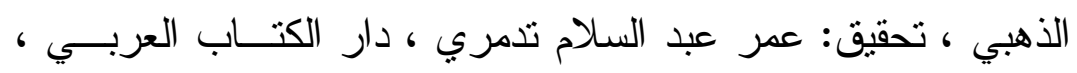

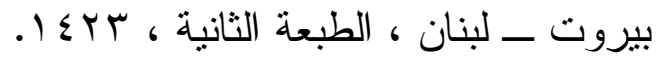

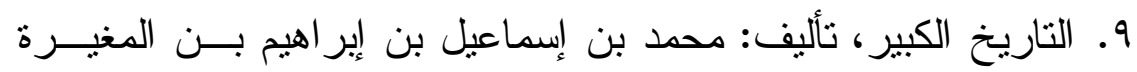

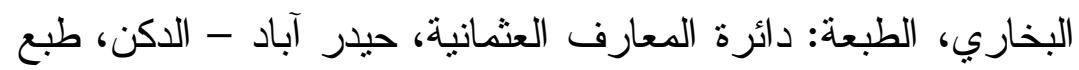

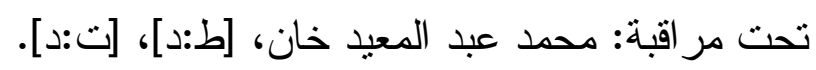

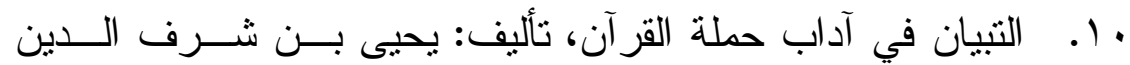
النووي، تحقيق: محمد الحجار، دار ابن حزم، بيروت، لبنان، الطبعة

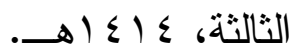

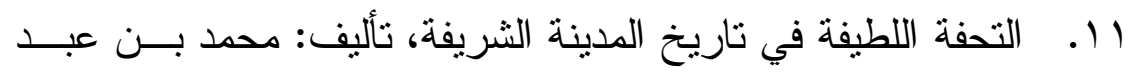

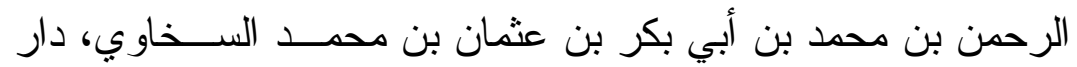

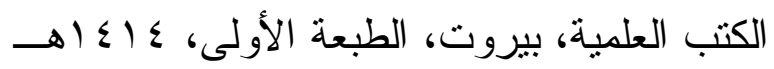

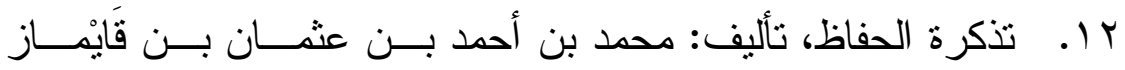

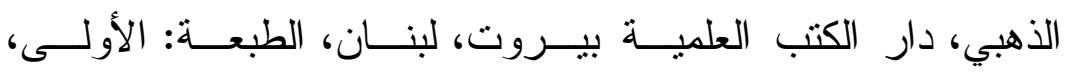
. 1519

با. . التصريح بمضمون التوضيح، تأليف: خالد زين الدين بن عبد الله

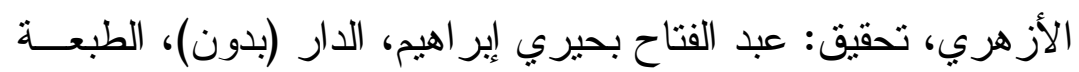

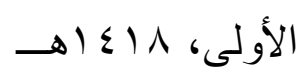

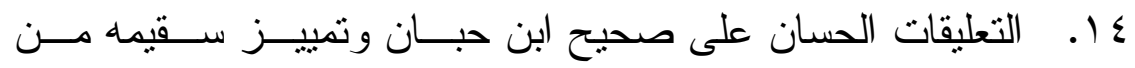

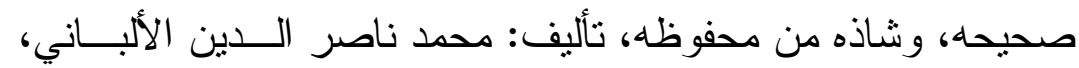

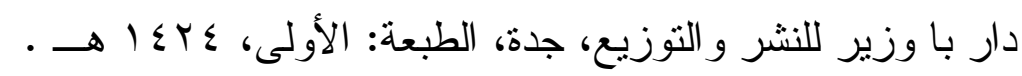

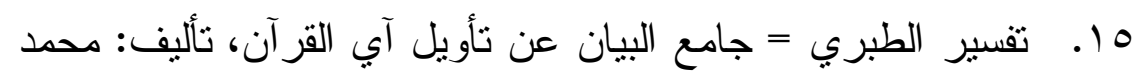

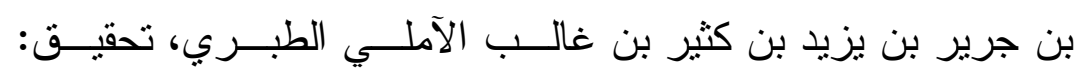

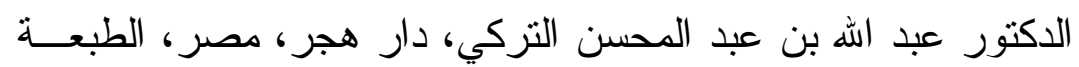

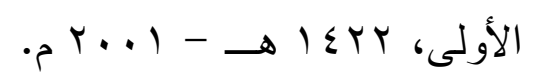


7 ا ـ تفسير القرآن العظيم، تأليف: عبد الرحمن بن محمد بن إدريس بن

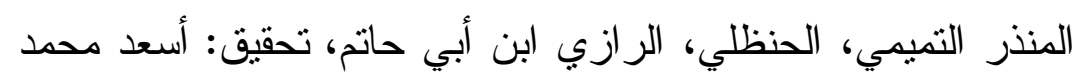

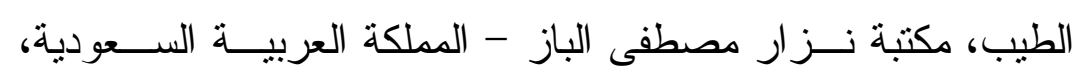

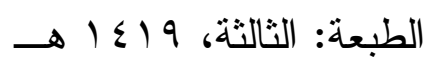

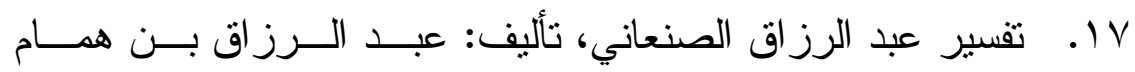
الصنعاني، دار الكتب العلمية، بيروت، الطبعة الأولى، [ت:دد].

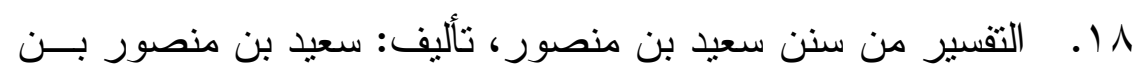

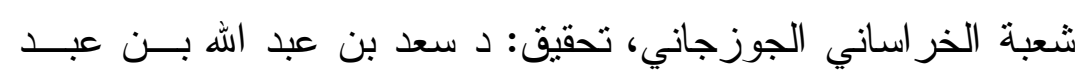

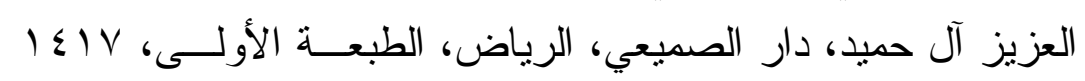

$$
\text { م) } 99 \mathrm{~V}-\mathrm{C}
$$

9 1. تقريب التهذيب، تأليف: أحمد بن علي بن محمد بن أحمد بن حجر

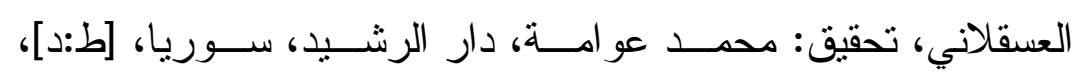

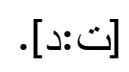

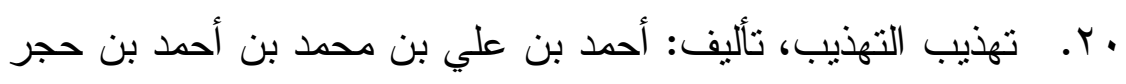

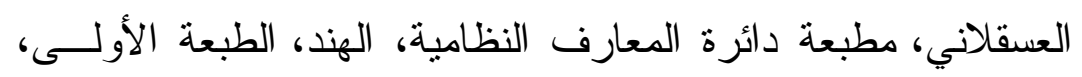

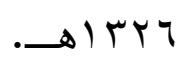

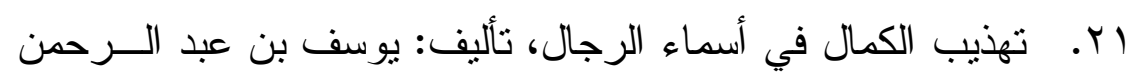

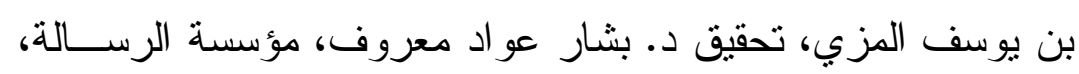

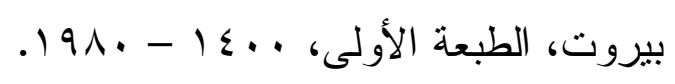

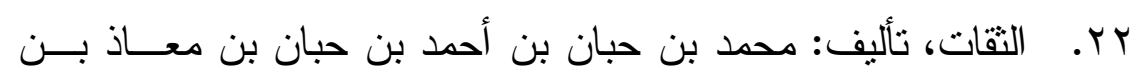

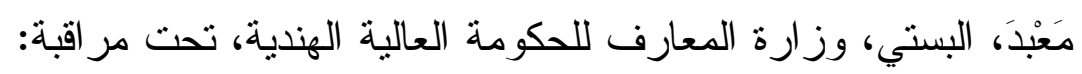

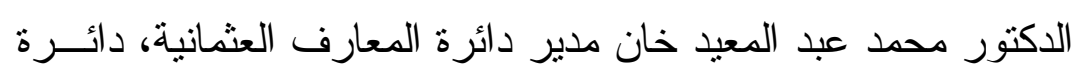

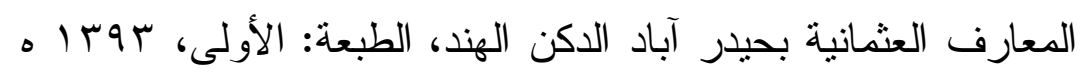

$$
19 V T=
$$


بr. الجامع لأحكام القرآن = تقسير القرطبي، تأليف: محمد بن أحمـــ

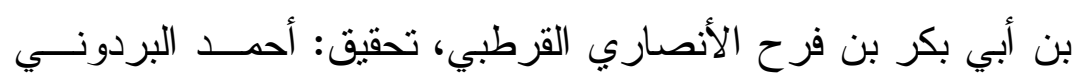

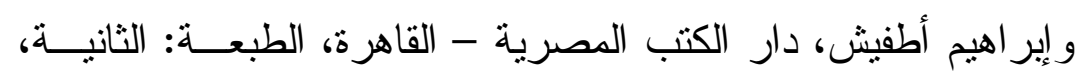

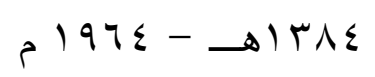

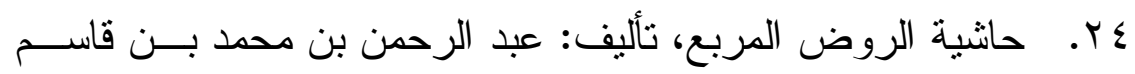

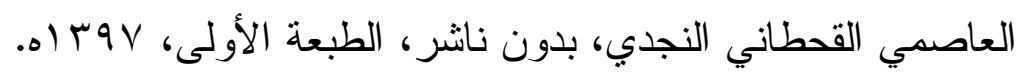

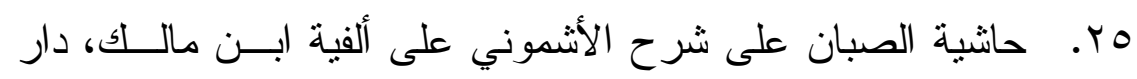

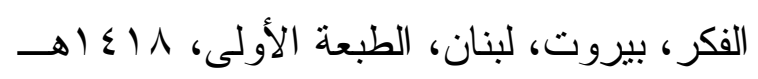

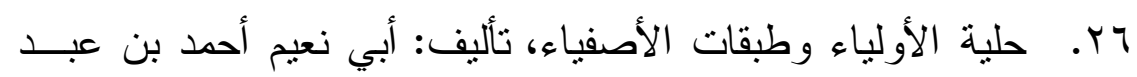

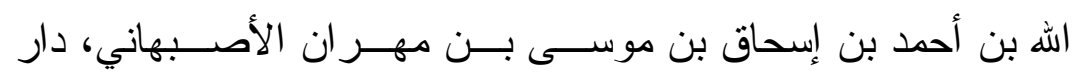

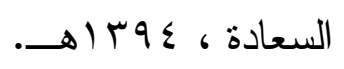

rV

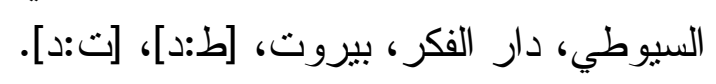

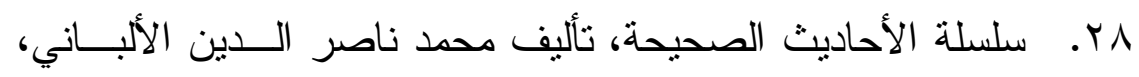

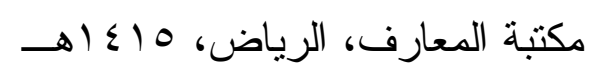

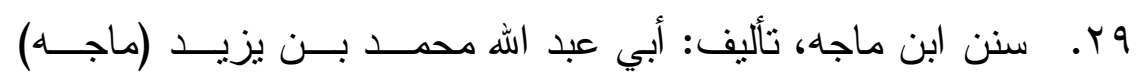

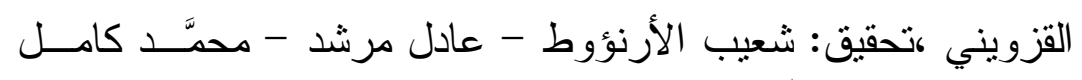

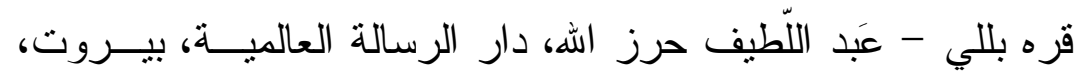

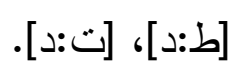

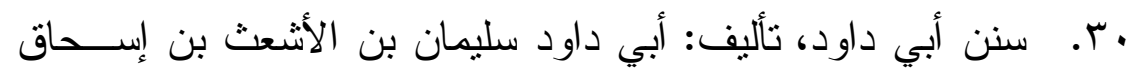

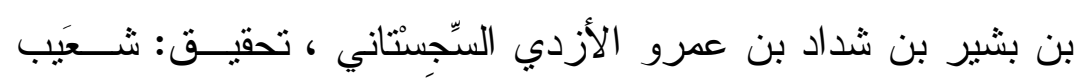

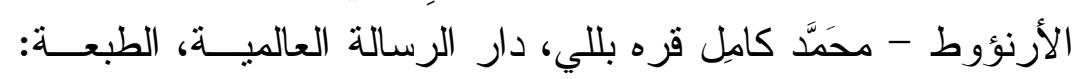

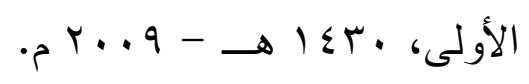


اس. سنـن الدارمي، تأليف: عبد الله بن عبد الرحمن بن الفضــل بــن

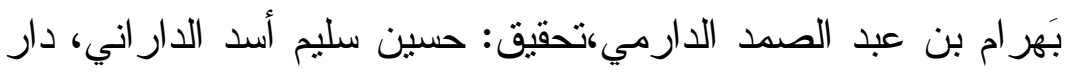

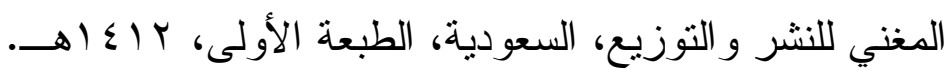

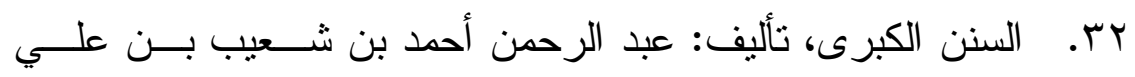

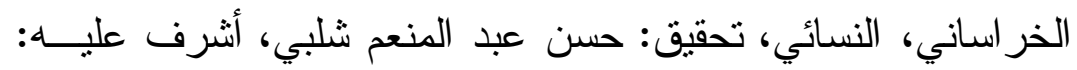

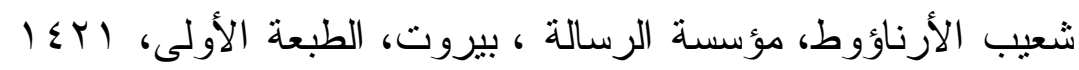

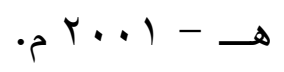

سب. سير أعلام النبلاء، تأليف: محمد بن أحمد بن عثمان بــن قَايْهــاز

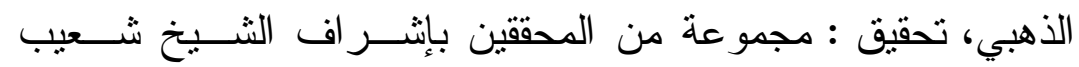

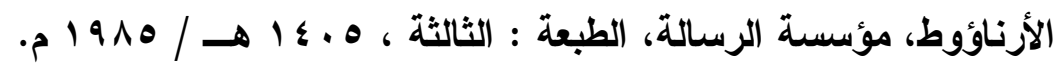

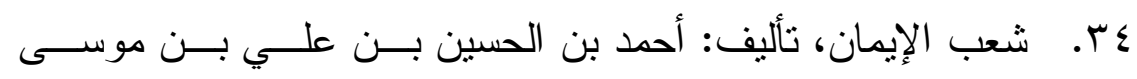

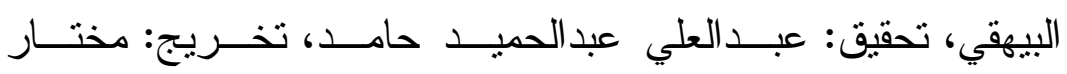

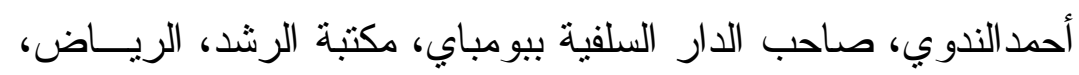

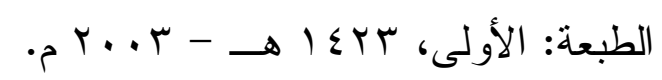

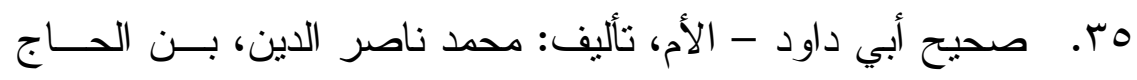

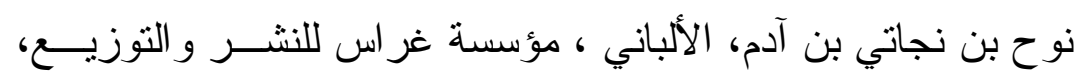

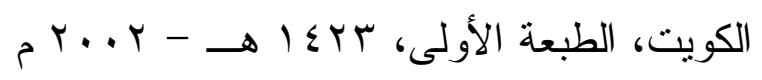

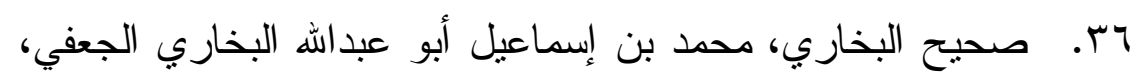

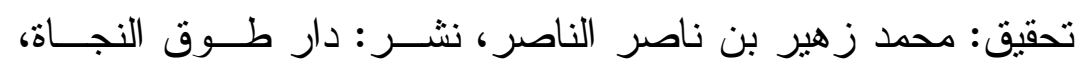

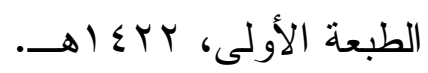

rV

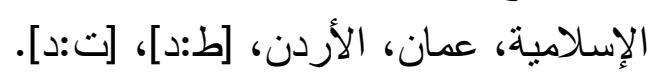

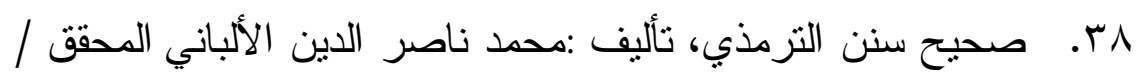

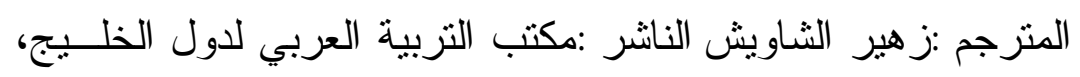

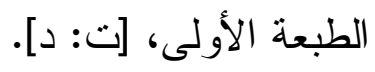

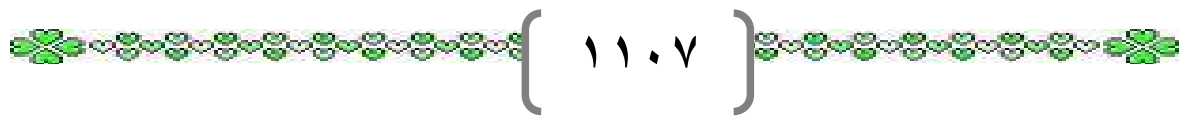


q. صحيح مسلم بن الحجاج أبو الحسن القتيري النيسابوري، تحقيق:

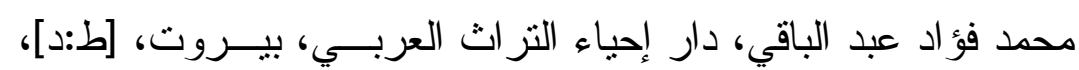

$$
\text { [ـ:ت] }
$$

• ع. صحيح وضعيف الجامع الصغير وزيادته، تأليف: محمــــ ناصــر الادين الألباني، المكتب الإسلامي، بيروت.

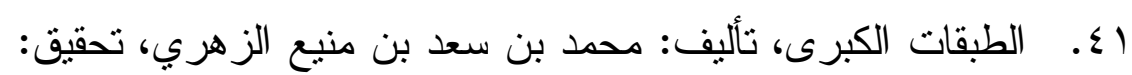

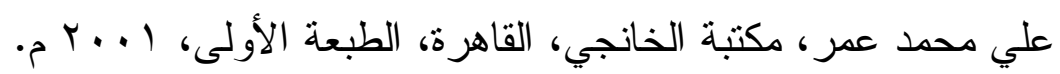

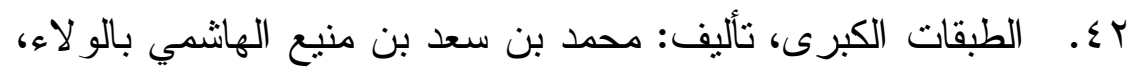

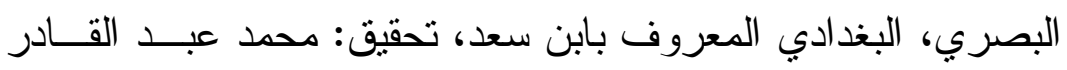

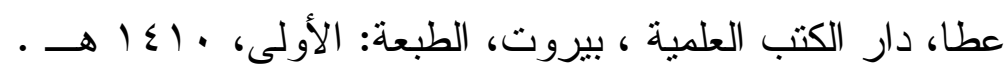

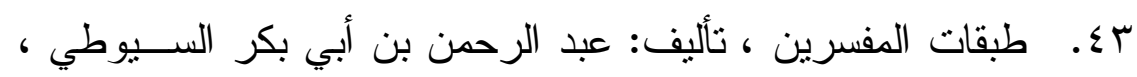
دار الكتب العلمية ، بيروت ـ لبنان ، [ط:د]، [ت:دئ.

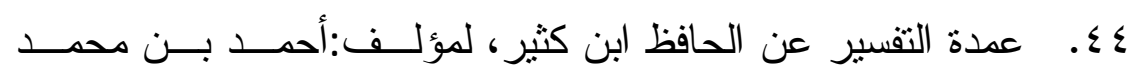

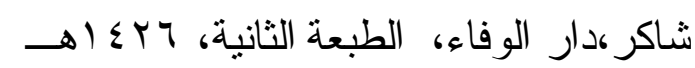

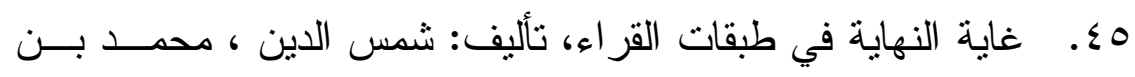

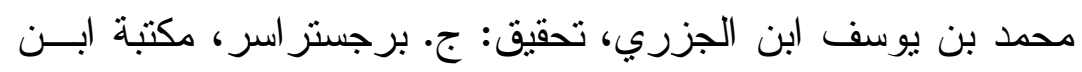

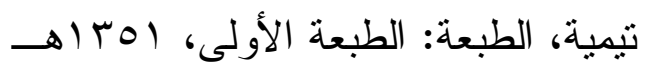

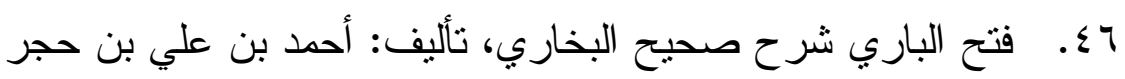

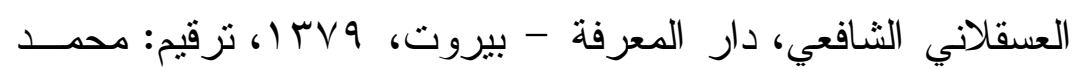

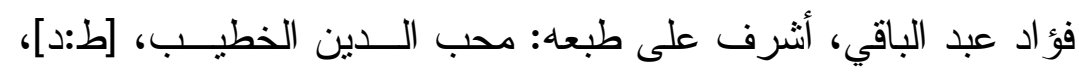

$$
\text { [ت: }
$$

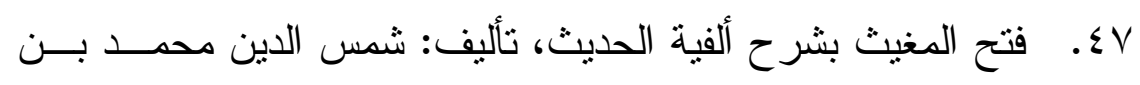

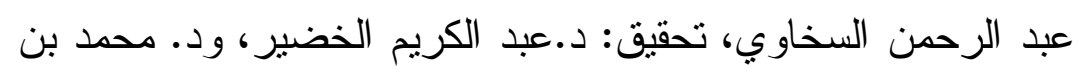

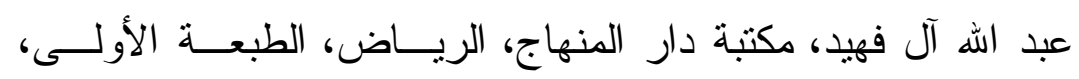
. إ

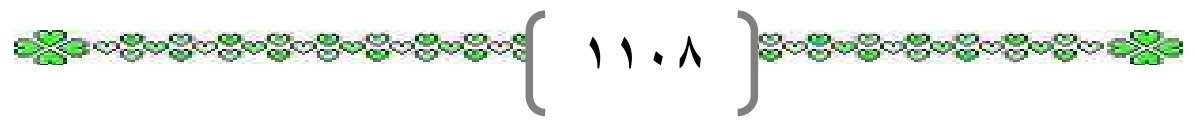


يــ فضائل الصحابة، تأليف: أحمد بن محمد بن حنبـلـ، تحقبــق : د.

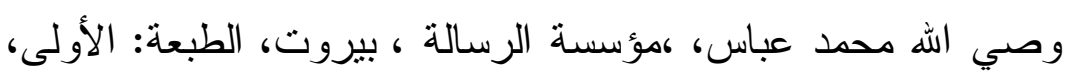

$$
\text { . } 15 \cdot r
$$

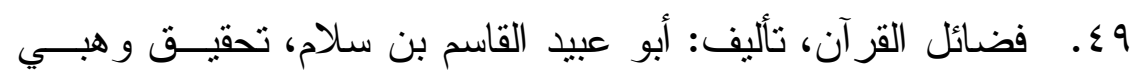

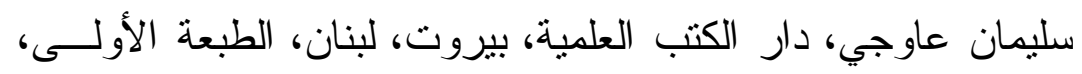
ه

•. . فضائل القرآن، تأليف: أبي عُبيد القاسم بن سلاّم البغدادي، تحقيق

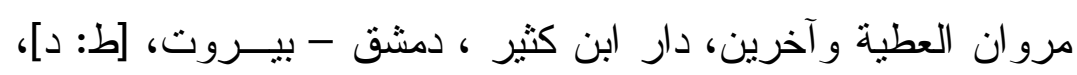
$\rightarrow 1 \leq r$.

10. القاموس المحيط، تأليف: محمد بن يعقوب القيروز آبادى، تحقيــق:

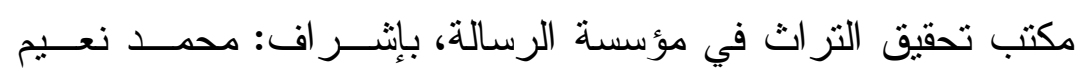

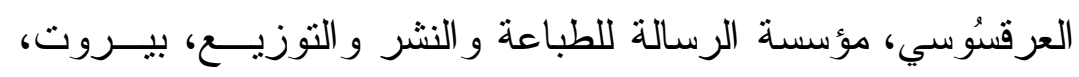

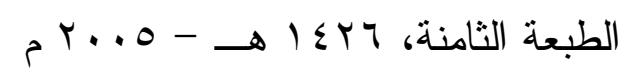

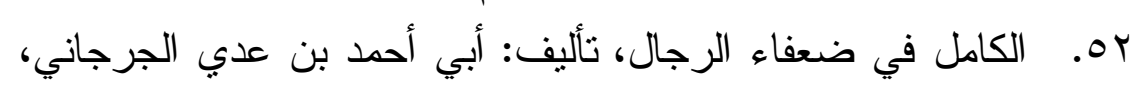

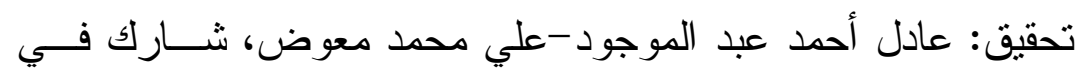

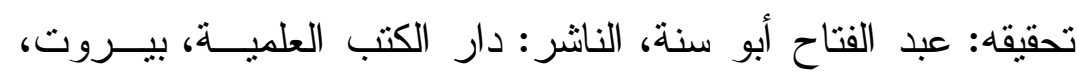

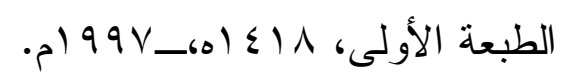

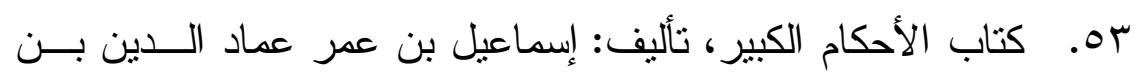

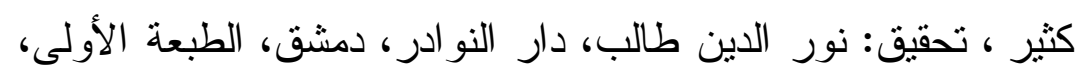

$$
.01 \leqslant 1
$$

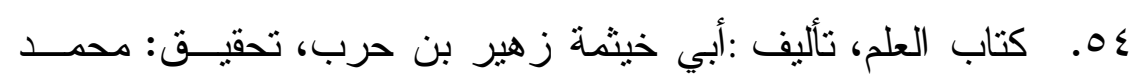

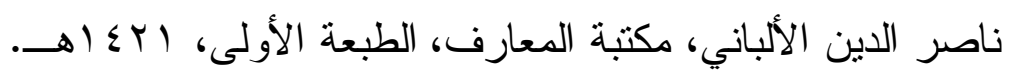

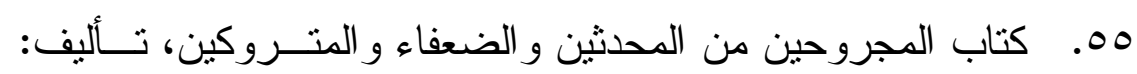

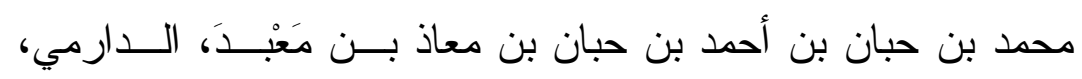




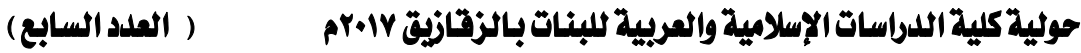

تحقيق: محمود إير اهيم ز ايد، دار الوعي، حلـب، الطبعــة الأولــى، . 1197

ه7. الكتاب المصنف في الأحاديث و الآثار ، تأليف: عبد الله بن محمـــ

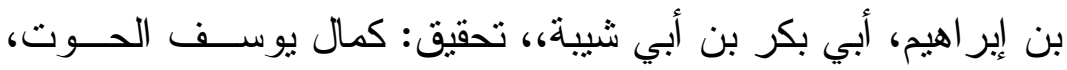

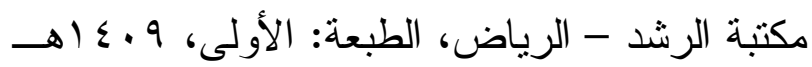

OV

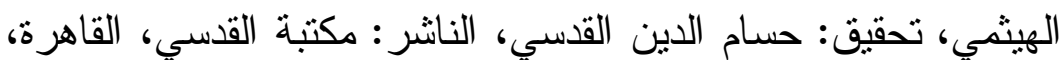

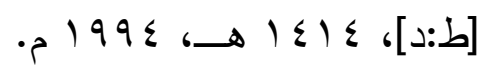

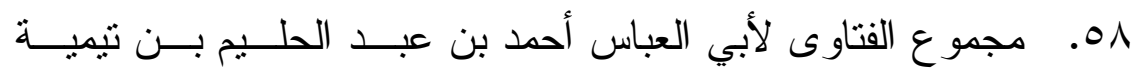

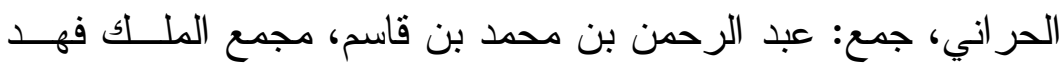

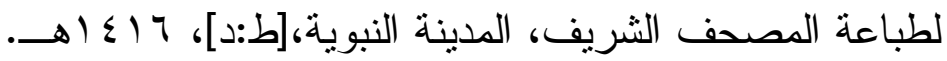
ه9. المحرر الوجيز في تفسير الكتاب العزيز، تأليف: عبد الحق بــن

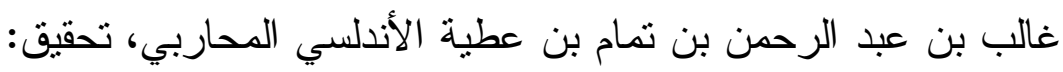

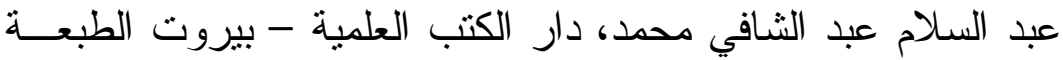

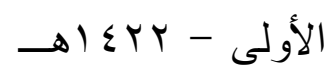

• 7. المدخل إلى السنن الكبرى، تأليف: أحمد بن الحسين بن علي بــن موسى البيهقي، تحقيق: محمد ضياء الرحمن الأعظمي، دار الخلفــاء

$$
\text { للكتاب الإسلامي - الكويت [ط:د]، [ت:دـ]. }
$$

ا7. المستدرك على الصحيحين، تأليف: أبي عبد الله الحاكم محمد بــن عبد الله بن محمد بن حمدويه بن نُعيم النيسابوري، تحقيق: مصطفى بـى عبد القادر عطا، دار الكتب العلمية ، بيروت، [ط:د]، [ت:دئ.

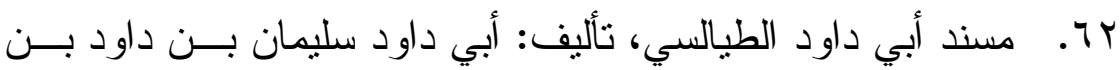

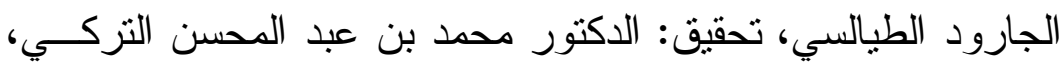

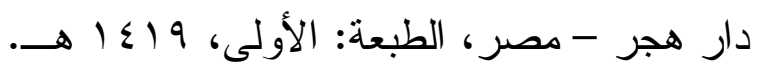


با7. مسند الإمام أحمد بن حنبل، تأليف: أبي عبد الله أحمد بن محمـــ

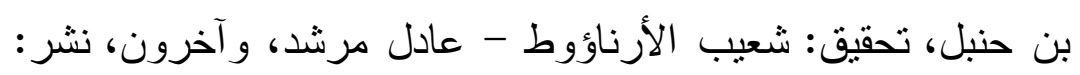

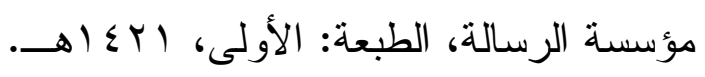

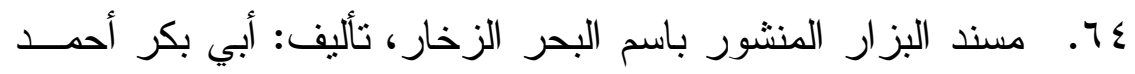

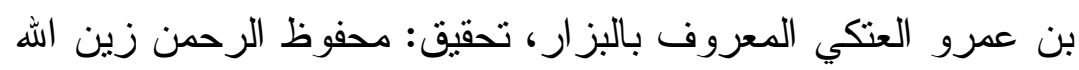

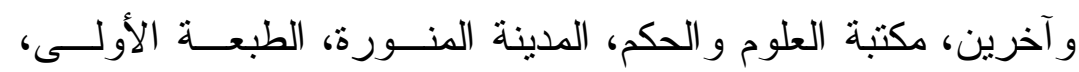
[ت]

7. . مسند الدارمي المعروف بـــ (سنن الدارمي)، المؤلف: أبو محمــــ

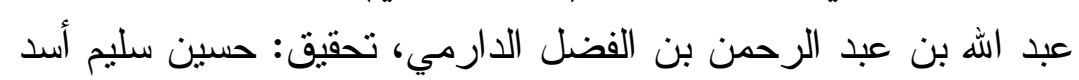

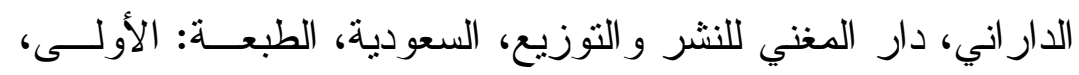

$$
\text { . r...- - ד I I }
$$

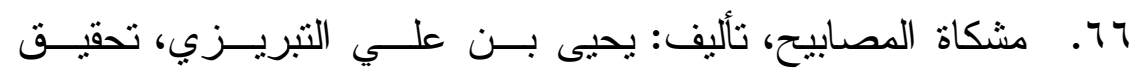

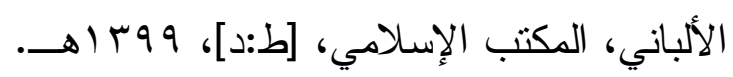

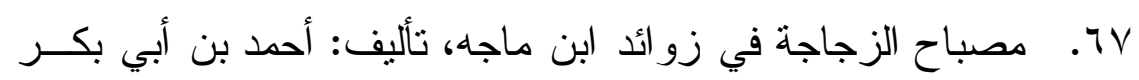

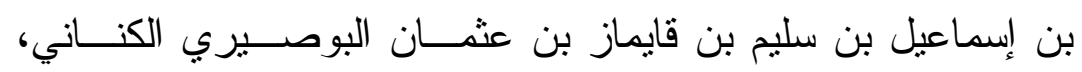

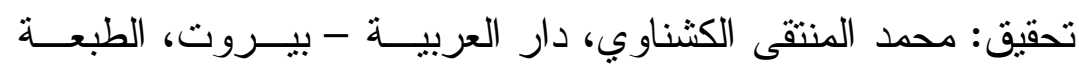

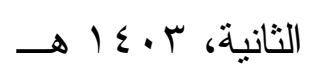

1 ا. المصنف، تأليف: عبد الرزاق بن همام بن نافع الحميري اليمـاني

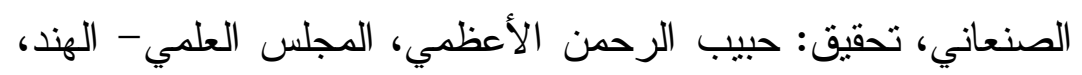

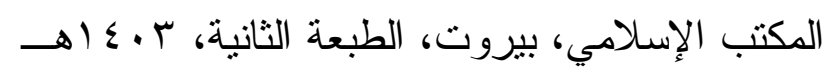

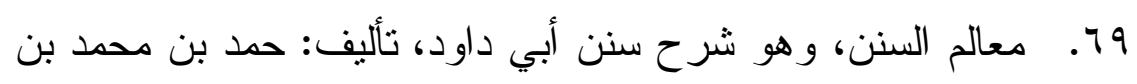

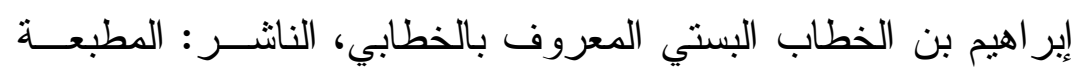

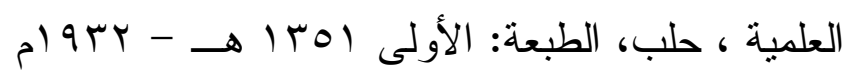


• .

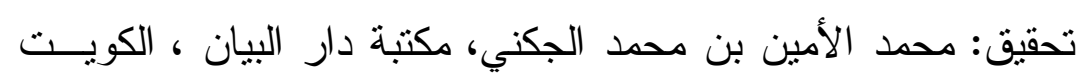

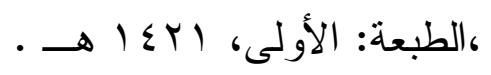

V) المعجم الكبير، تأليف: سليمان بن أحمد بن أيوب بن مطير اللخمي

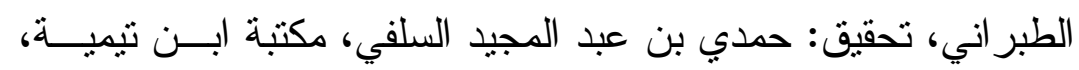

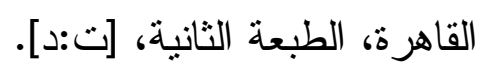
Vr

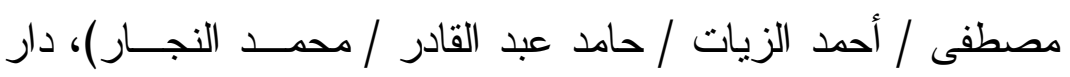

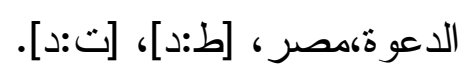

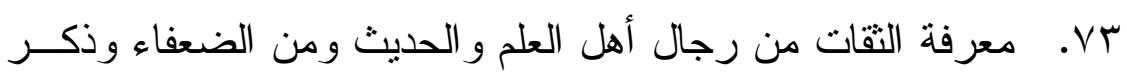

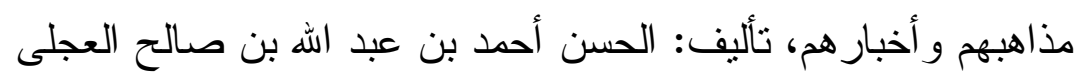

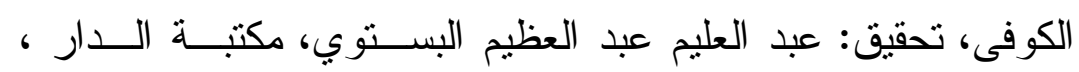

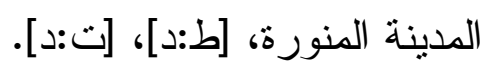

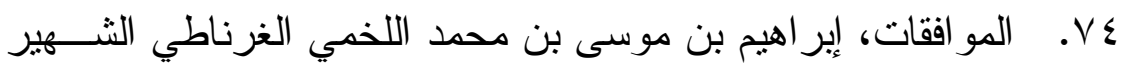

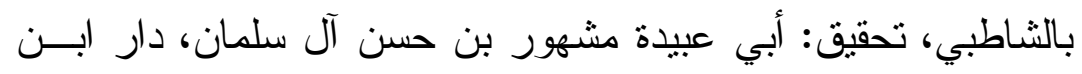

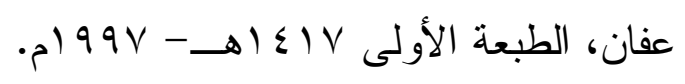

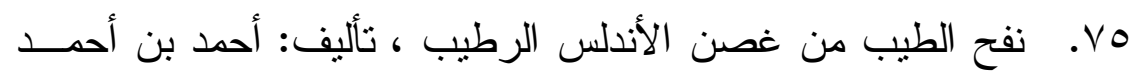

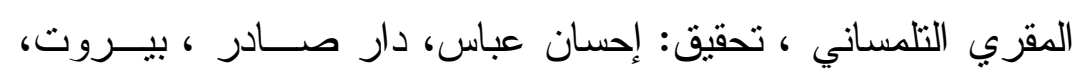

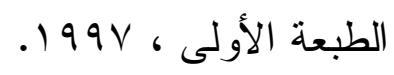
V7. النهاية في غريب الحديث و الأثز، تأليف: المبارك بن محمد بـن محمد بن محمد ابن عبد الكريم الثيباني الجزري ابن الأثير، تحقيق:

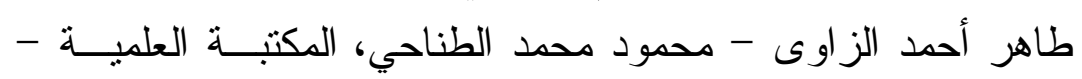

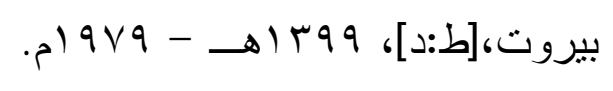




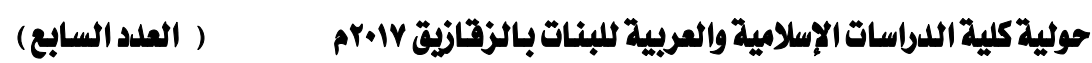

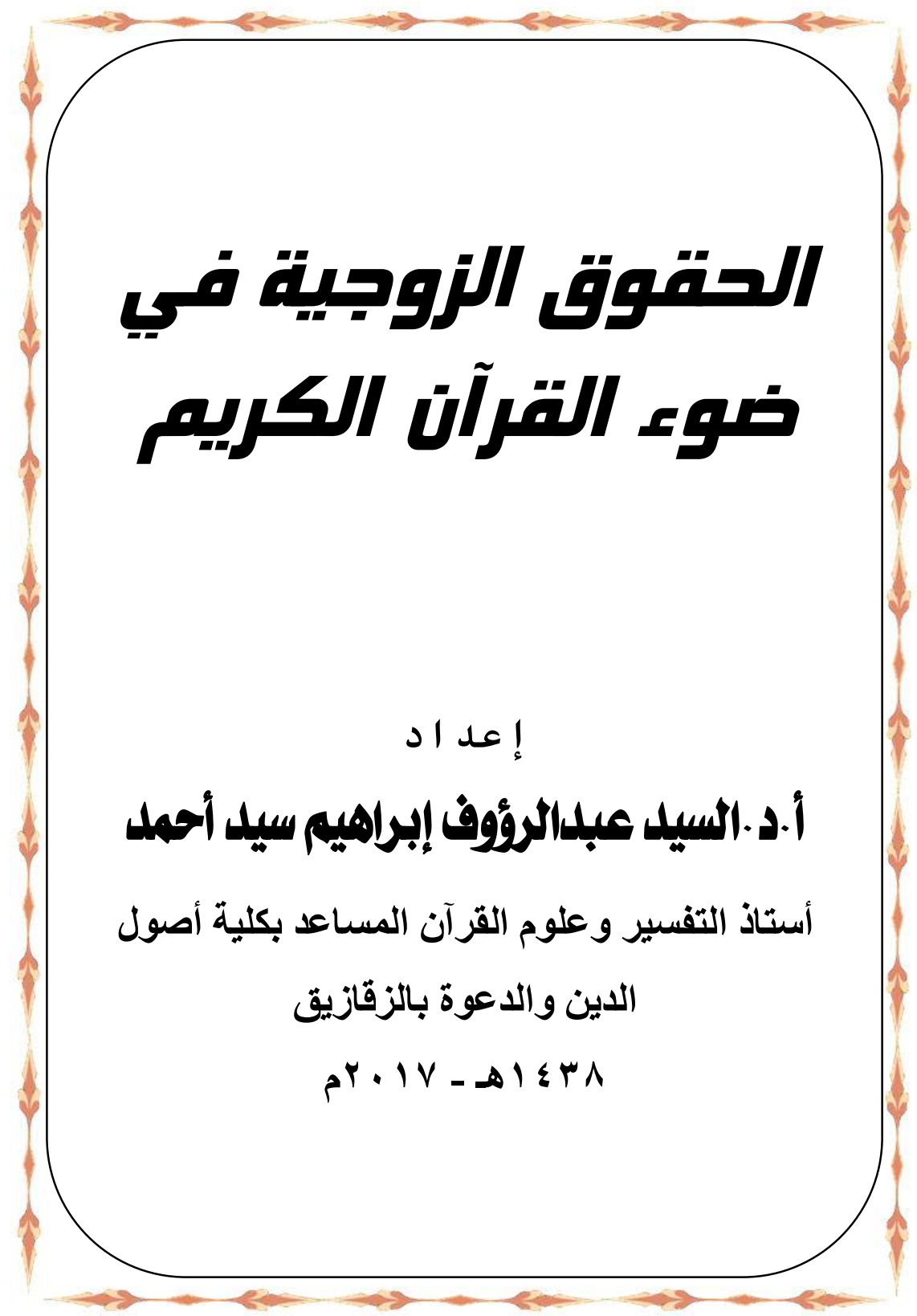




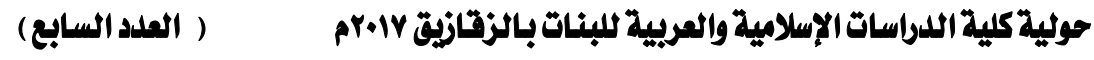

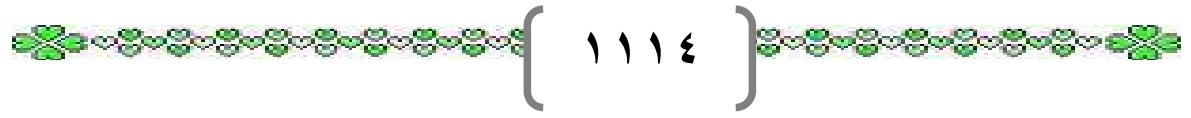




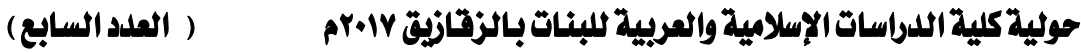

\section{مـقــل مـــ}

الحمد لله والصلاة و السلام على سيدنا رسول الله تو لاه؛

وبعد ؛؛؛

فقد شاءت حكمة الله تعالي أن تكون عمارة الأرض وصلاح الحياة فيها مرتبطك بالزوجية التي شرعها الله تعالي للإنسان، ونشاهدها في الحيوان، بل وفي عالم النبات .

قال تعالي:

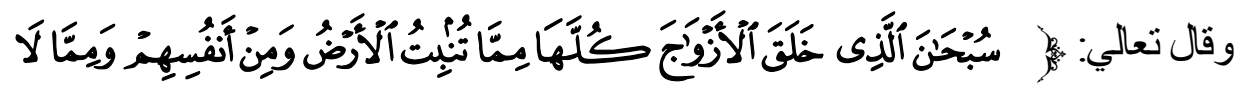

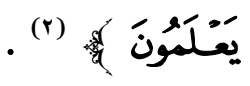

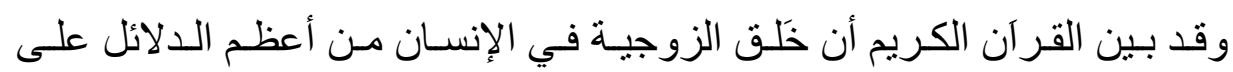

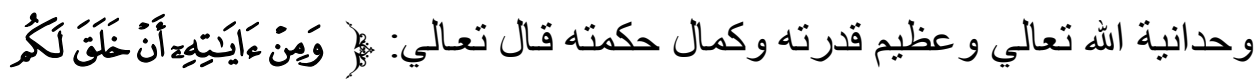

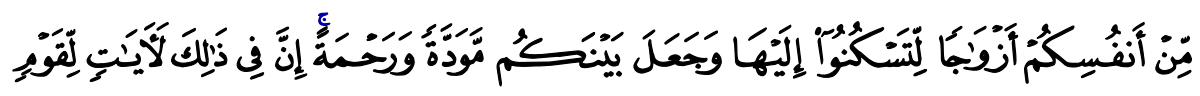

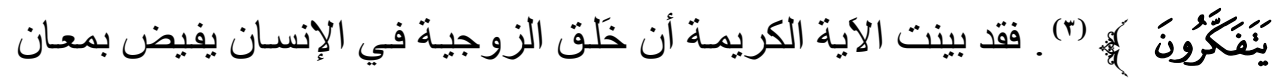
ثناث :السكن، و المودة، و الرحمـة ، ونحن في عصرنا الحاضـر نري المشـاكل في

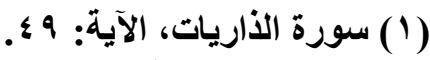

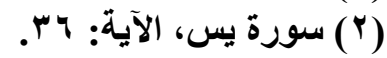

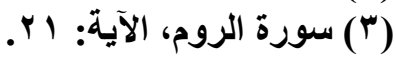




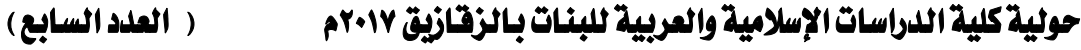

الحياة الزوجيـة تزداد يومـا بعد يوم، وتعصفـُ الأقلام المنحرفة عن هدي الإسـلام بالأسر و البيوت حتي أصبحت هذه المعاني أثراً بعد عين . ولمـا كـان واقع المجتمع يـن بمشـاكل زوجيـة طافحـة ترتب عليها قطع أواصـر المودة و الرحمة بين الناس حتى أصبح الزوجان الأليفان عدوين لدودين يتفنن كل واحـد منهمــا في أذيـة الآخـر و التخلص منـهـ ممــا تـرك آتـار ا سـلبية على الأسـرة و المجنمع. فكم من أسرة تمزق شملها بعد اجتمـاع، وكم من بيوت أتت عليها معاول الهدم و الفشـل و الضـياع، فكم من فتـاة شـابة طلقت في مهد زو اجها و أصسبحت عرضــة للانحر اف و الضياع ومـا أكثر هن، وكم من زوجة خلعت نفسها ر اكبـة متن التمرد و الشطط دون استماع للحق و انصياع. و مردُّ ذلك كله إلي البعد عن تعاليم الإسلام ومبادئه التي ترسم معالم الحياة السعيدة لكلا الزوجين وتضع الأسس القويمة لاستقرار الأسر والبيوت. إن سـعادة المجتمع لا تتحقق الإ بصيانة الأسرة عن طريـق الرجوع إلـي مبـادئ الثرع القويم الذي يرعاها، ويهيئ دعائم الاستقر ار لها بما أوجب علي كلا الزوجين من حقوق وو اجبات بحيث لا يطلب أحدهما من الأخر حقه إلا بعدما يؤدي الواجب

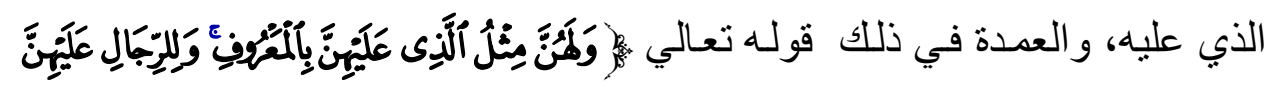

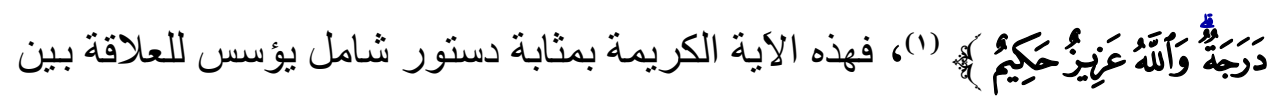
الزوجين، ويقرر المساو اة فى استيفاء الحق و أداء الواجب.

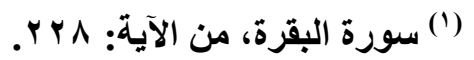

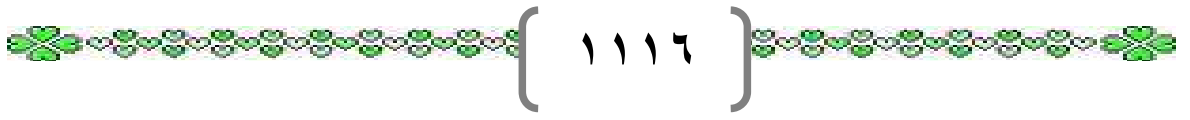




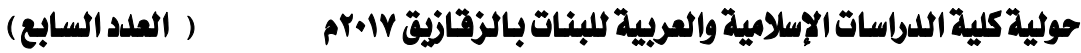

وقد بيَّنت الحقوق الزوجيـة في هذا البحث وجعلته تحت عنوان الحقـوق

\section{الزوجية في ضوء القرآن الكريم)}

وقد اشتمل هذا البحث على مقدمة، وتمهيد، وثلاثة مباحث، وخاتمة، وفهارس. أما المقدمة: تحدثت فيها عن الموضوع، وأهميته، ومنهج البحث فيه. وأما التمهيل: تحدثت فيه عن بيان معنى الحقوق الزوجية لغة و اصطلاحا. وجـاء المبحث الأول تحت عنوان ( حقوق الزوجـة) وبدأت بها باعتبار هـا وصية رسول الله

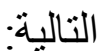

المطلب الأول: الصداق أو المهر. المطلب الثاني: النفقة.

المطلب الثالث: تعليمها أمور دينها. المطلب الرابع: العدل عند تعدد الزوجات. المطلب الخامس: الغيرة على نسائه. المطلب السادس: الخلع. المطلب السابع: المتعة. المبحث الثاني ( حقوق الزوج) وضمنته المطالب التالية: المطلب الأول: القوامة. المطلب الثاني: الطاعة. المطلب الثالث: القرار في البيت. المطلب الرابع: الطلاق. المطلب الخامس: الرجعة.

المبحث الثالث ( الحقوق المشتركة بين الزوجين) وقد ضمنته المطالب التالية: 


$$
\begin{aligned}
& \text { المطلب الأول: حسن العثرة. } \\
& \text { المطلب الثاني: الاستمتاع. } \\
& \text { المطلب الثالث: النظافة. } \\
& \text { المطلب الرابع: ثبوت النسب. } \\
& \text { المطلب الخامس: التوارث. } \\
& \text { ثم ذيلت البحث بخاتمة وفهارس. }
\end{aligned}
$$




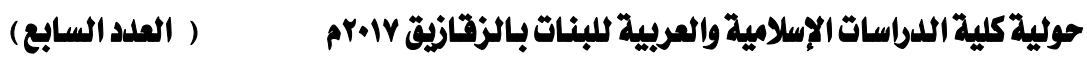

\section{تمهنيا \\ تعريف الحقوق الزوجية في اللغة والاصطلاح:- \\ أولأ : تعريف الحقوق في اللغة.}

الحقوق جمع حق والحق بطلق في اللغة علي عدة معان ذكرها صاحب

القاموس المحيط، فقال: الحق من أسماء الله تعالي، أو من صفاته والقرآن، وضد الباطل والأمر المُفضيُ، والعدل، والإسلام، والمال، والملك، والموجود الثابت، و الصدق، و الموت، و الحزم (1).

وقال الجوهري: وحق الثئ يَحِقُ ( بالكسر ) أي : وجب، وأحققت الثئ أي:

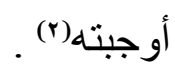

وقال الإمام الفيومي في المصباح المنير: الحق خلاف الباطل، وهومصدر حق الشئ من بَابَي ضرب وقتل إذا وجب (r) .

وقال الإمام المناوي: الحق لغة: الثابت الذي لا يُسوَغ إنكاره (๕) . وقال الإمام الر اغب: أصل الحق المطابقة والمو افقة (0). والخلاصة: أن مادة ( ح ق ق ) تدور حول عدة معان من أهمها :الوجوب، و الإلزام، و الثبات، والإحكام، والصحة، ولهذا قال ابن فارس: في مقاييس اللغة:

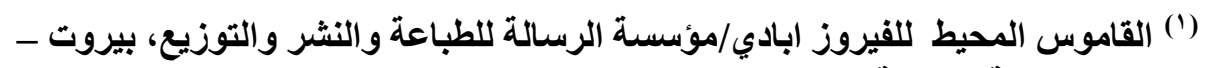

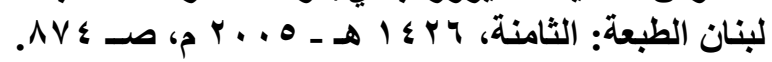

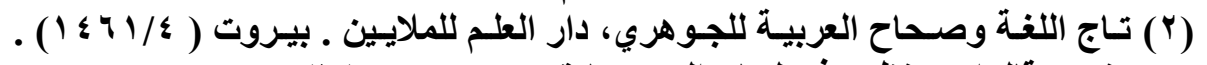

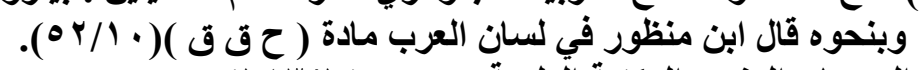

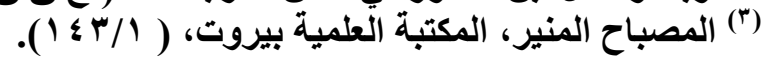

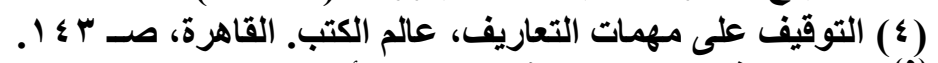

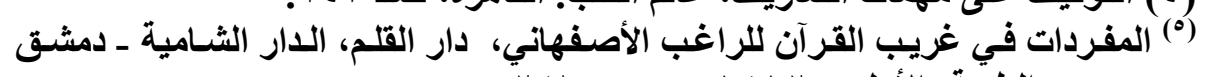

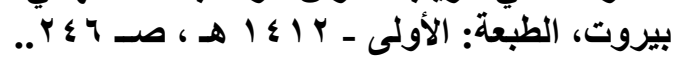

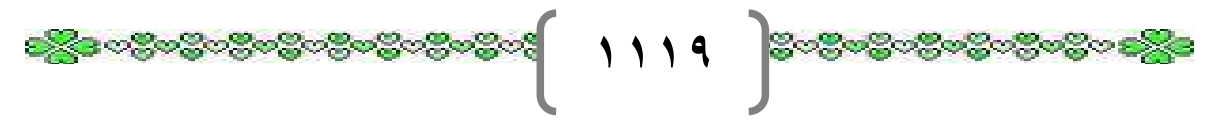


الحاء والقاف أصل واحد وهو بدل على إحكام الثئ وصحته. فالحق نقيض الباطل ثم يرجع كل فرع إليه بجودة الاستخر اج ويقال حق الثئ أي: وجب (1). ثانيا : تعريف الحقوق في الاصطلاح : قال الجرجاني :الحق في اصطلاح أهل المعاني هو الحكم المطابق للواقع، بطلق علي الأقوال و العقائد، والأديان ، و المذاهب باعتبار اثتماله علي ذلك،

ويقابله الباطل (r).

قال الأستاذ الدكتور وهبة الزحيلي : وأما عند الفقهاء فقد ورد تعريف للحق عند بعض المتأخرين فقال: الحق : هو الحكم الثابت شرعأ. ولكنه تعريف غير جامع و لا شامل لكل ما بطلق عليه لفظ الحق عند الفقهاء ـ فقد يطلق الحق على المال المملوك و هو ليس حكما، ويطلق على الملك نفسه، و على الوصف الثرعي كحق الولاية و الحضانة و الخيار ، ويطلق على مر افق العقار كحق الطريق و المسيل و المجري، ويطلق على الاثار المترتبة على العقود كالالتز ام بتسليم المبيع أو الثمن ـ و عرفه بعض الأساتذة المعاصرين فقال أستاذنا الشيخ علي الخفيف : هو مصلحة

$$
\text { مستحقة شر عاك. }
$$

لكنه تعريف بالغاية المقصودة من الحق، لا بذاتيته وحقيقته، فإن الحق هو علاقة اختصاصية بين صاحب الحق و المصلحة التي يستفيدها منه.

(1) مقاييس اللغة لابن فـارس، تـ عبدالسـلام هـارون، طـ دار الفكر، بيزوت 9 9 ب ا هـ، (10/r) (10)

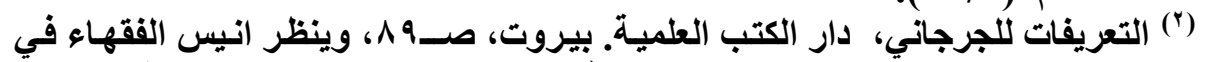

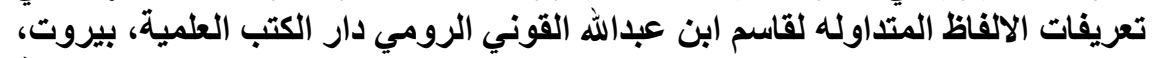

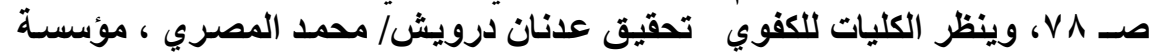

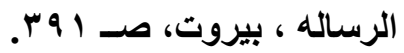

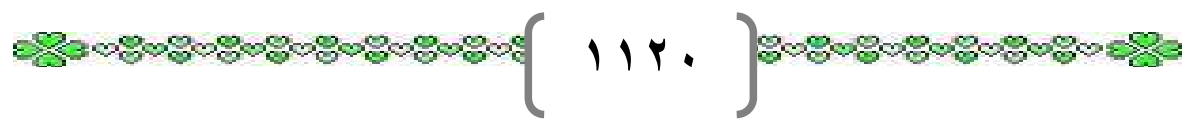




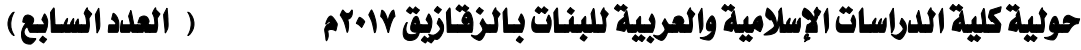

وقال الأستاذ مصطفي الزرقا: الحق: هو اختصاص يقرر به الثرع سلطة أو

تكليفا.

و هو تعريف جيد، لأنه يشمل أنواع الحقوق الدينية كحق الله تعالي علي عبادة من صلاة وصيام ونحو ها. و الحقوق المدنية كحق التملك، و الحقوق الأدبية كحق الطاعة للو الد على ولده، وللزوج علي زوجته، والحقوق العامة كحق الدولة في ولاء الرعية

لها، و الحقوق المالية كحق النفقة، وغير المالية كحق الو لاية على النفس.أ هـ (')

\section{تعريف الزوجية في اللغة والاصطلاح. أولا : تعريف الزوج في اللغة:}

قال ابن فارس : مادة ( زوج) " الزاي و الواو و الجيم " أصل يدل علي مقارنة شيء لشئ. من ذلك الزوج: زوج المرأة ـ والمرأة زوج بعلها، وهو الفصيح ـ قال

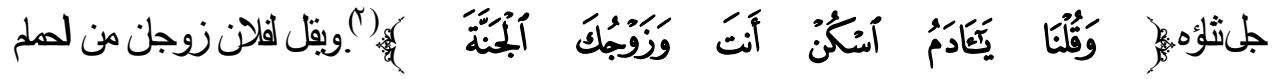

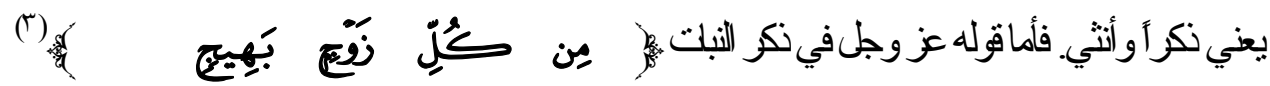
فيقال : أراد به اللون ، كأنه قال من كل لون بهيج ، وهذا لا يبعد أن يكون من الذي ذكرناه لأنه يزوج غيره مما يُقاربه. وكذلك قولهم للنَمط الذي يطرح علي الهودج زوجُ لأنه زوج لما يلقي عليه.أ. هـ (๕.).

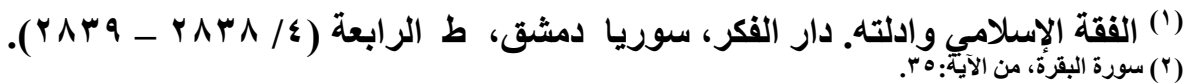

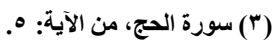

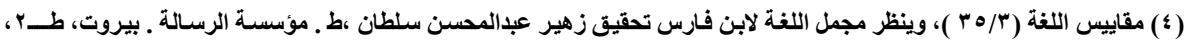

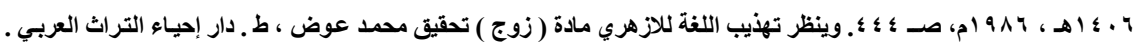

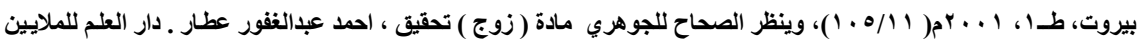

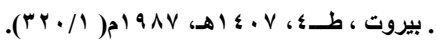


وقال صاحب القاموس المحيط : الزوج : البعل، و الزوجة، وخلاف الفرد، و النَمط يطرح علي الهودج، واللون من الديباج ونحوه، ويقال للاثنين: هما زوجان، وهما زوج)

وفي المعجم الوسيط : الزواج : اقتران الزوج بالزوجة، أو الذكر بالانثي (r). مما سبق ذكره نخلص إلي أن مادة ( زوج ) تدل علي الاقتران ومقارنة شيء بشئ

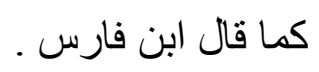
و هذا المعني موجود ومتحقق في المعاني المتفرعة عن هذه المادة كما بيَن ابن فارس. كما نلاحظ أن كلمة ( زوج ) من الألفاظ المشتركة التي اتحدت ألفاظها واختلفت معانيها ، فقد ذكر الفيروز ابادي معاني كثيرة للزوج، لكن عند التأمل نري أن هذه المعاني التي ذكر ها صاحب القاموس المحيط لا تخرج عن معني الاقتران . ثانيا : تعريف الزواج في الاصطلاح : إن الزواج عند الفقهاء يطلق وير اد به النكاح، ومن ثمَّ فإن تعريف الفقهاء للنكاح

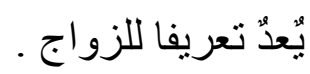
وقد عرف الحنفية النكاح بقولهم: عقد يفيد ملك المتعة قصدأ، أي حلِ استمتاع الرجل من امر أة لم يمنع من نكاحها مانع شرعي بالقصد المباشر (r) . وورد في البحر الرائق أن الزواج: عقد يَرِد علي ملك المتعة قصدا (1).

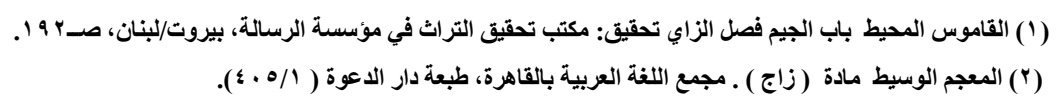
(r) القصد المباشر ينظر الفقة الإسلامي وادلتهـ للدكتور وهبة الزحيلِي ط دار الفكر.

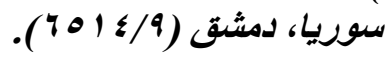

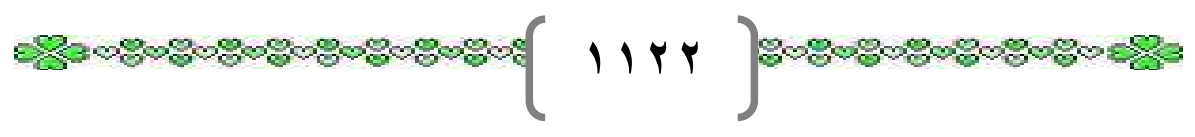


وقد عرفه الثيخ محمد أبو زهرة بقوله: الزواج: عقد يفيد حل العشرة بين الرجل

و المر أة ، وتعاونهما، ويحدد ما لكليهما من حقوق وما عليه من واجبات (r). وقريب منه تعريف الثيخ عبدالو هاب خلاف: فقد عرف الزواج بقوله : عقد يفيد حل استمتاع كل واحد من الزوجين بالاخر علي الوجه المشروع ، ويجعل لكل

$$
\text { منهما حقو قا قبل صاحبه وو اجبات عليه (r) }
$$

وقد عرفه الأستاذ الدكتور وهبة الزحيلي: فقال: الزواج: عقد يتضمن إباحة الاستمتاع بالمر أقبالوطء و المباشرة و التقبيل والضم و غير ذلك، إذا كانت المر أة غير محرم بنسب أو رضاع أو مصاهرة. أو هو عقد وضعه الشارع ليفيد ملك استمتاع الرجل بالمر أة. أي أن أثر هذا العقد بالنسبة للرجل يفيد الملك الخاص به فلا يحل لأحد غيره، و أما أثره بالنسبة للمر أة فهو حل الاستمتاع لا الملك الخاص بها، وإنما يجوز أن تتعدد الزوجات فيصبح الملك حقا مشتركا بينهن، أي أن تعدد الأزواج ممنوع شر عا وتعدد الزوجات جائز

شر عا

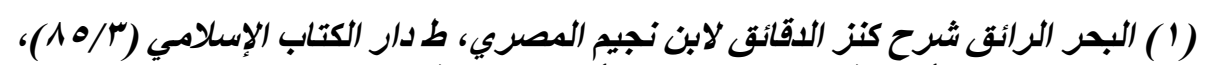

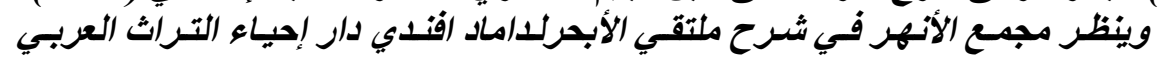
( ) ( ) ( $17 / 1)$

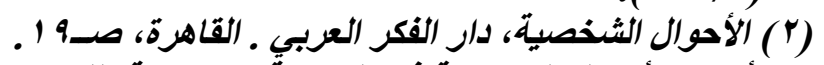

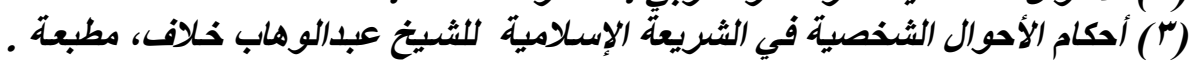

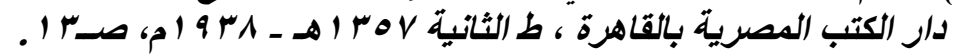

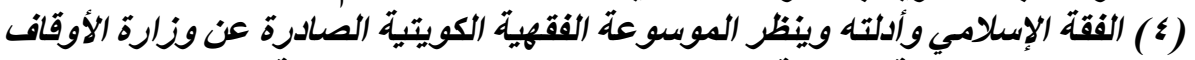

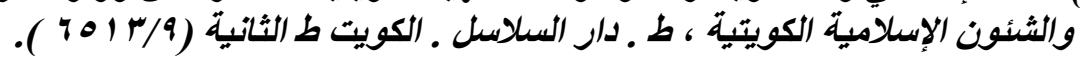




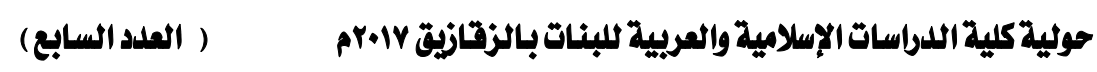

المبحث الأول: حقوق الزوجة.

وفيه مطالب:

المطلب الأول: المهر أو الصداق.

المهر أو الصداق:- هو اسم للمال الواجب على الرجل بالنكاح أو الوطء (1). وقد جعله الله حقا مفروضـا للهر أة التي برغب في الزواج منهـا للإشـعار بصدق

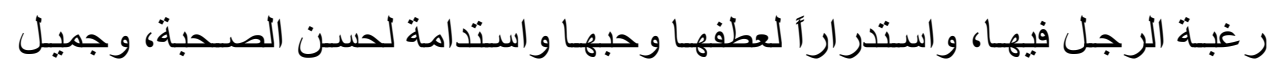

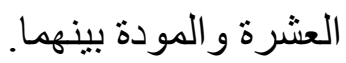

وقد دل على وجوب مشرو عيته الكتاب و السنة :-

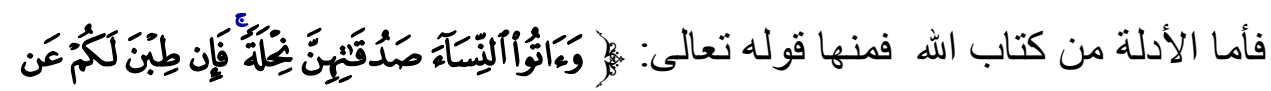

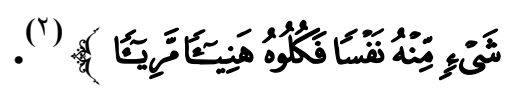

فقد دلت الآية على أن الصداق حق ثابت للمرأة على زوجها بالنكاح الصحيح، لا يجوز للزوج المماطلة فيه، ولا أن يأخذ منه شيئا إلا بطيب نفسها، وليس له الحق في إجبار ها في التنازل عنه.

يقول الإمـام القرطبي رحمـه الله تعـالى:- هذه الآيـة تدل على وجوب الصداق

للمرأة، وهو مجمع عليه ، ولا خلاف فيه (").

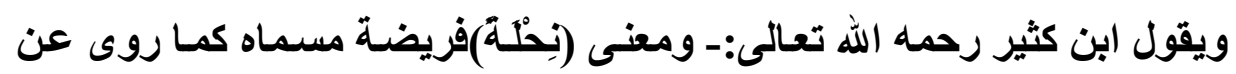

عائشة رضى الله عنها، وهو قول مقاتل، وقتادة وابن جريح.

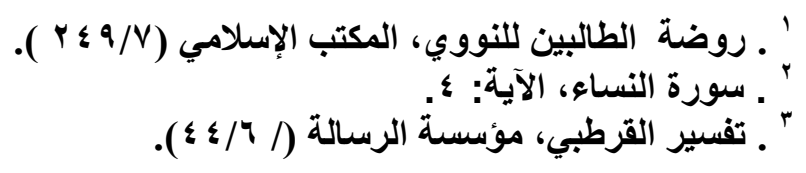


وقـال ابن زيــ :- النحلة في كـلام العرب: الواجب يقول: لاتتكهها إلا بشـيء واجب لها، وليس ينبغي لأحد بعد النبي صلى الله عليه وسـلم أن ينكح امرأة إلا بصداق واجب، ولا ينبغي أن يكون تسمية الصداق كذبا بغير حق. ومضمون كلامهم- والكلام لابن كثير رحمـه الله تعـالى ـ أن الرجل يجب عليه دفع الصداق الى المرأة حتماوأن يكون طيب النفس بذلك ، كما يمنح المنيحة، ويعطى النحلة طيبا بها، كذلك يجب أن يعطى المرأة صداقها طيبا بذلك، فـان طابت هي له به بعد تسميته أو عن شيء منه فليأكله حلالا طيبا أ.هـ (').

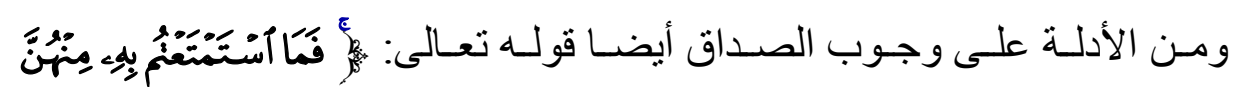

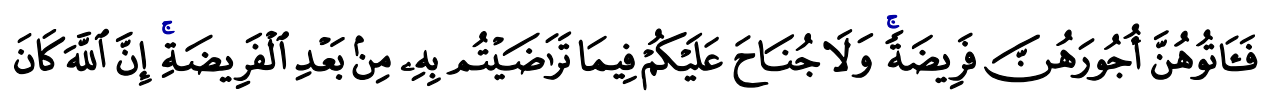

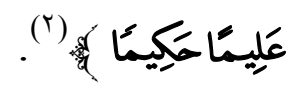

يقول القرطبي رحمـه الله تعـالى: اختلف العلمـاء في معنى الآيـة، فقال الحسن،

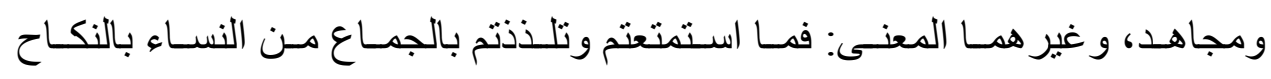

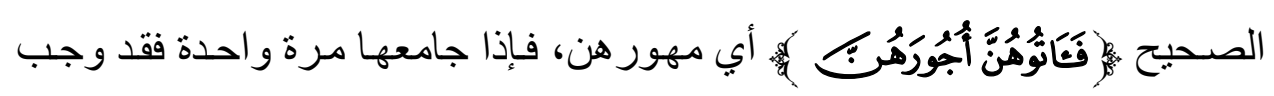
المهر كـاملا إن كـان مسـىى، أو مهر مثلهـا إن لـم يسم، وقـال الجمهور:المـراد ـ

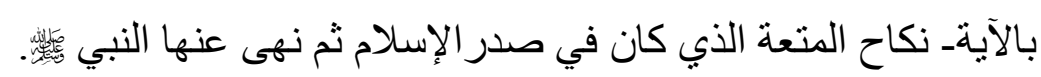
قال ابن خويز منداد :و لا يجوز أن تحمل الآيـة على جواز المتعـة لأن رسول الله

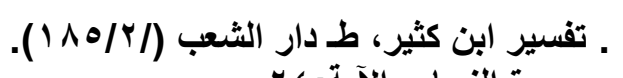

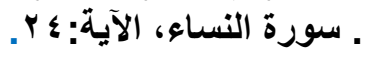

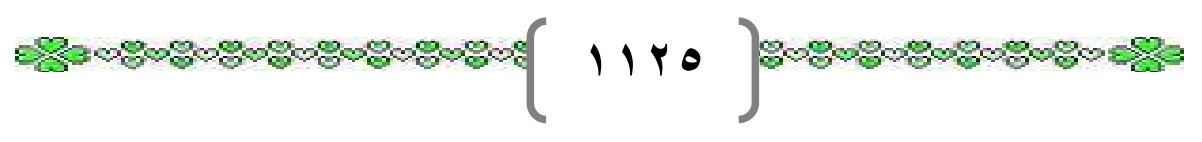




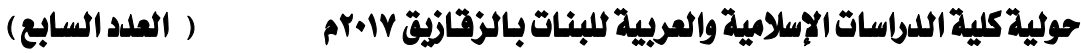

(') ومعلوم أن النكاح بإذن الأهلين هو النكاح الثرعي بولي وشـاهدين. ونكاح المتعـة

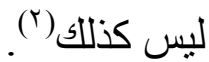

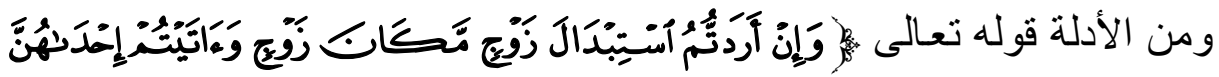

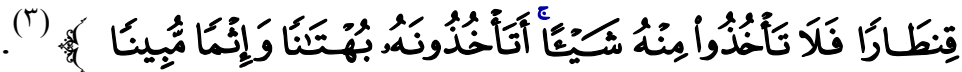

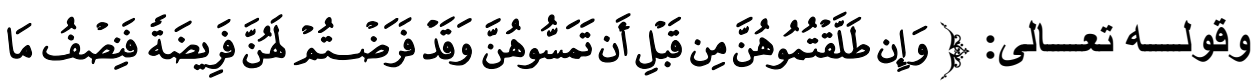

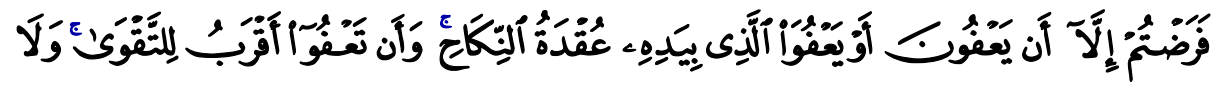

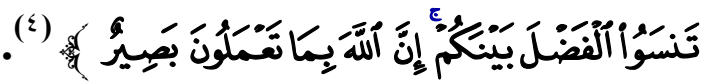

ففي هذه الآيات الكريمة دليل بين على وجوب المهر وفرضيته بحيث لا يجوز إسقاطه أو إجبار المرأة عن التنازل عنه أو بعضه إلا بطيب نفس منها. وأما الأدلة من السنة على وجوب المهر فمنها ما رواه ابن عباس رضي الله عنهما أن النبي صلى الله عليه وسـلم قال: أدوا العلائق ،قالوا يـا رسول الله ومـا العلائق؟

قال: ما تر اضى به الأهلون ولو قضيبا من أراك(ه). ومنها أيضا ما رو اه مسلم (') بسنده عن أبى سلمة بن عبدالرحمن أنه قـال سـألت عائشـة زوج النبـي النبـي

$$
\begin{aligned}
& \text { ' ' سورة النساء، الآية: هب هب. }
\end{aligned}
$$

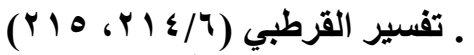

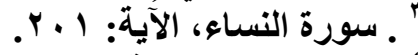

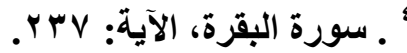

• . صحيح مسلم، تـ محمد فؤاد عبدالباقي، دار إحياء التراث العربي - بيروت، كتاب النكاح ، بـاب

$$
\text { الصداق، وجواز }
$$

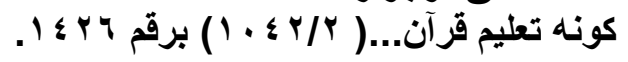


لأزو اجه ثثتي عشرة أوقية ونشَا قالت: أتدرى ما النش؟ قال: قلت: لا، قالت: نصف أوقية فتلك خمسمائة در هم فهذا صداق رسول الله هئس لأزو اجه.

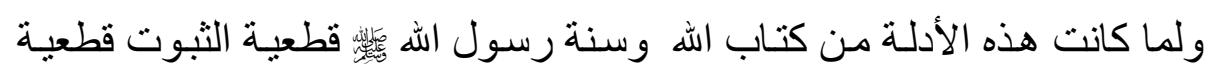
الدلالة على وجوب المهر، فقد أجمع العلماء على وجوب المهر ونقل عنهم ذلك ابن عبد البر حيث يقول رحمـه الهه تعـالى: أجمع علمـاء المسلمين أنه لا يجوز لـهـ أبي للزوج - وطء في نكاح بغير صداق دينا أو نقدا (r). وقال الماوردي: اجتمعت الأمم على أن صداق الزوجات مستحق (").

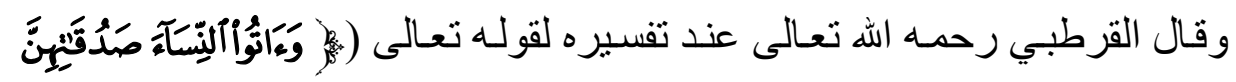

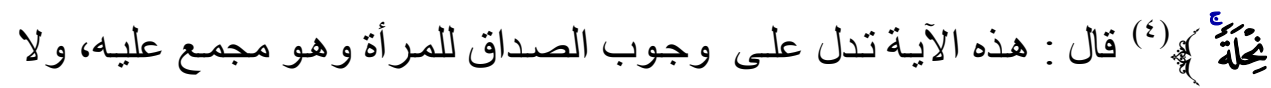
خلاف فيه(').

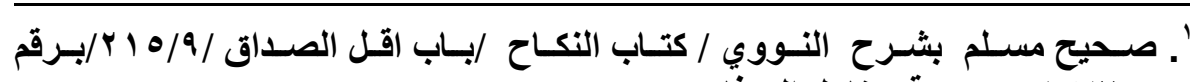

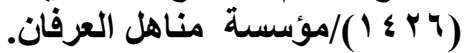

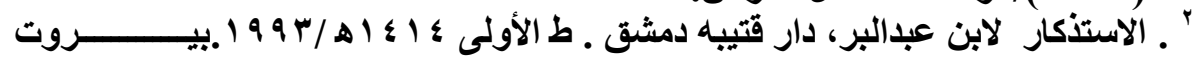

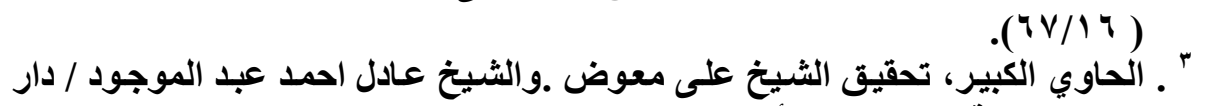

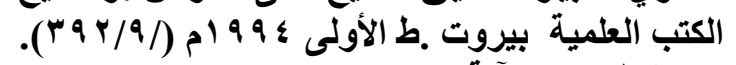

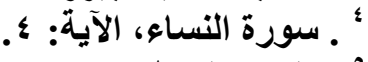

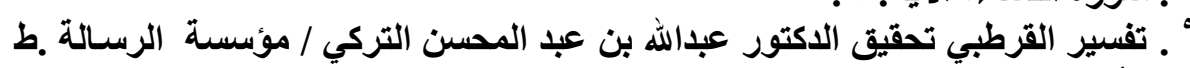

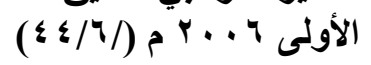

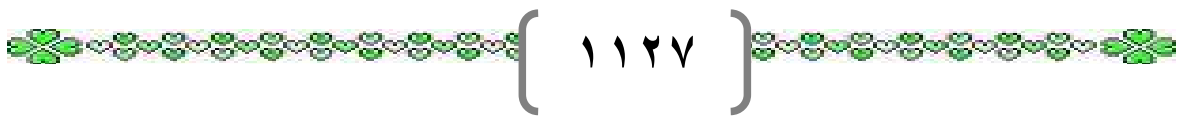




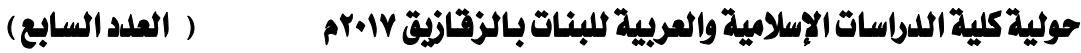

\section{الثروط التي يجب توافرها في المهر}

يشترط العلماء في المهر الثروط التي يشترطونها في ثمن البيع. قال الإمـام الماوردي رحمه الله تعالى: كل ما يصلح أن يكون ثمنا صلح أن يكون

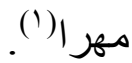

وقال ابن قدامة رحمه الله تعالى: كل ما جاز أن يكون ثمنا في البيع، أو أجرة في الإجارة جاز أن يكون صداقا من قليل أو كثير، وما لا يجوز أن يكون ثمنا في البيع كالمُحرَّ، و المعدوم، و المجهول، وما لا منفعة فيه، ومالا يتم ملكه عليه كالمبيع من هن المكيل والموزون قبل قبضـه، ومـالا يقدر على تسليمه كالطبر في الهو اء والسمك في المـاء، ومــــالا يتمـول عـادة كحبـة حنطـة وقشـرة جوزة لا يجوز أن يكون صداقا (r). (r) (1)

وقال الإمام الشافعي رحمه الله تعالى: كل مـا جـاز أن يكون ثمنـا لثـيء أو أجرة جاز أن يكون صداقا. وهذا قول جمهور أهل العلم، وجماعة أهل الحديث من أهل المدينة وغيرهم كلهم أجازوا الصداق بقليل المـال وكثيره، وهو قول عبداله بن

وهب صاحب مالك، و اختاره ابن المنذر و غيره(َ).

وفى حكم النكاح على منفعـة كالإجـارة وتعليم القرآن، ذهب الإمـام الثـافعي (؛)،

$$
\text { و أحمد (0) إلى جوازه. }
$$

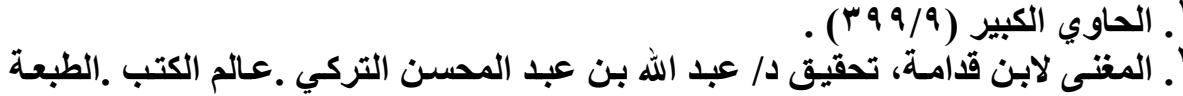

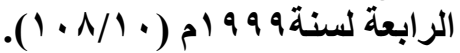

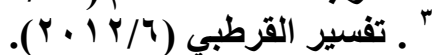

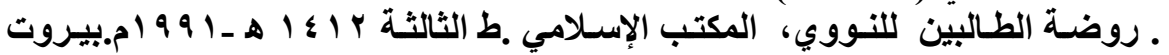

$$
\begin{aligned}
& \text { ( · • ₹/V/) }
\end{aligned}
$$

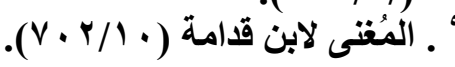


يقول الإمام النووي رحمه الله تعالى: كل عمل جاز الاستنجار عليه جاز جعله

صداقا، وذلك كتعليم القر آن و الصنائع، و الخياطة، و الخدمة، و البناء، و غير ها (').

ومنع منه الإمام أبو حنيفة، و المشهور عن الامام ماللك رحمه الله كر اهته (؟). قال الإمام القرطبي رحمه الله تعالى في مسألة النكاح على منفعـة: اختلف العلمـاء

في هذه المسألة على ثلاثة أقو ال:

فقد كرهه مالك، و منعه ابن القاسم، وقال أبو حنيفة: لا يصـح، وأجازه ابن حبيب، و هو قول الثافعي وأصحابه قالوا : يجوز أن تكون منفعة الحر صداقا كالخياطـة و البناء وتعليم القرآن، وقال أبو حنيفة لا يصـح. وقـال أبو الحسن الكرخى إن عقد

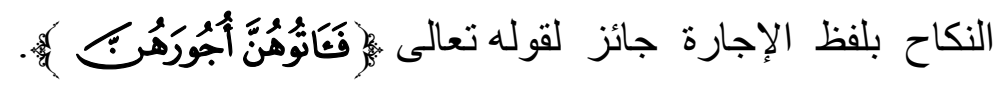
وقال أبو بكر الرازي: لا يصح لأن الإجـارة عقد مؤقت و عقد النكاح مؤبد فهــا متنافيان، وقال ابن القاسم: ينفسخ قبل البناء ويثبت بعده. وقال ابن خويز منداد: تضمنت هذه الآيـة النكاح على الإجـارة والعقد صحيح، ويكره أن تجعل الإجارة مهرا، وينبغي أن يكون المهر مـالا كما قال الله عز وجل:

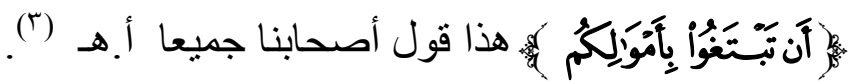

والراجح في المسألة ما ذهب إليه الإمامان الثافعي و أحمد من جواز النكاح على منفعة كالإجارة وتعليم القرآن، وقد ورد في كتاب الله وسنة رسول الله صلى الله عليه وسلم ما يؤيده.

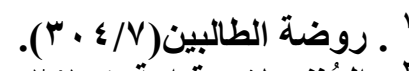

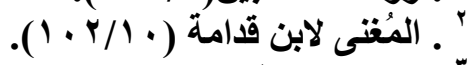

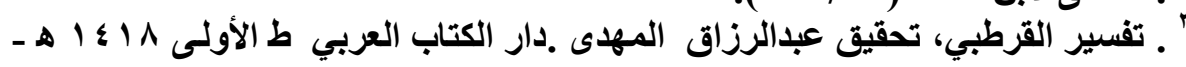

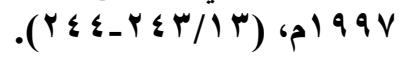


أما ما ورد في كتاب الله ففي قصة سيدنا موسى عليه السـام، وفيها أن الرجل الصـالح عليـه السـلام قد عرض على سيدنا موسىى عليه السـلام أن يزوجـه إحدى

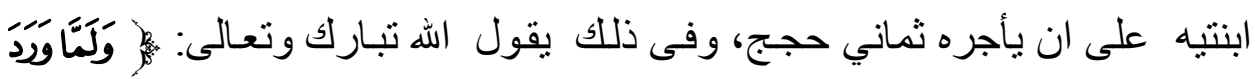

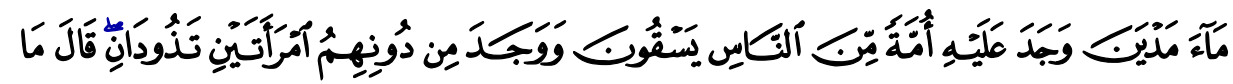

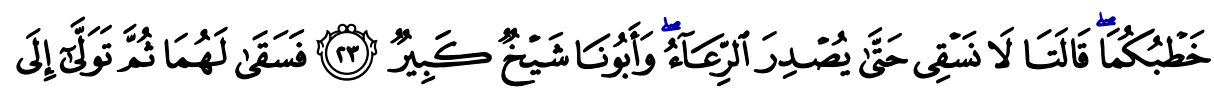

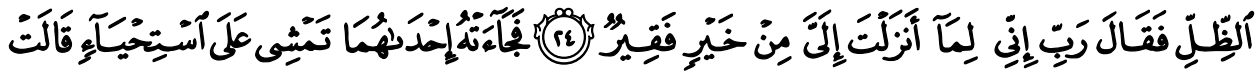

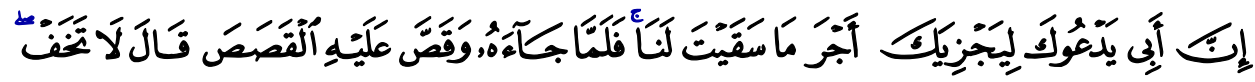

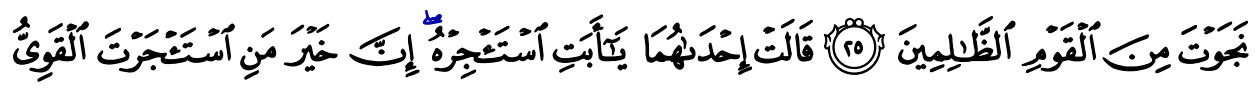

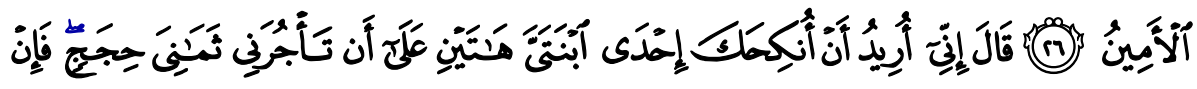

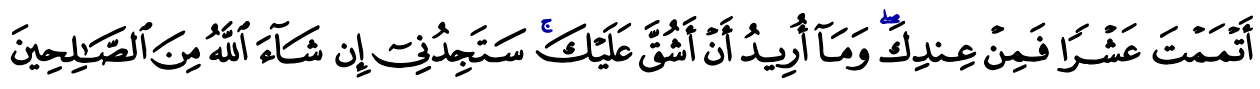

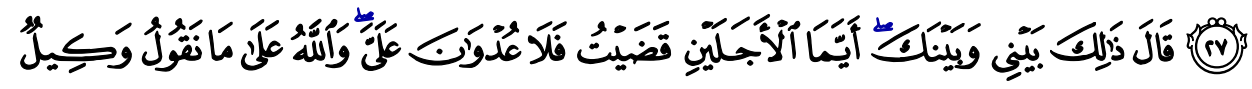

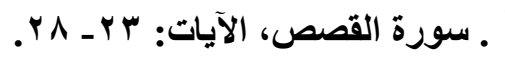




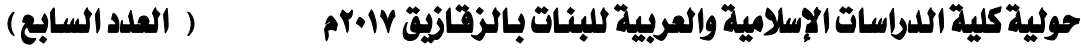

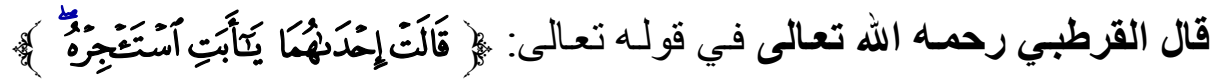
دليل على أن الإجـارة كانت عندهم مشـرو عة معلومـة، وكذلك كانت في كل ملـة، و هى من ضرورة الخليقة، ومصلحة الخلطة بين الناس(').

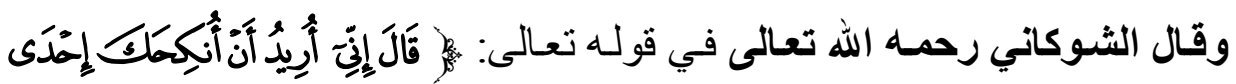

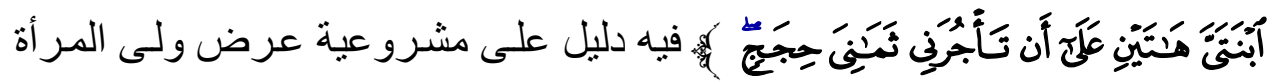
لها على الرجل، وهذه سنة ثابتة في الإسـام . كمـا ثبت من عرض عمر لابنته حفصـة على أبـى بكر و عثمـان رضـى الله عنهــا، و غيـر ذلك ممـا وقـع في أيـام الصحابة أيام النبوة، وكذللك ماوقع من عرض المرأة لنفسها على رسول الله صلى الله عليه وسلم (r). وأما الدليل من السنة المباركة على جواز النكاح على منفعـة كتعليم القرآن

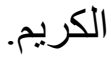

أخرج الإمام البخاري رحمه الله تعالى بسنده عن أبى حازم قال: سمعت ســل بن سعد السـاعدي يقول: إنى لفي القوم عند رسول الله صلى الله عليه وسلم إذ قامت امر أة فقالت: يا رسول الله انها قد وهبت نفسها لك فر فيها رأيك، فلم يجبها شيئا. ثم قامت الثالثة فقالت: إنها قد وهبت نفسها للك فر فيها رأيك. فقام رجل فقال يـا رسول اله أنكحنيها قال أعندك من شيء؟ قال: لا، قال اذهب فاطلب ولو خاتما من حديد. فذهب وطلب، ثم جاء فقال: مـاوجدت شيئا ولا خاتمـا من حديد، قال: هل

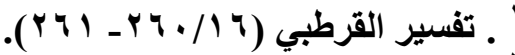

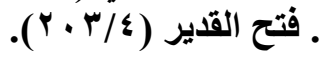




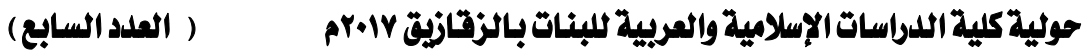

معك من القرآن شيء قال معي سورة كذا وسورة كذا. قال :اذهب فقد أنكحتكها

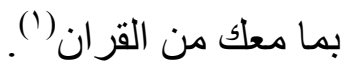

قـال ابـن حجررحمـه الله تعـالى: واسـتلـل بهذا الحـديث على جـواز جعـل المنفعـة

$$
\text { صداقا ولو كان تعليم القرآن(r) }
$$

وقـال ابو عيسى الترمذي رحمـه الله تعـالى بعد ذكره لهذا الحـيث: وقد ذهب الثافعي إلى هذا الحديث فقال: إن لم يكن لله شيء يصدقها فتزوجها على سورة من القرآن فالنكاح جائز ويعلمها سورة من القرآن(") . الحكمة من وجوب المهر

الحياة الزوجية أساسها المودةوالرحمة، والزوجة بالنسبة لزوجها سكنه الذى

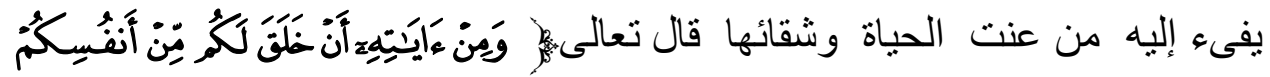

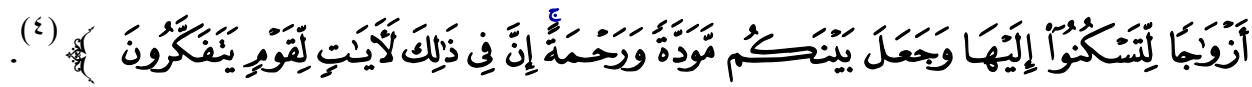

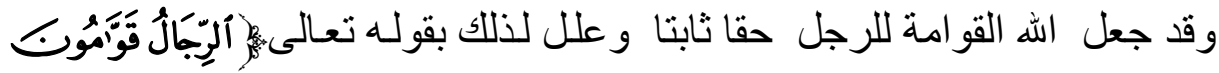

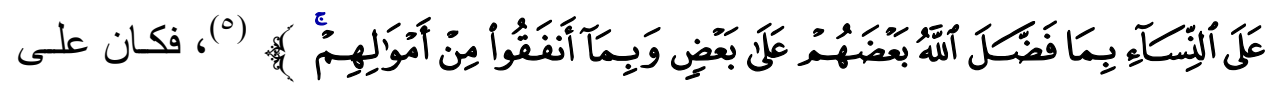
الرجل إذا تقدم للزواج من امر أة أن يفرض لها مهر اليُبر هن على رغبته فيها،

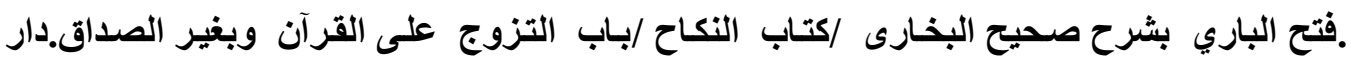

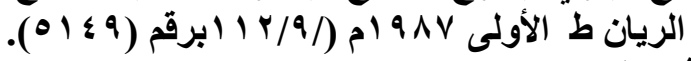

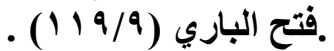

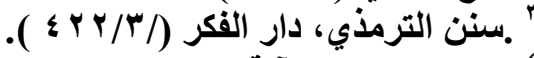

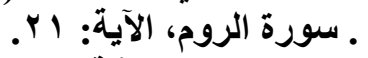

$$
\begin{aligned}
& \text {. سورة النساء، الآية: ؛ بـ. }
\end{aligned}
$$




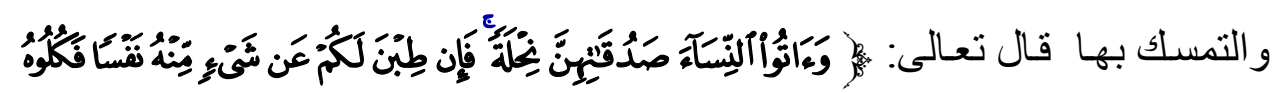

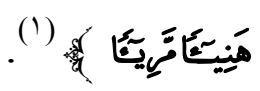

قال القرطبي: (نحلـة) أي عطية فالصداق عطية من الله للمر أة وقيل: نحلة أي:

عن طيب نفس من الأزواج من غير تنازع(؟).

وون المعلوم أن المال هو أعز ما يجود به الرجل لمن برغب في الزوراج منها

يدفعه إليها في سخاء وطيب نفس إظهار ا لشرفها، ورفعا لقدرها، وتعبير ا عن حبه الصـادق لها، فيبذل لها الغالي و الثمين في سبيل الوصول إليها و الظفر بها وفق

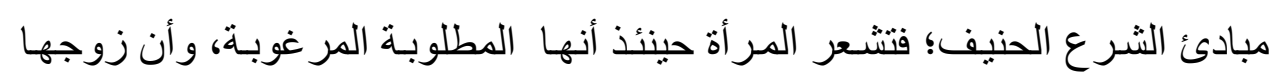
ما وصل إليها إلا وهى عزيزة الجانب، عالية المكانـة، وأنها موضـع برهو عطفه ور عايته.

يقول الأستاذ أحمد فائز: وبعد ثقرير هذا الحق للمر أة وفريضته يدع الباب مفتوحا لما يتر اضى عليه الزوجان بينهما وفق مقتضيات حياتهما المشتركة، ووفق مشـاعر

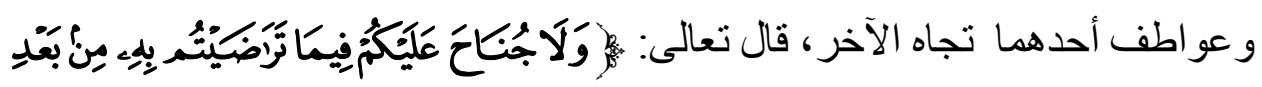

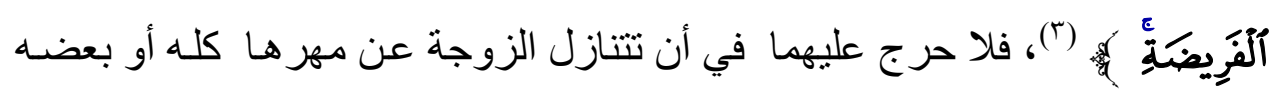
بعد بيانه وتحديده، وبعد أن أصبح حقا لها خالصـا تتصرف فيه كما تتصرف في

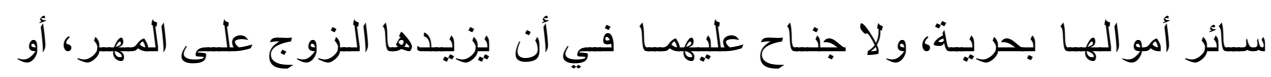
يزيدها فيه فهذا شأنه الخاص، وهذا شأنهما معا يتر اضيان عليه في حرية وسماحة،

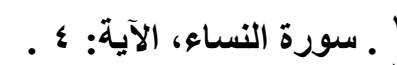

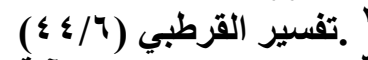

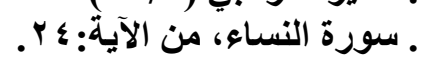

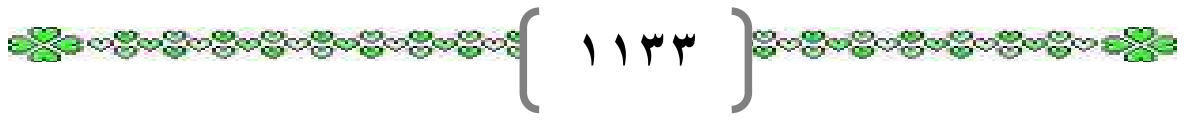


فإذا طابت نفس الزوجة لزوجها عن شيء من صداقها كله أو بعضه فهي صساحبة

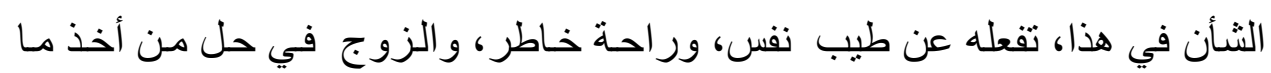
طابت نفس الزوجة عنه، وأكله حلالا طيبا هنيئا مريئا، لأن العلاقات بين الزوجين

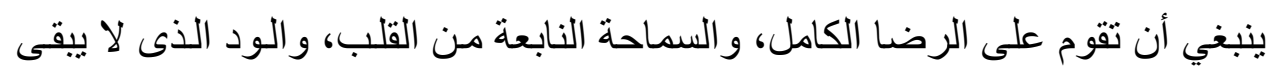
معه حرج من هنا أو هناك. وبهذا أزاح الإسـلام رواسب الجاهليـة في شـأن المـرأة وصـداقها، وحقها في نفسها ، وفى مالها، وكر امتها، ومنزلتها، وترك للسماحة و التر اضي و المودة أن تأخذ مجر اها في هذه الحياة المشتركة، وأن تبلل بنداو تها جوَّهذه الحياة ( (). هـ ـ. قال تعالَى:

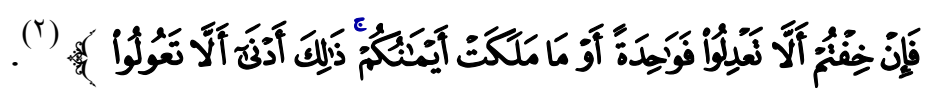

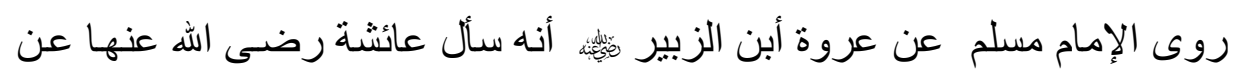

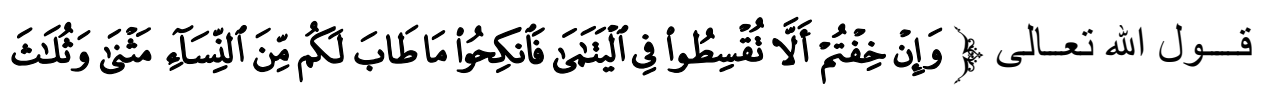

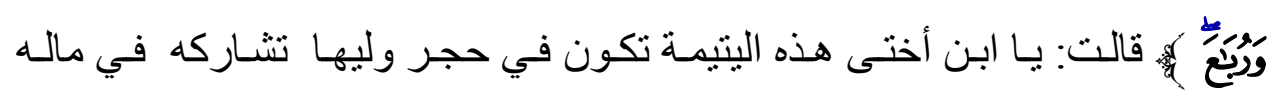
فيعجبه مالها وجمالها فيريد وليها أن يتزوجها بغير أن يقسط في صداقها فيعبها

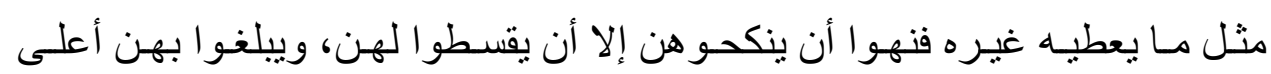
سننهن من الصداق، وأمروا أن ينكحوا ما طاب لهم من النساء سواهن (َ).

' ـ دستور الأسـرة في ظلال القرآن، للأستاذ أحمد فيائز، مؤسسـة الرسـالة ط الثانيـة

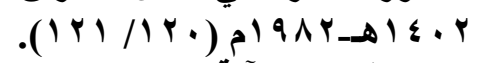

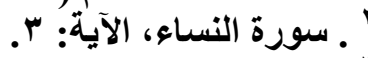

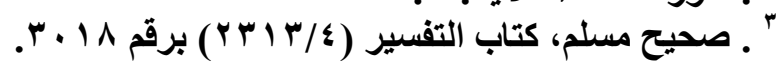

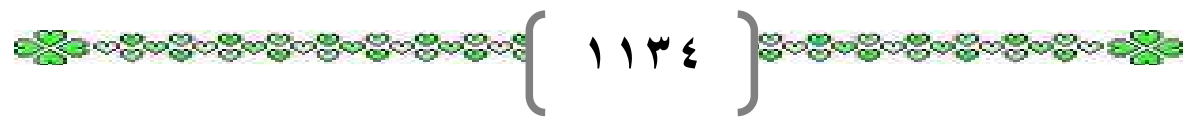




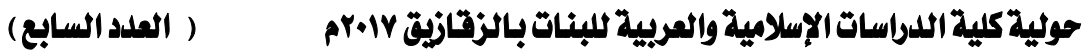

و هكذا تميز التشـريع الإسـلامي عن كل تشريع وضـعي في كل قو انينهه ومبادئه، ومنها تشريعه في تكريم النساء عند الزواج بهن حيث فرض على الرجل أن يدفع لمن أراد أن يقترن بها مهر ا أمر الله به وأوجبه في شريعته . لقد كانت بعض الثـعوب غير المسلمة تفرض على المر أة أن تدفع هي المهر للرجل، وكانو ا يسمونه باسم آخر فترى الفتاة الثـابة مضطرة إلى الكدو الكدح

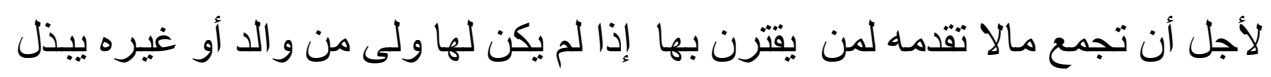
لها هذا المال، وكثير ا ما تركب الفتيات الناعمات أخشن المر اكب وتتعرض للعنت و التفريط في العرض و الثرف في سبيل تحصيل هذا المال . وشريعة اليهود تفرض للمر أة مهر الكنها لا تملكه بالفعل إلا إذا مات زوجها،

أو طلقها، لأنه ليس لها أن تتصرف بمالهاو هى منزوجة (1).

\section{مقدار الصداق}

ترك الثـارع الحكيم تحديد مقدار الصداق إلى ما يتفق عليه الزوجـان وأسرتيهما

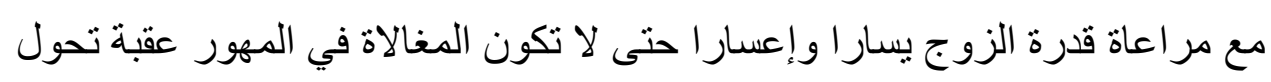

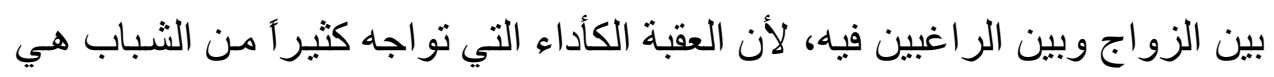
المغـالاة في المهور التي فرضتها ميول قد لا تتناسـب وحسال المتزوجين، فترى الرجل الفقير لا يرضى تزويج ابنته إلا بصداق عظيم، لأنسه يهوى أن يكون بيت

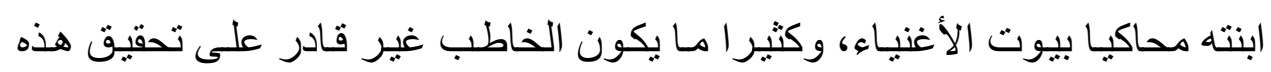
الأمـاني فينصـرف بـألم وحسرة، ويـذهب و الــ الفتـاة وقد عضـل ابنتهـه عـن النكـاح و عرَّضها ومن ير غب في خطبتها للفتنة و الفساد الكبير.

' ' حقوق النساء في الاسلام للمرحوم الاستاذ / محمد رشيد رضا، صـr Y.

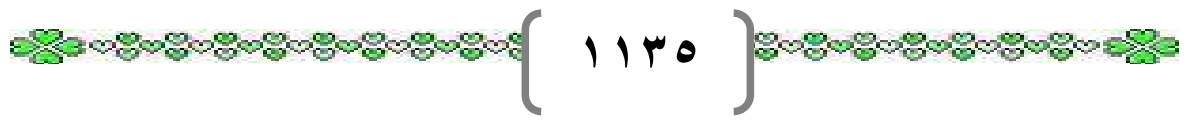


إن كثير ا من الآباء يفعلون هذا وينظرون في الأمر نظرة ماديـة فيردون الخاطب الصالح لفقره ويقبلون غير الصالح لغناه غير حاسبين للمستقبل حسابا، وكثير ا مـا تبوء الحياة الزوجية للفشل كما هو حاصل في زماننا.

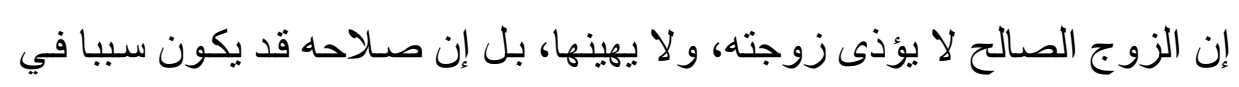
أن يبـارك الله لـه في رزقـه، وأن يحيـا وزوجتـه حيـاة طيـة، قـال تعـالى:

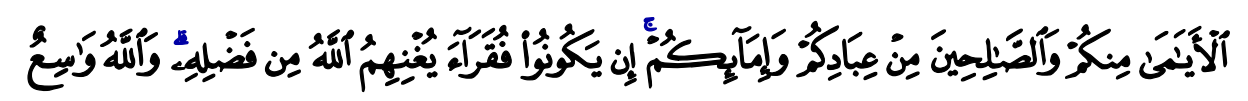

\section{(1) عكلِيمد)}

قال الإمام القرطبي رحمه الله تعالى: هذا و عد بـالغنى للمتزوجين طلب رضـا الله و اعتصاما من معاصيه. وقال ابن مسعود: التمسوا الغنى في النكاح وتلا هذه الآيـة، وقال عمر رضي الله عنه: عجبي ممن لا يطلب الغنى في النكاح. وروى هذا المعنى ولى هي

$$
\text { عن ابن عباس رضي الله عنهما أيضاب(؟). }
$$

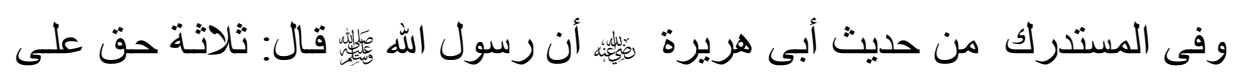
الله أن يعينهم المكاتب الذي يريد الأداء، و المجاهد في سبيل الله، و الناكح يريد أن

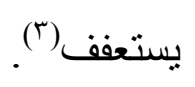

أيهـا الآبـاء: إن كنـتم تبغـون السـعادة لبنـاتكم فزوجـوهن مـن الصـالحين الأتقيـاء المصلين، و لا تمنعكم قلة المال من ذلك فإن أرزاق أهل الصـلاح و التقوى مباركة،

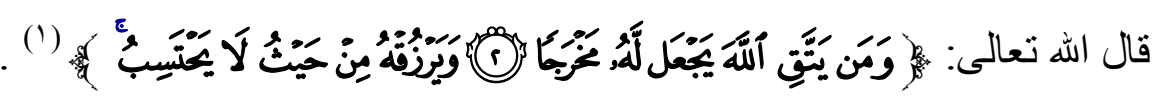

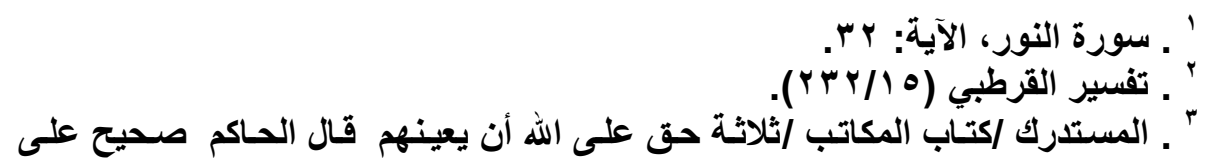

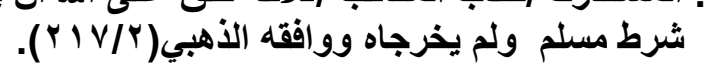


ولو لم يكن في الصـالح التقى إلا أن يطعهها حـالا، ويحفظ عليها دينها وشرفها لكفى، أمـا الفاست فقد يكون فسقه سببا للتضييق عليه وحرمانهه من الرزق فيتبدد ماله، وينكثف حاله، وتسوء عشرته لأهله، فيقع النزاع وتتحول الحياة الزوجية إلى لى

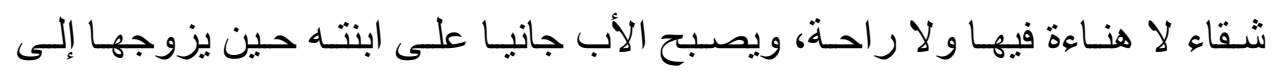
صاحب مال غير صالح طمعا في مـال زائل، أو رجل مدمن يجرى وراء نزواته وشهو اته ثم يأتيها مع طلوع الفجر وريح الخمر تفوح منه لا يقوم لصـلاة ولا ينهض لعبادة. هذا و لا خلاف بين الفقهاء في أنه لا حد لأكثر الصداق وهذا إجمـاع(ب)منهم، حيث أخبر الله في كتابه الكريم أن القنطار يجوز أن يكون صداقا، قال نعالى يُمَإِنْ

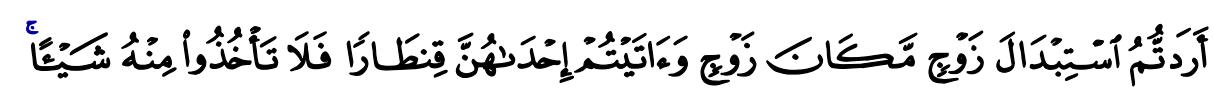

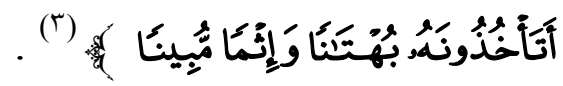

قـال ابـن كثير رحمـه اله تعـالى: في هذه الآيـة دليل على جواز الصـداق بالمـال

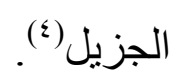

وقد اختلف المفسرون في المراد بالقنطار في الآية على أقو ال(ْ):

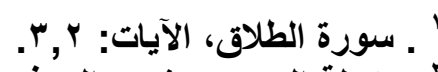

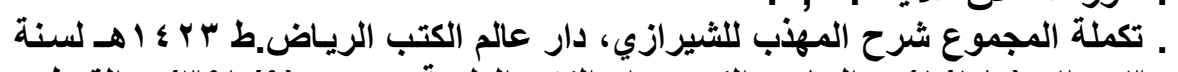

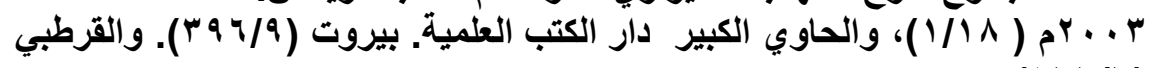
(1 (19/7)

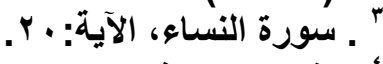

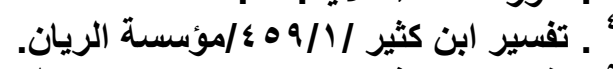

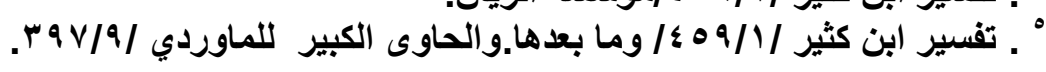

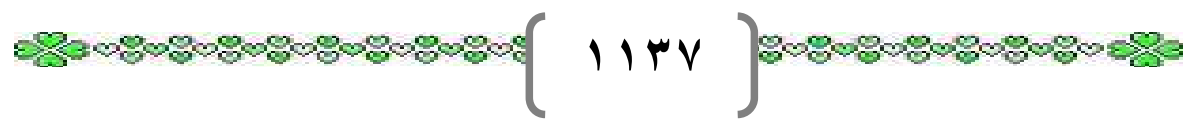


الأول : أنه ألف أوقية. ويؤيده ما أخرجه الحاكم (') بسنده من حديث أنس رضى الله عنه، أنه سأل رسول الله صلى الله عليه وسلم عن قول الله عز وجل: (و القناطير المقنطرة) قال القنطار ألف أوقية.

الثاني: أنه ألف ومائتا أوقية وهو قول معاذ، و أبى هريرة . الثالث: أنه ألف ومائتا دينار ـ وهو قول الحسن، وأحد قولي ابن عباس. الرابع: أنه اثنا عشر ألف درهم، أو ألف دينار وهو قول ابن عباس. الخـامس:أنـه ثــانون ألف درهـم، أو مائـة رطل وهـو قول سـعيد ابـن المسيب وقتادة.

السادس: أنه سبعون ألفاوهو قول عمر مجاهد. السابع: أنه المال الكثير وهو قول الربيع، و الضحاك. قال ابن كثير رحمه الله تعالى: وحاصل هذه الأقو ال أن القنطسار هو المـال الجزيل

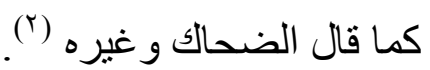
و قد كان عمر بن الخطاب رضى الله عنه ينهى عن المغالاة في المهور ثم تراجع بعد ما حاججته امر أة في ذلك. فقد أخرج الحاكم (ّ) في مستدركه بسنده عن نافع عن ابن عمر رضـى الله عنهـا أن عمر بن الخطاب رضي الله عنه خطب الناس فقال: أيها النـاس لا تغـالو امهر النساء فإنها لو كانت مكرمة لم يكن منكم أحد أحق بها ولا أولى من النبي صلى الله عليه وسلم ما أمهر أحدا من نسائه ولا أصدق أحدا من بناته أكثر من اثنتا عشرة

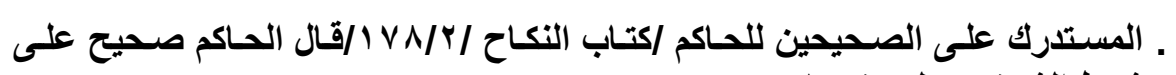

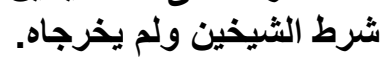

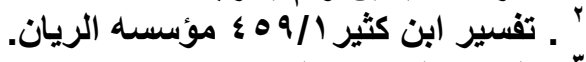

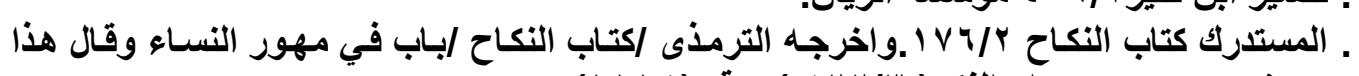

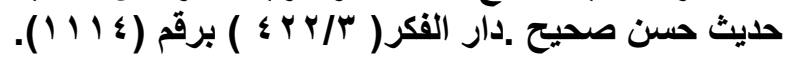


أوقيـة، و الأوقيـة أربعون درهــا فـذلك ثمـانون وأربعمائـة درهم ـ فقامـت امـر أة

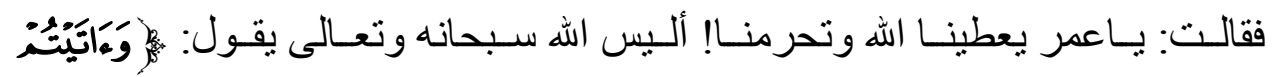

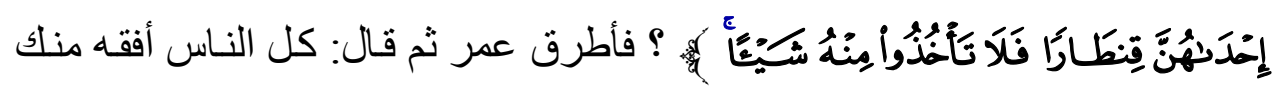
ياعمر، وترك الإنكار ('). قال الإمام الثافعي(؟) رضي الله عنه: والاقتصاد في المهر أحب إلىَّ من المغالاة فيه. لما روته السيدة عائشة رضي الله عنها أن النبي صلى الله عليه وسلم قال: أعظم النساء بركة أيسر هن صداقا(ّ).

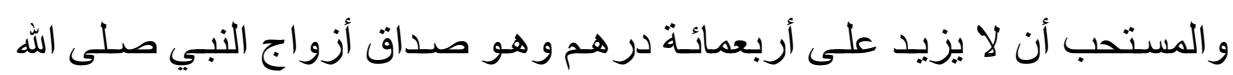
عليه وسلم وبناته عليهن سلام الله ورحمته. و إذا كان ظاهر قولهه تعالى: كان ظاهر هذا النص الكريم يشير إلى أن الرجل الموسر له أن يعطى من المهر مـا شاء ولو كان ما يدفعه قنطار ا من ذهب، لكن إذا كانت هذه المغالاة يترتب عليها عزوف غير القادرين من الثباب و الرجال، وانصر افهم عن الزواج، الأمر الذي يترتب عليه المفاسد الدينية، والأزمات النفسية التي تعرض الثباب إلى الانحر اف،

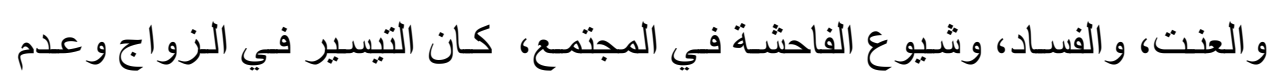
المغالاة في المهور لغير القادرين على مؤن النكاح ممـا تقتضيه المصلحة، و على

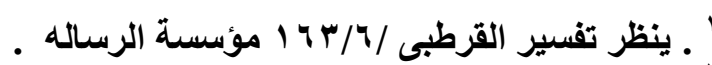

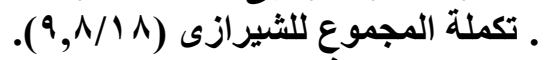

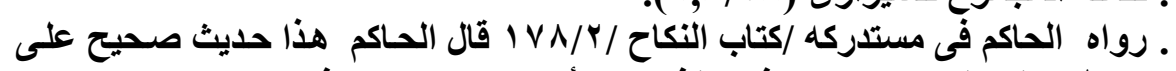

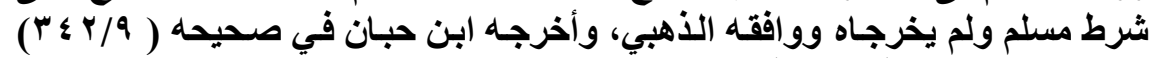

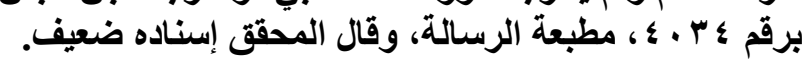

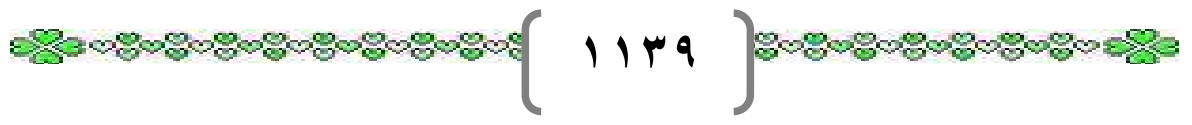




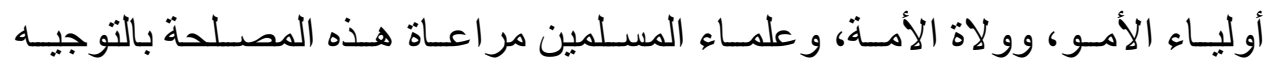
و الإرشاد عملا بقوله صلى الله عليه وسلم: إذا أتاكم من ترضون خلقه ودينه فأنكحوه

إلا تفعلو ا تكن فتنة وفساد عريض('). وقد أنكر الرسول لَّ

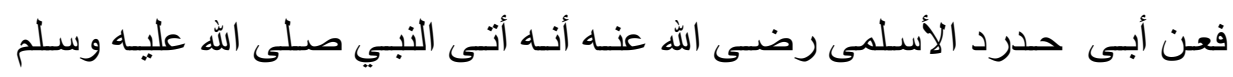
يستفتيه في مهر امر أة فقال: كم أمهرتها ؟ فقال مـائتي در هم. فقال صلى الله عليه وسلم: لو كنتم تغرفون من بطحان مازدنم (؟). قال الإمام القرطبي رحمه الله تعالى: و إنكار النبي صلى الله عليه وسلم على هذا الرجل المتزوج ليس إنكار الأجل المغالاة والإكثار في المهور، و إنمـا الإنكار لأنـه

كان فقير ا في تلك الحال فأحوج نفسه إلى الاستدانة و السؤال و هذا مكروه باتفاق("). و إذا كان أهل العلم قد أجمعوا على أنه لاحد لأكثر الصداق كمـا سبق إلا أنهم اختلفو ا في أقل المهر على أقو ال نوردها على النحو التالي (ع). القول الأول:- ذهب الثـافعية وأحمد - رحمهــا الله تعـالىـ إلى أن أقل المهر غير

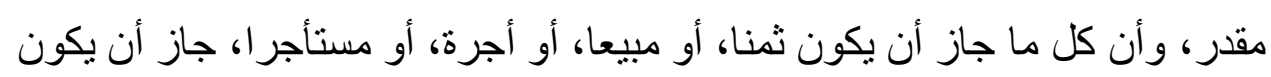

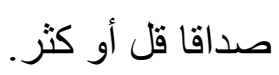

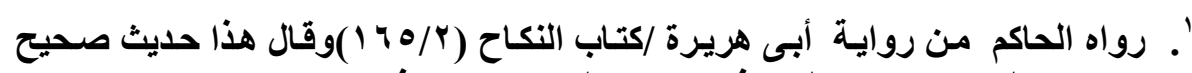

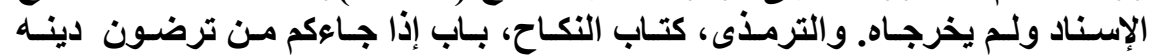

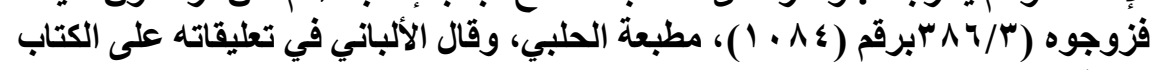

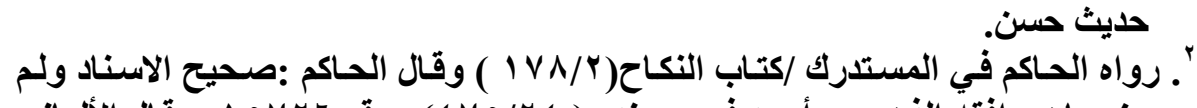

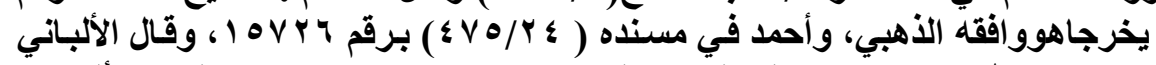

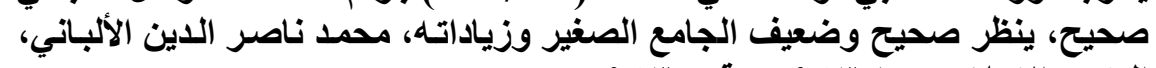

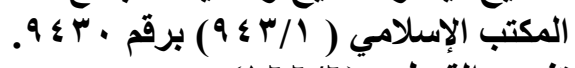

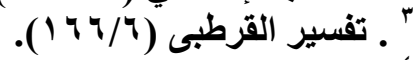

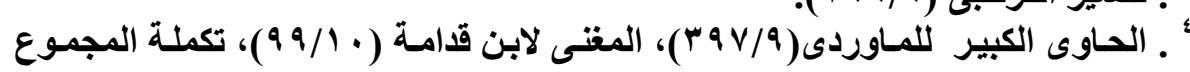
( $(\mathrm{V} / \wedge)$

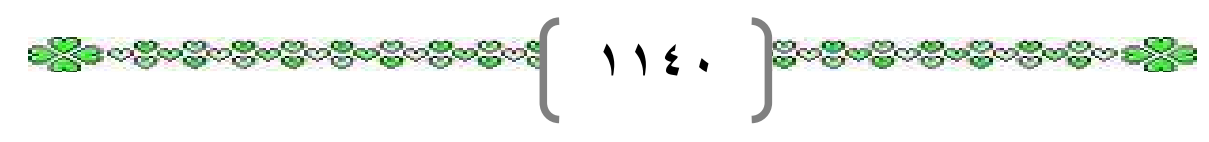




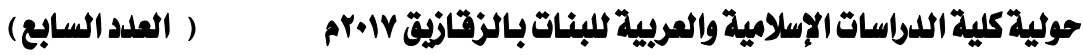

وقال بهذا من الصـحابة: عمر بن الخطاب، وابن عباس، ومن التابعين: الحسن البصرى، وسعيد بن المسيب. ومن الفقهاء: ربيعة، والأوزاعي، و الثوري، واسحاق

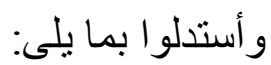

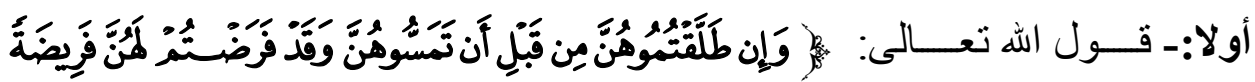

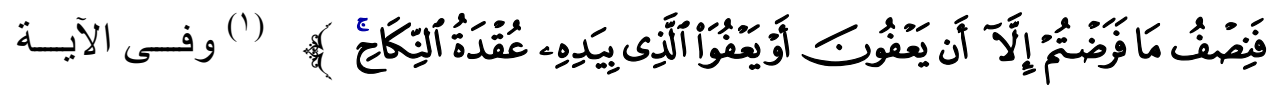
دليلان:

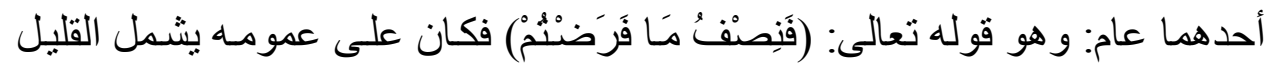
و الكثير.

و الثاني خاص: وهو أنه إذا فرض لها خمسة در اهم فطلقها قبل الدخول اقتضىى أنـه يجب لها در همان ونصف. و عند أبى حنيفة يجب لها الخمسة، وهذا خلاف النص. ثَانيا:- قو له تعالى:

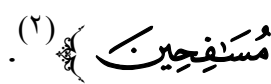

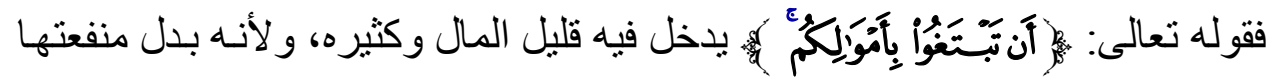
فجاز ما تر اضيا عليه من المال. قال الإمام القرطبي رحمه الله تعالى: وهو الصحيح(َ).

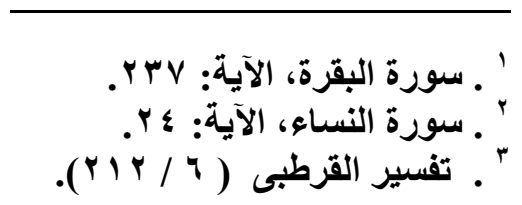




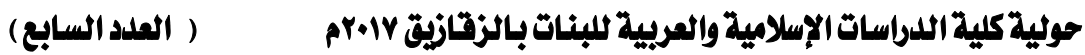

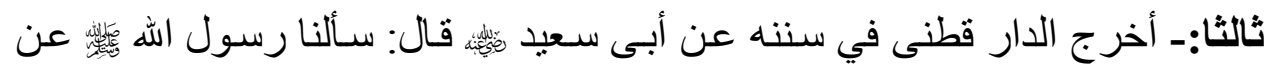

صداق النساء فقال: هو ما اصطلح عليه أهلوهم ('). وفى رواية أخرى عن ابن عباس قال: قـال رسول الله لهّ قيل: ما العلائق بينهم يا رسول اله؟ قال: مـا تر اضسى عليه الأهلون، ولو قضيبا من أر اك(؟). فدل الحديثان على عموم ما تر اضى به الأهلون من قليل المال أو كثيره.

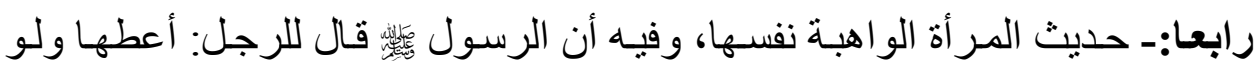
خاتمـا مـن حديد()، وخـاتم الحديد أقل الجو اهر قيمـة فدل على جواز القليل مـن المهر. خامسا:ـ ما أخرجه الترمذي عن عبداله بن عامر بن ربيعة عن أبيـه، أن امر أة من بنى فزارة تزوجت على نعلين فقال رسول الله صلى الله عليهه وسلم أرضيت من نفسك ومالك بنعلين؟ قالت نعم. قال: فأجازه(๕). قال الإمـام القرطبي رحمـه الله تعـالى: قـال الثـافعي: كل مـا جـاز أن يكون أجرة جاز أن يكون صداقا، وهذا قول جمهور أهل العلم، وجماعة أهل الحديث من أهل المدينة وغير ها كلهم أجازوا الصداق بقليل المال وكثيره، وهو قول عبداله بن و هب صاحب مالك و اختاره ابن المنذر و غيره(•).

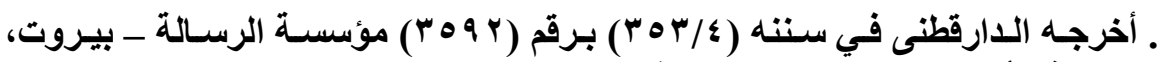

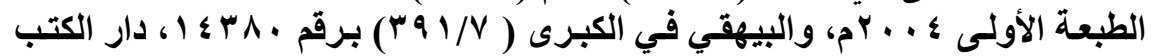

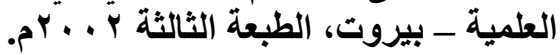

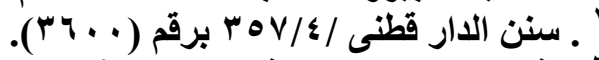

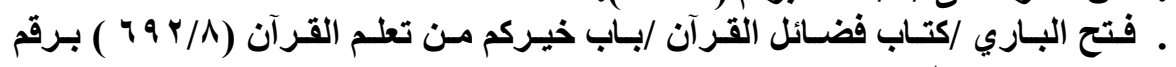

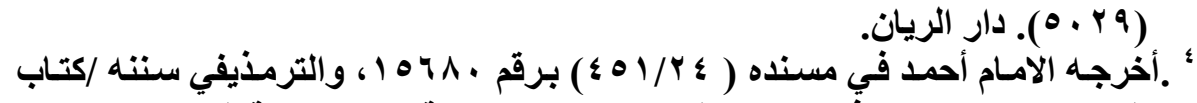

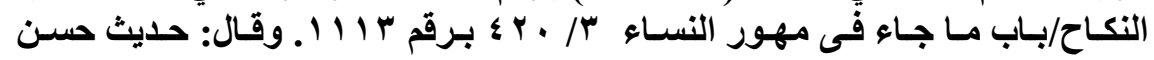

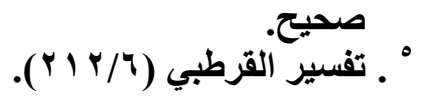

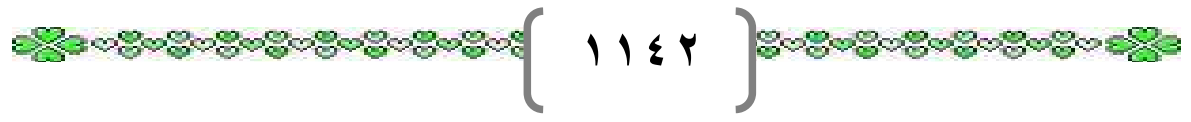


القول الثاني: ذهب أبو حنيفة ومالك إلى ضرورة تحديد حدٍ لأقل المهر ـ فحده أبو حنيفة و أصحابه بعثرة در اهم، وحده مالك بثلاثة در اهم وقال: أقل الصداق ما تقطع فيه اليد و هو ربع دينار ، أو ثلاثة در اهم فقاس الصداق عليه . و استدل الأحناف بما أخرجه الدار قطنىعن جابر بن عبداله قال: قال رسول الله صلى الله عليـة وسـلم : لا تتكحوا النسـاء إلا الأكَفاء،و لا يزوجْهن إلا الأولياء، ولا لا

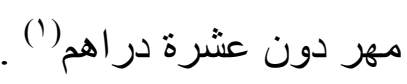
قال الشوكاني: ما استدل به الحنفية مردود عند المحدثين، وذلك لو صـح - يعنى حديث جـابر - لكان معارضـا بمـا هو أقوى منـه مـن الأحاديث الكثيرة التي ذكرنـا بعضنها (r) وقال ابن قدامـة في تعليقه على حديث جـابر الذي استدل بـه الأحنـاف لمذهبهم:

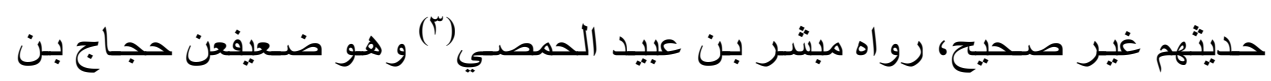

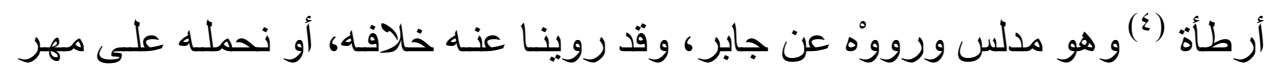
امر أة بعينها، أو على الاستحباب، وقياس من قاس لا يصـح فـإن النكاح استباحة الانتفـاع بالجملة، والقطع عــلاف عضدو دون استباحته وهو عقوبـة وحد، وهذا عوض فقياسه على الأعو اض أولى (0). وقال إبراهيم النخعى: أقل الصداق أربعون در همـا، وقـال سعيد بن جبير : أقله

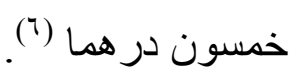

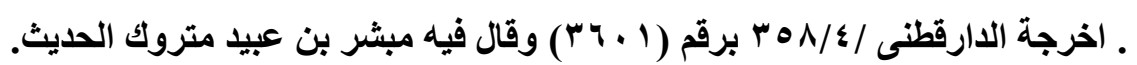

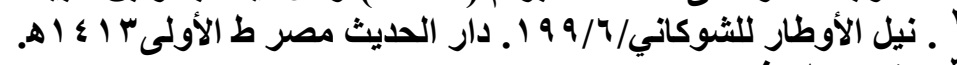

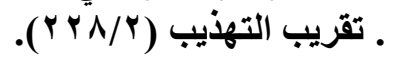

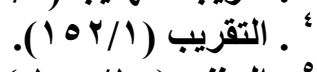

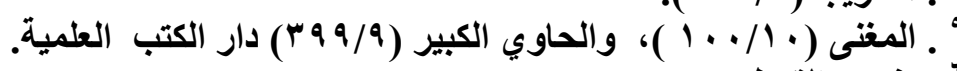

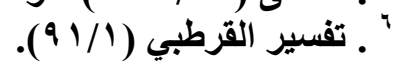

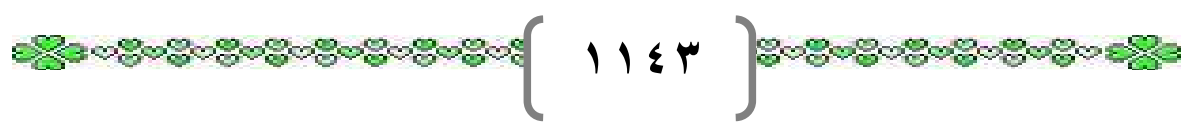


وقال ابن شبرمة: خمسة در اهم مستدلا بما أخرجه الدار قطنيعن ابن عباس عن

على رضي الله عنه قال: لا مهر أقل من خمسة در اهم ('). وبعد هذا العرض لأقو ال المفسرين والفقهاء أرى أن الذي تطمئن إليه النفس أنه لا حد لأقل المهر كما ذهب الثافعية والحنابلة، بل ذلك موكول إلى تقدير الزوجيين المتعاقدين، وما يتر اضى به الأهلون، وذللك ما يتفق مع يسر الإسـام وسماحته في

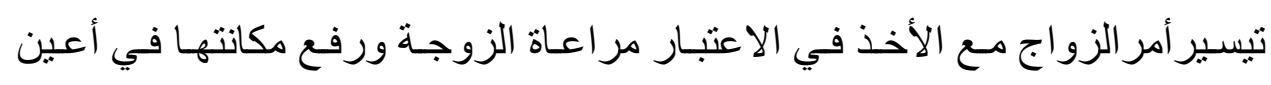
الأزواج حتى لا تكون سلعة رخيصـة يستهين بها المستهترون ممن خربت ذممهح ومن لا خلاق لهم. يقول الماوردي رحمه الله تعالى: فإذا ثبت أن أقل المهر و أكثره غير مقدر فهو متغير بما تراضى عليه الزوجان من قليل أو كثير وسو اء كان أكثر من مهر المثل،

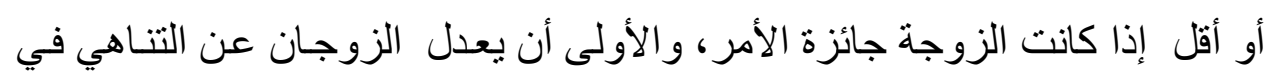

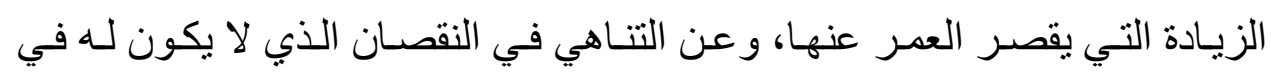
النفوس موقع، وخير الأمور أوسـاطها وأن نقتدى برسول الله صلى الله عليه وسلم في مهور نسائه طلبا للبركة، وهو خمسمائة درهم على ما روتـه عائشـة رضي الله

$$
\text { (r) (ن) }
$$

و هذا ما تطمئن إليه النفس لأنه المنهج الوسطى الذى أرشدنا إليه الرسول صلى الله عليه وسلم وهو عدم التقليل من المهور تقليلا ينزل من مكانـة المر أة، ويجعلها

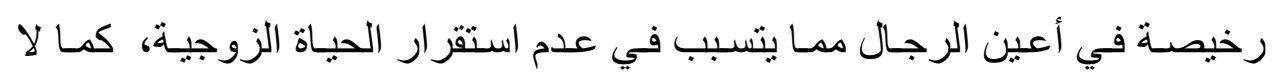

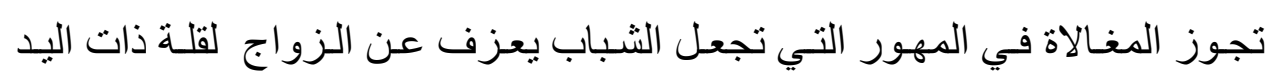
فتنتشر الرذيلة في المجتمع كما هو حاصل في وقتنا الحاضر .

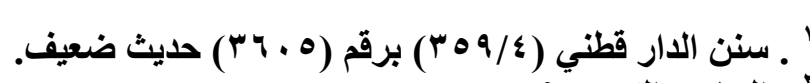

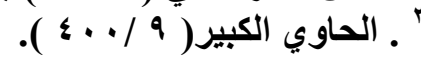

\section{\%3\%"}




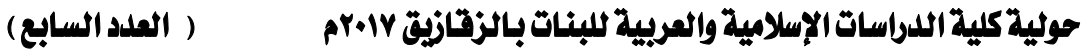

\section{أنواع المهر}

$$
\text { ينقسم المهر باعنبار ات مختلفة إلى أنواع: }
$$

فأحيانا يكون المهر مسمى قد اتفق عليه، وفي هذه الحالة يجب دفع المهر المتفق

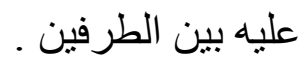

أما إذا كان المهر غير محدد و لا مسمى فوجب تسميته وتحديده بمهر المثل. وأحيانا ينقسم المهر باعتبار آخر إلى معجل ومؤجل. وينقسم باعتبار ثالث إلى ما يجب أداؤه كله، أو أداء نصفه وتأجيل النصف الآخر ،

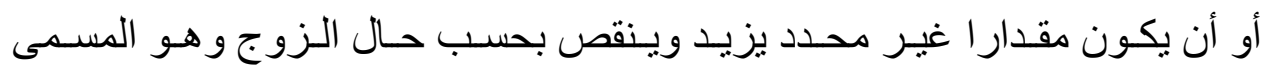
بالمتعة.

أولا : المهر المسمى ومهر المثل. المهر المسـى هو المهر الذى اتفق علي تسميته الزوجـان وأهلو هم عند العقد سو اء كان المسمى كثير ا أو قليلا، و السنة أن يسمى المهر عند العقد اقتداء برسول الله صلى الله عليه وسلم، وقد ذهب العلماء إلى استحباب تسمية المهر قطعا للنزاع، وو أدا للفتنـة التي قد تنشـأ عند تسميته بعد العقد والتي تعنّر الاتفـاق بين الزوجين وتعكر صفو حياتهما. قال ابن قدامسة: ويستحب أن لا يخلو عقد النكاح مـن تسمية الصداق لأن النبي صلى الله عليه وسلم كـان يزوج بناتهـ وغير هن ويتزوج فلم يكن يخلى ذلك من صداق('). وحتى لا ينبه نكاح الموهوبة التي كانت خاصة بالنبي، وحتى يكون أقطع

' ـ المغنى لابن قدامة / • 9 / / المالم الكتب /الرياض تحقيق الدكتور عبدالمحسن التركي. 


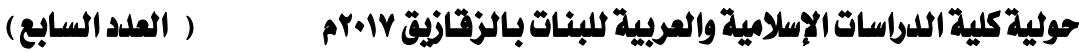

للخصومة و الاختلاف، حتى لو زوج أمته من عبده يستحب أن يسمى صداقا وإن

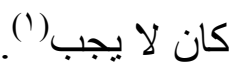

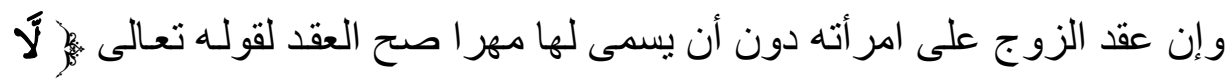

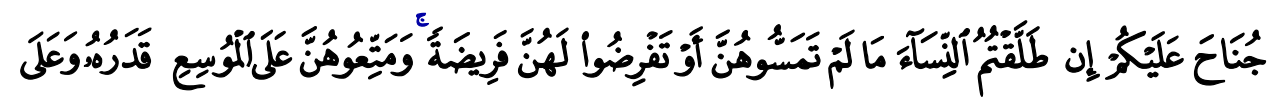

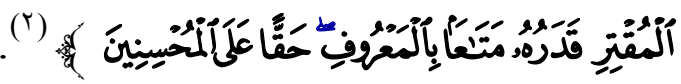
وفى معنى الآية قو لان ذكرهما الفقهاء:

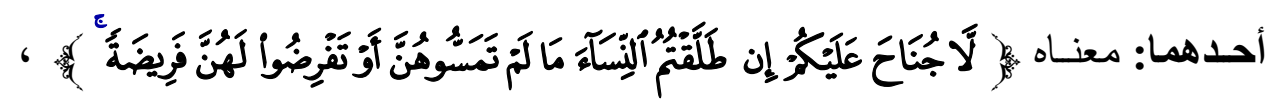
فتكون أو بمعنى لم . القول الثاني: أن في الكلام محذوفا تقديره: فرضـتم لهن فريضــة أولم تفرضوا،

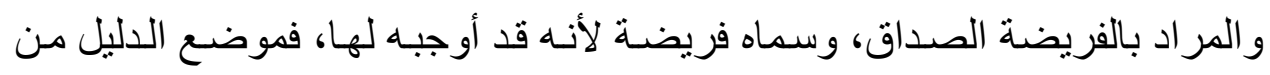
هذه الآية أن الله تعالى قد أثبت النكاح مع ترك الصداق وجوز فيه الطلاق، وحكم لها بالمتعة إن طلقت قبل الدخول، وبيَن أن الأولى لمن كره امر أة أن يطلقها قبل الدخول

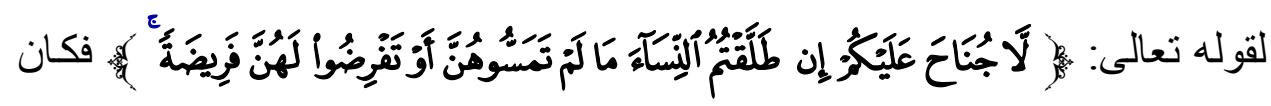
ذللك أولى طلافي الكاره(").

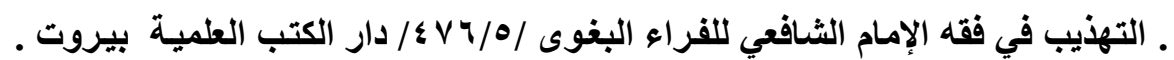

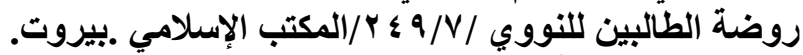

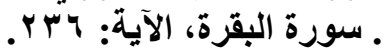

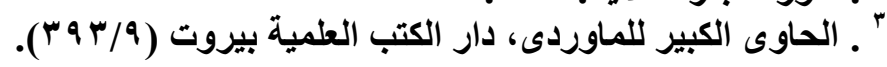


و إذا تم العقد من غير تسمية المهر وجب مهر المثل، والمر اد بمهر المثل كمـا قال

الإمام النووي رحمه الله تعالى: هو الذي ير غب به في أمثالهابل'

\section{تعجيل المهر وثأجيله}

أجاز العلماء تعجيل المهر كله أو تأجيله كله، كمـا أجـازوا تعجيل بعضـهـ وتأجيل البعض الآخر إلى أجل قريب أو بعيد، كما أجازوا كذللك دفعسه على أقساط متفاوتة،

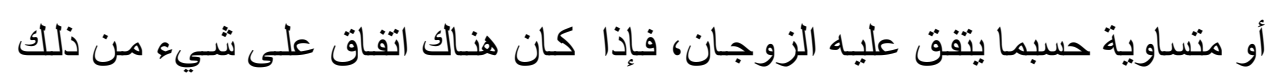

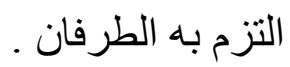

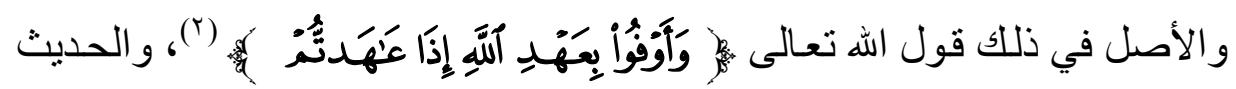

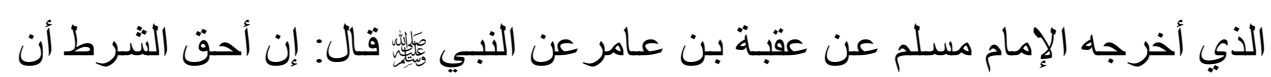

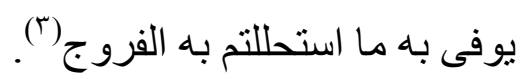
يقول ابن قدامة رحمه الله تعالى: ويجوز الصداق معجلا ومؤجلا، وبعضـه معجـا وبعضه مؤجلا، لأنه عوض في معاوضة فجاز ذلك فيه كالثمن، وإن شرطه مؤجلا إلى وقت فهو أجله، وإن أجله ولم يذكر أجله فقال القاضي: المهر صحيح ومحله الفرقة، فإن أحمد قال: إذا نزوج على العاجل والآجل لا يحل الآجل إلا بموت أو أو إله

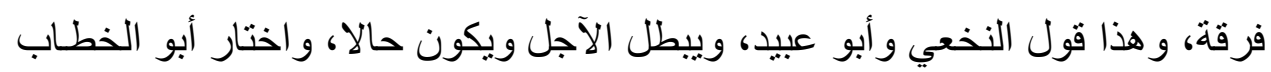

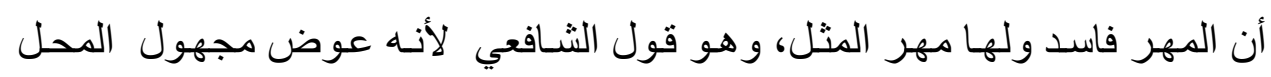
ففسد كالثمن في البيع أه (ع).

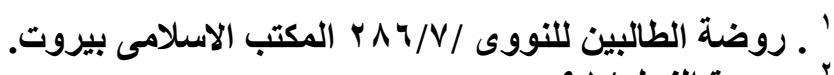

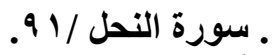

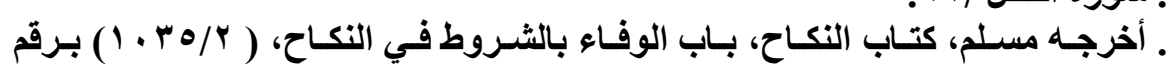
11 اخفجه " . المغنى لابن قدامة / ـ 10/1 / /عالم الكتب الرياض.

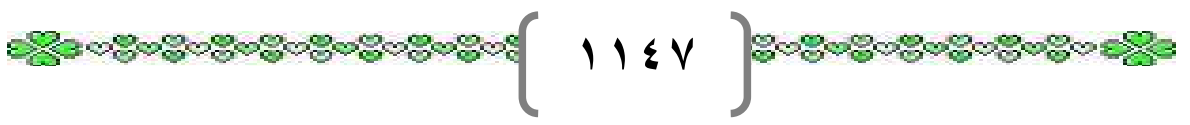




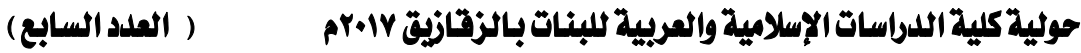

و السر في قبول المهر التعجيل و التأجيل أنه حق مالي كالدين. قال الإمام الثـافعي

رحمه الله تعالى: والصداق كالدين سواء (1).

وقـال المـاوردي شـارحا قـول الثــافعي بقولـه: لأنـهـه مـال ثبـت فـي الذهـة دينـا

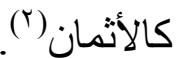

وممن أجـاز التأجيل شيخ الإسـلام ابن تيمية، ولكنه فضل التعجيل إتباعـا لهدى

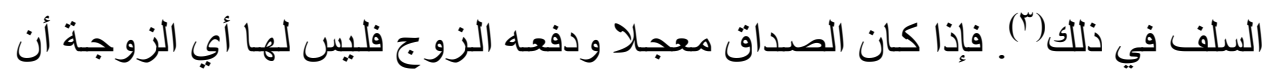

تمنع نفسها منه بل عليها أن تسلم نفسها له ليستمتع بها .

أما إذا لم يكن هنـاك اتفاق على تأجيل المهر فقد قـال المـاوردي رحمـه الله تعالى لها أن تمتنع عن تسليم نفسها لله حتى تقتضى صداقها، كما كان لبائع السلعة أن

يمتنع عن تسليمها على قبض ثمنها(؛).

قال ابن المنذرحمه الله تعالى: أجمع كل من أحفظ عنه من أهل العلم أن للمر أة

أن تمتتع من دخول الزوج عليها حتى يعطيها مهر ها(').

و عن ابن عباس رضـي الله عنهما أن عليـا قـال: تزوجت فاطمـة رضـي الله عنها

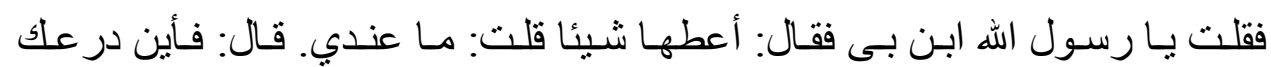
الحطمية؟ قلت: هي عندي قال: فأعطها إياها (ج).

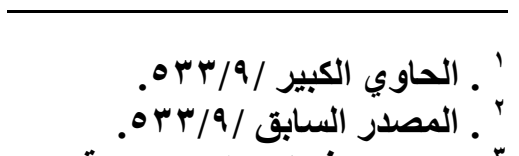

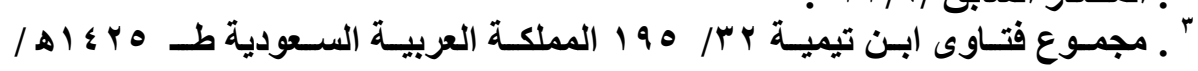

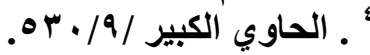

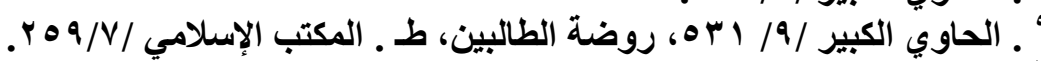

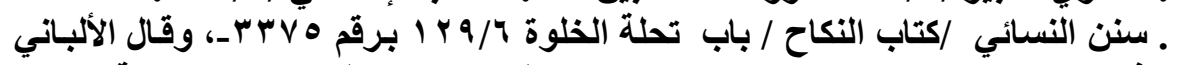
في تعليقاته على الكتاب حديث حسن صحيح، طـ مكتب المطبو البعات الإسلامية، حلب،

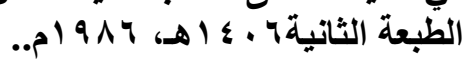




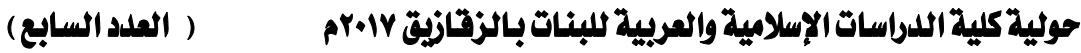

أما إذا أتفق الطرفان على تأجيل المهر فلا حق للمر أة في الامتناع عن زوجها لأن رضاها بتأجيل الكل يسقط حقها في الامتناع.

يقول الإمسام المـاوردي: إذا كـان الصـداق مؤجلا فعليها تسليم نفسها وليس لهـا الامتناع لقبض الصداق بعد حلول الأجل لأنها قد رضيت بتأخير حقها وتعجيل حقه .

كالبيع بالثمن المؤجل يجب على البائع تسليم المبيع قبل قبض الثمن(') متى تستحق الزوجة المهر كاملا؟

تستحق الزوجة المهر كاملا في الحالات الآتية:-

الحالة الأولى: إذا طلقها زوجها بعد الدخول بها.

لا خـلاف بين أهل العلم في استحقاق الزوجـة كامل المهر إذا دخل بهاز زوجها

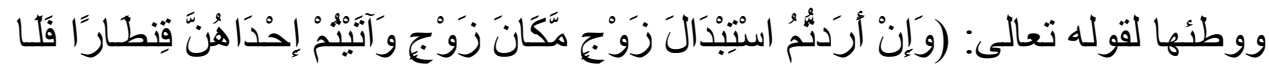

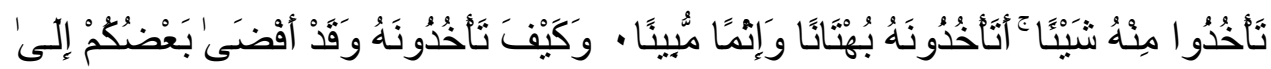

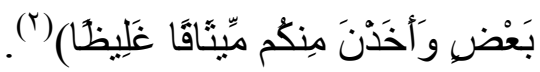
ففي الآيـة الكريمة نهى للأزواج عن أخذ شيء ممـا أعطوه لزوجاتهم ولو كان المهر المعطى لها قنطـار ا من المـال، وقد وصف الله هذا الأخذ بأنه بهنان و إثم

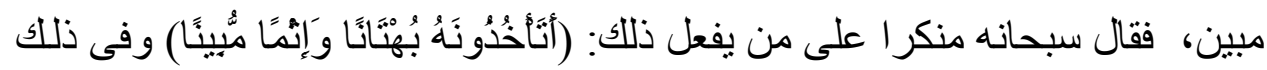
تحذير وو عيد لـأزواج من التجرء و الإقدام على أخذ شيء من ذلك، ثم أعـاد الله

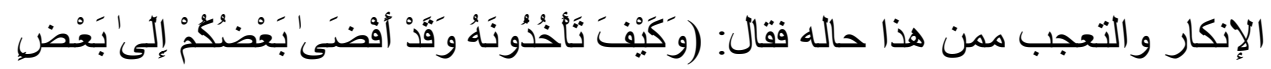

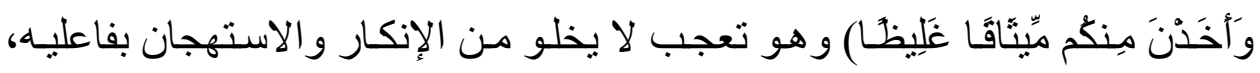
وخاصة بعد أن أفضى كل واحد منهما للآخر بأسر اره الجسدية و العاطفيـة بمقتضى لئس عقد النكاح الذى هو ميثاق غليظ يجب الحفاظ عليه وصيانته. 


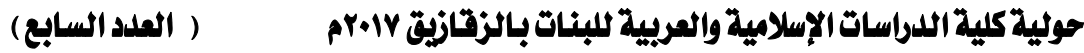

قـال الإمـام ابـن كثير رحمـه الله تعـالى: إذا أر اد أحدكم أن يفـارق امر أة ويستبدل

مكانها غير ها فلا يأخذ مما كان أصدق الأولى شيئا ولو كان قنطار ا من مال('). وقال الإمام القرطبي رحمـه الله تعـالى: لمـا مضـى في الآيـة المتقدمة حكم الفراق الذي سببه المر أة ، وأن للزوج أخذ المال منها، أعقب ذلك بذكر الفراق الذي سببه الزوج وبين أنه إذا أر اد الطلاق من غير نشوز وسوء عشرة فليس له أن يطلب منها مالا(י)

وقال الماوردي(ّ) رحمـه الله تعـالى: اتفق الفقهاء على أنـه لـو طلقها بعد الدخول بوطء تام تغيب بـه الحشفة فقد استقر لها جميع المهر الذى كانت مالكة لـه بالعقد

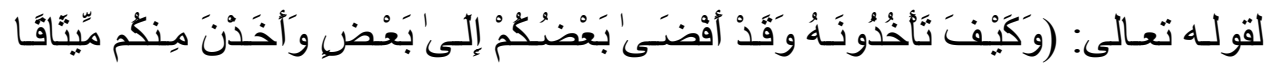
غَلَيظا).

الحالة الثاتية: الخلوة الصحيحة (£):

اختلف الفقهاء فيما تستحقه المر أة بالخلوة بعد تمام العقد الصحيح على قولين:-. القول الأول: ذهب الإمام الثافعي(0) في جديد مذهبه أنه ليس لها إلا نصف المهر و لا عدة عليها لأن الخلوة لا يجب بها كمال المهر بل لابد من إصـابتها بـالوطء، وبـه قال من الصحابة ابن عباس، وابن مسعود رضـي الله عنهما. ومن التابعين: الإمـام الشعبي، وشريح، وطاووس، وابن سيرين. ومن الفقهاء: أبو ثور .

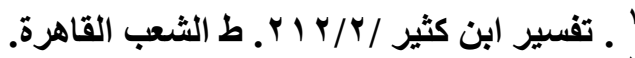

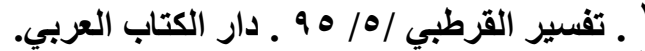

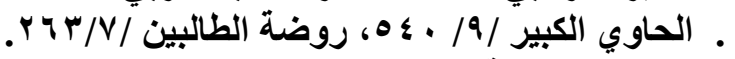

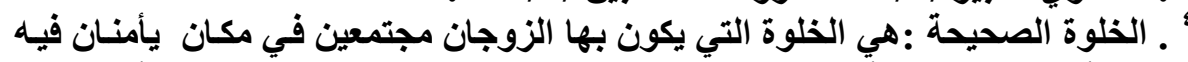

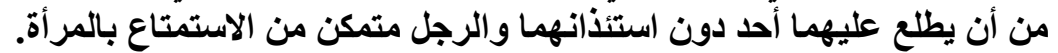

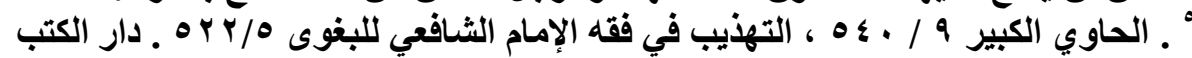

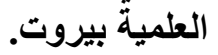

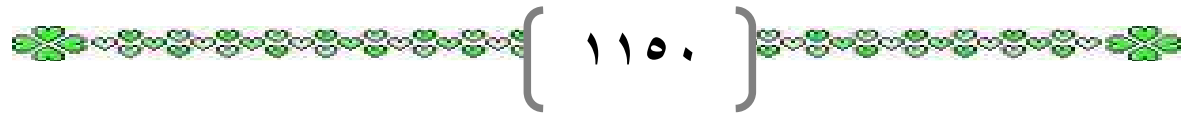




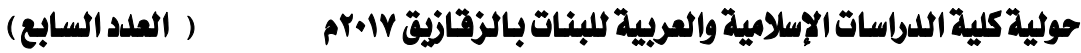

وقال الإمام أحمد إذا صدقته المر أة أنه لم يصبها لم يكمل لها الصداق('). وقال الامام ماللك: إذا لم يدَّعى أحدهما الإصـابة بـالوطء في الخلوة فليس لها إلا نصف المهر ،و لا تجب بالخلوة عدة(؟).

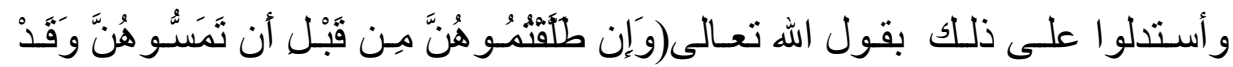

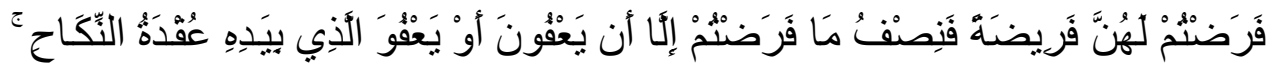

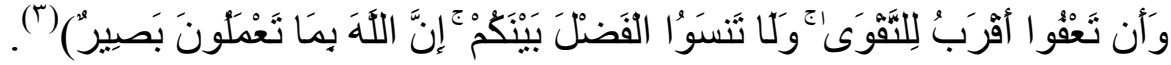
و المطلقة التي خلى بها زوجها من غير وطء مطلقة قبل المسيس لها نصف مـا

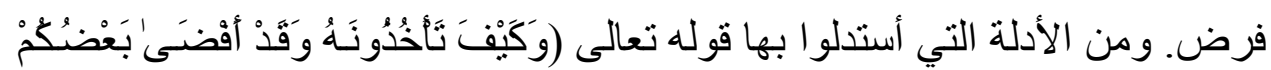

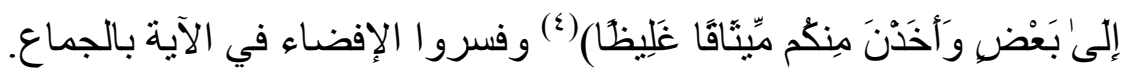
قال ابن عباس، ومجاهد، و السدى و غير هم: الإفضـاء في هذه الآيـة الجمـاع. قال ابن عباس: ولكن اله كريم يكنى (0). أخرج الإمام ابن كثير رحمـه الله تعـالى في تفسيره بسنده عن طـاووس عن ابن عباس رضي الله عنهــا أنـه قـال في الرجل يتزوج المر أة فيخلو ا بها و لا يمسها ثم

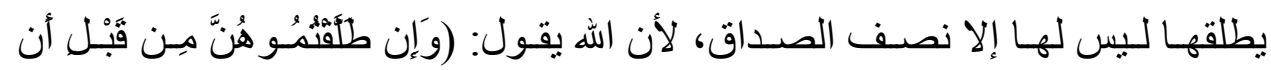

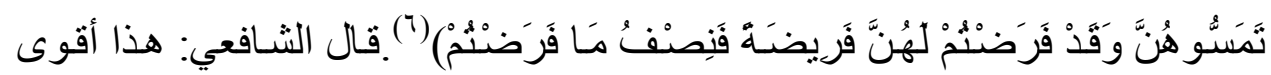

وهو ظاهر الكتاب أ هـ (v) - (v)

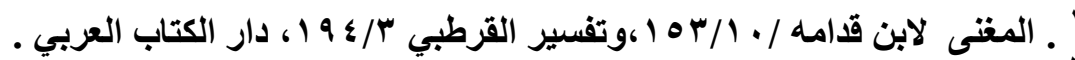

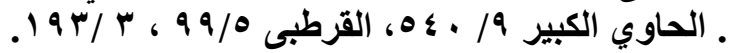
(

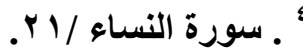

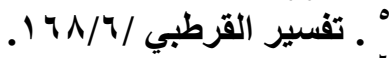

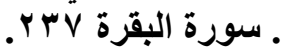

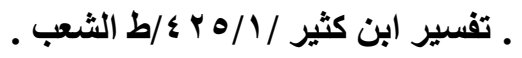


القول الثاني: ذهب الإمـام أبو حنيفة وأصحابه(') إلى أن الخلوة الصحيحة التي لا يمنع منها مانع من الوطء كالدخول في كمال المه ، لمـا رو اه الدار قطني عن محمد بن عبدالرحمن ابن ثوبان قال: قال رسول الله صلى الله عليه وسلم:من كثف خمـار

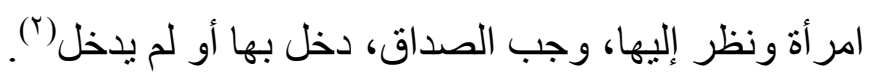

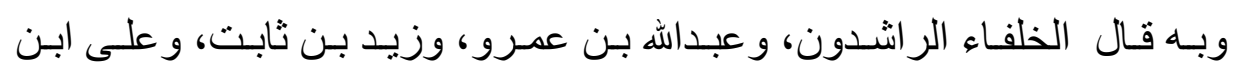
الحسين، و عروة ابن الزبير، و عطاء، و الزهري. قال عمر بن الخطاب رضى الله عنه: إذا أغلق بابـا وأرخى ستر ا فقد وجب عليه الصداق، و عليها العدة، ولها الميراث("). وقـال على رضـى الله عنـه: إذا أغلق بابـا وأرخى ستر ا أو رأي عورة فقد وجب واب

$$
\text { عليه الصداق(汭 }
$$

وممن قال بهذا من الفقهاء: الإمـام الثوري، واسحاق، وداود، و الثـافعي في قديم

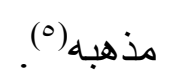

ورد أصحاب هذا القول على أدلة مخالفيهم بما يلى (ج). أولا: أن التسليم المستحق وجد مـن جهتها بـالخلوة الصـحيحة فيستقر بـه البدل الذي هو المهر كاملا كما لو وطنها، أو باعت دارها وسلمتها.

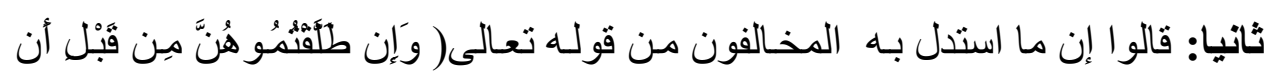

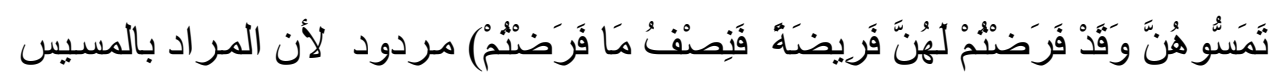

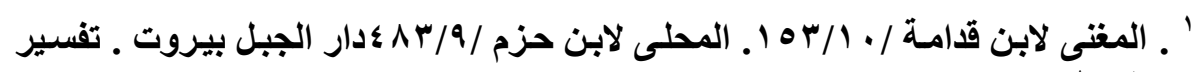

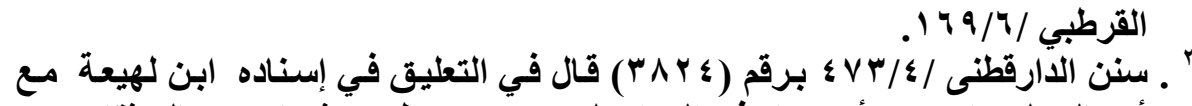

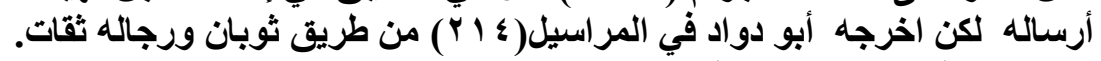

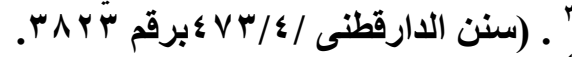

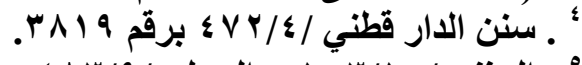

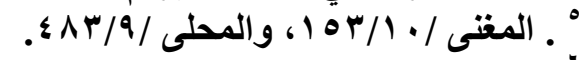

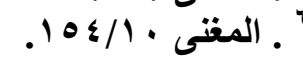




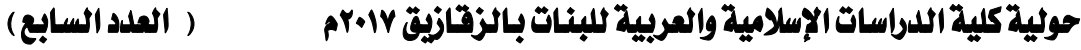

في الآية: الخلوة لأنها السبب في الجماع فيحتمل أنه كنى بالمسبب الذي هو الجماع عن السبب الذى هو الخلوة .

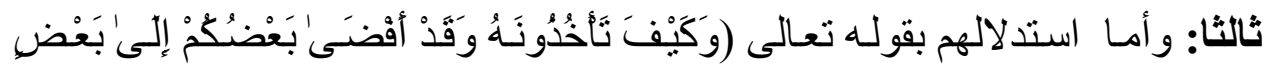

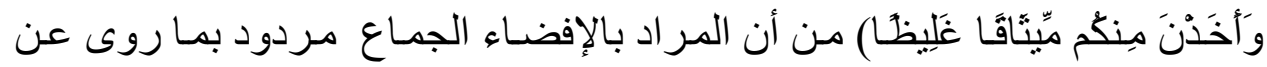
الفرّاء (') قال الإفضاء: أن يخلو الرجل بالمر أة وإن لم يجامعها، قالو ا: وهذا صديح

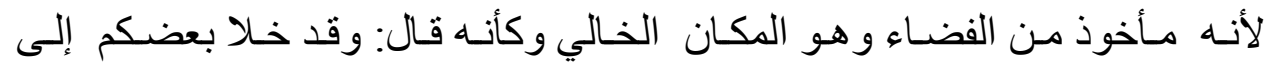

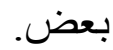

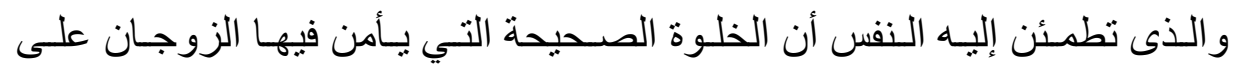
أنفسهما من أن يطلع أحد عليهما، ويتمكن الرجل فيها من الاستمتاع بزوجـه. هذه الخلوة بهذا الوصف كالدخول الحقيقي في وجوب المهر كله، وفى ثبوت العدة بالطلاق لإجماع(؟) الخلفاء الر اشدين على ذلك، وقضائهم به كما سبق بيانه، وهو مـا يـرجح مـا ذهـب إليـه أبـو حنيفـة وأصـحابه لأن الخلوة الصـحيحة مظنـة الاسـتمتاع بالجماع و غيره، فإذا خـلا بها فقد هيئت لهه الغرض وسلمت لله نفسها فوجب لها المهر كاملا.

\section{الحالة الثالثة: موت أحد الزوجين قبل الدخول.}

لا خلاف بين العلماء في أن المرأة إذا مـات زوجها بعد أن سمى لها المهر وقبل أن يدخل بها أنها تستحق المهر كاملا، وكذللك إذا ماتت المر أة بعد العقد الصحيح وقبل الاخول فلها المهر المسمى كاملا باتفاق، و إنمـا الخـلاف بينهم فيمـا إذا مـات

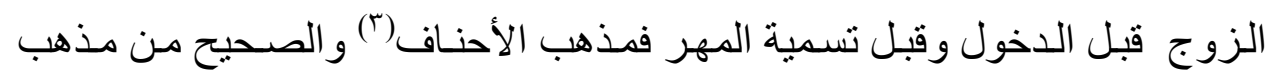

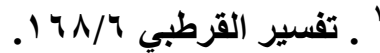

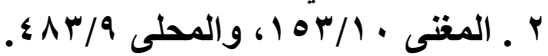

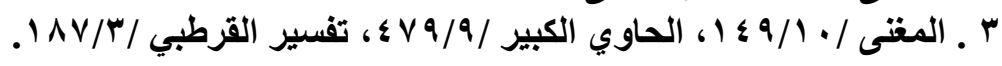


الحنابلـة أن لهـا مهر المثنل وهو أحد قولي الثـافعية، وبـه قـال ابـن مسـود، ومـن التـابعين:علقــة، و الثـعب، ومـن الفقهاء: ابـن أبى ليلى، وسفيان، والثورى، و ابـن شبرمة، و واسحاق. و قد استـل أصحاب هذا القول بمـا رواه الترمذي بسنده عن علقمـة عن ابن مسعود أنه سئل عن رجل تزوج امر أة ولم يفرض لها صداقا ولم يدخل بها حتى مات .فقال ابن مسعود : لها مثل صداق نسائها لا وكس و لا شطط، و عليها العدة ولها الميراث، فقام معقل ابن سنان الأشجعي فقال: قضى رسول الله صلى الله عليه وسلم في برْوع بنت واشق امر أة منا مثل الذى قضيت فقر ح بها ابن مسعود ('). قال أبو عيسى الترمذي رحمه الله تعـالى :حديث ابن مسعود حديث صـيح وقد روى عنه من غير وجه، و العمل به على هذا عند بعض أهل العلم من أصحاب النبي صلى الله عليه وسلم و غير هم، وبه قال الثوري وأحمد و إسحاق (؟). وذهب الإمام مالك(") والثافعي() في القول الآخر عنه أنه لا مهر لها لأنها فرقة وردت على تفويض صحيح قبل فرض ومسيس فلم يجب بها مهر كفرفة الطلاق، و عليها العدة . وبهذا قال من الصحابة:على ابن ابى طالب، و عبداله ابن عباس، و عبداله ابن عمر، وزيد بن ثابت(0) ،ومن التابعين: جابر بن زيد، والزهري، و عطاء، ومن الفقهاء:

$$
\text { ربيعة، و والأوز اعي. }
$$

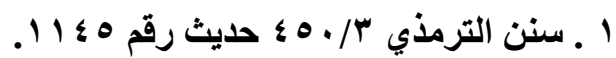

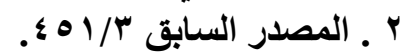

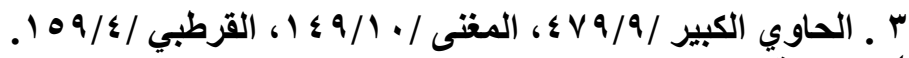

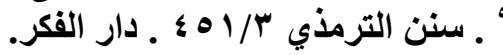

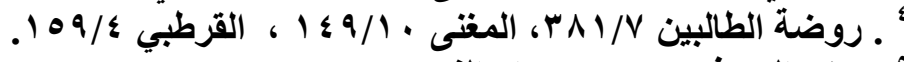


والراجح من الأقوال: ما ذهب إليه الأحنـاف والحنابلة في وجوب المهر المسمى،

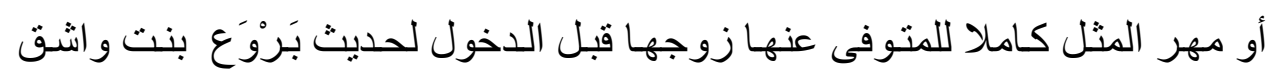
الذى رواه معقل بن سنان الأشجعى، و لأن المهر لـم يجب هنـا في مقابل الاستمتاع الحلال كما هو الثـأن في المهور إذ لا استمتاع، و إنمـا وجب تمتيعـا للمر أة وتخفيفا للوعـة الحزن والأسىى بمـوت الزورج، ومنـاط وجوبـه هـو مـوت الزوج بعد عقد صحيح وبدون دخول لا فرق بين من سُمى لها ومن لم يسمى لها. ولقد توقف الإمام الثافعي رحمه الله تعالى عن العمل بمقتضى هذا الحديث حيث لم يبلغه بإسناد صحيح، وفى ذلك يقول رحمـه الله تعـالى: فإن كان يثبت - يعنى حديث بَروع - فلا حجة في قول أحد دون النبي صلى الله عليه وسلم، وإن لم بثبت

$$
\text { فلا مهر لهاو لا مير اث('). }
$$

لكن الإمام الترمذي رحمه الله تعالى بعد مـا نقل عبارة الثـافعي هذه عقب عليها

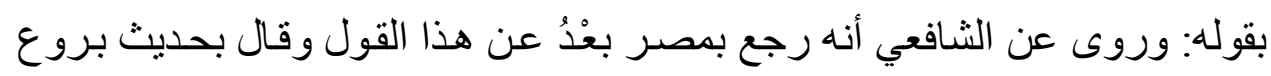
بنت و اشق بهو (r). وقد أطال الماوردي(ّ)رحمه الله تعالى القول في بيان ضـف حديث بَرْوْع بنت و اشـق، ولـم يـرتض النـووي رحمـه الله تعـالى تضـعيف المـاوردي للحديث وقـال برجاحة مذهب الإمام الثافعي في استحقاق الزوجة المهر و المير اث وفى ذلك يقول رحمه الله تعالى (£): الر اجح ترجيح الوجوب ـ أي وجوب استحقاق الزوجـة المهر كاملا - و الحديث صحيح رو اه أبو داود(')، و الترمذي(ج)، و النسائي (')، و غير هم.

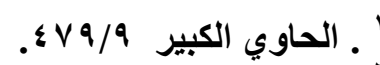

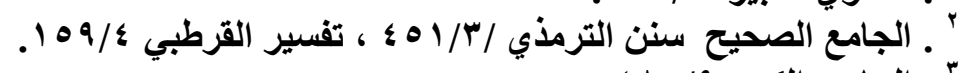

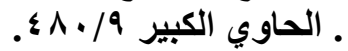

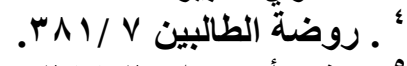

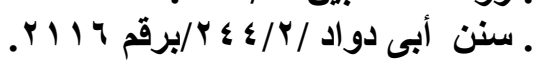
ـ سبق تخريجه . 


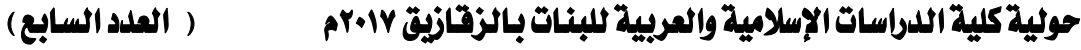

وقال الترمذي: حديث حسن صحيح، ولا اعتبار بما قيل في إسناده. وقياسا على الاخول فإن الموت مقرر كالاخول، و لا وجه للقول الآخر مع صحة الحديث أ. هـ.

\section{متى تستحق المرأة نصف المهر؟}

عقود الزواج من العقود و المو اثيق التي رغب الإسـام في احتر امهاوصيانتها من العبث، فإذا تعثرت الحياة الزوجيـة قبل الدخول و أصبح الوفاق بين الزوجين

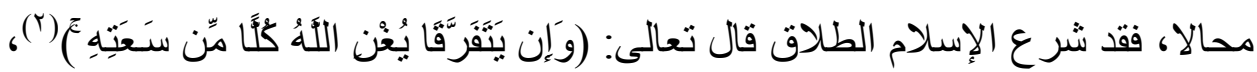
فإذا طلق الرجل امر أتـه المعقود عليها بعقد صحيح قبـل أن يـخل بها، فقد ألزمـهـ الثـرع بإعطاء الزوجـة نصف المهر ، ويأخذ هو النصف الأخر إلا أن يعفو أحد الزوجين فيتنازل عن حقه للأخر .

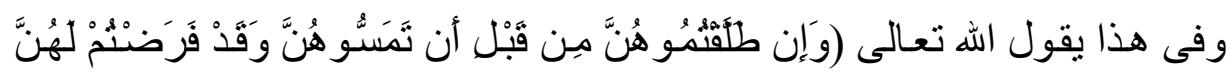

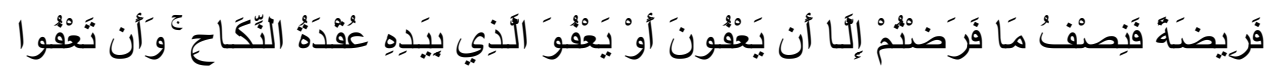

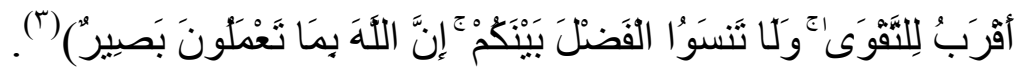
فقد أرشد الله تعالى في الآية الكريمـة الأزواج إلى الترفع و التسـامي عن المطالبـة

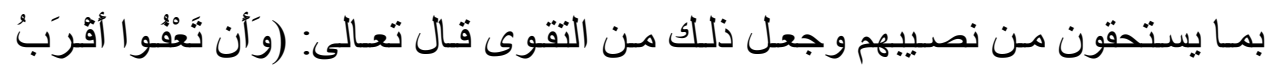

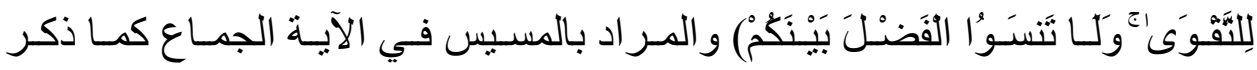

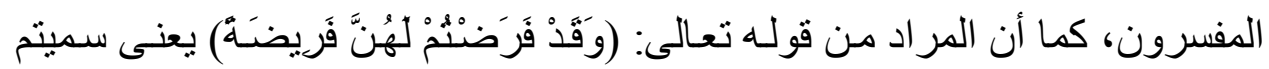
لـن صداقا.

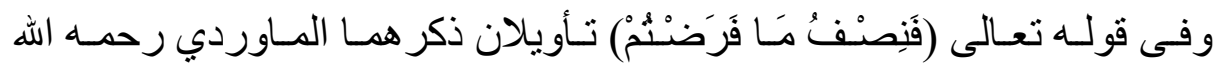
تعالى (') (1)

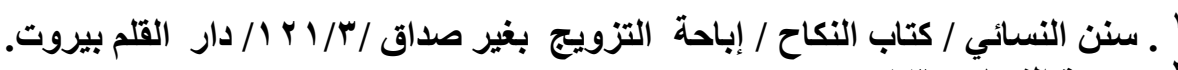

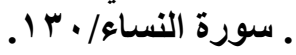

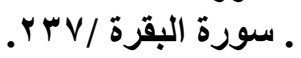




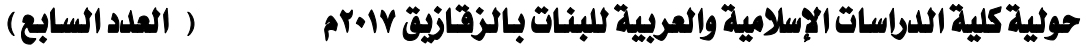

أحدهما: فنصف ما فرضتم لكم تسترجعونه منهن.

الثاني: فنصف ما فرضتم لهن ليس عليكم غيره لهن.

قال الإمام ابن كثير رحمه الله تعالى: أوجب الله تعالى في هذه الآيـة نصف المهر المفروض إذا طلق الزوج قبل الدخول وتشطير الصداق والحالـة هذه أمر مجمـع عليه بين العلماء، ولا خلاف بينهم في ذلك، فإنه متى قد سمى لها صداقا ثم فارقها

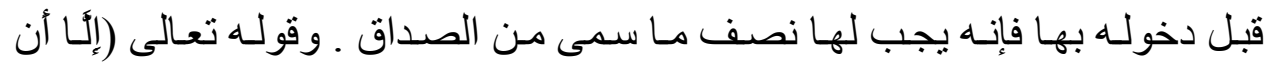
يَعْون) أي النساء عما وجب لها على زوجها فلا يجب لها عليه شيء، وهو قول ابن عبـاس، قـال ابـن أبسى حـاتم: وروى عـن شـريح، وسـعيد بـن المسـيب، و عكرمـة، ومجاهد، و الثـعبي، و الحسن، ونـافع، وقتادة، وجابر بن زيد، و عطـاء الخرسـاني، و الضحاك، و الزهري، ومقاتل بن حبان، وابن سيرين، و الربيع بن انس، و السدى نحو ذلك. قال وخالفهم محمد بن كعب القرظى وقال: (إلا أن يعفون) يعنى: الرجال وهو قول شاذ لم يُتابع عليه أ.هـ(؟).

وقد اختلف المفسرون فيمن بيده عقدة النكاح على أقو ال(r): فذهب بعض أهل العلم إلى أن الذي بيده عقدة النكاح هو الولي. وبـه قـال مـن الصـحابة ابـن عبـاس. ومـن التـابعين الحسـن، ومجاهـد، و عكرمـة، وطاووس، و عطاء، و الزهري، وربيعة. و معنى قوله (إلا أن يعفون ): أي الزوجة بترك نصيبها إلى الزوج ( أو يعفو الذي بيده عقدة النكاح ) أي وليهـا، فيتـرك نصـيهـا إن كانـت المـر أة بكر ا، أو غير 


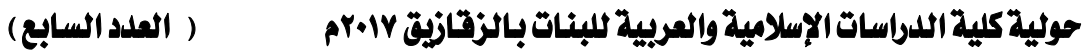

جائزة الأمر فيجوز عفو وليها. وهو قول الثـافعي في القديم وبـه قال مالك و إحدى الروايتين عن أحمد '(')

وقد استال أصحاب هذا القول بما يلى :أولا:- أن الله تعالى افتتح الآية بمخاطبة الأزواج مواجهة ثم عدل بقوله ( إلا أن يعفون ) إلى خطاب الزوجات كنايـة، ثم أرسل قولـه (أو يعفو الذي بيده عقدة النكاح ) و هو خطاب لمكنَى عنه غير مواجه، والخطاب إذا عدل عن المواجهة إلى الكنايـة اقتضـى ظـاهره أن يتوجـه إلى غير المواجـه، والزورج مواجـه فلم تعدد إليـه الكناية، و الزوجة قد تقدم حكمها، ولفظ الكنايـة مذكر فلم يجزئ أن يعود إليها فلم يبقى من يتوجه الخطاب إليه غير الولي . ثانيا:- قوله تعالى ( أو يعفو الذي بيده عقدة النكاح) وليس أحد بعد الطلاق بيده عقدة النكاح إلا الولي، لأنـه يملك أن يزوجها فاقتضـى أن يتوجـه الخطـاب إليـه و لا يتوجه إلى الزوج الذي ليس العقد إليه ليكون الخطاب محمو لا على الحقيقة من غير إضمار و لا يحمل على مجاز و إضمار. ثالثـا:- أن الذي يختص بـه الولي مـن النكاح أن يملك عقده، و الذي يختص بـه الزوج أن يملك الإستمتاع بعده، فكان حمل الذى بيده عقدة النكاح على الولي الذي يملك عقده أولى من حمله على الزوج الذى يملك الاستمتاع بعده. وقال أخرون: إن الذي بيده عقدة النكاح هو الزوج. وهو قول على. وقال ابن ابى حاتم: هي إحدى الروايات عن ابن عباس، وبـه قال سـيد بـن المسيب، وسـيد بـن جبيـر، وجبيـر بـن مطعم، وشـريح في أحد قوليـه، و مجاهد، و الشعبي، وقتادة، و عكرمة، ونافع، ومحمد بن سيرين، و الضحاك، وجابر

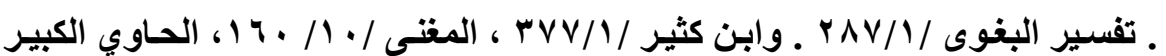

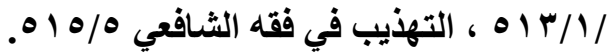




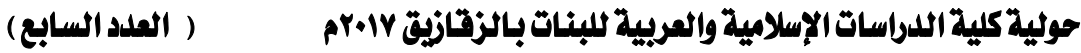

بن زيد، وابس مجاز ، و الربيع بن أنس، و إيـاس بن معاويـة، ومكحول، ومقاتل بن

حيان (').

و هو قول الثـافعي في الجديد، وبـه قال أبو حنيفة و أصـابه، و أحمد في القول

الآخر عنـه، والثوري، و إسحاق، وابن شبرمة، وأصحاب الرأي، والأوز اعي(َ) ،

و اختاره الطبري( آن.

واستدل أصحاب هذا القول بما يلى (๕):-

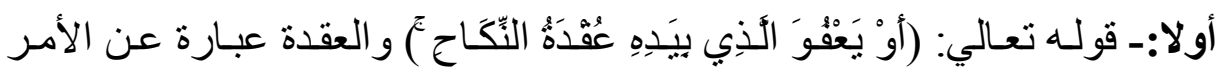

المنعقد، ومنه حبل معقود، و عهد معقود لما قد استقر عقده ونجزه، و النكاح بعد العقد يكون بيد الزوج دون الولي . - مان

ثانيـا:ـ أنـه أمـر بـالعفو، و إنمـا يعفو ا مـن ملك، و الزورج هـو المالك دون الـولي،

فاقتضي أن يتوجه الخطاب بالعفو إليه لا إلي الولي.

ثالثا :- إن حقيقة العفو هو الترك وذلك لا يصح إلا من الزوج لأنه ملك بالطلاق أن يتملك نصف الصداق، فإذا ترك أن يتملك لم يملك، فأما الولي فعفوه إما أن يكون هبة إن كان عينا، أو إبر اءَّ إن كان في الذمة. فصار حقيقة العفو أخص بـالزوج من حمله علي المجاز في الولي. رابعاً :- أنه إذا توجه بالعفو إلي الزوج كان محمو لا علي عمومـه في كل الأزواج و إذا توجها إلي الولي كان محمولا علي بعض الأولياء في بعض الزوجات، وهو الأب و الجد من بين سائر الأولياء مـع الصـيرة البكر التي لم يدخل بها دون سـائر

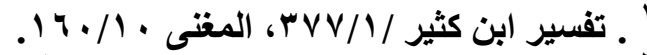

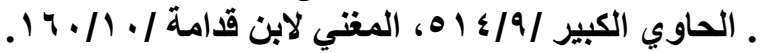

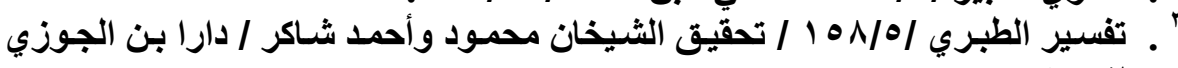




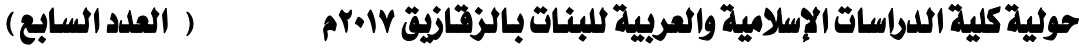

الزوجات، وكان حمل الخطاب علي ما يوجب العموم أولي من حمله علي مـا يوجب

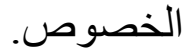

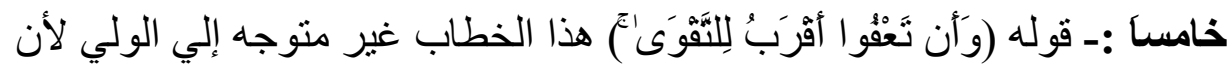
قربه من التقوي أن يحفظ مال من يلي عليه لا أن يعفو عنه ويير أ منه، فدل علي أنه الزوج دون الولي وهو راجع علي ما تقدمه فاقتضي أن يكون المتقدم قبلـه الذي بيده عقدة النكاح هو الزوج. سادسا :- ويدل عليه من السنة ما رواه ابن لهيعة عن عمرو بن شعيب عن أبيـ عن جده قال : قال رسول الله صلي الله عليه وسلم : ولي عقد النكاح الزوج. وهذا نص في ذلك(') - (') سابعاً :- روي الدار قطني () بسنده عن أبي سلمة أن جبير بن مطعم تزوج امر أة من بني فهر, فطلقها قبل أن بدخل بها، فأرسل اليها الصداق كاملاحَ فقال: أنـا أحق

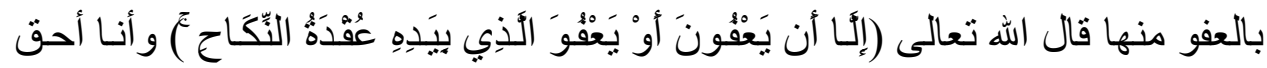

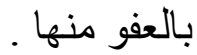
وهذا قول صحابيين فبإن قبل: خالفها ابن عبـاس قيـل: قد اختلفت الروايـة عنـه، فتعارضنا وثبت خلافه فصار الإجماع بغيره منعقدا. مما سبق يتبين أن الذي بيده عقدة النكاح هو الزوج وهو تطمئن إله النفس. متى يسقط المهر?

يسقط المهر كله إذا كانت الفرقـة من قِبـل الزوجـة بسبب ردتهـا عن الإسـلام، أو بسبب آخر يوجب الفرقة فيسقط المهر كله.

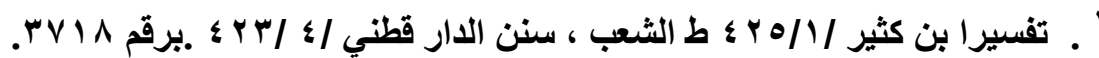

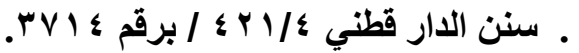


قال ابن قدامة: كل فُرققة جـاءت من قبلها ــ أي الزوجـة ـ قبـل الدخول كإسـلامها وردتها و إرضاعها ممن بنفسخ به نكاحها، وفسخها لعيبه أو إعساره، أو فسخه لعيبها يسقط مهر هاو متعتها ('). وفي تكملة المجموع للثير ازي: إن وقعت الفُرْقة بينهما قبل الدخول وكانت بسبب من جهة الزوجة بأن أسلمت أوارتدت أو أرضعته، أو أرضعت زوجـة لـه صغيرة، أو وجد أحدهما بالآخر عيبـا ففسخخ النكاح سقط جميع المهر، لأن البضـع تلف قبـل الاخول بسبب من جهتها فسقط ما يقابله إذا تلف قبل القبض أ هـ(؟). وقال ابن قدامة رحمه الله تعالي: وكل فُرَقة كانت قبل الدخول من قِبـل المر أة قبل

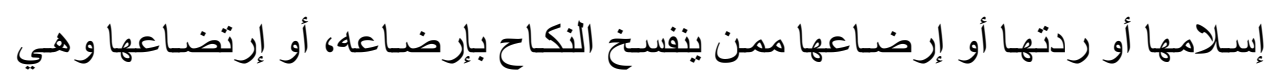

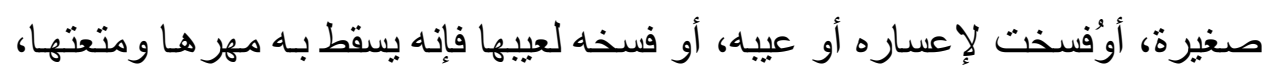
لأنها أتلفت المعوضّ قبل تسليمه فسقط البدل كله كالبائع يتلف المبيع قبل تسليمه(؟).

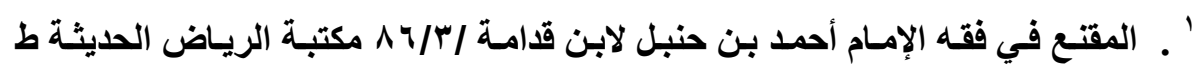

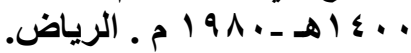

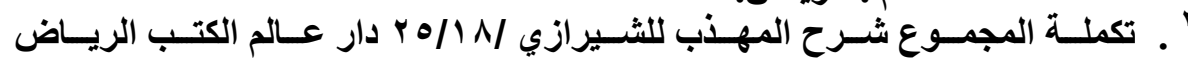

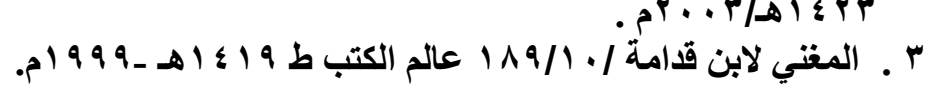

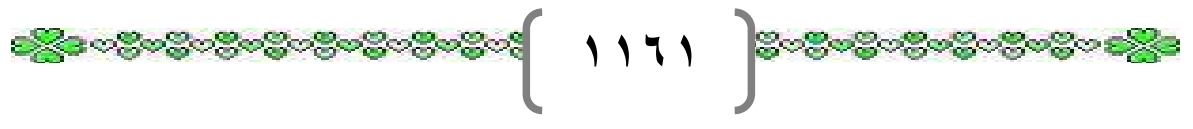




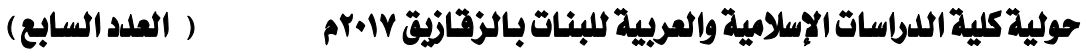

\section{المطلب الثاني: النفقة}

من الحقوق الماليـة الو اجبـة على الزوج لزوجته حق النفقة وهو: مـا يطالب بـه الزوج شرعا نحو زوجته من طعام، وشراب، وكسوة، ومسكن، وفر اش، وخدمة، وما يتبع ذلك حسب العرف في إطار القو اعد الثرعية. وقد عرفها ابن عرفـة المـالكي بقوالهالنفقة: مـا بـه قو ام معتـاد حسال الآدمسي دون

سرف(') - (1)

و المر اد ما تعتمد عليه حياة الآدمي وما به قو امه من القوت و الكسوة ومؤن الحياة من غير إسر اف، أو زيادة على المألوف و المعتاد .

و عرفها الأحناف بقولهم النفقة: هي الإدرار على الثيء بما به بقاؤه(؟).

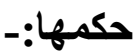

ذهب الفقهاء إلى وجوب نفقة الزوجة على زوجها باعتبار هاـ أي النفقةـ أثر ا من آثار العقد الصحيح، وحقا من الحقوق الثابتة للزوجـة على زوجها. وهى تجب على على الزوج حتى ولو كانت الزوجة غنية، وسو اء كانت مسلمة أو غير مسلمة، لأن سبب وجوبها هو الزواج الصحيح وهو أمر متحقق في جميع الزوجات .

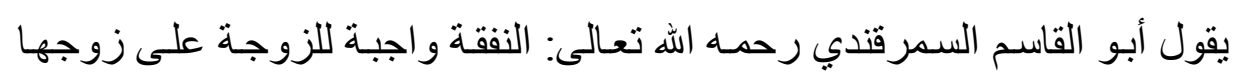
مسـلمة كانـت أو كـافرة لقولـه تعـالى: ( وعلى المولـود لـهـ رزقهـن وكسـوتهن بالمعروف ) و لأنها محتبسة لحقه فعليه كفايتها، و هذا إذا سلمت نفسها لـه في منزلـه

فعليه النفقة و السكن و الكسوة:(ॅ).

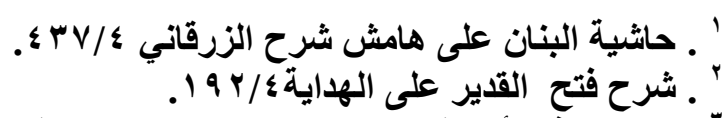

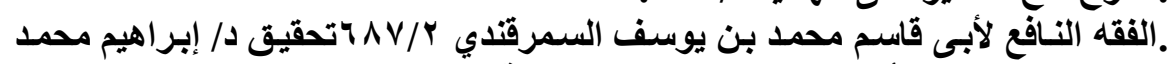

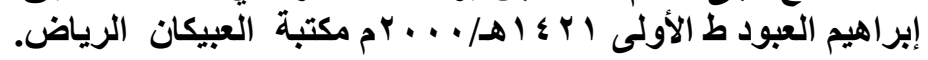




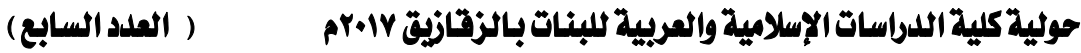

ومما يدل على وجوبها الكتاب والسنة والإجماع والمعقول: أما الأدلة من الكتاب على وجوب النفقة:

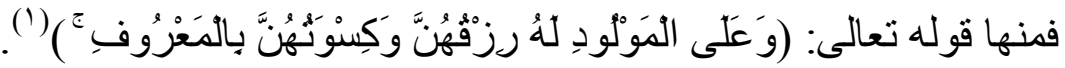
ووجه الدلالة في الآية: أن الله تعالى أوجب على الأزواج النفقة والكسوة لزوجاتهم و هذا الوجوب مستفاد من لفظة (على) الدالة على الإلز ام المفيد للوجوب، و الضمير

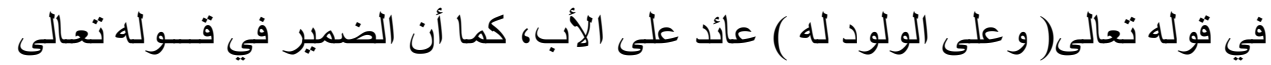
(رزقهن وكسوتهن) راجع إلى أمهات الأولاد و هن الزوجات.

يقول الإمام ابن كثير رحمه الله تعالى: و على و الد الطفل نفقة الو الدات وكسوتهن (بـالمعروف ) أي بمـا جرت بـه عـادة أمثنالهم في بلدهن من غير إسر اف ولا إقتـار بحسب قدرته في يساره وتوسطه و إقتاره(؟). وقال الإمام القرطبي رحمه الله تعالى: الأظهر أن الآية في الزوجات في حال بقاء النكاح لأنهن المستحقات للنفقة والكسوة، والزوجة تستحق النفقة والكسوة أرضعت أو لم ترضع، و النفقة و الكسوة في مقابلة التمكين(r) ومن الأدلة على وجوب النفقة للزوجة على زوجها قوله تعالى: (الرِّجَالُ قوَّامُونَ

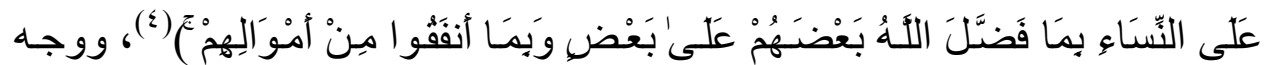
الدلالـة في الآيـة: أن الله تعـالى أنثبت للرجل حق القوامـة على زوجـه وربط ذلك بأمور منها: مسئوليته عن النفقة على زوجه فيبذل لها كفايتها و أو لادها بالمعروف .

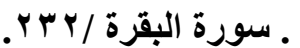

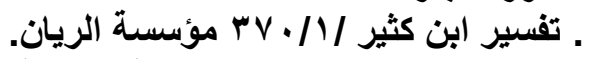

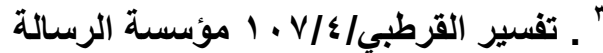

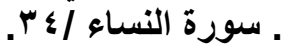


قال ابن كثيررحمه الله تعالى: (الرجال قو امون على النسـاء) أي: الرجل قيّم على المر أة أي هو رئيسها وكبيرهـاو الحساكم عليها ومؤدبها إذا اعوجت (بما فضل الله بعضهم على بعض وبما أنفقو ا من أمو الهم) أي: من المهور و النفقات و الكلف التي وهي وهي أوجبها الله عليهم لهن في كتابه وسنة نبيه صلى الله عليه وسلم ('). وقال الخازن رحمه الله تعالى في بيان سبب قو امة الرجـال على النسـاء: لمـا أثبت

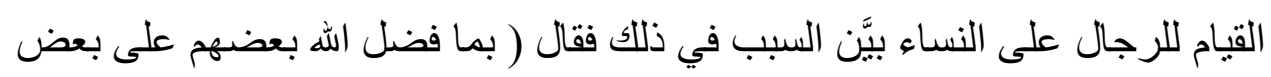
) يعنى أن الله فضل الرجال على النساء بأمور منها: زيـادة العقل و الولايـة والشـهادة

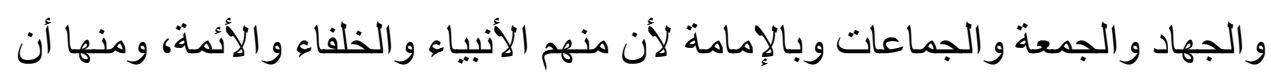
الرجل يتزوج بأربع نسوة ولا يجوز للمر أة غير زوج واحد، ومنها زيادة النصبي في الميـراث و التعصـيب في الميـر اث، وبيـده الطـلاق و النكــاح و الرجعـة، و إليـهـ الانتساب، فكل هذا يدل على فضل الرجال على النساء، ثم قال تعالى: ( وبمـا انفقوا من امو الهم ) يعنى: وبما أعطو امن مهور النساء والنفقة عليهن أهـ (º).

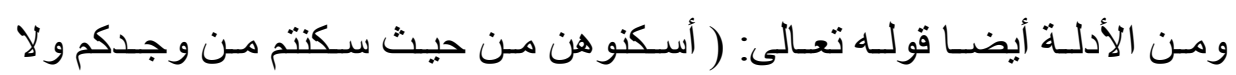

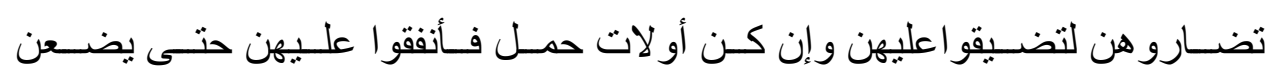
حملهن (r). ووجه الالالة في الآية :أن الله خاطب الأزو اج بتوفير السكن لزوجاتهم المطلقات مـا دمن في العدة وجـاء الخطاب بأسلوب الأمر الدال على الوجوب في قوله (أسكنو هن ) ممـا يدل على أن الزوج مطالب شر عا بإسكان زوجته مـا دامت في العدة، لأن العدة تعتبر امتدادا للحياة الزوجية، و إذا كانت السكنى للزوجة المطلقة واجبة على الزوج حال عدتها

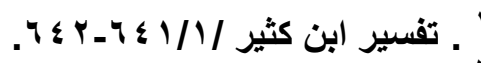

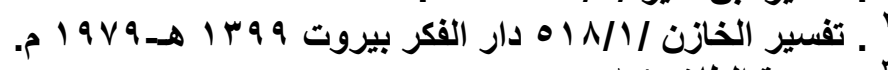
ـ سورة الطلاق /؟ آ. 


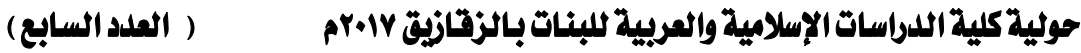

فمن باب أولى وجوبها على الزوج لزوجته التي لم تطلق، ولا يخفى أن السكن أحد

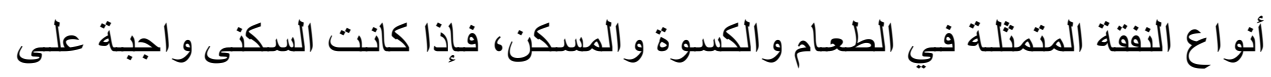
الزوج بنص الآية القر آنية فبقية الأنواع واجبة كذلك لأنها تتفق في الحكم دون تمييز بعضها عن بعض . يقول الإمام القرطبي رحمه الله تعالى: وقال نافع: قال مالك: في قوله (أسكنو هن من حيث سكنتم من وجدكم...) يعنى المطلقات اللاتي بنَّ من أزواجهن فلا رجعة

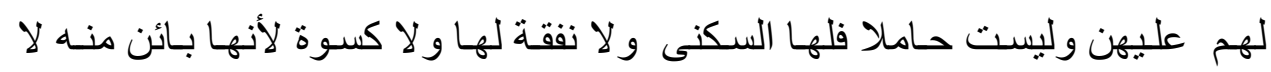
يتو ارثان ولا رجعة لـه عليها، و إن كانت حاملا فلها النفقة و الكسوة و المسكن حتى تتقضي عدتها، فأما من لم تَبنْ منهن فإنهن نساؤه يتو ارثون، و لا يخرجن إلا أن يأذن وهن لهن أزواجهن ما كن في عدتهن، ولم يؤمروا بالسكنى لهن لأن ذلك لازم لأزواجهن مع نفقتهن وكسوتهن حوامل كن أو غير حوامل، و إنما أمر الله بالسكنى للآتي بنَّ أى طلقن - من أزواجهن مع نفقتهن قال تعالى ( و إن كن أولات حمل فأنفقو العيهن حتى يضـن حملهن ) فجعل الله عز وجل للحوامل اللاتي قد بنْ من أزواجهن السكنى و النفقة أ هـ ('). ومن الأدلة على وجوب النفقة للزوجة على زوجها: قولـه تعـالى (لِيُنِفِقْ دُو سَعَةٍة

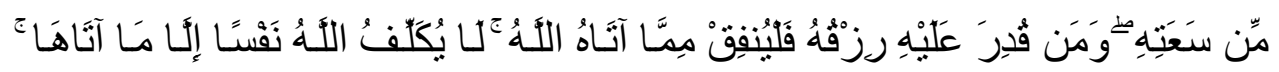

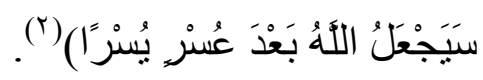

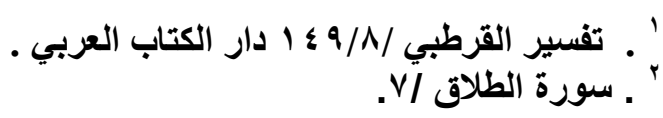

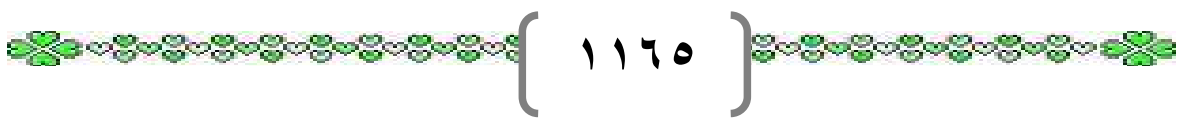


وأما الأدلة من السنة على وجوب النفقة:

فمنها ما رو اه البخاري رحمه الله تعالى في صحيحه عن هشـام بن عروة عن

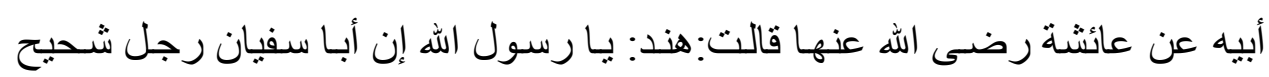

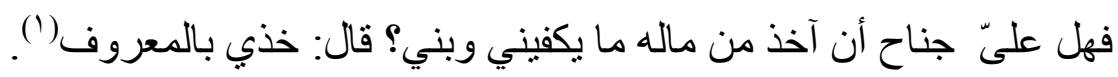
ووجه الدلالة في الحديث: وجوب نفقة الزوجـة على زوجها، قبل الزوج أو لـ

يقبل، علم أو لم يعلم، مادام الأخذ بالمعروف وبقدر كفاية الزوجة لأو لادها.

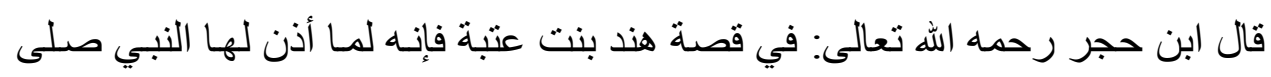

الله عليه وسلم أخذ نفقة بنيها من مال الأب فذل على أنها تجب عليه دونها(؟).

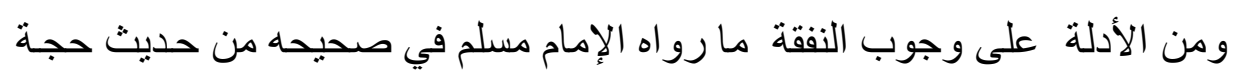
النبي صلى الله عليه وسلم وفيه: فـاتقوا الله في النسـاء فإنكم أخذتموهن بأمسان الله و استحللتم فروجهن بكلمة الله ولكم عليهن أن لا يوطئن فرشكم أحدا تكر هونه فإن

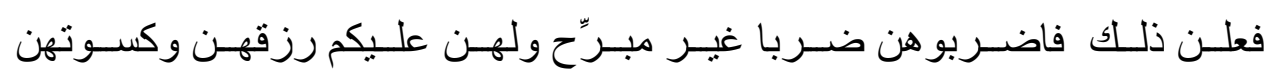

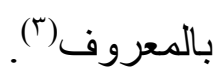

قـال الإمـام النووي رحمـه الله تعـالى: قولـه صـلى الله عليه وسـلم ( ولهن عليكم

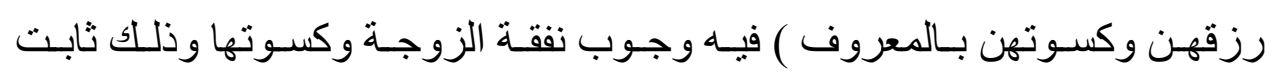

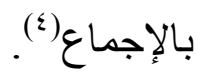

ومن الأحاديـث مـا رو اه أبو داود في سنتهه عن معاويـة القشيري رضـي الله عنـه

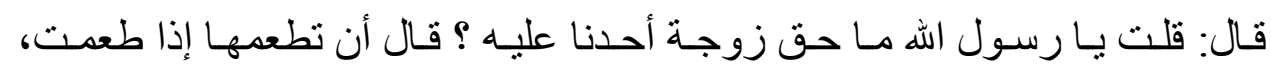
وتكسو ها إذا اكتسيت، ولا تضرب الوجه، ولا تقبح و لا تهجر إلا في البيت(1).

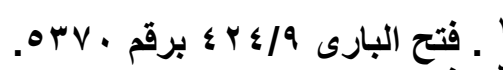

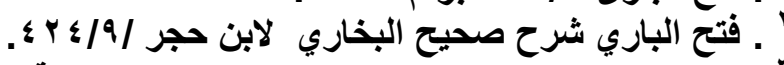

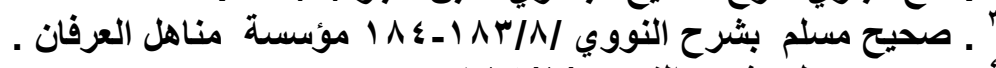

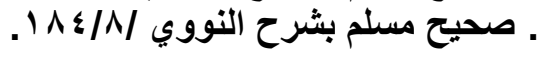




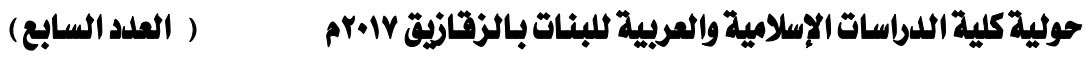

ووجه الدلالة في الحديث: أنه صلى الله عليه وسلم أمر بإطعامهن وكسوتهن ممـا يأكل الزوج، وفى ذلك إثارة إلى وجوب النفقة على حسب يسار الزوج و إعساره. وأما الإجماع : (1) فقد أجمع العلمـاء على أن نفقة الزوج على زوجته و اجبـة بنـاء على مـا جـاء في كتاب الله وسنة رسول الله صلى الهه عليه وسلم (؟).

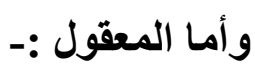
فيستدل على وجوب النفقة للزوجة على زوجها أخذا من القواعد الثر عية المتفق على صحة العمل بها ومنها أن من حُبس لحق غيره تكن نفقته واجبة عليه. ولما كانت الزوجة محبوسة لحق الزوج ومفر غة نفسها لله استوجبت الكفايـة عليه في ماله كالعامل على الصدقات لمـا فرغ نفسـه لعمل المسـاكين استوجب كفايته في

مـالهم، و القاضـي لمـا فر غ نفسـه لعملـه للمسـلمين استوجب الكفايـة في مـالهم (r). و المر أة صارت بعقد النكاح محبوسة لحق الزوج ومنفعته حيث تمكنه من الاستمتاع بها متى شاء كما أنها تقوم بالمقصود من الحياة الزوجيـة من حفظ النسل وتربيـة الأو لاد ور عاية شئون البيت، ومن هنا استحقت النفقة وجوبا على زوجها، و الذميـة كالمسـلمة في النفقة و المسكن و الكسـوة في قول عامـة أهل العلـم وبـه يقول مالكك و الثافعي و أبو ثور و أصحاب الر أي لعموم النصوص الواردة في ذلك(؛).

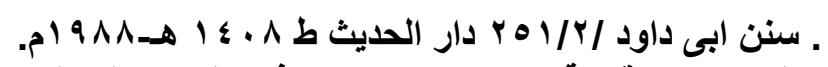

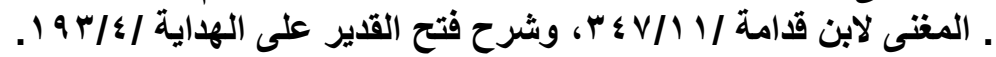

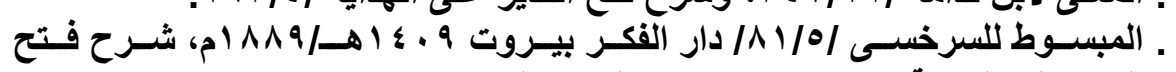

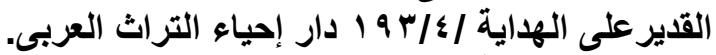

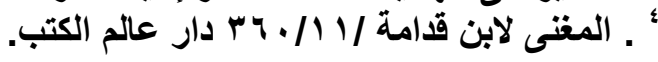




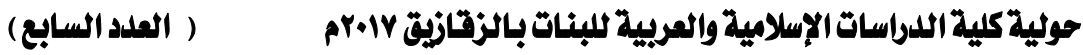

\section{الحكمة من مشروعية وجوب النفقة على الزوج}

اقتضت حكمة الله تعالى أن بتقاسم الزوجان مهمة الحياة الزوجية وممـا لاشك فيه أن لكل من الرجل و المر أة دوره المهم في تكوين الأسرة و أمنها واستقرارها، ومـا الحياة الزوجيـة إلا مؤسسـة اجتماعيـة يؤدى كل من الزوجين دوره حسبما يو افق طبيعته ويلائم تكوينه الذي خلقه الله عليه . فقد خص الله الرجل بخصائص تتفق مع ما أسنـد إليـه من قوامته على بيته، كمـا خص المر آه بخصائص تتناسب مع دور ها في بيتها لتربية أو لادها والقيام بشؤنهم، ور عايـة مصـالح زوجها، فهي بالنسـبة لـلأو لاد مصـدر الحنـان و الرعايـة، ترضـع الصغير، وتحنو ا على الكبير ، وتقضى حو ائج الجميع فى حدود طاقتها دون كلل أو ملل، و هى القدوة الصالحة و السراج الذى يضئ حياة أو لادها. وبالنسبة للزوج فهي محل ر احته وسكونه، ومستودع استقر اره وهدوئه، فعليها تقوم مهمة الإدارة الداخلية للبيت، وبها يتم تدبير شئونه. أما الرجل فقد خصـه الله بخصـائص تتناسب مـع إدارتـه لشئون البيت في الداخل و الخارج، ففي خارج البيت هو الر اعي الكادح المكافح الذى يضرب في أرض الله

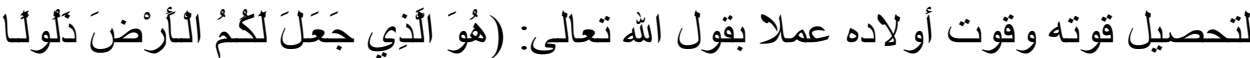

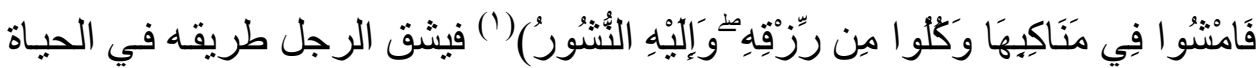

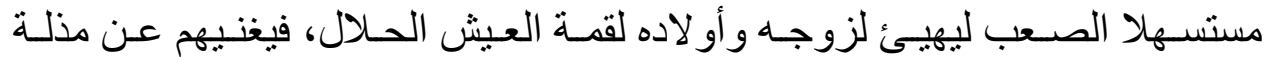
السؤال، ويحفظ عليهم عز هم وحياءهم، وهو داخل البيت المعلم و المرشد و المؤدب، فـلا عجـب إذَا أن تلـزم الثـريعة الغـر اء الرجـال بالنفقـة على زوجـاتهم وأو لادهـه، وتخصـهم بـذلك دون الزوجـات، و الثـريعة في هذا لـم تأت بـدعا مـن القول، و إنمـا

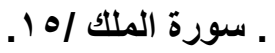


وضعت الأمور في نصـابها، وأناطت بـالتكليف أهله، و ألزمت الأمانـة من يقوم بها ويؤديها على وجهها الأكمل، فالحياة الزوجية كفاح خارجي، وتعاون داخلي.

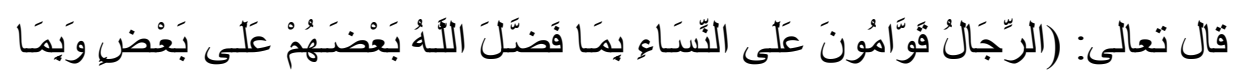

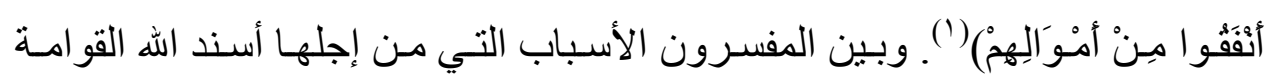
للرجل على ضوء ما ذكر سبحانه وتعالى في كتابه.

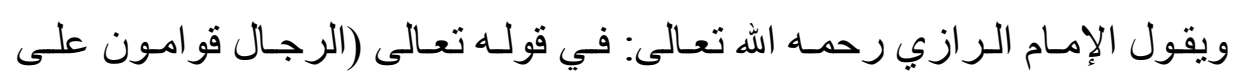
النسـاء ) أي: مسلطون على أدبهن و الأخذ فوق أيديهن، فكأنـه تعـالى جعلـه أميـرا عليها، ونافذ الحكم في حقها، ثم إنه لما أثبت للرجـال سلطانا على النسـاء ونفاذ أمر عليهن بين أنه فعل ذلك معلا بأمرين : أحدهما: قولـه تعالى (بمـا فضل الله بعضـهن على بعض) و اعلم أن فضـل الرجـال

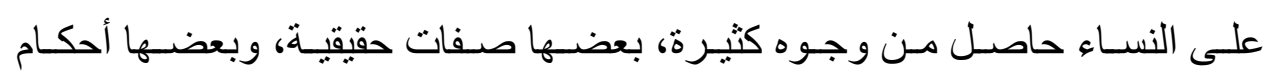
شر عية، أما الصفات الحقيقية فاعلم أن الفضائل الحقيقية يرجع حاصلها إلى أمريين: إلى العلم و القدوة و لا شك أن عقول الرجـال و علومهم أكثر ، ولا شك أن قدرتهم على الأعمال الثاقة أكمل، ولهذين السببين حصلت الفضيلة للرجال على النسـاء في الفضل و الحزم و القوة و الفروسية و الرمي، و إن منهم الأنبياء و العلماء، وفيهم الإمامة

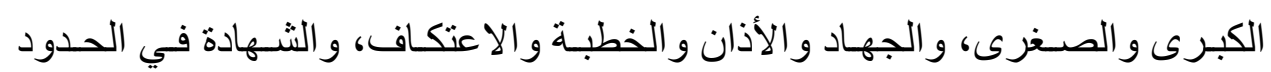

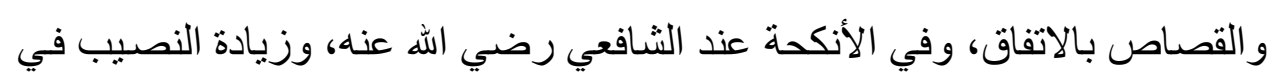
الميـر اث، والتعصـيب في الميـر اث وتحمـل الديـة في القتـل الخطـأ، وفي القســامة و الو لايـة في النكاح و الطلاق و الرجعة و عدد الأزواج، و إليهم الانتسـاب، فكل ذلك ولك يدل على فضل الرجال على النساء.

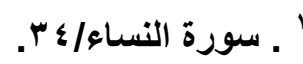

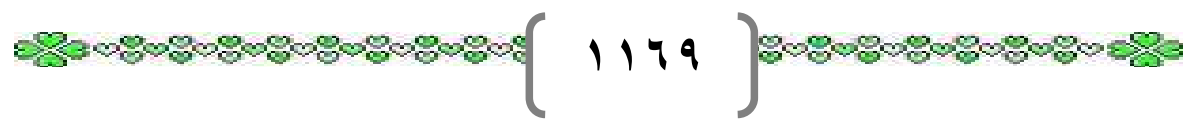


والسبب الثاني لحصول هذه الفضيلة: قوله (وبمـا أنفقو ا من أمو الهم ) يعنى الرجل أفضل من المر أة لأنه يعطيها المهر وينفق عليها أ. هـ ('). قال ابن عباس: الرجال أمر اء على النساء(). ويقول الشيخ المراغي رحمه الله تعالى: الحياة المشتركة بين الزوجين لا تكون سعيدة إلا بـاحتر ام كل من الزوجين للآخر ، و القيام بحقوقه، وهذه الحقوق أجملها

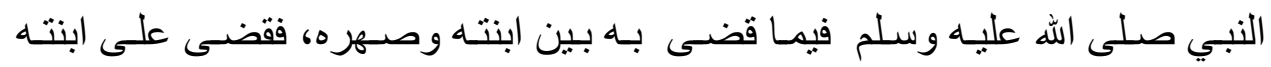
بخدمة البيت و على علىِ في خارجه من الأعمال، وهذا ما تحكم به الفطرة في توزيع الأعمال بين الزوجين فعلى المر أة تدبير شئون البيت والقيام بحوائج المعيشة، و وعلى الرجل السعي و الكسب خارجه(ّ).

\section{نوع التفقة التي تلزم الزوج لزوجته}

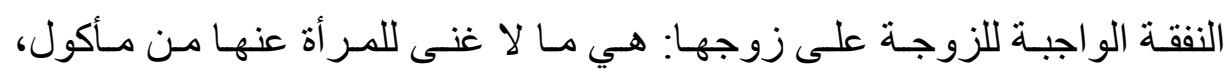

و ملبوس، و مشروب، ومسكن (\&). و أما نفقة الخادم فقيها يقول ابن قدامة(0) رحمه اللة: فان كانت المر أة ممن لا تخدم نفسـها لكونها من ذوى الأقدار ، أو مريضـة، وجب لهـا خـادم، وبـه قـال الجمهور (7) لقوله تعالى :( و عاشروهن بالمعروف ) ومن العشرة بـالمعروف أن يقيم لها خادما و لأنها مما تحتاج اليه في الدوام فأنثبه النفقة ولا يجب لها أكثر من خـادم واحد لأن المستحق خدمتها في نفسها و ويحصل ذلك بو اجب وهذا قول الثـافعي و أصـحاب

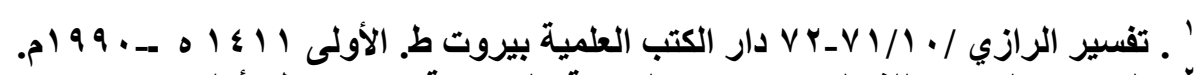

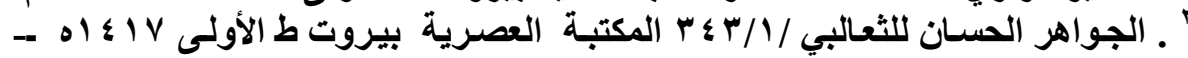

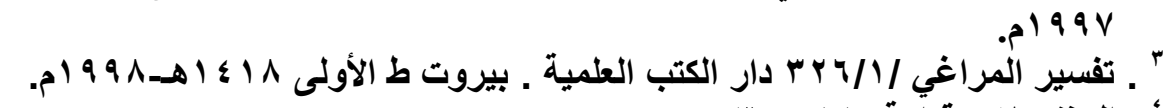

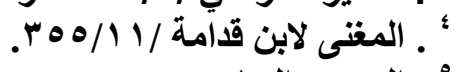

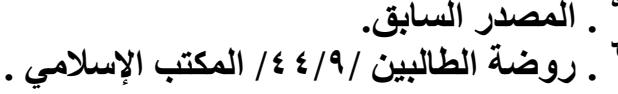

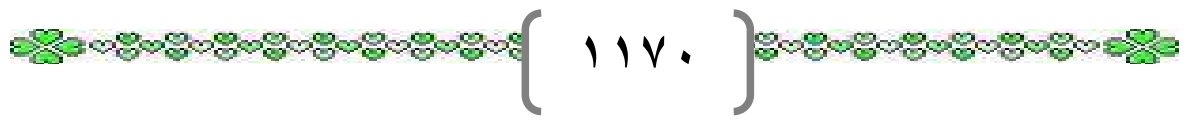




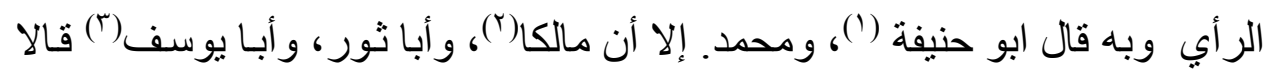

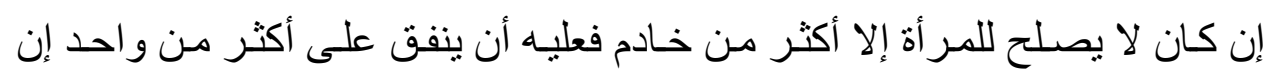
احتمل الزوج ذلك، فان لم يكن لها خادم وكانت ممن تخدم نفسها وتقدر على ذلك، أو

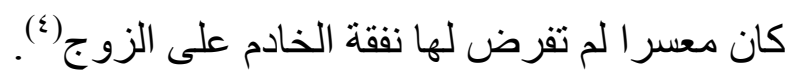
وبناءا على مـا سبق فإن الزوج إذا كان موسر اوجب عليه نفقة الخـادم لزوجته بحسب العرف، وخاصة إذا كانت الزوجـة من ذوات الاقدار، ومن عادتها ألا تخدم نفسها، أو مريضة. فيلزمه نفقة خادم له. أما إذا كان الزوج معسر اوكانت الزوجـة ممن تخدم نفسها فلا تجب عليهـ نفقة خادم، لأن في إلز امه بذللك حرجا وتكلفا له ما لا يطيق، و الله تعالى يقول: (وَمَـا جَعَلَ

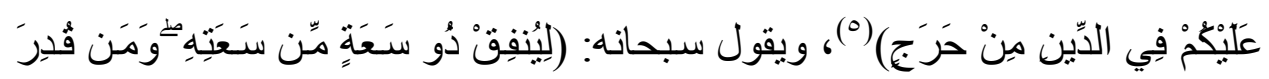

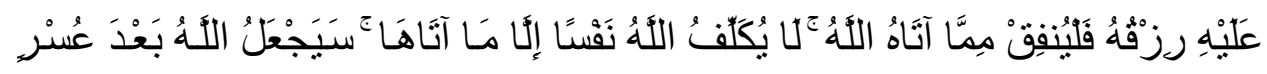

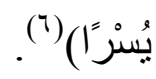
وأما نفقة علاج الزوجة وتطبيبها فالآيات القر آنية والأحاديث النبويـة الواردة فيها صر احة لم توجبان إلا الإطعام و اللباس و السكنى دون التطبيب، ومن هنا فإن الفقهاء يرون أن الزوج غير ملزم بعلاج زوجته بحجة أن ذلك لا يدخل في النفقة شر عأ.

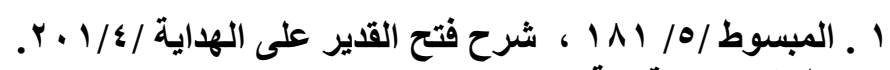

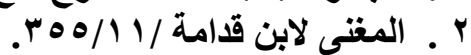

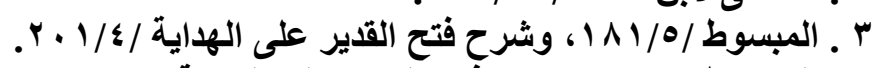

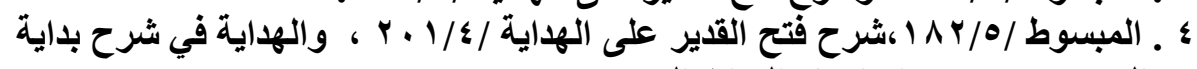

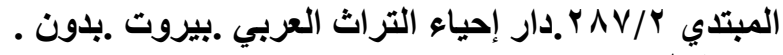

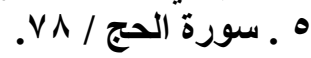

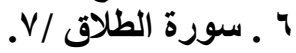


يقول ابن قدامة رحمه الله تعالى: ولا يجب على الزوج شر اء الأدويـة، ولا أجرة الطبيب، وكذلك أجرة الحجام، ولا الفاصد ('). ويقول الإمـام النووي رحمـه الله تعـالى: لا تسـتحق الزوجـة الدواء للمـرض، ولا أجرة الطبيب و الفصاد و الحجام والختان، لأن هذه الأمور لحفظ الأصل فكانت عليها كما يكون على المكري ما يحفظ العين المكر اة(؟). ويرى البعض أن نفقة التمريض و العلاج واجبة على الزوج إذا كان الأمر يتعلق بالأمر اض العادية، و التي قلما يخلو منها أحد من الناس، مـا إذا طـال المرض بحيث يعجز عن معالجتها، أو كان تطبيبها يتوقف على عملية جر احيـة تتطلب مـالا يعجز عنه الزوج وكانت الزوجة غنية فإن نفقة العلاج لا تلزمه . يقـول الإمـام السرخسى رحمـه الله: وفى المريضــة إن تحولـت إلى بيتـه وهـى مريضة فله أن يردها إلى أن تبرأ، و إن مرضت في بيته بعدما تحولت إليه فليس له له أن يردها بل ينفق عليها، و هذا استحسان لأن النكاح يعقد للصحبة و الألفة، وليس من الألفة أن يمتـع عن الإنفـاق عليها، أو يردهـا لقليـل مـرض، فـإذا تطـاول ذلك فهو بمنزلة الرتق الذي لا يزول عادة فتسقط نفقتها("). و اللذي تطمـئن إليـه الـفس، ويتماشـى مـع مـا أمـر بـه الإسـلام مـن حسـن العثـرة وجميل الإحسان أن نفقة تطبيب الزوجـة و علاجها واجبة على الزوج مـا دامت قد

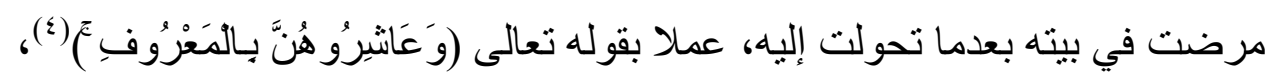

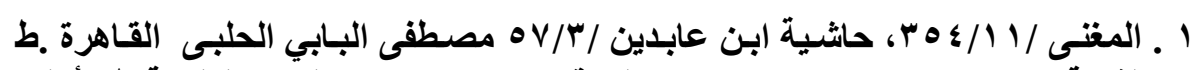

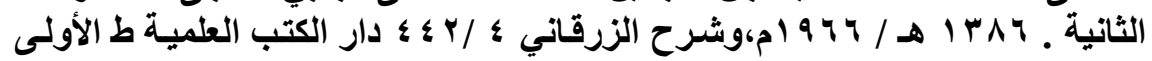

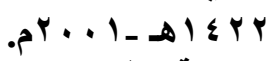

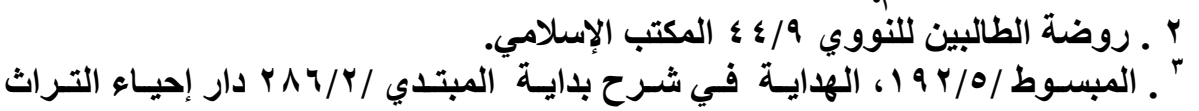
العربي بلون .

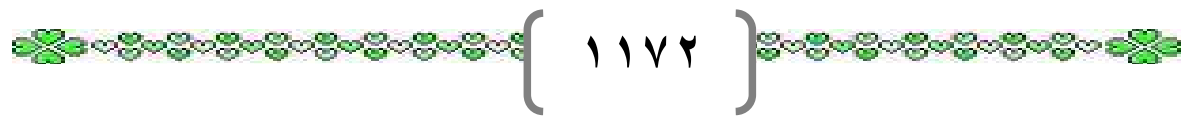




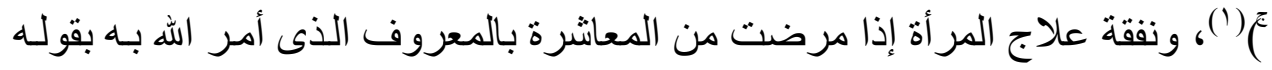

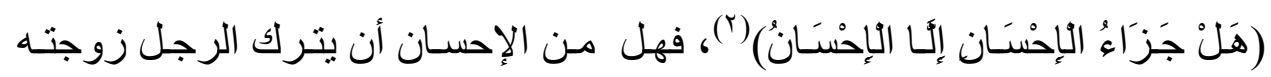
مريضـة دون أن ينفق على علاجها؟ وهى التي قضـت زهرة حياتها وشبابها مـع زوجها محسنة باذلة الخير والمعروف، هل من الإحسان إذا سقطت مريضـة بسبب مشاكل البيت العائلية التي نالت من قوتها، أو كان الزوج سبب عنائها ومرضهها، فإذا قلنا بعد ذلك أن نفقة علاجها وتمريضها لا تلزم الزوج كان ذلك إجحافا ونكر انا للجميل مع من أفنت شبابها وقوتها في خدمة زوجها و أو لاده. ألم تكن يوما سكنه الذي يفىء إليه فيجد فيه الأنس و الألفة و المودة و الرحمـة؟ قـال

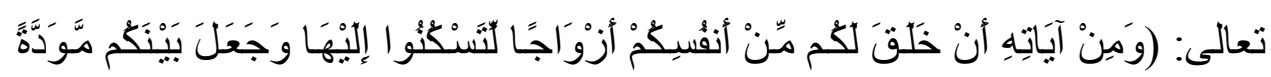

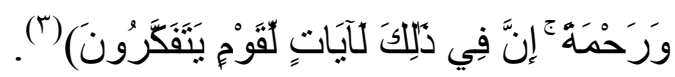
ألم تكن هذه الزوجة يوما لباسة الذى يستره ويتعفف بـه عن الحر ام؟ قال تعالى:

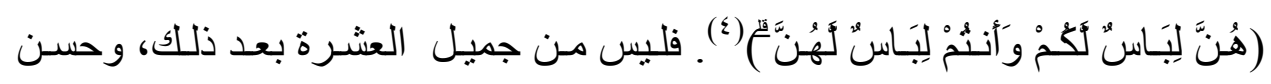
الصحبة أن نأكل شبابها، ونتركها حال مرضها، إن ذللك يتنافى مع قوله تعالى: (هل جز اء الإحسان إلا الإحسان )، نعم إذا كان الزوج فقير ا و لا يستطيع علاجهاوهى لهى غنية، ففي هذه الحالة عليها أن تعالج نفسها من مالها إيقاءا لحياتها . يقول الإمام السمرقندي رحمه الله تعالى: لو مرضت في منزل الزوج فلهاالنفقة لأنه مستمتع بها من الأنس فلا يسقط بالثك و الاحتمال(ه).

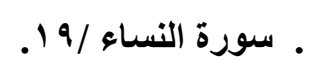

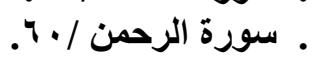

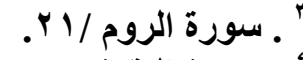

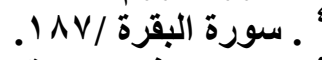

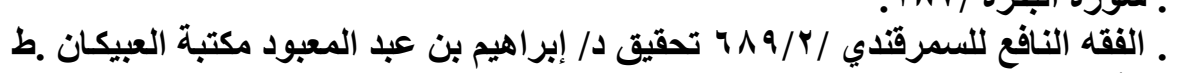

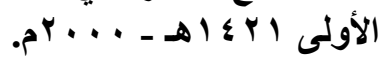




\section{حكم النفقة على الزوجة المحترفة أو العاملة، وكذلك المرأة الناشز؟}

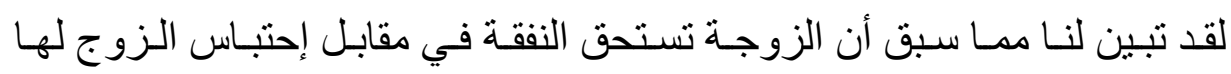
وتمكينه من الاستمتاع بها وقيامها على مصالح بيته وقضاء حو التهائه.

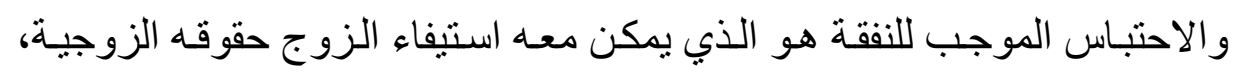

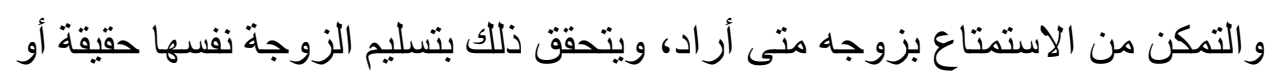

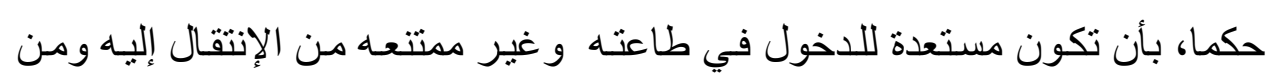
دخوله بها دون مبرر شرعي .

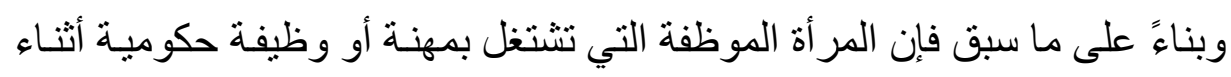

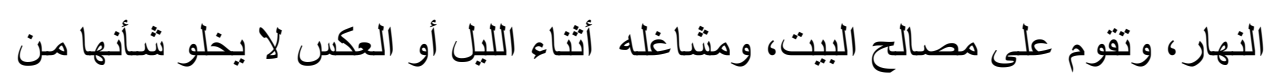

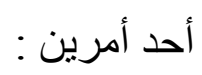

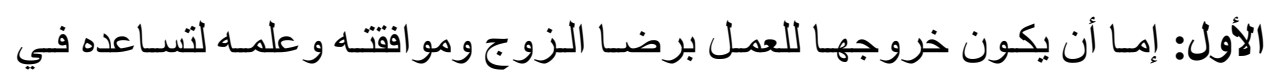

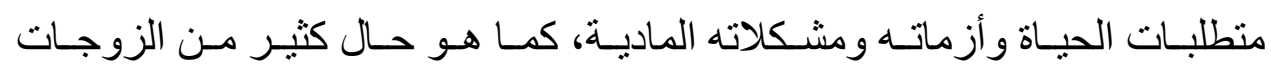
العاملات في عصرنا الحاضر ، ففي هذه الحالة يطالب الزوج بالإنفاق عليها لأنها

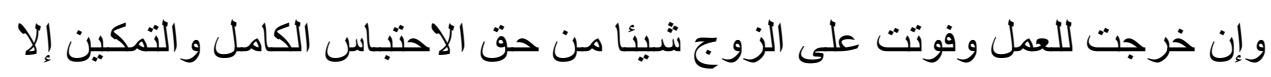
أن ذلك كان بعلمه ورضاه ومو افقته على ذلك.

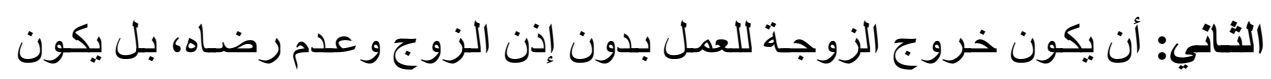

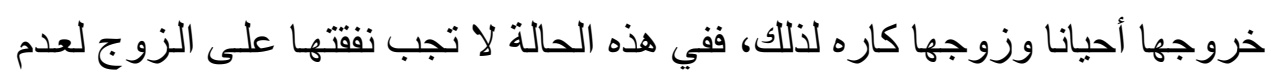

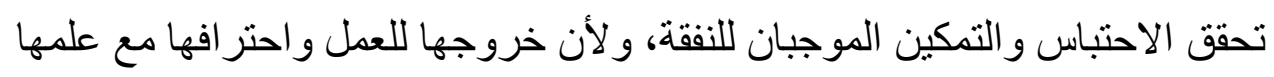

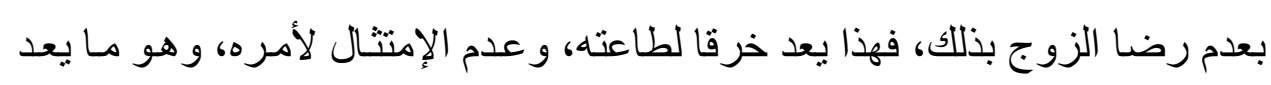

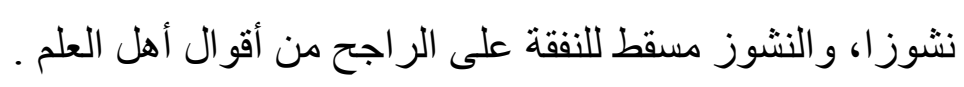


يقول ابن قدامة رحمه الله تعالى: اتفق أهل العلم على وجوب نفقة الزوجات على

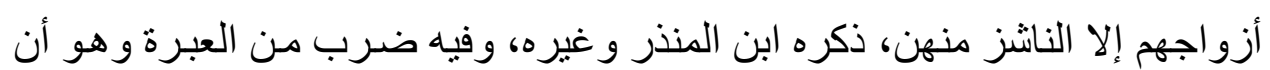
المر أة محبوسة على الزوج يمنعها من التصرف والاكتساب فلابد أن ينفق عليهاب('). ويقول رحمـه الله تعـالى في تعريف النشـوز وبيـان حكم النفقـة للناشـز : النشـوز

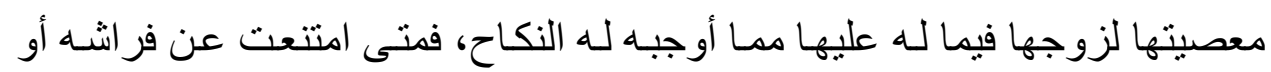
خرجت من منزله بغير إذنه أو امتنعت من الانتقال معسه فلا نفقة لهاو لا سكنى في قـول عامـة أهـل العلـم، مـنهم الثـعبي، وحمـاد، ومالـك، والأوز اعـي، و الثــافعي، و أصحاب الر أي، وأبو ثور. وقال الحكم: لها النفقة وقـال ابن المنذر: لا أعلم أحدا خالف هؤلاء إلا الحكم، ولعله يحتج أن النشوز لا يسقط مهر ها فكذلك نفقتها ولنا: أن النفقة إنما تجب في مقابلة تمكينها، فإذا منعته التمكين كان له منعها من النفقة، و إذا منعها النفقة كان لها منعه من التمكين، فأما إذا كان له منها ولد فعليه نفقة وللده لأنها و اجبة له فلا تسقط بمعصيتها و عليه أن يعطيها إياهـا إذا كانت هي الحاضنة لـه أو أو له المرضعة له وكذلك أجر رضاعها يلزمه تسليمه إليهاج(؟).

\section{المعتبر في تقدير النفقة}

المعتبر في النفقة الواجبة كفاية الرجل لزوجه وأولاده، وهذا هو المعروف الوارد في قوله صلى الله عليه وسلم لهند امر أة أبي سفيان عندما جاءته قائلة: إن أبا سفيان

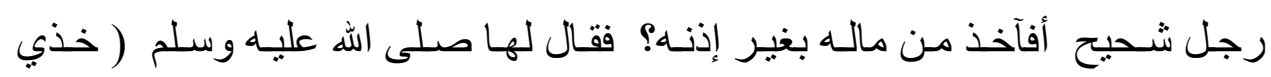
بالمعروف (r) (ب)

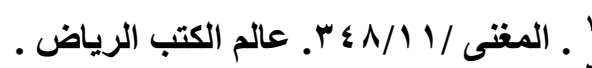

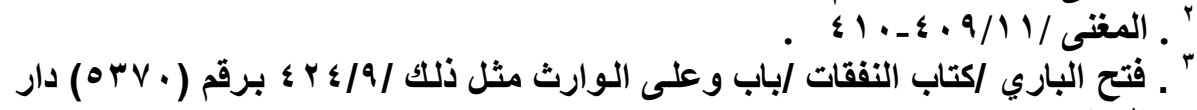
الريان .

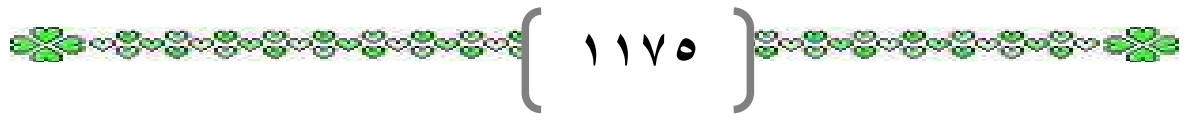




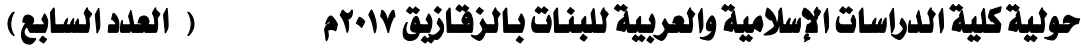

قـال السرخسـي رحمـهـ الله تعـالى: يُفـرض بمقـدار مـا تقع بــهـ الكفايـة ويعتبـر

المعروف في ذللك وهو فوق التقتير ودون الإسراف(').

هذا وقد اختلف الفقهاء فيمـا ير اعى في تقدير النفقة هل ير اعى حـال الزورج أم

$$
\text { ير اعى حال الزوجة أم حالهما معا ؟. }
$$

قـال ابـن قدامـة رحمـه الله تعـالى: قـال أصـحابنا: ونفقتهـا معتبرة بحسال الزوجين جميعا، فإن كانـا موسرين فعليه لها نفقة الموسـرين، و إن كانـا معسرين فعليه نفقة المعسرين، و إن كانا متوسطين فلها عليه نفقة المتوسطين أيهما كان الموسر . وقال أبو حنيفة، ومالك: يعتبر حال المر أة على قدر كفايتها لقوله تعـالى: (وَعَلى :

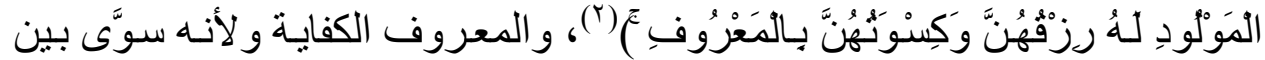
النفقة و الكسوة على قدر حالها فكذلك النفقة، وقال النبي صلى الله عليه وسـلم لهند ( خذي ما يكفيك وولدك بالمعروف)(َ)، فاعتبر كفايتها دون حال زوجها، و لأن نفقتها و اجبة لدفع حاجتها فكان الاعتبـار بمـا تتدفع بـه حاجتها دون حال من وجبت عليه

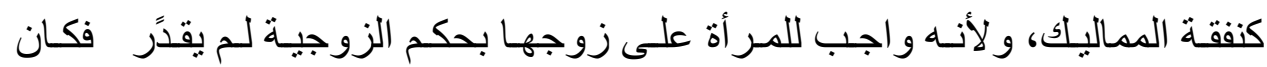
معتبر ا بها كمهر ها وكسوتها.

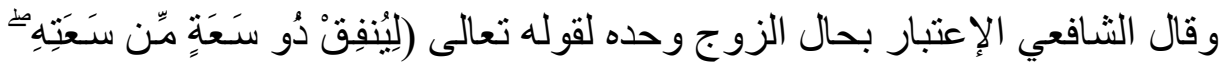

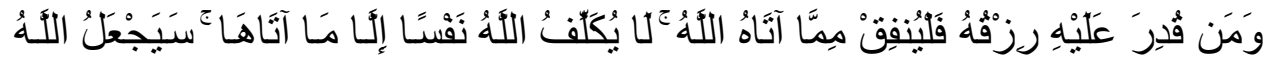

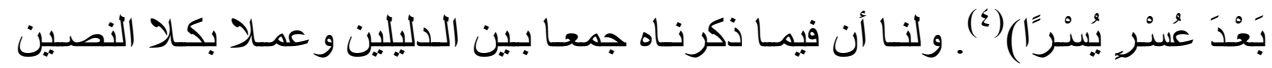
ور عاية لكلا الجانبين فيكون أولى أ.هـ (0).

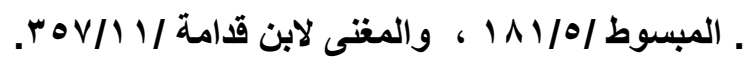

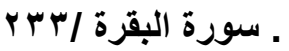

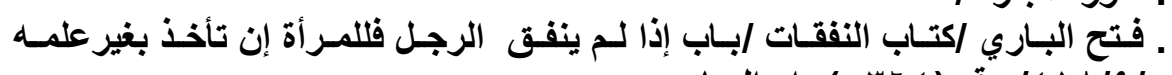

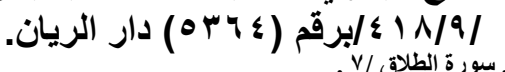

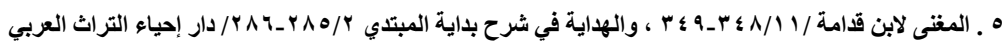




\section{و هذا هو الراجح الذي تطمئن إليه النفس بالقبول. \\ نفقة المعتدات}

إن المر أة إذا فارقهازوجها وجب عليها أن تعتد، والعدة إمـا أن تكون من طلاق رجعى، أو من طلاق بـائن، أو من وفـاة، وفى هذه الأحو ال إمـا أن تكون الزوجـة

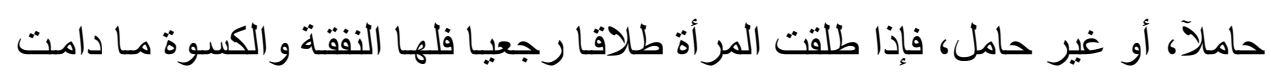

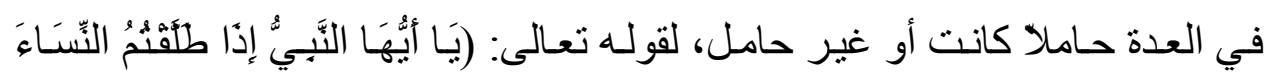

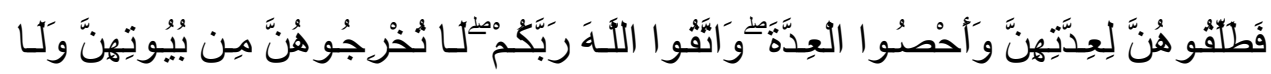

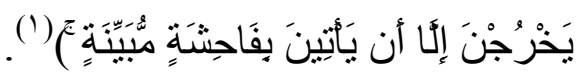
ووجه الدلالـة في الآيـة: أن الله تعالى أوجب للمطلقة طلاقـا رجعيا على زوجها السكنى مـا دامـت في العدة، و لا يجوز أن تخر ج منـه بنفسـها و لا يخرجها غير هـا مادامت في العدة، و إلا كانت مخالفة لأمر ربها، وحيث وجبت لها السكنى وهى جزء من النفقة فقد وجبت لها حينئذ بقية أنواع النفقة من طعام وكسوة . قال ابن عبد البر: لا خلاف بين علماء الأمة أن اللواتي لأزواجهن عليهن الرجعة وله

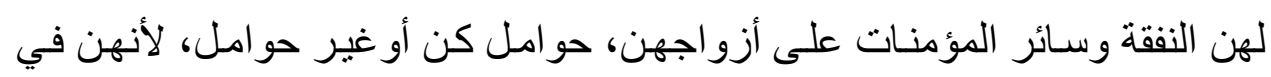
حكم الزوجات في النفقة و السكنــــــى و المير اث ما كنّ في العدة(؟). و أما المطلقة طلاقا بائنا بينونة صغرى فهذه إمـا أن تكون حاملا أو غير حامل، فإن كانت حاملا فلها النفقة والسكنى على زوجها حتى تضـع حملها بإجماع أهل

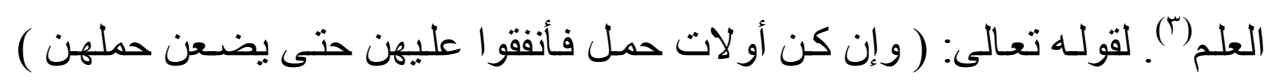
و الأمر في الآية للوجوب، وهو محدود بغاية وضع الحمل، ثم تصبر النفقة بعد ذلك ونك

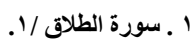

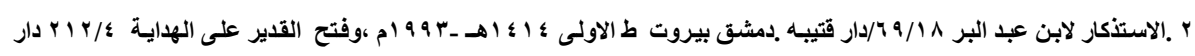

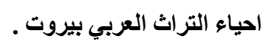

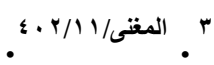


للولا. وإن كانت غير حامل فلا نفقة لها، و أمـا المبتوتـة وهى البائنـة بينونـة كبرى أي: المطلقة ثنلاثـا فهي محرمـة على زوجها بـالثلاث حتى تنكح زوجـا غيرهو ولا يخلو ا حالها من أحد أمرين: إما أن تكون حاملا أو غير حامل، فـإن كانت حساملا فلها النفقة عملا بقوله تعالى (و إن كن أولات حمل فأنفقو اعليهن حتى يضعن حملهن )، و إن كانت غير حامل فقد اختلف الفقهاء فيها على أقو ال('): القول الأول: ذهب أصحاب هذا القول إلى أن لها السكنى دون النفقة، وهو قول ابن عمر ، وأبيـه عمـر ابـن الخطـاب، و ابـن مسـود، و عائشـة، و فقهاء المدينـة السبعة، و مالك، و إحدى الروايات عن أحمد، و الثافعي مستدلين بقوله تعالى: ( اسكنو هن من

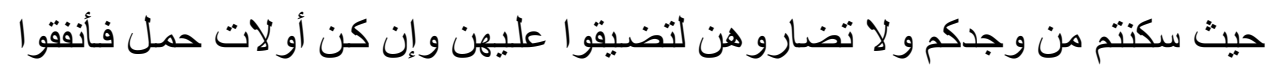
عليهن حتى يضعن حملهن...... (.... ووجـه الدلالـة في الآيـة: أن الأمـر بالإسكان في الآيـة الكريمـة عـام في كل مطلقـة رجعية كانت أو بائنة مادامت في العدة . قال القرطبي رحمه الله تعالى: وقال نافع: قال ماللك في قوله تعالى (اسكنو هن من حيث سكنتم) يعنى المطلقات اللآتي بنَّ من أزواجهن فلا رجعة لهم عليهن وليست

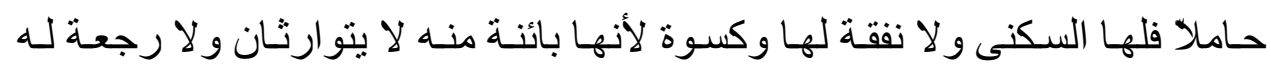

عليهاب(r) القول الثاني: ذهب أصحابه إلى أنه لا سكنى لها ولا نفقة، وبـه قـال الإمـام على، و ابن عباس، وجابر ، و عطاء، وطاووس، و الحسن، و عكرمة، وميمون ابن مهران، و إسحاق، وأبو ثور، وداود، وهو ظاهر مذهب الإمام أحمد رضي الله عنهم .

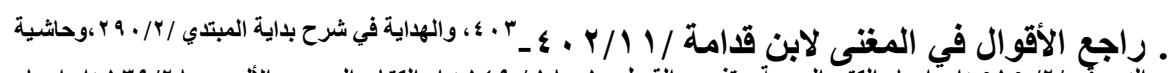

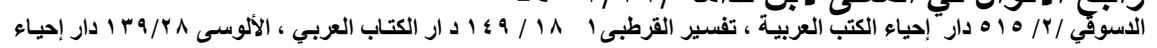

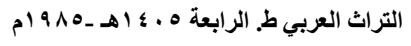

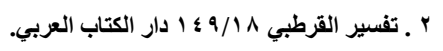




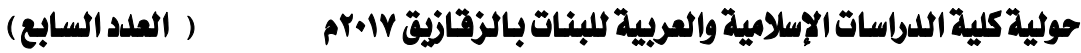

و استدل أصحاب هذا القول بما رو اه الإمام مسلم في صحيحه عن أبى سلمة عن فاطمة بنت قيس أنه طلقهازوجها في عهد النبي صلى الله عليه وسلم وكان أنفق عليها نفقة دون، فلما رأت ذلك قالت: و الله لأعلمن رسول الله صلى الله عليه وسلم فإن كان لي نفقة أخذت الذي يصلحني، و إن لم تكن لي نفقة لم آخذ منـه شيئا، قالت:

فذكرت ذلك لرسول الله صلى اله عليه وسلم فقال لا نفقة للك و لا سكنى ('). القول الثالث: ذهب أصحابه إلى أن لها السكنى والنفقة وهو قول أكثر فقهاء العراق وبـه قال عمر ابن الخطاب()، و ابن مسعود، وابن شبرمة، وابن أبى ليلى، والثوري، و الحسن بن صالح، وأبو حنيفة وأصحابه. و احتجو ا بوجوب السكنى بظـاهر قولـه تعـالى: (اسكنو هن مـن حيـث سكنتم مـن وجدكم ) وفيها أمر بالسكنى، و أمـا النفقة فلأنها محبوسـة عليـه مـا دامت في العدة وردوا خبر فاطمة بنت قيس بما روى عن عمر ابن الخطاب أنه قال: لا ندع كتاب ربنا وسنة نبينا لقول امر أة جهلت أو نسيت ويقصد رضي الله عنه بكتاب ربنـا هذه الآية التي أمرت بالسكنى . و الذي تميـل إليـه النفس وتطمـن في هذه المسـألة القول القائل: إن المبتوتـة التي بانت من زوجها ولم تكن حاملا لا نفقة لها و لا سكنى لثبوت الخبر الصحيح بذللك، و هو متفق عليه أعنى حديث فاطمـة بنت قيس رضـي الله عنها و الرسول صلى الله عليه وسلم مبين عن الله تعالى. 


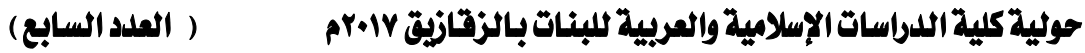

\section{المطلب الثالث: تعليمها أمور دينها}

من الحقوق الزوجية الواجبة للزوجة على زوجها أن يعلهها أمور دينها وير اعى سـوكهاويعتنى بتوجيهرها إلى الخير و الفـلاح، فيجعل مـن نفسـه قدوة لهـا ور ائدا بصير ا وناصحا أمينا، وليس من الأمانة أن يترك الرجل إمر أتهه جاهلـة بأحكام دينها و ومـا تعبد بـه ربها، ويجعل كل هــه استيفاء حقوقها الماديـة، وتوفير الر احـة لها،

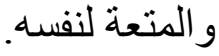

إن الروح لابد ان تأخذ من الدين و العبادة حظها كما يأخذ الجسد حظه من المأكل و المشرب والملذات فإذا كان الرجل جـاهلا بـأمور دينهه وجب عليه أن يسأل أهل العلم و الذكر ثم يعود إلى أهله معلما ومرشدآ كما كان يفعل صحابة النبي صلى الله عليه وسلم في بيوتهم. إن الرجل عندما يفعل ذلك إنمـا يفعلـه من منطلق المسؤولية التي أوجبها الشـرع

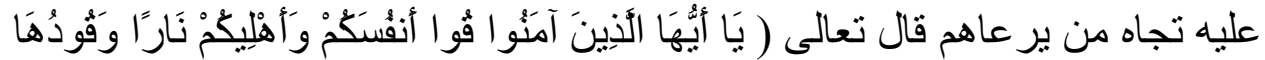

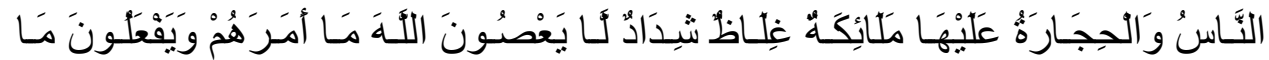

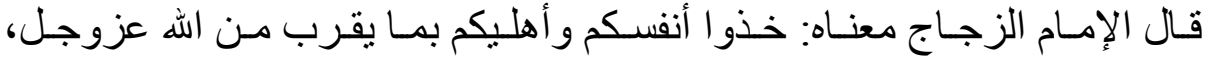
وجنبو ا أنفسكم و أهليكم المعاصسي، وجـاء في التفسبر رحم الله رجـلا قـال: يـأهلاه صـلاتكم صيامكم مسكينكم يتيمكم جير انكم معنـاه:الزمو ا و احفظو ا صـلاتكم و هذه الأشياء المذكورة أدوا فرض الله فيها(؟).

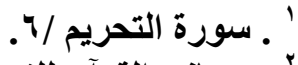

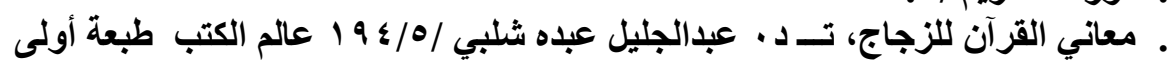

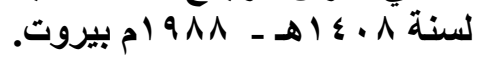


وقـال الإمـام الخـازن رحمـهـ الله تعـالى في قولـه (قو ا أنفسـمم) قـال ابـن عبـاس:

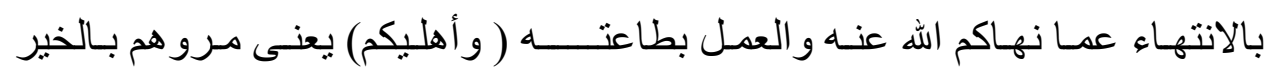

و انهو هم عن الثر و علمو هم و أدبو هم يقو هم بذلك نار آ وقودها الناس و الحجارة('). ولن يقي أحد أهله وذويه من النار إلا بحسن التوجيه و إخلاص النصـح و الإرشـاد، ووصايتهم بطاعة الله و عبادته وترك مخالفته وحسن مر اقبته. لقــ أوجـد الإسـلام بـين المؤمنين و المؤمنـات و ولايـة الإيمـان التـي على أساسـهـا يتو اصلون ويتو اصون بـالحق و المعروف ويتتـاهون عن المنكر و البغي. فمـا ظنك بزوجين مؤمنين متآلفين متقاربين إن ذلك يؤكد الولاية و العهد بينهمـا على التو اصـي

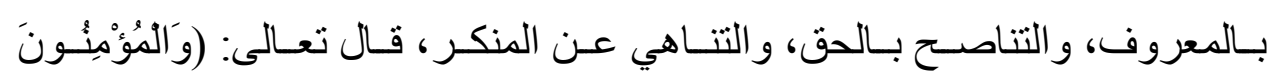

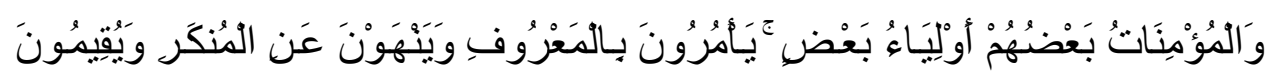

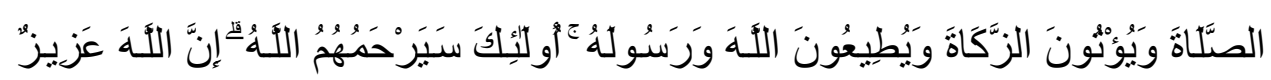

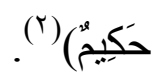
يقول الشيخ عبدالكريم الخطيب رحمه الله تعـلى: في هذا الموكب الذى ينتظم المؤمنين يرى الرائي لهم، بعضهم أولياء بعض تجمعهم الأخوة وتؤلف بينهم المودة

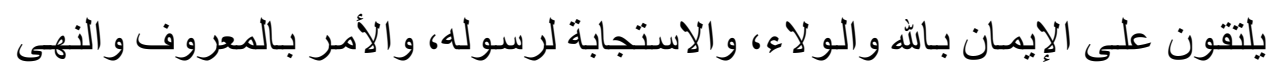
عن المنكر، ويقيمون الصـلاة، ويؤتون الزكاة، ويطيعون الله ورسوله، فتلك هي سبيل المؤمنين، وذلك هو حبل الله الذى يعتصمون بـه ويشدون أيديهم عليه (أولئك

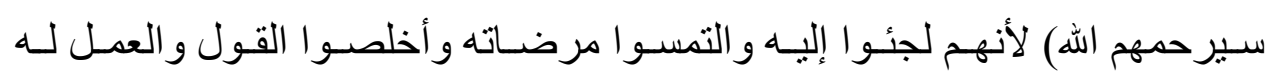

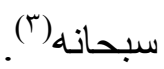

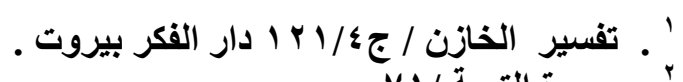

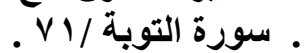

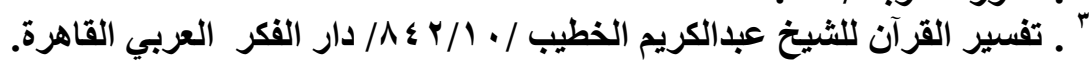

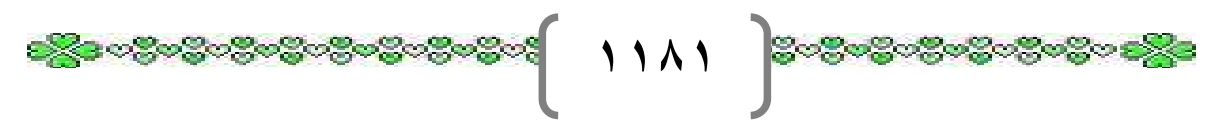


ولقد أمـر الله نبيـه محمدا صـلى الله عليهه وسـلم أن يـأمر أهلـه ومـن اتبعـه بإقامـة

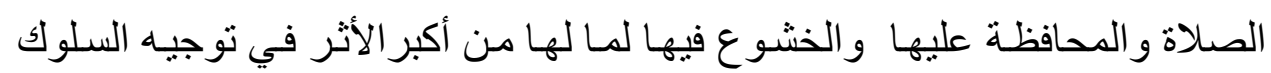

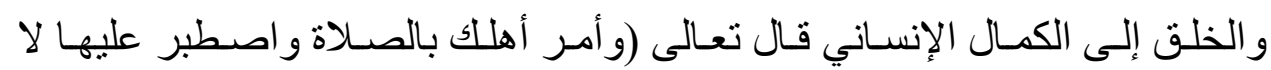
نسألك رزقا نحن نرزقلك و العاقبة للتقوى ) (').

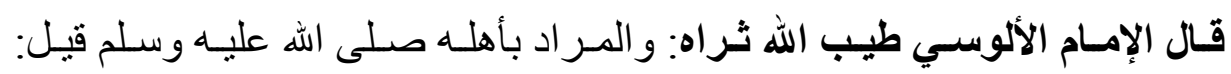

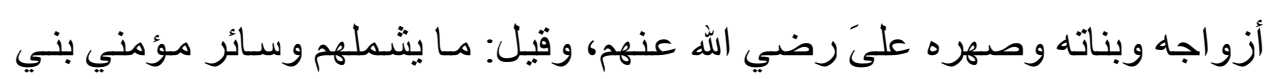

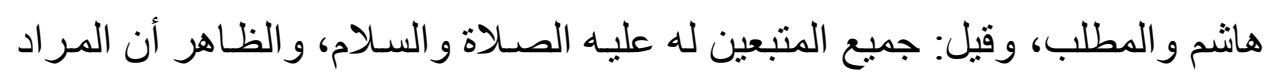

أهل بيته صلى الهه عليه وسلم (r). وقال الإمام الفخر الرازي رحمه الله تعالى: وكان رسول الله صلى الله عليه وسلم بعد نزول هذه الآية يذهب إلى فاطمة و علىّ عليهما السلام كل صباح يقول: الصلاة

رحمكم الله وكان يفعل ذلك أشهر ب("). وروى أن عبداله بن الزبير رضى الله عنه كان إذا رأى شيئًا من أخبار السـلاطين

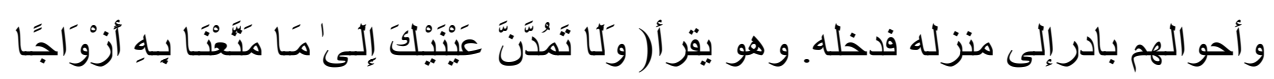

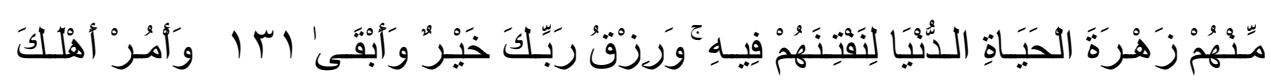

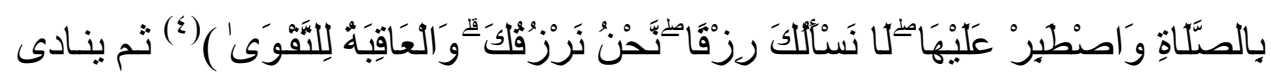
الصلاة الصلاة يرحمكم الله. وكان عمر رضي الله عنه يوقظ أهل داره لصـلاة الليل ويصلى و هو يتمثل بهذه الآية(0).

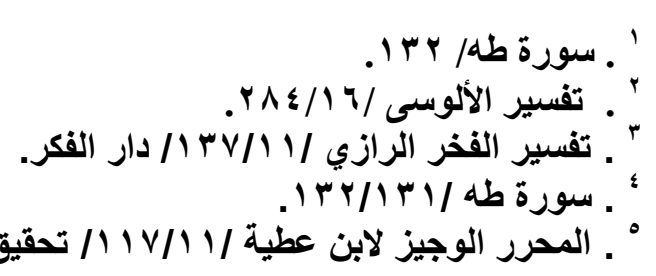

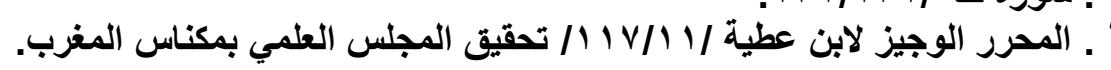


وقال الداودي: وعن عبداله بن سلام قال: كان النبي صلى الله عليه وسلم إذا نزل

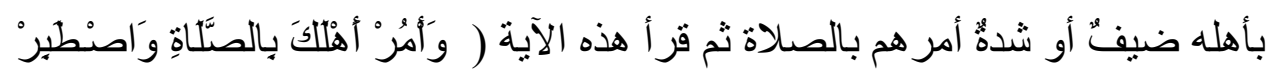

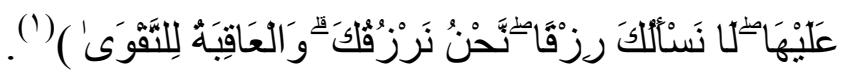
ولقد أثنى الله تعالى على نبيه إسماعيل عليه السلام لأنه كان صـادق الوعد وكان يأمر أهل بيته وقومه بالصلاة و الزكاة، قال تعالى ( وَادْكرْ فِي الكِتَابِ إِنْمَاعِيلَ َإِنَّهُ

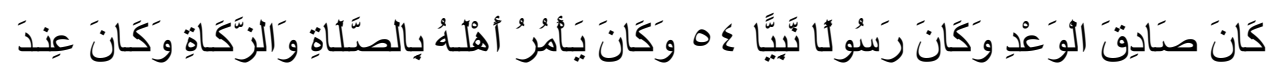

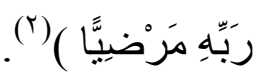
قال الإمـام ابن كثيز رحمـه الله تعـالى: هذا ثناء مـن الله تعـالى على إسماعيل بن إبر اهيم الخليل عليهما السلام بأنه كان صادق الو عد. قال ابن جريج: لم يعد ربه عدة

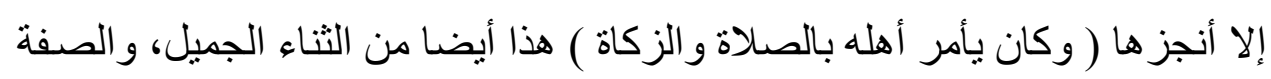
الحميدة، ، والخلة السديدة، حيث كان صابر ا على طاعة ربه آررآ بها أهله (َ).

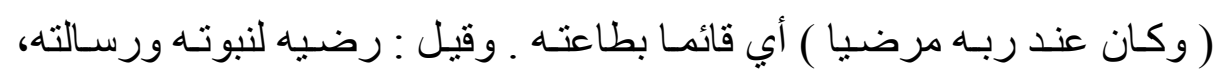
وهذا نهاية في المدح لأن المرضى هو الفائز في كل طاعة بأعلى الدرجات(؛).

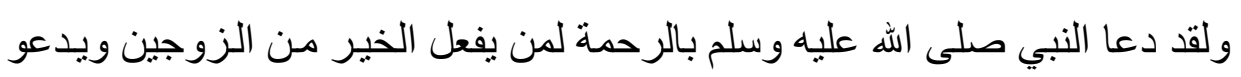
صـاحبه إليهه، فعن أبى هريرة رضـي الله عنـه قـال: قال رسول الله صـلى الله عليه وسلم: رحم الله رجلا قام من الليل فصلى و أيقظ امر أته فصلت فإن أبت رش في

' . 'الجواهر الحسان للثعالبي /تحقيق محمد الفاضلى ب/ه ـ ـ ؛/المكتبة العصرية بيروت

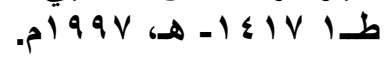

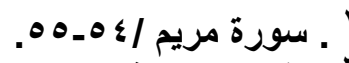

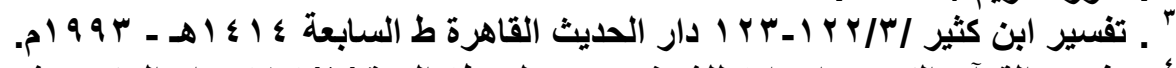

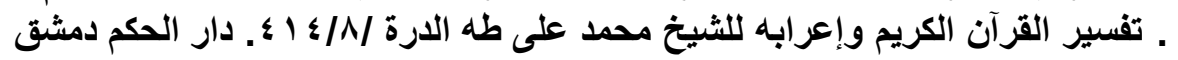
بيروت.

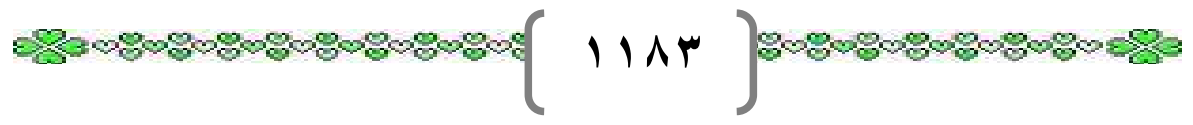




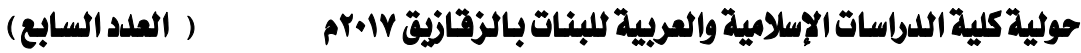

وجهها الماء. رحم الله امر أة قامت من الليل فصلت وأيقظت زوجها فصلى فإن أبى ر.

رشت في وجهه الماء (').

إن الحديث الثريف يوضح لنا صورة كريمة لزوجين مؤمنين مخبتين يقبلان على طاعة الله تعالى ويتذوقان حلاوة الإيمان، ولذة الطاعة، ويتعاونان على طلبها و أدائها وقد جفت جنوبهـا النوم، و هجروا المضـاجع عمـا بقولـه تعـالى: ( تتجافى جنوبهر عن المضاجع يدعون ربهم خوفا وطمعا ومما رزقنهم ينفقون )("). ولو تأملنا واقع المجتمعات المسلمة لوجدنا والحمد لله كثير ا من الأسر المسلمة ملتزمة بأمور دينها مقبلة على تعلمها محسنة تربية أولادها، إن المر أة بتعلمها أمور دينها تعرف كيف تعبد ربها وتصل أرحامها وتوفى حق زوجها ، وتعرف الحلال

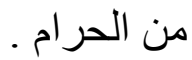

و لا يمنع ذلك من أن هنالك بعض الأسر لا بعتنون بتعلم أمور دينهم، ولا بتعلم أحكامـه فـلا أمّ يخطر ببالها ذلك حتى غدت لاتعرف الأحكام الخاصـة بالنسـاء في العبادات، وأصبح الاهتمـام مقصور آعلى اللذات و الثـهوات، و الهمحم مصروفة إلى اللهو و المـرح، و الجهد مبذول لبلوغ مدارج الجـاهو التـرف، ممـا أدى إلى ضـياع المبادئ و الحقوق، وفناء الواجبات بين الزوجيين الأمر الذي أدى إلى ضـعف الأسر وجهاه وتفككها وتربص القنن بها من كل جانب آذنة بالظهور، فاجتاحتها المشـاكل، وفرقها الجهل بأمور الدين.

إن الإيمان والاستقامة في البيوت ضرورة ملحة لأمن المجتمع ور احته، و التز ام الأسر بالدين والخلق له أكبر الأثر في استقرار ها وسعادتها.

ـ صحيح سنن ابن ماجه / باب ما جاء فيمن أيقظ أهله من الليل / / آب / / مكتب التربية. العربي لدول الخليج.

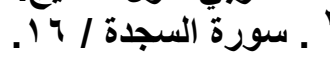




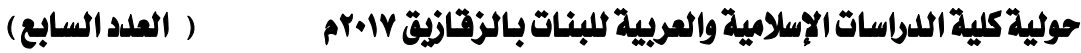

\section{المطلب الرابع: العدل عند تعدد الزوجات}

لقد كان تعدد الزوجات موجودآ في الجاهلية دون حد أو قيد، أخرج أبو داوود بسنده عن الحرث بن قيس قال مسدد بن عميرة وقال وهب الأسدي: أسلمت و عندي ثمان نسوة فذكرت ذلك للنبي فقال صلى الله عليه وسلم: (اختر منهن أربعا)('). هكذا كان بعض الرجال في الجاهلية يتزوجون بـأكثر من أربع دون حد أو قيد، فجاء الإسلام وحدد للرجل أربعا، ورخص في ذلك لمو اجهة واقع الحياة البشرية، وضرور ات الفطرة الإنسانية، وحمايـة المجتمع من الانحر اف، وشرط الإسـلام قيد العدل ليحمى الحياة الزوجيـة من الفوضـى والاختلال، ويحمي الزوجـة مـن الجور

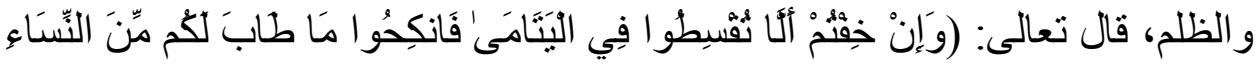

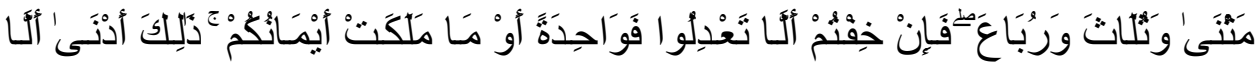

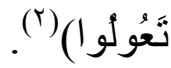
و العـل المطلوب هو العـل في المعاملـة والنفقة و المعاثـرة، وهو مـا يقدر عليهـ الإنسان ويملكه، أما ما لا يملكه من ميل القلب و أحاسيس النفس فلا يطالب بـه أحد لأنه خارج عن إر ادة الإنسـان، وقد أشنـار إليهه رب العزة بقوله: (وَلَن تَنْنَطِيعُو أن

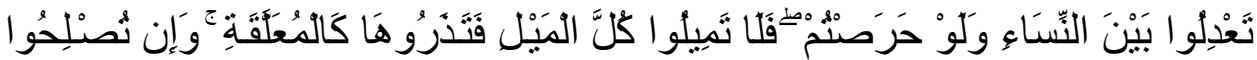

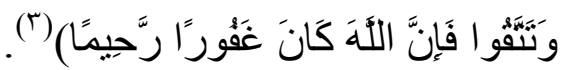
و القلوب ليست ملكت لأصحابها، و إنما هي ملك لخالقها وموجدها فهي بين أصبعين من أصابعه سبحانه يقلبها كيف يشاء.

ـ سـنن أبس داود / كتـاب الطلاق / بـاب فيمن أسـلم وعنده أكثر مـن أربـع أو أختـان

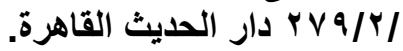

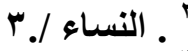

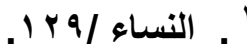


لقد كان النبي صلى الله عليه وسلم يحب عائشة رضـى الله عنها ويؤثرهـا بعاطفة قلبيه خاصة أكثر من بقية نسائه، وكان يقول في دعائه (اللهم هذا قسمي فيما أملك فلا تؤاخذني فيما تملك و لا أملك) ('). يقول ابن العربي رحمه الهة تعالى: قال علماؤنا: في قولـه(فـإن خفتم ألا تعدلو ا..) معناه في القَسَم بين الزوجات، و التسوية في حقوق النكاح، وهو فرض وقد كان النبي صلى الله عليه وسلم يعتمده ويقدر عليه إذا فعل الظـاهر من ذلك في الأفعال ووجد قلبه السليم يميل لعائشة رضى الله عنها فكان يقول: (اللهم هذا قسمي فيمـا أملك فلا

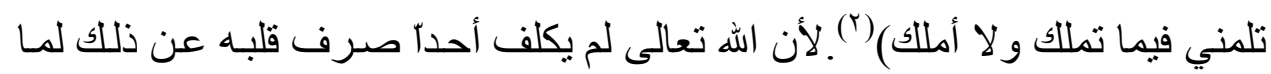

\section{فيه من المشقة)(").}

و الآية و إن كانت نازلة في شأن التحر ج من ظلم اليتيمات بعدم إقامـة العدل فيهن

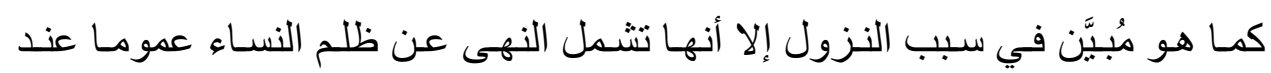
التعدد، ومر اعاة العدل بينهن في المأكل و المشرب و الكسوة و المبيت. أخرج الإمام البخاري في صحيحه بسنده عن ابن شهاب قال:أخبرني عروة ابن الزبير أنـه سـأل عائشـة عن قول الله تعـالى (وإن خفتم أن لا تقسطو ا في اليتامى ) فقالت يا ابن أختي هذه اليتيمـة تكون في حجر وليها تشركه في ماله ويعجبـه مالها وجمالها فيريد وليها أن يتزوجها بغير أن يقسط في صداقها فيعطيها مثل مـا يعطيها غيره، فنهو ا عن أن بنكحوهن إلا أن يقسطو الهـن وييلغو الهـن أعلى سننهن في أني

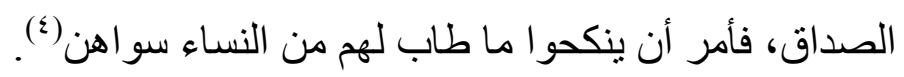

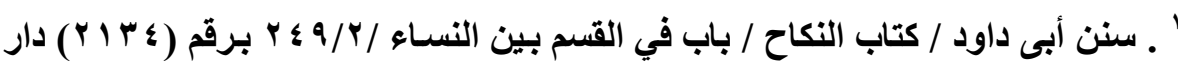
الحديث القاهرة. ل ' ل الحديث سبق تخريجه.

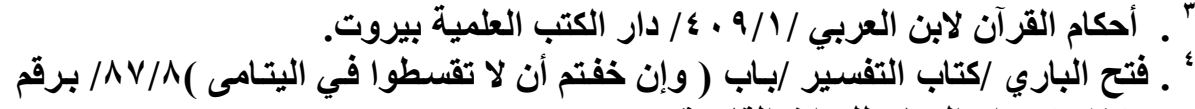

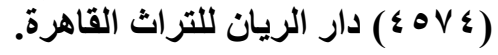

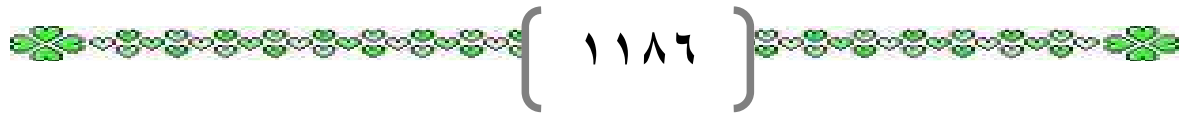




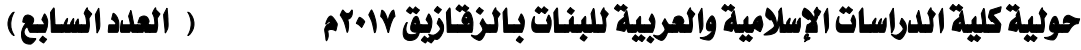

فإن خيف عدم العدل عند الزواج بأكثر من واحدة فيتعين الإقتصـار على واحدة أو

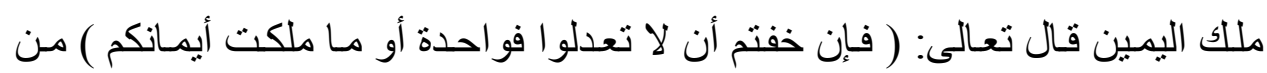

$$
\text { الإماء زو اجا أو تسرِّيا. }
$$

ثم بين الله تعالى الحكمة من الاكتفاء بواحدة أو ما ملكت الأيمان عند انتفاء العدل

$$
\text { بقوله (ذللك أدنى ألا تعولوا). }
$$

قال الإمام الخازن- رحمه الله- : ( أن لا تعولوا ): أي لا تميلوا ولا تجوروا وهو

قول أكثر المفسرين(') - (1)

ولقد أكد رسول الله صلى الله عليه وسلم في سنته على إقامـة العدل بين الزوجـات ونهى عن الميل إلى إحداهن دون الأخرى. فعن أبى هريرة رضي الله عنه قال : قال رسول الله صلى الله عليه وسـلم : مـن كانت له امر أتان يميل مع إحداهما على الأخرى جاء يوم القيامة وأحد شقيه ساقط (؟). أما إذا كانت الزوجة كبيرة مسنة و لا يَمكّنها ذلك من القيام بو اجباتها الثر عية تجاه زوجها، وتخشى من مفارقته لها فلها في هذه الحالة أن تتصـالح معـه وذلك بالتنـازل عن بعض حقوقها الشـر عية في مقابل بقائها في عصـته، وللزوج أن يقبـل ذلك ويذهب إليها ويبيت عندها ويحنو عليها ويطيب خاطر ها بالكلمة الطيبـة والمعاثـرة بالمعروف وبالدنو منها أسوة برسول الله صلى الله عليه وسلم. أخرج الإمام البخاري رحمه الله تعالى في صحيحه بسنده عن عائشـة رضـى الله عنها في قوله تعالى ( و إن امر أة خافت من بعلها نشوز او إعر اضلا). قالت هي المر أة تكون عند الرجل لا يستكثر منها فيريد طلاقها ويتزوج غير ها تقول له :أمسكني و لا

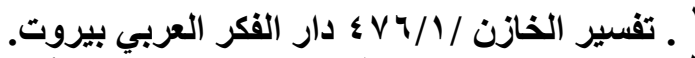

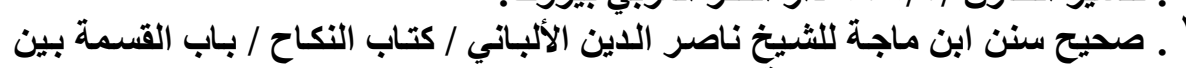

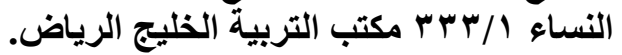




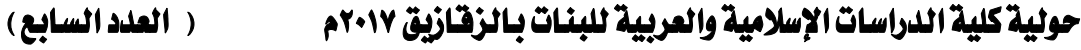

تطلقني ثم تزوج غيرى فأنت في حل من النفقة علىّيّ والقسمة لي فذللك قولـه تعالى

(فلا جناح عليهما أن يصلحا بينهما صلحا و الصلح خير) (').

وقد فعلت ذللك السيدة سـودة بنـت زمعـة رضـى الله عنهـا وو هبـت ليلتهـا لعائشـة

$$
\text { رضى الله عنها . }
$$

فقد أخرج الحـاكم في مستـركه بسنده عن هشـام بن عروة عن أبيـه عن عائشـة

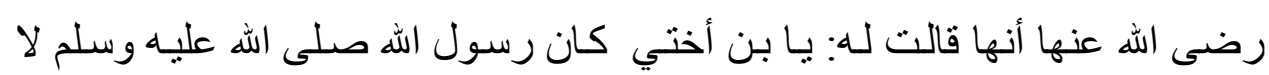
يفضل بعضنا على بعض في مكثه عندنا وكان قلّ يوم إلا وهو يطوف علينا فيدنو ا من كل امر أة من غير مسيس حتى يبلغ إلى من هو يومها فيبيت عندها ولقد قالت

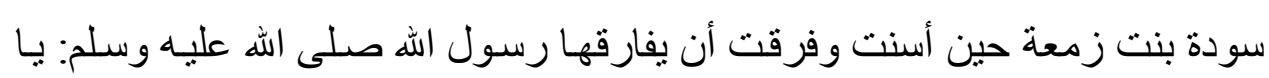
رسول الله يومي هو لعائشة فقبل ذلك منها رسول الله صلى الله عليه وسلم وفى ذلك

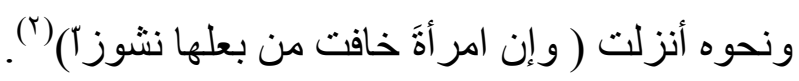

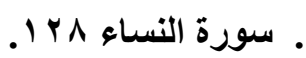

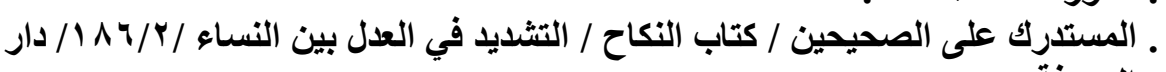

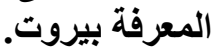




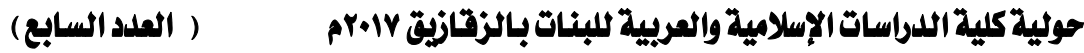

\section{المطلب الخامس: الغيرة على نسائه}

نَبَّه الإسلام الزوج إلى القيام بمسئوليته تجاه بيتهـه وزوجته و أولاده، و أرشده إلى و عى الرقابة وحسن القيادة وتأمين البيت، و المبادرة إلى الوقايـة مهـا يدنس الشرف قبل استفحال الخطر وتمكن الداء. ومن هنـا شَرَّع الإسـلام الغيرة وجعلهـا مـن الحقوق الزوجيـة غيرة الرجل على أهله، فيجب على الزوج أن يصون زوجتهـ و أو لاده من الفتــة بحسن خلقه و عفافه وطهارة سلوكه وقيامه بحق ربه وحق أهله، كما يجب عليه أن يصون زوجه من كل

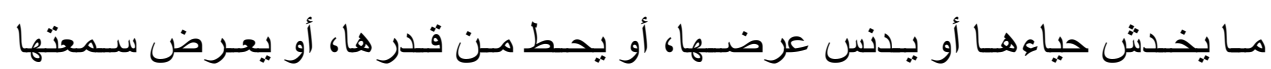
للتجريح، أو يُرى هو في مواطن التهم بـأن يزنى بـامر أة أخرى أو يخـادن أو يخالل

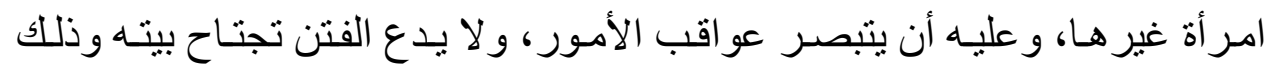
بخروج زوجته وبناته مبتذلات كاثـفات عن مفاتنهن مختلطات بالرجـال اختلاطـا سافر ا في كل ميادين الشر وساحات الهوى تحت مسمى الصداقة أو الزمالة، و عليه أن يأمر هن بالعفاف و الحشمة وستر مفاتنهن عن الرجال عملا بقولـه تعـالى: (وَمَرْنَ

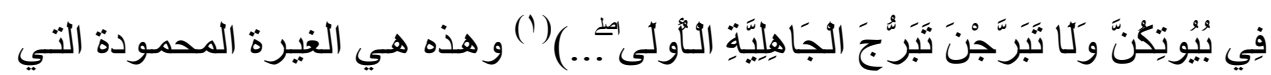
يقر ها الإسلام كحق للزوجة على زوجها. إن الغيرة من صفات الله تعـالى وقد فسر النبي الكريم صلى الله عليه وسلم تلك الغيرة بقوله صلى الله عليه وسلم ( إن الله يغار وغيرة الله أن يأتي المؤمن مـا حرّم

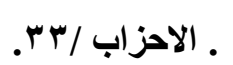

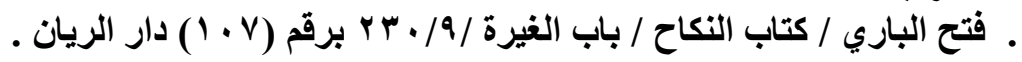


وفى رواية أخرى من طريق ابن مسعود عن النبي صلى الله عليه وسلم قـال: مـا من أحد أغير من الله من أجل ذلك حرّم الفواحش، ومـا أحد أحب إليه المدح من

أخرج البخاري رحمـه الله تعـالى في صـحيحه بسنده عن عائشـة رضـى الله عنهـا قالت: قال رسول الله صلى الله عليه وسلم: يا أمة محمد ما أحد أغير من الله أن يرى

عبده أو أمته تزني، يا أمه محمد لو تعلمون ما أعلم لضحكتم قليلا ولبكيتم كثير ب(؟). ولقد كان صلى الله عليه وسلم من أشد الناس غيرة لأنه كان يغار لله ولدينه.

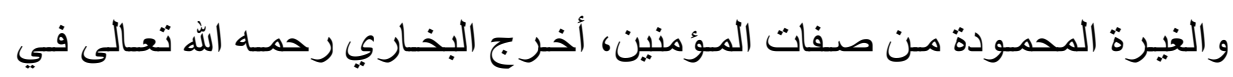
صحيحه بسنده عن أسماء بنت أبسى بكر قالت: ( لقيني رسول الله صلى الله عليـه

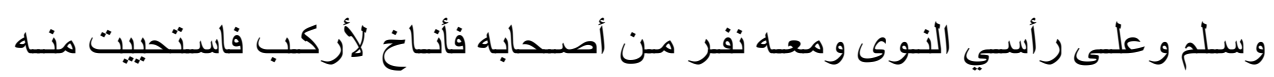

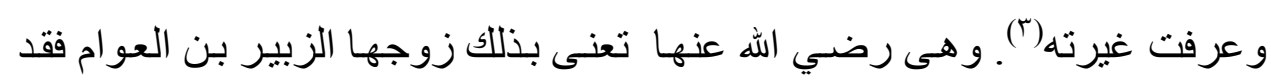
كان معروفا بغيرته على نسائه .

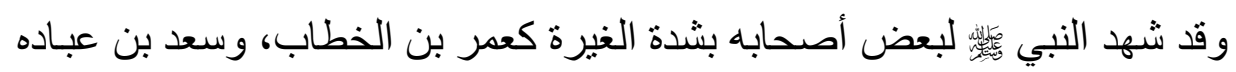
رضى الله عنهما. أخرج البخاري في صحيحه بسنده عن أبى هريرة رضى الله عنه قال بينما نحن عند رسول الله صلى الله عليه وسلم جلوس فقال: بينما أنا نائم رأيتني في الجنـة فإذا امر أة تتوضاً إلى جانب قصر فقلت: لمن هذا؟ قال: هذا لعمر . فذكرت غيرته فوليت مدبر آ فبكى عمر وهو في المجلس ثم قال: أو عليك يارسول الله أغار (๕.).

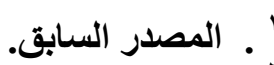

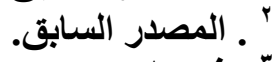

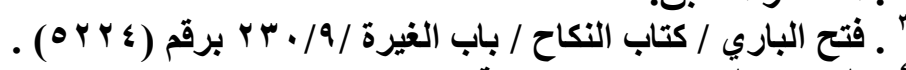

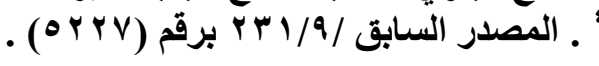


و عن المغيرة قال سعد بن عبادة: لو رأيت رجلا مع امر أتي لضربته بالسيف غير مصفح، فقال النبي صلى الله عليه وسلم: أتعجبون من غيرة سعد؟ لأنا أغير منه و الله

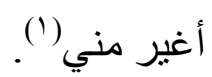

أما الغيرة التي في غير موضعها فهي الغيرة في ريبة وهى مذمومـة يمقتها الله بعَّلت

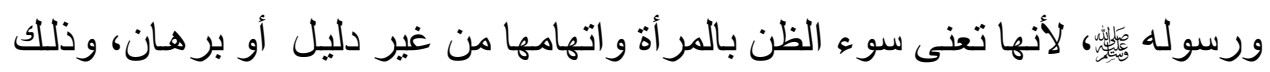

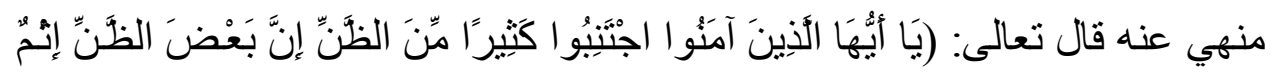
(r) $(\ldots . . .$. و عن أبى هريرة رضي الله عنه قـال: قال رسول الله صـلى الله عليه وسـلم: مـن الغيرة ما يحب الله ومنها ما يكره فأما ما يحب الله فالغيرة في الريبـة، وأمـا مـا يكره وهره الله فالغيرة في غير ريبة (ॅ). قال ابن القيم: و التي يكر هها الله أن يغار من غير ريبـة بـل مجرد سوء ظن وهذه الغيرة تفسد المحبة وتوقع العداوة بين المحب ومحبوبه(؛). فعلى الرجال أن يدركو ا ذلك و لا بطلقو ا العنـان لإسـاءة الظن بنسائهم وبناتهم من

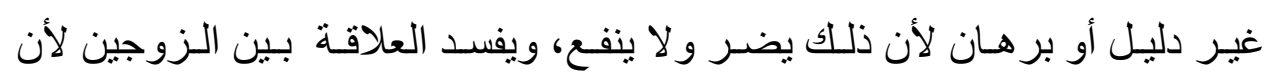

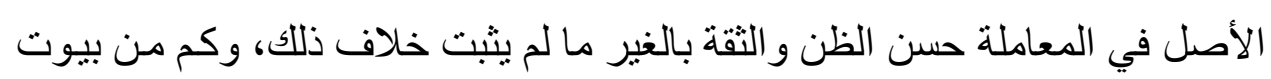
تهمدت، وكم من أسر تحطمت وتثردت بسبب الأوهام و الظنون الفاسدة. كما أن على الزوج أن يصون زوجه من الفتــة فلا يُرى هو في مو اطن التهم أو ونه

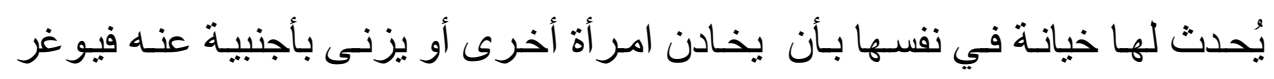

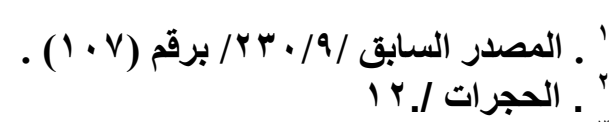

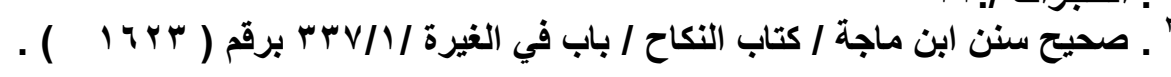

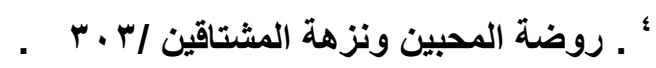

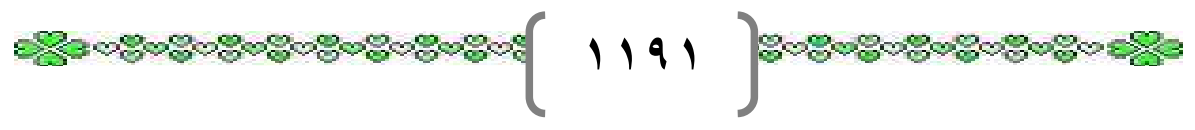


صدر ها ويكسر قلبها، و على الزوجة كذللك ألا تأذن لأحد في الدخول عليها بغير إذن زوجها وفى غيابه، فإن ذلك يعد انتهاكا للحرمات ووقو عاّ في النكبات. أخرج البخاري رحمه الله تعالى في صحيحه بسنده عن عقبة ابن عامر : أن رسول الله صلى الله عليه وسلم قال: إياكم والدخول على النساء فقال رجل من الأنصـار يـا رسول الله أفرأيت الحَمُوْ قال الحَمْوُ الموت('). والحمو هو أخو الزوج ومـا أثنبهه من أقارب الزوج كابن العم وكذلك أقارب الزوجة من غير محارمها، و إنمـا شبهه بالموت لأنه بحكم صلة القر ابة لهما قد ينتهلك حرمة البيت و العرض فيهلك. قـال النووي رحمـه الله تعـالى في بيـان معنى قولـه صلى الله عليه وسـلم (الحَمَّو الموت): المـر اد أن الخلوة بقريب الزورج أكثر مـن الخلوة بغيرهو الثـر يتوقع منـهـ أكثر من غيرهو الفتنة به أمكن لتمكنة من الوصول إلى المرأة والخلوة بها من غير بره نكير بخلاف الأجنبي (r). وقال عياض: معناه أن الخلوة بالإحماء مؤدية إلى الفتنة و الهالاك في الدين تجعله

كهلاك الموت و أورد الكلام مورد التغليظ(َ).

. فتح الباري / كتاب النكاح / باب لا يخلون رجل بامرأة إلا ذو محرم/9/ ع ب برقم

-

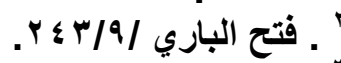

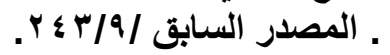




\section{المطلب السادس: الخلع}

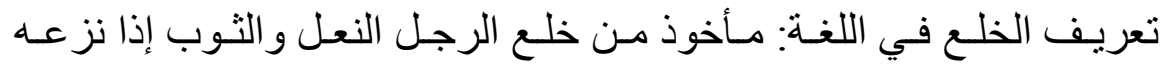
و أز الـه، وخالعـت المـر أة زوجهـا مخالعـة إذا افتـدت منـهـ وطلقهـا على الفديـة، فخلعها هو خلعا، والاسم الخلع بالضم، وهو استعارة عند خلع اللباس، لأن كل و احد منهما لباس للآخر ، فإذا فعلا ذلك فكأن كل واحد نزع لباسـه عنهـ(1)، قـال

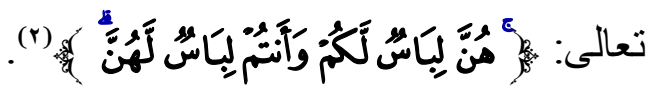
تعريف الخلع في اصطلاح الفقهاء:هو فراق الزوج امر أته بعوض يأخذه الزوج بألفاظ مخصوصة(r).

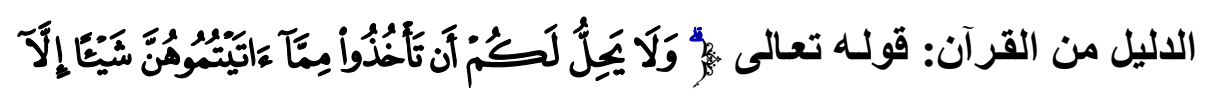

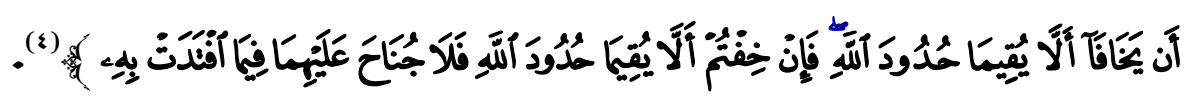
وأما الدليل من السنتهُ فقد روى البخاري عن ابن عباس: أن امر أة ثابت بن قيس أتت النبي صلى الله عليه و سلم فقالت يـا رسول الله ثابت بن قيس مـا أعتب عليه في خلق و لا دين ولكني أكره الكفر في الإسلام فقال رسول الله

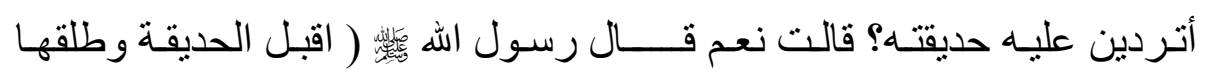
تطليقة )

$$
\begin{aligned}
& \text { (1) المصباح المنير في غريب الشرح الكبير للفيومي ، 10 ـ1018. }
\end{aligned}
$$

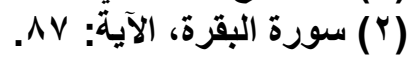

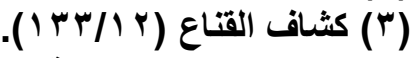

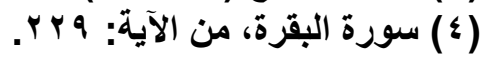

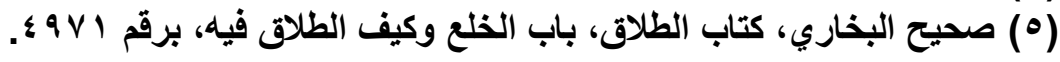


قال الإمـام القرطبي: وهذا الحديث أصل في الخلع، و عليهه جمهور الفقهاء. قال مالك: لـم أزل أسمع ذلك من أهل العلم، وهو الأمر المجتمع عليهه عندنا، وهيه

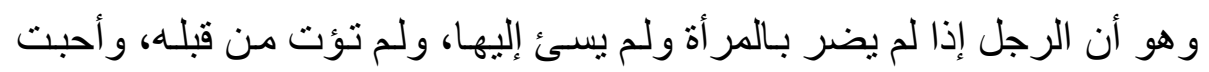
فر اقه فإنه يحل له أن يأخذ منها كل ما افتدت به، كما فعل النبي صلى الله عليه

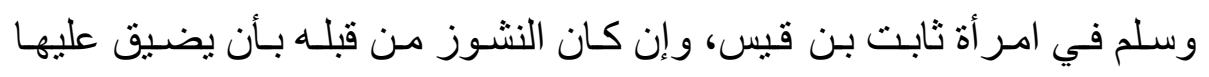
ويضر هار رد عليها ما أخذ منهاب(1). ألفاظ الخلع:- يقسم الفقهاء ألفاظ الخلع إلى قسمين(r): ا ـ ألفاظ صريحة: كأن يقول الرجل لزوجته خالعتلك لثبوت هذا اللفظ في

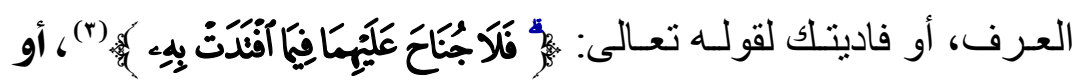

\section{فستخ نكاحك لأنه حقيقت في الخلع.}

r- ألفـاظ كنايـة: مثل: بار أتلك، و أبر أتك، و أبنتك، ونحو ذلك، و لا بـ في

$$
\text { الكنايات من نية الخلع ممن أتى بها. }
$$
الحكمة من مشروعية الخلع:

لقد جعل الإسـلام الطلاق بيد الرجل لاعتبـار ات معقولة، وقد يلحق بـالمر أة

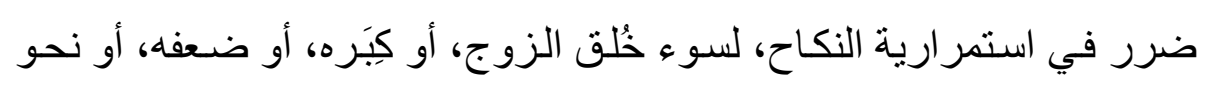
ذلك وخثيت المر أة ألا تؤدي حق الله تعالى في طاعته، فشرع الإسلام لها الخلع بعوض تفتدي به نفسها.

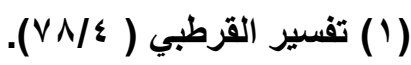

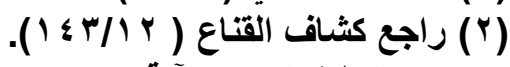

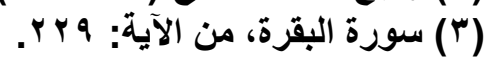


قال ابن رشد رحمه الله :- و الفقه أن الفداء إنما جعل للمر أة في مقابلة مـا بيد الرجل من الطلاق، فإنه لما جعل الطلاق بيد الرجل إذا فرَك ــ أب كرهـ المرأة، جعل الخلع بيد المرأة إذا فركت الرجل ـ أي كرهتهـ.

\section{المبحث السابع: المتعة.}

إن عقد النكاح جعلـه الله موضـع ألفـة وتر احم بين الزورجين فعندما أر اد الزورج الارتباط بزوجته بالعقد الصحيح أمره الإسـلام أن يبذل لها بسخاء وطيب نفس مـا لـا

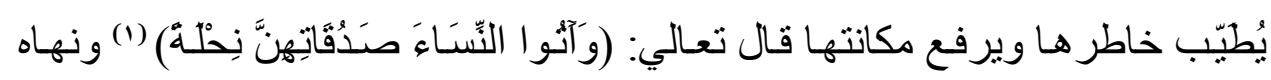

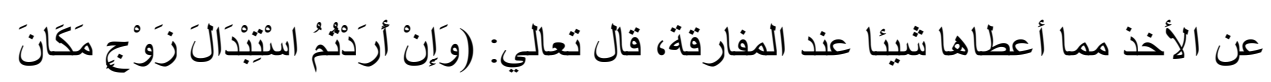

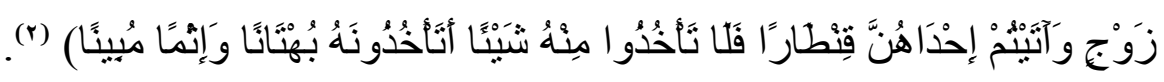
و إذا حدث الفراق بين الزوجين بالطلاق وقبل الدخول وقد فرض لها المهر، أمره الإسلام أن يكون سمحا كريما وأن يتنازل عن نصيبه لها فهو أحق بـالعفو منها قال

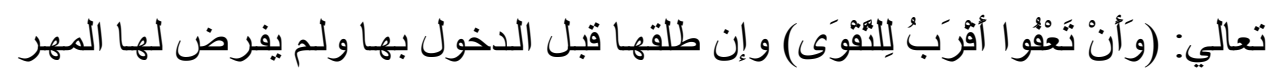
فقد أمره الإسلام أن يحسن إليها، وأن يعوضها عما لحق بها من ضرر الطلاق وكسر خاطر ها بالمتعة التي شر عها الله لها حقا علي المتقين.

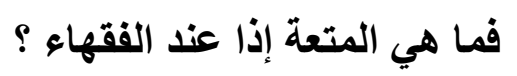

(r) المتعة شرعا: هي اسم للمال الذي يعطيه الرجل لأمر أته عند فر اقها وقد اختلف الفقهاء في حكم وجوب المتعة للمُفوضة علي أقوال(') :-

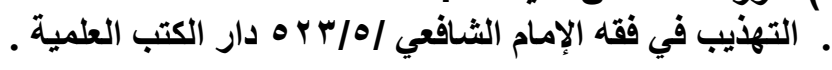


ذهب الأحناف و الثافعية(') إلي وجوب المتعة للمفوضة وهي كل امر أة طلقت قبل الدخول ولم يفرض لها مهر عند العقد أو بعده، وبهذا قـال الأوزاعي، وحمـاد بـن سليمان، و أحمد في رواية الجماعة.

قال ابن قدامة() رحمه الله تعالي: فإذا طلقت المفوضة البضع قبل الدخول فليس لها إلا المتعة، نص عليه أحمد في رواية الجماعة، وهو قول ابن عمر ، وابن عباس،

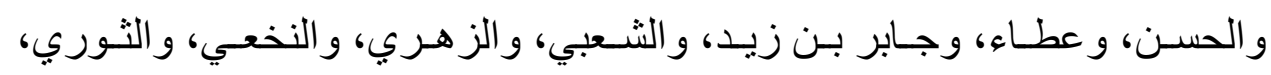
و الثافعي، و إسحاق، و أبي عبيد، و أصحاب الرأي . وقال القرطبي رحمه الله تعالى: أجمع أهل العلم على أن التي لم يفرض لها ولم بلمخل بها لا شيء لها غير المتعة (๕). وقد أستدل اصحاب هذا القول بما يلى (0):-

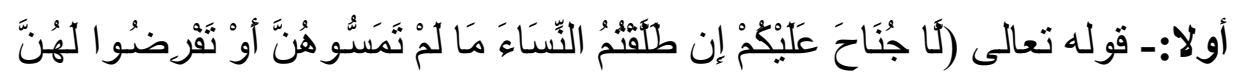

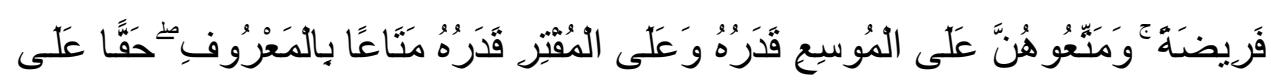
الوُحْسِنِينَ)(1) ووجـه الدلالـة في الآيـة الكريمـة: أن الله علق وجوب المتعـة فيهـا على شـرطين و هما أن يكون الطلاق قبل الفرض، وقبل المسيس، وقد وجد الشرطان فوجبت

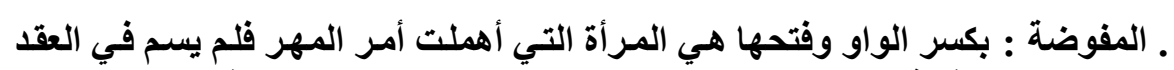

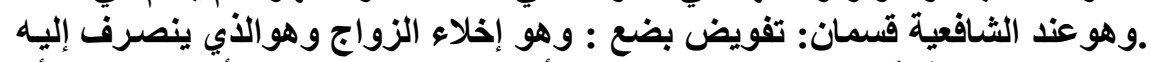

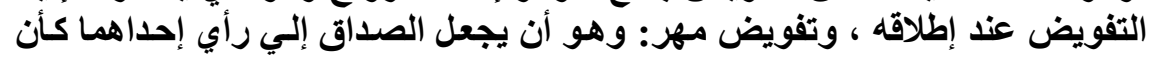

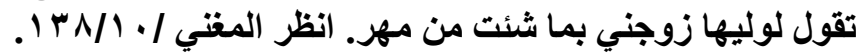

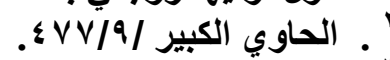

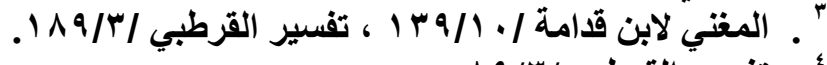

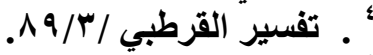

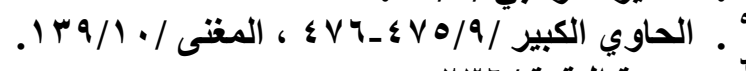

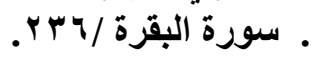




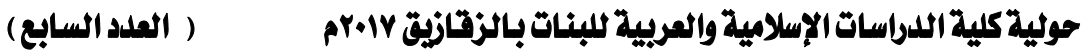

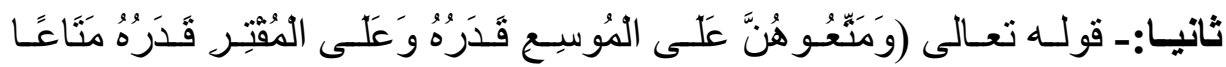

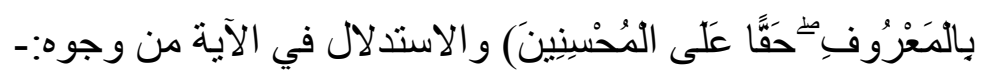

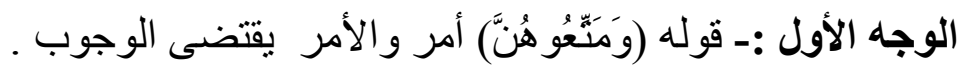

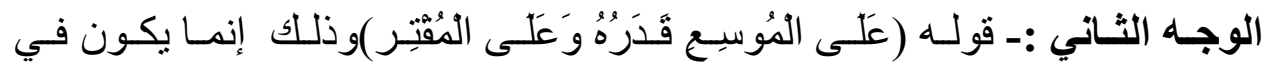
الو اجبات دون التطوع . الوجه الثالث :- قوله (حَقَّا) و الحقوق هي التي تكون واجبة الوجه الر ابع:- قوله (عَلى المُحْسِنِينَ) و على من حروف الإلز ام التي تقيد الوجوب . ثالثا:- من الأدلة على وجوب المتعة قوله تعالى (وللمطلقات متاع بـالمعروف حقا على المتقين) و الاستدلال في الآية من وجوه : الوجه الأول:- قوله (وللمطلقات )و اللام تقيد الملكية فدل ذللك على استحقاقهن للمتعـة

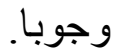
الوجه الثاني:- قوله (بـالمعروف ) بيان لقدر المتعـة وأنها ممـا تعارف عليه النـاس وما لا يجب فليس بمقدر.

الوجه الثالث:- قوله تعالى (حقا على المتقين ) فلل على أن مَنْ منعهاــ أبي المتعـة ـ فليس بمتق، و إنما خص المتقين بالذكر تشريفا لهم وهو لا ينافى عموم الوجوب في المتقين و غير هم. رابعا :- أنه طلاق في نكاح يقتضى عوضا فلم يَعْرَى عن العوض كمـا لو سمى مهز ا، وأداء الو اجب من الإحسان فلا تعارض بينهما' '). خامسا:- بوجوب المتعة فال عمر بن الخطاب، و على بن أبى طالب ـرضى الله عنهما- وليس يُعرف لهما فى الصحابة مخالف فصار إجماعا؟).

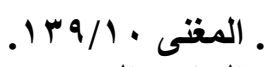

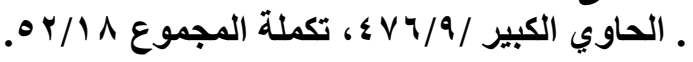


وأما المطلقة قبل الدخول و التي لم يفرض لها المهر عند العقد لكن فرض لها بعد

العقد عليها.

فذهب الثـافعي(') بـأن لهـا نصـف المهر و لا متعـة لهـا، وهذا قول ابـن عمر،

و عطـاء، و الثـعبي، و النخعى، وأبـي عبيد، و استـدلو المـذهبهم بقولـه تعـالى: (وَإن

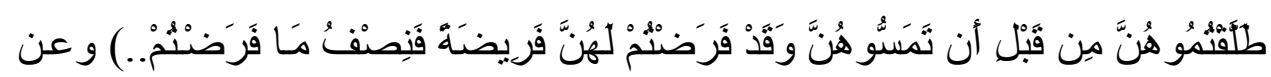
ابن عمر رضى الله عنهما قال : لكل مطلقة متعة إلا التي فرض لها ولم يُدخل بها

فحسبها نصف المهز (r).

وذهب الإمام أبو حنيفة و أحمد أن لها المتعة ويسقط المهر لأنه نكاح عُرِّىَ عن

تسمية المهر فوجبت به المتعة كما لو لم يُفرض لهاب(َ).

القول الثاني :- ذهب الإمـام مالك(؛)و الليث، وابن أبى لبلى، وشريح، و الحكم،

إلى أن المتعة مستحبة مطلقا وليست واجبة، و استدل اصحاب هذا القول بما يلى (0):

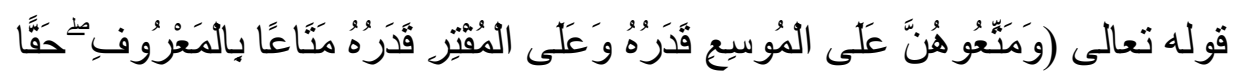

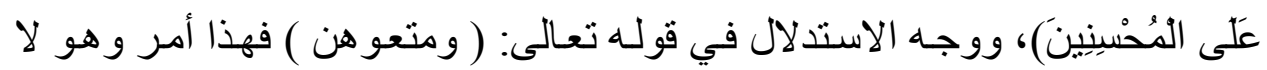
يفيد الوجوب بل يفيد الاستحباب، والذى صرفه عن الوجوب إلى الاستحباب أن الله خص المحسنين بها فقال (حقا على المحسنين ) دون غيرهم، وفى آيـة أخرى جعله (حقا على المتقين) وقيده بالمعروف في كلتا الآيتين، ولو كان و اجبا لمـا خص بـه

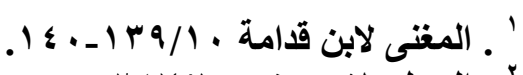

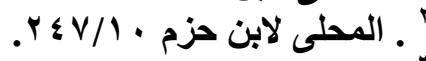

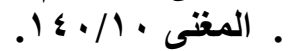

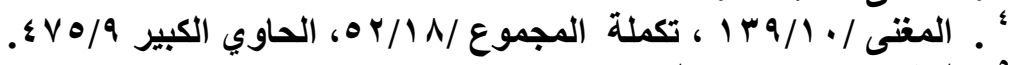

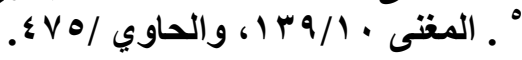




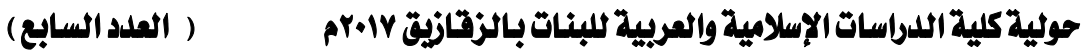

المحسنين و المتقين، ولما قيده بالمعروف في كلتا الآيتين، فدل ذلك على استحباب المتعة لا على وجوبها.

القول الثالث: ذهب أصحاب هذا القول إلى وجوب المتعة مطلقا. قال ابن قدامة: روى عن أحمد: لكل مطلقة متاع، وروى ذلك عن على ابن أبى طالب، و الحسن، وسعيد ابن جبير، و أبى قلابة، و الزهري، وقتادة، و الضحاك، وأبى ثور (') وقـال ابـن شـهاب : كل مطلقة في الأرض لها متـاع. وو افقهم على ذلك أهل

(r) ( الظاهر

قال ابن حزم رحمه الله تعالى: المتعة فرض على كل مطلّق وطئها أم لم بطأهـا،

$$
\text { فرض لها صداقها أم لم يفرض لها شيئا(ّ). }
$$

وممـا استـل بـه أصـحاب هذا القول عموم النصـوص التي أمـرت بالمتعـة لكل

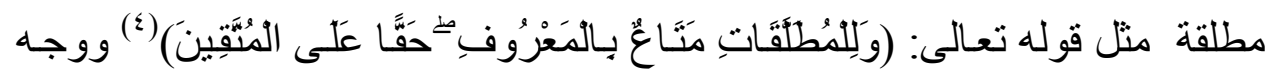
الدلالة في الآيـة شمول النص لكل مطلقة سواء كانت مفوضـة، أو مسمى لها،

$$
\text { مدخو لا بها، أو غير مدخول بها. }
$$

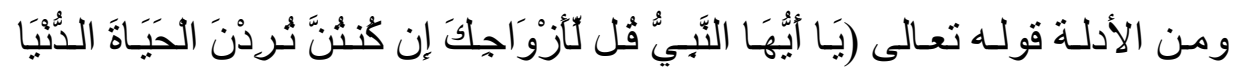

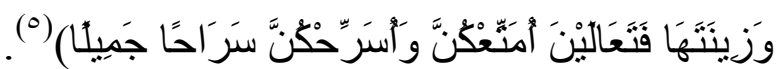

ووجـه الدلالـة في الآيـة: أن الله تعـالى أمـر نبيـه صـلى الله عليهـ وسـلم أن يخير نساءه بين البقاء معهه ر اضبين بما قسم الله لهن من العيش وبين الطلاق و المفارقة

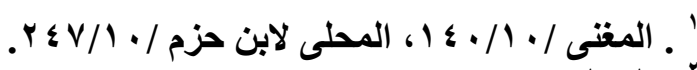

$$
\begin{aligned}
& \text {. }
\end{aligned}
$$

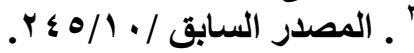

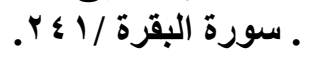

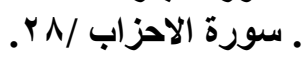


إن أر ادوا الحياة الدنيا وزينتها وأمر لهن بالمتعة مع أنه مدخول بهن وقد سمى لهن المهر فدل ذلك على وجوب المتعة لكل مطلقة.

ومن الأدلة التي استدل بها أصحاب هذا القول: أنهم قالوا إنمـا جعلت المتعـة لمـا لحق بالزوجـة المطلقة مـن الابتـذال بالعقد و الطـلاق، والمهـر في مقابلـة الـوطء،

و الابتذال موجود فكان لها المتعة(').

و الـذى تطمـئن إليـه الـفس هـو: أن المتعـة واجبـة لكل مطلقـة عمـلا بعدوم

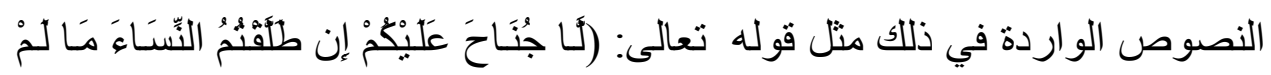

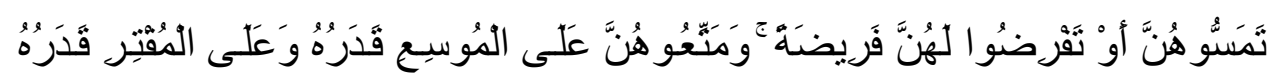

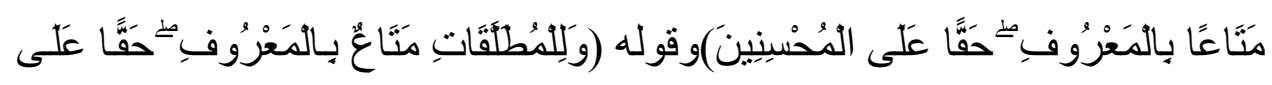
الوُنَّقينَ) فالآيات على عمومها تفيد وجوب المتعة لكل مطلقة: إلا ما خصه الدليل. ووجـه الاســـلال في الآيتـين هـو: مجـيء الـلام الدالـة على الملكيـة في قولـه (وللمطلقات) و هذا دال على استحقاق المطلقات المتعـة، وكذللك قوله (بـالمعروف) حيث قدر المتعة، ولو لم تكن واجبة لما قدر ها الثار ع الحكيم بالقدر المتعـارف عليه وهيه بين الناس. ومما يدل على وجوبها قوله تعالى ( حقا ) و الحق هو الواجب اللازم، وفى قولـه (على المتقين) مـا يؤكد هـذا الوجـوب وذلـلك بمجـيء (على) التـي تفيـــ الإلـزام

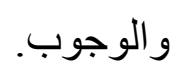

و فيه أيضا أن من لم بمتع امر أته فليس بمحسن و لا متق .

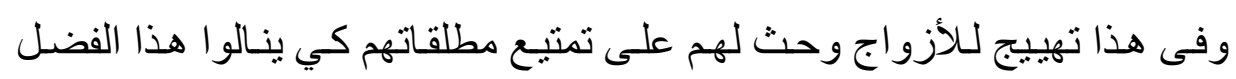
ويدخلوا في زمرة المتقين المحسنين.

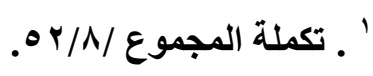

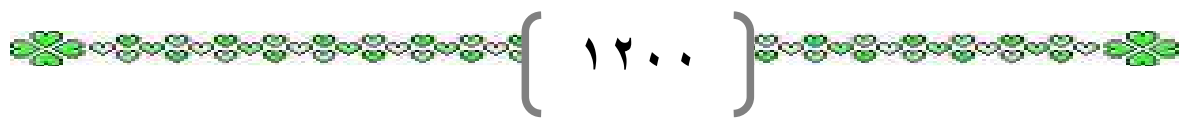




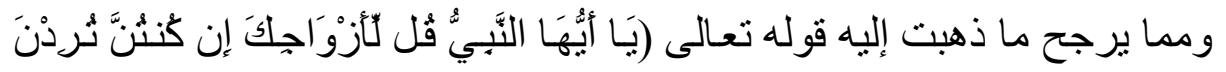

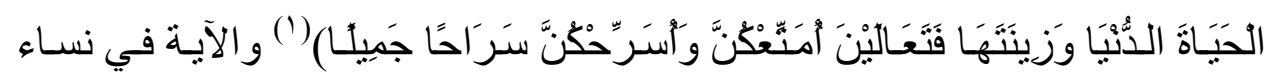
النبي صلى الله عليه وسـلم اللاتي دخل بهن، وقد سمى لهن المهر بدليل حديث

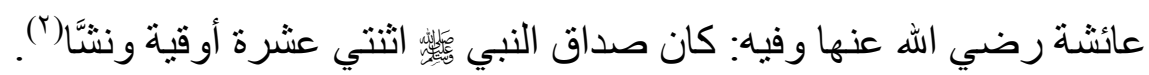
أما المطلقة قبل الاخول بها و المفروض لها مهر ا فخصهـن الدليل من بين عموم

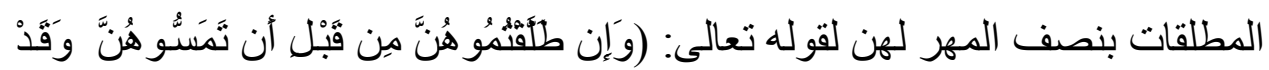

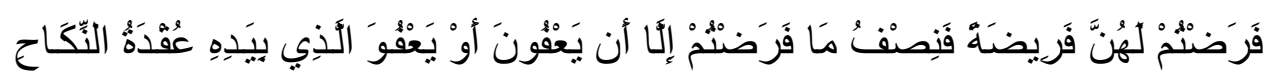

ع (") فمن وجب لها نصف المهر لم تجب لها متعة(")

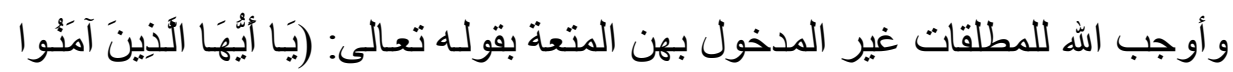

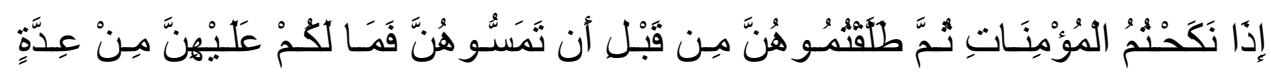

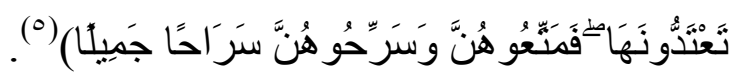
و أما المتوفى عنها زوجها فلا متعـة لها بإجمـاع العلمـاء لأن النصـوص العامـة لم لم تتناولها، وإنما تناولت المطلقات، و لأن المتوفى عنها أخذت العوض المسمى لها في عقد المعاوضة فلم يجب لها به سو اه كما في سائر العقود (†). و المتعة تكون بحسب يسار الزوج و إعساره لقوله تعالى: (ومتعوهن على الموسع قدرهو على المقتر قدره ....) (V) ومرجع التقدير فيها إلى الاجتهاد في ضو ضو مـا تعارف عليه الناس، وهذا مما يختلف باختلاف الاشخاص و العصور و البلدان.

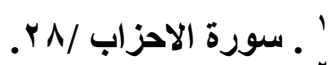

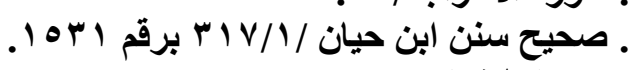

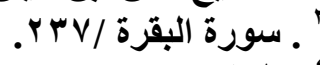

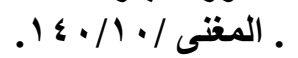

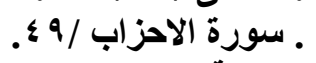

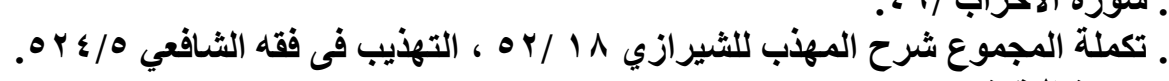

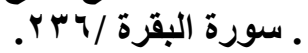




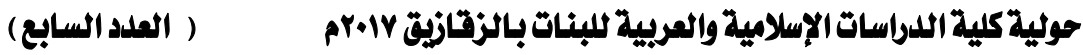

\section{المبحث الثاني: حقوق الزوج}

جعل الإسلام للزوج حقوقَ على زوجته وبشر ها إن هى أدت هذه الحقوق وقامت بها نالت رضـا الله والجنه، وحذر ها إن هـى ضـيعت هذه الحقوق عرضـت نفسها لغضب الله وسخطه، و إليك بيان هذه الحقوق.

\section{المطلب الأول: القوامة}

إن أي مؤسسـة لابـد لهـا مـن رئِيس يقوم عليهـا ومسؤول يتـولى شـئونها وإلا ضربت الفوضى جميع جو انبها و عادة الخسارة فيها على الجميع ، و الأسرة مؤسسـة مـن مؤسسـات المجتمـع ولبنـة مـن لبناتـه فكان و لا بـد لهـا مـن مسؤل يسوسـها وقائد يدير ها.

و هنا يطر أ سؤ ال مفاده أيهما أحق و أجدر بالقو امة وقيادة الأسرة بما في ذلك من تبعات أهو الرجل بقوته و عقله ؟ أم المر أة بضعفها و عاطفتها و انفعالاتها ؟ الجواب: إن القادر على ذلك و الأصلح لتلك المهمهة هو الرجل بحكم الفطرة التي

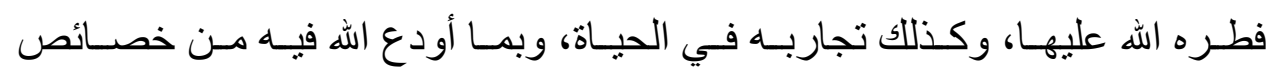
ومميز ات تتناسب مع هذا الحق الذي كلفه الله به، فتكوينه العقلي و العضلي و النفسي جعله أقدر على إدارة الحياة الزوجية و القيام بشؤنها، و إحكام قيادتهـا، كمـا أن تكليف الله لـه بالإنفـاق على زوجتـه و أو لاده جعلـه أحـق بالقو امـة مـن المـر أة، لأن تـدابير المعـاش و الإشـر اف على تصـربف الأمـور داخل الأسـرة أقرب إلى وظيفـة الرجلـ

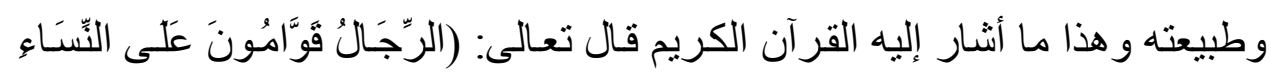

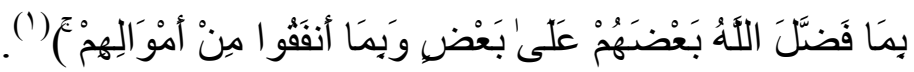

( بورة النساء /ع ب.

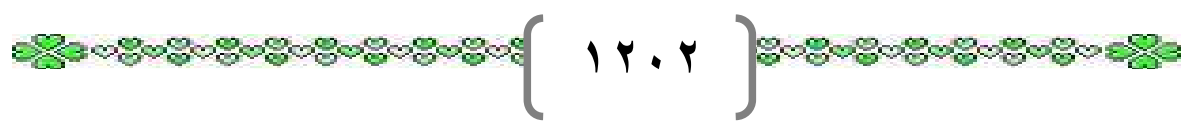


و المـر أة بطبيعـة تكوينها الأنثوي لا تثـعر بـالأمن إلا في ظل رجل ارتبطت بـه برباط شر عي، و لا تهدأ مشاعر ها ويستقيم أمر ها إلا في حمى رجل قوَّام عليها، و لا

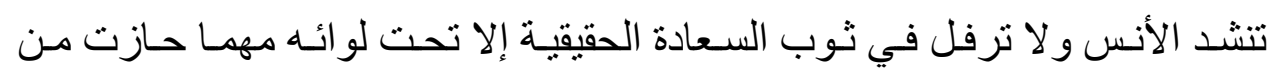

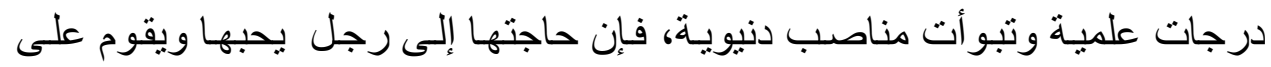
أمر ها وشؤنها يظل أمر آ فطريا لا يمكن كتمانه أو الاستغناء عنه. وحينما نزلت هذه

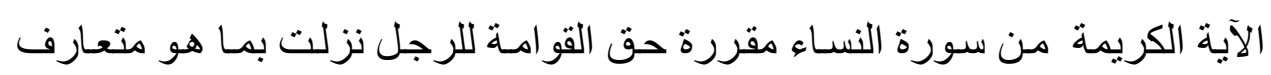
عليه مألوف في المجتمع الذى نزل فيه القرآن تماشيا مع الفطرة التي فطر الله الناس هرو عليها. يقول الإمسام الفخر الرازي رحمـه الله: تعـالى وطيب ثر اه مـا نصـه:- ـ لمـا أثتبت

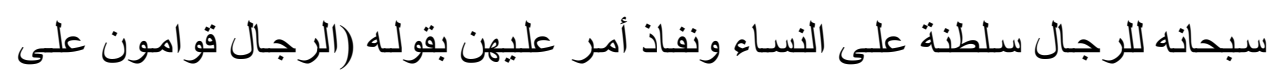
النساء) بيّن أنه فعل ذلك معلا بأمرين

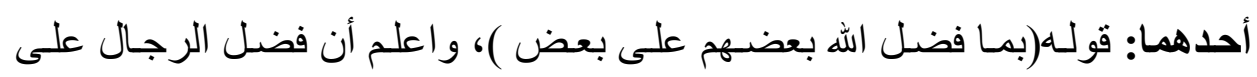

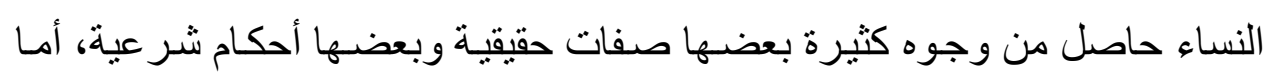
الصفات الحقيقية: فاعلم أن الفضـائل الحقيقيـة يرجع حاصلها إلى أمرين: إلى العلم و إلى القدرة و لا شـك أن عقول الرجـال و علـومهم أكثر ، و لا شـك أن قدرتهم على يلى الأعمال الثاقة أكمل، ولهذين السببين حصلت الفضيلة للرجال على النساء في العقل و الحزم و القوة و الكتابـة في الغالب، و الفروسية و الرمسي وأن منهم الأنبياء و العلمـاء وفيهم الإمامة الكبرى و الصغرى و الجهاد و الأذان و الخطبة و الاعتكاف و الثهادة في الحـدود و القصـاص بالاتفـاق وفـى الإنكحـه عنـــ الثـافعي رضـي الله عنـهـ وزيـادة النصيب في المير اث و التعصيب في المير اث وفى تحمل الديـة في التنل الخطأ وفى ولى القسامة و الو لاية في النكاح و الطلاق و الرجعة و عدد الأزواج و إليهم الانتسـاب فكل ذلك يدل على فضل الرجال على النساء. والسبب الثاني لحصول هذه الفضيلة: قوله 
تعالى ( وبما أنفقو ا من أمو الهم ) يعنى الرجل أفضل من المر أة لأنـه يعطيها المهر وينفق عليها أ. هـ (') - (') يفهم مـن كـلام الإمـام الـرازي رحمـه الله أن القوَّام هـو القائم بالمصــالح و التـدبير و التأديب و الحفظ وخص الله الرجال بهذا الحق لما فضل الله بعضهم على بعض في العقل و الر أي والقوة، وبما أنفقو امن أمو الهم في المهور و أقوات المعاش.

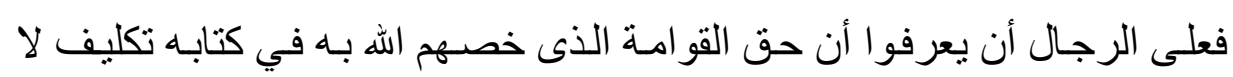
تشريف، و أعباء ومسئولية لا مغنم فيها إلا الأجر و الثواب مـن الله تعـالى، تكليف

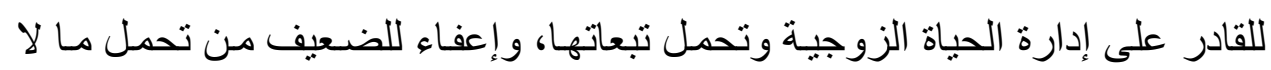

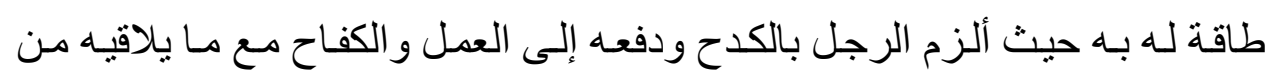
المشقة والتعب، قال تعالى محذر آدم وزوجـه عليهمـا السـلام من مكائد إبليس عليه اللعنة (فقلنا يا آدم إن هذا عدو للك ولزوجك فلا يخرجنكما من الجنة فنشقى)(؟). قـال الألوسـي رحمـه الله تعـالى: وفهى إسـناد ذلك ـ أي الشقاء ـ إليهه عليه السـلام خاصة بعد تعليق الإخر اج الموجب لله بهمـا معـا لأصـالته في الأمور و استلز ام تعبهـ لتعبها مع ما في ذلك من مر اعاة الفو اصل على أتم وجه. وقيل: المر اد بالثقاء التعب في تحصيل مبادى العيش وهو من وظائف الرجال، ويؤيد ذلك مـا روى عن سعيد بن جبير قال: إن آدم عليه السلام لما أهبط من الجنة استقبله ثور أبلق فقيل له: اعمل هل عليه فجعل يمسح العرق عن جبينه ويقول هذا ما وعدني ربى ( فلا يخرجنكما من الجنة فتشقى ) ولعل القول بالعموم أولى ().

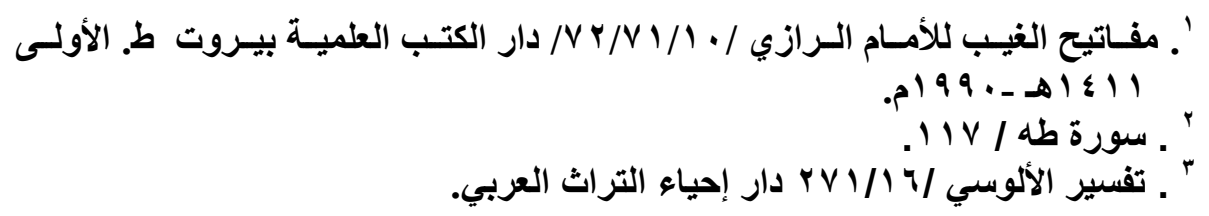

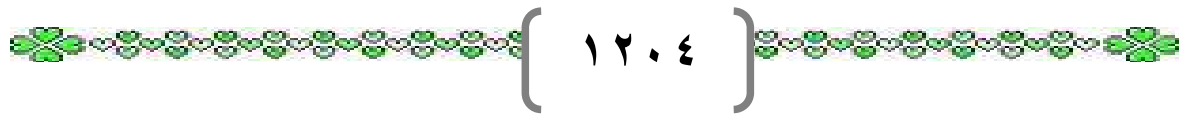


إذا فالقو امـة للرجـال شقاء وتعب، وتحديد للمسؤولية، وتكليف للقادر على إدارة الحياة الزوجية وليست تسلط واستعباد للمر أة، بل هي كما ترى جهاد ومثابرة، وبذل و عطاء، بينما المر أة في الغالب تر اهـا ترفُل في ثوب سعادنها تروح وتغدو اوسط مملكتها في ظل ظليل، ور غد من العيش نضير. وأود التنبيـه على أن وجـود القيم أو الـرئيس في أي مؤسسـة لا يلغنى وجـود و لا

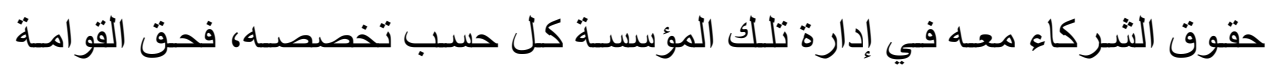
للرجل الذى يعني التبعة و المسؤولية عن أسرته لا يُلغى شخصية المر أة في المشورة

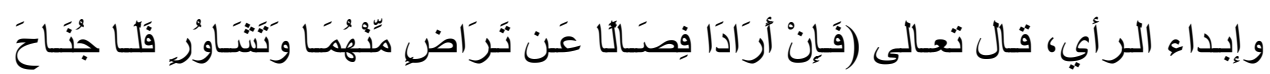
عَلْيْهَمَامَ)(') فقد دلت الآية الكريمة على حق الزوجة في إبداء ر أيها في شـأن وليدها بإر ادة ناثئة عن التو افق و التر اضي بين الزوجين بما يحقق المصلحة للرضيع. يقول الثيخ المر اغي رحمه الهه تعالى: و إنما اعتبر رضا الأم مع أن ولىَّ الولد هو الأب، وصلاحه منوط بنظره مر اعاة لمصلحة الطفل إذ هي لكمال شفقتها عليه لا تفكر إلا فيما فيه خير وفائدة(؟). وها أنت ترى إرشاد القرآن إلى استعمال المشورة في أدنى الأعمال لتربية الولد، ولم يبح لأحد الو الدين الاستبداد بذلك دون الأخر. يقول الثـيخ محمــ الغز الـي رحمـهـ الله تعـالى: إن أي مؤسسـة تربويـة أو شـركة اقتصـادية لا بـــ لها مـن رئيس، و الرياسـة لا تلغـى البتـة المشـورة و التفـاهم وتبـادل الر أي، و البحث المخلص عن المصلحة، إذ هذا قانون مطرد في شئون الحياة كلها فلماذا يستثنى منه البيت؟، وقوله تعالى في صفه المؤمنين ( و أمر هم شورى بينهم)

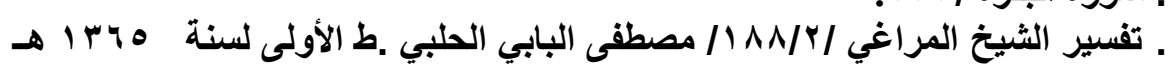
/

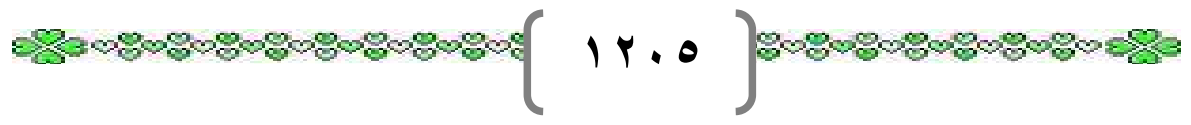


نزلت في مكة قبل أن تكون هنالك شئون عسكرية أو دستورية، و عموم الآيـة يتناول

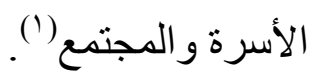
وقد ورد في السنه المباركة مـا يؤكد حق الزوجـة في المشـورة وإبـاء الر أي، و الأخذ بر أيها ومشورتها في ذلك إذا اتضحت المصلحة، ففي يوم الحديبيـة لمـا فرغ رسـول الله صـلى الله عليـه وسـلم مـن قضـية كتـاب الصـلح قـال لأصــابه (قومـوا فانحروا ثم احلقو ا ) قالت أم سلمة: فو الله مـا قام رجل منهم حتى قـال ذلك ثـلاث مـرات، فاشتــ ذلك عليه، فـخل على أم سـلمة فقـال: (هلك المسـلمون أمـرتهم أن ينحروا ويحلقو ا فلم يفعلوا)فقالت أم سلمة: يـا رسول الله ( لا تلمهم فإنهم قد دخلهم أمر عظيم مما أدخلت على نفسك من المشقة في أمر الصلح ورجوعهم بغير فتح بـا نبي الله: أخرج ولا تكلم أحدا كلمة حتى تتحر بُدنك وتدعو حالقك فيحْلقك فجلي الله تعالى عن الناس بأم سلمة(؟). إن القوامة الناجحة هي التي تقوم على التفاهم الكامل، و التعاطف و التعاون بين الزوجين، و لابـــــــهـ الروح أن تسود وسط جـو الأسـرة، لأن مـن تبعـات القوامـة

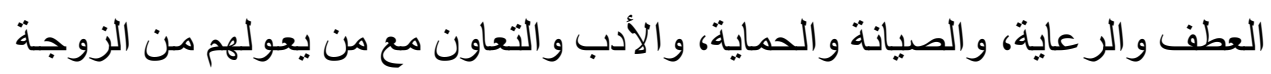
و الأو لاد، بـل إن النبي صلى الله عليه وسـلم جعل المقيـاس الصـحيح في الأفضلية و الخيرية لمن يبذل الخير للأخر ويمد لله اليد بالعطلاء، حيث يقول صلى الله عليه

$$
\text { وسلم : خيركم خيركم لأهله و أنا خيركم لأهلي (ॅ). }
$$

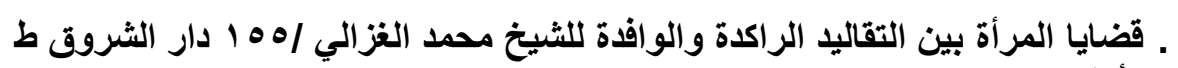

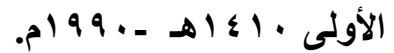

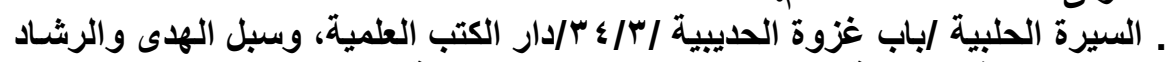
ه ه آه باب ذكر الهذنة وكيف جرى الصلح يوم الحديبية.

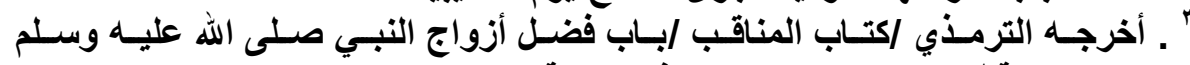
ا \%3\%" 


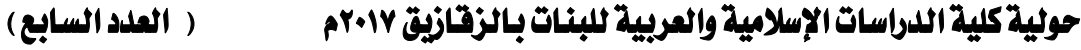

و أخرج الترمذي في سننه بسنده عن ابن مسعود رضـى الله عنهه عن النبي صلى

الله عليه وسلم قال: نفقة الرجل على أهله صدقة ('). ولقد جعل الإسلام رعاية الرجل لأو لاده والسعي على معاشهم لكفايتهم من السؤال تعدل الجهاد في سبيل الله تعالى. أخرج البيهقي في سننه عن ابن عمر رضى الله عنهما قال: مر بهم رجل فتعجبوا من خَلَقهِ فقالوا: لو كان هذا في سبيل الله، فأتوا النبي صلى الله عليه وسلم فقال: إن كان بسعى على أبويه شيخين كبيرين فهو في سبيل الله، وإن كان بسعى على ولد صغار فهو في سبيل الله، وإن كان يسعى على نفسه ليغنيها فهو في سبيل الله(؟). ولو نظرنا إلى بعض المجتمعات التي نادت بمناز عة المر أة للرجل في هذا الحق، ودعت إلى خروجها للعمل و التكسب من غير ضـرورة تلجؤهـا لذللك، و أنها متى أنتجت وتكسبت وكَفت نفسها فلا حاجة لها إلى قو امـة الرجل، لو نظرنـا إلى الأسر في هذه المجتمعات لوجدناها قد عتهـا الفوضسى، واختل توازنها حتى أصبحت مفككة مهلهلة بين زوج لا سلطان له على بيته، وزوجة يقودها الفضول و الهوى إلى متن الثطط و التمرد، و أبناء ضائعين بين أبوين متناز عين على أمر قضى الله بـه في

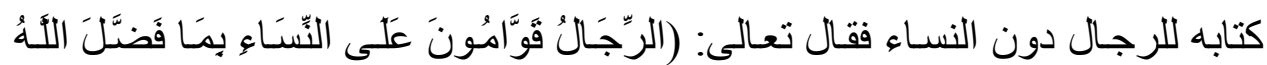

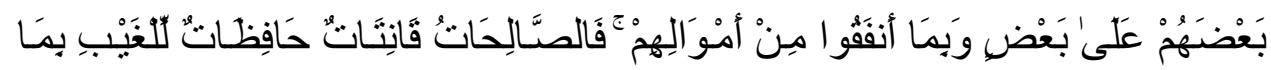
حَفِظ اللَّهُ)(َ). أما إذا كانت المر أة لا عائل لها يعولها ويقوم على مصالحها و أو لادها، فلا مانع أن تخرج لتعف نفسها عن المسألة وتقضى مصالحها وشئون أو لادها.

' . اخرجه الترمذي /كتاب البر والصلة /باب ما جاء في النفقة على الأهل /\&/ب ـ ب وقـال

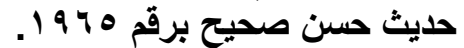

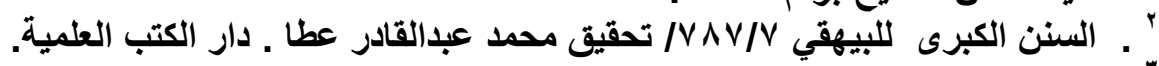

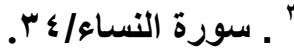




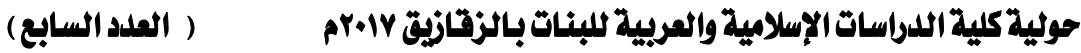

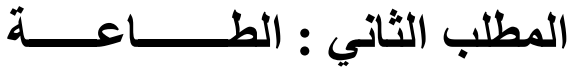

من الحقوق الو اجبة على المرأة لزوجها حق الطاعة بالمعروف ، وذلك في مقابل وفائه بحقها، و القيام بشؤنها، و الإنفاق عليها، وهذا الحق الذي أمر بـه الإسـلام يتمثل في السمع و الطاعة للزوج، واحتر ام رأيه، وتحقيق الحياة الهادئة الهانئة له و لأو لاده،

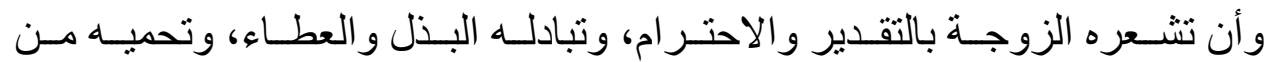
المنغصات و الأكدار، وحتى يجد الرجل في حياتـه الزوجيـة مـا ينشده من الراحة، ومـا يرجوه مـن الطمأنينـة والسـادة، فعلى الزوجـة أن تطيعـه فهي موضـع سكنه،

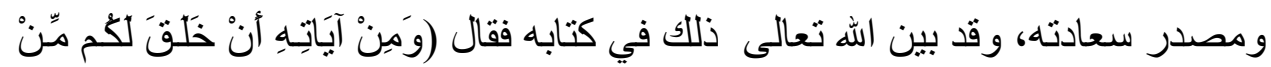

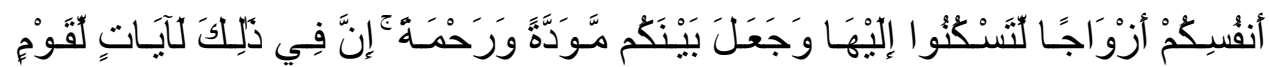

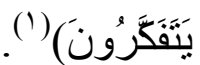

يقول الإمام الثوكاني رحمه الله تعالى في تفسير هذه الآية: ومن علاماته ودلالاته الدالة على البعث أن خلق لكم من أنفسكم أزواجـا أي: مـن جنسكم في البشـرية و الإنسانية، وقيل: المر اد حو اء فإنه خلقها من ضلع آدم (لتسكنوا إليها ) أي : لتألفو ها وتميلو إليها، فإن الجنسين المختلفين لا يسكن أحدهما إلى الآخر و لا يميل قلبه إليه

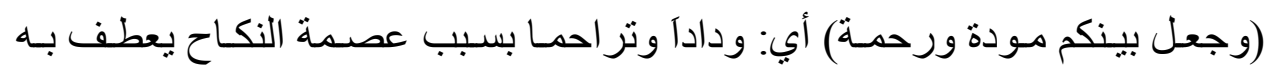
بعضكم على بعض من غير أن يكون بينكم قبل ذلك معرفة فضـلا عن مودة ورحمة.

قـال مجاهد: المـودة الجمـاع، و الرحمـة الولد، وبـهـ قـال الحسـن، وقال السـدى: المودة المحبة، والرحمة الثفقة، وقيل: المودة حب الرجل امرأته، والرحمة رحمته

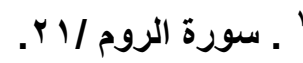

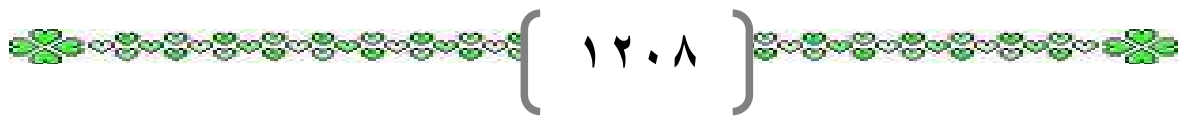




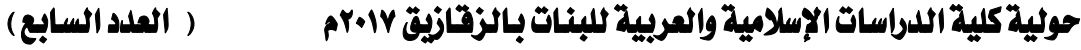

إياها من أن يصييها بسوء (إن في ذلك لآيات )عظيمة الثـأن بديعة البيان، و اضحة

الدلالة على قدرته سبحانه على البعث و النشور أ ــــ"( ). وحتى تتحقق السعادة الزوجية، ويحصل السكن النفسي و الجسدي، وتسرى المودة و الرحمة بين الزوجين لابد أن تكون الزوجة مطيعـة لزوجها في كل أمر ليس فيه معصية لله تعالى، وفى مقدور ها القيام بـه، مـع مر عاة ألا يكلفها الزوج فوق طاقتها

و لا يسبب لها حرجا لقوله صلى الله عليه وسلم : إنما الطاعة في المعروف(؟). و عن على ابن أبى طلحة عن ابن عباس في قوله تعالى(الرجال قو امون على النساء) يعنى أمر اء، عليها أن تطيعهـ فيمـا أمر هـا بـه من طاعته، وطاعتـه أن تكون محسنة لأهله حافظة لماله (") يقول ابن كثثر رحمه الله تعالى: إذا أطاعة المر أة زوجها في جميع مـا يريده منها مما أباحه الله له فلا سبيل لله عليها بعد ذلك(؛)، قال تعالى (فإن أطعنكم فلا تبتغوا عليهن سبيلا إن الله كان عليا كبير|('). إن طاعة المر أة لزوجها تشعره بمسؤوليته و مكانته وسط بيته و عياله، لأن القوامـة بيده وتصريف أمور البيت بأمره، وقد أكد النبي صلى الله عليه وسلم على حق طاعة المر أة لزوجها وتقديره و احتر امسه بقوله صـلى الله عليه وسلم لعمر رضـى الله عنهـ:

ـ فتح القدير للإمام الثوكاني /\&/بآץ/تحقيق عبدالرزاق المهلى / دار الكتاب العربي

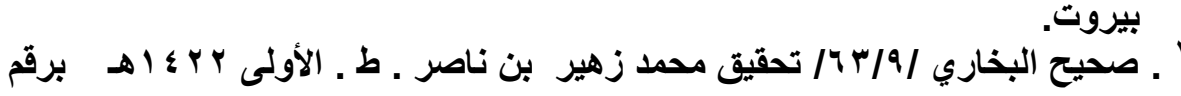




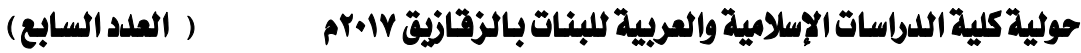

ألا أخبرك بخير مـا يكنزه المرء؟ المر أة الصـالحة إذا نظر إلبها سرنه، و إذا أمرهـا أطاعنه، و إذا غاب عنها حفظته('). وقد ورد ذلك فى حديث آخر بأسلوب يُشعر بالمهابة والتوقير و الاحتر ام للزوج . أخرج الحاكم في مستدركه بسنده عن قيس بن سعد رضى الله عنه أن رسول الله

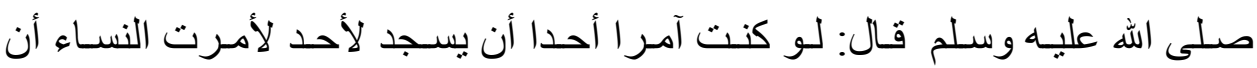
يسجدن لأزواجهن لما جعل الله لهم عليهن من حق(؟). و السجود الوارد في الحديث ليس سجود عبادة فذللك لله وحده لا يشركه فيه أحد، ولكنه التقدير و الاحتر ام، و الطاعة في المعروف، و الثـكر و العرفـان بالجميل لهذا الزوج الباذل والمجاهد الصابر. يقول الثـيخ عبد المتعـال الجبـري رحمـهـ الله تعـالى: إن طاعـة الزوجـة لزوجها مجلبة للهناء و الرضـا، و المخالفة تولد الثـناء و البغضـاء، وتفسد عو اطف الإخاء، وتنبت القسوة في قلوب الأبناء، وما من امر أة نبذت طاعة زوجها إلا حل بها الثقاء ولحقهـا الـبلاء، وكلمـا زادت طاعـة الزوجـة لزوجهـا إزداد الحـب و الـو لاء بينهمـا وتو ارثـه أبناؤ هما لأن الأخـلاق المألوفـة إذا تمكنت صسارت ملكات موروثه يأخذها البنون عن أبائهم و البنات عن أمهاتهم (َ).

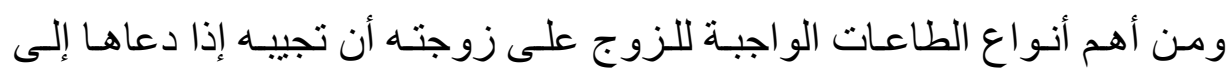
فر اشه ما لم تكن هنالك ضرورة شر عية تمنع من ذلك، فـإن امتنعت أوغرت صدره

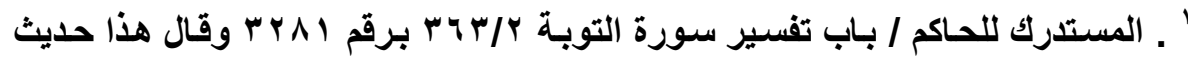
صحيح الإسناد ولم يخرجاء المباه.

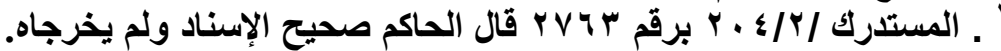

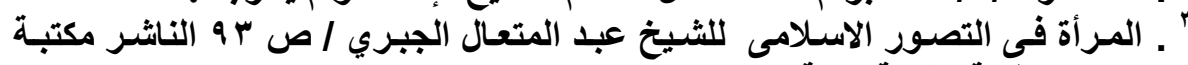

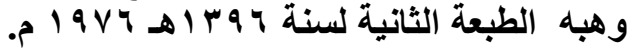

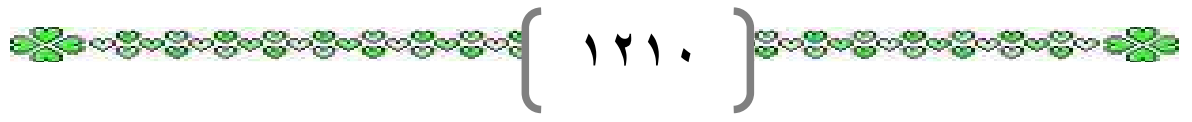




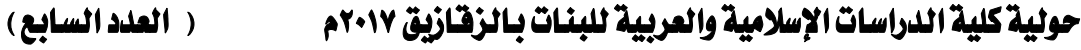

و عرضت نفسها لسخط الله تعالى قـال صلى الله عليه وسـلم: إذا دعـا الرجل امر أته

إلى فر اشها فأبت عليه لعنتها الملائكة حتى تصبح ('). فعلى المر أة الصالحة العاقلة أن تفي بحاجة الزوج من هذا الجانب حتى تعف نفسه

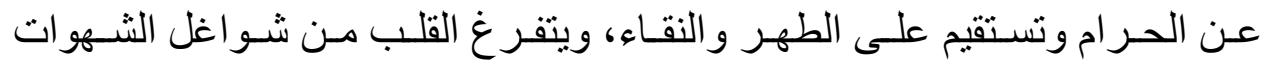
و الملذات لذكر الله تعالى و عبادته، ولتعلم المر أة أن هذه الطاعة لها عظيم الأثر في نفس الزوج فضلا عن الثواب العظيم الذي ينتظرها، و المكانة الرفيعة التى أعدها الله

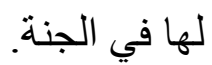
أخرج ابن ماجه في سننه بسنده عن أم سلمه رضي الله عنها قالت سمعت رسول الله صلى الله عليه وسلم يقول: أيما امر أة ماتت وزوجها عنها راض دخلت الجنة(؟).

\section{المطلب الثالث : القرار في البيث}

من الحقوق الزوجية التى أوجبها الإسـلام على الزوجة لزوجها قرارهـا فى بيت الزوجية وعدم الخروج منـه إلا بإذنه ورضـاه، قـال تعـالى: (وقرن في بيوتكن ولا تبرجن تبرج الجاهلية الأولى و أقـن الصـلاة و آتين الزكاة و أطعن الله ورسوله إنمـا يريد الله ليذهب عنكم الرجس أهل البيت ويطهركم تطهيرا)("). قال ابن كثير رحمـه الله تعـالى: هذه آداب أمر الله بها نسـاء النبي صـلى الله عليه وسلم ونساء الأمة تبع لهن في ذلك(ع).

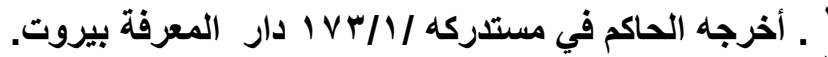

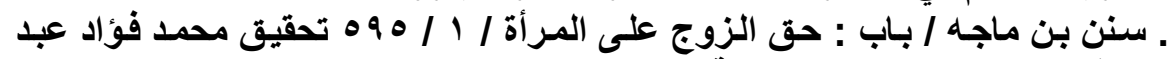

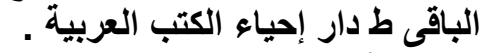

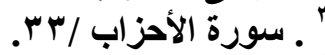

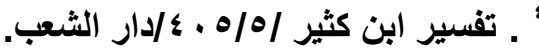


وقـال القرطبـي رحمـه الله تعـالى: معنى هذه الآيـة: الأمـر بلززوم البيـــ و إن كـان الخطاب لنساء النبي صلى الله عليه وسلم فقد دخل غير هن فيه بـالمعنى، هذا لو لم يـرد دليـل يخـص جميـع النسـاء، كيـــ و الثــريعة طافحــة بلـزوم النســاء بيـوتهن

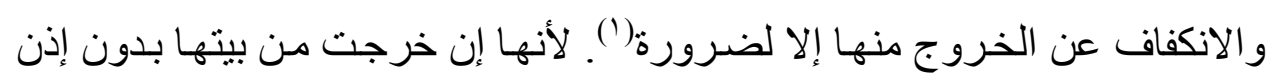
زوجها وبغير ضـرورة تقتضى ذلك، أو مبرر شرعي فـإن خروجها يكون مدعاة للفتنة ومجلبة للريّية و الثك و المخاوف و القلق، وتلك معاول الهدم للحيـاة الزوجيـة،

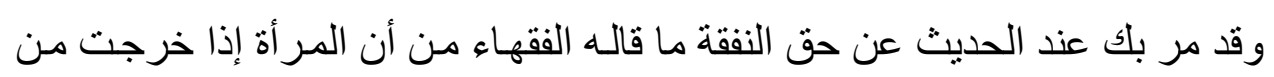
بيت زوجها متى وكيف شـاءت بدون إذن الزوج ورضـاه، أو امتنعت عن الانتقال الى مسكن الزوجية من غير عذر مقبول تكون بذلك ناشزا، و الناشز لا نفقة لها على

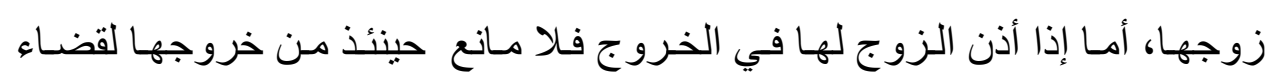
حوائجها، أو زيارة أرحامها، أو تحصيل علم يعود بـالنفع عليها و على أو لادهـا، وأن

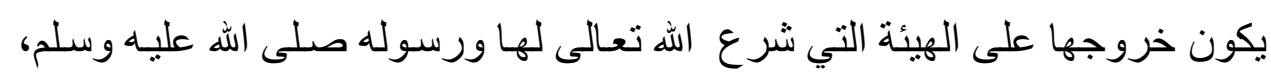
و إلا فقرار ها في بيتها واجب شرعي أمر الله تعالى به في كتابه. قال ابن كثثر رحمه الله تعالى في معنى الآية: الِزمن بيوتكن فلا تخرجن من غير حاجة) (r) (بن)

يقول الثـيخ أحمـد بـن عبدالعظيم المنصـور: إن وظيفـة المـر أة الكبرى ومهيتهـا

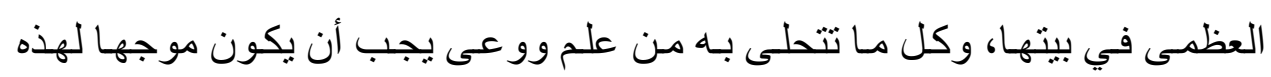

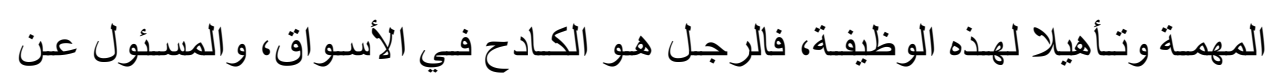

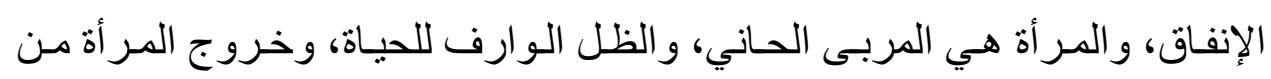

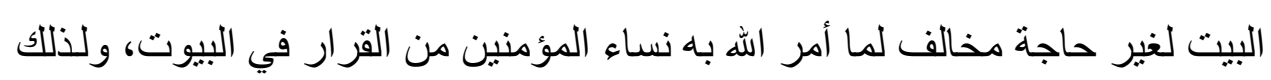

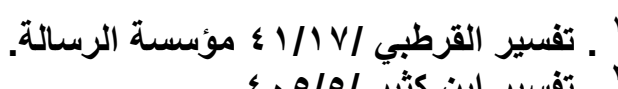

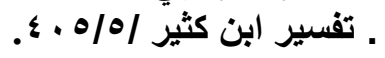

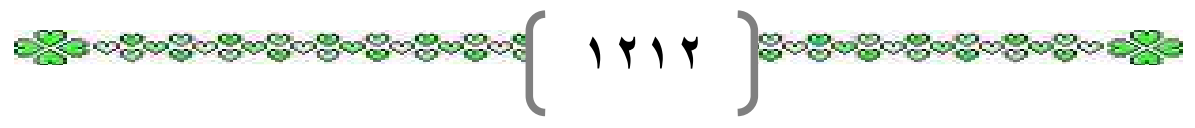




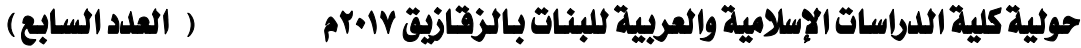

أسـقط الله عزوجـل عـن المـر أة صــلاة الجماعـة و الجمعـة والحـج مشـروط بوجـود المحرم، حتى أن النبـي صـلى الله عليه وسـلم أمـر نسـاءه بعد حجهن معـه بلـزوم بيوتهن، وعدم الذهاب للحج مرة أخرى مع ما في الحج وتكراره من الأجر العظيم

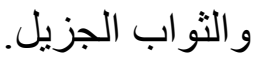

فعن ابن أبي و اقد الليثي عن أبيه رضى الله عنه قـال سمعت رسول الله صلى الله عليه وسلم يقول لأزواجه في حجة الوداع (هذه ثم ظهور الحصر)(')، قال ابن كثثر رحمه الله تعالى يعنى : ثم الزمن ظهور الحصر و لا تخرجن من البيوت(؟). فإن كان هذا النهـى مـن النبي صـلى الله عليهـ وسـلم من أجل الحج فمـا هو الحـال في خروج المر أة من بيتها للأسواق العامة والمتنزهات مع ما يصاحب ذلك من التهنك و إظهار الزينة المنهى عنها ومخالطة الرجال الأجانب فلا شك في تحريم ذلك وأن خروجها بهذه الصورة أعظم من خروجها للحج لا سيما وأن الله تعالى قال لهن (

$$
\text { وقرن في بيوتكن) أ.هـ (r). }
$$

قال الشيخ محمد الغز الي رحمه الله: إن كيان المر أة النفسي والجسدي قد خلقه الله على هيئة تخالف تكوين الرجل، فقد خلق الله جسم المر أة على نحو يتلاءم ووظيفة الأمومة تلاؤما كاملا، كما أن نفسيتها قد هيئت لتكون ربـة الأسرة وسيدة البيت، وبالجملة فإن أعضـاء المر أة الظـاهرة و الخفية، و عضـلاتها و عظامها، وكثير ا من وظائفها العضوية مختلفة إلى حد كبير عن مثيلاتها في الرجل وذللك لحكمـة، فهيكل الرجل قد بُنيَ ليخرج إلى ميدان العمل كادحأ مكافحا، أما المر أة فلها وظيفة عظمى

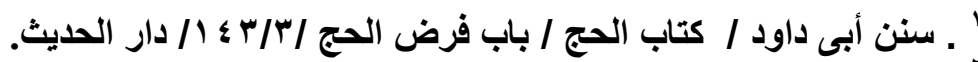

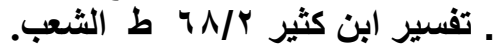

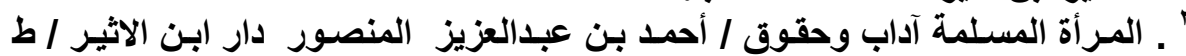

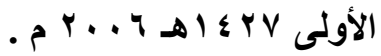

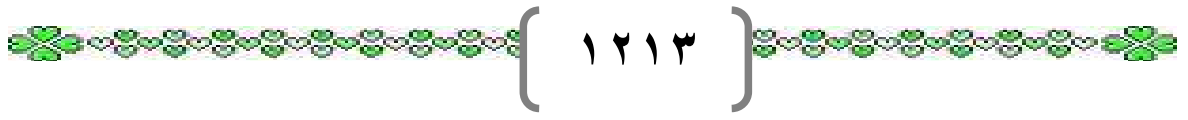




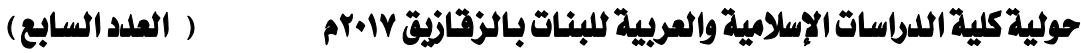

هي الحمل و الو لادة وتربيـة الأطفال، وتهيئة عش الزوجيـة ليسكن إليها الرجل بعد الكدح و الثنقاء (').

فعلى المر أة أن تصون نفسها وأن تحـافظ على بيتها، و عليها أن تعلم أن قر ارهـا في البيـت إذا مـا طلب منهـا ذلك واجب شـرعي وحـق مـن حقوق الزوج يجب

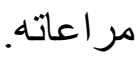

ويستحب للزوج أن يأذن لها بـالخروج إذا مرض أحد و الديها أومحار مها، أو في موت و احد منهم، لأن ذلك وسيلة لصلة الرحم.

يقول الإمام التنوخى طيب الله ثر اه: وله منعها من الخروج من منزلـه فـإن مرض بعض محارمها أو مـات استحب لـه أن يـأذن لها في الخروج إليهه لأن في منعها

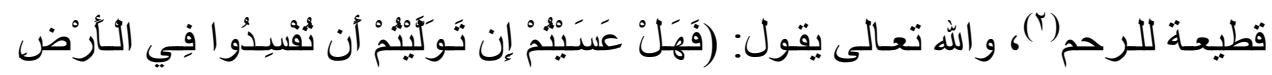

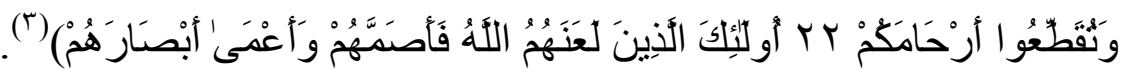
ويقول ابـن قدامـة رحمـه الله تعـالى: لا ينبخـي للـزوج منعهـا مـن عيـادة والـديها وزيارتهما لأن في ذلك قطيعة لهما، وحملا لزوجته على مخالفته، وقد أمر الله تعالى بالمعاثرة بالمعروف وليس هذا من المعاثرة بالمعروف. و أما خروجها إلى المساجد فقال القاضـي رحمـه الله : لـه منعها من الخروج إلى لى

المساجد وهو مذهب الشافعي(؟).

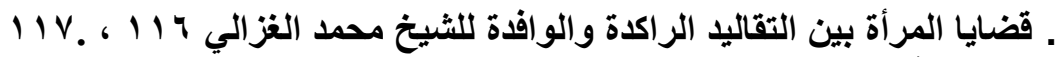

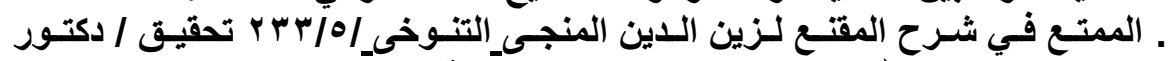

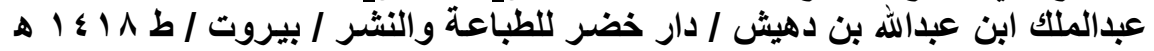

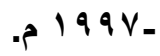

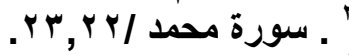

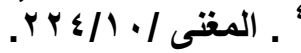




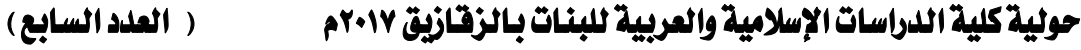

لكن ابن قدامه رحمه الله عقب على ذلك بقوله: وظـاهر الأحاديث ـ الواردة في جواز خروجها - يمنعه من منعها لقوله صلى الله عليه وسلم : (لا تمنعوا إمـاء الله مساجد الله)(').

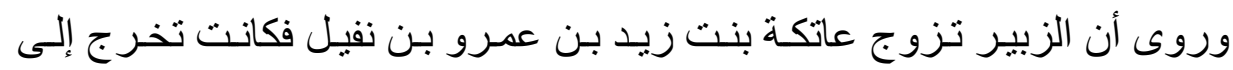
المساجد وكان غيور آفيقول لها: لو صليت في بيتلك فتقول لا أزال أخرج أو تمنعي فكره منعها لهذا الخبر (r). وفى خروجها لشهود الجمعة أخرج الإمام مسلم في صحيحه بسنده عن عمرة بنت عبدالرحمن عن أخت لعمرة قالت: أخذت (ق و القران المجيد) من فيّ رسول الله صلى الله عليه وسلم يوم الجمعة وهو يقر أ بها على المنبر في كل جمعة (َ). وهكذا كانـت المـر أة على عهد رسـول الله صـلى الله عليهه وسـلم تشـهـ الجمعـة و الجماعة، لكن هذا مشروط بأمن الطريق و عدم الفتنة، و التخلق بآداب الإسـلام عند الخروج، وذلك بـأن تخرج على الهيئة المطلوبـة شر عا من العفة و الحشمة، و عدم إبداء الزينـة ووضـع الطيب، لأن ذلك منهى عنه، و إلا فصـلاتها في بيتها خير لها و أفضل. أخرج ابن حبـان فى صحيحه عن أم حميد امر أة أبى حميد السـاعدي رضـى الله عنه أنها جاءت إلى النبي صلى الله عليه وسلم فقالت: يا رسول اله إنى أحب الصـلاة معك قال: قد علمت أنك تحبين الصلاة معي وصلاتلك في بيتك خير من صـلاتك في حجرتلك، وصلاتلك في حجرتلك خير من صلاتلك في دارك، وصلاتك في دارك خير

ـ رواه مسلم / كتاب الصلاة / باب خروج المرأة الى الصلاة إذا لم يترتب عليه فتنـة

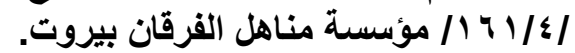

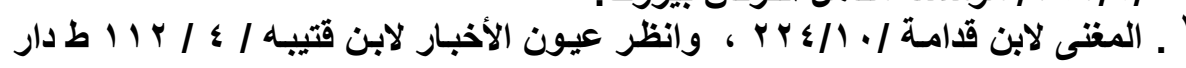

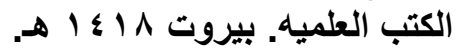

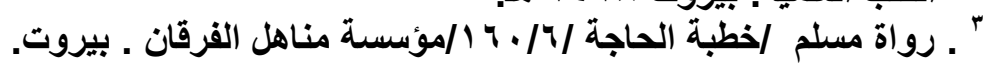

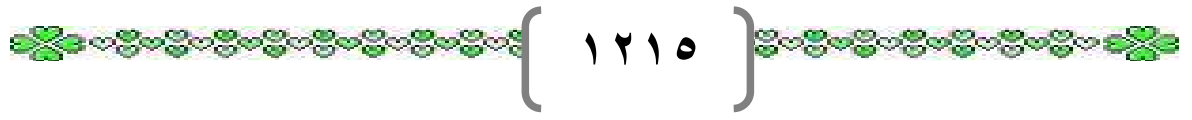


مـن صـلاتكك في مسـد قوملك، وصـلاتلك في مسـد قومـك خير مـن صـلاتلك في مسجدي هذا، قال: فأمرت فبنى لها مسجد في أقصى شيء من بيتهاو أظلمـه وكانت تصلى فيه حتى لقيت الله جلا و علا ('). هذا هو هدى الإسلام في إصلاح البيوت، واستقامة من فيها حيث أبـاح للمر أة أن تخرج إن دعتهـا الضـرورة للخروج، وأذن لهـا الزوج في ذلك، بشـرط أن يكون خروجها في عفة وحشمة، ملتزمة بأو امر ربها وأحكام دينها.

\section{المطلب الرابع: خدمة الزوجة لزوجها}

يقول ابن القيم رحمه الله تعالى : اختلف الفقهاء في ذلك فأوجب طائفة من السلف و الخلف خدمتها للزوج في مصالح البيت وممن قال بهذا أبو ثور و غيره. ومنعت طائفة وجوب خدمته عليها في شيء. و ومن ذهب إلى ذلك ماللك، و الثـافعي، و أبو

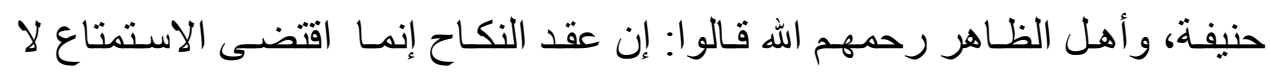

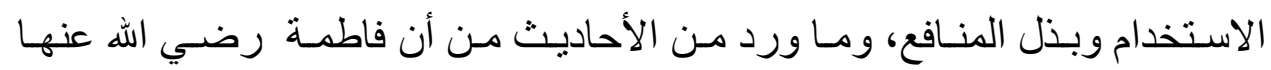
كانت تقوم بالخدمـة لزوجهاعلى رضي الله عنه، وأن أسماء رضـي الله عنها كانت تقوم بخدمـة الزبير ر رضـي الله عنه، إنمـا تـدل على التطوع ومكـارم الأخـلاق بين

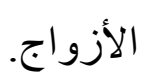

واحتج من أوجب الخدمـة بأن هذا هو المعروف عند من خاطبهم الله سبحانه

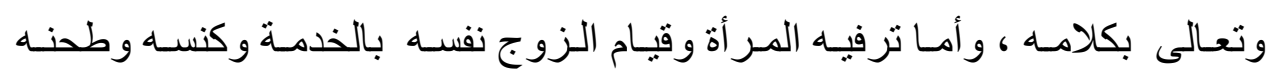
و عجنه وغسيله وفرشه وقيامـه بخدمـة البيت فمن المنكر والله تعالى يقول (ولهن مثل الذى عليهن بالمعروف) ويقول: ( الرجال قو امون على النسـاء) و إذا لم تخدمـه

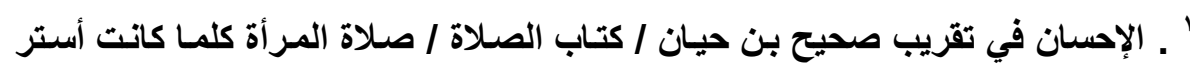

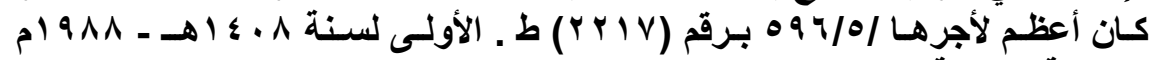
مؤسسة الرسالة ألمانة

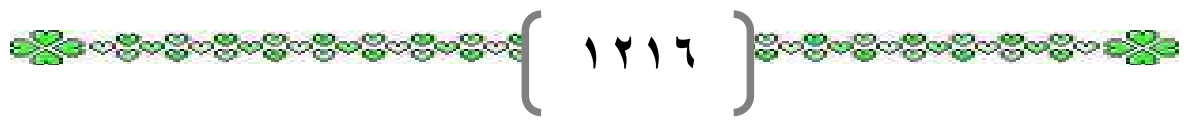


المـر أة ويكون هو الخـادم لها فهي القوامـة عليهه ، و أيضـا المهر في مقابلـة البضـع وكـلا مـن الـزوجين يقضـى وطـره مـن صـاحبه فإنمـا أوجـب الله سـبحانه نفقتهـا وكسوتها وسكنها في مقابل استمناعه بها وخدمتها له. واحتجو أيضا بأن العقود المطلقة إنما تنزل على العرف و العرف جـار على أن وهن خدمة المرأة لزوجها وقيامها بمصالح البيت الداخلية مما يجب عليها. مناقشة ادلة الفريق الثاني: أمـا احتجـاجهم بـأن مـا حـدث مـن فاطمـة و أسـماء رضـي الله عنهـــا كـان تبر عـا و إحسانا يرده أن فاطمـة رضـي الهه عنها كانت تشتكى مـا تلقى من الخدمـة فلم يقل صلى الله عليه وسلم لعلى رضـي الله عنـه لا خدمـة عليها و إنمـا الخدمـة عليك وهو صلى الله عليه وسـلم لا يحابى في الحكم أحدا. ولمـار أى أسـاء رضـي الله عنها و العلق على رأسها و الزبير معه لم يقل له لا خدمة عليهاو أن هذا ظلم لها بل أقرهـا على خدمتها لزوجها الزبير و أقر سائر الصحابة على جواز خدمة أزو اجهن لهم مـع علمه بأن منهن الكار هة و الر اضية ـ. و هذا أمر لاشك فيه و لا يصلح التفريق فيه بين

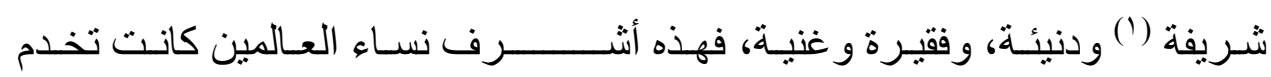

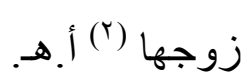

و الذي تطمئن إليه النفس في هذه المسألة: أن المرأة مطالبة بخدمة زوجهاو القيام بشئون بيته ما دامت قادرة على ذلك، وقد جرى بذلك العرف في كل العصور حيث كانت النساء تقمن بخدمة أزو اجهن دون أن يشعرن بغضاضة من ذلك. فهذه فاطمـة

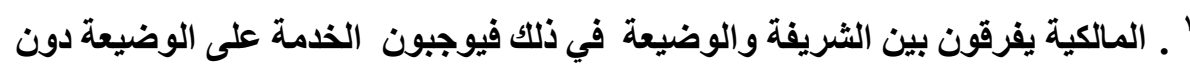

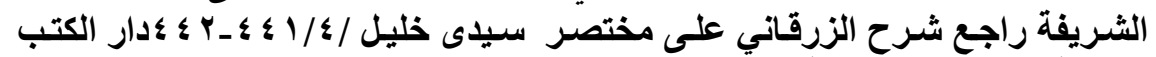

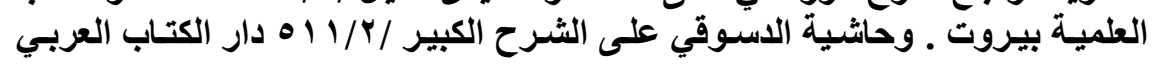

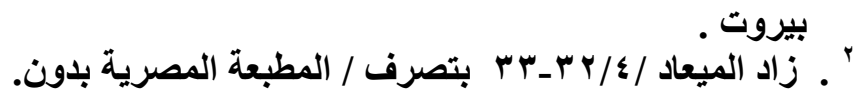

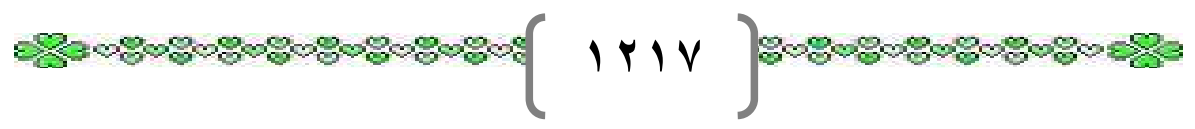


سبدة نسـاء العـالمين كانت تقوم بخدمـة زوجها وبيتها، و عندما أحست بثـيء من التعب بسبب ذلك، و أصاب يديها ما أصابها بسبب إدارة الرحى لم تطلب من زوجها

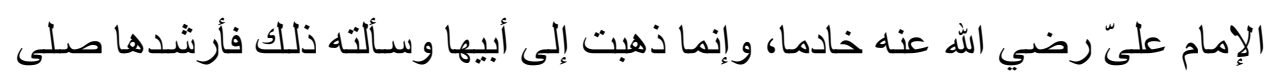
الله عليه وسلم إلى ما فيه خير من خادم. أخرج البخاري في صحيحه بسنده عن ابن أبى ليلى قال: حدثنا علىّ أن فاطمـة عليها السلام أتت النبي تشكو إلبه ما تلقى في يدها من الرحى وبلغها أنه جاءه رقيق لهن فلم تصادفه فذكرت ذلك لعائشة، فلما جـاء أخبرتـه عائشـة قـال: فجاءنـا وقد أخذنا مضاجعنا فذهبنا نقوم، فقال على مكانكما، فجاء فقعد بيني وبينها حتى وجدت برد

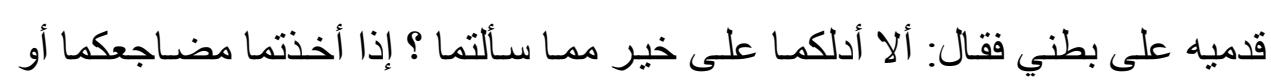
أتيتما إلى فر اشكما فسبحا ثناثا وثلاثين، واحمدا ثثلاثا وثلاثين، وكبر ا أربعا وثثلاثين

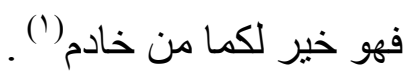
يقول ابـن قدامـة رحمـه الله تعـالى: فقضـى رسول الله صـلى الله عليه وسـلم على هـى فاطمة بخدمة البيت وأرشدها إلى ملازمة الذكر و الدعاء، وقضى على علىّ بمـا كان خارج البيت من عمل(r). و نقل ابن حجر عن الطبري قوله: يؤخذ من الحديث أن كل من كانت لها طاقة من النسـاء على خدمـة بيتهـا في خبز ، أو طحن، أوغير ذلك لا يلـزم الزوج إذا كـان

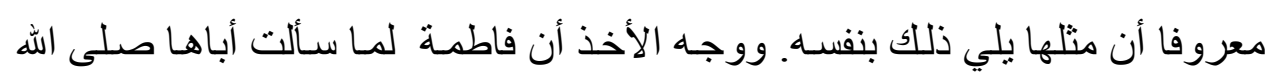
عليه وسلم الخادم لم يأمر زوجها بأن يكفيها ذللك إمـا بإخدامها خادما، أو باستنئجار

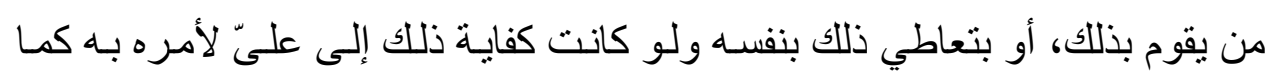

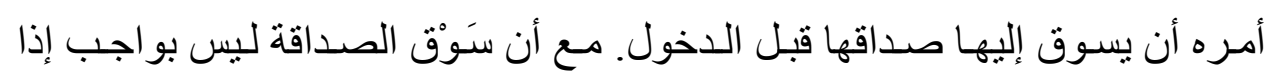

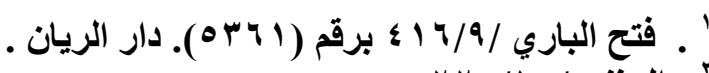

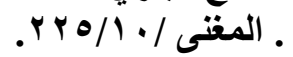


رضيت المـر أة أن تؤخره فكيف يـأمره بمـا ليس بو اجب عليـه ، ويترك أن يـأمره بالو اجب. وحكى ابن حبيب عن اصبغ وابن الماجشون عن مالك أن خدمـه البيت تلزم المرأة ولو كانت الزوجة ذات قدر وشرف إذا كان الزوج معسر اقلال : ولذلك ألزم النبي فاطمة بالخدمة الباطنة و عليّا بالخدمة الظاهرة أ.هـ ( '). وروى مسلم في صحيحه بسنده عن ابن أبي مليكة، أن أسماء، قالت: كنت أخدم

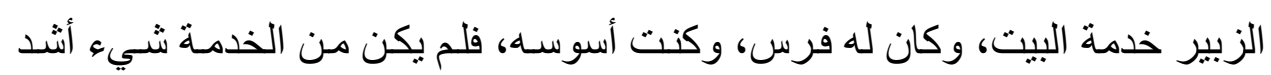
علي من سياسة الفرس، كنت أحتش لله وأقوم عليه و أسوسـه، قـا : ثم إنها أصـابت خادمـا جـاء النبي صلى الله عليه وسـلم سبي فأعطاهـا خادمـا، قالت : كفتني سياسـة الفرس، فألقت عني مؤونته... (r).

فبين الحديث أن أسماء بنت أبى بكر رضي الله عنها امر أة الزبير رضي الله عنه كانت تخدمه خدمة البيت وخدمـة الفرس، وكانت أشقها عليها خدمة الفرس فكانت تحمل النوى على رأسها ولم ينكر النبي على زوجها هذا مـع العلم بـأن النبي رآهـا و هى تحمل النوى و أناخ ناقته ليحملها خلفه إلا أنها استحيت من الرجال الذين كانوا معه وكان فيهم الزبير ـ وهؤلاء أمهات المؤمنين كن يخدمن النبي صلى الله عليه وسلم، ونساء الصحابة فعلن ذلك مع أزو اجهن ولم ينكر ذلك عليهم أحد.

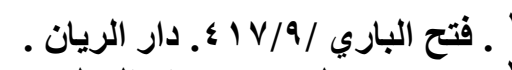

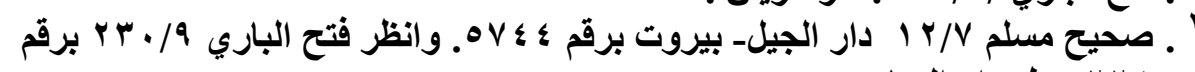
צ צro طـ دار الريان.

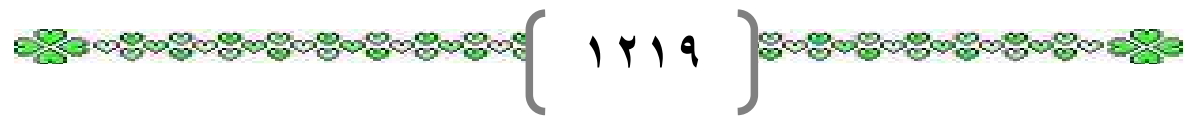




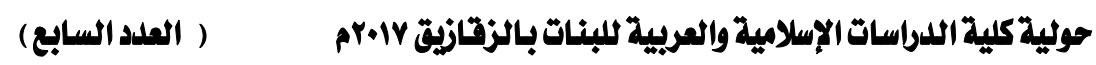

المطلب الخامس: الــطـلاق

تعريف الطلاق في اللغة:

الطلاق في اللغة هو: حلُّ الوثاق، مشتق من الإطلاق، وهو الإرسـال و الترك،

يقال طلق اليد، أي كثير البذل و العطاء(1).

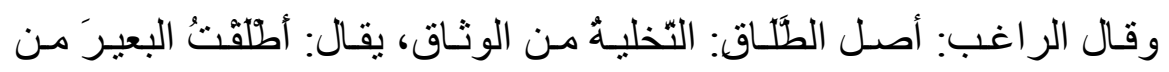

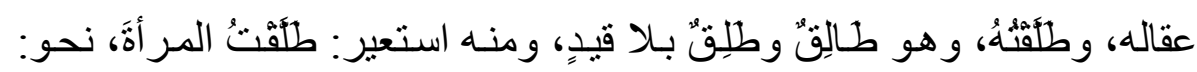

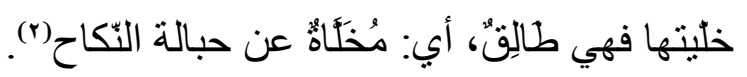

تعريف الطلاق في الاصطلاح:

عرَّف الفقهاء الطـلاق بتعريفـات متعددة، منهـا مـا عرَّفهـه ابـن قدامـة بقولـه:

$$
\text { الطلاق: حلُّ قيد النكاح(؟). }
$$

وعرفه الإمام القرطبي بقوله: حل عقدة النكاح()

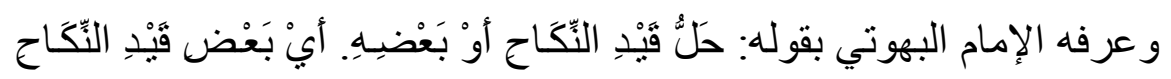

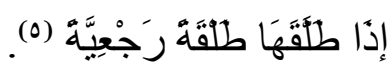

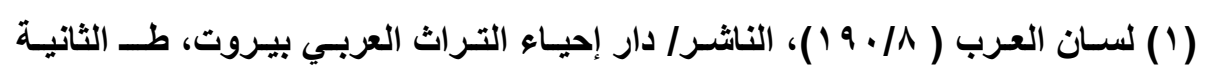

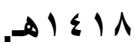

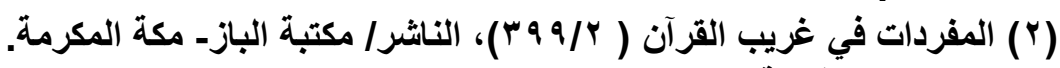

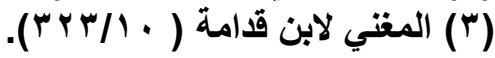

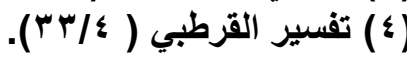

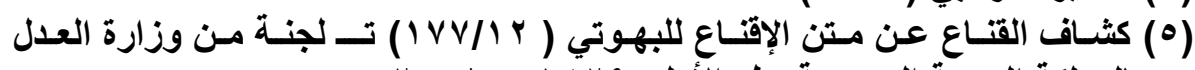

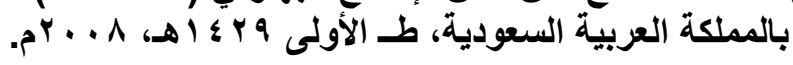


دليل مشروعيته من الكتاب والسنة والإجماع

أما دليل مشروعيته من الكتاب: فقد دل عليه من آيـات القرآن الكريم قولـه تعالى:

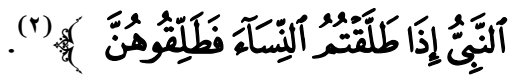 وأما دليل مشروعيته من السنة:}

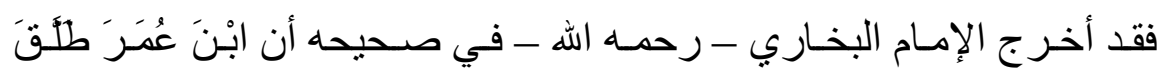

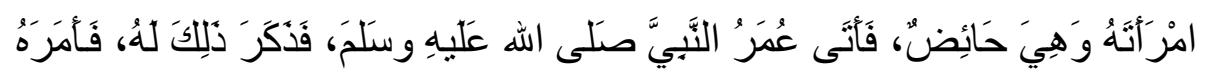

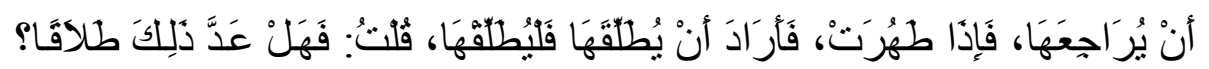

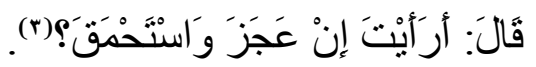

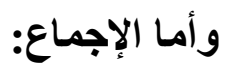
قال ابن قدامة: أجمع النـاس على جواز الطلاق، و العبرة دالة على جوازه،

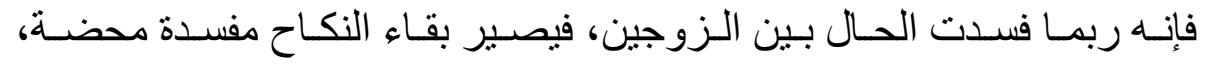
وضررا مجردا بإلزام الزوج النفقة والسكنى، وحبس المر أة، مع سوء العشرة، و الخصومة الدائمة من غير فائدة، فاقتضى ذلك شر ع مـا يزيل النكاح، لتزول المفسدة الحاصلة منه(؛).

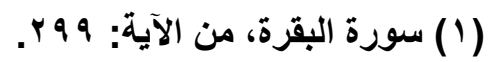

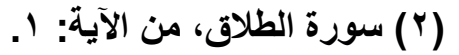

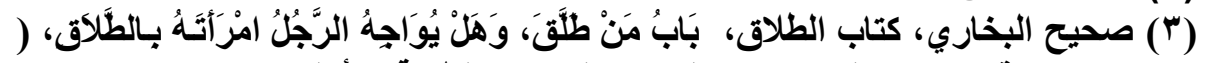

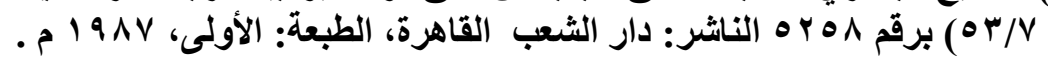

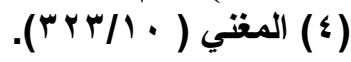

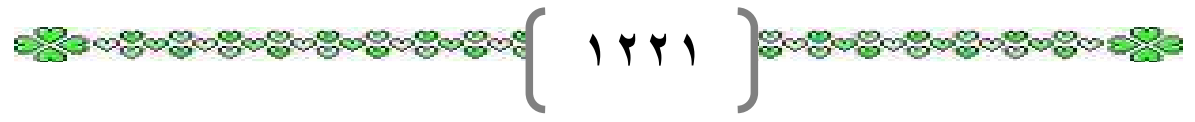




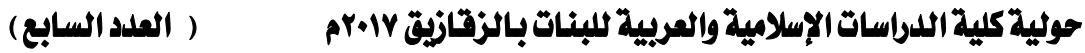

وقال العلامة البهوتي: وأجمعو ا على جوازه. (1) أي الطلاق.

\section{حكمه:}

و أمـا حكم الطـلاق فهو يختلف بـاختلاف الظروف و الأحـوال، فتارة يكون

مباحا، وتارة يكون واجبا، وتارة يكون مكروهـا، وتارة يكون مستحبا، وتارة

$$
\text { يكون حر اما. }
$$

فهذه أحكام خمسة تعتري الطلاق.

فيكون مباحا: إذا ترتب على استمرار الحياة الزوجية ضرر لأحد الزوجين

$$
\text { بسبب سوء العشرة و الخلق. }
$$

قال ابن قدامة: وهو مباح - أي الطلاق ـ عند الحاجة إليه لسوء خُلق المر أة،

$$
\text { وسوء عشرتها(r). }
$$

ويكون واجبا: وذللك في طلاق المُولى بعد التربص أربعة أشهر إن امتنع عن

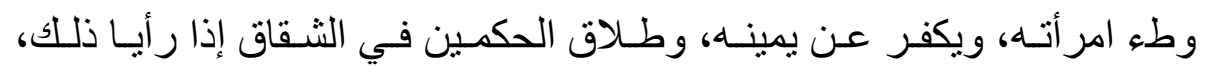
وطلاق المُلاعن، أو كان الرجل عنينـا ففي هذه الأحو ال يجب الطـلاق لرفع

$$
\text { الضرر عن الزوجة. }
$$

يقول ابن قدامـة رحمـه الله: الطلاق الواجب كطلاق المُولي بعد التربص إذا أبى الفيئة، وطلاق الحكمين في الثقاق، إذا رأيـا ذلك، وقال الإمـام أحمد: إذا كانت المر أة غير عفيفة لا ينبغي إمساكها، وذلك لأن فيه نقصـا لدينه، و لا يأمن من إفسادها لفر اشه، و إلحاقها به ولدا ليس هو منه (r).

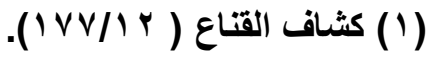

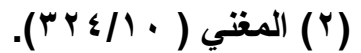

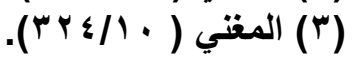




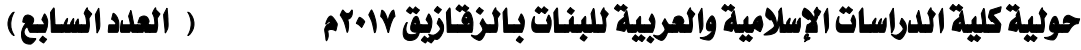

وقال شيخ الإسلام ابن تيمية: إذا كانت المر أة تزني لم يكن له أن يمسكها على

تللك الحال بل يفارقها و إلا كان ديوثا(1).

ويكون مكروها: إذا كان لغير حاجةو كانت أحوال الزوجين مستقيمة، و عند بعض الأئمة أن الطلاق يحرم في هذه الحال، و عند آخرين أنه مباح مع الكر اهة

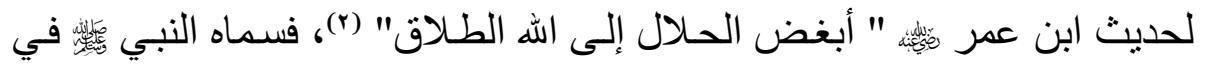
هذا الحديث حلالا مع كونه مبغضـا عند الله، فدل على كر اهيته في تلك الحسال مع إباحته، ووجه كر اهته أن فيه إز الة للنكاح المشتمل على المصـالح المطلوبـة

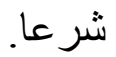

يقول ابـن قدامـة: الطـلاق المكروه: هـو الطـلاق مـن غير حاجـة إليـهــوقـال القاضي: فيه روايتان؛ إحداهما: أنه محرم ؛ لأنه ضرر بنفسه وزوجتهه، و إعدام للمصـلحة الحاصـلة لهمـا مـن غيـر حاجـة إلبـه، فكـان حر امـا كـاتِلاف المـال، والثانية، أنه مباح ؛ لقول النبي و إنما يكون مبغضـا من غير حاجـة إليه، وقد سماه النبي صلـى الله عليه وسلم

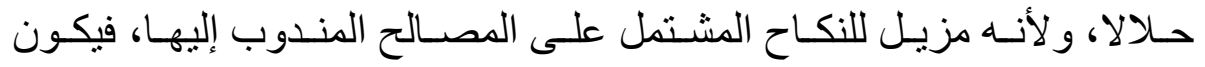

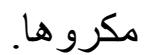

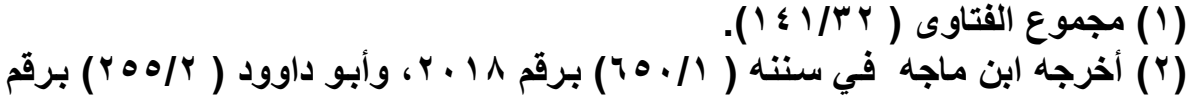

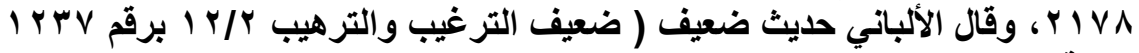

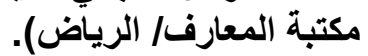

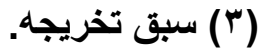

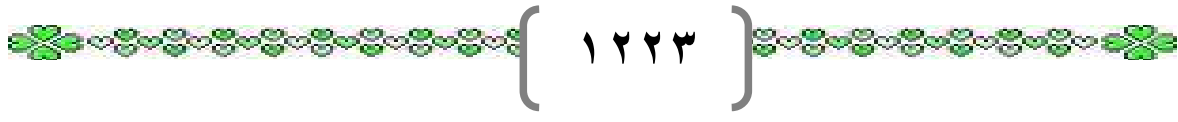


ويكون مستحبا: وذلك في حسال الحاجـة إليـه، بحيث يكون في بقـاء الحيـاة الزوجية ضرر على الزوجة كما في حال الثقاق بينها وبين الزوج، وفي حسال كر اهتها له، فإن في بقاء النكاح في هذه الحال ضررا على الزوجة و الرسول فئس يقول " لا ضرر ولا ضرار" (1). يقول ابن قدامة: ومن المندوب إليه الطلاق في حال الثقاق، وفي الحال التي تحوج المر أة إلى المخالعة لتزيل عنها الضرر (r). ويكون حراما: إذا كان الطلاق بدعيا، كأن بطلقها بلفظ الثناث دفعة واحدة،

$$
\text { أو في حيض، أو في طهر جامعها فيه. }
$$

قال ابن قدامة: و أما المحظور ، فالطلاق في الحيض، أو في طهر جامعها فيه،

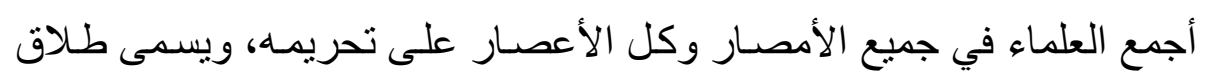

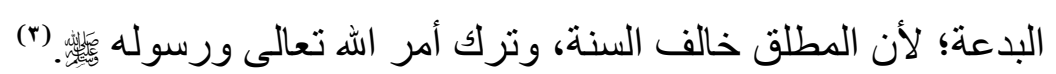
وممـا يجب التتبيـه إلبـه أن الأصـل في الطـلاق الإباحـة و الحل رحمـة مـن الله بعباده لحاجتهم إليه أحيانا. قـال القرطبـي رحمـه الله: دل الكتاب والسـنة و إجمـاع الأمـة على أن الطـلاق مباح غير محظور (₹)

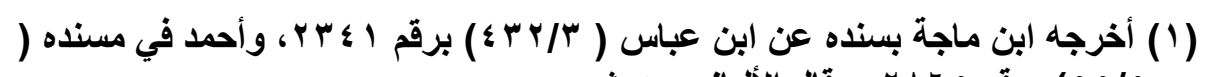

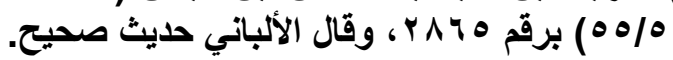

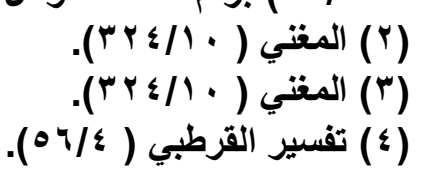

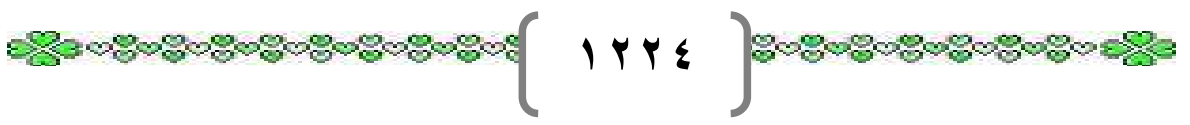


لكن الشرع حذر من الطلاق من غير أسباب داعية إلبه، لحديث " \}أبغض

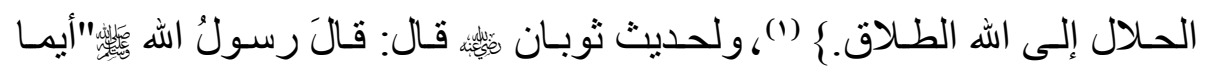
امر أةٍ سألتُ زوجَها طلاقَ في غير ما بأس، فحر امٌ عليها رائحةُ الجنةِ"(r). الحكمة من مشروعية الطلاق:

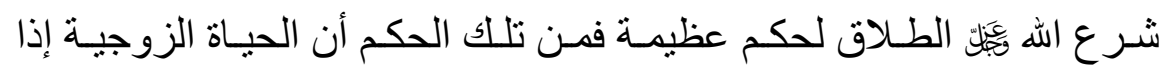
تعسرت بين الزوجين، واستحالة العشرة بينهمـا، وتلاشت المحبـة والألفة بين الزوجين وحل محلها الثقاق و البغضـاء و الكر اهيـة فمن غير المعقول أن يؤمر الزوجان بالبقاء معـا مـع وجود مـا يعكر صفو الحياة الزوجيـة، فمن رحمـة الله

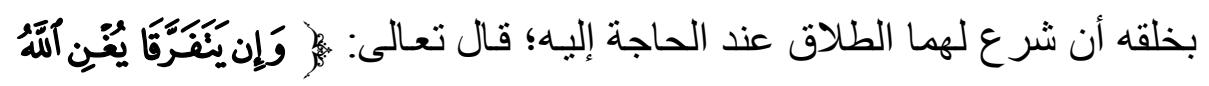

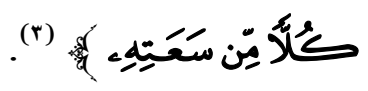

قال ابن قدامة: وأجمع الناس على جواز الطلاق، و العبرة دالة على جوازه،

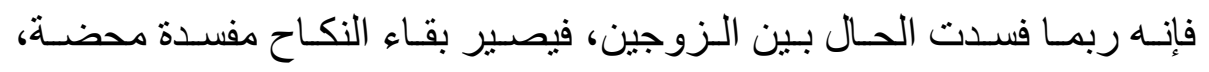
وضررا مجردا بإلز ام الزوج النفقة والسكنى، وحبس المر أة، مـع سوء العشرة، و الخصومة الدائمة من غير فائدة، فاقتضى ذلك شر ع مـا يزيلـ النكاح، لتزول المفسدة الحاصلة منهـ(₹).

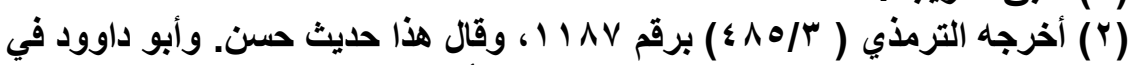

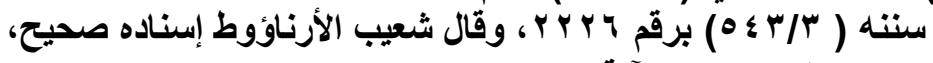

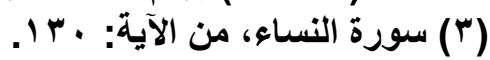

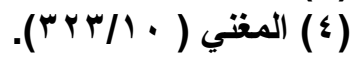




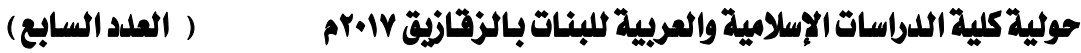

\section{أقسام الطلاق:}

قسم الققهاء الطلاق من حيثيات مختلفة إلى أقسام متعددة. أولا: أقسام الطلاق من حيث المشروعية: ينقسم الطلاق من حيث مشرو عيته إلى قسمين: القسم الأول: الطلاق السني: وهو الطلاق الواقع على الوجـه الذي نـدب إليهـ الشرع، وهو أن يطلق الرجل زوجته طلقة واحدة في طهر لـم يمسها فيه، ثم ير اجعها، ثم يطلقها، ثم بر اجعها، ثم إن شاء أمسك و إن شاء طلق. أي أن الطلاق السني يكون طلقة تعقبها رجعة، ثم طلقـة ثانيـة تعقبها رجعة، ثم بكون المطلق بعد ذلك بالخيار ، إن شاء أمسك بمعروف، أو فارق بإحسان. قال تعالى :

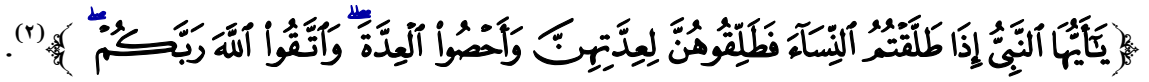

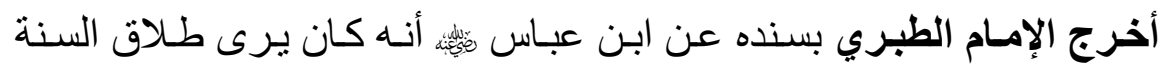
طاهر ا من غير جماع، وفي كل طهر، وهي العدة التي أمر الله بها(؟). وقال الإمـام القرطبي - رحمـه الله -: قـال ابن مسـود و ابن عباس ومجاهد و غير هم: المر اد بالآية التعريف بسنة الطلاق، أب من طلق اثتتين فليتق اله في

الثالثة، فإما تركها غير مظلومة شيئا من حقها، و إما أمسكها محسنا عشرتها.

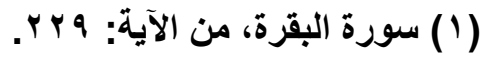

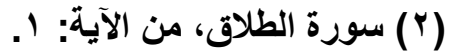

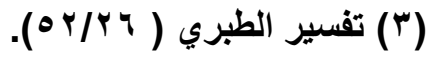


و أجمـع العلمـاء على أن من طلق امر أتـه طـاهر ا في طهر لـم يمسها فيـه أنـه مطلق للسنة، وللعدة التي أمر الله تعـالى بها، وأن لـه الرجعة إذا كانت مدخو لا

بها قبل أن تنقضي عدتها، فإذا انقضت فهو خاطب من الخطاب(1). ويقول ابن قدامة - رحمه الله -: معنى طلاق السنة الطلاق الذي و افق أمر الله تعالى و أمر رسوله صلى الله عليه وسـلم، وهو الطلاق في طهر لم يصبها فيه، ثم يتركها حتى تتقضـي عدتها و لا خـلاف في أنها إذا طلقها في طهر لـم لم يصبها فيه، ثم تركها حتى تنقضي عدتها، أنه مصيب للسنة(r). فطلاق السنة يتحقق بكونه طلقة واحدة في طهر لـم يصبها فيه، و الحكمـة في ذلك: أن المـر أة إذا طلقت وهـي حسائض تتضـرر بطـول العـدة، لأن بقيـة مـدة الحيض لا تحسب من العدة فتطول.

و إن طلقت في طهر مسها فيه فإنها لا تدري هل حملت أم لا؟ فلا تدري بم تعتد،

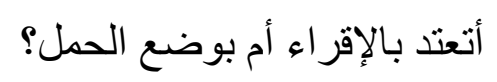

قال ابن قدامـة: إذا طلق في الحيض طوَّل العدة عليها ؛ فإن الحيضــة التي طلق فيها لا تحسب من عدتها، و لا الطهر الذي بعدها عند من يجعل الأقراء الحيض، و إذا طلق في طهر أصابها فيه، لم يأمن أن تكون حاملا، فيندم، وتكون بهن لهن مرتابة لا تدري أتعتد بالحمل أو الأقر اء ؟(r). ثانيا: الطلاق البدعي: - مان و هو الطلاق الو اقع على غير الوجه المشروع، كأن يطلقها ثلاثا بلفظو احد، أو متفرقات في مجلس واحد، و هذا النوع بدعي في عدد الطلقات.

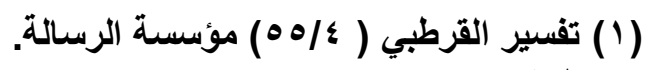

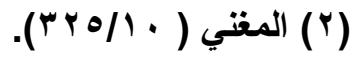

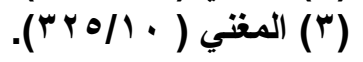


أو يطلقها في حيض أو نفاس، أو في طهر أصابها فيه، فهو بدعي في الوقت الذي أوقع فيه الطلاق،

قـال ابـن قدامـة: أجمـع العلمـاء في جميـع الأمصـار وكل الأعصـار على تحريمه، ويسمى طلاق البدعة؛ لأن المطلق خالف السنة، وترك أمر الله تعالى ورسوله

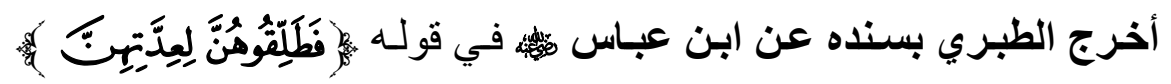
يقول: لا يطلقها و هي حائض، و لا في طهر قد جامعها فيه، ولكن يتركها حتى

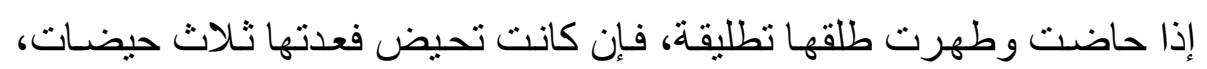

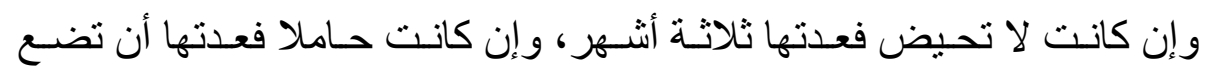
حملها.(r). وقال ابن قدامة: إنَّ جَمْع الثناث طلاق بدعة محرم. وهي روايـة عن الإمـام أحمد اختار ها أبو بكر، وأبو حفص. روي ذلك عن عمر، و علي، وابن مسعود، وابن عباس، و ابن عمر. وهو قول ماللك، وأبي حنيفة(؛). ويـرى جمهـور الفقهـاء أن طـلاق البدعـة يقع، لأنــه منـدرج تحــ الآيـات و الأحاديث العامة.

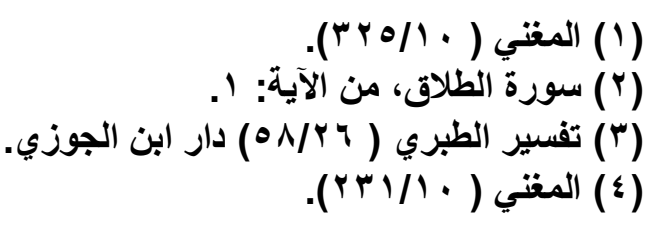

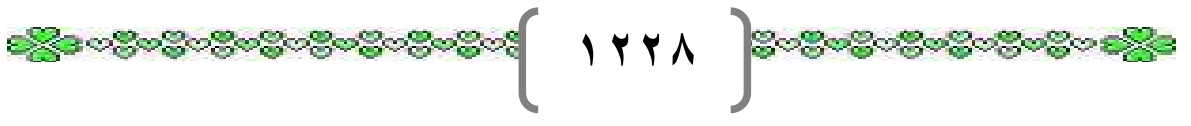


وذهب البعض الآخر إلى عدم وقو عه؛ لأنه واقع على غير الوجـه المشروع،

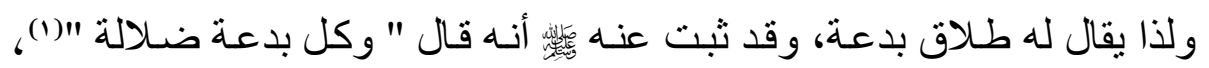

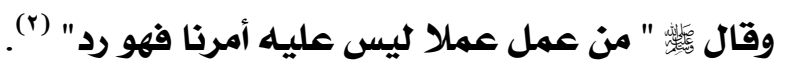
قال الإمام القرطبي: قال علماؤنا: واتفق أئمة القتوى على لزوم إيقاع الطـلاق الثلاث في كلمـة واحدة، وهو قول جمهور السلف، وشـ طـاوس وبعض أهل الظاهر إلى أن طلاق الثلاث في كلمة واحدة يقع واحدة، ويروى هذا عن محمد ابن إسحاق و الحجاج بن أرطاة. وقيل عنهما: لا يلزم منه شي، وهو قول مقاتل. ويحكى عن داود أنه قال لا يقع (r). وقال الإمام الثوكاني: وقد اختلف أهل العلم في إرسـال الثناث دفعـة واحدة: هل يقع ثلاثا، أو واحدة فقط. فذهب إلى الأول الجمهور، وذهب إلى الثاني هن

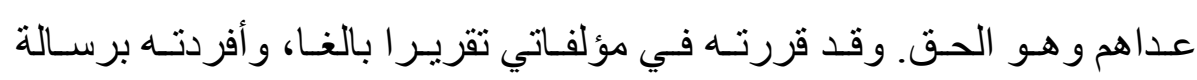
مستقلة:(\&) م

ولشيخ الإسلام ابن تيمية كلام طيب نفيس في هذه المسألة لا ماتع من ذكره للفائدة حيث يقول رحمه الله: و إن طلقها في الحيض أو طلقها بعد أن وطئها وقبـ أن يتبين حملها: فهذا الطلاق محرم ويسمى " طلاق البدعة " وهو حر ام بالكتاب و السنـة والإجمـاع.

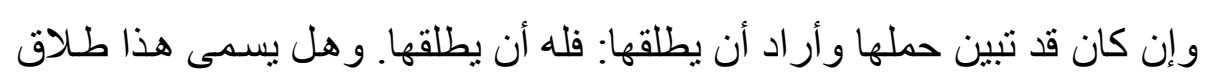

(1) أخرجه الإمام مسلم عن جابر بن عبد الله، كتاب الجمعة، باب تخفيف الصلاة

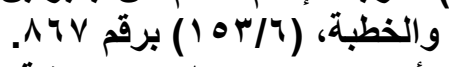

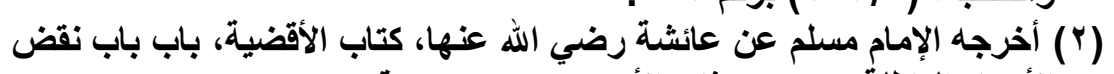

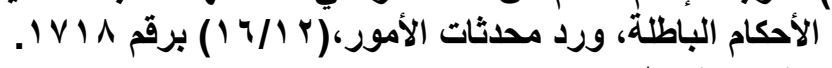

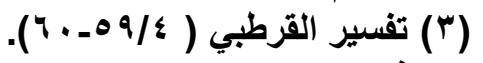

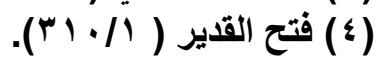


سنة؟ أو لا يسمى طلاق سنة ولا بدعة؟ فيه نز اع لفظي. وهذا " الطلاق المحرم " في الحيض وبعد الوطء وقبل تبين الحمل هل يقع؟ أو لا يقع؟ سواء كانت واحدة أو ثناثا؟ فيه قو لان معروفان للسلف و الخلف. و إن طلقها ثلاثا في طهر واحد بكلمة واحدة أو كلمات؛ مثل أن يقول: أنت طالق ثلاثا. أو أنت طالق وطالق وطسالق. أو أنت طسالق ثم طـالق ثم طسالق. أو يقول: أنت طالق ثم يقول: أنت طالق ثم يقول: أنت طالق. أو يقول: أنت طالق ثناثا. أو عشر طلقات أو مائة طلقة أو ألف طلقة ونحو ذلك من العبار ات: فهذا للعلماء من السلف و الخلف فيه ثناثة أقو ال سواء كانت مدخو لا بها أو غير مدخول بها. ومن السـف مـن فرق بين المدخول بها و غير المدخول بها. وفيـه قول رابع

$$
\text { محدث مبتدع. }
$$

أحدها: أنه طلاق مباح لازم وهو قول الثافعي وأحمد في الروايـة القديمـة عنه:

$$
\text { اختار ها الخرقي. }
$$

الثاني: أنـه طلاق محرم لازم وهو قول مالك وأبي حنيفة وأحمد في الروايـة المتأخرة عنه. اختار ها أكثر أصحابه وهذا القول منقول عن كثير من السلف:

$$
\text { من الصحابة والتابعين. و الذي قبله منقول عن بعضهم. }
$$

الثالث: أنه محرم و لا بلزم منه إلا طلقة واحدة. و هذا القول منقول عن طائفة من

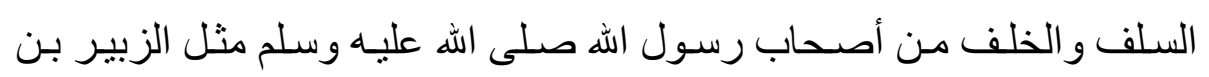
العوام و عبد الرحمن بـن عوف ويـروى عن علي وابن مسـود وابـن عبـاس القو لان؛ وهو قول كثير من التابعين ومن بعدهم: مثنل طساووس وخـلاس بـن عمرو؛ ومحمد بن إسحاق؛ وهو قول داود و أكثر أصحابه؛ ويروى ذلك عن أبي جعفر محمد بن علي بن الحسين وابنه جعفر بن محمد ولهذا ذهب إلى ذلك من ذهب من الثيعة وهو قول بعض أصحاب أبي حنيفة ومالك و أحمد بن حنبل. 
و أما القول الر ابع الذي قاله بعض المعتزلة و الثيعة: فلا يعرف عن أحد من السلف وهو أنه لا يلزمه شيء.

و القول الثالث هو الذي يدل عليه الكتاب و السنة؛ فإن كل طلاق شر عه اله في القرآن في المدخول بها إنما هو الطلاق الرجعي؛ لم يشرع اله لأحد أن يطلق الثلاث جميعا ولم يُشَرِّع لله أن يطلق المدخول بها طلاقا بائنسا ولكن إذا طلقها قبل الدخول بها بانت منه فإذا انقضت عدتها بانت منه(1). فالإمام ابن تيمية والإمام الثوكاني - رحمهما الله - يذهبان إلى أن من طلق امر أته ثناثا بلفظ و احد، أو في مجلس واحد لا يلزم منـه إلا طلقة و احدة، و هذا القول منقول عن طائفة من السلف، واستدلو ا بما أخرجه الإمام مسلم بسنده عن إلن

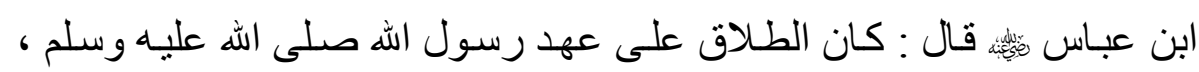
و أبي بكر، وسـنتين مـن خلافة عمر ، طـلاق الثلاث واحدة ، فقال عمر بـن الخطاب : إن الناس قد استعجلو ا في أمر قد كانت لهم فيه أنـاة ، فلو أمضيناه عليهم ، فأمضاه عليهم (r). وروى الإمام أحمد في مسنده بسنده عن عكرمةهولى ابن عباس ، عن ابن عباس، قال : طلق ركانة بن عبد يزيد أخو بني المطلب امر أته ثناثا في مجلس واحد ، فحزن عليها حزنا شديدا ، قال : فسأله رسول الله صلى الله عليه وسلم : كيف طلقتها ؟ قال : طلقتها ثلاثا ، قال : فقال : في مجلس واحد ؟ قال : نعم قال : فإنما تللك و احدة فأرجعها إن شئت قال : فرجعهامهامه :

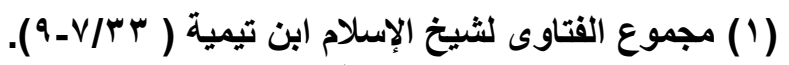

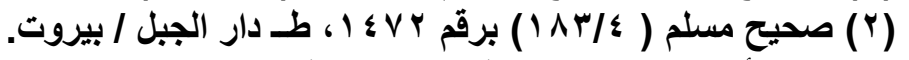

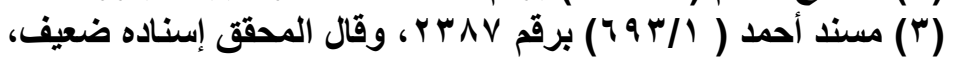


و هذا مـا أميل إليـه خاصـة عند عموم البلوى، وتفاديـا لتفكلك الأسـر وخراب

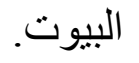

ثانيا: أقسام الطلاق من حيث بقاء عقد الزوجية وعدم بقائه. ينقسم الطلاق من حيث بقاء عقد الزوجية و عدم بقائه إلى قسمين: أولا: الطلاق الرجعي: وهو الطلاق الذي يملك المطلق فيه مراجعة زوجته إلى عصمته ما دامت في العدة، من طلقة أو طلقتين، من غير حاجة إلى عقد ومهر جديدين، سو اء رضيت الزوجة أم لا؛ لأنها زوجته ما دامت في العدة، وذلك إذا

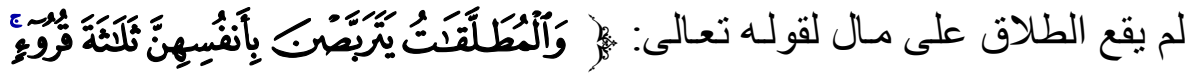

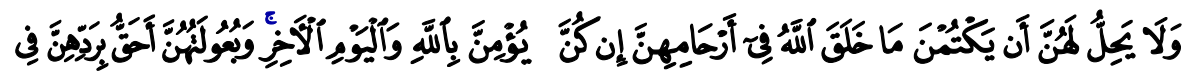

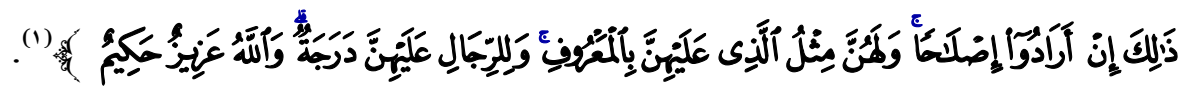

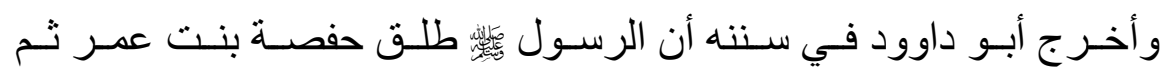

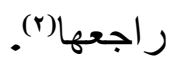

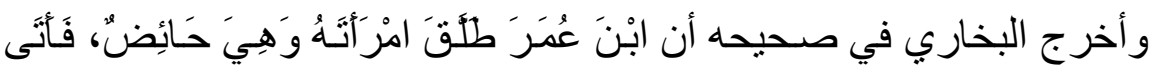

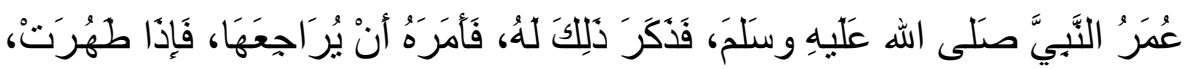

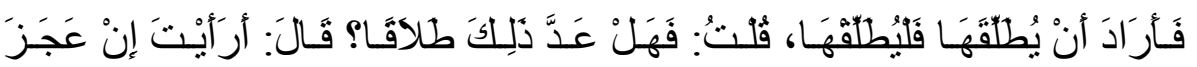

$$
\text { وَاسْتَحْمَقَبَ(r). }
$$

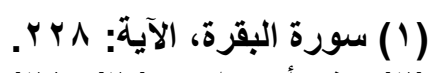

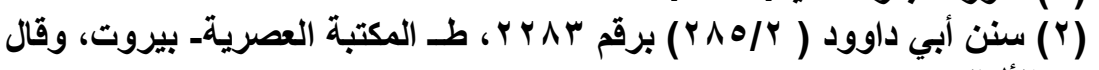
الألباني صحيح.

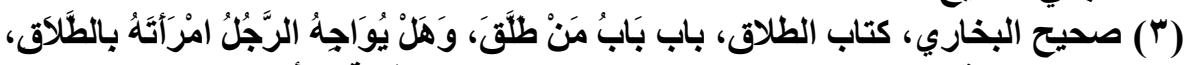

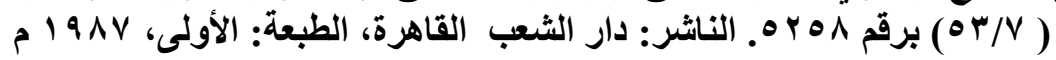


قـال الإمسام القرطبـي: أجمـع العلمـاء على أن الحر إذا طلاق زوجتـه الحرة،

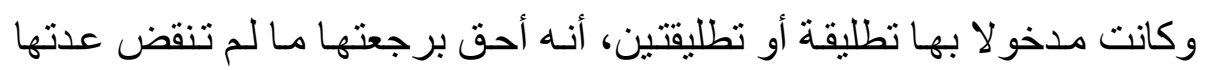

$$
\text { و وإن كر هت المر أة)(1) }
$$

الآثار المترتبة على الطلاق الرجعي:-

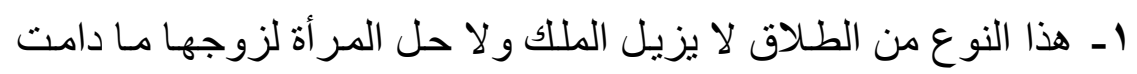

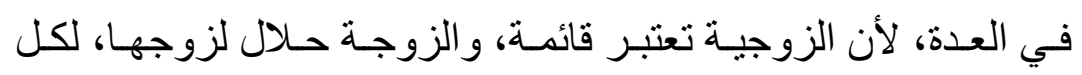
منهما كافة الحقوق، و هذا هو معنى الملك، فإذا انتهت العدة زال المِلك

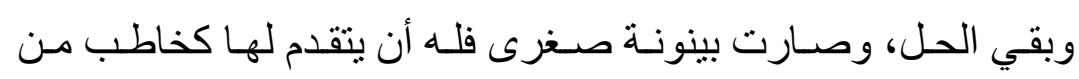
الخطاب، وله أن يعقد عليها برضاها. r ـ للزوج أن ير اجع زوجته في أنتـاء العدة في أي وقت شـاء مـع الإشههاد

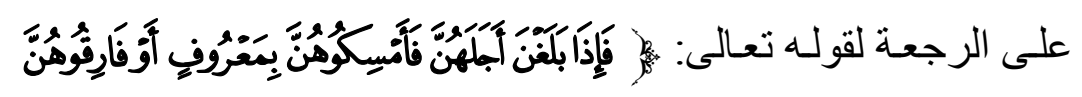

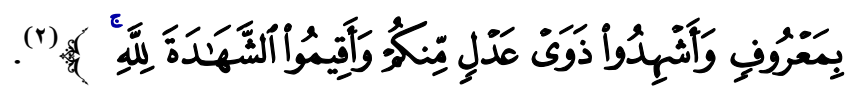

r- إذا مات أحدهما في أثناء العدة ورثه الآخر.

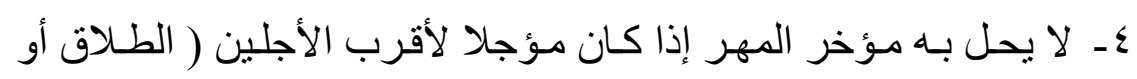

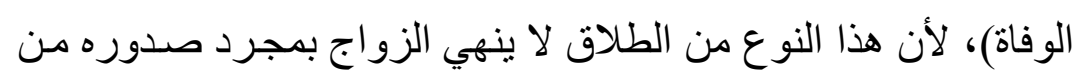
الزوج، بل بعد انتهاء العدة من غير مراجعة.

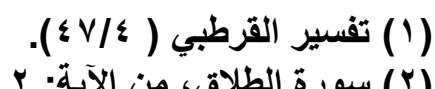

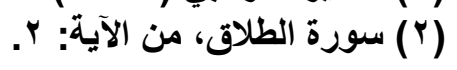




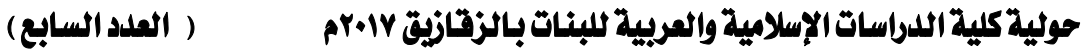

ثانيا: الطلاق البائن:- و هو الطلاق الذي لا يملك المطلق إعـادة زوجته إلى عصمته إلا بعقد ومهر جديدين، أو بعد نكاح زوج غيره. والطلاق البائن على ضربين:-

1 - بائن بينونة صغرى: وهو الذي يجوز فيه للمطلق إعادة مطلقته التي

انقضت عدتها من طلقة أو طلقتين برضاها بعقد ومهر جديدين.

قـال العلامـة القرطبـي- رحمـه الله-: فـإن لـم ير اجعها المطلاق حتى انقضـت عدتها فهـي أحـق بنفسـها وتصـير أجنبيـة منـه، لا تحلـ لـه إلا بخطبـة ونكـاح

مستأفف بولي و إثهاد، ليس على سنة المر اجعة، وهذا إجماع من العلماء(1) وهذا النوع من الطلاق له ثلاث صور:-

الصورة الأولى:- انتهاء العدة من طلاق رجعي، ففي هذه الحالة للمطلق أن يردها إليه بعقد ومهر جديدين إذا رضيت ذلك.

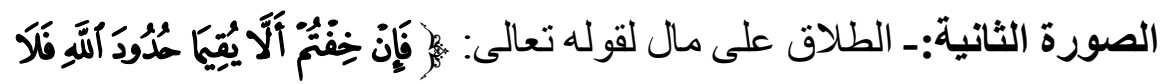

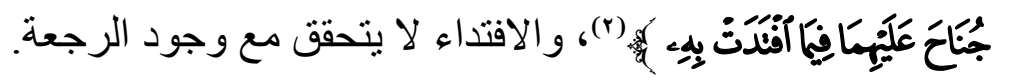

الصورة الثالثة:ـ الطلاق قبل الدخول، لأن الطلاق قبل الدخول يكون لغير

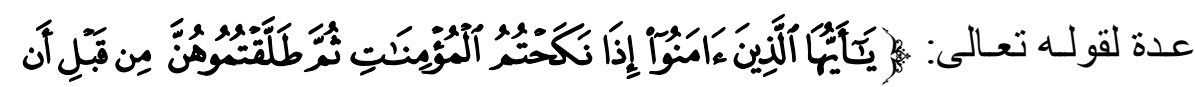

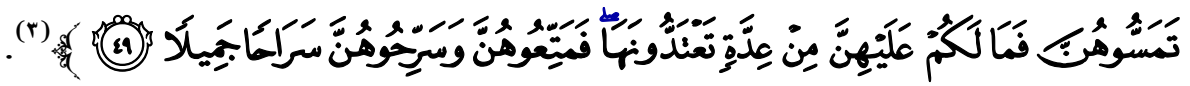

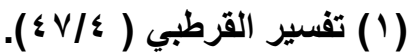

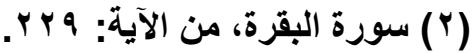

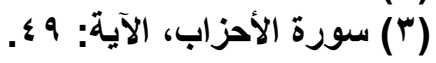


وثمرة الطلاق الرجعي تظهر في قدرة الزوج على المراجعة من غير عقد ومهر جديدين ما دامت العدة قائمة، وحيث انتفت العدة فليس ثََّّ طلاق رجعي. قال ابن قدامة رحمه الله:- أجمـع أهل العلم على أن غير المدخول بها ثَبين بطلقة واحدة و لا يستحق مطلقها رجعتها ؛ وذللك لأن الرجعة إنما تكون في العدة و لا عدة قبل الدخول ؛ لقول اله سبحانه:

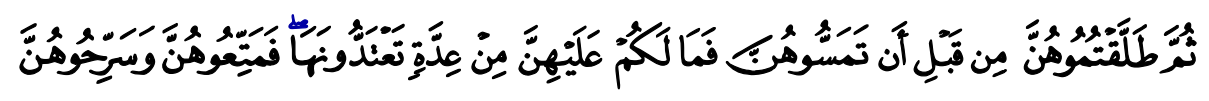

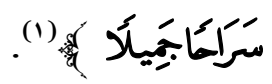
فبين الله سـبحانه أنـه لا عدة عليهـا فتَبين بمجرد طلاقهـا - بينونـة صـغرى وتصسير كالمدخول بهـا بعد انقضـاء عدتها لا رجعـة عليها ولا نفقـة لها، و إن رغب مطلقها فيها فهو خاطب مـن الخطـاب يتزوجها برضــاها بنكـاح جديــ وترجع إليه بطلقتين و إن طلقها اثنتين ثم تزوجها رجعت إليه بطلقة واحدة بغير خلاف بين أهل العلم)(r). بائن بينونة كبرى:- وهو الطلاق المكمل للثناث، فإذا طلق الرجل امرأته ثم راجعها، ثم طلقها الثانية ور اجعها، ثم طلقها الثالثة كان هذا الطلاق بائنا بينونة كبرى، لقولـه تعالى بعد ذكر الطلقتين اللتين فيهما الرجعـة: الطلقة الثالثة

$$
\begin{aligned}
& \text { (1) سورة الأحزاب، الآية: } 9 \text { ؛. }
\end{aligned}
$$

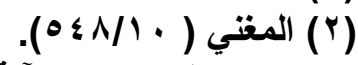

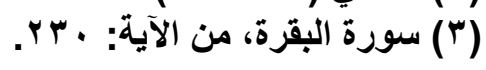

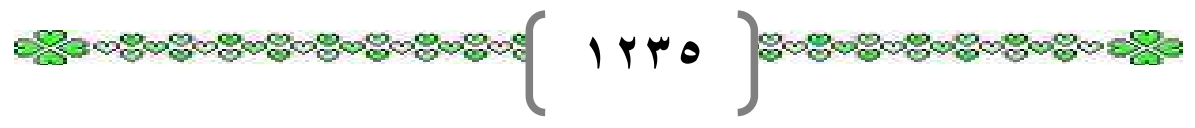


مزيلة للملك و الحل، فلا يملك الزوج مر اجعتها، و لا العقد عليها إلا بعد أن تنكح زوجا غيره نكاح رغبة لا نكاح تحليل، بمعنى أن يدخل بها الزوج دخو لا حقيقيا وتذق عسيلته ويذق عسيلتها، لحديث عائشة رضي الله عنها: أن رفاعة القرظي

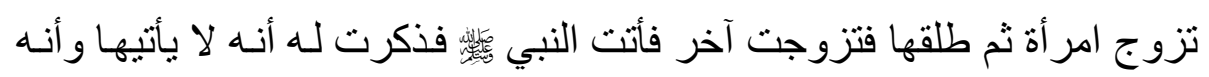
ليس معه إلا مثل هدبة(1) فقال ( لا حتى تذوقي عسيلته ويذوق عسيلتك ) (r). فإذا مـات عنها الزوج الثاني، أو فارقها مختار ا غير مكره فيجوز أن بنكحها الزوج الأول بعد انقضاء عدتها من الثاني بعقد ومهر جديدين. أخرج الإمـام الطبري في تفسبره بسـنده عن علي ابن أبي طلحسة عن ابن عباس نِيّن: في قوله ( فإن طلقها فلا تحل لله من بعد حتى تنكح زوجـا غيره) يقول: إن طلقها ثلاثا فلا تحل له حتى تنكح زوجا غيره(『). وقال الإمام الثوكاني -رحمه الله-: ذهب الجمهور من السلف والخلف: إلى أنه لا بد مع العقد من الوطء، لما ثبت عن النبي صلى الله عليه وسلم من اعتبـار ذلك، و هو زيادة يتعين قبولها، وقد خالفهم في ذلك سعيد بن المسيب ومن و اققه،

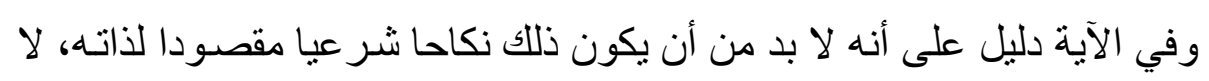
نكاحا غير مقصود لذاته، بل حيلة للتحليل، وذريعة إلى ردها إلى الزوج الأول،

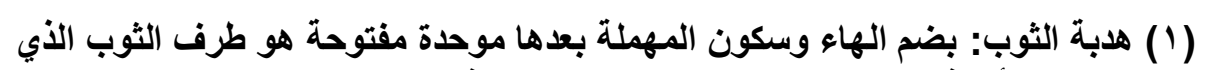

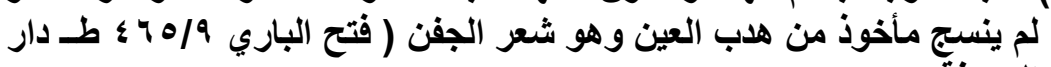
المعرفة- بيروت)

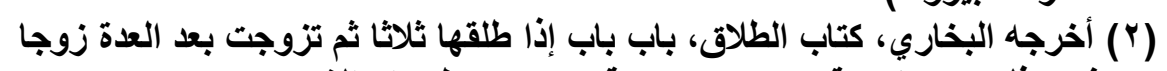

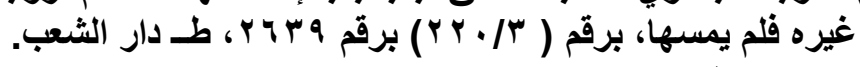

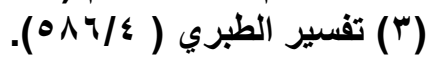

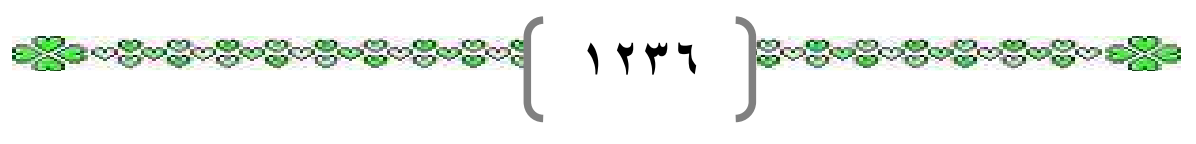


فإن ذللك حر ام للأدلة الواردة في ذمه وذم فاعله، و أنه التيس المستعار الذي لعنه الشار ع، ولعن من اتخذه لذلك(1).

وقال ابن قدامة رحمه الله: لا خلاف بينهم في أن المطلقة ثلاثنا بعد الدخول لا

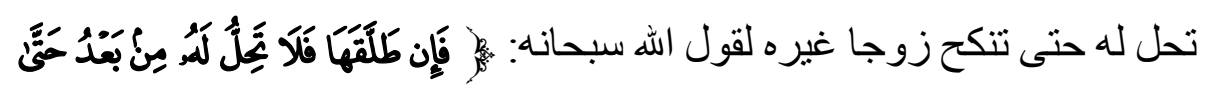

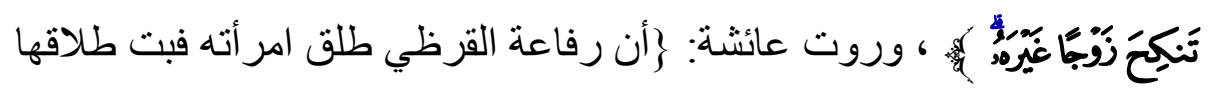
فتزوجت بعده عبد الرحمن بن الزبير فجاءت رسول الله عند رفاعة فطلقها آخر ثلاث تطليقات فنزوجت بعده بعبد الرحمن بن الزبير و إنه و الله مـا معه إلا منتل هذه الهدبـة، وأخذت بهدبـة من جلبابها قالت: فتبسم رسـول الله صـلى الله عليه وسـلم ضـاحكا وقـال: لعلك تريـدين أن نرجعي إلى هـ رفاعة ؟ لا حتى يذوق عسيلتك وتذوفي عسيلته هذا غنيـة عن الإطالة فيه، وجمهور أهل العلم على أنها لا تحل للأول حتى يطأها الزوج الثاني وطئًا يوجد فيه التقاء الختانين إلا أن سعيد بن المسيب من

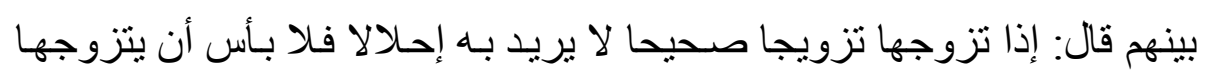

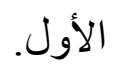

قال ابن المنذر: لا نعلم أحدا من أهل العلم قال بقول سعيد بن المسيب هذا إلا الخوارج أخذو ا بظاهر قوله سبحانه: \}حتى تنكح زوجا غيره؛ ومـع تصريح النبي صلى الله عليه وسلم ببيان المر اد من كتاب الله تعالى وأنها لا تحل للأول حتى يذوق الثاني عسيلتها وتذوق عسيلته لا يعرج على شيء سواه، و لا يسوغ

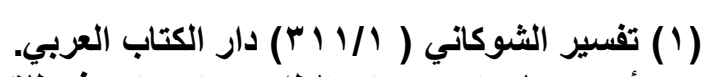

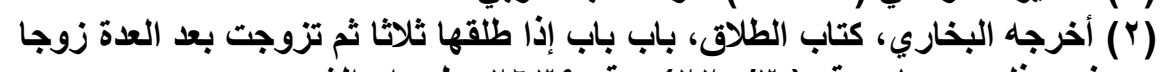

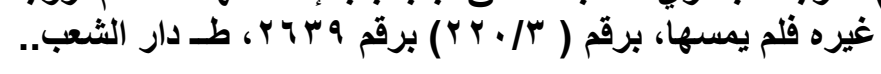


لأحد المصير إلى غيره مع ما عليه جملة أهل العلم ؛ منهم علي بن أبي طالب و ابن عمر وابن عباس وجابر و عائشـة رضـي الله عنهم وممن بعدهم مسروق

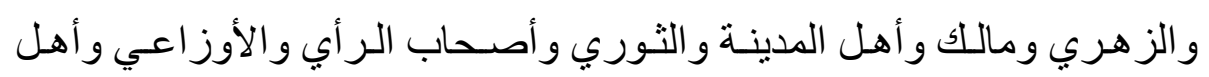
الثام و الشافعي و أبو عبيدة و غير هم(1). أقسام الطلاق من حيث اللفظ:بنقسم الطلاق من حيث اللفظ إلى قسمين: الأول:- صريح بألفاظ تدل عليه دون قر ائن تحتاج إلى نية الطلاق، لأنه لا ير اد بها غيره، وهي لفظ الطلاق وما تصرف عنه من فعل ماض ( كطلقتك)، و اسم الفاعل (كأنت طالق)، و اسم المفعول كأن يقول ( أنت مطلقة). الثاني:- كناية بألفاظ تدل على الكناية، و هي التي تحمل معنى الطلاق ومعنى غيره لا ينصرف إلى الطلاق، و لا يقع إلا إذا نواه الزوج، أو كانت هنـاك قرينـة تدل عليه، كأن يقول الرجل لأهلـه: أنـت خليـة، وبريـة، وأنـت بـائن، و الحقي بأهلك، أو فارقتلك، أو أنت مفارقة، أو سرحتلك، أو أنت مسرحة...

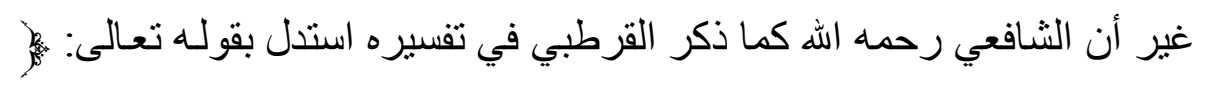

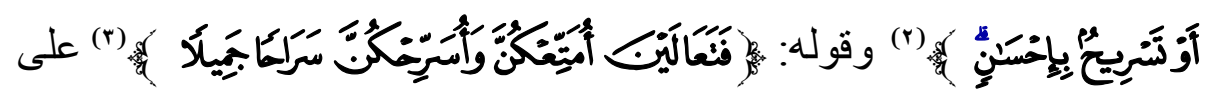
أن هذا اللفظ من صريح الطلاق(๕).

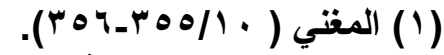

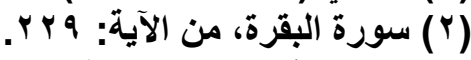

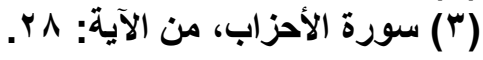

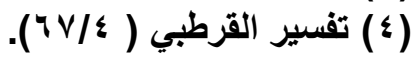


و الفرق بين الألفاظ الصريحة و ألفاظ الكناية في الطلاق: أن الألفاظ الصريحة

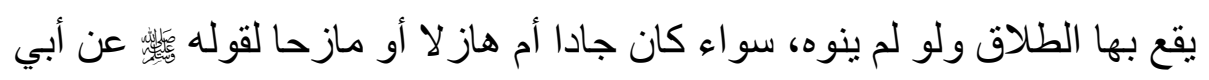

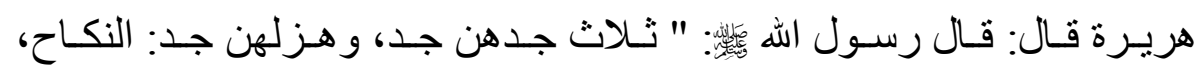

$$
\text { و الطلاق، و الرجعة"(1). }
$$

و أمـا الكنايـة فلا يقع بها طلاق إلا إذا نواه نيـة مقارنـة للفظه، لأن هذه الألفاظ تحتمل الطلاق و غيره من المعاني، فإذا لم ينو بها الطلاق لم يقع. قال الإمـام القرطبي: الطلاق على ضـربين: صـريح وكنايـة، فذهب القاضـي أبو محمد إلى أن الصريح ما تضمن لفظ الطلاق على أي وجـه، مثنل أن يقول:

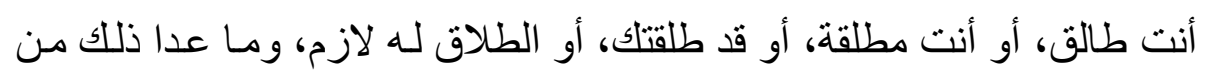
ألفاظ الطلاق مما يستعمل فيه فهو كناية، وبهذا قال أبو حنيفة. وقال القاضي أبو الحسن: صريح ألفاظ الطلاق كثيرة، وبعضها أبيَنْ من بعض: الطلاق و السراح و الفراق و الحر ام و الخلية والبرية. وقال الثافعي: الصريح ثلاثة ألفاظ، وهو مـا ورد بـه القرآن من لفظ الطلاق و السر اح و الفراق، قال الله تعـالى:" أو فارقوهن بمعروف " وقال:" أو تسريح بإحسان" وقال:" فطلقو هن لعدتهن". قلت: و الكلام مـا زال للإمـام القرطبي: والفرق بينهما أن الصريح لا بفتقر إلى بـ نية، بل بمجرد اللفظ يقع الطلاق، و الكناية تفتقر إلى نية(r).

ويقـول ابـن قدامـة طيب الله ثـراه: صـريح الطـلاق ثلاثـة ألفـاظ؛ الطـلاق، و الفراق، و السر اح، وما تصرف منهن. وهذا مذهب الثـافعي. وذهب أبو عبد

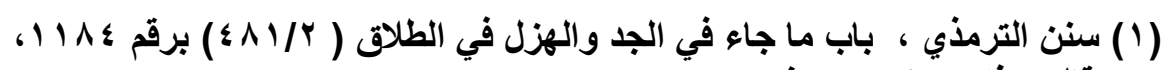
وقال: هذا حديث حسن غريب.

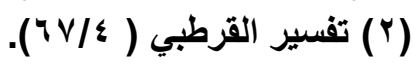

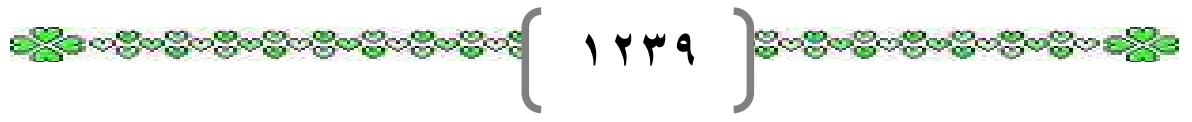


الله بن حامد، إلى أن صـريح الطـلاق لفظ الطلاق وحده، ومـا تصـرف منـه لا لا غير. وهو مذهب أبي حنيفة، وماللك، إلا أن مالكا يوقع الطلاق به بغير نية؛ لأن

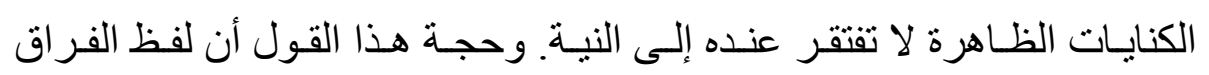
و السـر اح يستعملان في غير الطـلاق كثيـر ا، فلم يكونـا صـريحين فيـهـ كسـائر كناياته.

ووجه الأول أن هذه الألفاظ ورد بها الكتاب بمعنى الفرقة بين الزوجين، فكانـا صريحين فيه، كلفظ الطلاق، وقول ابن حامد أصح؛ فإن الصريح في الثيء مـا كان نصا فيه لا يحتمل غيره، إلا احتمالا بعيدا، ولفظة الفراق و السر اح إن وردا في القرآن بمعنى الفرقة بين الزوجين، فقد وردا لغير ذلك المعنى وفي العرف كثير ا فلا معنى لخصوصيته بفرقة الطلاق(1).

\section{الإشهاد على الطلاق والرجعة}

بقيت مسـألة جديرة بالاهتمـام طالمـا خـاض النـاس فيها قديما وحديثا، وهي

الإشهاد على الطلاق و الرجعة؛ و إلبك بيان هذه المسألة بتوفيق الله تعالى. اتفق الفقهاء على مشرو عية الإشهاد على الطلاق و على الرجعة منـه؛ لكنهم اختلفو ا في حكم هذه المشرو عية على قولين:

القول الأول: ذهب الحنفية، وهو المشهور من مذهب مالك و الثـافعية والحنابلة

$$
\text { إلى أن الإشهاد على الرجعة مندوب(r). }
$$

القول الثاني: ذهب ابن حزم، و الثيعة الإمامية أنها على الوجوب(†).

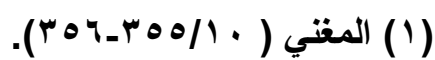

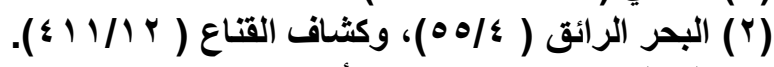

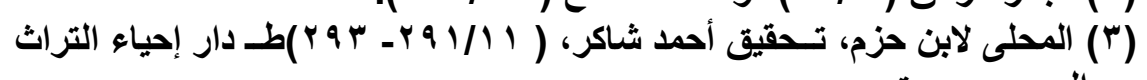

$$
\begin{aligned}
& \text { العربي- بيروت. }
\end{aligned}
$$


وثمرة هذا الخلاف مؤداه صحة الطلاق الذي لم يشهد عليه، ووقوعه عند من

$$
\text { قال بالندب في الإشهاد عند الطلاق و الرجعة. }
$$

و عدم وقوع الطلاق و الرجعة اللذين لم يُشهد عليهما، حيث إن الإشهاد عليهما

$$
\text { شرط لصحة وقو عهما عند من قال بوجوبه. }
$$

و هذا الخلاف بين الفقهاء و المفسرين راجع إلى اختلافهم في دلالـة الأمر في

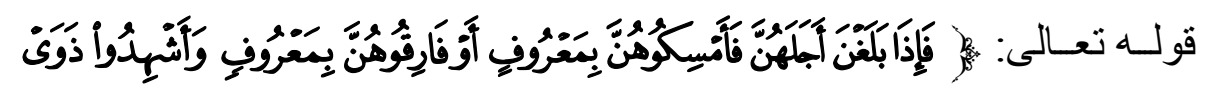

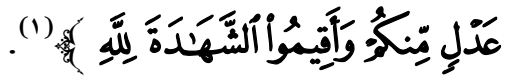

فمن رأى دلالة الأمر تقتضي الوجوب وأنه لا توجد قرينة تصرف الأمر عن ظاهره، قال بوجوب الإشهاد على الطلاق والرجعة، ومن ذهب إلى أن دلالة الأمـر صـرفت مـن الوجـوب إلى النـدب بقرائن قـال إن الإشـهاد على الطـلاق

$$
\text { و الرجعة مندوب مستحب لا واجب. }
$$

وبناء على ما سبق يمكن القول: اختلف العلماء في حكم الإشهاد على الطلاق

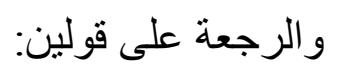

القول الأول: الإشـهاد على الطلاق و الرجعـة مستحب مندوب وليس بو اجب،

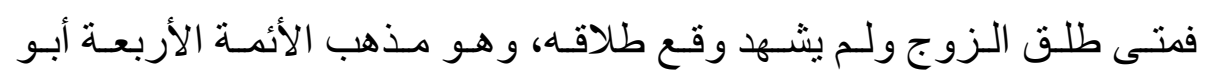

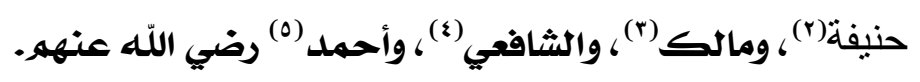

$$
\text { (1) (1) سورة الطلاق، من الآية: ب. ب. }
$$

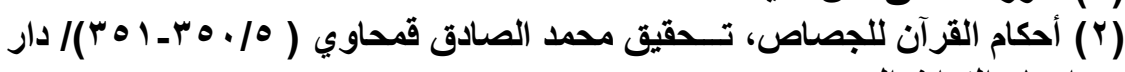

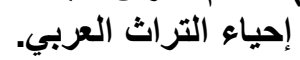

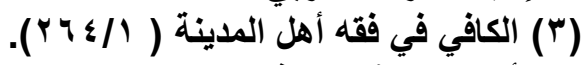

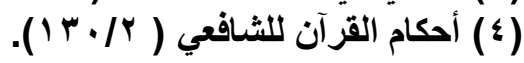

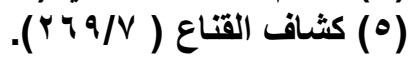




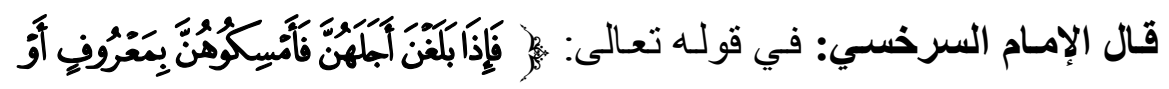

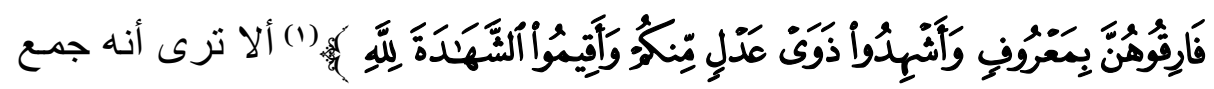
بين الرجعة والفُرقة وأمر بالإثـهاد عليهما ثم الإثـهاد على الفرقة مستحب لا لاحل

$$
\text { و اجب فكذللك على الرجعة(r). }
$$

و الإثهاد على الطلاق ليس بو اجب فرضا عند جمهور أهل العلم، ولكنه ندب

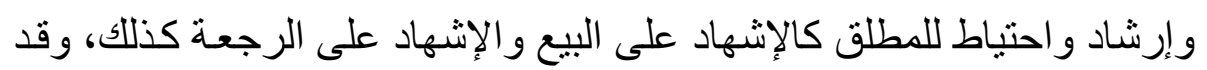

$$
\text { قيل الإثهاد على الرجعة أوكد (r). }
$$

يقول ابـن عاثـور: ومستتند هذا القول عـدم جريـان العـل بالتز امـه بين

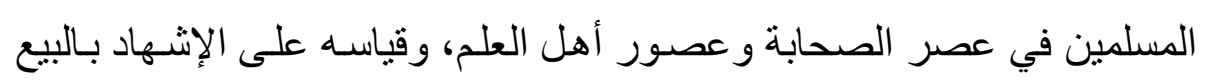

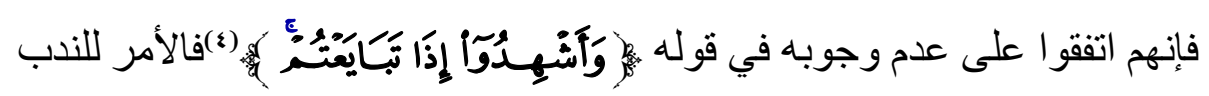
و الاستحباب، فكذلك الإشهاد على الطلاق(0). كما أن النصوص الواردة بإباحة الطلاق وردت مطلقة غير مقيدة بالإثهاد

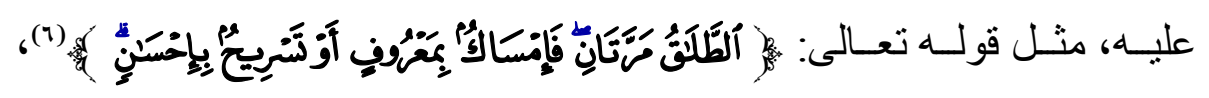

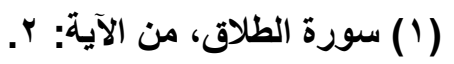

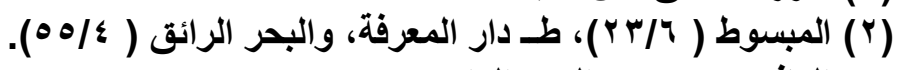

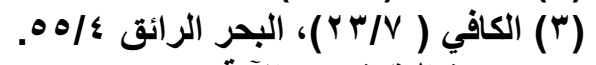

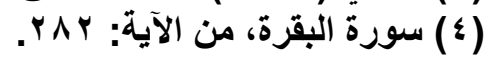

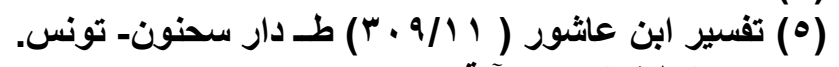

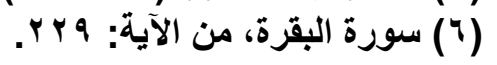

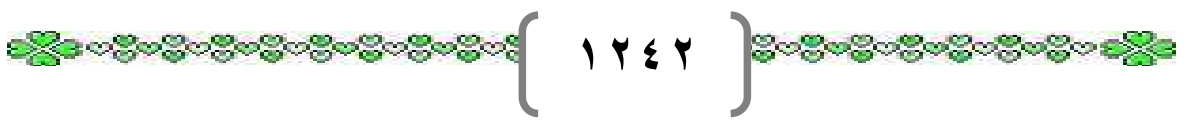




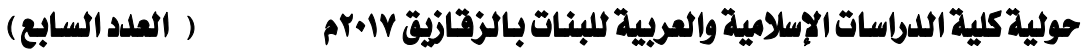

وبناء عليه فإن الأمر في قوله تعالى:

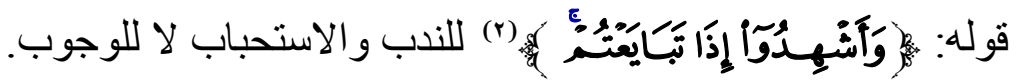
يقول الإمـام الشـوكاني: وقد وقع الإجماع على عدم وجوب الإشـهاد على الطلاق كما حكاه الموزعي في تفسيره، و الأمر عند عمران بن حصين لا يصلح للاحتجاج به، لأنه قول صـابي في أمر من مسـايغ الاجتهاد، ومـا كان كذللك

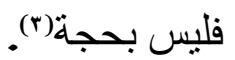

ويقول الإمام الموزعي: قد اتفق الناس على أن الطلاق من غير إثهاد جائز (๕). القول الثاني: قال أصحابه بوجوب الإشهاد على الطلاق و الرجعة، وممن قـال بذلك من الصحابة ابن عباس، و عمر ان بن حصين، ومن التابعين الإمـام جعفر

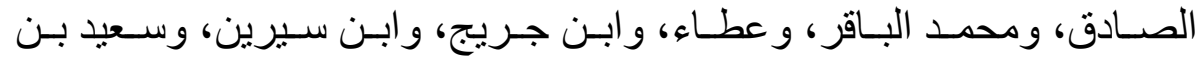

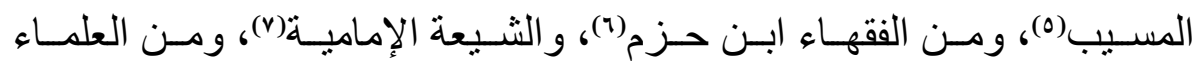

(1) سورة الطلاق، من الآية: r.

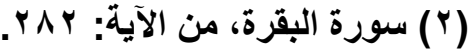

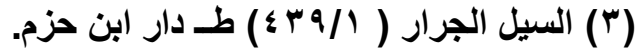

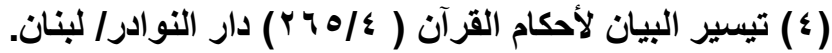

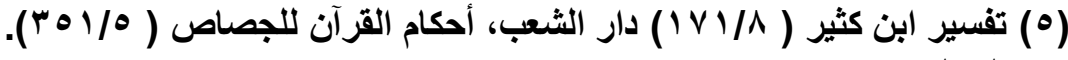

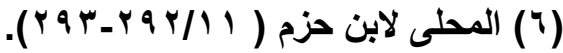
أصل الثيعة وأصولها، صـ (V) 


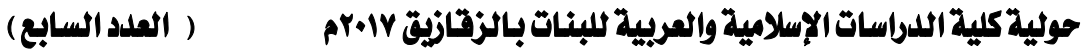

المعاصرين الثيخ محمد أبو زهرة(1)، و الأستاذ مصطفى الزرقا(r)، والدكتور

$$
\text { بدران أبو العينين()، و الدكتور علي الخفيف(\&). }
$$

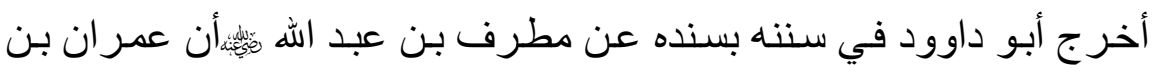

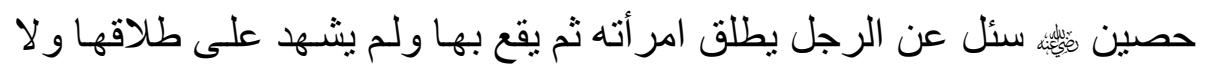
على رجعتها فقال: طلقت لغير سنة، ور اجعت لغير سنة، أشهـ على طلاقها

$$
\text { و على رجعتها و لا تعد (0). }
$$

و عن سفيان بن جريج عن عطاء قال: الفرقة والرجعة بالثهودد(1).

وقال ابن حزم: ولم يُفرق عز وجل بين المراجعة و الطلاق و الإشـهاد، فلا يجوز إفراد بعض ذلك عن بعض، وكل من طلق ولم يشهذ ذوى عدل، أو رجع ولم يشهد ذوى عدل متعديا لحدود الله تعالى (v). وبعد أن سقنا للك طرفا من أقو ال الققهاء نسوق للك طرفا من أقو ال المفسرين في هذه المسألة.

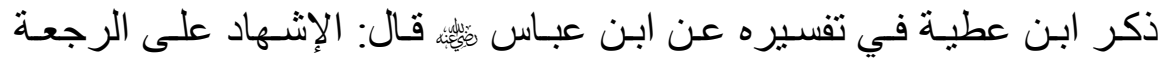
وعلى الطلاق يرفع أشكالا من النوازل كثيرة(A).

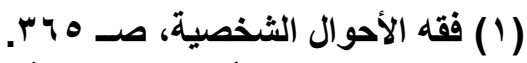

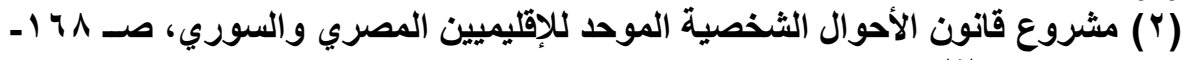

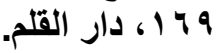

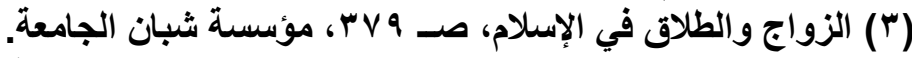

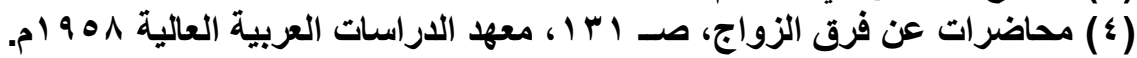

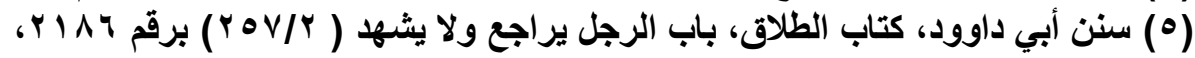

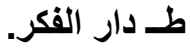

(7) المصنف لابن أبي شيبة، كتاب الطلاق، باب الفرقة والرجعة بالثهود، (1/9/9 (0)

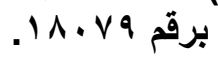

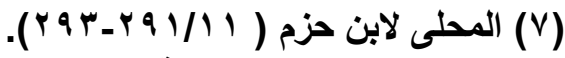

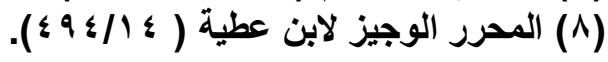




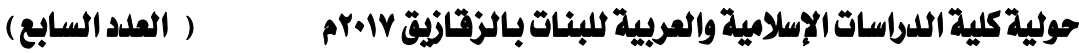

ويقـول الجصـاص: روي عـن عطـاء أنـهـهــال: الطـلاق و النكــاح و الرجعـة

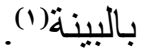

وقـال القرطبي: قولـه تعـالى: "و أثـهدو ا" أمر بالإشـهاد على الطـلاق. وقيل:

على الرجعة. و الظاهر رجو عه إلى الرجعة لا إلى الطلاق(汭

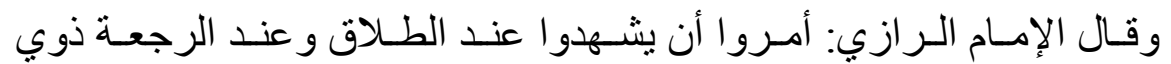

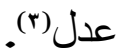

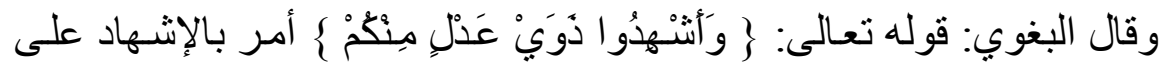

الرجعة و على الطلاق(๕)

قـال ابن عاثـور : ظـاهر وقوع هذا الأمـر بعد ذكر الإمسـاك أو الفراق، أنـه راجع إلى كليهما لأن الإشهاد جعل تتمة للمأمور بـه في معنى الشرط للإمساك أو الفراق لأن هذا العطف يثبه القيد و إن لم يكن قيدا وشأن الشروط الواردة بعد جمل أن تعود إلى جميعها، وظاهر صيغة الأمر الدلالة على الوجوب فيتركب مـن هذذين أن يكون الإشـهاد على المر اجعـة وعلى بـت الطـلاق و اجبـا على لـى الأزواج لأن الإشـهاد يرفع أشنكالا مـن النوازل وهو قول ابن عباس وأخذ بـه يحيى بن بكير من المالكية والثـافعي في أحد قوليه و ابن حنبل في أحد قوليه وروي عن عمر ان بـن حصين وطـاوس وإبـر اهيم وأبي قلابـة و عطساء. وقـال الجمهور: الإشهاد المأمور به الإشهاد على المر اجعة دون بت الطلاق(0).

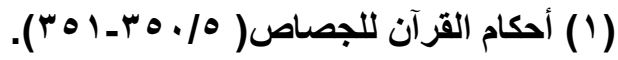

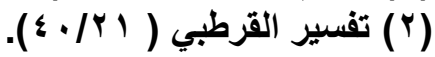

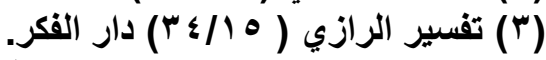

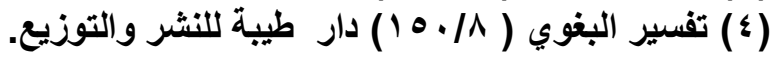

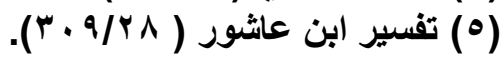




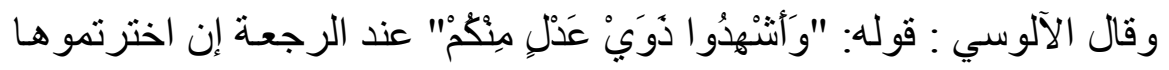

أو الفرقة إن اخترتمو ها تبريا عن الريبة وقطعا للنزاع(1).

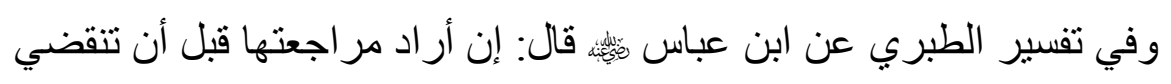
عدتها، أثهد رجلين كما قال الله \}و أشهدو اذوي عدل منكمج عند الطلاق و عند المر اجعة، وهو قول عطاء أيضا(r).

يقول الأسـتاذ أحمــ شـاكر : الظـاهر مــن ســاق الآيتـين أن قولـه تعـالى

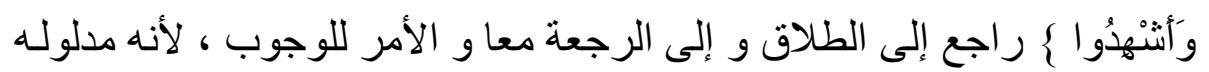
الحقيقي ، و لا ينصرف إلى غير الوجوب ـ كالندبـ إلا بقرينة ، و لاقرينـة هنـا تصرفه عن الوجوب ـ بـل القرائن هنـا تؤيد حمله على الوجوب : لأن الطلاق عمل استثنائي يقوم به الرجل - و هو أحد طرفي العقد - وحده ـ سواء أوافقته المر أة أم لا ، كما أوضحنا ذلك مرارَ ، و وتترتب عليه حقوق للرجل قبل المر أة ، وحقوق للمر أة قبل الرجل ، وكذلك الرجعة ، ويخشى فيهما الإنكار من أحدهما، فإنثهاد الثهود يرفع احتمـال الجحد ، ويثبت لكل منهما حقه قبل الآخر ـ فمن

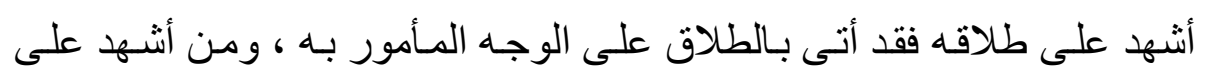
الرجعة فكذلك ، ومن لم يفعل فقد تعدى حد الله الذي حده له فوقع عمله باطلا لا

$$
\text { يترتب عليه أي أثز من آثاره () }
$$

وقد أصدرت هيئة كبار العلماء بالأزهر الثريف بيانا حول هذه المسألة جـاء

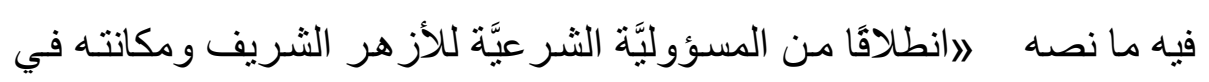

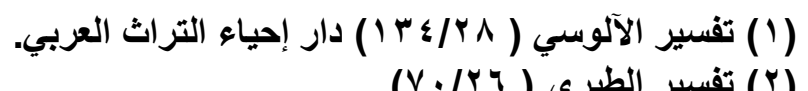

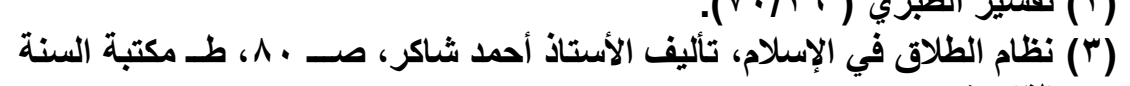
بالقاهرة.

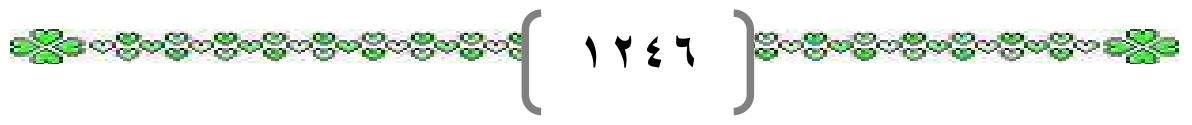


وجدان الأمَّة المصــريَّة التـي أكَدـدها الدسـتور المصـري، وأداءً للأمانـة التـي بحملها على عاتقِه في الحفِاظ على الإسـلام وشريعته السمحة على مدى أكثر

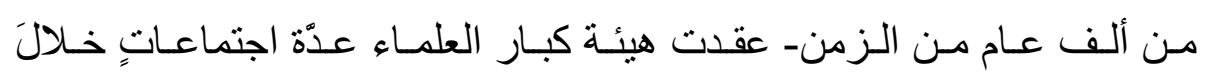
الثـهور الماضية لبحثب عدد من القضـايا الاجتماعيـة المعاصـرة؛ ومنهـا حكم الطلاق الثفويِّ، و أثره الثرعي، وقد أعدَّت اللجان المختصنَّة تقاريرهـا العلمية المختلفة، وقدَّتها إلى مجلس هيئة كبار العلمـاء الذي انعقد اليوم الأحد م من ون

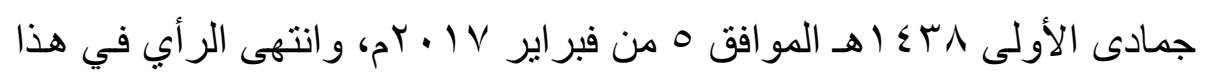

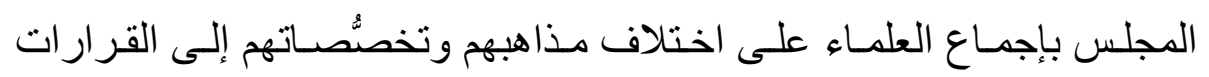

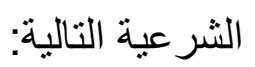
أولاً: وقوع الطلاق الثفوي المستوفي أركانَه وشروطه، و الصـادر من الزوج

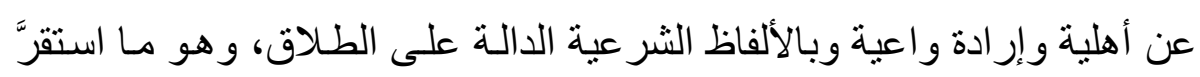

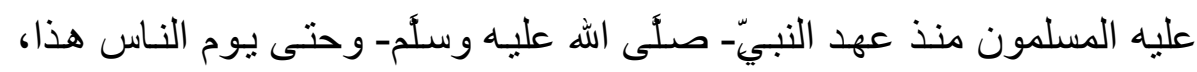
دونَ اشتر اط إثهاد أو توثيق.

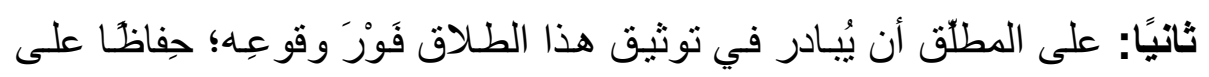

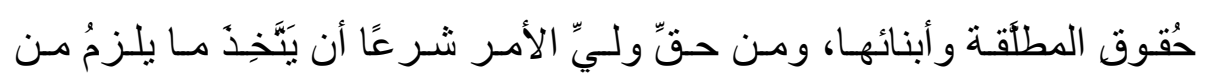

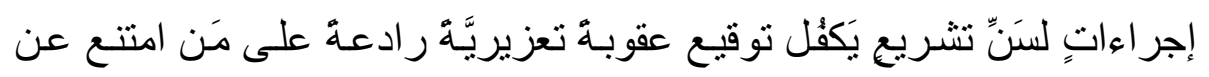
التوثيق أو ماطل فيه؛ لأنَّ في ذلك إضر ارًا بالمر أة وبحقوقها الشرعيَّة.

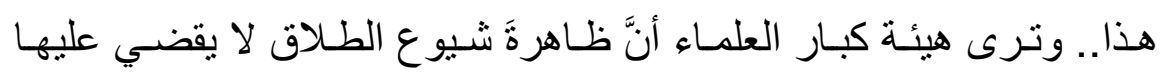

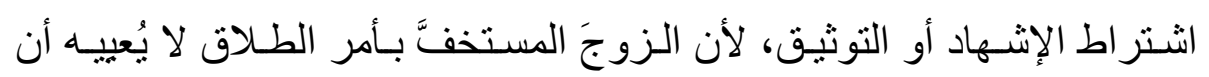
يذهب للمـأذون أو القاضـي لتوثيق طلاقه، علمًا بـأنْ كاقهة إحصـاءات الطـلاق

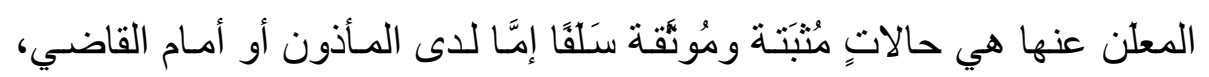

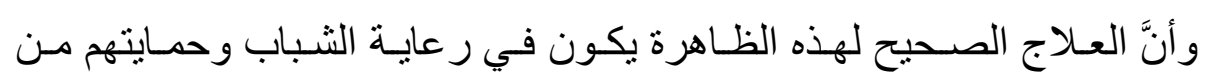


المخدرات بكلِّ أنو اعها، وتثقيفهم عن طريق أجهزة الإعلام المختلفة، والفن

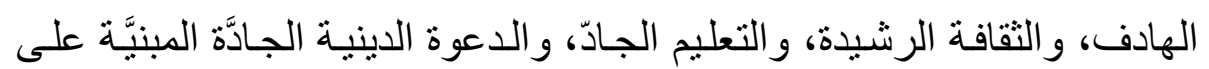
تدريب الدُعاة وتو عيتهم بفقه الأسرة و عِظم شـأنها في الإسـلام؛ وذلك لتوجيه

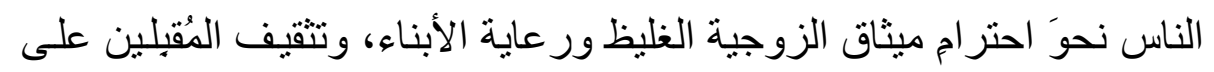

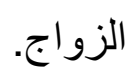

كما ثُناثيدِ الهيئة جميعَ المسلمين في مشـارق الأرض ومغاربها الحذر من

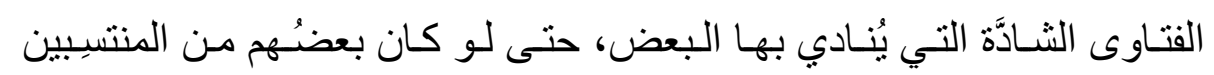
للأزهر ؛ لأنْ الأخذ بهذه الفتاوى الثـادَّة يُوقِع المسلمين في الحُرمة.

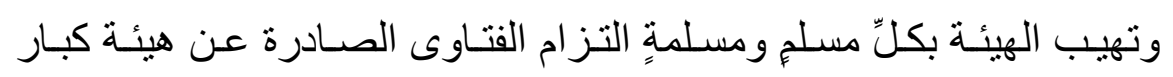
العلماء، و الاستمساك بما استقرَت عليه الأمَّة؛ صـونًا للأسرة من الانز لاق إلى

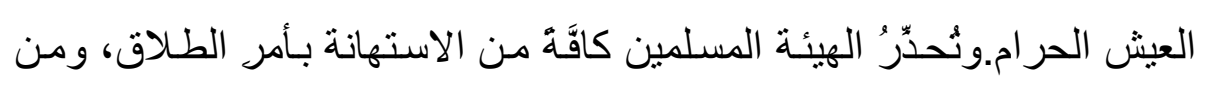

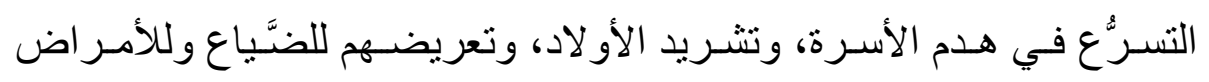

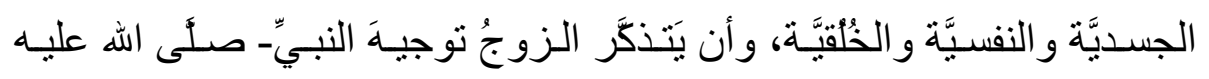

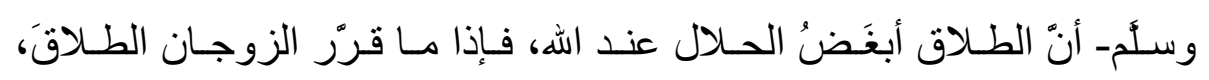
و استُنفِت كلُّ طرق الإصلاح، وتحنَّم الفراق، فعلى الزوج أن يلتزم بعد طلاقهـ

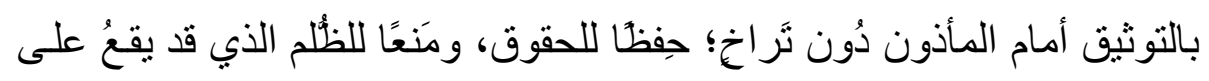

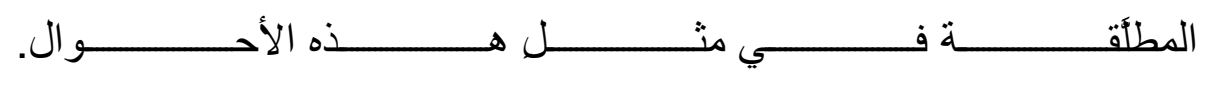
كما تقترحُ الهيئة أن يُعادَ النظرُ في تقدير النفقات التي تترَّب على الطلاق

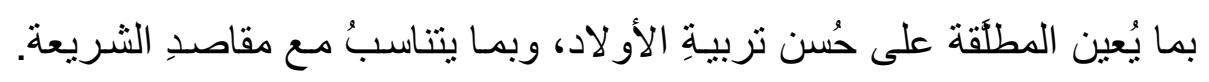

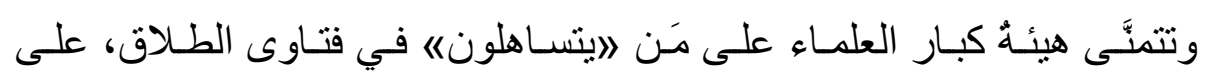

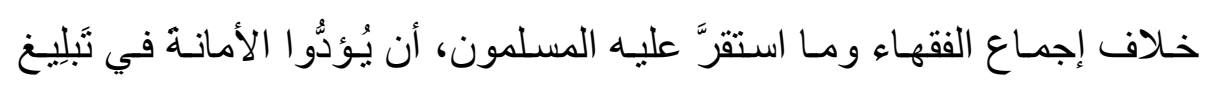

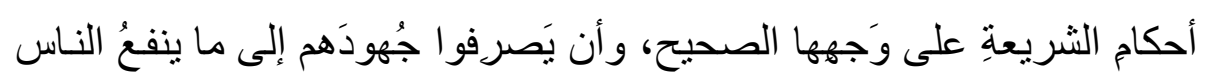


ويُسهم في حل مشكلاتهم على أرض الواقع؛ فليس النـاس الآن في حاجةٍ إلى تغيير أحكام الطلاق، بقدر ما هم في حاجـة إلى البحث عن وسـائل ثُيسِّرُ سُبُّلَ العيش الكريم. و هو ما نميل إليه ونعمل به.

\section{المطلب الخامس: الرجعة}

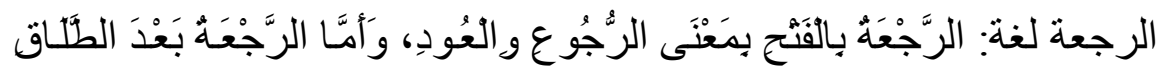

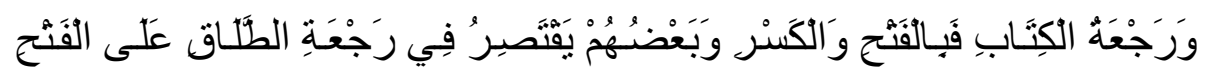

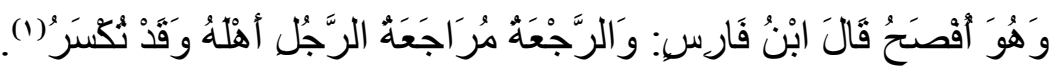
تعريف الرجعة عند الققهاء: الرجعـة عنـــ الفقهاء: هي إعـادة مطلقة غير بـائن إلى مـا كانـت عليه بغير عقد)

وقيـ: هي رد المـر أة إلى النكاح مـن طـلاق غير بـائن في العدة على وجـهـ

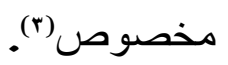

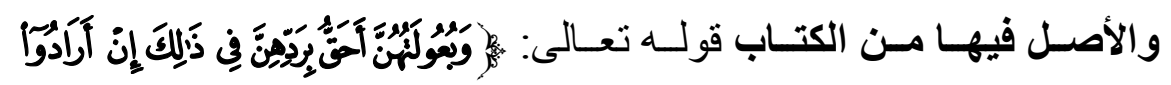

(₹)

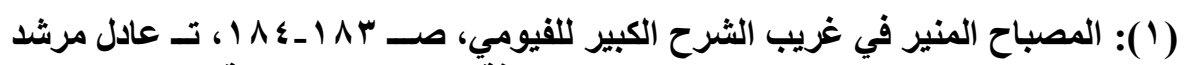

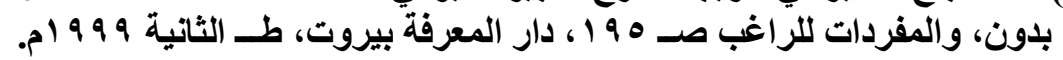

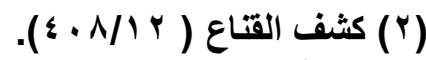

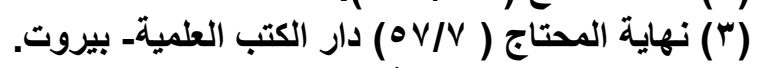

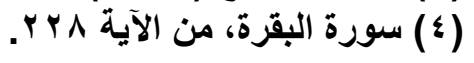


و أخر ج الطبري بسنده عن علي بـن أبي طلحة، عن ابن عبـاس في قولـه

تعالى:

تطليقة أو تطليقتين و هي حامل، فهو أحق برجعتها ما لم تضع حملها (1).

وقـال الإمـام القرطبي: أجمع العلمـاء على أن الحر إذا طلق زوجتـه الحرة،

وكانت مدخو لا بها تطليقة أو تطليقتين، أنه أحق برجعتها ما لم تنقض عدتها(r).

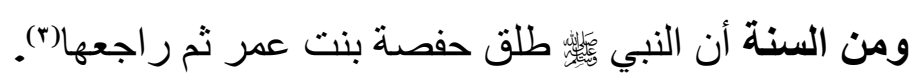

وقوله له ذللك فقال: مره فلير اجعها().

بمَ تكون الرجعة؟ تتحقق الرجعة بما يلي:-

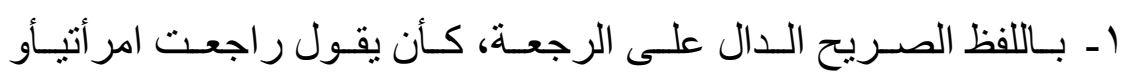
راجعتلك، أو رددتلك، أو أمسكتلك، أو نحو ذلك.

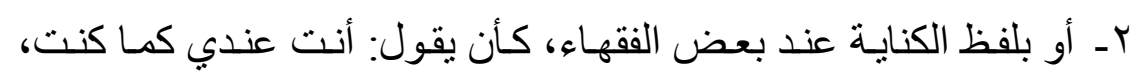

$$
\text { و أنت امر أتي. }
$$

قال القرطبي رحمه الله: وفي المنتقى قال: ولا خلاف في صحة الارتجاع

بالقول(1).

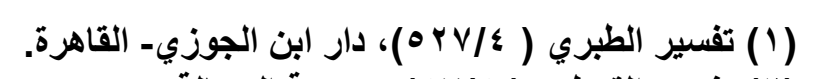

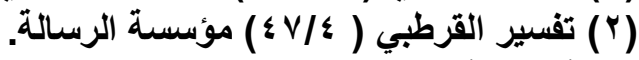

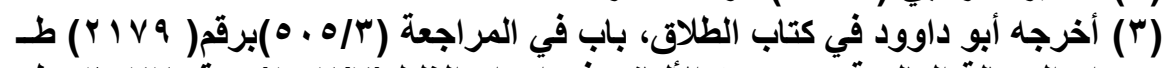

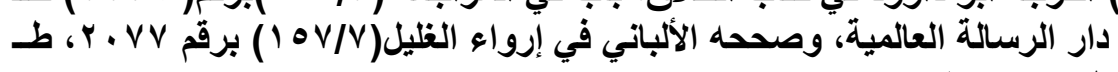

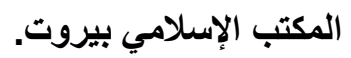

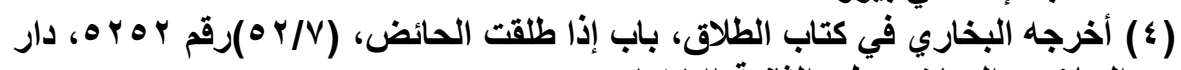

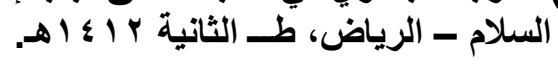


وقـال ابـن قدامـة: أمـا القول فتحصـل بـه الرجعـة. بغير خـلاف. و ألفاظـه:

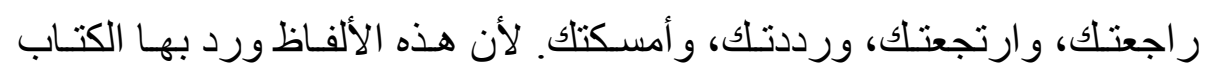

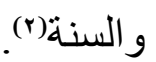

r- وقد تكون الرجعة بالفعل، كأن بطأها، أو يقبلها، أو يلمسها بشهوة. قال الإمام القرطبي: واختلفو ا فيمـا يكون بـه الرجل مر اجعا في العدة، فقال مالك: إذا وطئها في العدة وهو يريد الرجعة وجهل أن يشهد فهي رجعة. وينبغي للمـر أة أن تمنعـه الـوطي حتى يشـهـ، وقالت طائفة: إذا جامعهـا فقد راجعها، و هكذا قال سعيد بن المسيب و الحسن البصري و ابن سرين و الز هري و عطاء وطاوس والثوري. قال: ويشهد، وبه قال أصحاب الر أي والأوز اعي وابن أبي ليلى، حكاه ابن المنذر. وقال أبو عمر : وقد قيل: وطؤه مر اجعة على كل حال، نو اها أو لم ينوها، ويروى ذلك عن طائفة من أصحاب ماللك، و إليه ذهب الليث، وقال أبو حنيفة وأصحابه: إن وطئها أو لمسها بشهوة أو نظر إلى فرجها بشـهوة

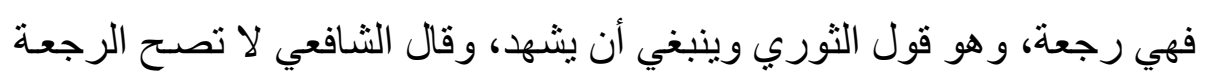
إلا بالقول، وحكاه ابن المنذر عن أبي ثور وجابر بن زيد وأبي قلابة(『). و المطلقـة الرجعيـة زوجـة مـا دامـت في العـدة لهـا مـا للزوجـات مـن النفقـة و الكسوة والمسكن، ويرث كل و احد من الزوجين صاحبه إذا مات في العدة. وينتهي وقت الرجعة بانتهاء العدة، فإذا انتهت العدة لا يصح للزوج المر اجعة إلا بعقد ومهر جديدين بولي وشاهدي عدل، وهذا مـا يفهم من قولـــــــه تعـالى:

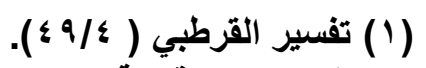

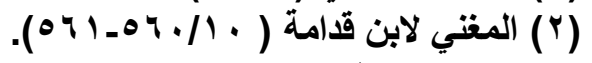

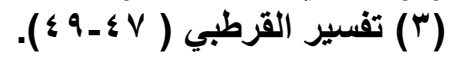




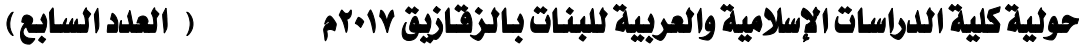

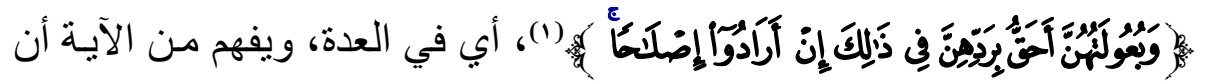

الزوجة إذا انتهـت من عدتها دون أن ير اجعها زوجها، لا تحل إلا بعقد ومهر جديدين، أما إذا راجعها في العدة رجعة صحيحة، لم يملك الزوج من الطلاق إلا بها ما بقي من عدده. 


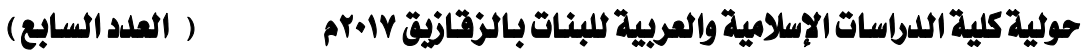

\section{المبحث الثالث:الحقوق المشتركة بين الزوجين وفيه مطالب: \\ المطلب الأول : حسن العثرة}

من الحقوق المشتركة بين الزوجين حسن العشرة، وجميل الصحبة بين الزوجين، فعلى الزوج أن يعاشر زوجته بالمعروف، وأن يعاملها برفق ولين، وأن يحسن إليها

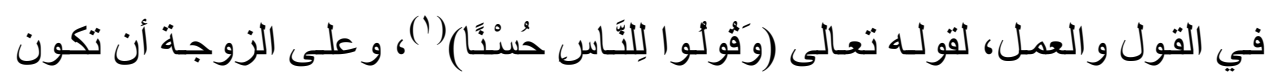
حسنة الخلق في تعاملها مع زوجها قو لا وفعلا من غير تأفف ولا ضَجَرَ، لأن بين الزوجين وشائج ثابتة، وصلات متينة تحملهما على التر احم و التآلف، وتعصدهما

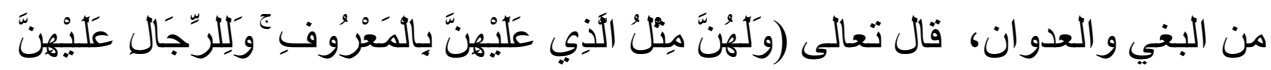

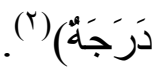

قال ابن كثير رحمه الله: أي ولهن علي الرجـال من الحق مثل مـا للرجـال عليهن

$$
\text { فليؤد كل و احد منهما إلي الآخر ما يجب عليه بالمعروف(") . }
$$

وقال القرطبي: قال ابن عباس رضـي الله عنه: لهن من حسن العشرة والصحبة

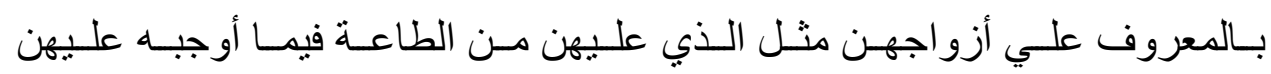
لأزو اجهن، و الدرجة إنـارة إلي حق الرجال علي حسن العشرة والتوسع للنسـاء في

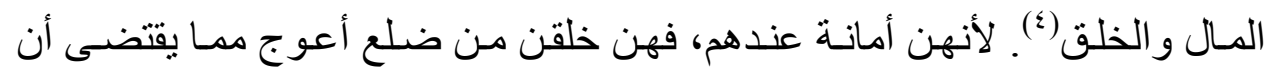
يكون الرجل حسن الخلق، واسـع الصـدر، عنده مـن الحكمـة و الكياسـة و المرونـة مـا

$$
\begin{aligned}
& \text { ـ سورة البقرة / مبرد. }
\end{aligned}
$$

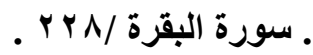

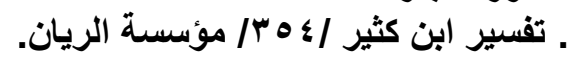

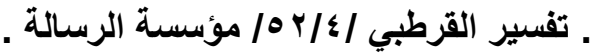




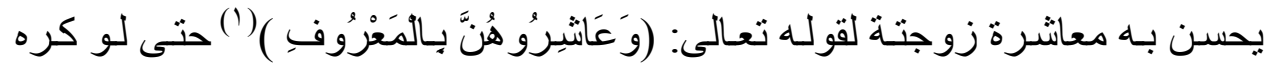

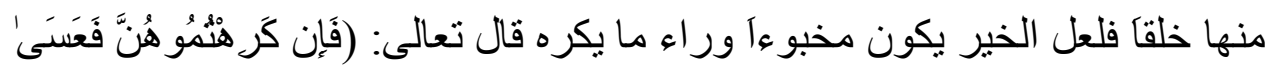

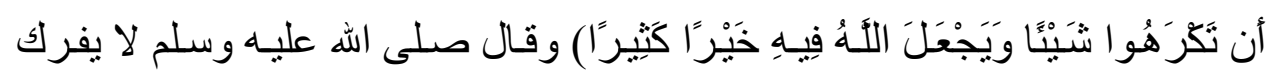

مؤمن مؤمنة إن كره منها خلقأ رضى منها آخر (r). ومـن مظـاهر حسـن العشـرة وجميل الصــبة أن يتلطف الرجل مـع أهلـه أقتـداءً برسول الله صلى الله عليه وسلم، فقد كان دائم البشر يداعب أهله ويتلطف بهم، حتى انى

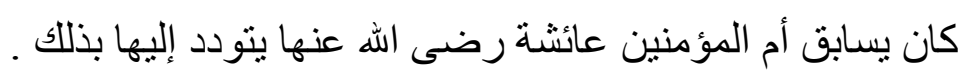

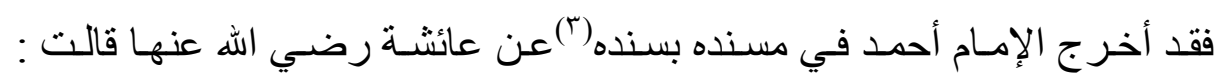
خرجت مع النبي صلى الله عليه وسلم في بعض أسفاره وأنـا جاريـة لم أحمل اللحم ولم أبدن فقال للنـاس: تقدموا، فتقدمو ا، ثم قـال لي: تعـالى أسـابقلك فسـابقته فسبقته، فسكت عنى إذا حملت اللحم وبـنت ونسيت خرجت معـه في بعض أسفاره فقال للناس تقدمو ا تقدموا ثم قال لي: تعـالى حتى أسـابقك فسـابقته فسبقني فجعل يضـك بك وهو يقول هذه بتلك.

ولقد جعل الرسول صلى الله عليه وسلم مداعبة الرجل أهله من اللهو المباح . . أخرج الإمام أحمد في مسنده بسنده عن عقبة بن عامر الجني قال: قال رسول الله صلى الله عليه وسلم: كل شيء يلهوا به ابن آدم فهو باطل إلا ثلاثا: رميه عن فرسه،

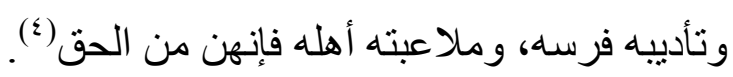

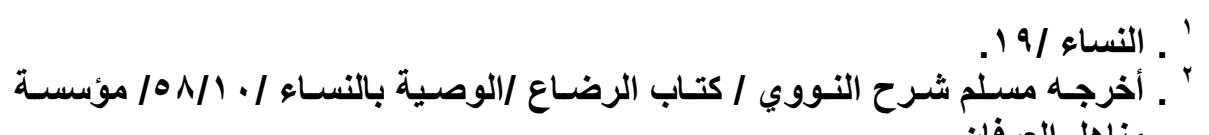

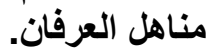

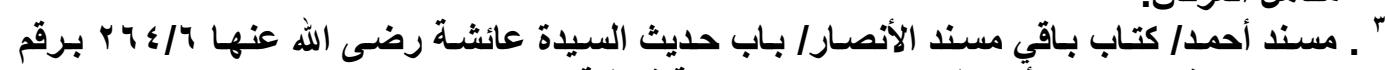

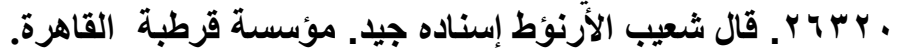

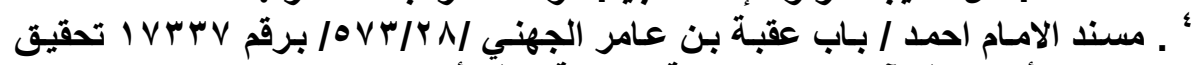

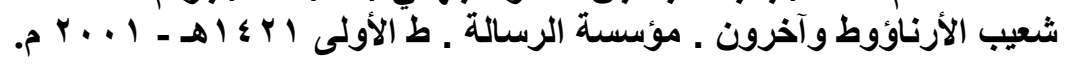

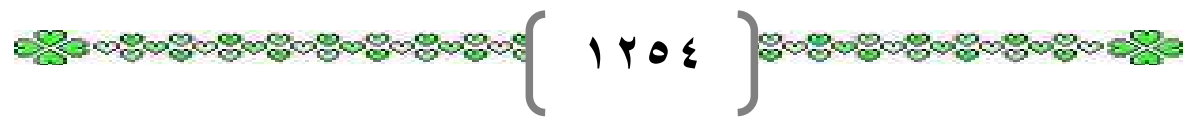


ومن مظـاهر حسن العشرة بين الزوجين أن يحسن كل منهمـا الظن بـالآخر من

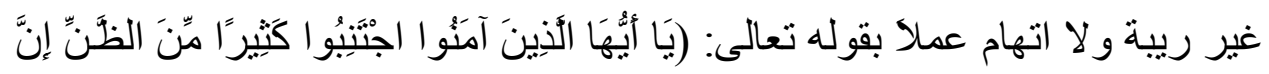

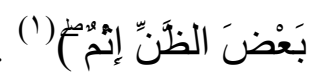
وومن مظـاهر حسن العشـرة أن لا يتتبع كل منهمـا عثر ات الآخر بغيـة إثـاعتها

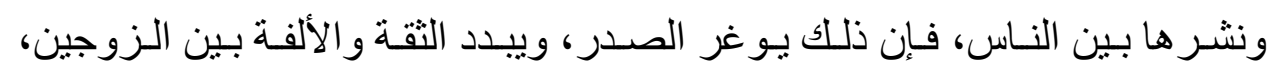
ويصيب الحياة الزوجية في مقتل، من أجل ذللك نهى رسول اله صلى اله عليه وسلم أن بطرق الرجل أهله ليلا يتخونهم أو يطلب عثر اتهم .

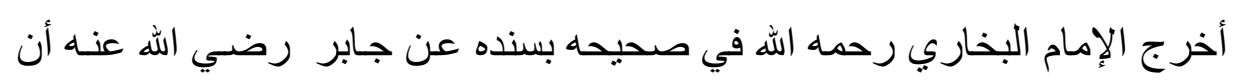
النبي صلى الله عليه وسلم قال : إذا دخلت على أهلك فلا تدخل حتى تستحد المغيبة

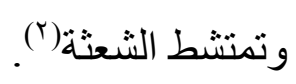

و على الزوجة المؤمنة أن تحسن معاملة زوجها فلا تقع عينه منها على قبيح، و لا يشـم منهـا إلا أطيب ريحح، و لاتسـعه إلا أطيب الكلم، وأن تكون صسبورة معسه في

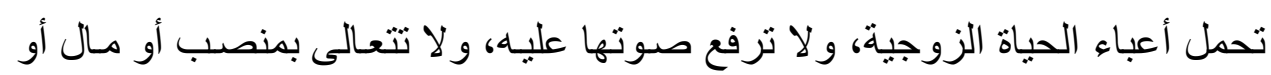
جاه، و لا تعبس في وجهه، و عليها أن تبادره بالصلح إذا أغضبته لتنـال رضي الله تعالى و الجنة .

أخرج الطبر انى عن أنس رضي الله عنه أن رسول الله صلى الله عليه وسلم قـال: ألا أخبركم بنسائكم في الجنة ؟ قلن بلى يا رسول الله قال: كل ودود ولود إذا أغضبت أو أسيىئ إليها قالت: هذه بدي في بدك لا أكتحل بغمض حتى ترضى (r).

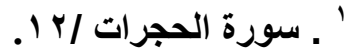

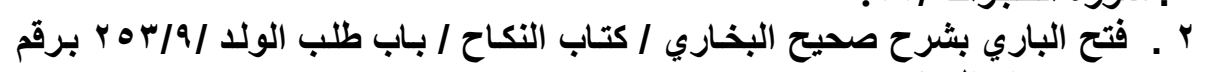

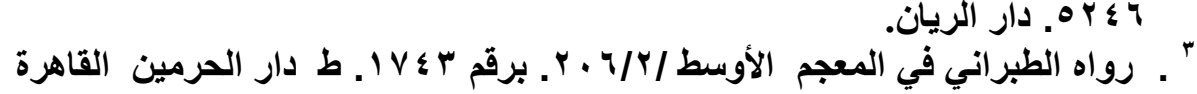
إ إن الهـ

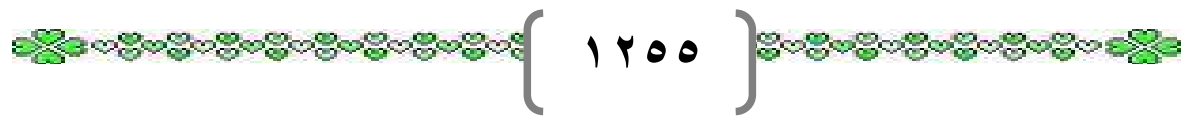




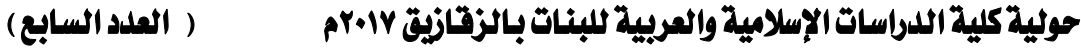

إن الكلمة الطيـة الحانيـة يُسمعها كل و احد من الزوجين للأخر يكون لها عظيم الأثر في تطبيب جر احات القلوب و النفوس، ونداوتها بعد جفافها وجفائها، فإذ بالحياة الزوجية تسودها المحبة و الألفة والسعادة . أما البطش والانتقام وفو احش الأقو ال والأفعال لن يصلح زوجة ركبت متن التمرد و الثطط والغرور، كما أن الجفاء والبعد لا يقيم اعوجاج زوجة تعالت وتمردت على لى زوجها، و إنمـا الذى يصلحهما معا هو تقوى الله وحسن العشرة، وكريم الصـحبة

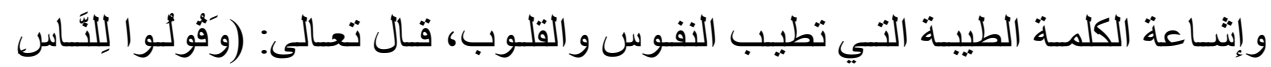
حُسنًْا)(') و أولى الناس بهذه الكلمة وسماعها كل من الزوجين يسمعها للآخر.

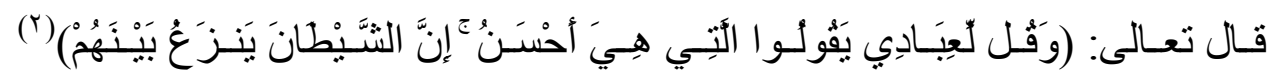
فالثيطان بنزغ بين الزوجين بالكلمة الخشنة تقلت، وبـالرد السيئ بيتلوهـا، فإذ بجو الود و المحبـة و الوفـاق مشـوب بالخشـونة و الكدر ، و الجفاء و الكر اهيـة، فيـأتي دور الكلمـة الطيبـة ليقطع نزغـات الثيطان في إثـارة الفتنـة، ويستمطر الدفع بـالتي هي أحسن الألفة و المودة، فإذ الأسرة تسودها الطمأنينـة والاستقر ار، و المحبـة و الحنـان،

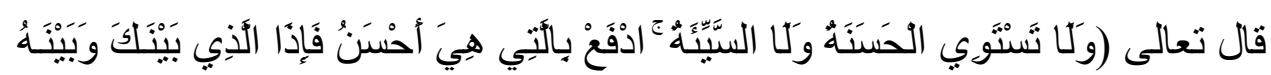

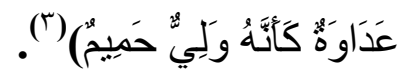

ولعل من المناسب فى هذا المقام أن نسوق وصية أعرابية لابنتها أم إياس لمـا فيها من الفائدة وحسن التوجيه:

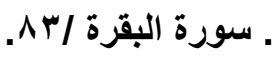

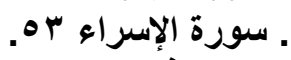

سورة فصلت /ع اعبر. 


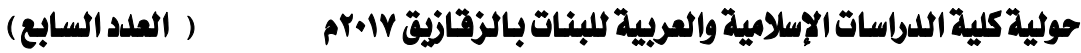

لما خطب عمرو بن حِجر الكندي(') إلى عوف بن محلم الثيباني (r)(بتته أم إياس قـال نعم أزوجكها على أن أسمى بنيها، وأزوج بناتها فقال عمرو بن حُجر : أمـا بنونـا

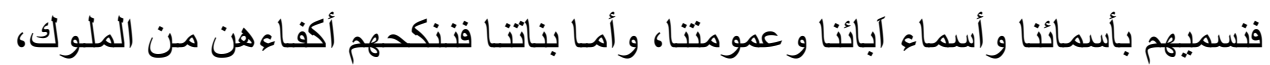
ولكنى أصدقها عقار آ في كندة، و أمنحها حاجات قومها لا ترد لأحد منهم حاجة، فقبل ذلك منه أبوها و أنكحه إياها، فلما كان بناؤه بها خلت بها أمها فقالت :أي بنية : إنك فارقت بيتك الذى منه خرجت و عثك الذى فيه درجت الى رجل لم تعرفيه وقرين لم تأليفية فكونى له أمة يكن للك عبداك، واحفظى له خصالا عشر تكن للك فخر ا. أما الأولى والثانية : فالخشوع له بالقناعة، وحسن السمع و الطاعة. وأما الثالثة والرابعة: فالتفقد لموضع عينه و أنفه، فلا تقع عينه منك على قبيح و لا يشم منك إلا أطبيب ريح. وأما الخامسة والسـادسـة: فالتفقد لوقت منامـه وطعامـه فإن حر ارة الجوع ملهبـة، وتنغيص النوم مغضبة. وأمسا السـابعة والثامنـة: فالاحتفاظ بمالـه، و الإر عـاء على حشـهه و عيالـه، ومـلاك الأمر في المال حسن التقدير وفى العيال حسن التدبير.

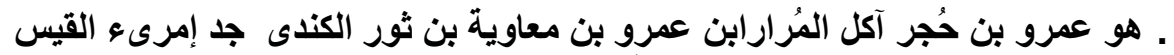

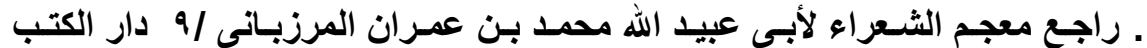

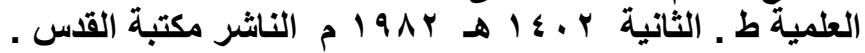

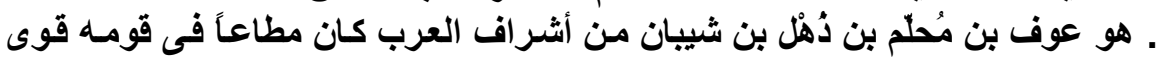

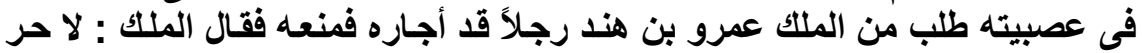

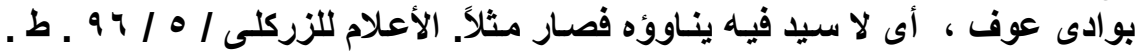

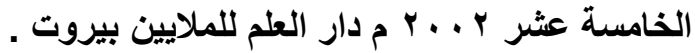


وأما التاسعة والعاشرة: فلا تعص له أمر آ، و لا تفش له سر آ، فإنك إن خالفت أمره أوغرت صدره، وإن أفثنيت سره لم تأمني غدره، ثم إيالك و الفرح بين يديه إذا كان

$$
\text { مهتما، و الكآبة بين يديه إذا كان فرحكا' ('). }
$$

لقد كانت المر أة المسلمة العربيـة على قدر من المسؤولية و الأمانـة حيث ربَّتـ بناتها و علمتهم كيف تكون الو احدة منهن زوجةٌ مثاليهة تحظى بحب زوجها وتقديره

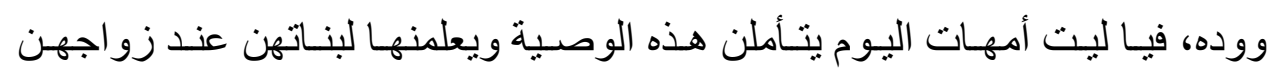
فينتفعن بها، ويعلمهن كيف يحسن معامله أزو اجهن ليكسبن ودهم وحبهم . فقد جاء في وصية أم إياس لابنتها أن المرأة يجب عليها أن تقوم على بيت زوجها فتر عى ماله و عياله، وأن هذه الرعاية تكليف تُشـأل عنه الزوجـة أمسام الله تعـالى كمـا يُسأل الحاكم عن رعيته .

أخرج البخـاري في صـحيحه عن عبد الله بـن مسـود رضـي الله عنه قـال : قـال النبي صـلى الله عليه وسـلم كلكم راع وكلكم مسـؤل ، فالإمـام راع وهو مسئول ،

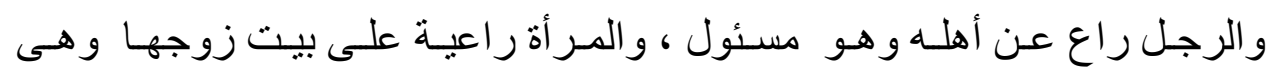
مسئولة ، و العبد راع على مال سيده وهو مسئول ، ألا فكلكم راع وكلكم مسئول(؟). فيجب على الزوجة أن تعلم أن مال زوجها أمانة تحت يدها لا يجوز لها أن تأخذ

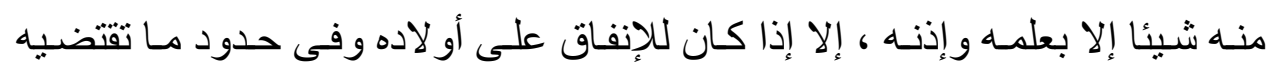

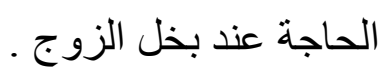
أخرج البخاري في صحيحةبسنده عن عائشـة رضـي الله عنها أن هند بنت عتبهـ قالت للنبي صلى الله عليه وسلم : إن أبا سفيان رجل شحيح وليس يعطيني ما يكفيني

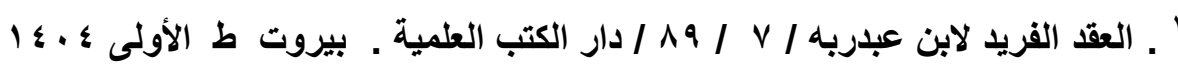

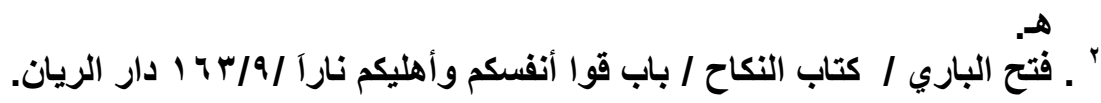

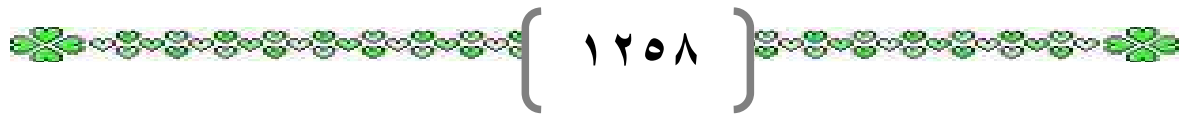


وولاي إلا ما أخذت منه وهو لا يعلم فقال رسول الله صلى الله عليه وسلم خذي مـا

يكفيك وولدك بالمعروف (').

و الزوجة حين تتفق على بيتها يجب عليها أن تتوخى القصد والاعتدال بلا إسر اف

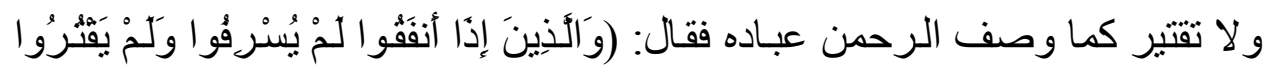

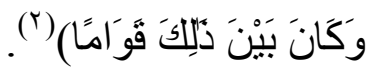

وقد ذم الله المبذرين فوصفهم بمـا تَنَفر منـه النفوس و الطبـاع السليمة فقال تعـالى:

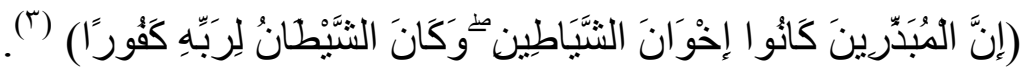

ولو تأملنـا الواقع الذى نعيشـه لتبين لنـا أن كثير آ من النسـاء يتولين شـؤن البيت

وليس عندهن مـن الأهليـة مـا يمكنهن مـن رعايـة الزورج ومالـه و أو لاده، فــا تكـاد الزوجة تمسك بمال زوجها حتى تبعثره ذات اليمين وذات اليسار ـ وتكون النتيجة أن تدفع بزوجها إلى الإستدانة، أو إلى بيع شيء من أثاث البيت، أو إلى السرقة، فينبغي على الآباء و الأمهات أن يبذلو ا جهدهم لتربيـة أو لادهم وخاصـة البنات بمـا يسعدهم

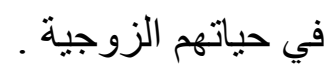

وممـا يجب على الزوجـة أيضـا كمـا في وصـية الأعر ابيـة لابنتهـا أم إيـاس عند

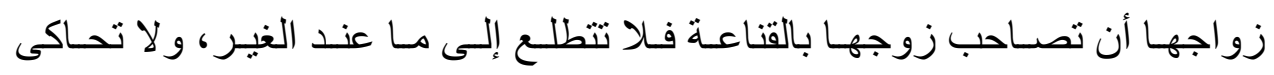
مثيلاتها من النساء، بل تنظر إلى أزواج النبي صلى الله عليه وسلم ومعيشتهن فقد كانت حياتهن كفافا وقد تخلو ا بيوتهن من الطعام .

' فتح الباري / كتاب النفقات / باب إذا لم ينفق الرجل فللمرأة أن تأخذ بغير علمهـ مـا

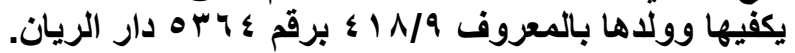

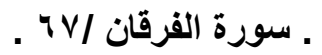

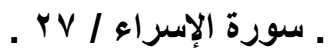


أخرج البخاري في صحيحه بسنده عن عروة عن عائشـة أنها قالت لعروة : ابن أختي إنا كنا لننظر إلى الهلال ثلاثة أهله في شهرين وما أوقدت في أبيات رسول اله صلى الله عليه وسلم نار ا. فقلت: ما كان يعيشكم؟ قالت: الأسودان التمر والماء ('). وفى رواية عن الأسود عن عائشـة رضى الله عنها قالت: مـا شبع آل محمد منذ

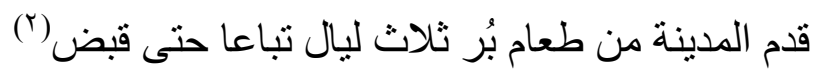
هذه هي أحوال بيوت النبي صلى الله عليه وسلم وأزواجـه، فلتقنع المر أة المسلمة بما قسم اله لها من الرزق ولا تحمل الزوج فوق طاقته. لقـد أوجـب الله تعـالى على كـل مـن الـزوجين إعفـاف صـاحبه بتحصـيل المتعـة بالمباشرة التي أحلها الله تعـالى لهما بمقتضى عقد النكاح الصـيح الذي شر عه الله

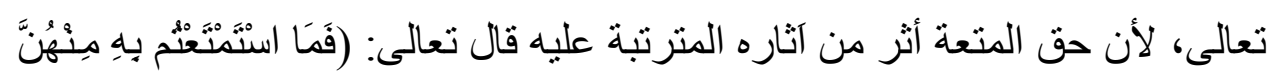

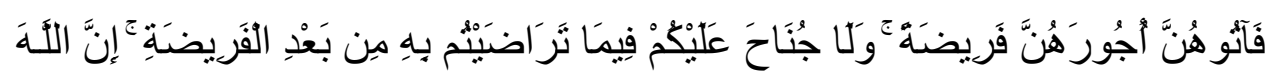

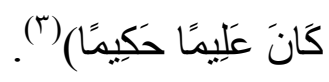
قال القرطبي رحمه الله تعالى: اختلف العلماء في المعقود عليه في النكاح مـا هو: بدن المر أة، أو منفعـة البُضـع، أو الحل، ثنلاثـة أقو ال: والظـاهر المجموع فإن العقد يقتضى كل ذلك ـ وفى معنى الآيـة يقول الحسـن ومجاهــ و غير همـا: فــا أنفقتم وتلذذنتم بالجمـاع مـن النسـاء بالنكاح الصـيح (فآتوهن أجور هن ) أي مهورهن .

ـ فتح البـاري / كتـاب الرقـاق / بـاب كيف كسان يعيش النبـي صلـى الله عليسه وسـلم r

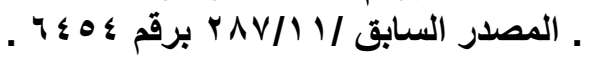
. سورة النساء/ع ب. 
وقال ابن خويز منداد : و لا يجوز أن تُحمل الآيـة على جواز المتعـة لأن رسول الله

صلى الله عليه وسلم نهى عن نكاح المتعة وحرمه أ.هـ (').

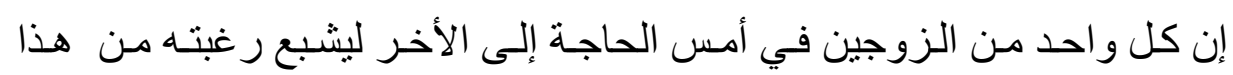

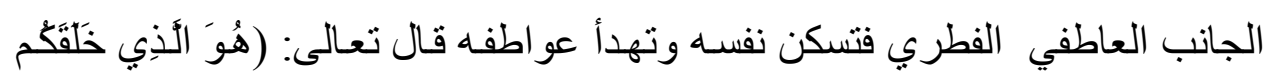

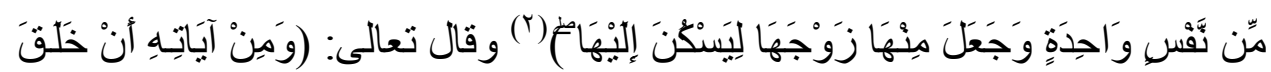

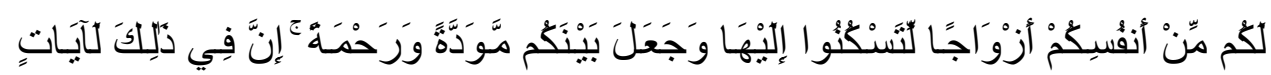

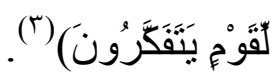
يقول الإمام الرازي رحمه الله تعالى: قوله (من أنفسكم ) بعضـهم قال: المر اد أن

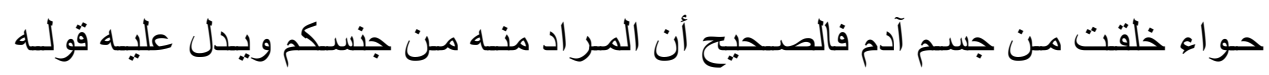
(لتسكنو إليها ) يعنى: أن الجنسين الحيين المختلفين لا يسكن أحدهما إلى الآخر أي لا تثبت نفسه معه و لا يمل قلبه إليه، يقال سكن إليه للسكون القلبي، ويقال سكن عنده

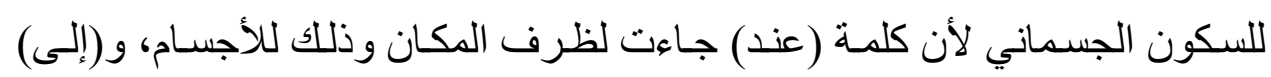
جاءت للغاية وهى للقلوب.

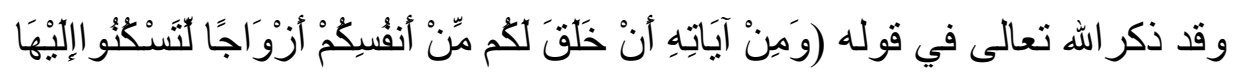

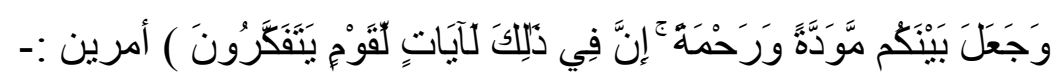
أحدهما: كون الزوج من جنسه. والثاني: ما تفضى إليه الجنسية من السكون إليه، فالجنسية توجب السكون والألفة.

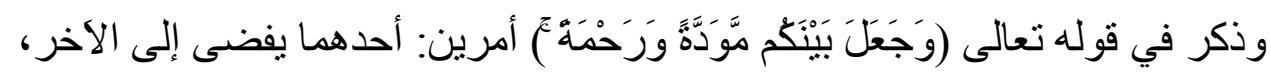
فالمودة تكون أو لا ثم إنها ثفضي إلى الرحمة، ولهذا فإن الزوجة قد تخرج مده من محل

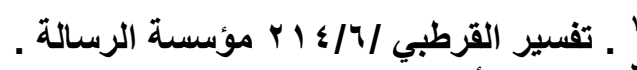

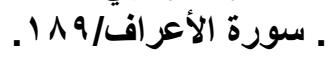

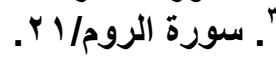




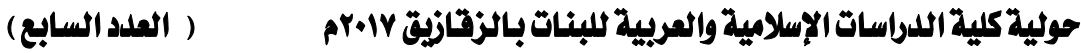

الثهوة بكبر أو مرض وييقى قيام الزوج لهاو العكس وذلك بالرحمة التي جعلها الله

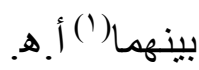

قال ابن عاثور رحمه الله تعالى: السكون في الآية مجاز في الاطمئنان و التأنس، أي جعل من نوع الرجل زوجة ليألفها ولا يجفوا قربها، ففي ذلك منة الإيناس وكثرة ممارستها لينسـاق إلى غشـيانها، فلـو جعل الله التناسـل حاصـلا بغيـر داع الثــهوة لكانت نفس الرجل غير حريصة على الاستكثار من نسله، ولو جعله حاصـلا بحالة ألم لكانت نفس الرجل مقلة منـه بحيث لا تتصرف إليـه إلا في حالـة الاضطر ار و التأمل و التردد، كما ينصرف إلى شر اء الدواء ونحوه (r) أ.ـه ـ. ولقد بين القران الكريم الكيفية التي بها يُشبع كل واحد مـن الزوجين حاجته من

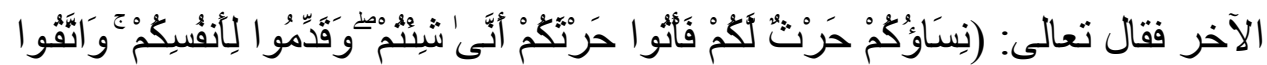

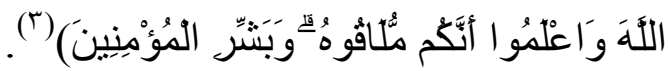
أخرج الإمام البخاري رحمه الله تعالى في سبب نزول هذه الآية بسنده عن جابر رضى الله عنه قـال : كانت اليهود تقول إذا جامعها من ور ائها جاء الولد أحول

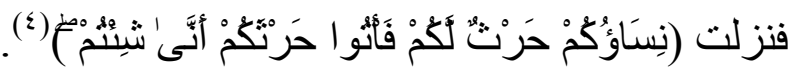
وقال ابن عطية رحمه الله تعالى: هذه الآيـة نص في إباحة الحـال و الهيئات كلها إذا كان الوطء في معرض الحرث أي : كيف شئتم من خلف ومـن قدام وباركة

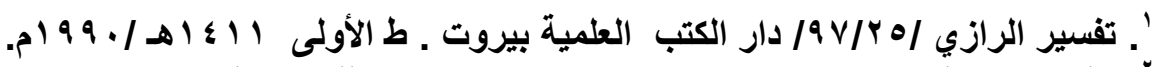

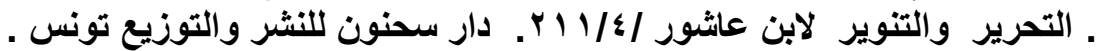

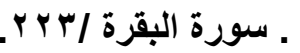

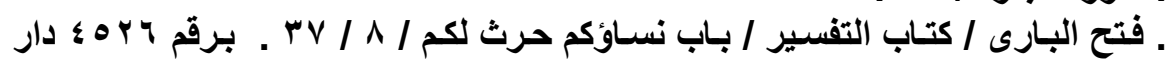

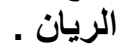


ومستلقية ومضطجعة، فأما الإتيان من غير المأتى ( يعنى في الدبر ) فما كان مباحا و لا يباح، وذِكر الحرث يدل على أن الإتيان في غير المأتى محرم('(1).ـه.

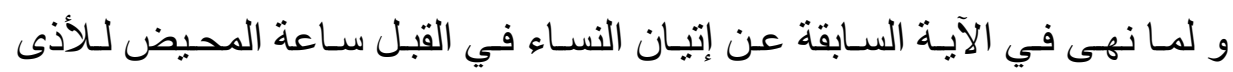

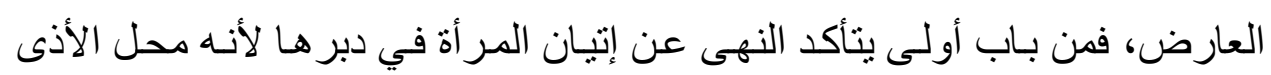

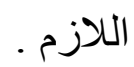
قال القرطبي رحمـه الله تعـالى: فلفظ (الحرث) يعطى أن الإباحـة لم تقع إلا في

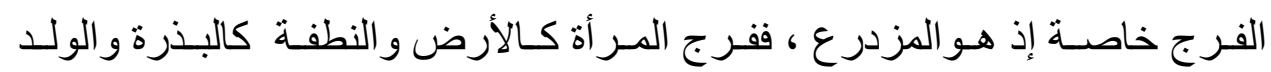

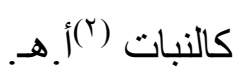
ثم بين الله تعالى في الآيـة الكريمـة أن العلاقـة الزوجيـة يجب أن تسموا بأهدافها فوق لذة الجسد إلى غايـة أسمى وهدف أفضل فقال (وقدموا لأنفسكم ) وفى ذلك لفت للزوجين إلى تفعيل تللك المقدمات كطلب الولد الصالح الذي يكون امتدادأ لـه في الحيـاة بعد موتـه، و غير ذلك مـن المقدمات الحسية و المعنويـة كالقبلـة و اللمســة

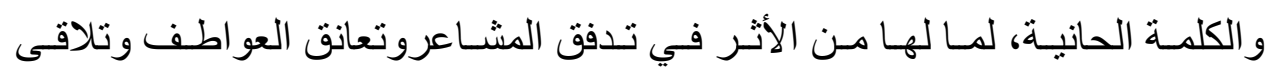
الأجساد فيتحقق السكون النفسي والجسدي على الوجه الأكمل. ومن المقدمات التي تثير الثـهوة وتحركها مص لسـان الزوجة وتحسس مو اطن الإثارة فيها، فقد كان النبي صلى الله عليه وسـم يفحل ذلك مع نسائه رضوان الله عليهم، وقال صلى الله عليه وسلم لجابر رضـي الله عنه مـا تزوجت ؟ قال تزوجت ثيبا فقال: مالك وللعذارى ولعابها ، ثم قال صلى الله عليـه وسـلم: هـلا بكر آ تلاعبها

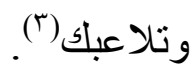

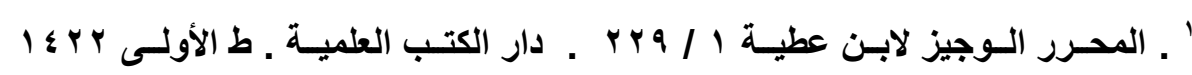

$$
\begin{aligned}
& \text { بيروت. }
\end{aligned}
$$

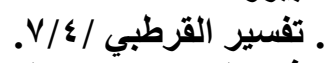

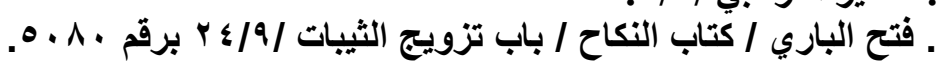


وتُختم الآية الكريمة بتبشير المؤمنين بالحسنى في الدنيا بما يقدمونه عند إتيانهم

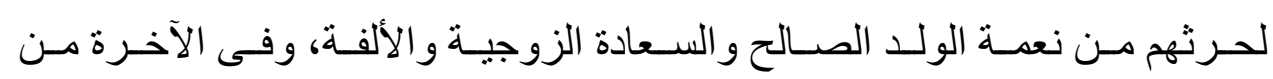
الأجر العظيم والجنة يقول سبحانه ( وبشر المؤمنين ). و قد أكد الرسول الكريم صلى الله عليه وسلم أن الرجل إذا أتى أهله فإنه بؤجر على ذلك، فقال صلى الله عليه وسلم وفى بُضـع أحدكم صدقة قالو ا بـا رسول الله أيأتي أحدنا شهوته ويكون له فيها أجر ؟ قال أرايتم لو وضعها في حر ام أكان عليه وزر؟ قالو ا : نعم قال : فكذلك إذا وضعها في الحلال يكون له أجر ('). و لا يكفى في حق الزوجة مجرد الجماع وذللك بأن يقضى الرجل حاجته فقط دونها

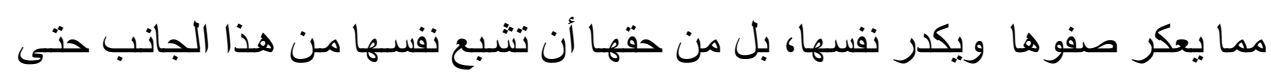
تصـل إلى ذروة الاستمتاع بإنز ال المـاء فيحصل لهـا مـن الإحصـان مـا يعفها عن الانحر اف، ومما يؤكد ذلك قوله صلى الله عليه وسلم: إذا جامع أحدكم أهله فليصدقها فإذا قضى حاجته قبل أن تقضى حاجتها فلا يعجلها حتى تقضى حاجتهاه (؟).

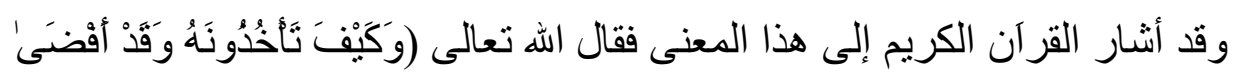

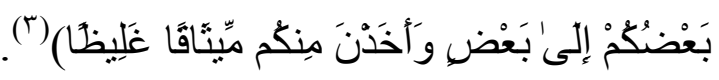

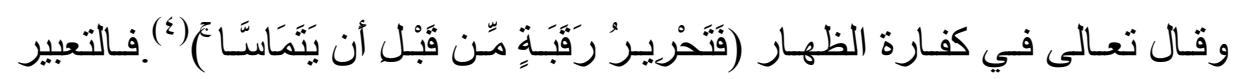
بالإفضاء و النتديد الوارد في المسيس لبيان المبالغـة في تحقيق الغايـة من الإشباع الجسدي و العاطفي من المتعة و اللذة الحاصلة بالجماع بين الزوجين .

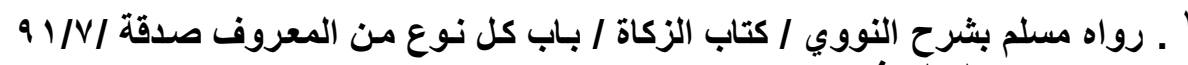

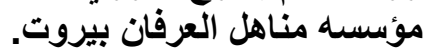

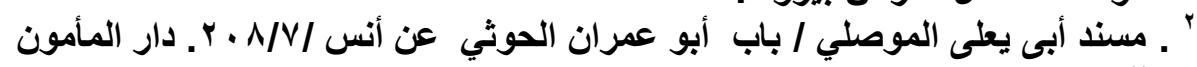




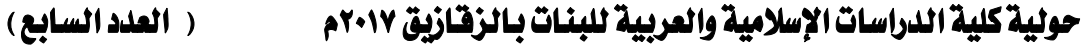

قال الإمام الرازي رحمه الله تعالى: الإفضاء هنا كناية عن الجماع وهو قول ابن عباس ومجاهد والسدى واختيار الزجاج وابن قتيبه و الثافعي (') أ. هـ. وفى قولـه تعـالى (هن لباس لكم و أنتم لباس لهن ) يقول ابن عاثـور رحمـه الله

تعالى: فيه استعارة بجامع شدة الاتصال حينئ(؟).

ويقول الجمل رحمه الله تعالى: في الآيـة كنايـة عن تعانقهما أو احتيـاج كل منهــا إلى صاحبه، يعنى: أنه سبحانه شبه كل واحد من الزوجين لاشتماله على صاحبه في العناق و الضم باللباس المشتمل على لابسه("). ولما كان الجماع بين الزوجين فيه كمال اللذة والإحسان، وكمال العفة والإحصـان و اعتدال المزاج، كان الواجب على الزوجين ألا يمتنع أحدهما عن صـاحبه إذا مـا طلب منه هذا الحق، فعلى المر أة أن تستجيب لزوجهاو لا تهجر فر اشه مـا دامت في حال لا تمنع من ذللك شر عأ حتى لا تعرض نفسها لسخط الله تعالى. أخرج الإمام البخاري في صحيحه بسنده عن أبى هريرة رضي الله عنه عن النبي صلى الله عليه وسلم قـال : إذا دعا الرجل امر أتهه إلى فر اثـه فأبت أن تجئ لعنتها

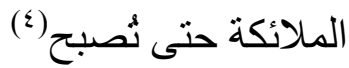
و الرجل كذلك قد يأخذ نصيبه من هذا الوعيد لو هجر فر اش امر أته بغير مبرر

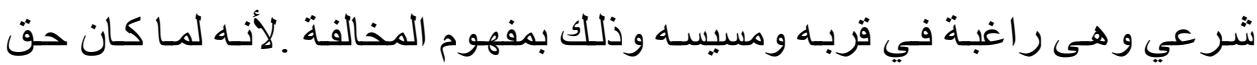
الزوج على زوجته ألا تمتنع عنه إذا دعاها لفر اشه ، كان عليه أيضـا ألا بمتتع عنها

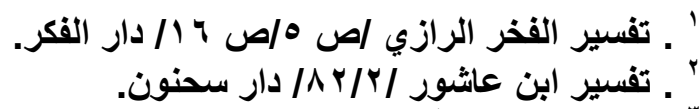

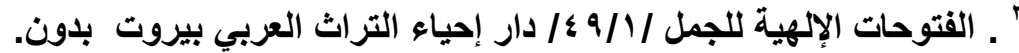

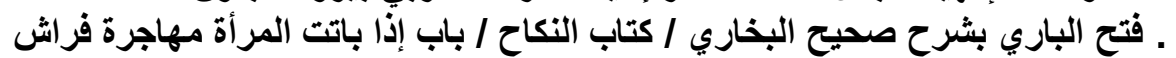

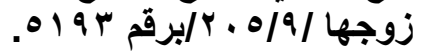




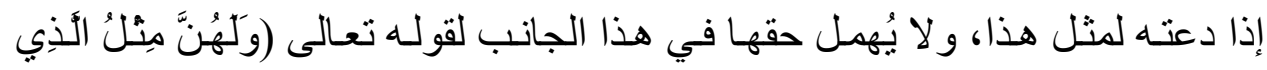

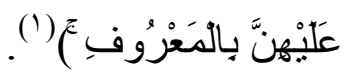

يقول ابن القيم رحمـه الله تعـالى: أخبر سبحانه في الآيـة أن للمـر أة من الحـق مثنل الذي عليها، فـإذا كـان الجمـاع حقـأ للزوج عليهـا فهو حق لهـا على الزورج بنص

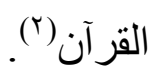
وقال صلى الله عليه وسلم لعبد الله بن عمرو ابن العـاص: يـا عبد الله ألم أخبرك أنك تصوم النهار وتقوم الليل ؟ قلت: بلى يـارسول الله قال فلا تفعل، صم و أفطر ،

وقم ونم، فإن لجسدك عليك حقا، و إن لعينك عليك حقا، و إن لزوجك عليك حقام"). وكان عثمان بن مظعون رضي الله عنه ممن حَّرم النسـاء فكان لا يدنو ا من أهلـه و لا يدنون منـه فأتـت امر أتـه إلى السيدة عائشـة وكان يقال لها الحو لاء، فقالت لها عائشة ومن عندها من نسـاء النبي صلى الله عليه وسلم مـا باللك بـا حولاء متغيرة اللون لا تمنتطين و لا تتطيبين؟ فقالت: وكيف أتطيب و أمتشط وما وقع على زوجي و لا رفع عنى ثوبا منذ كذا وكذا، فجعلن يضحكن من كلامها، فدخل رسول اله صلى الله عليه وسلم و هن بضحكن فقال: ما يضحككن قالت: يا رسول الله، الحولاء سألتها عن أمر ها فقالت: ما رفع عنى زوجي ثوبا منذ كذا وكذا فأرسل إليـه فدعاه فقال: مـا باللك يا عثمان؟ قال: إنى تركته لله لكى أتخلى للعبادة وقص عليه أمره، وكان عثمـان

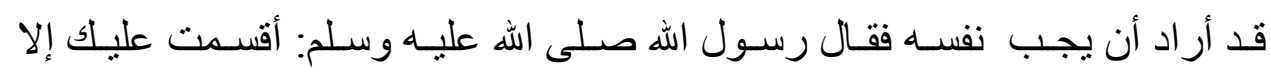
رجعت فو اقعت أهلك، فقال يـا رسول الله: إنى صـائم قال: أفطر فأفطر و أتىى أهله فرجعت الحولاء إلى عائشة قد اكتحلت وامتشطت وتطيبت فضحكت عائشة، فقالت: ما باللك يا حو لاء؟ فقالت: إنه أتاها أمس فقال رسول الله صلى الله عليه وسلم: مـا بـال

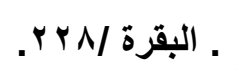

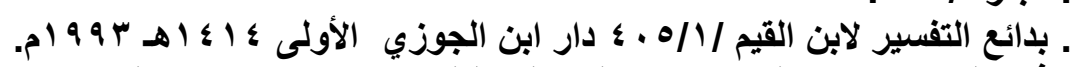

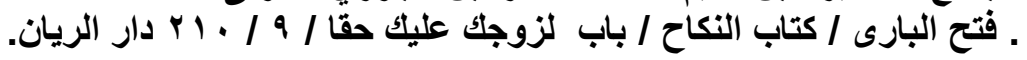


أقو ام حرَّموا النسـاء و الطعـام والنوم؟ ألا إنـى أنـام وأقوم، و أفطر و أصـوم، و أنكح

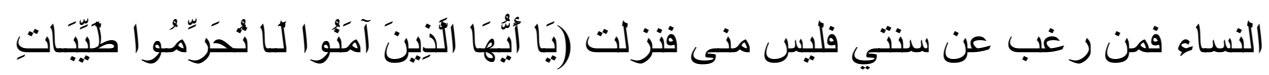

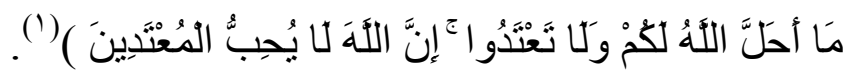
و أخرج البخاري في صحيحة بسنده عن أبى جحيفة عن أبيـة قـال : أخي النبي صلى الله عليه وسلم بين سلمان وأبى الدرداء فزار سلمان أبـا الدرداء فرأى أم الدرداء مبتزله فقال لها : ما شأنك ؟ قالت : أخوك أبو الدرداء ليس لله حاجـة في الدنيا ، فجاء أبو الدرداء فصنع له طعاما فقال له كل فقال :فإني صـائم ، قال مـا أنـا بأكل حتى تأكل ـ قال : فأكل ـ فلما كان الليل ذهب أبو الدرداء يقوم ـ فقال : نم فنام ، ثم ذهب يقوم فقال : نم فلما كان من أخر الليل قال سلمان : قم الآن فصليا فقال لـه سلمان : إن لربك عليك حقا، ولنفسك عليك حقا و لأهلك عليك حقا فأعط كل ذي حق حقه فأتى النبي صلى الله عليه وسلم فذكر ذلك لـه فقال صلى الله عليه وسلم صدق سلمان ـ وفى هذا بيـان لفضل المعاثـرة الزوجية وأن مجامعة الرجل لأهله كفضل

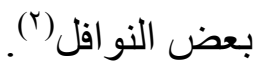

ومـن أجل ذلك نهى رسول الله صـلى الله عليـه وسـلم الزوجـة أن تصـوم تطو عـاـ

$$
\text { وزوجها شاهد إلا بإذنه حتى لا تفوت عليه رغبته في معاشرتها . }
$$

روى البخاري في صحيحه عن أبى هريرة رضي الله عنه عن النبي صلى الله

عليه وسلم قال: لا تصوم المر أة وبعلها شاهد إلا بإذنه(ب).

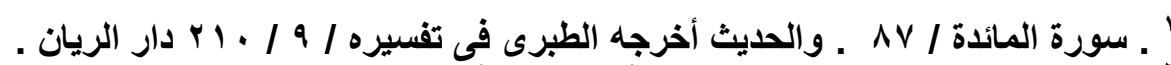

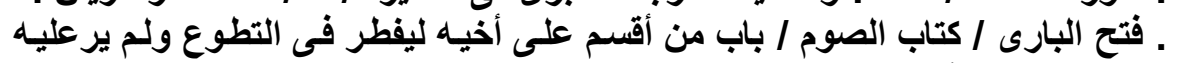

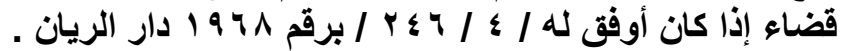

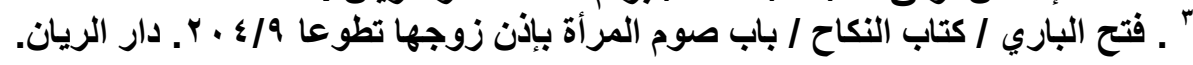


ومعلوم أن من ذاق اللذة المعسولة تكن رغبته فيها أثند و أقوى من رغبـة من لـ يذقها، و المر أة إذا ذاقت عسيلة زوجها و لا سيما أول عسبلة لم تكد تصبر عنه بعد ذللك، قال أيمن بن خريم (')

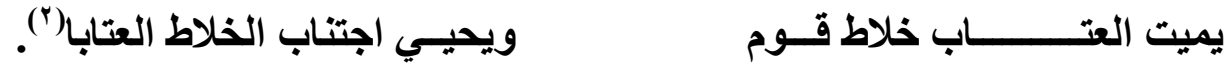

وقال بعض السلف ينبغي للرجل أن لا يدع الجماع فإن البئر إذا لم ينزح ذهب مـاؤه

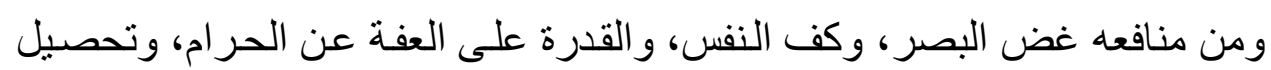

ذللك للمر أة(").

و إهمال الجماع يميت الحب ويفسد العشرة.

\section{حكم الجماع ومدته؟}

قال ابن القيم رحمه الله تعالى عند تفسير قول الله تعـالى ( ولهن مثل الذي عليهن بالمعروف)ما نصه::- المان

أخبر سبحانه في الآيـة أن للمر أة مـن الحق مثنل الذي عليها فإذا كان الجمـاع حقا للزوج عليها فهو حق لها على الزوج بنص القرآن، وأيضا فإنه سبحانه أمر الأزواج أن يعاشروا الزوجات بالمعروف، ومن ضد المعروف أن يكون عنده شـابة شهوتها تعدل شهوة الرجل وتزيد عليها بأضعاف مضاعفه و لا يذيقها لذة الوطء مرة واحدة، ومن زعم أن هذا من المعروف كفاه طبعه ردأ عليه، و الله سبحانه وتعالى إنما أباح

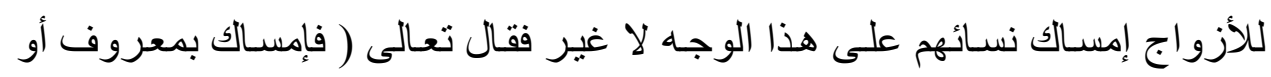

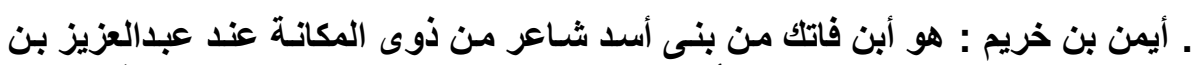

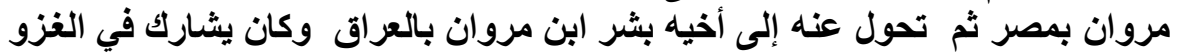

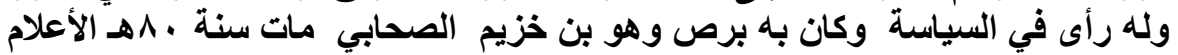

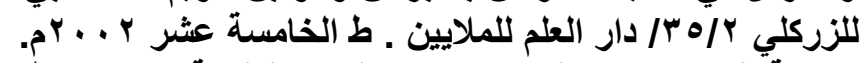

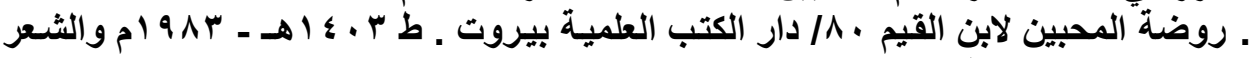

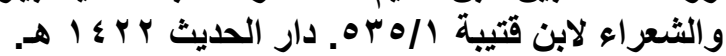

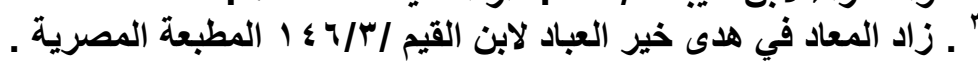


تسريح بإحسان ). وقالت طائفة : يجب عليه وطؤها في العمر مرة واحدة . و هذا من

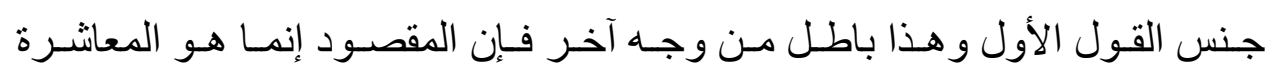
بالمعروف، و الصداق دخل في العقد تعظيما لحرمته وفرقا بينه وبين السفاح فوجوب المقصود بالنكاح أقوى من وجوب الصداق . وقالت طائفة: يجب عليه وطؤهـا في كل أربعة أنشهر واحتجو ا على ذلك بأن الله سبحانه أباح للمُولى تربص أربعة أشهر وخيَّر المر أة بعد ذلك في أن تقيم أو تفارق، و هذا ليس بصحيح لأنه غير المعروف الذي لها عليه.

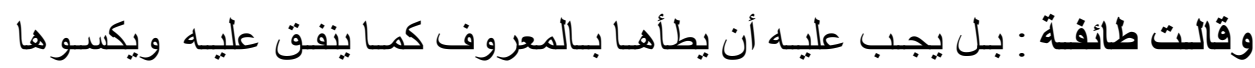

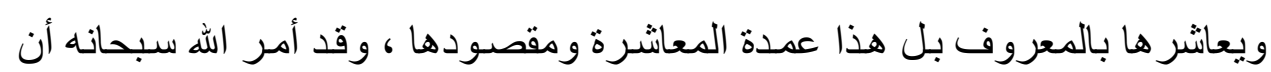
يعاشـروهن بـالمعروف فـالوطء داخل في هذه المعاشـرة و لا بـد، قـالو ا : و عليـه أن يشبعها وطأ أذا أمكنه ذلك كما عليه أن يشبعها قوتاهوكان شيخنا يرجح هذا القول

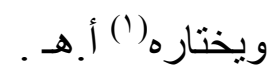

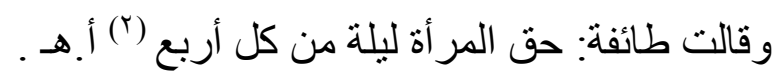
و استدلو ا على ذلك بمـا ذكره القرطبي رحمـه الله تعالى () في تفسيره قال: ذكر الزبير بن بكار : حدثني إبر اهيم الحِز امسى، عن محمد بن مَعْنِ الغفاري قـال: أتت امر أة إلى عمر بن الخطاب رضي الله عنه فقالت: با أمير المؤمنين إن زوجي يصوم

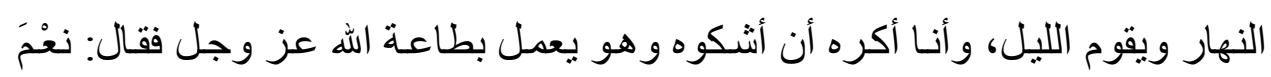
الزوج زوجُك. فجعلت تكرر عليه القول وهو يكرر عليها الجواب، فقال لله كعب

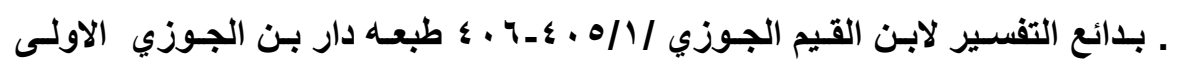

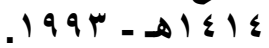

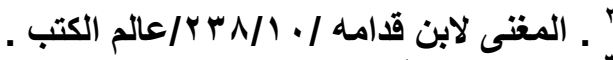

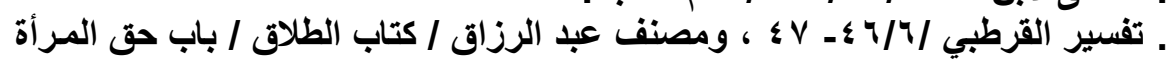

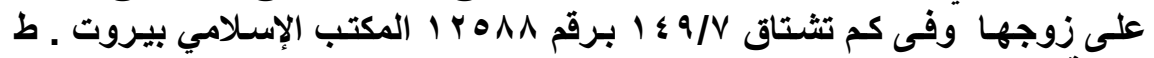
الثانية ب ـ ـ أهـ بيروت .

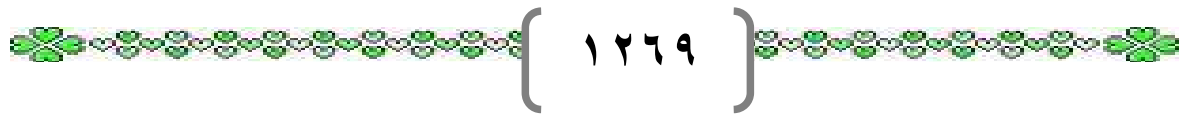


الأزدي: يا أمير المؤمنين، هذه المر أة تشكو زوجها في مباعدته إياهـا عن فر اثـه: فقال عمر : كما فهمت كلامها فاقض بينهما ، فقال كعب: على بزوجها فأتى بـه، فقال له: إن امر أنتك هذه نشكوك قال: أفي طعام أم شراب ؟ قال :لا فقالت المر أة : ألهى خليلي عن فراشي مســدُه فقــــ القضا كعـبُ ولا يُردده يا أيها القاضي الحكيم رَشَدَه فـلست في أمسر الـنسـاء أحمده زهـــده في مضــــي تعبدُ

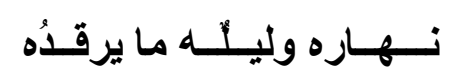
فقال زوجها :

أنــى امرؤ أذهلني ما قــــن نزل وفـي كتـاب الله تخويــف جَلْ أل في سورة النحل وفى السبع الطوَّْ

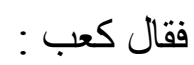

\section{نصيبها في أربع لمن عَقلْ} إن لها عليك حقا يا رجل :

\section{فأعطها ذاك ودع عنك العلل}

ثم قال إن الله قد أحل للك من النساء مثنى وثلاث ورباع فلك ثلاثة أيام ولياليهن تعبد فيهن ربك. فقال عمر: واله لا ادرى من أي أمريْك أعجب؟ أمن فهمك أمر همـا، أم من حكمك بينهما؟ اذهب فقد وليتلك قضاء البصرة أ. هـ. و الذى تميل إليه النفس أن على الزوج أن بطـأزوجته بـالمعروف كمـا ينفق عليه بالمعروف، وإن قدر على أن يثبعها من الوطء متى قدر على ذلك فلا مانع لأن في

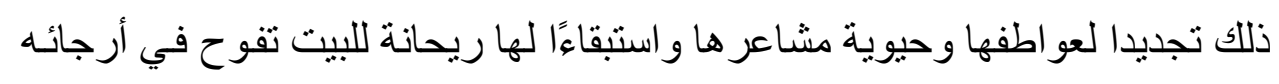

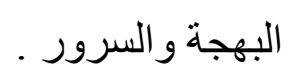




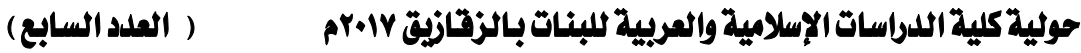

\section{أمور يجب مراعاتها عند الجماع}

لقد أرشد الثار ع الحكيم إلى طائفة من الآداب التي يجب مر اعاتها ليتحقق الخير و النفع لكـلا الـزوجين وتـدوم الحيـاة الزوجيـة بينهمـا دون منغصـات تكـدر الصـفو و تجلب الكأبة، وفى هديه صلى الله عليه وسلم ما يربط الزوجين بـاله تعالى، ويقوى أو اصر المودة بينهما ويحفظ عليهما الصحة والعافية وكمـال اللذة، وسرور النفس

$$
\text { و هذه الآداب على النحو التالي :- }
$$

ا - التستر عند الجماع: لقد أرشد الرسول صلى الله عليه وسلم إلى مـا يجب على المسلم من ستر عورتـه في كل الأحو ال و أذن بكثف مـا دعت الضـرورة إليه

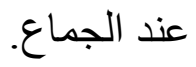

أخرج الترمذي في سننه بسنده عن بهز بن حكيم عن أبيه عن جده قال : قلت: يـا رسول الله عور اتنا ما نأتي منها وما نذر؟ قال: احفظ عورتلك إلا من زوجتلك، أو مـا ملكت يمينك قلت : يا رسول الله إذا كان القوم بعضـهم مـع بعض ؟ قـال إن استطعت

ألا ير اها فافعل قلت:الرجل يكون خاليا قال : فالله أحق أن يستحيا منه الناس('). وقد حذر النبـي صـلى الله عليـه وسـلم مـن التعـري عنــ الجمـاع إلا مـا دعت الضرورة إليه وأرشد إلى التستر فعن ابن عمر رضى الله عنهما أن رسول الله صلى الله عليه وسلم قال إياكم و التعري فـإن معكم من لا يفارقكم إلا عند الغـائط وحين يُفضى الرجل إلى أهله فاستحيوهم و أكرموهم (؟).

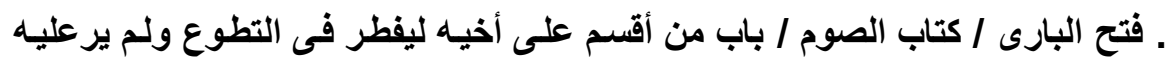

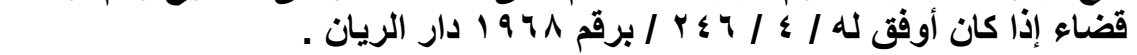

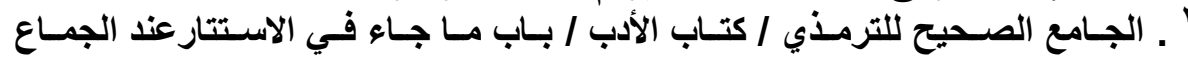

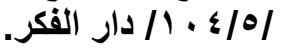


Y ـ التسـمية: يســـب للرجل إذا أراد أن يجـامع أهلـه أن يبـدأ بـذكر اسـم الله تعـالى

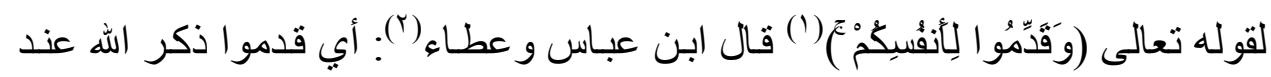

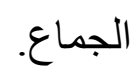
وقد روى البخاري(") بسنده عن ابن عباس رضى الله عنهما قال: قال النبي صلى الله عليه وسلم: أما لو أن أحدهم يقول حين يأتي أهله: بسم الله اللهم جنبني الثبطان وجنب الثيطان ما رزقتنا ثم قُر بينههـا في ذلك ، أو قضى ولد لـ يضره شيطان

rـ النهى عن التحدث بما يكون بين الزوجين حال المسيس. أوجب الإسلام على الزوجين أن يكتما ما يحدث بينهما حال الجماع وحَّرم عليهـا نشر ما يحدث بينهما من قول أو فعل لما يترتب عليه من الفضيحة، وقد نهَّر رسول

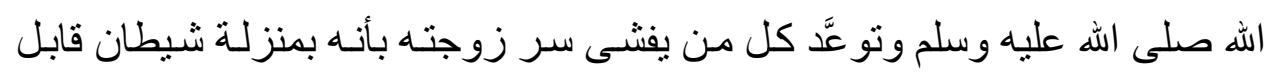
شيطانة على الطريق فقضى حاجته منها و الناس ينظرون . فقد أخرج الإمام مسلم في صحيحه(؛)عن أبى سعيد الخدري قـال: قال رسول الله صلى الله عليه وسلم: إن من أشر الناس عند الله منزلة يوم القيامة الرجل يفضى إلى الى امر أنه وتفضى إليه ثم ينشر سرها. وروى أبو داود في سننه بسنده عن أبى هريرة رضى الله عنه قال: صنَّلى رسول

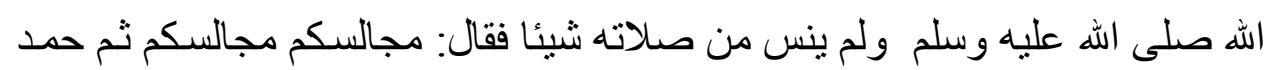
الله و أثنى عليه ثم قال: أما بعد: ثم أقبل على الرجـال فقال: هل منكم الرجل إذا أتى

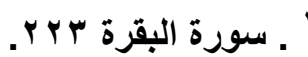

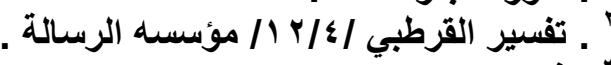

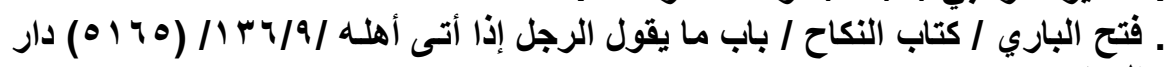

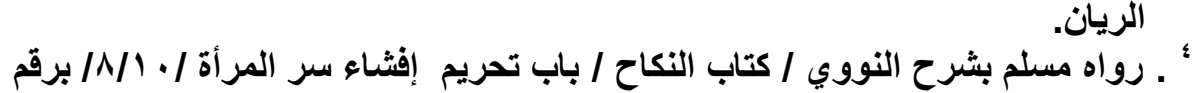

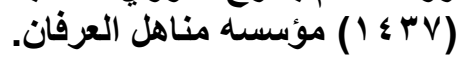

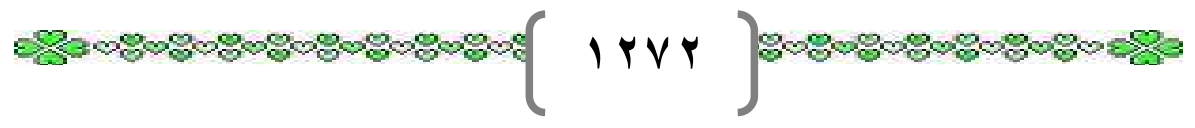


أهله فأغلق عليه بابه وألقى عليه ستره واستتر بستر الله قالو ا: نعم، قال: ثم يجلس بعد ذلك فيقول فعلت كذا، فعلت كذا قال: فسكتو ا قال: فأقبل على النسـاء فقال: هل منكن من تُحدّت؟ فسكتن، فجثت فناة على إحدى ركبتيها وتطاولت لرسول الله صلى الله عليـه وسـلم لير اهـا ويسـع كلامهـا فقالت: يـا رسـول الله إنهم ليتحدثون، و أنهن ليتحدثن، فقـال: هل تدرون مـا مَثنل ذلك؟ فقال: إنمـا مَتْل ذلك مَتْل شبطانة لقيت شيطانا في السكة فقضى منها حاجته و الناس ينظرون إليه('). لكن إذا دعت الضرورة والحاجة إلى ذكر الجماع ومـا يتعلق بـه، كما لو الَّهمت

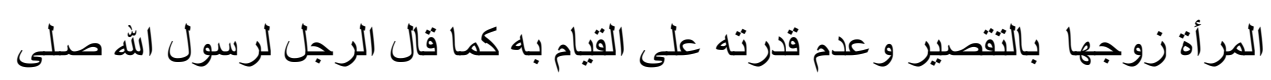

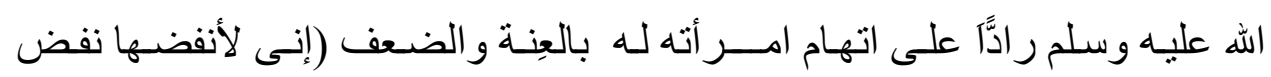

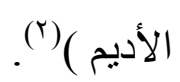
وكـذلك فـي التعلـيم ومعرفـة الأحكـام الثــر عية أخـرج الإمــام مسـلم فـي صحيحه(r)عن أم كلتوم عن عائشة زوج النبي صلى الله عليه وسلم قالت: إن رجلا سأل رسول اله صلى الله عليه وسلم عن الرجل يجـامع أهله ثم يكسل هل عليهــا الغسل؟ و عائشـة جالسـة: فقال رسول اله صلى الله عليه وسـلم: إنى لأفعل ذلك أنـا

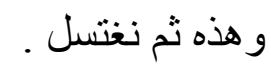
ع - عدم إتيان المرأة وهى حائض: من مقاصد الزواج و غاياته بقاء النسل ودوامهه و إتيـان المر أة ومجامعتها في حـال

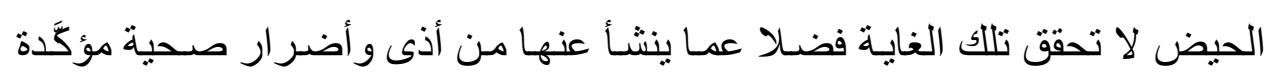

ـ سنن أبى داود / كتاب النكاح / باب ما يكره من ذكر الرجل ما يكون من إصـابته أهله

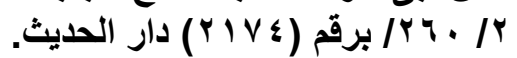

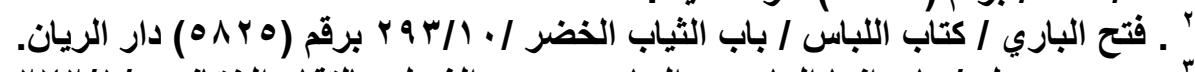

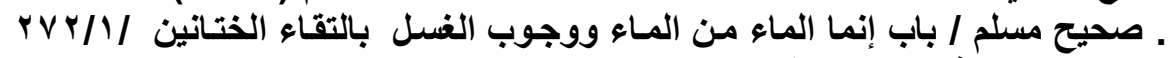
تحقيق محمد فؤاد عبد الباقي.

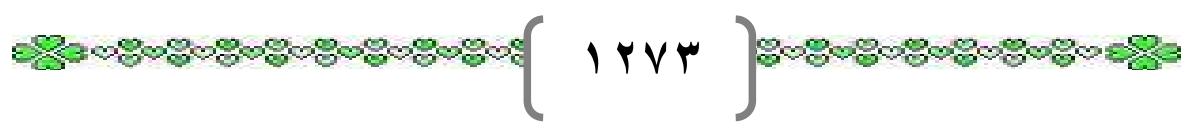


للمر أة و الرجل على السواء، ومن ثََّّ نهى الله تعـالى الرجال عن مباثـرة نسـائهم في المحيض حتى ينقطع الدم ويتطهرن بالمـاء، وأبـاح لهم أن يستمتعو ا بهن فيما دون

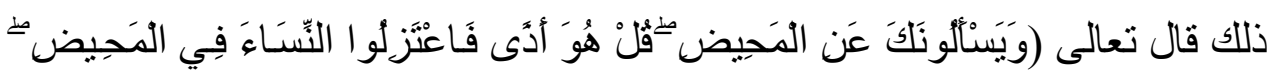

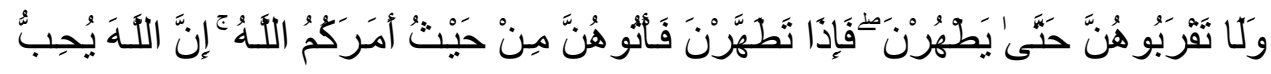

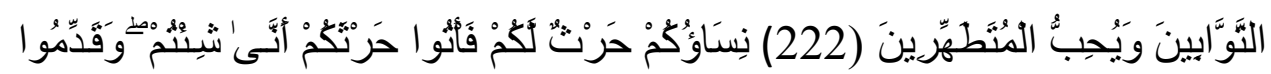

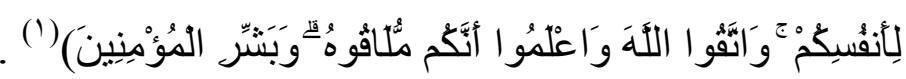
ذكر الإمـام السيوطي رحمـه الله تعـالى (؟) في سبب نزول هذه الآيـة عن أنس أن

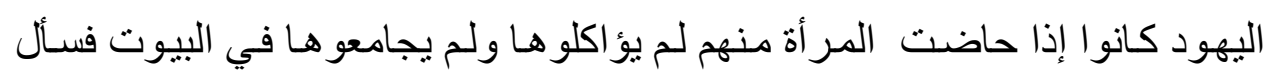
أصحاب النبي صلى الله عليه وسلم فأنزل الله (وَيَسنأكونَكَ عَن المَحِيض) الآيـة ، فقال صنعو ا كل شيء الا النكاح . قال الإمام النووي رحمه الله تعالى: اعلم أن مباشرة الحائض أقسام : -

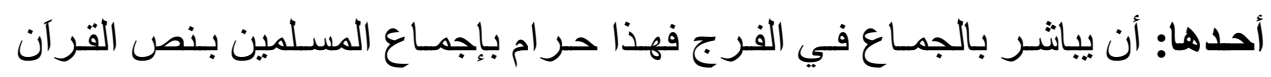
العزيز و السنة الصـحيحة، قـال أصـحابنا: ولو أعتقد مسلم حل جمـاع الحائض في فرجها صار كافر أ مرتدآ، ولو فعله إنسان غيره معتقد حله فإن كان ناسياً أو جـاهلا بوجود الحيض أو جـاهلا بتحريمـه أو مُكر هـا فلا إثم عليه و لا كفاره، و إن وطئها عامداَ عالمأ بالحيض و التحريم مختار آ فقد ارتكب معصية وتجب عليه التوبة . القسم الثاني: المباشرة فيما فوق السرة وتحت الركبة بالذكر ، أو القبلة، أو المعانقة،

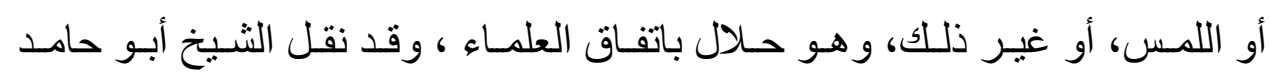

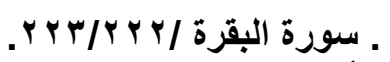

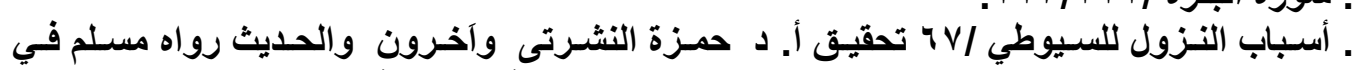

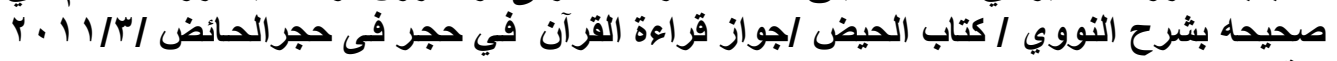

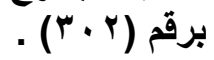




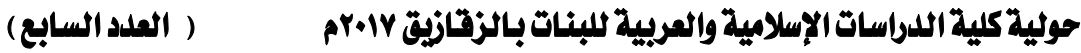

الإسفر اينى الإجماع على هذا ويؤيد هذا مارواه الإمام مسلم (')بسنده عن عبد الله بن شداد عن ميمونة قالت: كان رسول الله صلى الله عليه وسلم يباشر نساءه فوق الإزار وهن حُيَّض.

القسم الثالث : المباشرة فيما بين السرة والركبة في غير القبل والدبر فذهب البعض إلى الإباحسة إذا كان المباشـر يضبط نفسـه عن الفرج ويثق مـن نفسـه باجتتابـه إمـا

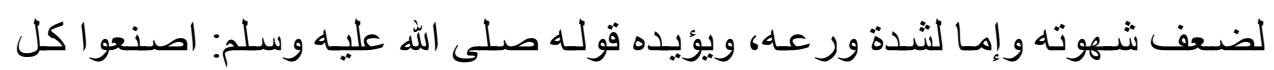
شيء إلا النكاح(؟). وذهب آخرون إلى الحرمة لقول عائشـة رضى الله عنها : و أيكم

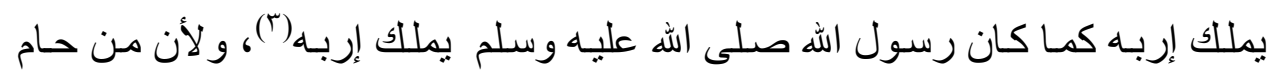
حول الحمى يوشك أن يقع فيـهـ وذهب قوم إلى أنها ليست بحر ام ولكن المباشـرة مكرو هة كر اهة تنزيه، وهذا الوجه أقوى من حيث الدليل وهو المختار (\&) أ. هـ ـ. أقول: الأولى أن يباشر الرجل الحائض وهى متزرة أخذا بالأحوطوسداً للذرائع.

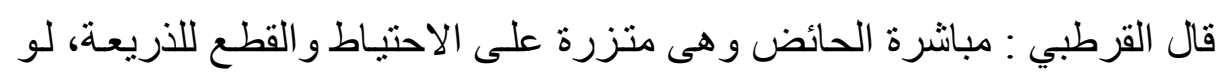

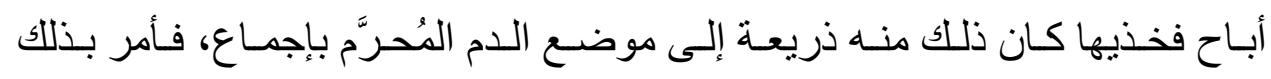

احتياطا، و المحرَّمُ نفسه موضع الدم فتتفق بذلك معانى الآثار و لا تضساد (0)

$$
\text { هـ تحريم إتيان المرأة في دبرها : }
$$

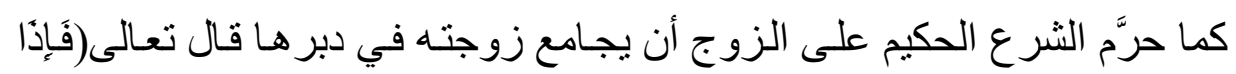

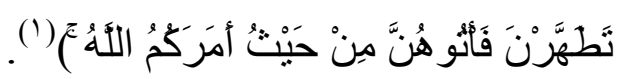

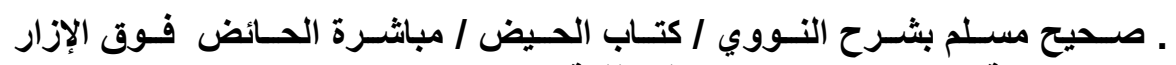

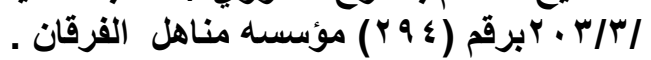

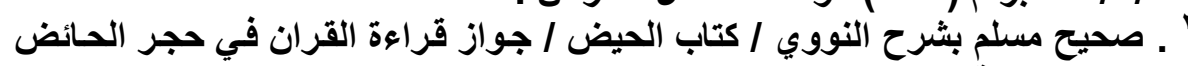
ا

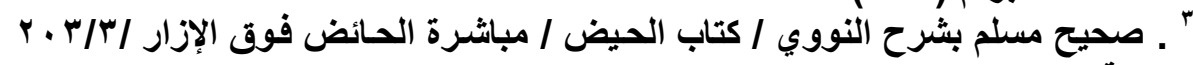

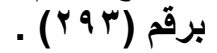

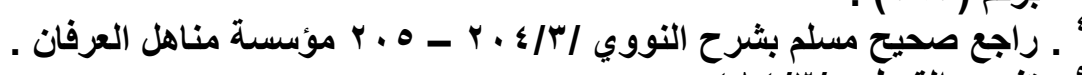

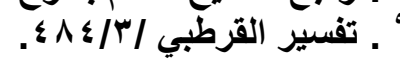




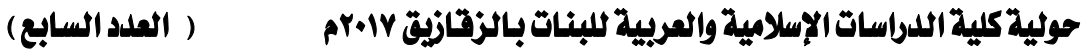

قال ابن عباس(؟) أي : في الفَرَج و لا تعدُوه إلى غبره فمن فعل شيئًا من ذلك فقد

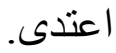

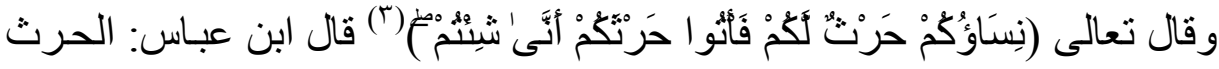

$$
\text { موضع الولا أى كيف شئتم مقبلة ومدبرة في صمام واحد(؛). }
$$

روى الإمام مسلم بسنده عن جابر بن عبداله أن يهود كانت تقول إذا أتيت المر أة من دبر ها في قبلها ثم حملت كان ولدها أحول قال : فأنزلت نسـاؤكم حرث لكم فأنو ا حرثكم أنَّى شُتتم وفى رواية : إن شاء مجبية وإن شاء غير مجبية غير أن ذلك في صمام و احد (0). و عليه فالدبر ليس بحرث ولا موضع زرع الولد فلا يجوز الوطء فيه. وقد جاء النهى والتحذير من هذا الأمر في سنة رسول الله صلى الله عليه وسلم فقد روى ابن ماجة بسنده عن أبى هريرة رضى الله عنه عن النبي صلى الله عليه وسلم قال: لا ينظر الله إلى رجل جامع امر أته في دبرها؟؟). وروى ابن ماجة أيضـا بسنده عن خزيمـة بن ثابت قـال: قال رسول الله صلى الله عليه وسلم: (إن الله لا يستحيى من الحق ) ثلاث مرات (لا تأتو ا النسـاء في أدبـارهن

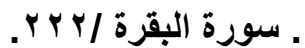

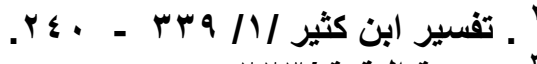

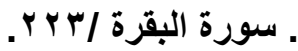

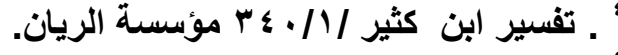

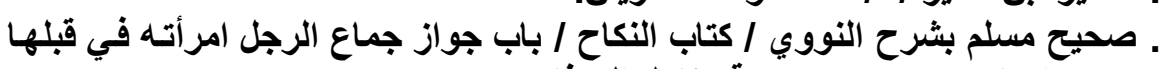

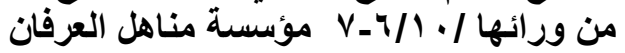

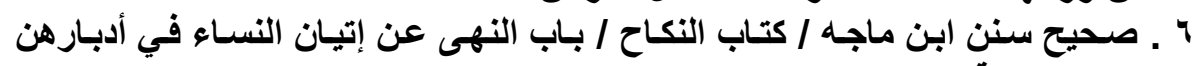

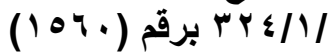

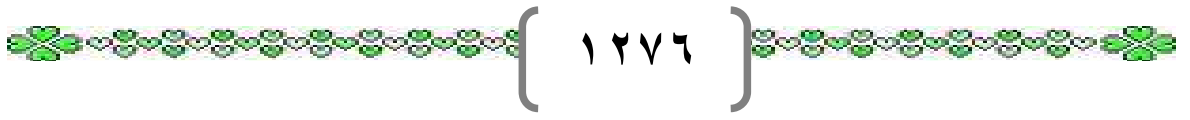




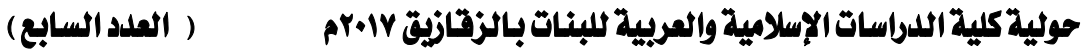

) ' ". وفى رواية الترمذي عن ابن عباس قال رسول الله صلى الله عليه وسـلم : لا ينظر الله إلى رجل أتى رجلا أو امر أة في الدبر . قال: أبو عيسى هذا حديث حسن غريب(؟).

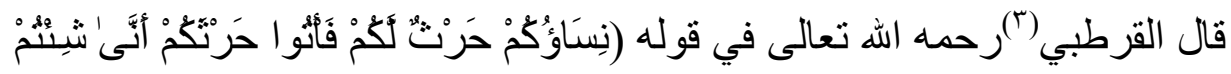
ت): هذه الآية نص في إباحة الحال و الهيئات كلها إذا كان الوطء في موضـع الحرث، أي كيف شـئتم من خلف ومن قدام وباركة ومستلقية ومضطجعة فأمسا الإتيان في غير المأتى فمـا كـان مباحسا ولا يبـاح، وذِكر الحرث يـدل على أن الإتيان في غير المأتى محرًّ، وقد حرم الله تعـالى الفرج في حـال الحيض لأجل النجاسـة العارضــة

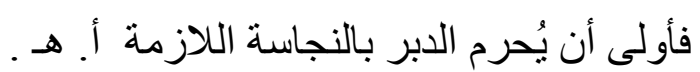

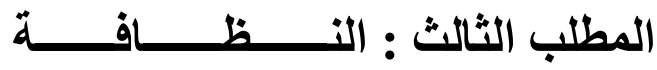

من الأمور التي يجب على كلا الزوجين الاهتمـام بها أن يعتتى كل واحد منهــا

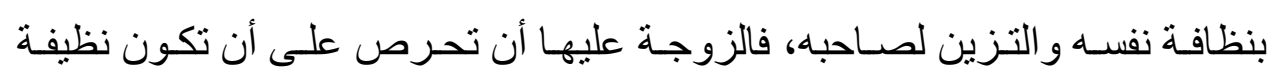
جميلة في كل سـجاياها، فمظهر هـا جميل، وريحها طيب، وكلامها رقيق، وفعلهـا حسن، وأن يكون ذللك من الزوجين معأ. و النظافة في المر أة تزيدها جمالا إلى جمالها، فكم من نظيفة محبوبـة إلى زوجها، وكم من جميلة مبغوضة عند زوجها، ومن هنـا شرع الإسـام الاستنجاء و الوضوء

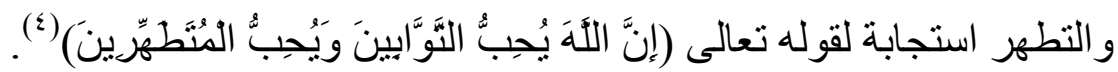

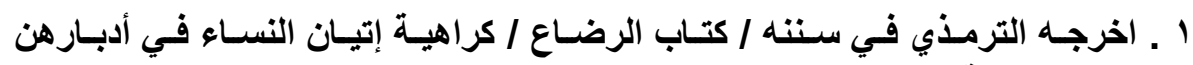

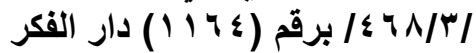

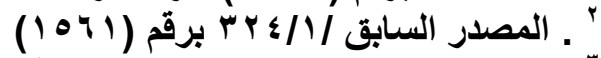

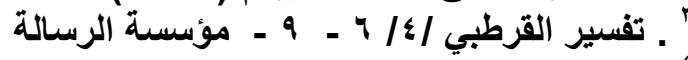

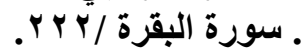


ومما يدخل في باب النظافة حلق العانة، ونتف الإبط، وتقليم الأظفار ، وهذه من سنن الفطرة التي فطر الله الناس عليها، قال صلى الله عليه وسلم (خمس من الفطرة الخِتان ، وحلق العانة ، وتقليم الأظفار ، وقص الثارب، ونتف الابط)(').

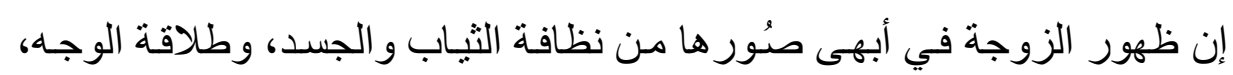

و ابتسامة الثغر، يجعلها تحوز قلب زوجها ورضاه عنها فلا يلتفت إلى غيرهاب(؟).

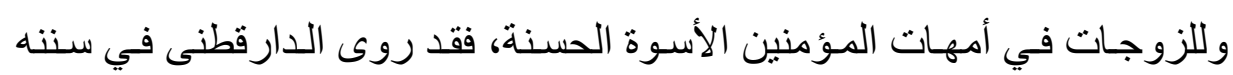
بسنده عن عبداله بن شـداد أنه قـال: دخلنـا على عائشـة زوج النبي صلى الله عليه وسلم فقالت: دخل علىَّ رسول الله صلى الله عليه وسلم فر أى في يدها فتخات(") من ورَرق فقال ما هذا با عائشةُ؟ فقلت: صنعتهن أتزين للك فيهن يـا رسول لله صلى الله

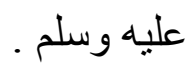
وقد بينت إحدى النساء على عهد رسول الله صلى الله عليه وسلم أن الزوجـة التي تهمل نظافتها وزينتها لزوجها تقل رغبته فيها و إقباله عليها . فقد روى الإمام النسائي في سننه عن أبى هريرة رضى الله عنه قال: كنت قاعداً عند النبي صلى الله عليه وسلم وأتته امر أة فقالت يا رسول الله إن المر أة إذا لم تتزين لزوجها صتَفت عنده)(؛) أي قل خير ها عنده و إقباله عليها.

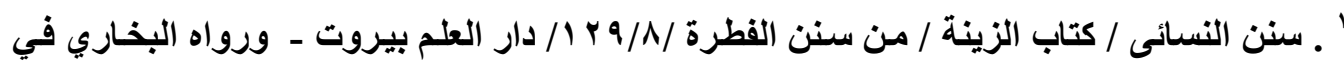

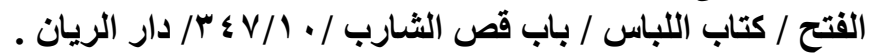

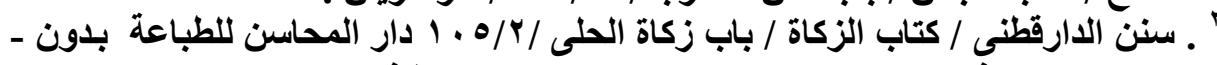

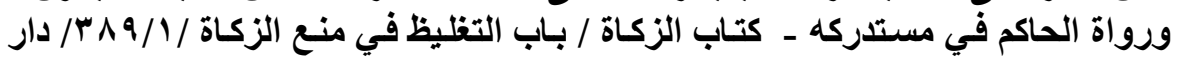

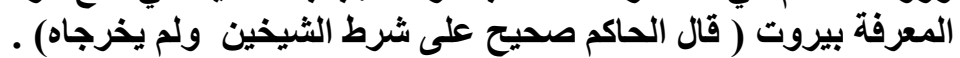

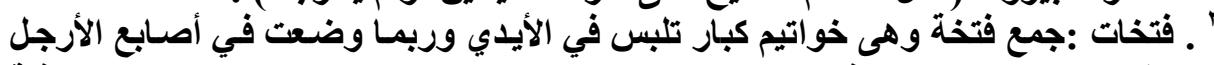

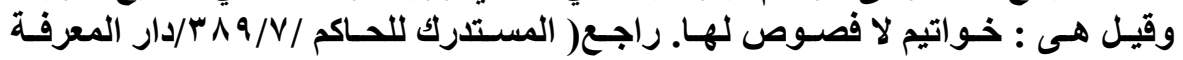

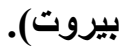
" . سنن النسائي بشرح جلال الدين السيوطي / كتاب الزينة / الكراهية للنساء إظهار الحلى الكى والذهب /1/ 9 ه ه / دار القلم بيروت .

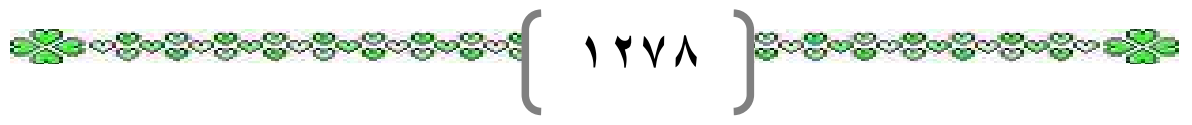




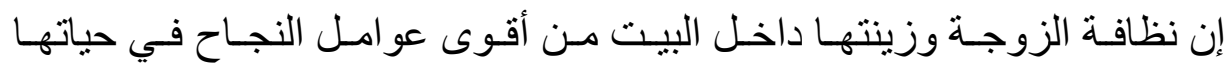
الزوجية، ومن الأمور المهــة التي يجب على المـر أة أن تعتنى بها ، هوأن تغتسل

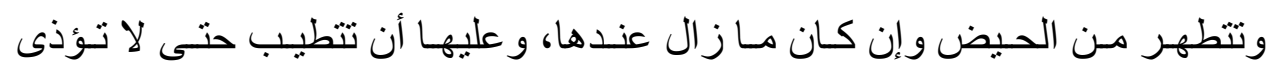
زوجها بر ائحة دم الحيض. فقد روى البخاري في صحيحه بسنده عن عائشـة أن امر أة سألت النبي صلى الله عليه وسلم عن غسلها من المحيض فأمر ها كيف تغتسل قال: خذي فرصسة من مسنك فتطهري بها قالت: كيف أتطهر؟ قال: تطهري بها قالت كيف؟ قـال: سبحان الله تطهري، فاجتذبئها إلى فقلت تتبعي بها أثر الدم ('). و المقصود من استعمال الطيب كما هو وارد في الحديث لدفع الر ائحسة الكريهة، ولتعلم المر أة أن استعمالها الطيب إنما يكون لزوجها وبيتها ويَحْرم عليها أن تتطيب عند خروجها مـن البيت ومخالطتها الرجال، لأن ذلك يدعو للفتنـة ويدفع ضـعاف الإيمان للتعرض لها، وقد حذر رسول الله صلى الله عليه وسلم من ذلك.

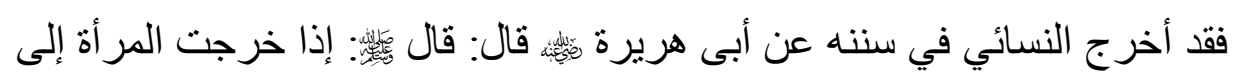
المسجد فلتغتسل من الطيب كما تغتسل من الجنابة(؟). و عن زينب امر أة عبد الله قالت: قال رسول الله صلى الله عليه وسلم إذا ثـهدت إحداكن العشاء فلا تمس طيباَ"). فإذا كان هذا النهى عن مس الطيب وهى خارجة إلى الصلاة فمن باب أولى وهى خارجة لقضاء حو ائجها لأن الفتنة منوقعة.

ـ فتح الباري / كتاب الحيض / باب دلك المرأة نفسها إذا تطهرت من الحيض / / ـ ؟ ؛ ؛

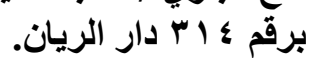

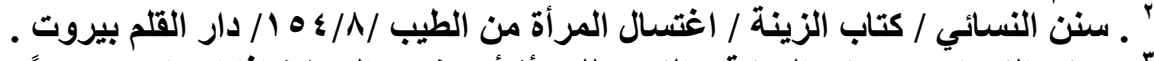

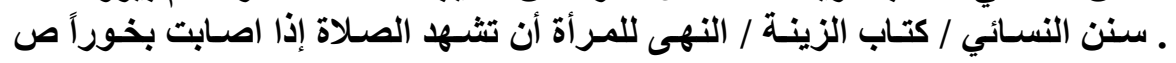

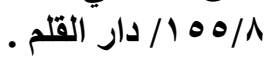

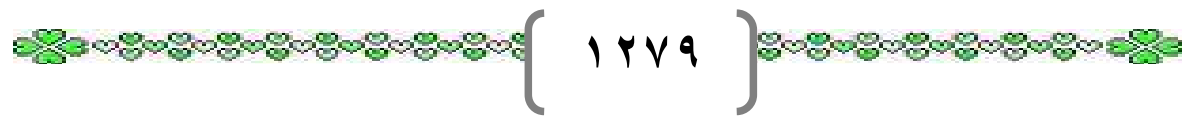


ومن الزينـة المستحبة للزوجـة الكحل، فإنـهـ يُجلى العين ويُظهر المر أة في أبهى

صورة، مما يجعل الرجل يستزيد من النظر إليها ويُسر برؤيتها.

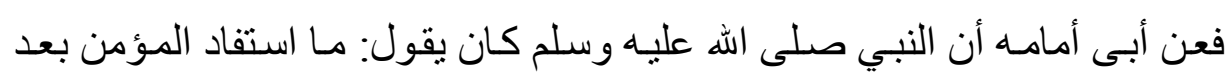

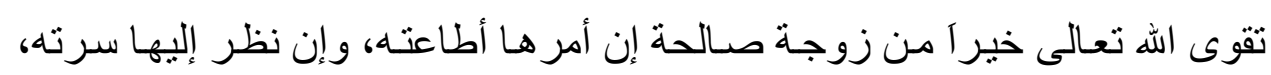

و إن أقسم عليها أبرته، و إن غاب عنها حفظته في نفسها وماله ('). و عن ابن عباس رضى الله عنهما أن رسول الله صلى الله عليه وسلم قال: إن من

خير أكحالكم الإثمد إنه يجلو البصر وينبت الثعر (r). و لا مـانع للزوجـة مـن طـلاء أظـافر يـديها ورجليهـا بالحنـاء و غير هـا مـن أدوات الت الزينة، وترجيل شعر ها لنُحبب لزوجها المقام في البيت وئدخل عليه السرور. فقد روى النسائي بسنده عن أبى هريرة رضى الله عنه قال: قال رسول الله صلى الله عليه وسلم: طِيب الرجال ما ظهر ريحه وخفى لونه. وطيب النساء ما ظهر لونـه وخفى ريحه كالحناء و الز عفران.

و عن أبى داود(ّ) عن عائشـة رضى الله عنها قالت: أومد امر أة من وراء ستر بيدها كتاب رسول الله صلى الله عليه وسلم فقبض النبي صلى الله عليه وسلم يـده فقال: ( ما أدرى أيد رجل أم يد امر أة ) قالت: بل امر أة قال ( لو كنت امر أة لغيرت أظافرك ) بعنى بالحناء، هذا إذا أر ادات المر أة الخروج، أما عند زوجها وداخل بيتها

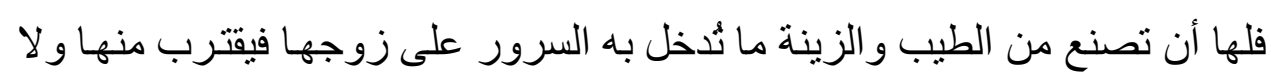
يلتقت إلى غير ها .

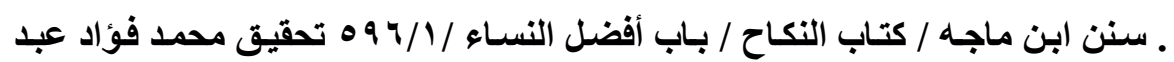

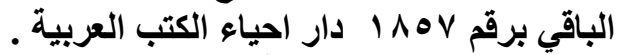

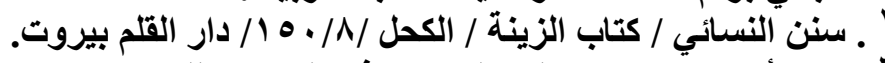

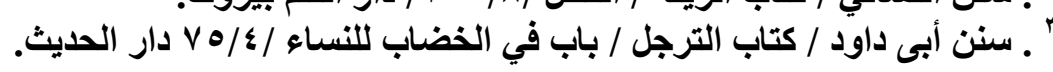




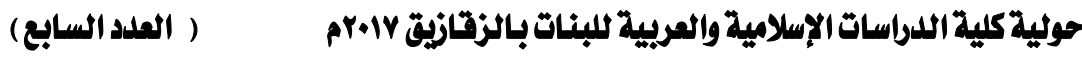

أما الزينة المحرمة فلا يجوز للمر أة أن تفعلها لأنها من إغو اء الثبطان كالنمص و الوشم وتقليج الأسنان .قال تعالى حكايـة عن الثيطان الرجيم وهو يتو عد بنى آدم

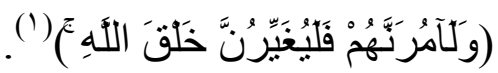

قال القرطبي رحمه الله تعالى: قالت طائفة: الإشارة بالتغيير إلى الوشـم ومـا جرى (بـ

مجر اه من التصنع للحسن قاله ابن مسعود و الحسن(؟). وفى سنة رسول الله مسـعود رضـى الله عنـهـهــال : لعـن الله الواشـمات و المستوشـمات و المتنمصــات و المتقلجات للحسن المغير ات خلق الله تعالى مالي لا ألعن من لعنه رسول الله صلى الله عليه وسلم و هو ملعون في كتاب اله(ّ). قال النووي: يستثنى من النمـاص مـا إذا نبـت للمر أة لحيـة أو شـارب أو عنقةـة فـلا يحرم عليها إز التها بل يُستحب . بئ. وذهب كثثير من الفقهاء إلى منع وصل الشعر بالثعر ، أمسا إذا وصلت شعرها من غير الشعر من خرقة و غير ها فلا يدخل فى النهى، وذهب الجمهور فمنعواو وصل الشعر بشيء أخر سواء كان شعر آم لأ) أ. فعن عائشة رضي الله عنها أن جارية من الأنصار تزوجت و أنها مرضت فتمعَّط

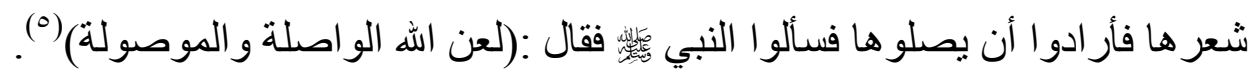
وروى أبو داود: بسنده عن سعيد بن جبير قال :قال : لا بأس بالقر امل (`).

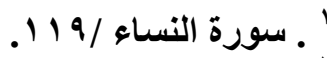

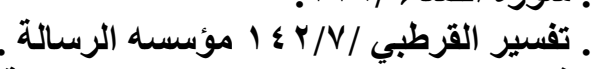

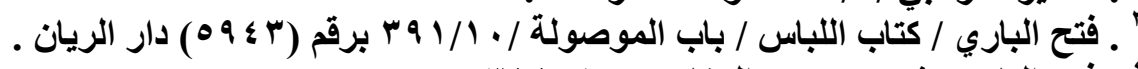

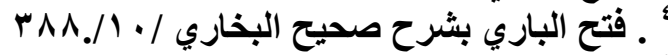

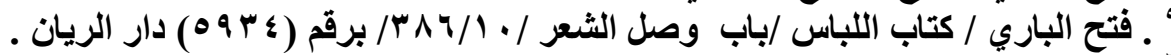

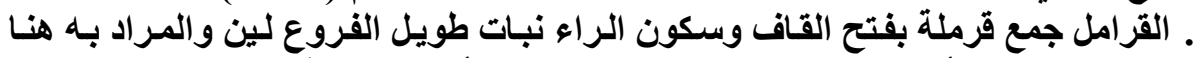

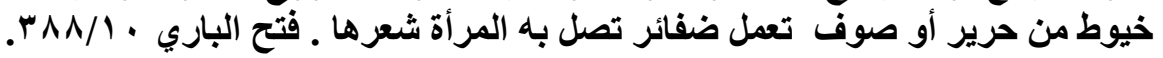


قال أبو داود: كأنه يذهب إلى أن المنهي عنه شعور النساء، وقال : كان أحمد يقول

: القر امل ليس به بأس (') :

و على الرجـال كذلك أن يتفقدو ا أنفسهم بنظافـة البدن و التجمـل و التزين باللبـاس

الحسنة و الطيب و غير ذلك ممـا يليق بالرجل المؤمن ، و القرَن الكريم يُرشـنـا إلى لـ

ذلك قال تعالى (ولهن مثل الذى عليهن بالمعروف ).

فعن ابن عباس رضى الهه عنهما أنه قال: إنى لأتزين لامر أتي كما تتزين لي (؟) لقوله تعالى ( ولهن مثل الذى عليهن بالمعروف ).

و لأهمية السو اك في نظافة الفم فـإن رسول الله صلى الله عليه وسلم قد حـث كلا

الزوجين على استعماله و العناية بـه و تتظيفه.

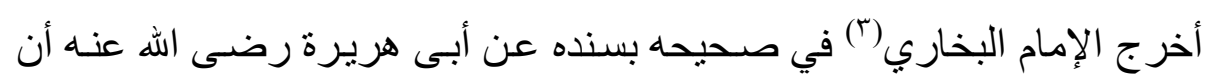

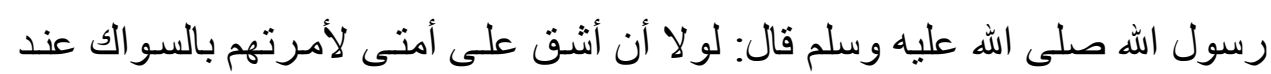

كل صلاة.

و أخرج البيهقي في سننه بسنده عن عائشـة رضسى الله عنه قالت: كان رسول الله

صلى الله عليه وسلم يستاك فيعطيني السو اك فأبدأ به فأستالك ثم أغسله و أدفعه أليه(؛).

ومن النظافة التي يجب على الأزواج أن يقومو ا بها إكر ام الشعر بغسله، وترجيله، و غسل الوجه و الجسم، وتطبيبه وقص الأظفار و الختان .

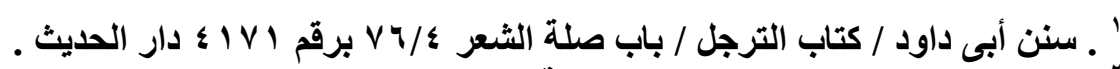

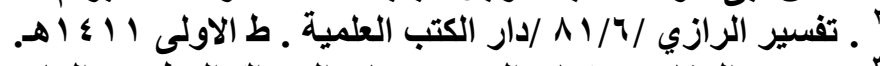

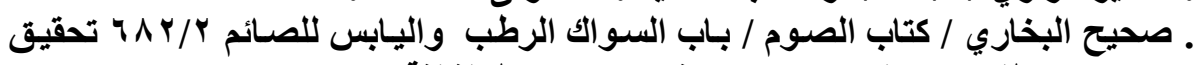

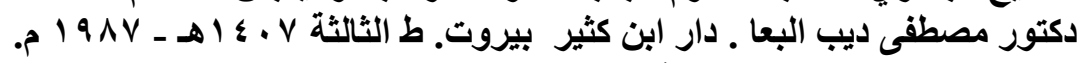

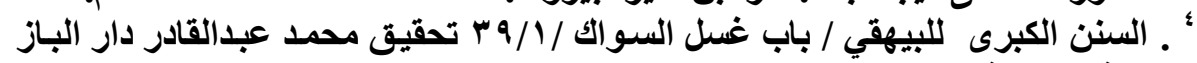

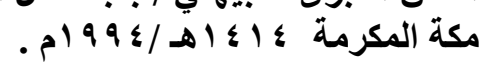

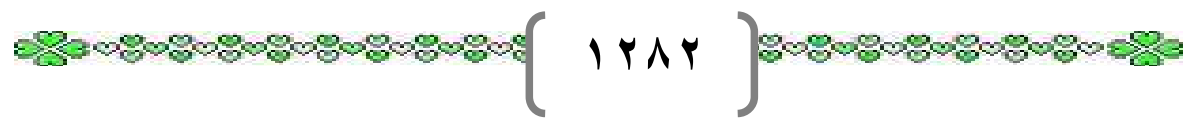




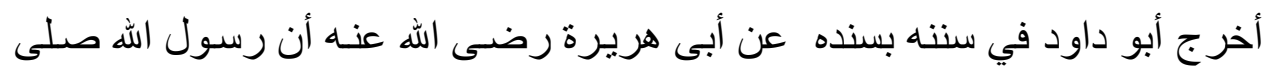
الله عليه وسلم قال: (من كان له شعر فليكرمه) (').

وقد كانت السيدة عائشة رضى الله عنها تطيب رسول الله صلى الله عليه وسلم. ففي صحيح البخاري عن عائشة رضى الله عنها قالت كنت أطيب النبي صلى الله عليه وسلم بأطيب ما يجد حتى أجد وبيض الطيب في رأسه ولحيته(؟). وكانت رضي اله عنها تأمر النساء بأن يأمرن أزواجهن بإز الة أثر البول والغائط بالماء. فقد روى الترمذي() بسنده عن عائشـة رضـى الله عنها قالت: مرن أزو اجكن أن يستطيبو ا بالماء فإني أستحيهح فإن رسول الله صلى الله عليه وسلم كان يفعله.

\section{المطلب الرابع : ثبوث النسب}

مـن الحقوق المشـتركة بين الزوجين ثبوت نسـب الأو لاد إليهــا، فـالأولاد ثــرة

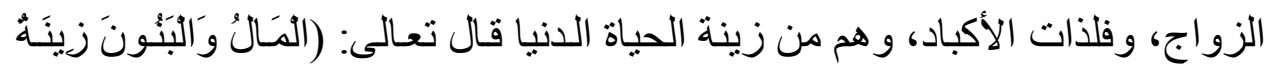

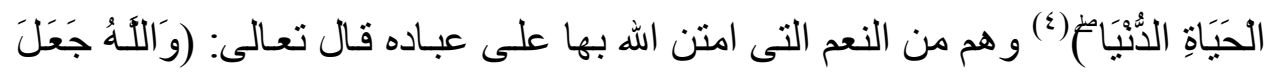

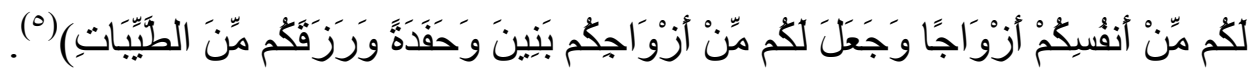
ومن هنا أمر الإسـام بصيانة النسب من الضياع و العبث و الكذب، و عدم تركه ونه لأهو اء من يدَّعونه أو ينفونه. فإذا تم العقد صحيحا وحدث الإنجاب بين الزوجين فقد

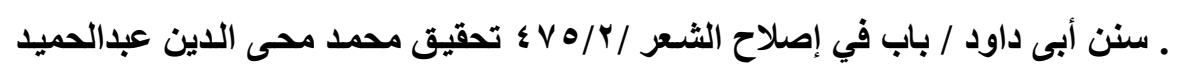

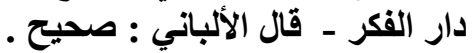

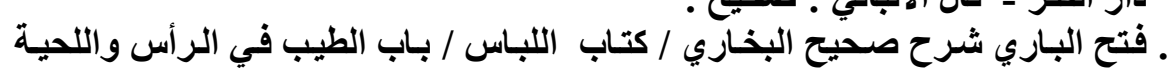

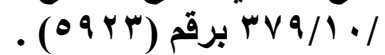

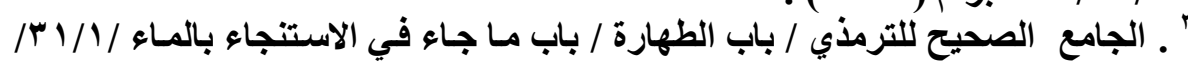
برقم (9 (19) دار الفكر.

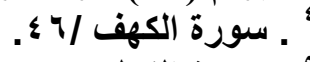
. سورة النحل / س الكورك. 


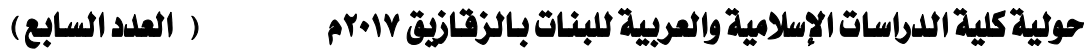

ثبت نسب المولود إليهما، فلا يصح لأحد أن يحرمهما من ذللك كما لا يجوز لأحدهما

أن يحرم الأخر منه ، و لا يجوز لهما أن يتنازلا عنه حتى لا يضيع حق المولود (').

ويتعلق بالمولود عدة حقوق :-

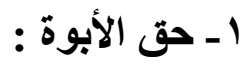

إن اقتـران الرجـل بـالمر أة عـن طريـق الـزواج الثـرعي وتكـوين الأسـرة بضــن للأبناء الانتساب إلى آبائهم ممـا يشـعر هم بقيمة ذواتهم وكر امتهم الإنسـانية ، فالولد فرع من شجرة معروفة الأصل و المنبت، وبهذا يرجع كل فرع إلى أصله فيسعى للمحافظة عليه نقيأ طاهر آعفيفاً فيعتز به ويفخر. ولو لا هذا التنظيم الربـاني لجموع البشرية لتحولت المجتمعات إلى أمشاج وأنواع لا تعرف رابطة النسب و لا يضمها كيان ـ ولغدا الناس كالبهائم يهيمون في كل و اد. إن ثبوت نسب الولد الى أبيه يترتب علية ثبوت و لاية الأب عليه مما يوجب النفقة

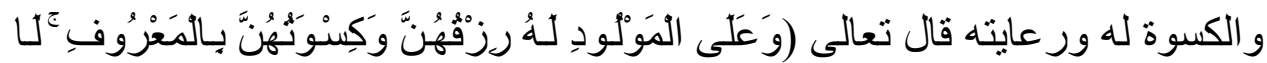

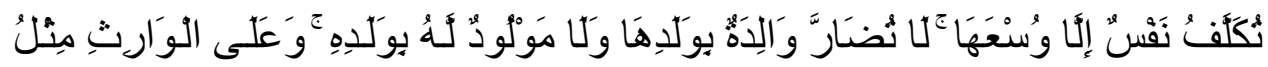

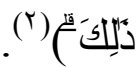

أخرج البخاري في صحيحه عن ابن عمر أن رسول الله صلى الله عليه وسلم قال (كلكم راع وكلكم مسئول عن ر عيته)(").

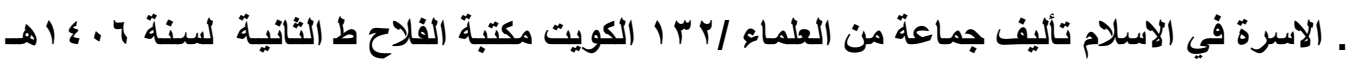

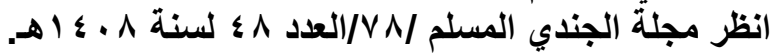

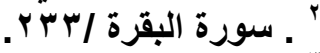

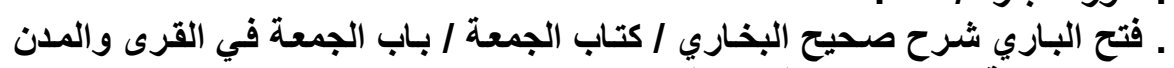

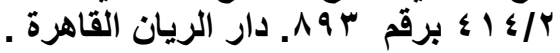




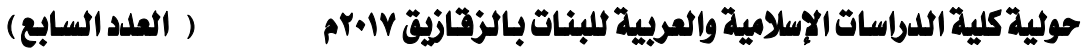

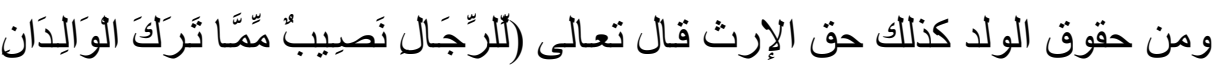

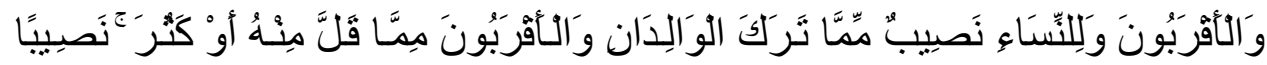

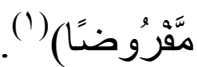

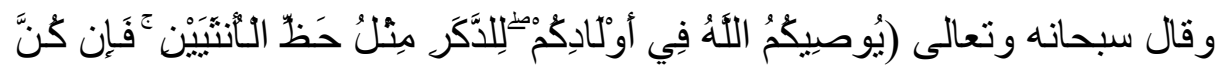

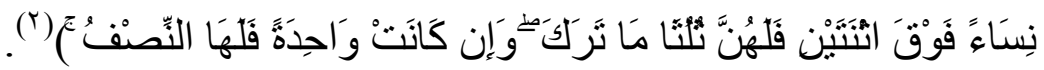
فقد بينت الآيـة الكريمـة أن الابن يرث بطريق التعصيب فيأخذ التركة كلها إذا انفرد ولم يوجد وارث غيره، فإن كانو ا أكثر من واحد ذكور أ قسمت بينهم التركة بالتسـاوي، و إن كانو ا ذكورَّ و إناثـا فللبنت سـهم ولإبـن سـهمان وليس هذا تحيزا للأكور أو ظلما للإناث معاذ الله، لكن الحاجة وظروف كل منهمـا هي التي اقتضت هذه القسمة فالولد يتكلف تكاليف لا تلزم بها البنت كدفع المهر وتأثيث بيت الزوجية و الإنفاق على الزوجـة و الأو لاد، أمسا أختـه فإنها تأخذ مير اثها ملكا خالصـا لها غير منقوص وهو القائم على أمرها.

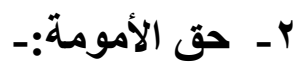

فمن حق الولد أن تكون له أمأ تقوم على ر عايته وصيانته من الضياع ويثبت له

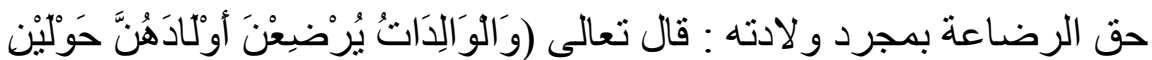

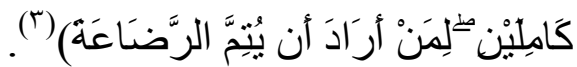
و النص و إن كان واردًا بصيغة الخبر إلا أنه في معنى الأمر الدال على الوجوب(ء). وكذلك حق الحضانة و الإرث، فالطفل يحتاج إلى العناية به و القيام بشئونه منذ و لادته من تربية ونظافة وتمريض ومعاونة في المأكل و المشرب

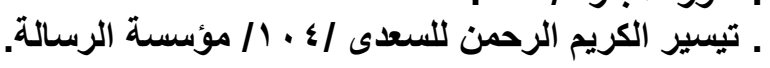


و الملبس، وهو ما يطلق الفقهاء عليه بـ ( الحضانة ) فهي حق للصغير وواجب على الأم و هى أحق الناس به و أقدر هم على حضانته لما جُبلت عليه من مشاعر الحنان و الثفقة، والقدرة على التحمل والصبر ، ومن هنا أعطاها الإسلام ثلاثة أرباع البر. روى الإمام البخاري في صحيحه عن أبى هريرة رضي الله عنه قال: جاء رجل

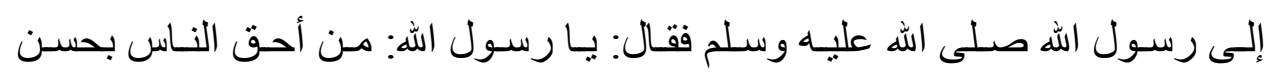
صحابتي؟ قال: أمك. قال: ثم من؟ قال أملك، قال ثم من؟ قال: أمك ـ قال ثم من؟ قال:

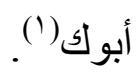

r- حق الرضاعة والسكن والنفقة: من الحقوق الواجبـة للمولود حق الرضـاعة والسكن و النفقة إلى أن يستطيع إعالة

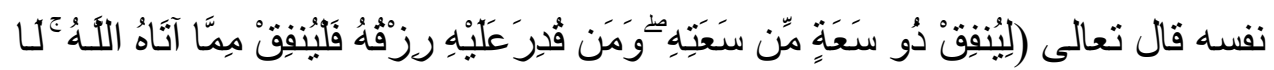

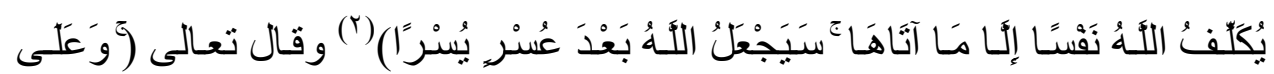

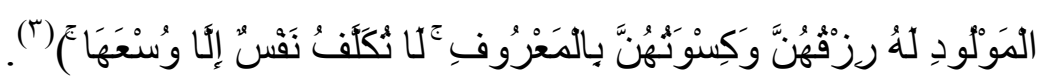
روى الإمام البخاري في صحيحه.بسنده عن عائشة رضي الله عنها ( أن هند بنت عتبه قالت: با رسول الله إن أبا سفيان رجل شحيح وليس يعطيني مـا بكفيني وولدي إلا ما أخذت منه وهو يعلم فقال: خذي ما يكفيك وولاك بالمعرف(ع). وتتضــن النفقـة بالإضـافة إلـي المأكل و المشـرب و الملبس و العـلاج نفقـة التربيـة و التعليم في جميع المر احل

ـ فتح الباري شرح صحيح البخاري / كتاب الأدب / باب من أحق الناس بحسن الصحبة

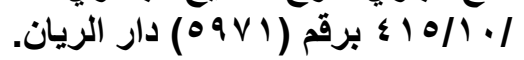

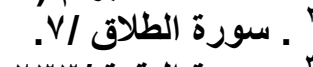

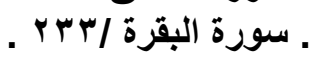
" فتح الباري بشرح صحيح البخاري / كتاب النفقات / باب إذا لم ينفق الرجل فلامر أمة أن تأخذ

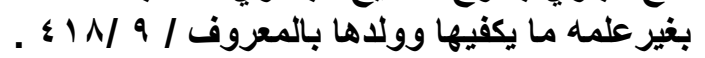
برقم ع بهاه دار الريان.

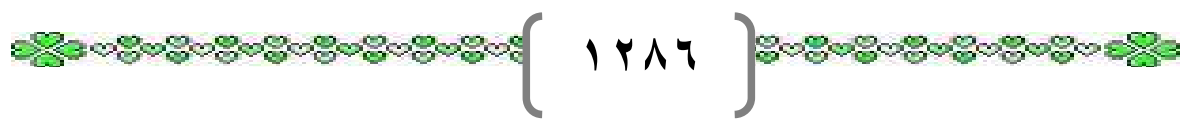




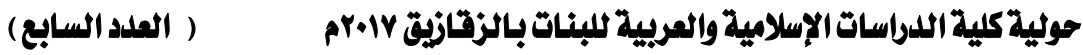

\section{المطلب الخامس: التوارث}

من الحقوق المشتركة بين الزوجين حق الإرث فيرث الزوج زوجته بعد وفاتها كمـا تـرث الزوجـة زوجهـا بعـد وفاتـه، وذللك إذ تـو افرت شـروط الميـراث و انتفـت مو انعـه الشـر عية، قال تعـالى مبينـا الأنصبة المستحقة للكل من الزوجين في كتابـه

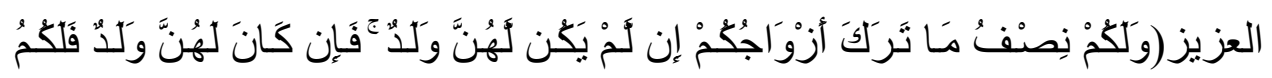

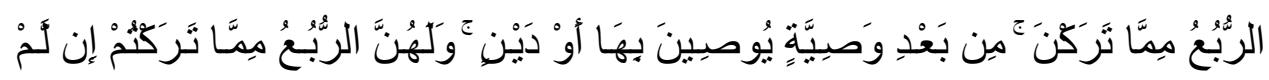

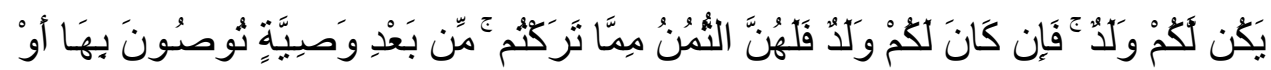
(') دَيْنِ)

فقد بين الله تعـالى في الآيـة الكريمـة نصيب الزوج في حسال موت زوجته فله

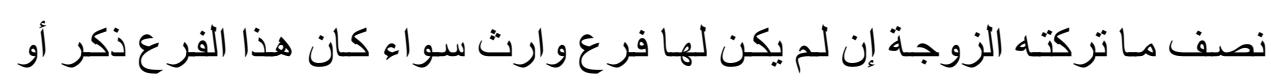

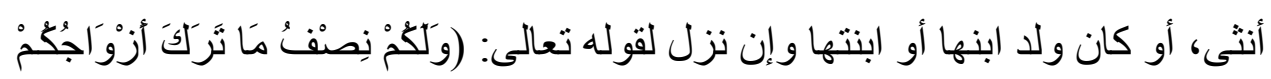

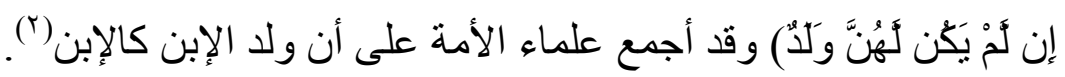
أما إذا كان للزوجة فرع وارث من زوجها أو من رجل آخر فحق الزوج حينئذ

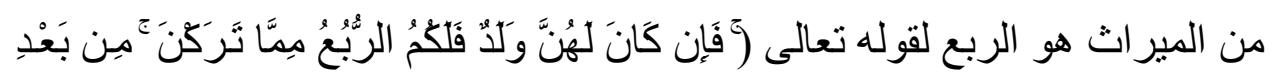

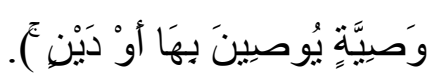

وحق الزوجة في ميراث زوجها بعد موته ربع ما ترك إن لم يكن لـه فرع وارث

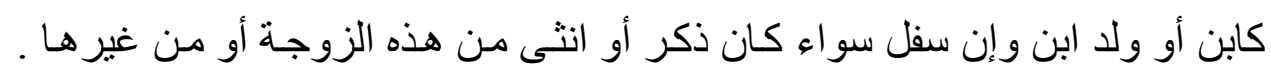

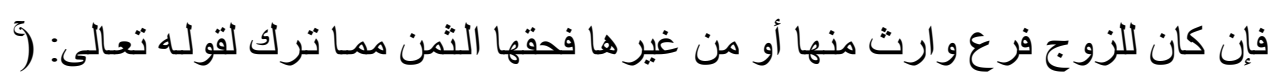

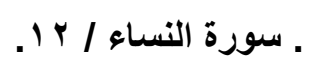

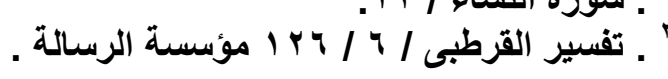




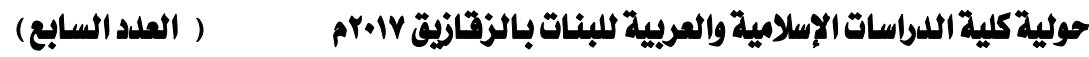

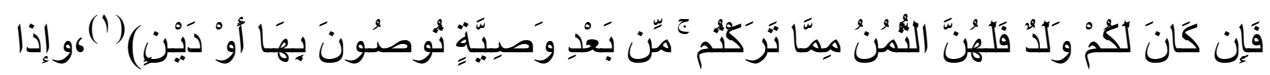
توفى الرجل وترك أكثر من زوجة له فالربع أو الثمن بقسم بينهن بالسوية.

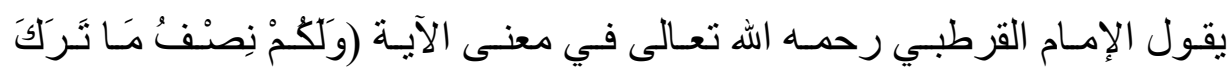

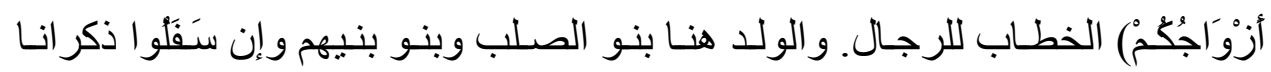

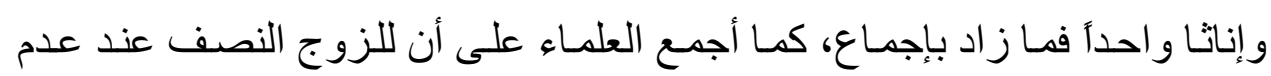

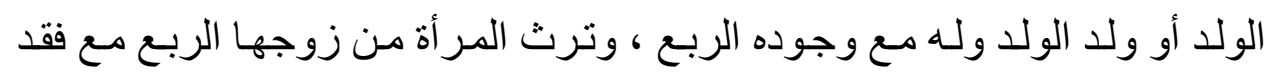
الولد، و الثمن مـع وجـوده، و أجمعو ا على أن حكم الو احدة مـن الأزواج و الثنتين و الثلاث و الأربع في الربع إن لم يكن له ولد. وفى الثمن إن كان لـه ولد و احد و أنهن شركاء في ذللك، لأن الله تعالى لم يفرق بين حكم الواحدة منهن وبين حكم الجميع كما

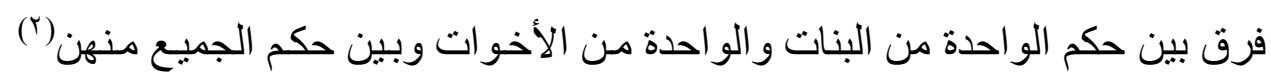

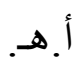

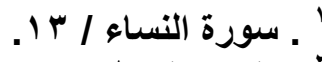

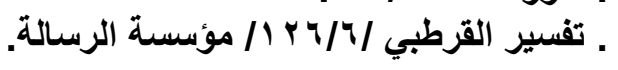




\section{الخاتمة:}

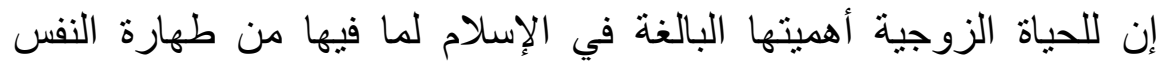
و القلب، و عفة الجسد، وصيانة العرض و الثرف، ولنة وبقاء النوع، وحفظ الأنساب،

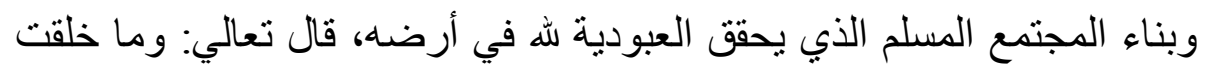
الجن و الإنس إلا ليعبدون) من هنا بين القرآن الكريم أن العلاقة بين الزوجين في إطار الأسرة إنما قصد

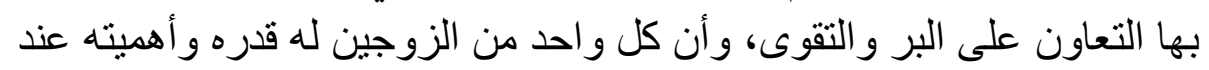

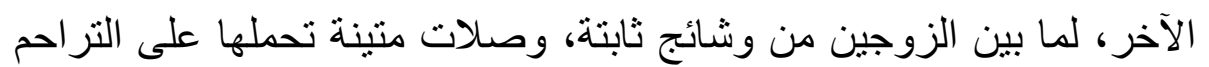

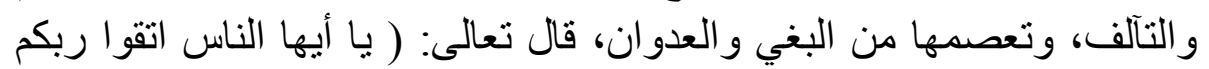

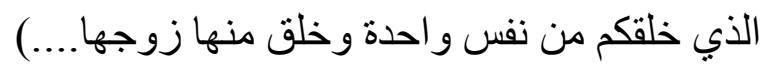

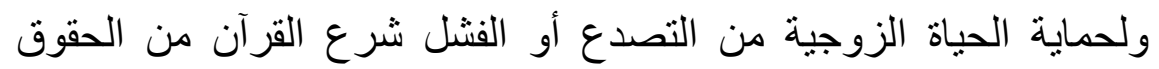

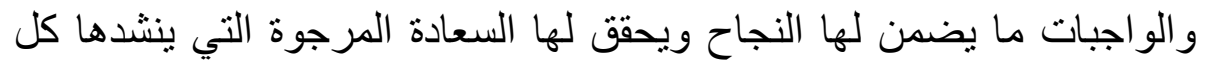
من الزوجين و المجتمع المسلم كله. قال تعالي: "ولهن مثل الذي عليهن بالمعروف ولالرجال عليهن درجة والله عزيز حكيم". فهذه الآية الكريمة بمثابة دستور شامل يجمع في طياته قوانين العلاقة بين

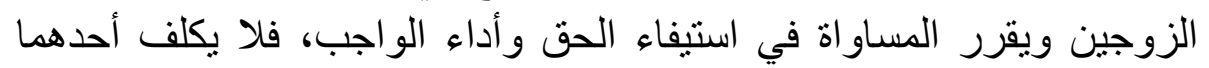
صاحبه ما ليس له، و لا يبخسه من حقه شيئا.

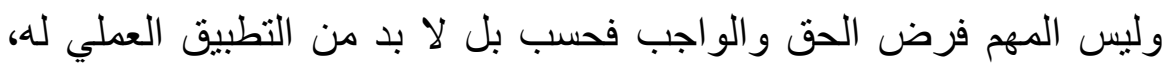

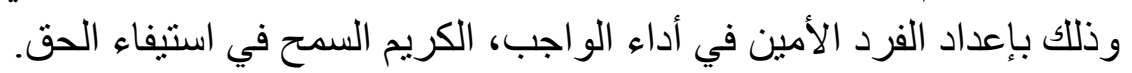

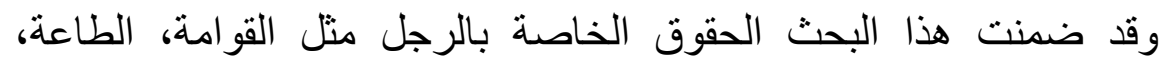

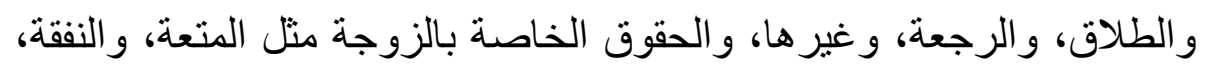

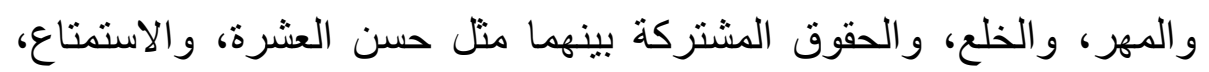
و الإر 


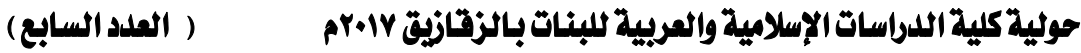

\section{فهرس المصادر والمراجع.}

أولا: القرآن الكريم.

ثانيا: مصادر التفسير وعلوم القرآن.

1 ـ أحكام الفرآن للجصاص، تحقيق محمد الصادق قمحاوي، طـ دار إحياء

$$
\text { التر اث العربي. }
$$

r- بدائع التفسير الجامع لتفسير الإمام ابن القيم ، جمع وتخريج: يسري السيد محمد، طا، ع إعا اهـ. ب99 ام، دار ابن القيم الجوزي،

$$
\text { السعودية. }
$$

rـ التحرير و التتوير، لمحمد الطاهر بن محمد بن محمد الطاهر بن عاشور

$$
\text { التونسي (ت س } 999 \text { (م) دار سحنون، تونس. }
$$

ع ـ تفسير القرآن العظيم، لأبي الفذاء إسماعيل بن كثير الدمشقي ( ت ع (VV

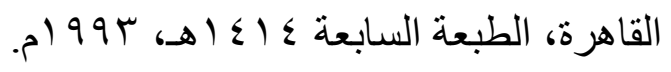

0ـ تفسير القرآن و إعرابه وبيانه، للثيخ محمد علي طه الدرة،طا،

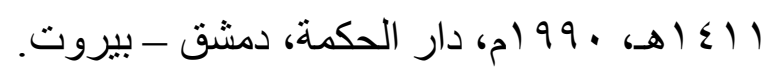

7ـ تفسير القرآن للشيخ عبد الكريم الخطيب، طدار الفكر العربي، القاهرة. V- تفسير الثيخ محمد المراغي. ط دار الكتب العلمية، بيروت، طا،

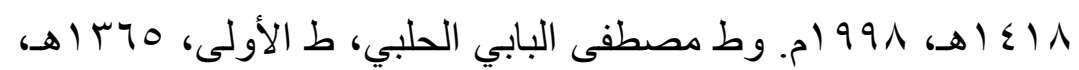
.) $99 \mathrm{~V}$

^ـ تيسير البيان لاحكام القرآن للإمام الموزعي، الناشر /دار النوادر لبنان. 
9- جامع البيان في تفسير القرآن، لأبي جعفر محمد بن جرير الطبري (ت • (اسهـ)، تحقيق/ محمود أحمد شاكر، الناشر/ دار ابن الجوزيالقاهرة.

• اـ الجامع لأحكام القرآن لأبي عبداله محمد بن أحمد الأنصاري القرطبي، تحقيق عبدالرازق مهدي، الناشر/ دار الكتاب العربي-

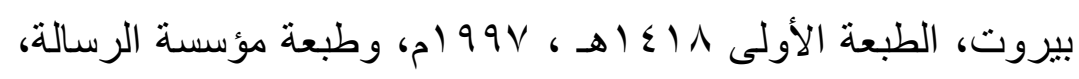

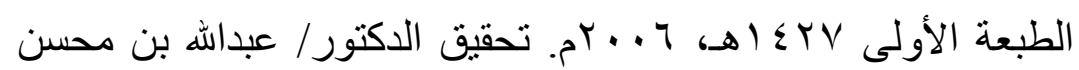
التركي.

/ اـ الجواهر الحسان للإمام الثعالبي، تحقيق محمد الفضلي، النانشر/ المكتبة العصرية- بيروت.

r ا ـ فتح القدير الجامع بين فني الرواية والدراية من علم التفسير، لمحمد بن علي بن محمد بن عبد الله الشوكاتي اليمني (ت: ـ ب ا))، تحقيق:

$$
\text { عبدالرازق المهدي، ط دار الكتاب العربي، بيروت. }
$$

با ــ الفتوحات الإلهية بتوضيح تفسير الجلالين للاقائق الخفية للعلامة الثيخ سليمان الجمل ، طدار إحياء التراث العربي ، بيروت. ع ا - روح المعاني في تفسير القرآن العظيم والسبع المثاني لأبي الفضل شهاب الدين السيد محمود الألوسي البغدادي (ت: V I اهـ)، دار إخياء

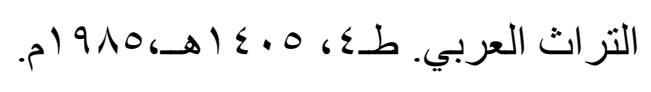

1 ـ لباب التأويل في معاني التنزيل، تأليف علاء الدين على بن محمد بن

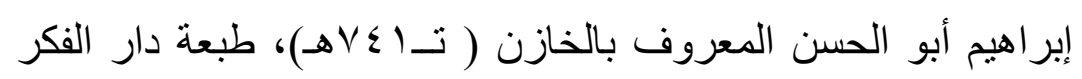

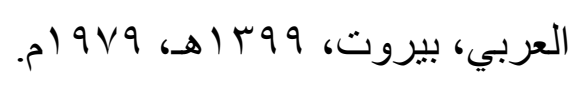


7 ا ـ المحرر الوجيز في تفسير الكتاب العزيز للقاضي أبو محمد عبدالحق ابن غالب بن عطية الأندلسي (ت 7؟ـهـ)، تحقيق المجلس العلمي

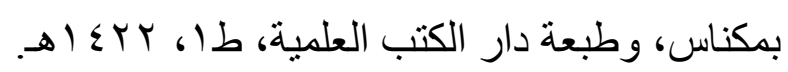
V ا ـ معالم التنزيل في تفسير القرآن = تفسير البغوي، تحقيق/ محمد عبداله النمر ، الناشر / دار طيبة- الرياض، الطبعة الثانية 7 (اء ( هـ، 990 (م. 1 ا ـ مفاتيح الغيب (التفسير الكبير)، للإمام محمد الرازي فخر الدين ابن العلامة ضياء الدين عمر المشتهر بخطيب الرى (تء . 7هـ)، دار

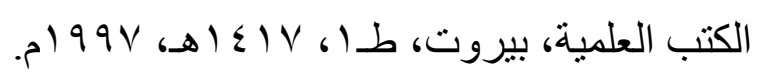
9 ا ـ معاني القرآن و إعر ابه للزجاج (ت: إسهـ)، ط عالم الكتب، بيروت،

$$
\text { الأولى، 1 +ـ أهـ، } 1911 \text { أم. }
$$

ثالثا: مصادر الحديث الثريف.

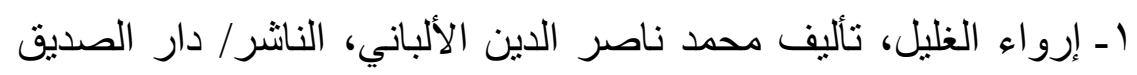

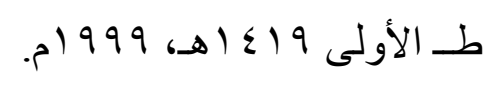

r الإحسان في تقريب صحيح ابن حيان، للأمير علاء الدين علي بن بَّبَان

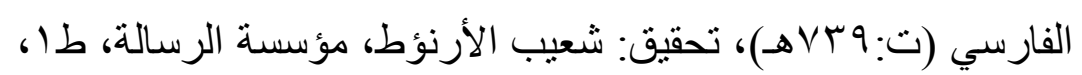

$$
\text { م • ع اهـ، } 991 \text { (م، بيروت. }
$$

rـ الاستذكار، لأبي عمر يوسف بن عبداله بن محمد بن عبدالبر القرطبي

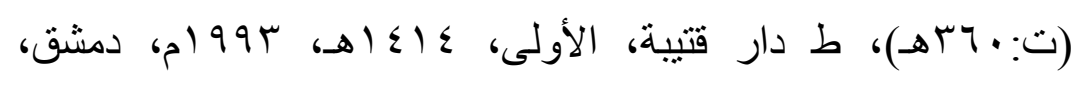

$$
\text { بيروت. }
$$

ع - سنن أبي داود، لأبي داود سليمان بن الأشعث السجناني (ت: YVOهـ)

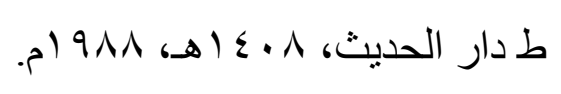


๑ـ سنن الدارقطني، لأبي الحسن علي بن عمر بن أحمد بن مهدي بن مسعود بن النعمان بن دينار البغدادي المعروف بالدار قطني

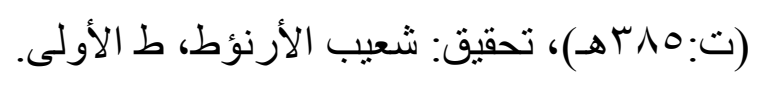

7ـ سنن النسائي بشرح الحافظ جلال الدين السيوطي، وبحاثيته الإمام

$$
\text { السندي، دار القلم،بيروت لبنان. }
$$

Vـ الجامع الصحيح من سنن الترمذي، لأبي عيسى محمد بن عيسى بن

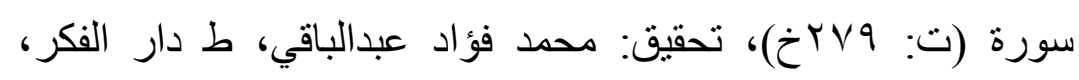

$$
\text { بيروت. }
$$

^ـ السنن الكبرى، للإمام أبي بكر أحمد بن الحسين بن علي البيهقي

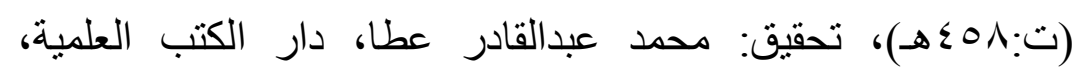

$$
\text { بيروت. }
$$

9 ـ المستدرك على الصحيحين، للإمام الحافظ أبي عبداله محمد بن عبداله

$$
\text { الحاكم النيسابوري. ط دار المعرفة، بيروت. }
$$

• (-ـصيح الإمام البخاري، تحقيق: محمد زهير بن ناصر، طا،

$$
\text { ه } 1 \leqslant Y r
$$

1 ا ـ صحيح الإمام مسلم، للإمام أبي الحسن مسلم بن الحجاج القثيري

$$
\text { النيسابوري (ت: (بT هـ)، مؤسسة مناهل العرفان، بيروت. }
$$

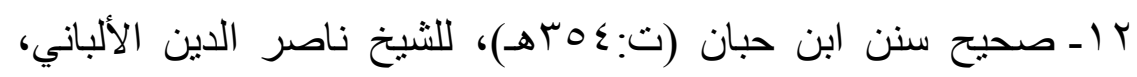
تعليق: زهير الثاويش، الناشر مكتب التربية العربي لدول الخليج،

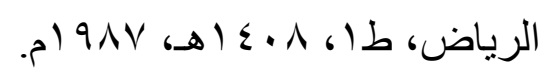


با ـ فتح الباري شرح صحيح البخاري، تاليف الإمام أحمد بن علي بن حجر العسقلاني(ت:بماخ)، تحقيق: محب الدين الخطيب ومحمد

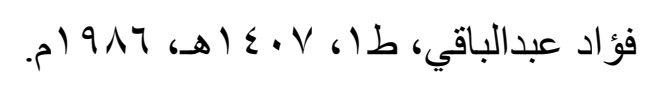

ع ا ــ مسند أبي بعلي، تأليف: أبو يعلي أحمد بن علي بن المننى بن يحيى بن عيسى بن هلال التميمي الموصلي (ت: • •rهـ)، تحقيق: حسين سليم

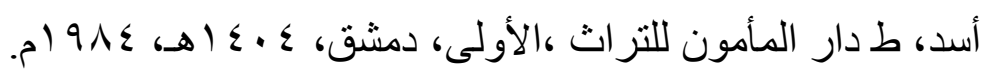
1ـ المسند للإمام أحمد بن حنبل (ت:إكاخ)، تحقيق: شعيب أرنؤط،

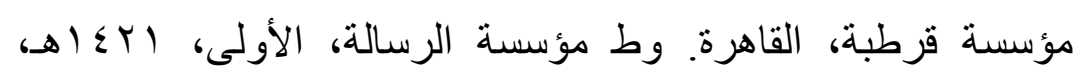

$$
\text { ק.. }
$$

7 ـ المعجم الأوسط، لسليمان بن أحمد بن أيوبن مطير الثنامي أبو القاسم

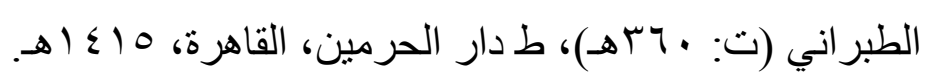
VI ال المصنف لأبي بكر عبدالرازق بن همام الصنعاني (ت: (I آهـ)، تحقيق: حبيب الرحمن الأعظمي، ط المكتب الإسلامي، الثانية،

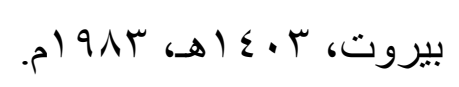

1 ا ـ المصنف لابن أبي شيبة، تحقيق محمد عوامة، الناشر : دار القبلة،

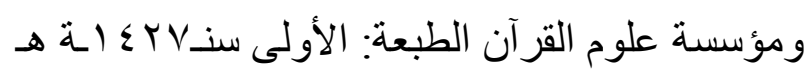

9 اـ نيل الأوطار، ناليف: محمد بن علي بن محمد بن عبداله الشوكاني اليمني (ت:0 ب (هـ)، تحقيق: عصام الدين الصبالطي، ط دار الحديث،

$$
\begin{aligned}
& \text { الأولى، ساء إهـ، سو } 9 \text { (م، مصر. } \\
& \text { رابعا: مصادر كتب الققه والأصول: }
\end{aligned}
$$

ا ـ أحكام القرآن، تاليف: محمد بن عبداله أبوبكر بن العربي المالكي (ت:

$$
\text { بـ 0ـه) دار الكتب العلمية، بيروت. }
$$




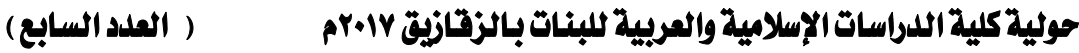

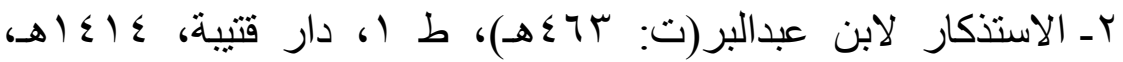

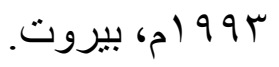

rـ البحر الر ائق شرح كنز الدقائق لابن نجم المصري، طـ دار الكتاب

$$
\text { الإسلامي، الطبعة الثانية. }
$$

ع - بداية المجتهذ ونهاية المقتصد، تأليف محمد بن أحمد بن بثير القرطبي، تحقيق ماجد الحموي، الناشر/ دار ابن حزم بيروت، الطبعة الأولى

$$
.1 \leq 17
$$

هـ تكملة المجموع شرح المهذب للثيرازي، تصنيف محمد نجيب

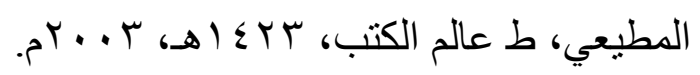

7ـ التهذيب في فقه الإمام الثافعي للفراء البغوي، دار الكتب العلمية،

$$
\text { بيروت- لبنان. }
$$

Vـ الحاوي الكبير في فقه مذهب الإمام الثافعي، وهو شرح مختصر المزني، تحقيق: الثيخ علي محمد معوض، والثيخ عادل احمد، طا،

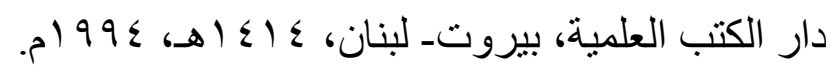

1- حاثية ابن عابدين،ط مصطفى البابي الحلبي، الثانية، القاهرة،

$$
\text { (1) }
$$$$
9 \text { - 2 - حاثشية البنان على هامش شرح الزرقاني. }
$$

• 1 ـ حاثية الدسوقي، ط دار إحياء الكتب العربية، بدون.

11 ـ الفقه الإسلامي وأدلته للاكتور و هبة الزحيلي، طــــدار الفكر - سوريا-

$$
\text { دمشق. }
$$


r ا - روضة الطالبيين و عمدة المفتيين للإمام النووي، ط المكتب الإسلامي،

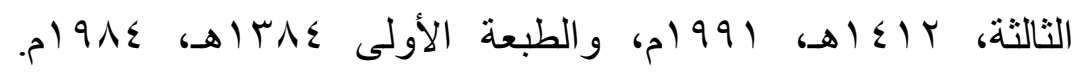
بيروت.

س ا ـ الزو اج و الطلاق في الإسلام، الناشر / مؤسسة شبان الجامعة. ع ا ـ شرح فتح القدير على الهداية، للثيخ كمال الدين محمد بن عبدالواحد

$$
\text { بن الهمام، دار إحياء التراث العربي. }
$$

1 ــ السيل الجرار المتدفق على حدائق الأزهار للإمام الشوكاني، طــ دار

$$
\text { ابن حزم. }
$$

7 ا ـ الفقه النافع لأبي القاسم محمد بن يوسف السمرقندي، تحقيق: د/

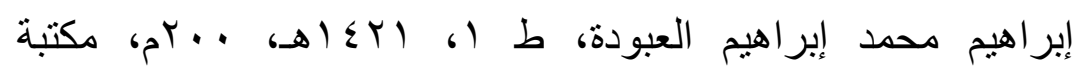

$$
\text { العبيكان، الرياض. }
$$

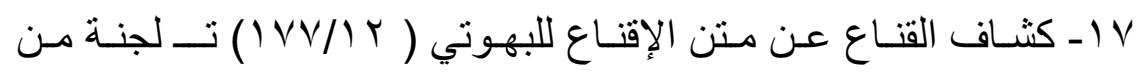

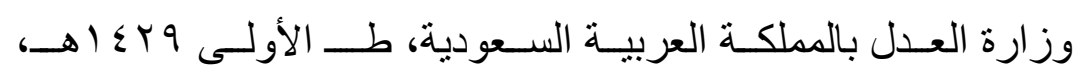

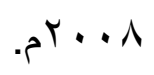

1 اـ المبسوط لشمس الدين أبو بكر محمد بن ابي سهل السرخسي (ت:

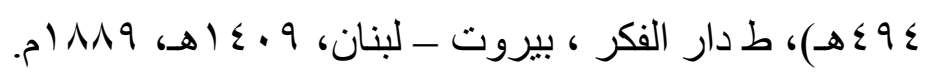

9 اـ المحلى لابن حزم، تأليف: أبو محمد علي بن أحمد بن سعيد بن حزم

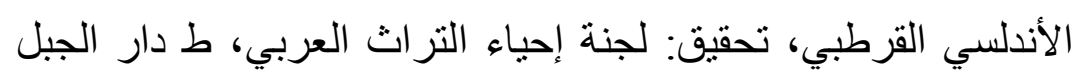
بيروت، ودار الآفاق الجديدة، بيروت، من دون سنة الطبع. وطبعة دار احياء التراث العبي/بيروت، تحقيق الأستاذ أحمد محمد شاكر. • r ـ محاضر ات عن فرق الزواج، الناثر / معهد الدراسات العربية العالية.

$$
\text { م) } 901
$$




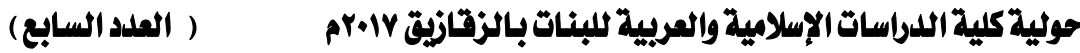

آ ــ مشروع قانون الأحوال الثخصية الموحد للإقليمين المصري

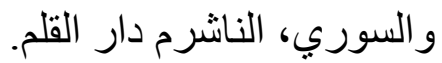

r Yـ المغني لابن قدامة المقدي (ت: • ب Tـه)، تحقيق: د/ عبداله بن عبدالمحسن التركي، ود/ عبدالفتاح الحلو، ط عالم الكتب، الرياض،

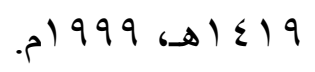

r ــ المقتع في فقه الإمام أحدد بن حنبل لابن قدامة، مكتبة الرياض

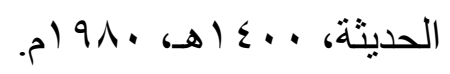

ـ ــ الممتع في شرح المقنع لزيد الدين المنجي التنوخي، تحقيق: د/ عبدالملك بن عبدالله بن دهيش، دار خضر، بيروت - لبنان، ط

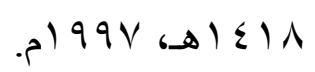

0 ــ الهداية في شرح بداية المبتدي، لعلي بن أبي بكر بن عبدالجليل الفرغاني بر هان الدين (ت: بوهــ)، تصحيح الثيخ طلال يوسف، ط دار إحياء التراث العربي، بيروتــ لبنان، من دون سنة الطبع. דr ـ مجمع الأنهر في شرح ملتقى الأبحر، تأليف عبد الرحمن بن محمد بن سليمان المدعو بشيخي زاده، يعرف بداماد أفندي (المتوفى:

$$
\text { ( ) }(1) \cdot \vee \wedge
$$

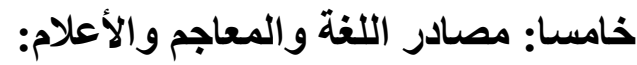
ا ـ الأعلام للزركلي، دار العلم للملايين، طه (، ب + . rم. r التعريفات للجرجاني، تحقيق جماعة من العلماء، طا، دار الكتب

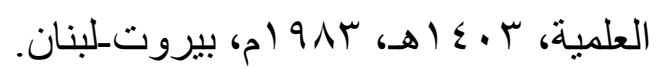
rـ العقد الفريد لابن عبد ربه، دار الكتب العلمية، طا، ـ ـ ـ أهـ. 


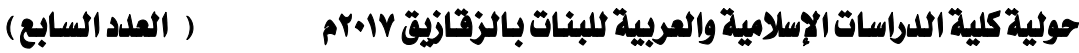

ع ـ القاموس المحيط للفيروزآبادي (ت: VI Vهـ)، تحقيق: مكتب تحقيق

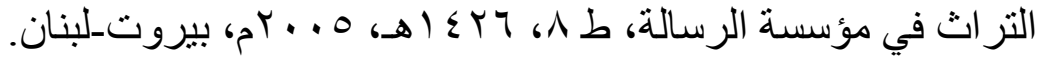
هـ لسان العرب لابن منظور، تحقيق أمين عبدالوهاب، ومحمد صادق العبيدي، الناثر/دار إحياء التراث العربي بيروت، طـ الثانية

$$
\rightarrow 1 \leqslant
$$

7ـ مجمل اللغة لابن فارس ، تحقيق: زهير عبدالمحن سلطان، طب،

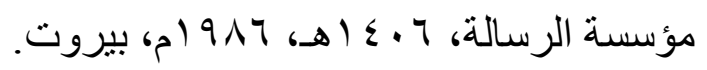

V- معجم الشعر اء لأبي عبيد الله محمد بن المهران المرزباني، طب، مكتبة

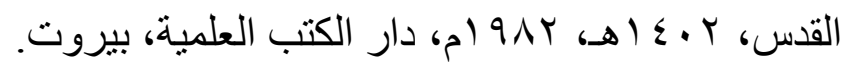

ᄉـ المعجم الوسيط، مجمع اللغة العربية بالقاهرة، ط دار الدعوة. 9ـ المفردات في غريب القرآن للر اغب الأصفهاني، دار القلم، الدار

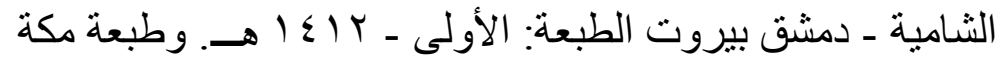

$$
\text { المكرمة مكتبة الباز. }
$$

• ـ المصباح المنير في غريب الثرح الكبير للفيومي الكتبة العلمية،

$$
\text { بيروت_لبنان. }
$$

1 اــ مقاييس اللغة لابن فارس، تحقيق: عبدالسلام محمد هارون، ط دار

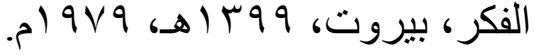

$$
\begin{aligned}
& \text { سادسا: مصادر ومر اجع متنوعة. }
\end{aligned}
$$

1 ـ أحكام الأحوال الثخصية في الثريعة الإسلامية، للشيخ عبدالوهاب خلاف، الناشر/ مطبعة دار الكتب العلمبة المصرية ـ القاهرة، طـ

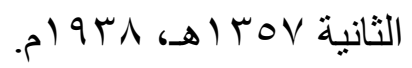




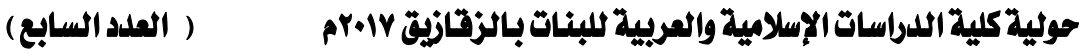

rـ الأحوال الثخصية للشيخ محمد أبو زهرة، طــــدار الفكر العربي-

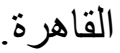

r- حقوق النساء في الإسلام لمحمد رشيد رضا. ع ـ دستور المرأة في ظلال القرآن، للأستاذ أحمد فائز، مؤسسة الرسالة،

$$
\text { ط طr، }
$$

0ـ روضة المحبين لابن القيم دار الكتب العلمية بيروت ـ ط ب. ــ اهـ ـ

$$
\text { م) } 9 \wedge \mu
$$

T- و الشعر و الشعر اء لابن قتيبة. دار الحديث بr ع ا هـ.

V- ز اد المعاد لابن القيم، المطبعة المصرية، بيروت.

ᄉـ عيون الأخبار لابن قتيبة الدنيوري، ط دار الكتب العلمية بيروت،

$$
\text { هـ } 1 \text { (1) }
$$

9 ـ السيرة الجلية، طـ دار الكتب العلمية.

• ـ ـضايا المر أة بين التقاليد الر اكدة والواقدة للشيخ محمد الغزالي، دار

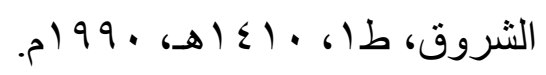

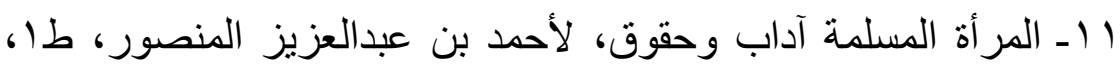

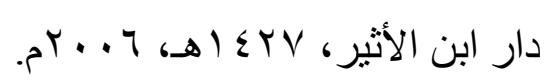

ץ ا ـ المر أة في التصور الإسلامي، للشيخ عبدالمتعال الحبري، طب، مكتبة

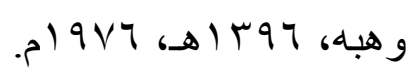

با ــ أصل الثيعة و أصولها للإمام محمد بن حبيب، منشوار ات البزار. 


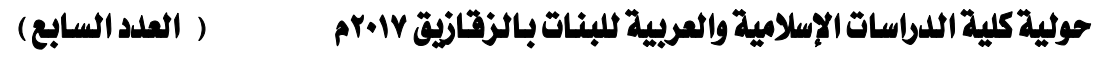

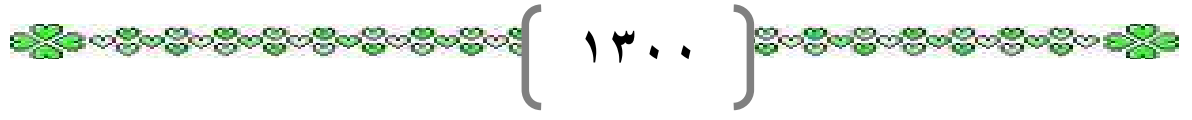




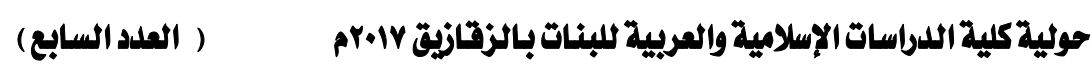

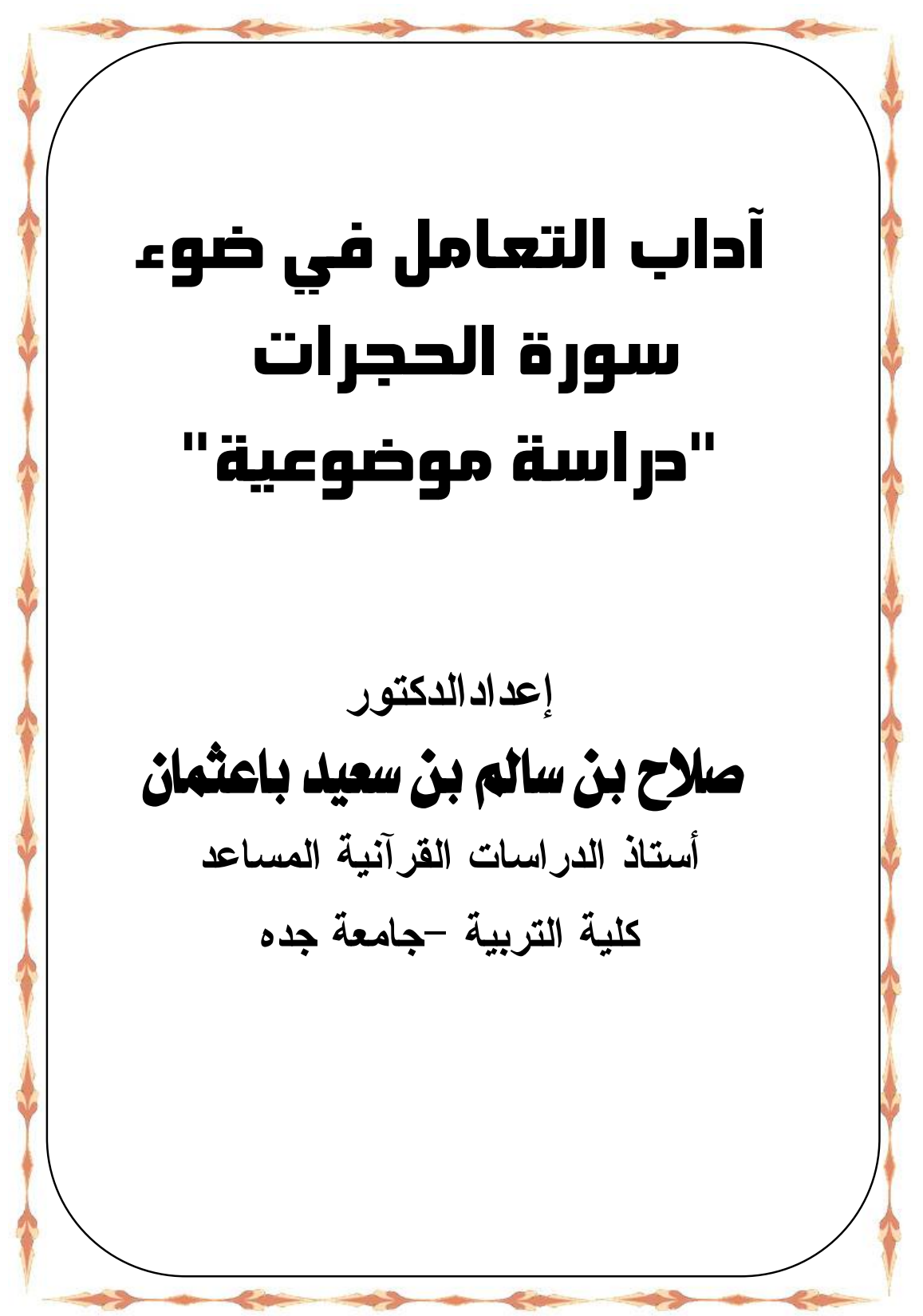

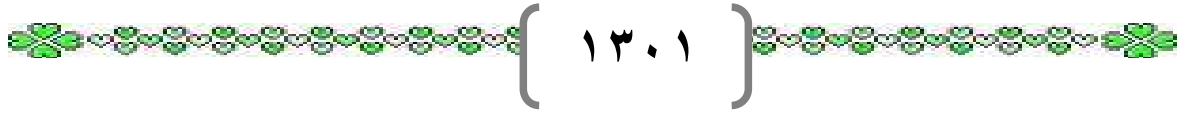




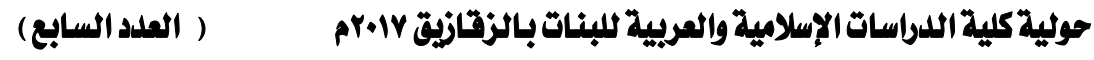

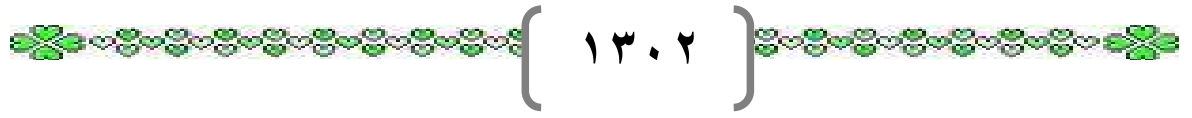




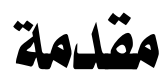

إن الحمد لله، نحمده، ونستعينه، ونستغفره، ونعوذ بالله من شرور أنفسنا، وسيئات أعمالنا، من يهده الله فلا مضل له، ومن يضلل فلا هادي له، و أثنهد أن لا إله إلا اله وحده لا شريك له، وأشهد أن محمدًا عبده ورسوله، اللهم صل على سيدنا محمد، وآله وصحبه الكرام، الطيبين، الطاهرين، و احشرنا

$$
\text { في زمرتهم يا أرحم الر احمين. }
$$

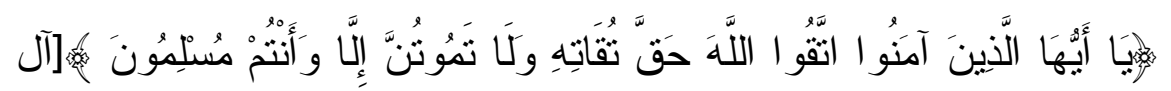

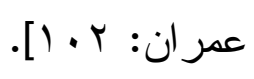

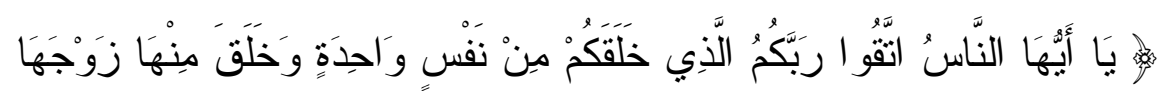

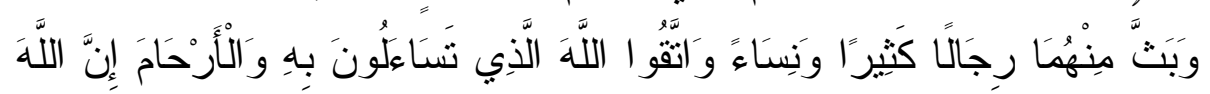

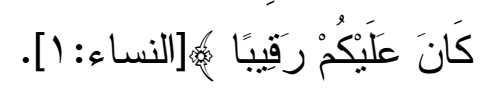

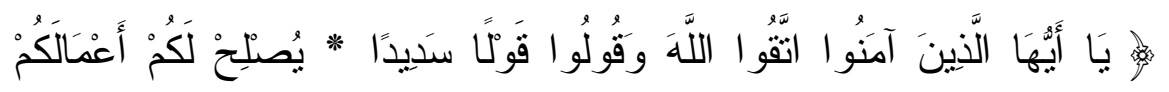

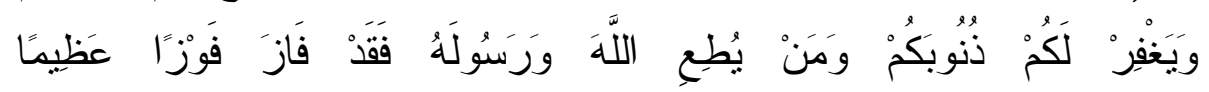

$$
\text { . }
$$

أما بعد: فإن سورة الحجرات نتضمن جملة من الآداب، والأمة في أمس الحاجة إلى تدبر ها و الاهتداء بها في مسيرتها الحياتية، لتهتدي بها إلى طريق الله المستقيم الذي لا اعوجاج فيه ولا التواء، والذي وصفه الحق سبحانه

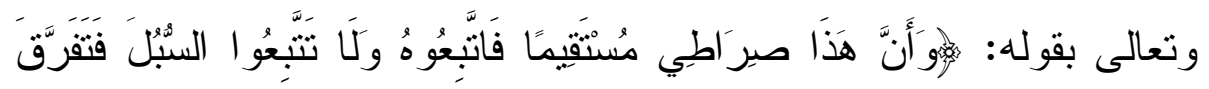

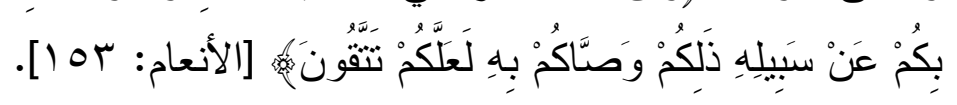

ومن هنا تكمن أهمية هذا الموضوع المبارك، وبخاصة في زمان تلفق

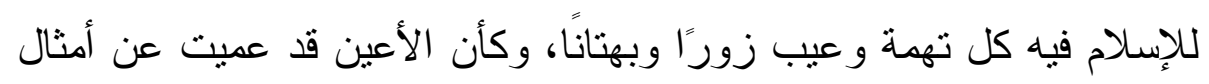


سورة الحجرات التي تهدي - كما يهدي القرآن كله - إلى التي هي أقوم، لا سيما بعد عقود من تخبط البشرية بين نظريات الثرق و الغرب، وتُرَّهات

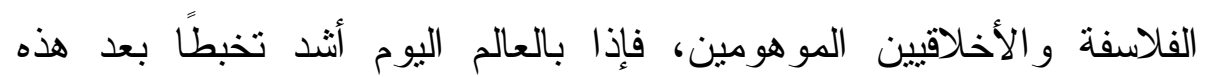
النظريات منه قبلها، وبات لزامًا علينا- معشر المسلمين - أن نبين للعالم كنوز هذا الدين وروائعه في التعاملات مع المسلمين و غيرهم، عساهم يفيئون إلى الله ويفرون إليه من شقاو ات الثيطان، ويعودون إلى القرآن الكريم، ذلك ولك المعين الذي لا ينضب.

و الأي دفعني لاختيار هذا الموضوع عدة أسباب من أهمها ما يلي: أولاً: لقد استر عتني هذه السورة المعجزة بما تضمنته من توجيهات ربانية تعيد للأذهان قول بعض السلف: "إنه ليمر بالقلب أوقات أقول فيها: إن كان أهل الجنة في منل هذا، إنهم لفي عيش طيب!"( ). ثانياً: تزسم لنا سورة الحجرات صورة محددة المعالم لمجتمع إسلامي: رباني في غايته ومنهجه، إنساني وعالمي في طبيعة تكوينه، مجتمع تسمو

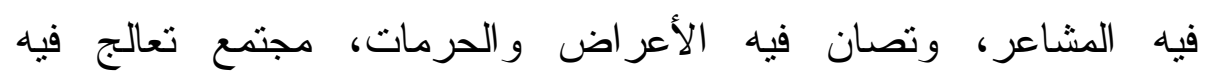
الانحر افات بسلطان الثريعة، وبروح الإخوة الإسلامية الجامعة، مجتمع وله

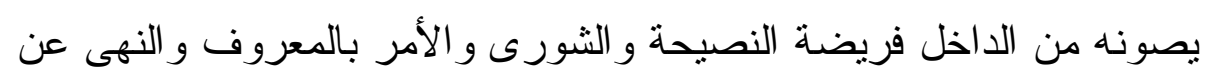
المنكر ، ويحميه من الخارج فريضة الجهاد و البذل في سبيل الله، مجتمع تتظم حركته مجمو عة من المبادئ في مجالات الحياة كافة.

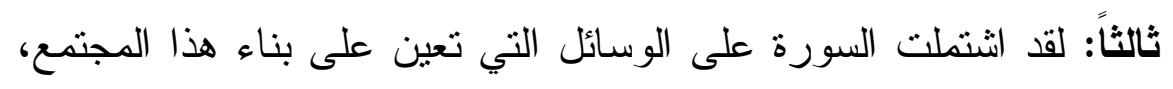
وتحقيق هذه المبادئ، وإخر اجها من نطاق القول إلى مجالات العمل، ومن لئ لئن سطور الكتاب إلى دروب الحياة.

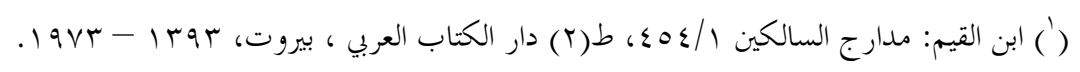

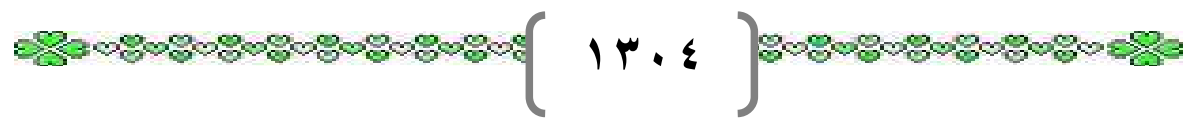


رابعاً: سورة الحجر ات مدرسة منكاملة، ثربى في ضوئها أصحاب محمد فإنها مع قصر ها، وقلة عدد آياتها جاءت شاملة لأحكام و آداب و أو امر ونو اه لا تجدها مجتمعة في سورة سو اها.

خامساً: إن سورة الحجرات جاءت لتربي الأمة على سمو الأخلاق، وفضائل الأعمال و علو الهمم.

سادساً: إنها مدرسة عقدية وتتريعية وتربوية، ولذلك فلا عجب ألأب أن نرى

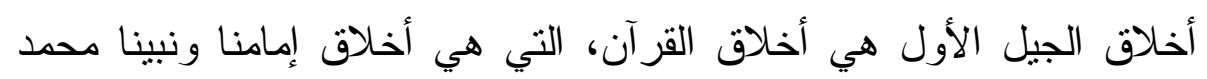
الذي كان خلقه القرآن؛ ولذلك قادوا الدنيا بأسرها، لا بسيوفهر و لا بأمو الهم،

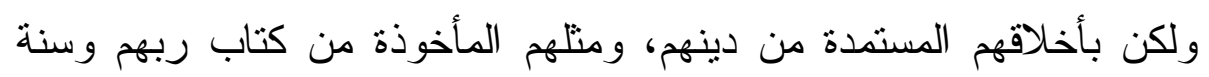
نبيهم( (1) سابعاً: أمتتا اليوم أحوج ما تكون إلى منقذ لها مما هي فيه جائعة و الز اد بين يديها، عطشى و الماء فوق ظهور ها محمول، ولن يصلح آخر هذه الأمة

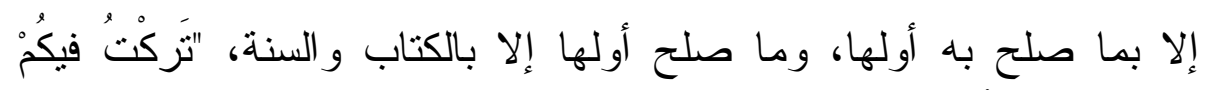

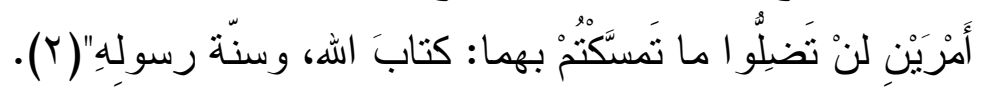

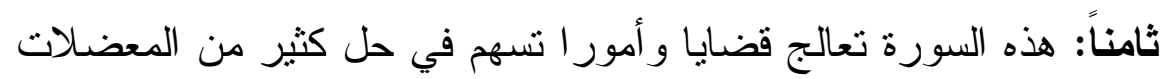
التي تو اجهها الأمة اليوم. خطة البحث: يشتمل البحث على مقدمة، وتمهيد وأربعة مباحث وخاتمة،

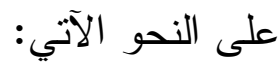

(1) (1) ناصر بن سليمان العمر: سورة الحجرات دراسة تحليلية وموضوعية ص با، بدون تاريخ

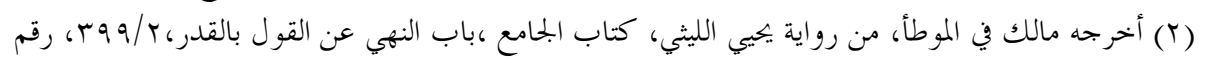

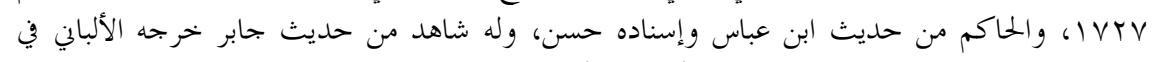

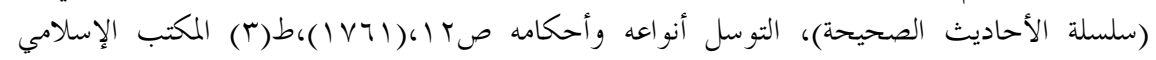




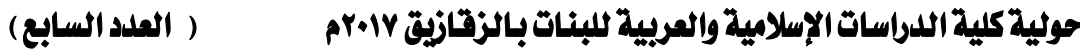

مقدمة: وتشتمل على أهمية الموضوع، وأسباب اختياره، وخطة البحث، ومنهج الباحث.

التمهيد: وفيه ثلاثة مطالب: المطلب الأول: سورة الحجر ات آداب و أحكام. المطلب الثاني: مناسبة السورة لما قبلها وما بعدها. المطلب الثالث: منهج السورة في تقرير آداب التعامل في المجتمع المسلم. المبحث الأول: آداب التعامل مع الله ورسوله، وفيه مطلبان: المطلب الأول: أهمية الأدب ومكانته في الكتاب و السنة. المطلب الثاني: آداب التعامل مع الهه ورسوله.

المبحث الثاني: التتبت في الأخبار ودوره في تحصين الأمة، وفيه مطلبان: المطلب الأول: حقيقة التثبت و أهميته. المطلب الثاني: الثائعات و أثزها الخطير في هدم كيان الأمة المبحث الرابع: آداب التعاملات الأخلاقية في ضوء سورة الحجرات، وفيه أربعة مطالب: المطلب الأول: النهي عن السخرية. المطلب الثاني: النهي عن الظن. المطلب الثالث: النهي عن التجسس. المطلب الر ابع: النهي عن الغيبة. الخاتمة: وتشمل أهم النتائج، ثبت المصادر و المر اجع ،و المحتوى.

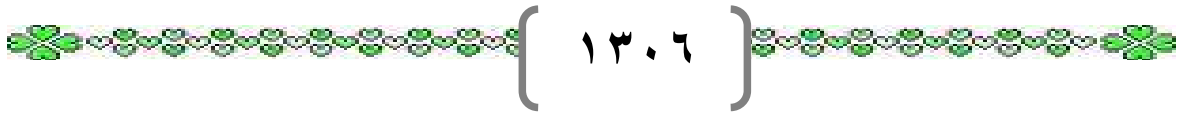




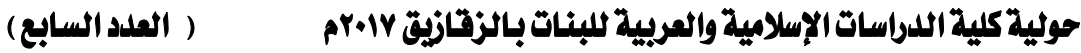

منهج الباحث: وسرت في هذا البحث على المنهج الآتي: أما عن المنهج الذي اتبعته في هذا البحث، فقد اجتهدت أن أسلك في بحثي المنهج التحليلي، أثناء تحليل الأفكار حتى أصل إلى هدفي وهو إبراز المنهج

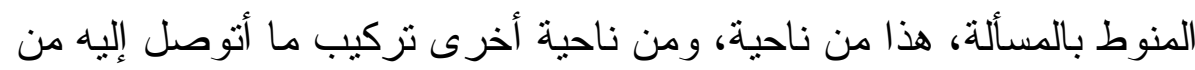
عناصر في نسق منكامل يبرز القضية. الاعتماد في هذا البحث على مصادر البحث ومر اجعه الرئيسة، إلى جانب بعض المصادر و المر اجع الأخرى التي تتضمن موضوع البحث. كنت أثتاء عرضي المسألة أو القضية المراد در استها أبدأ بعرض الفكرة كما تتاولتها السورة، ثم بعد ذلك أعرض التوجيهات و الإرشادات القرآنية،

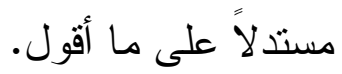

أثناء عرضي للقضايا أبا كان نوعها، التزمت بوضع تصور عام لكل مسألة دون أن أدخل في نقاش و أخذ ورد، ثم بعد ذلك أبرز الرؤية الشرعية

و أقوم بالتعقيب على ما ذكر في شكل ملاحظات على المسألة المر اد بحتها. الترجمة للأعلام الواردة في البحث توثيق النصوص الواردة في البحث،

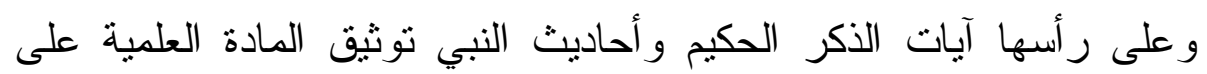

$$
\text { النحو الآتي: عزو الآيات القر آنية إلى سور ها. }
$$

عزو القر اءات القر آنية إلى مصادر ها المعتمدة مع بيان المتو اتر من الثـاذ.

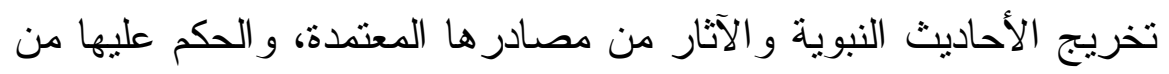

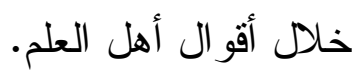
توثيق الأقو ال المنقولة عن العلماء. ترجمة لأهم الأعلام الواردة. 
وبعدُ: فإني أحمد اله حمداً كثيرًا مباركاً فيه، فهو الذي وفق و أعان، فله

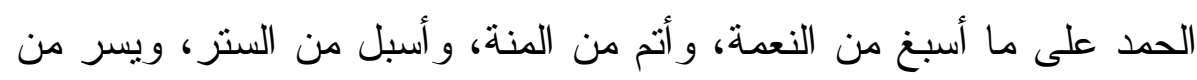
العسر، وقرب من النجاح، وقدر من الصلاح. و الثكر الله وهو المبتدي النو ال قبل السؤال، و المعطي من الإفضال فوق الآمال، فأي نعمة أحصى عددها، و أي عطائه أقوم بشكره: ما أسبغ علي من ون الإن النعماء، أو ما صرف عني من الضر اء. أدماء

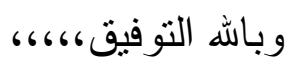




\section{التمهيد \\ المطلب الأول: سورة الحجرات آداب وأحكام}

سورة الحجر ات سورة قر آنية معجزة بلفظها ومعناها، وهى مبهجة ومنجية لمن أخذ بها وعمل بما فيها، وهى من السور المباركة المليئة بالآداب العالية، و الأخلاق السامية، و المنل النيرة التي تقود الأمة إلى الكمال و العلياء. وهي سورة مدنية( () * نزلت بعد سورة المجادلة و آياتها ثماني عشرة آية، كلماتها ثلاثمائة وثلاث و أربعون، وحروفها ألف و أربعمائة وسبعون، وسميت

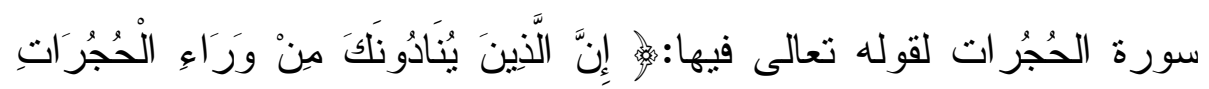

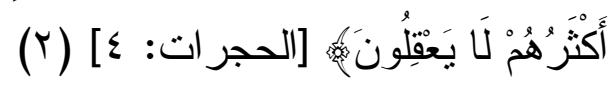

يقول (القاسمي): "سميث بها لدلالة آياتها على سلب إنسانية من لا يعظم رسول الله غاية التعظيم، و لا يحترمه غاية الاحتر ام، وهو من أعظم مقاصد

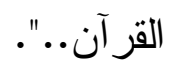

و هذا فهم دقيق وتعليل شفاف من القاسمي وكأنه يقول: إن من يعاملون

رسول الله بهذه الغلظة قد تحجرت عقولهم وقلوبهم، فهي كالحجارة أو أنثد

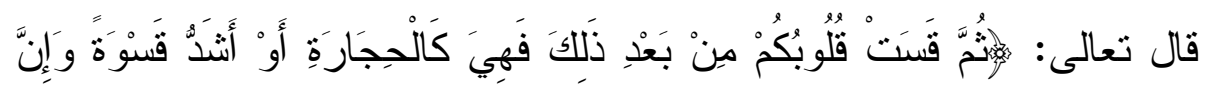

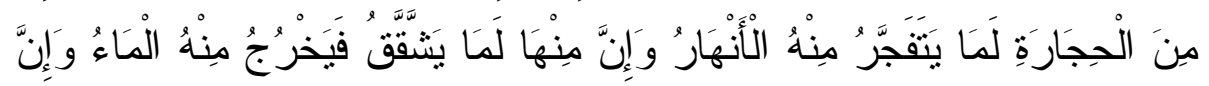

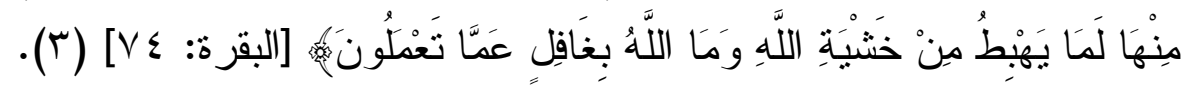

$$
\begin{aligned}
& \text { (1) النيسابوري: تفسير غرائب القرآن، آل/ 100، دار الكتب العلمية بيروت لبنان. }
\end{aligned}
$$

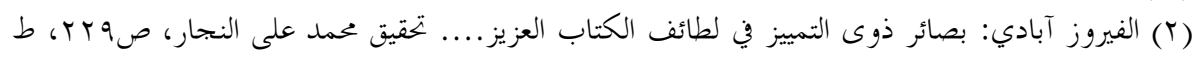

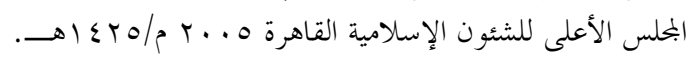

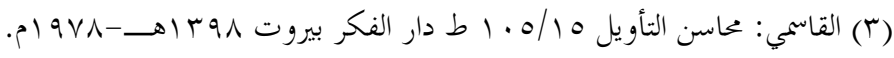

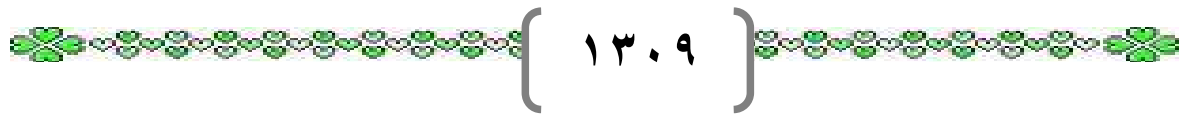


و هي على وجازتها سورة جليلة ضخمة، تتضمن حقائق التربية الخالدة، و أسس المدنية الفاضلة، حتى سماها بعض المفسرين (سورة الأخلاق)، و ابتدأت السورة الكريمة بالأدب الرفيع الذي أدب اله به المؤمنين، تجاه

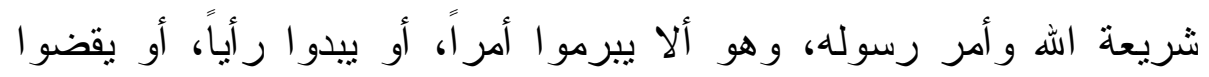

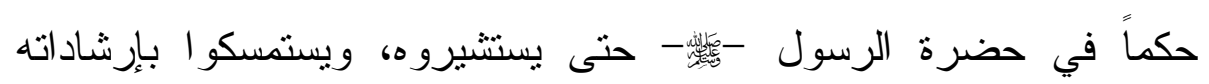

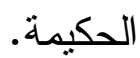

ثم انتقلت إلى أدب آخر وهو خفض الصوت إذا تحدثوا مع الرسول -

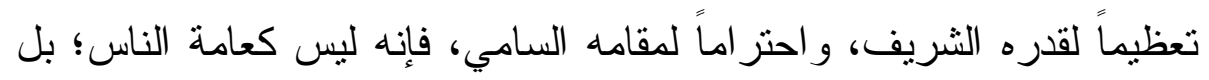
هو رسول الله، ومن واجب المؤمنين أن يتأدبو ا معه في الخطاب مع التوقير

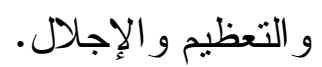

ومن الأدب الخاص إلى الأدب العام، تتنقل السورة لتقرير دعائم المجتمع الفاضل، فتأمر المؤمنين بعدم السماع للإثشاعات، و التثبت من الأنباء و الأخبار، لاسيما إن كان الخبر صادراً عن شخص غير عدو علد أو شخص متهم، فكم من كلمة نقلها فاجر فاسق، سببت كارثة من الكوارث، وكم من خبر لم يتثبت منه سامعه، جر وبالاً، و أحدث انقساماً.

ودعت السورة إلى الإصلاح بين المتخاصمين، ودفع عدوان الباغين، وحذرت السورة من السخرية و الهمز و اللمز، ونفرت من الغيبة و التجس،

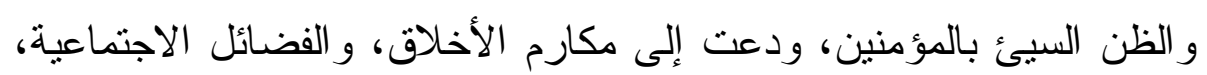
وحين حذرت من الغيبة جاء النهي في تعبير رائع عجيب، أبدعه القرآن غاية الإبداع، صورة رجل يجلس إلى جنب أخ له ميت ينهش منه ويأكل لحمه،

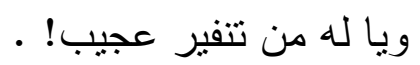


وختمت السورة بالحديث عن الأعراب الذين ظنوا الإيمان كلمة ثقال باللسان، وجاءوا يمنون على الرسول إيمانهم، وقد وضحت حقيقة الإيمان، وحقيقة الإسلام، وشروط المؤمن الكامل، وهو الذي جمع الإيمان، و الإخلاص و الجهاد، و العمل الصالح.

وسميت (سورة الحجرات) لأن الله تعالى ذكر فيها حرمة بيوت النبي  عليهن(1) (1) - (1)

و هي ترسم لنا صورة محددة المعالم لمجتمع إسلامي رباني في غايته ومنهجه، إنساني وعالمي في طبيعة تكوينه، مجتمع تسمو فيه المشاعر، وتصان فيه الأعر اض و الحرمات، مجتمع تعالج فيه الانحر افات بسلطات الثريعة وبروح الإخوة الإسـلاية الجامعة، مجتمع يصونه من الداخل فريضة النصيحة والثورى والأمر بالمعروف والنهى عن المنكر ويحميه من الخارج فريضة الجهاد و البذل في سبيل الله.

و أغر اض هذه السورة كما حكى ابن عاثور في (التحرير و التتوير ) : "تتعلق أغر اضها بحو ادث جدت منقاربة كانت سببا لنزول ما فيها من أحكام

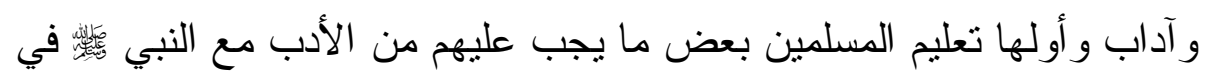
معاملته وخطابه وندائه دعا إلى تعليمهم إياها ما ارتكبه وفد بني تميم من

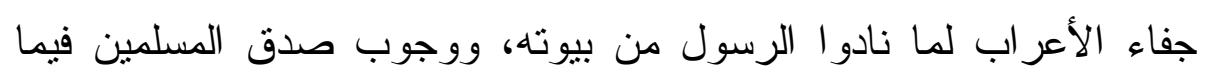


يخبرون به و التثبت في نقل الخبر مطلقا وأن ذلك خلق المؤمنين ومجانبة

$$
\text { أخلاق الكافرين و الفاسقين"( (1) ). }
$$

ولقد الثتملت السورة على عدة مبادئ من أهمها ما يأتي:

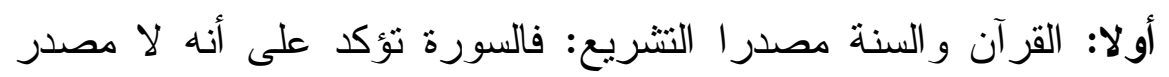

للتشريع أو وضع للمناهج والنظم ولا دستور للحياة المسلمة إلا الكتاب و السنة، مما يضمن ثبات المفاهيم و القيم، و عدم اختلال المو ازين قال تعالى ولى

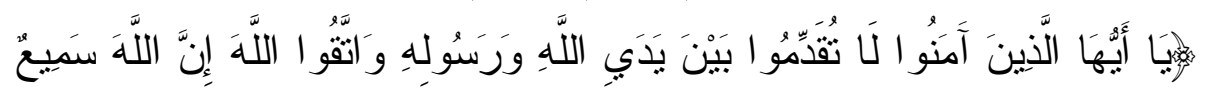

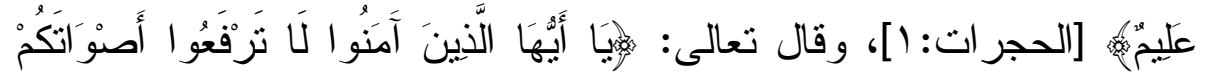

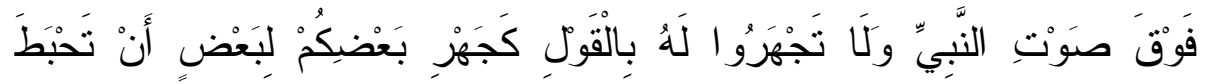

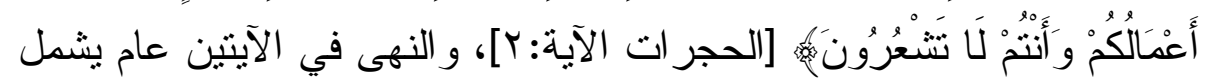

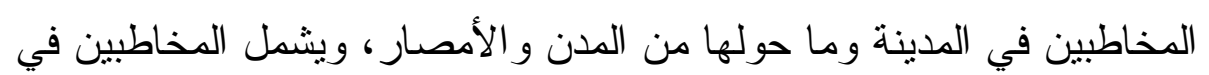
عصر النبوة وما يتلوه من أزمنة وعصور .

ثانيا: الإخوة الإسلامية هي الأس في توثثق الروابط: الرباط الذي يربط

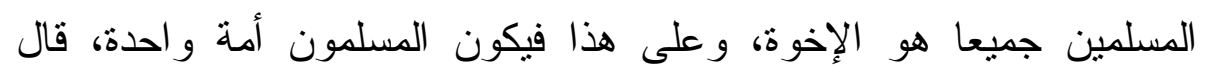

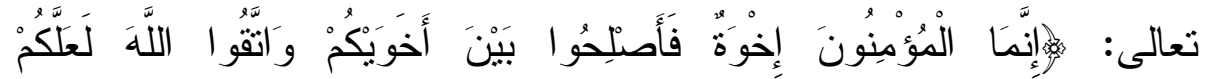

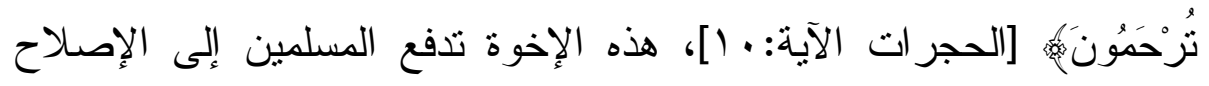

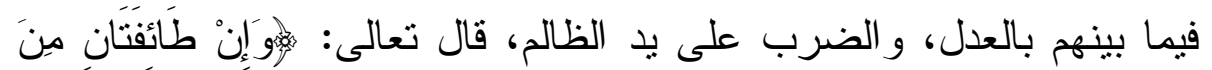

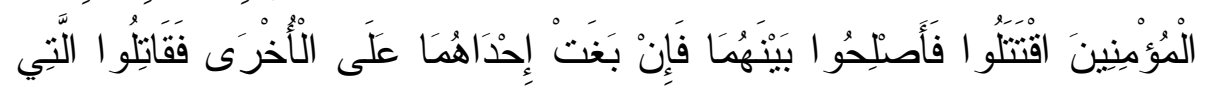

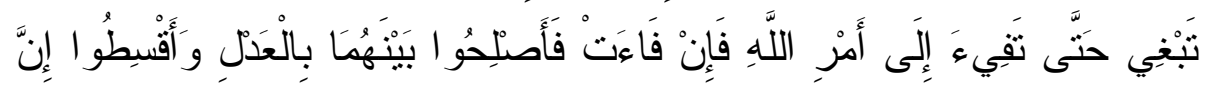

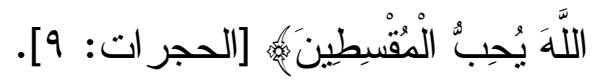

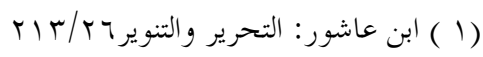

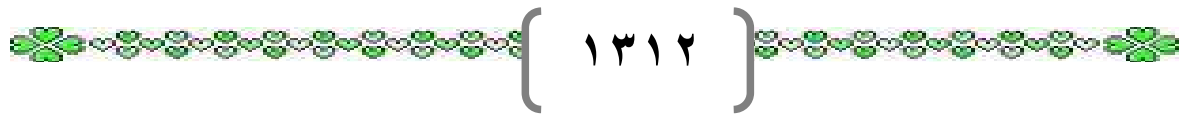


بالإضافة إلى هذا فالإخوة تدفع إلى المحافظة على المسلم، وعدم إيذائه

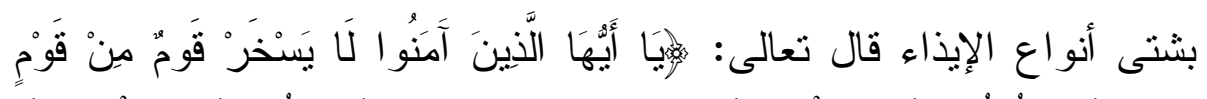

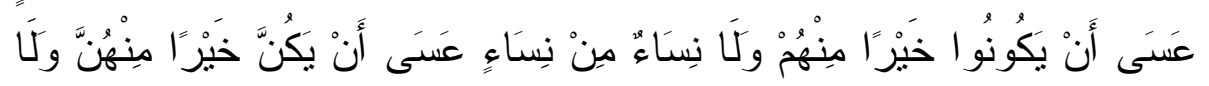

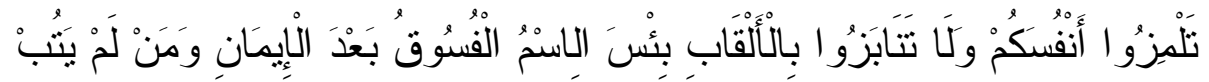

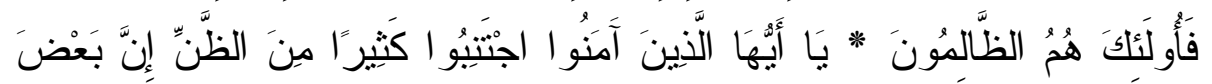

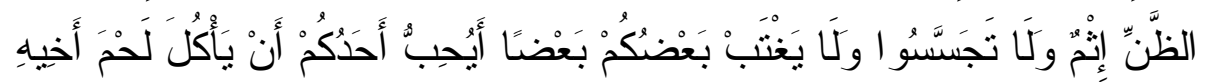

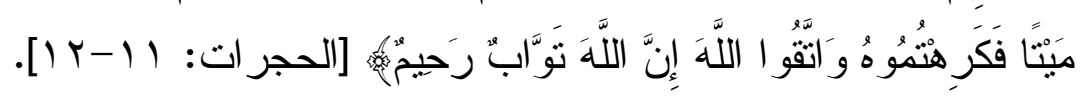

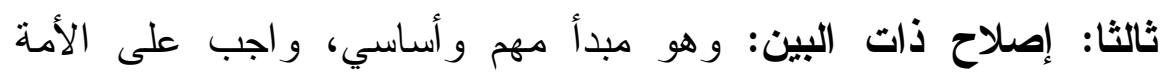

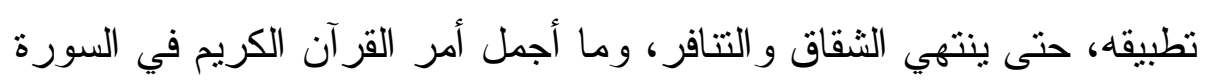

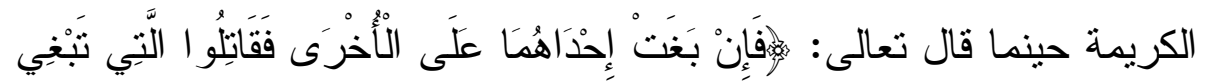

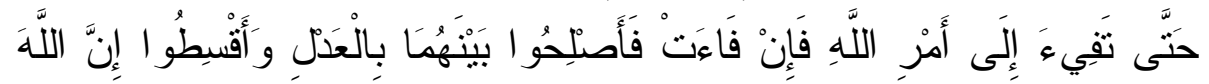

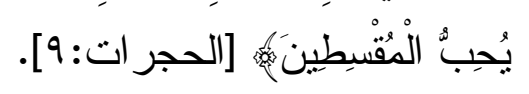

يقول (الر ازي): "أي الظالم يجب عليه دفعه عنه، ثم إن الظالم إن كان هو الرعية فالواجب على الأمير دفعهم، وإن كان هو الأمير فالواجب على لى إنى المسلمين منعه بالنصيحة شريطة ألا تكون فتتة مثل التي في اقتتال الطائفتين

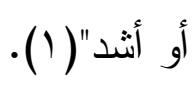

رابعاً: إقامة مجتمع الإسلام على العدل والتثبت: ومن العدل التثبت

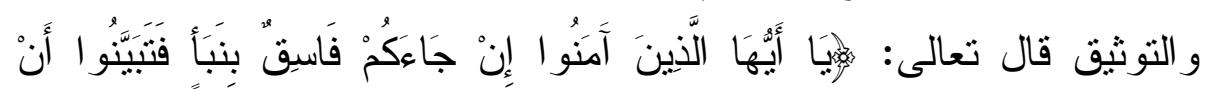

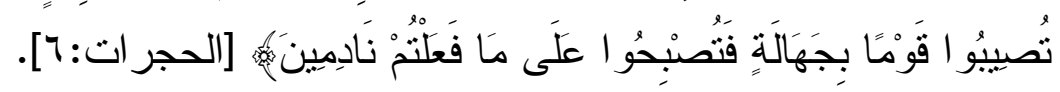
ولهذا المبدأ أهمية كبيرة، حيث أنه يحمى المجتمع من التفكلى، ويمنع اقتتال أبنائه، كما يحمى الأمن الثخصي لكل أفراد المجتمع، مسلمين وغير

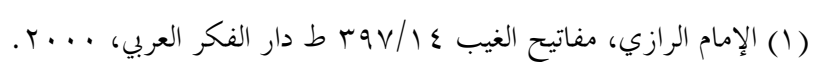

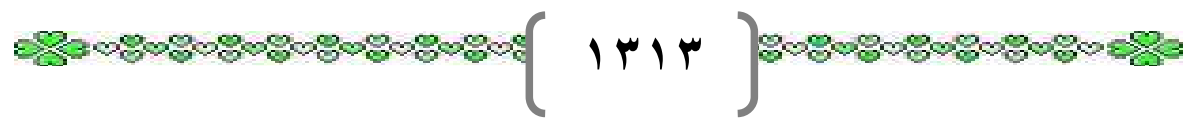


مسلمين، كما برتقى هذا المبدأ بأخلاقيات المجتمع بإغلاق أبواب الكذب و النميمة و البهنان و الافتر اء، ويُعلّم الأمة آداب التأني في إصدار الأحكام. خامسا: قتال البغاة: وهذا ما أثنار إلبه الحق سبحانه وتعالى في قوله له

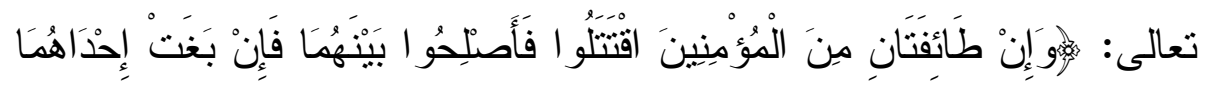

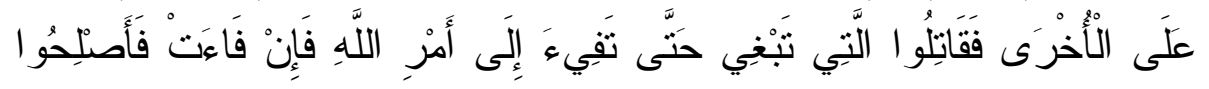

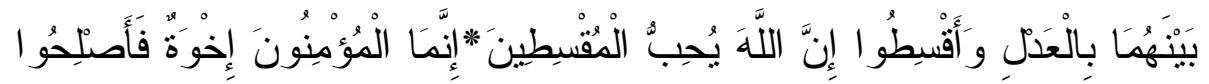

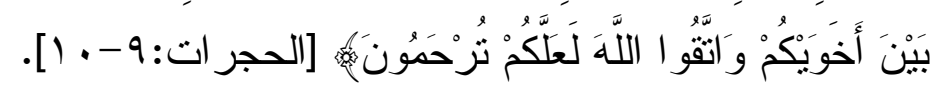

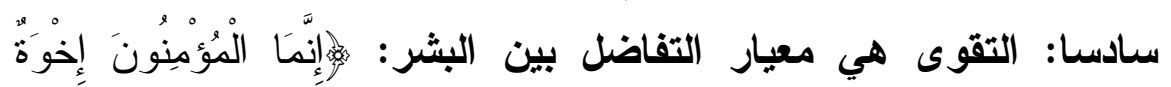

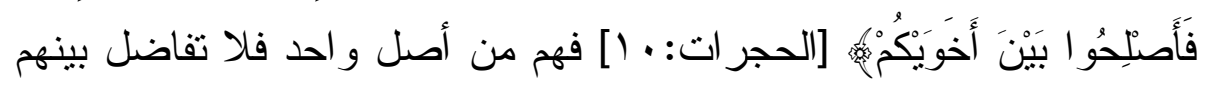
إلا بالتقوى، و لا تمييز بينهم بحسب أو نسب أو لون أو جنس أو مال أو

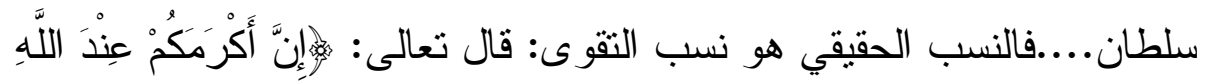

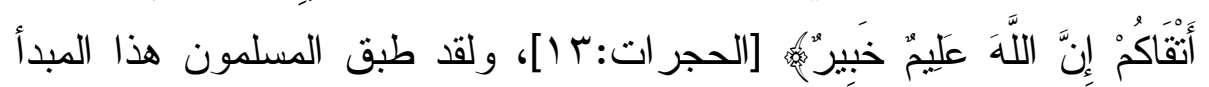

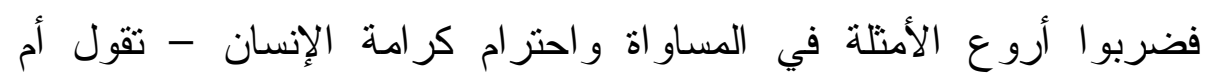

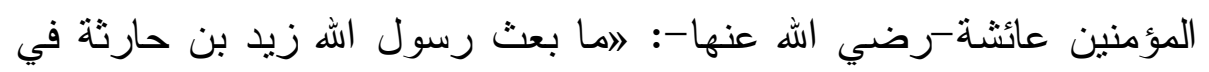
سرية إلا أمّره عليهم، ولو بقى بعد لاستخلفهی( (1)

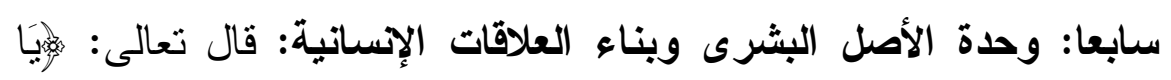

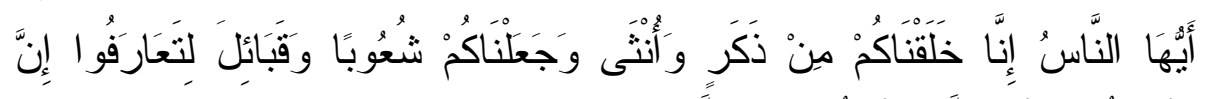

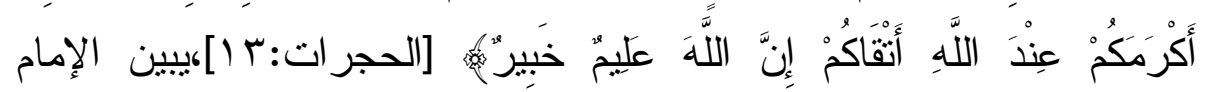
(الرازي) الحكمة من ذلك قائلاً: "هي التعارف وفيه وجهان: أحدهما: أن فائدة ذلك التتاصر لا التفاخر، ثانيهما: أن فائدته التعارف لا التناكر"(Y).

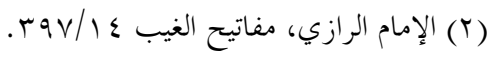




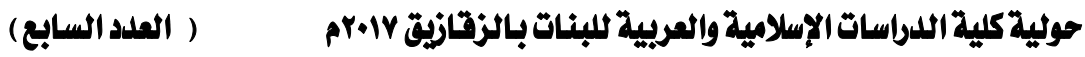

لذلك فإن الآية الكريمة تدعو الأمة المسلمة إلى التواصل و التعارف بين أمم الأرض، إعلاء لقيمة التقوى وبما يقدم النموذج الإسلامي القدوة إلى الى لهُه البشرية ويدعو ها إليه بصورة عملية. ثامنا: الجهاد في سبيل الله: فهو ذروة سنام الإسلام وشعار الأنبياء و المرسلين، وهو الدليل الحي و الثاهد الذي لا يكذب على رسوخ العقيدة في

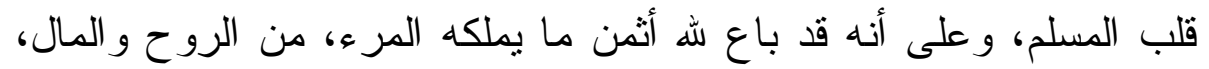

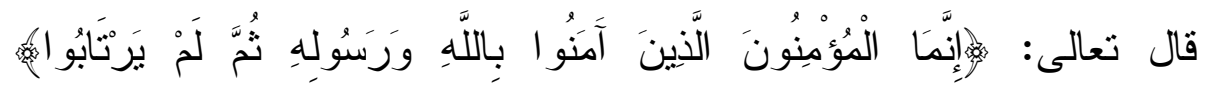

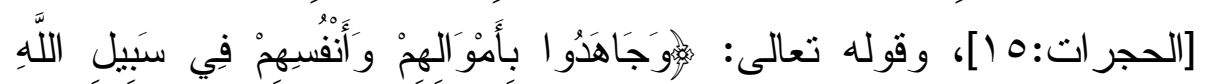

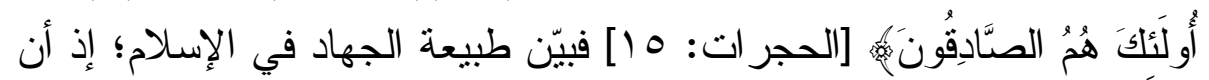
سبيل الله هو سبيل الحق المنضبط بشريعة الله الهادف إلى مرضاته و إعلاء كلمته.

تلكم هي أهم الآداب والأحكام التي اشتملت عليها هذه السورة الكريمة، و التي اثتملت على معانٍ أهمها الأدب مع الهه ورسوله، ومع كل فرد من

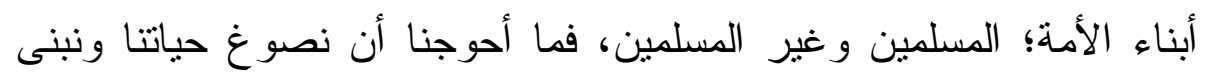
مجتمعنا وفق هذه السورة الكريمة وهذا الهدى الرباني..! 


\section{المطلب الثاني: مناسية السورة لما قيلها وما بعصها}

سورة الحجرات نزلت بعد سورة المجادلة في تزتيب النزول، أما في ترتيب المصحف فقد جاءت بعد سورة الفتح، وفي نهاية هذه السورة مدح الله نبيه و الذين معه و أثنى عليهم، وذكر مثلهم في التور اة و الإتجيل بقوله تعالى:

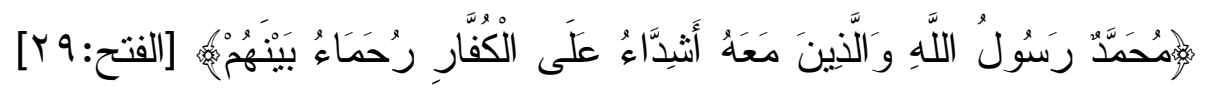
فناسب في سورة الحجرات أن يفتتحها بانشتر اط الأدب مع النبي -

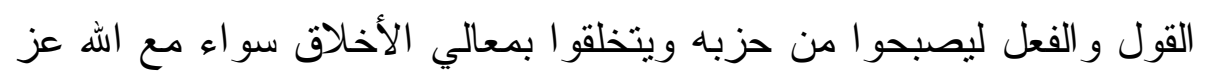

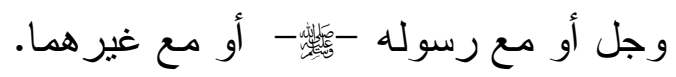

وقد ذكر الإمام (المر اغي) ثلاثة أوجه لهذه المناسبة مع السورة السابقة، فقال: ذكر

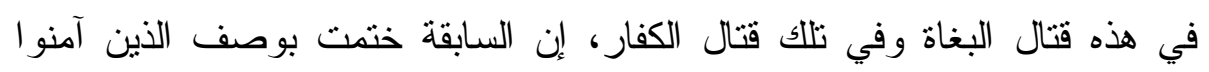

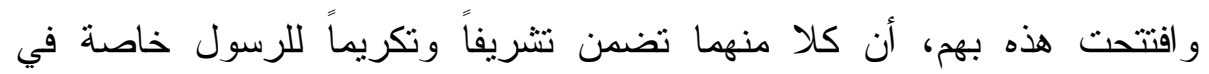

مطلعيهما. (1) مدهن

و أما مناسبة السورة لما بعدها: فلما ختم الحق سورة الحجرات بإحاطة العلم،

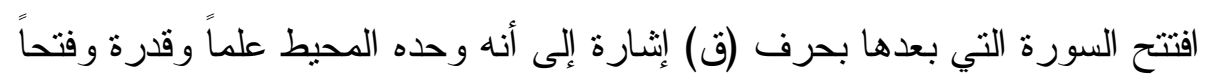
لما أر اد من المغلقات (r).

وعن مناسبة نهاية السورة لأولها: ختم اله السورة بعلمه لغيب السموات

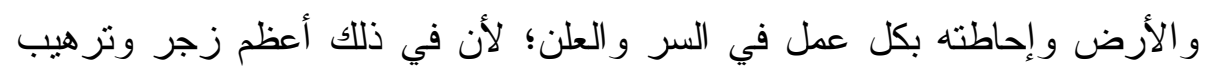

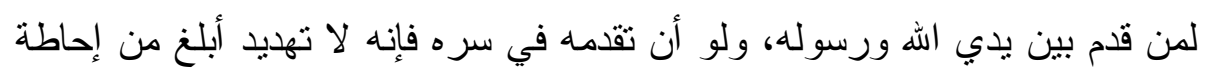

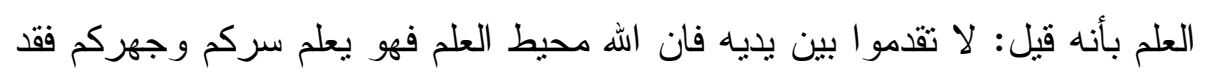

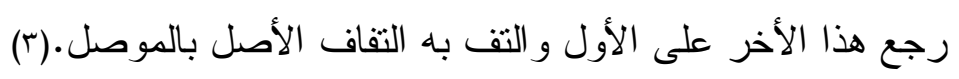

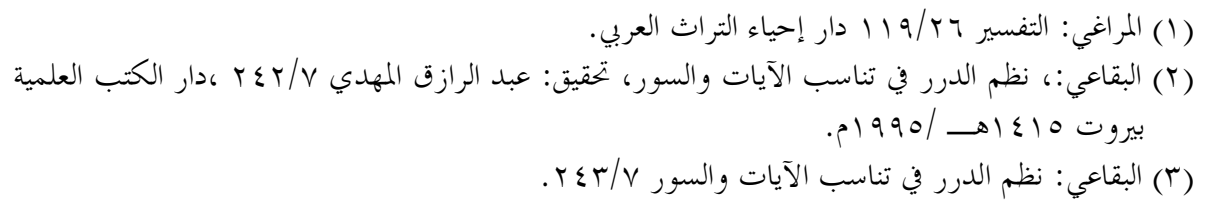

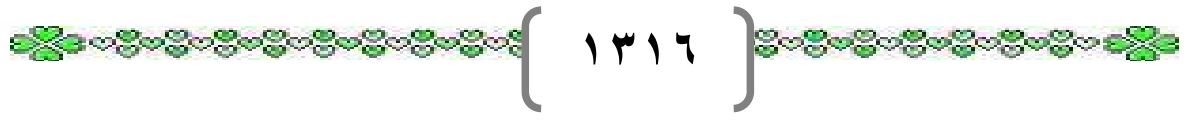




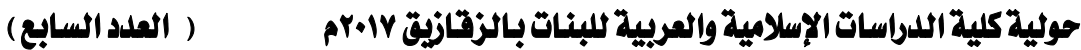

\section{المطلب الثالث: - الث}

\section{منهج السورة في تقرير آداب التعامل في المجتمع المسلم}

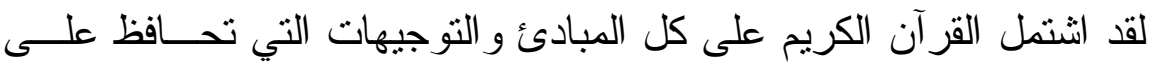

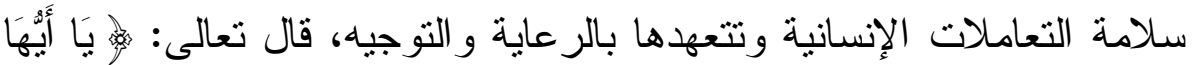

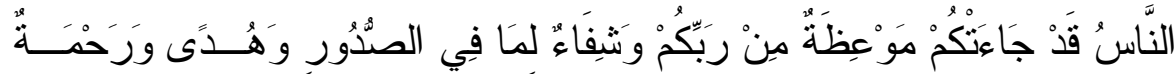

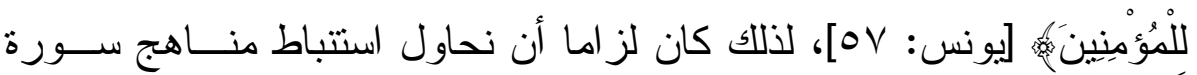
الحجر ات في تقرير آداب التعاملات في المجتمع المسلم، هذه المنـــاهج التــي تحمل بين ثثاياها العديد من ألوان وصنوف التعاملات بين أفــر اد المجتمـــع، فالسورة الكريمة ترسم المنهج الصحيح في عملية التعامل بين الله تعالى وبين

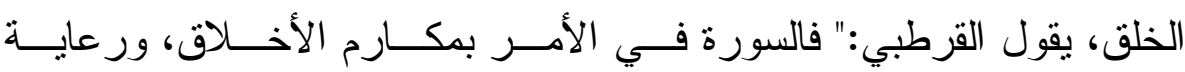

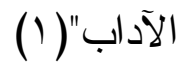

ويقول سيد قطب في الظلال: " هذه السورة التي لا تتجاوز ثماني عثــرة آية ، سورة جليلة ضخمة، تتضمن حقائق كبيرة من حقائق العقيدة و الثريعة، ومن حقائق الوجود و الإنسانية؛ حقائق تفتح للقلب وللعقل آفاقا عالية، وآماداً بعيدة، وتثير في النفس و الذهن خو اطر عميقة، ومعاني كبيرة، وتثــــ مــن مناهج التكوين و التنظيم وقو اعد التربية و التهذيب، ومبادئ التشريع و التوجيـهـ ما يتجاوز حجمها و عدد آياتها مئات المر ات!..." ويوضتح أيضاً أن السورة تحوي جانباً مهما من التفكر و التدبر، لعالم يخلو من المشكلات، وفي هذا يقول:" وهي تبرز أمام النظر أمرين عظيمين للتدبر

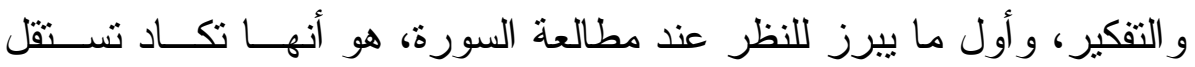
بوضع معالم كاملة، لعالم رفيع كريم نظيف سليم، متضمنة القو اعد و الأصول

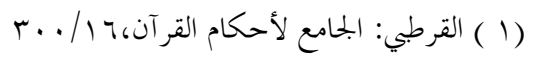


و المبادئ و المناهج التي يقوم عليها هذا العالم و التي تكفل قيامه أولاً، وصيانته

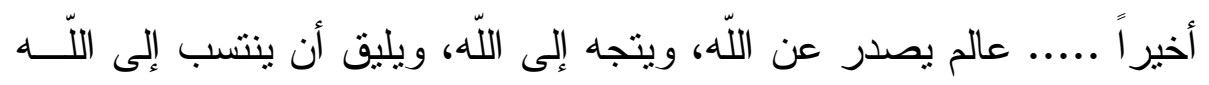
..... عالم نقي القلب، نظيف المشاعر، عف اللسان، وقبل ذلك عف السريرة

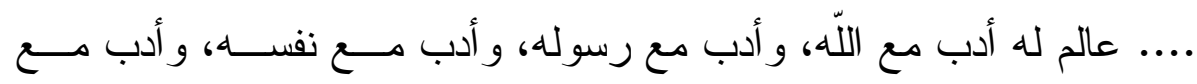

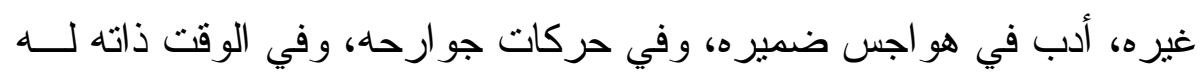

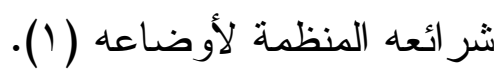

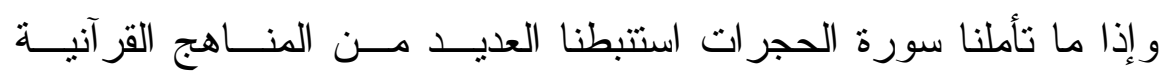
العظيمة، منها على سبيل المثال لا الحصر ما يأتي:

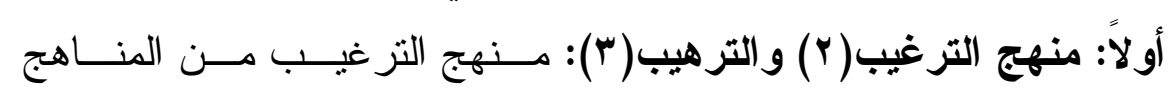
القرآنية التي وردت في غير موضع منه، ونر اه في سورة الحجرات بصورة

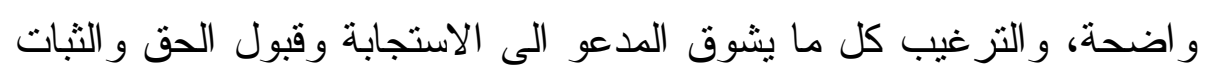

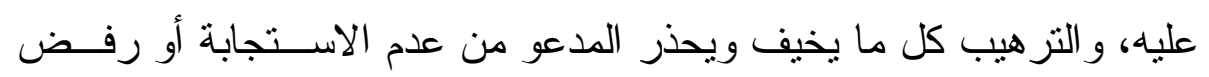

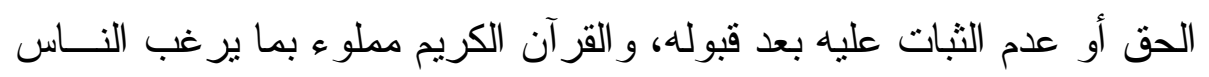

(1) سيد قطب: في ظلال القرآنج/هrrr، دار الشروق القاهرة، بدون تاريخ.

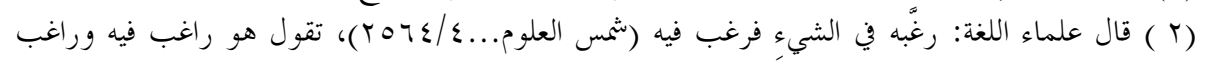

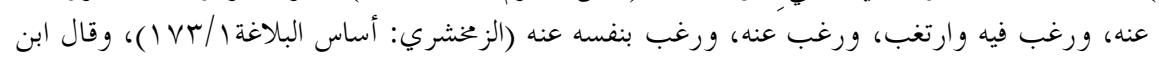

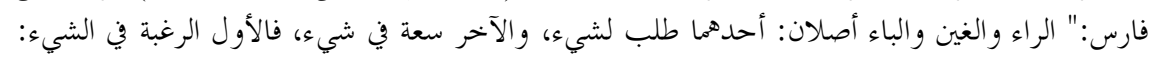

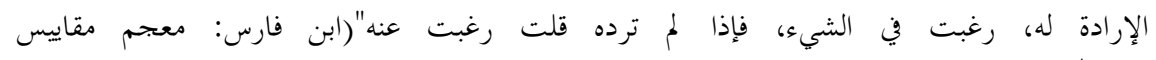

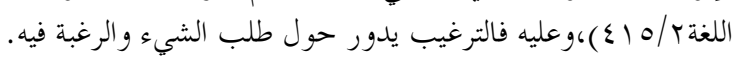

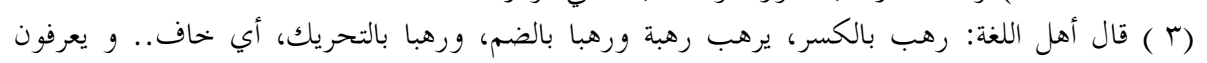

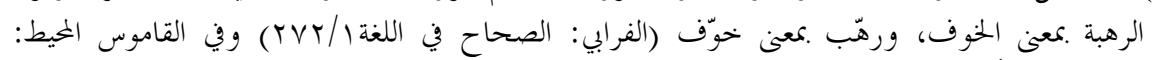

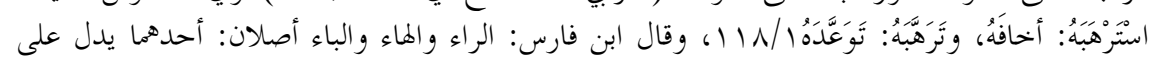

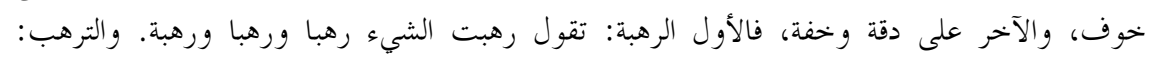

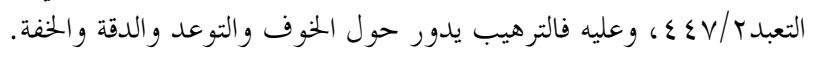

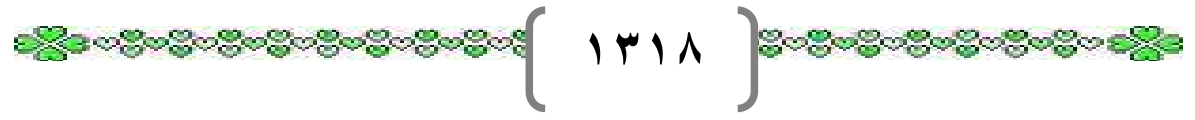


في قبول دعوة الإسلام و التحذير من رفضها، مما يدل دلالـــة قاطعــة علـى

$$
\text { أهمية هذا الأسلوب( (1). }
$$

و الأصل في التزغيب أن يكون في نيل رضى الله ورحمته وجزيل ثو ابه في الآخرة، وأن يكون الترهيب بالتخويف من غضب الله و عذابه في الآخرة وهذا هو نهج رسل الله الكرام كما بينه القرآن الكريم وجاءت به السنة النبوية المطهرة.

و أسلوب الترغيب له مر اتب وصنوَر كثيرة، وهو في الغالب يلائم معظم

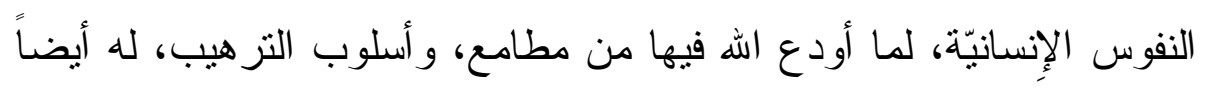

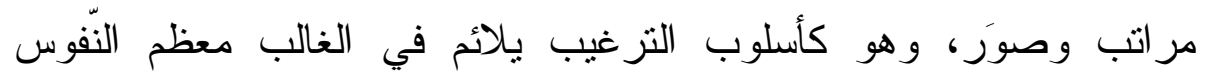
الإنسانبة، لما أودع الله فيها من حذر وخوف (ب).

ولقد ورد منهج الترغيب في هذه السورة الكريمة في قوله نعالى:

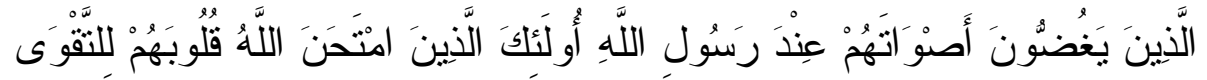

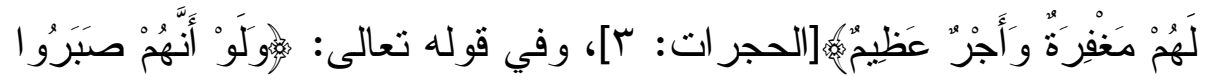

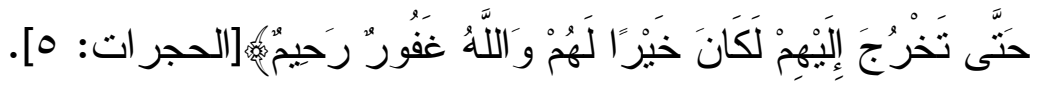

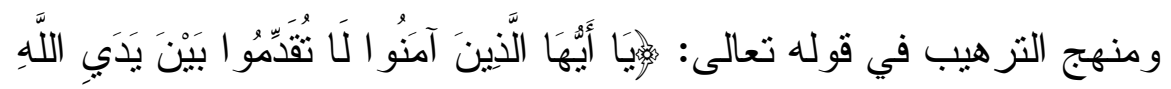

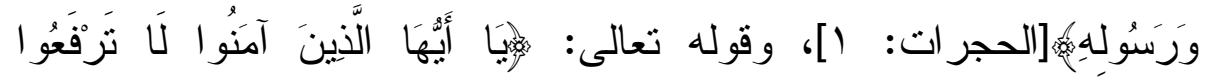

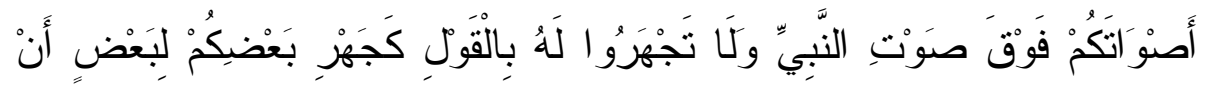

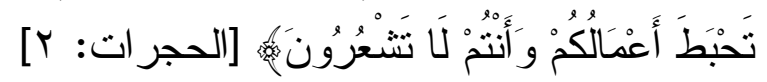


ثانياً: منهج الأمر( (1) و النهي(ץ): من أهم مناهج القرآن العظيمة؛ مــنهج

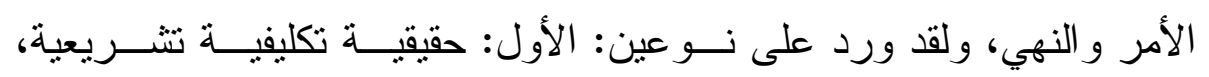

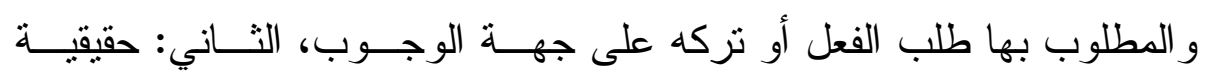

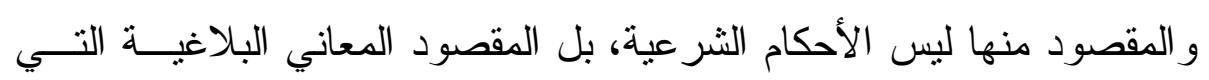
تستفاد من السياق، منها النصح و الإيمان و الإباحة و التهديد و غير ذلك (بان).

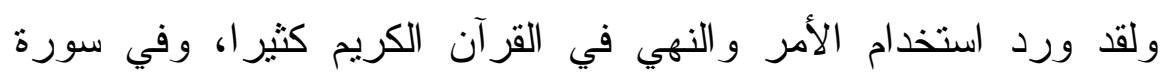

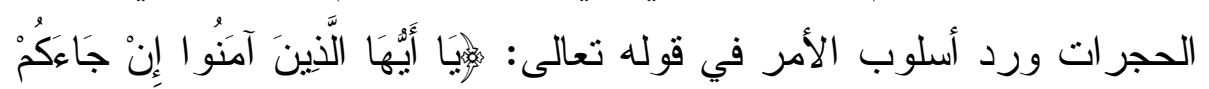

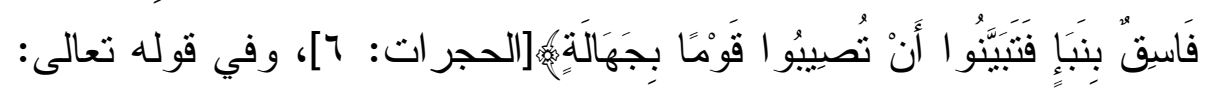

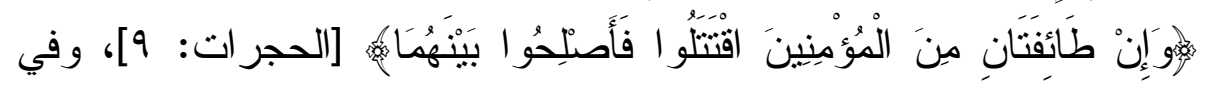

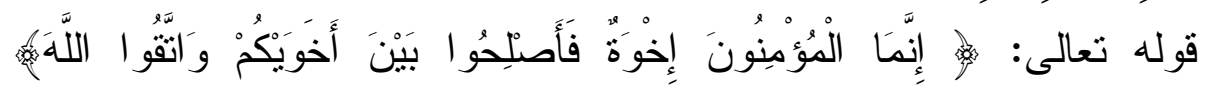

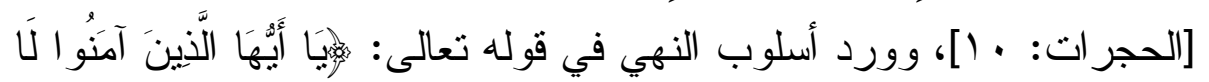

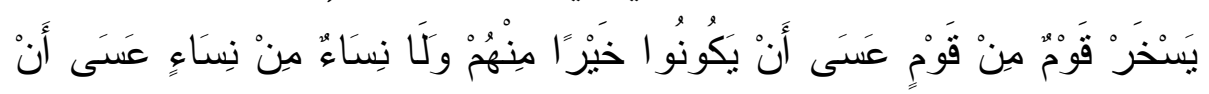

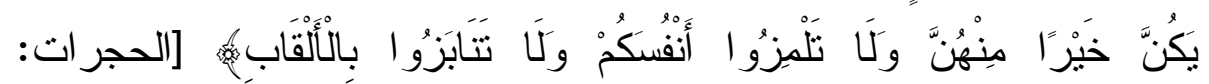

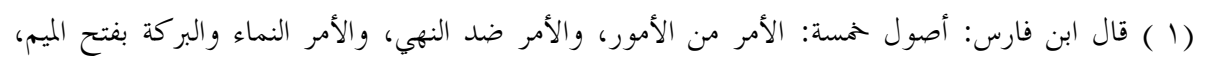

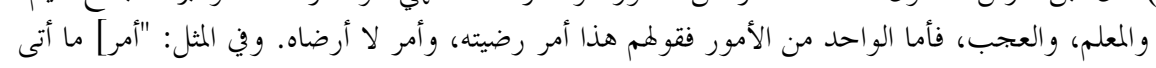

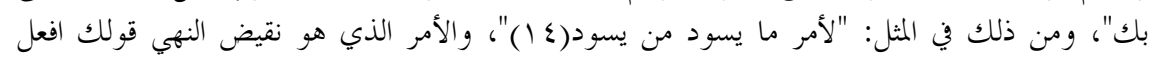

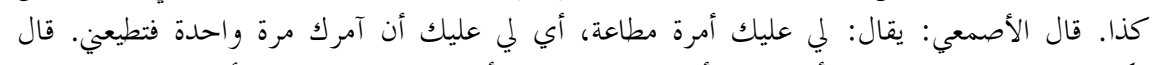

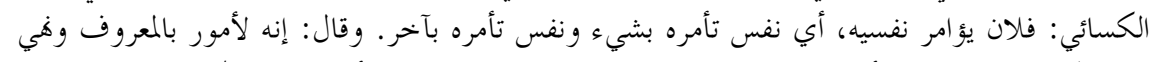

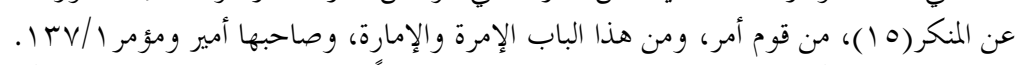

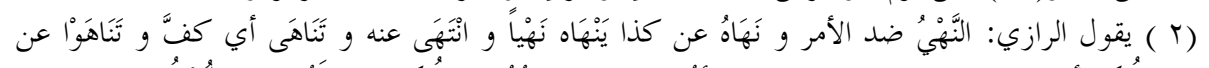

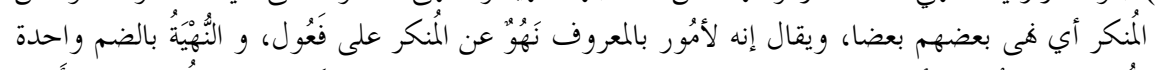

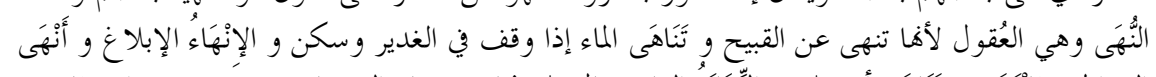

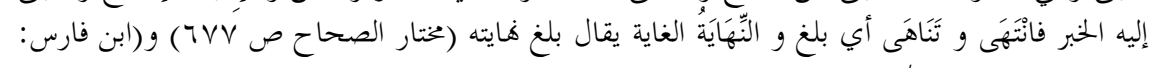

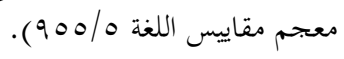

$$
\begin{aligned}
& \text { (r) يو سف الأنصاري: أساليب الأمر والنهي في القرآن، المقدمة بتصرف. }
\end{aligned}
$$

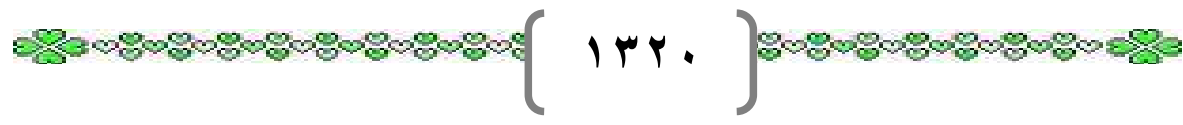




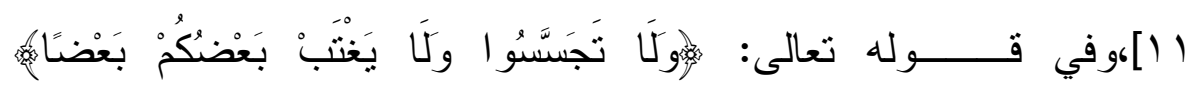

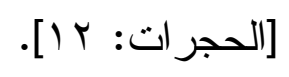

و المتأمل في هذا المنهج يلاحظ أن السورة الكريمة نهت عن رفع الصوت

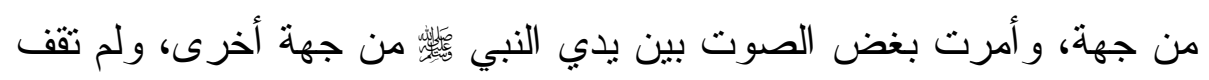
الآية الكريمة عند هذا الحد بل أكدت على أن تحقيق هذا الأدب هو المعيـار

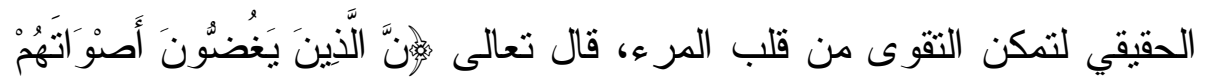

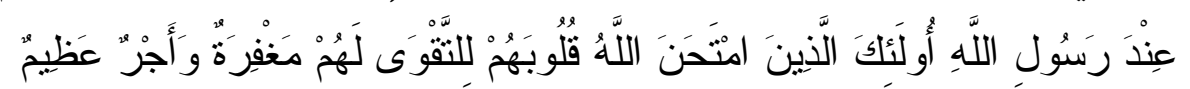
هُ [الحجر ات: r]، و هذا النص يدل بمفهوم المخالفة على أن الذين لا يغضون

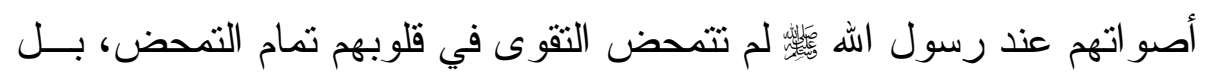

$$
\text { ربما لم تكن أهلاً للتقوى و لا محلاً قابلاً لها و العياذ بالهة ( ). }
$$

ثالثاً: منهج ضرب الأمثال(Y): بطلق المنل على الحال و القصة العجيبة

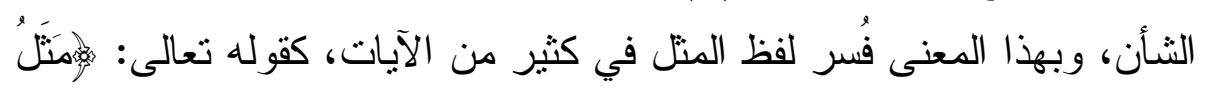

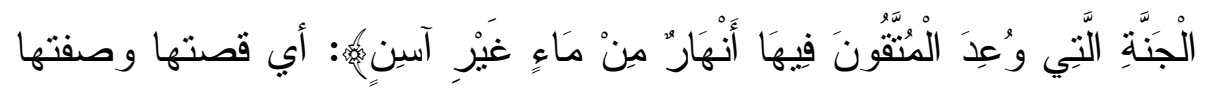
التي بُتْعجب منها.

و أثنار الزمخشري إلى هذه المعاني الثناثة في الكثاف فقال: "و المثل في

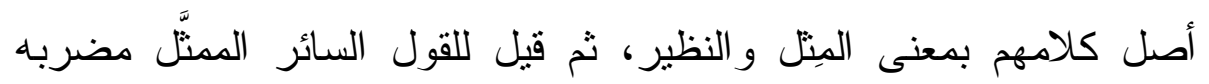

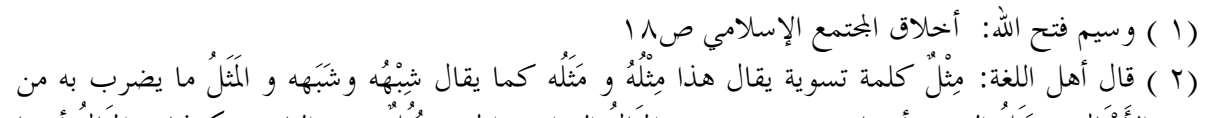

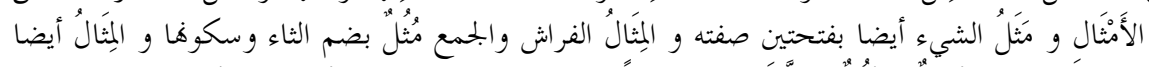

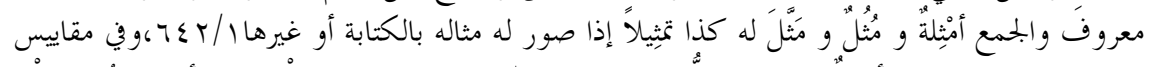

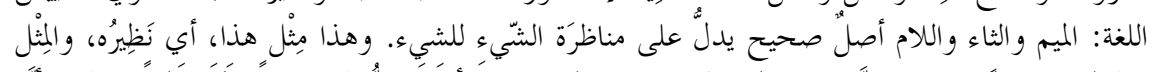

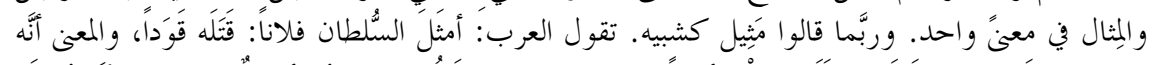

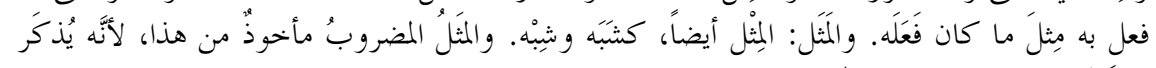

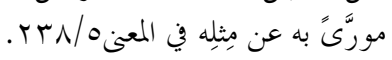

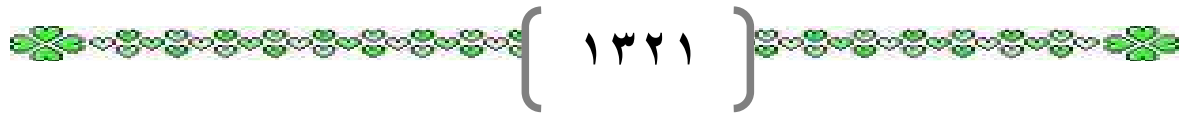


بمورده: منت، ولم يضربو ا متًاً و لا رأوه أهلًا للتسيير، و لا جديرًا بالتداول و القبول إلا قونًا فيه غر ابة من بعض الوجوه"، ثم قال: "وقد استعير المنل ولت للحال أو الصفة أو القصة إذا كان لها شأن وفيها غر ابة"( (1). وهو منهج قر آني أصيل استعمل في القرآن كثير المعالجة العديد من المشكلات، و أثنار الحق في كتابه العزيز أنه يضرب الأمثال: قال تعالى:

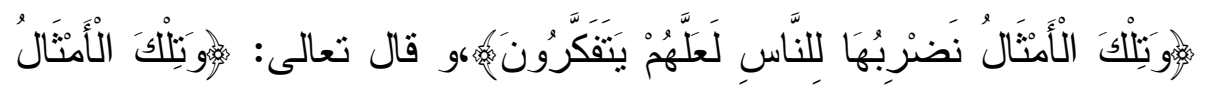

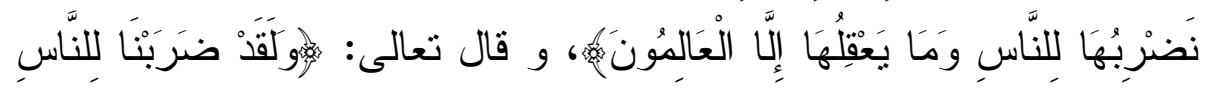

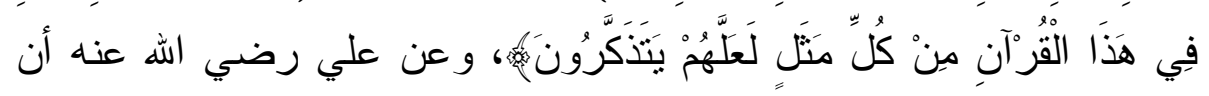

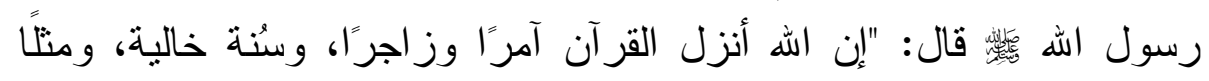

مضروبًا"

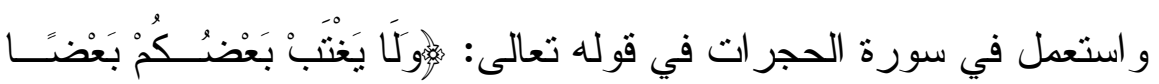

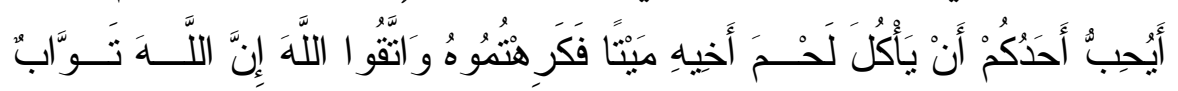

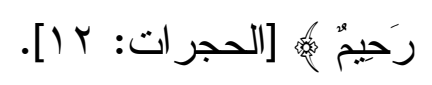

ولهذا المنهج أهمية عظيمة، وفو ائد عديدة منها، الكثف عن الحقائق،

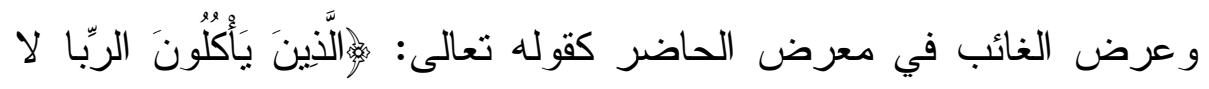

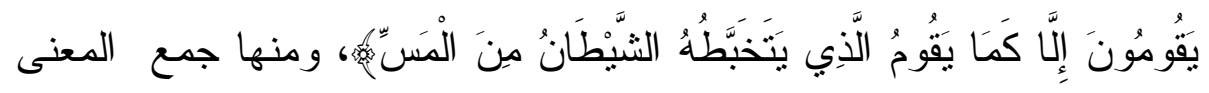
الرائع في عبارة موجزة كالأمثال الكامنة والأمثال المرسلة في الآيات الآنفة

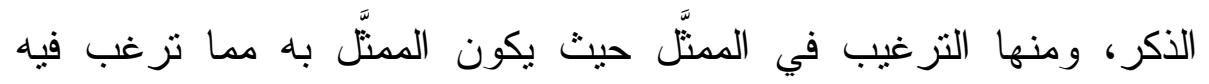
النفوس، كما ضرب الله مثنًا لحال المنفق في سبيل الله حيث يعود عليه الإنفاق بخير كثير، فقال تعالى :

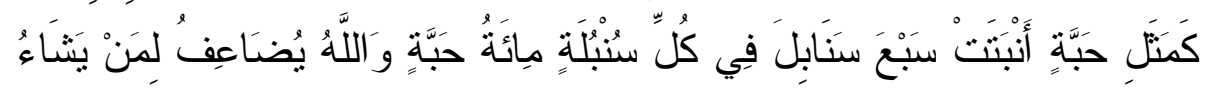

(1) ( ) الزخشري: الكشاف

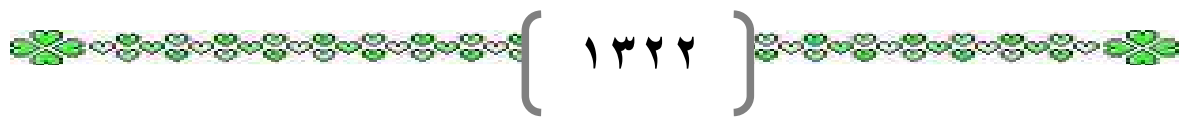




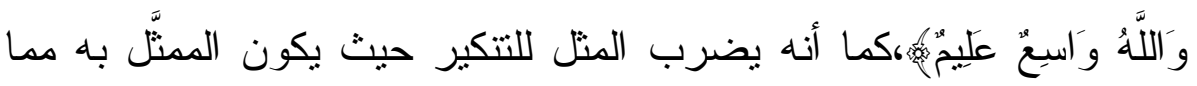

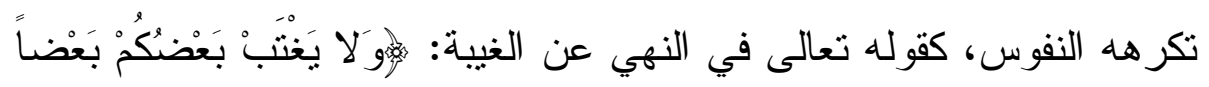

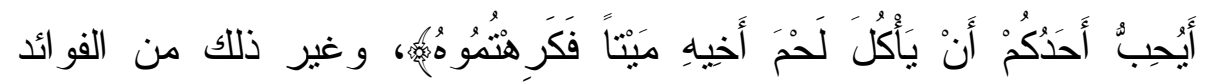

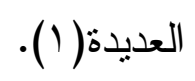

رابعاً: الموعظة الحسنة (Y):و هو منهج قر آني فريد يحمل في ثنايا العديد

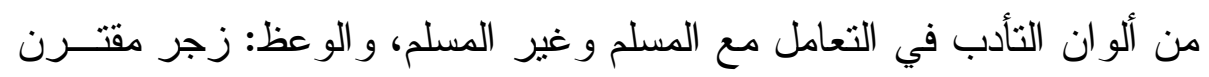

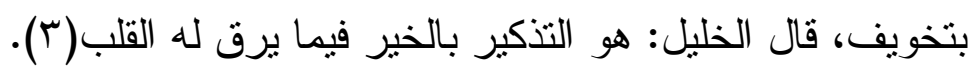

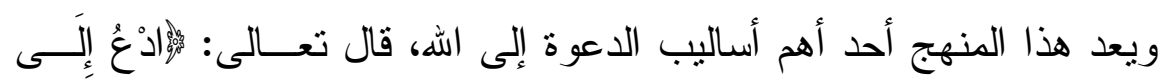

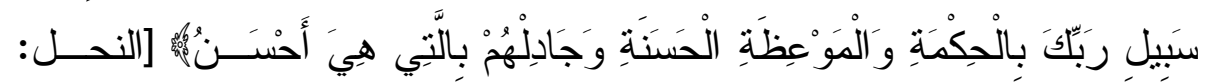

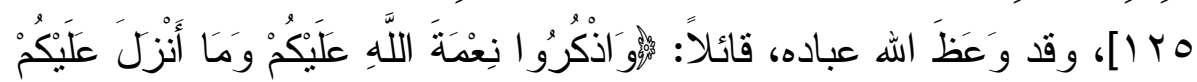

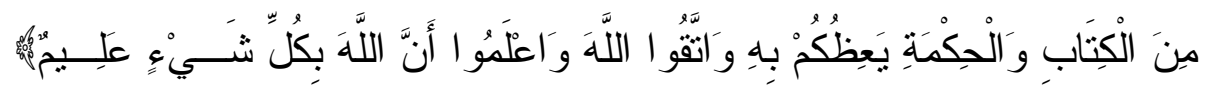

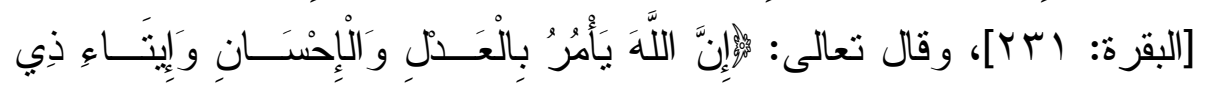

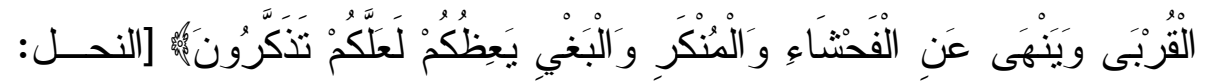

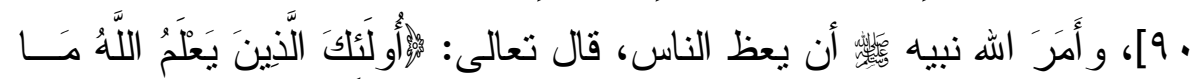

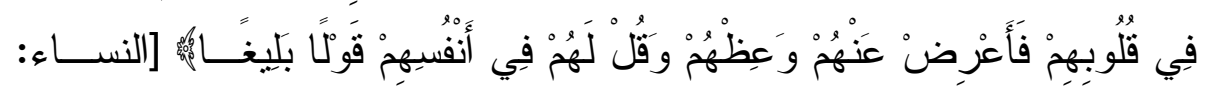
[4T

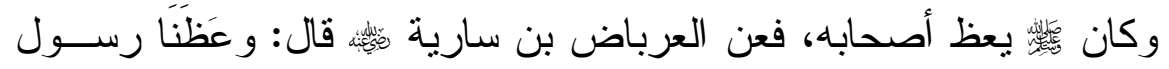

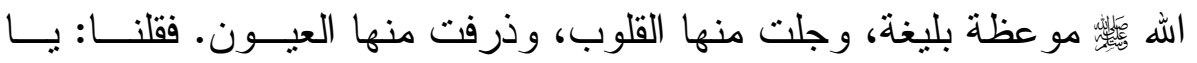

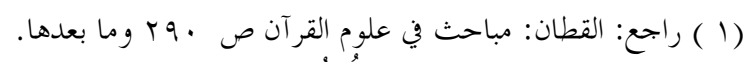

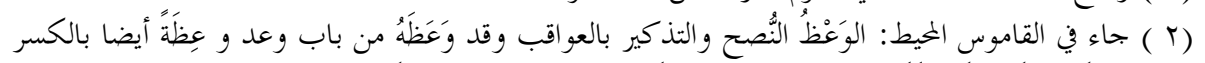

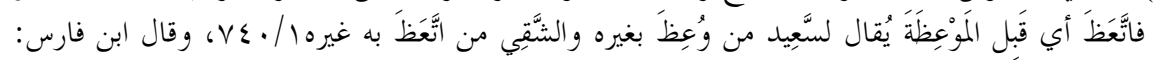

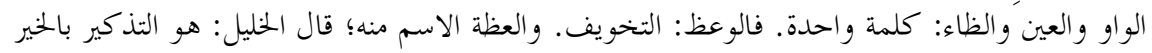

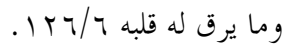

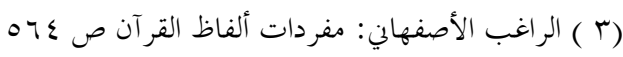

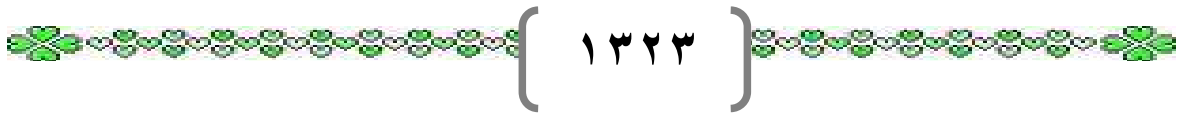


رسول الله، كأنَّها موعظة مودِّع فأوصِينا. قال : اأوصـــيكم بتقــوى الله عـز

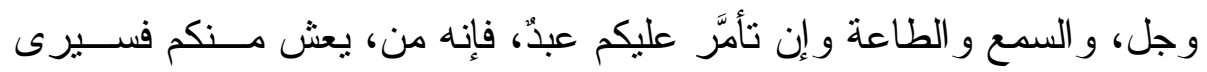

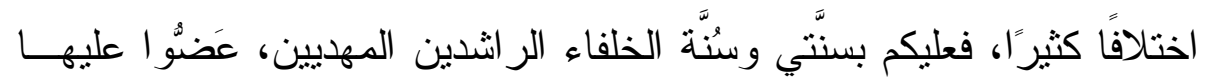

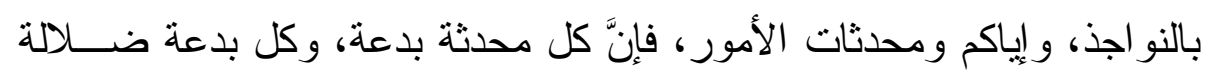

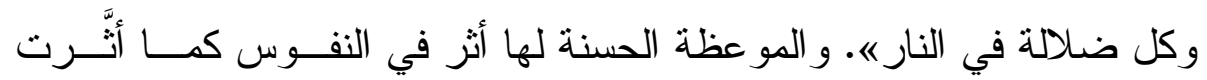

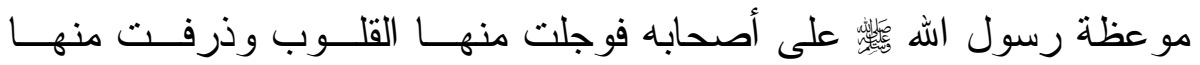

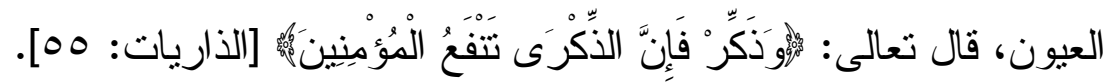

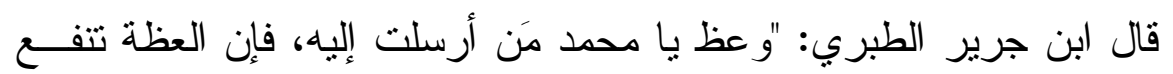

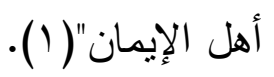
ولقد طبق هذا المنهج في القرآن الكريم في غير آية من آياته، بيد أنه فــي

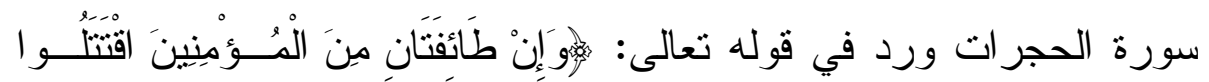

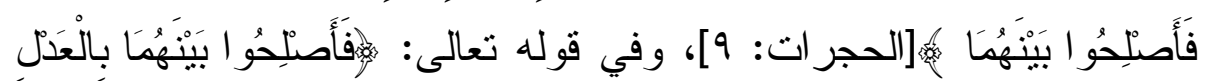

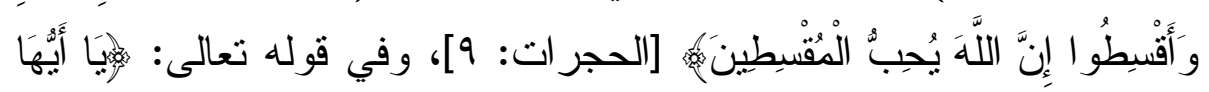

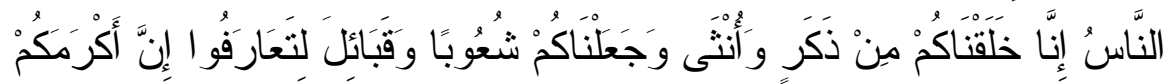

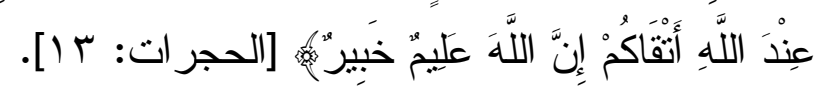

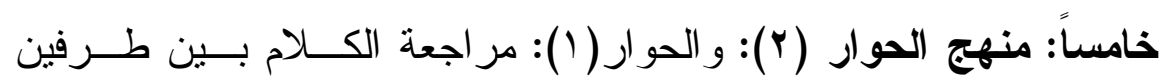
مختلفين ، مع تقديم الحجج و البر اهين لإقناع أحدهما بر أي الآخر ، أو لتقريب لئ

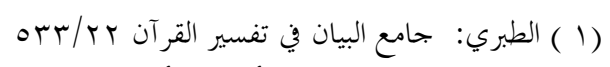

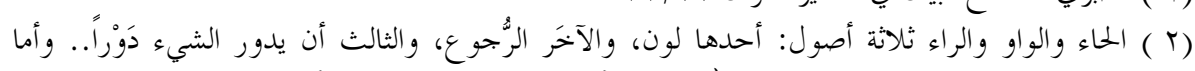

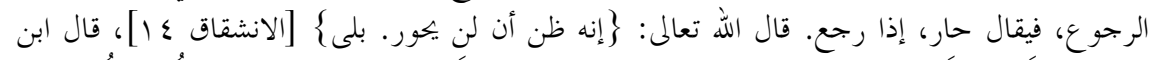

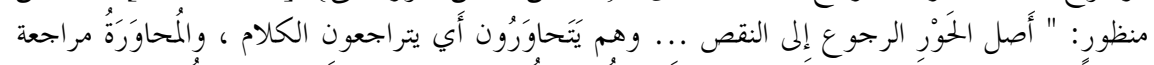

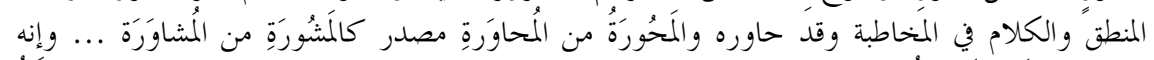

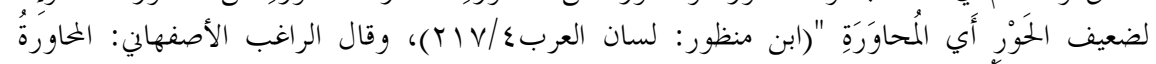

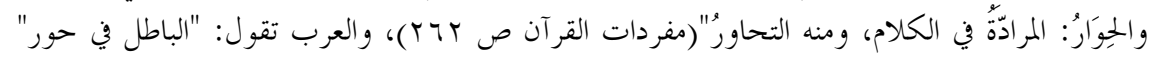

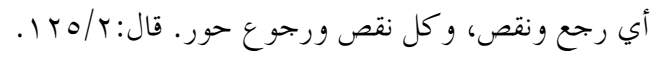


وجهات النظر، وهو لونَ من ألوان الجهاد : فعَنْ أَنَس - رضي الله عنــهـ -

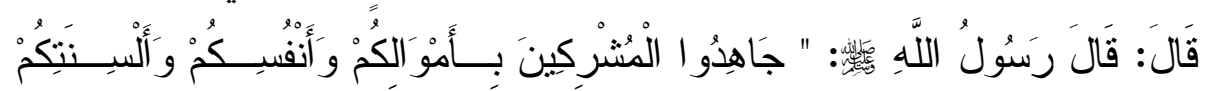

وتكرر استخدام هذا المنهج في القرآن الكريم كثير ا، ولم يستغن عنه نبي، أو رسول، والغرض من الحوار الوصول إلى الحق وإظهار الصواب، قال

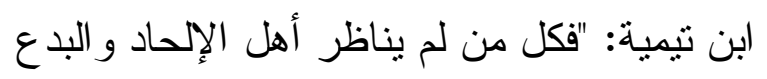
مناظرة تقطع دابرهم لم يكن أعطى الإسلام حقه ولا وفى بموجب العلم

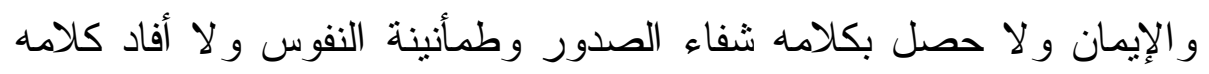

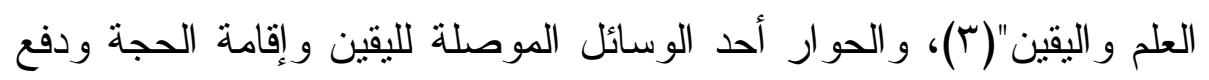
الثبهة، قال الذهبي: "إنما وضعت المناظرة لكثف الحق و إفادة العالم إلا ذكر

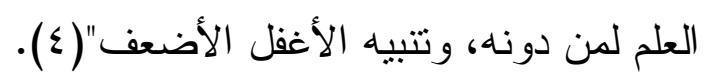
وقد طبق هذا المنهج في القرآن الكريم في العديد من المحاورات

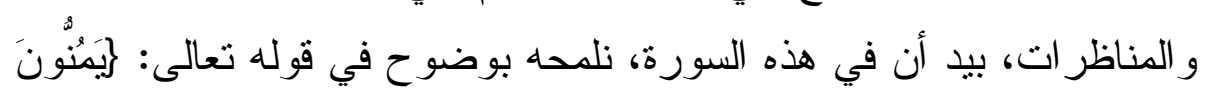

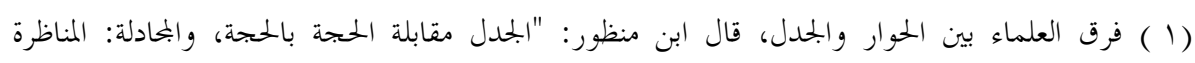

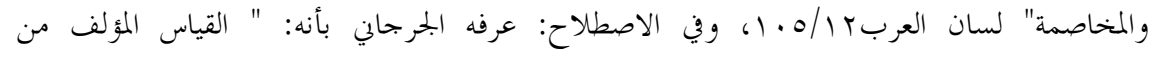

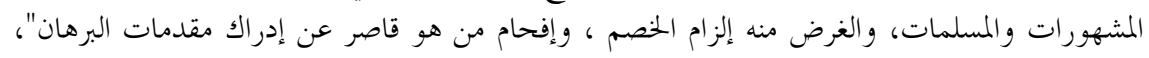

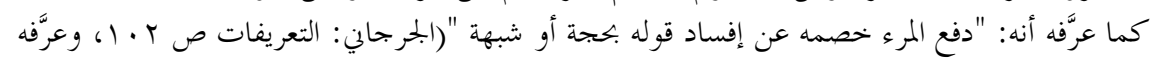

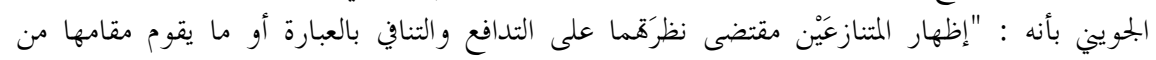

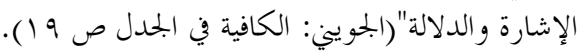

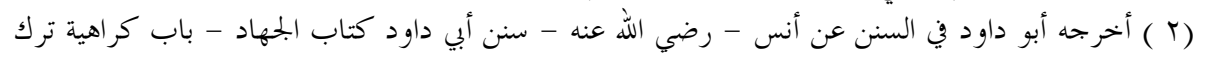

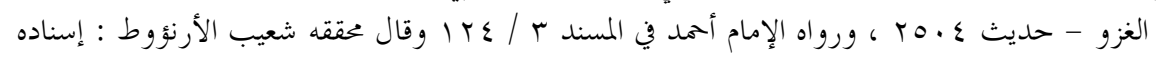

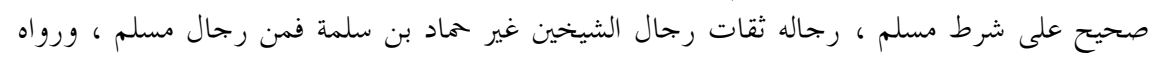

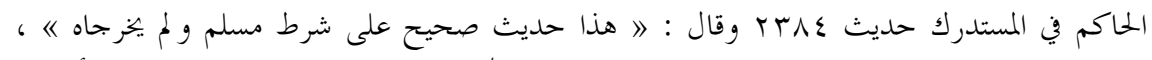

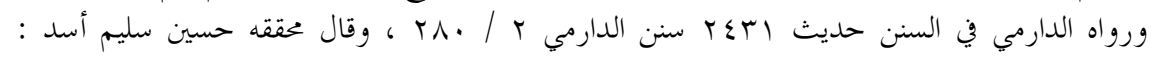

$$
\begin{aligned}
& \text { إسناده صحيح · }
\end{aligned}
$$

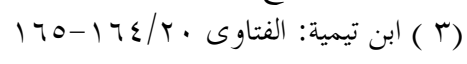

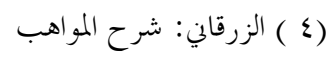




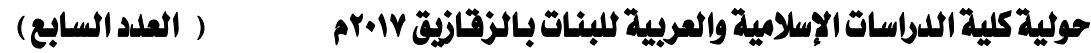

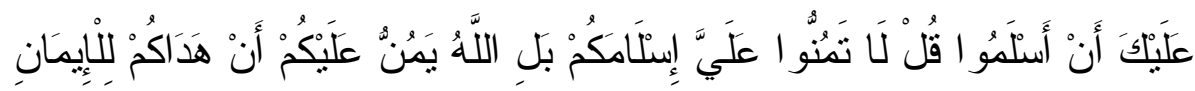

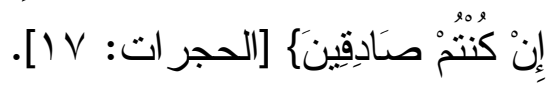

تبين مما سبق أنواع المناهج القرآنية في سورة الحجرات، التي توضح آداب التعامل بين أفراد المجتمع، والتي جمعت بين الترغيب والترهيب، و الموعظة الحسنة، و الحوار البناء، و الأمر و النهي، وضرب جئ الأمثال. 


\section{الميحث الأول: آداب التعامل مع الله ورسوله}

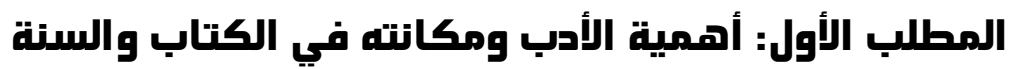

الأدب: أدب النفس والدرس، تقول منه: أدب الرجل بالضم فهو أديب، و أدبته فتأدب، و ابن فلان قد استأدب، في معنى تأدب، و الأدب: العجب، و الأدب أيضا: مصدر أدب القوم يأدبهم إذا دعاهم إلى طعامه، و الآدب: الداعي، ويقال أيضاً: آدب القوم إلى طعامه يؤدبهم إيداباً، واسم الطعام

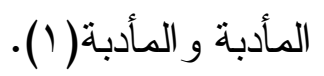

و هو : رياضة النفس بالتعليم و التهذيب على ما ينبغي، وجملة ما ينبغي لذي

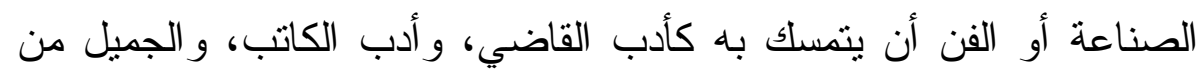

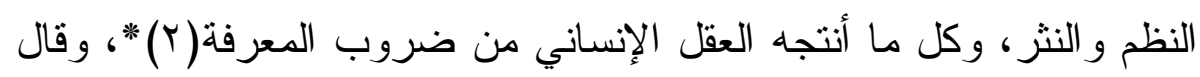

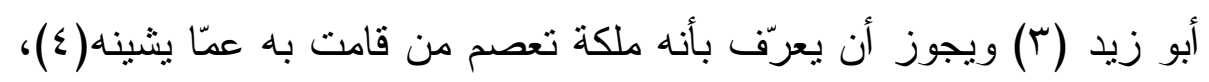

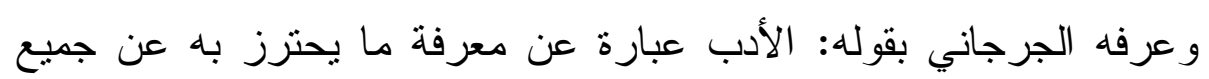
أنو اع الخطأ (0).

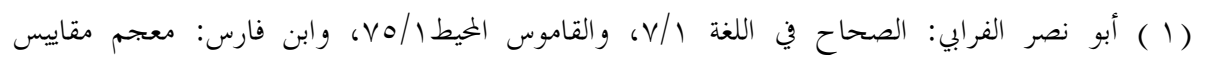

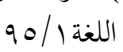

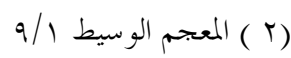

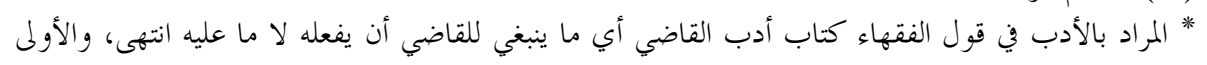

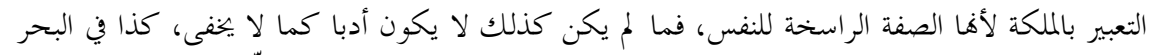

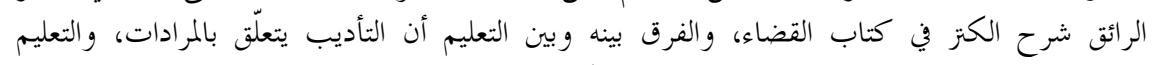

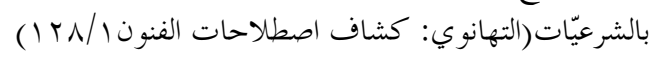

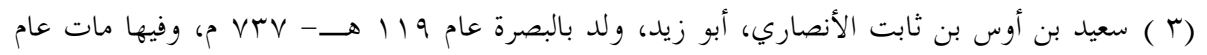

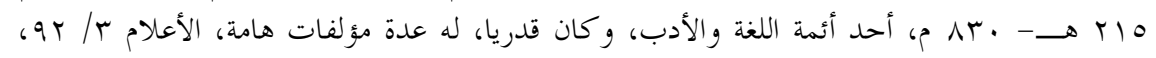

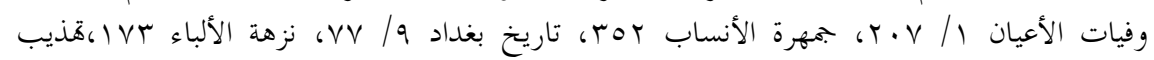

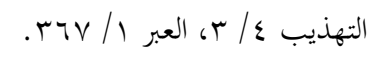

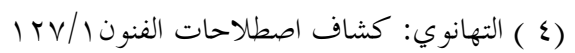

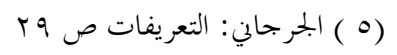

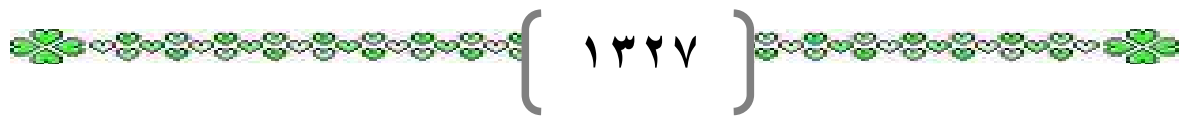


وقال ابن منظور: الأدب: الذي يتأدب به الأديب من الناس؛ سمي أدباً؛

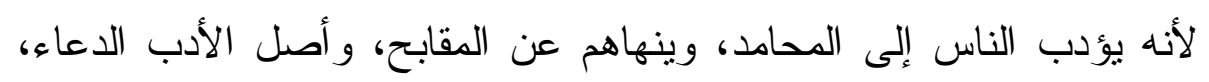
ومنه قيل للصنيع يدعى إليه الناس: مدعاة ومأدبة( (1).

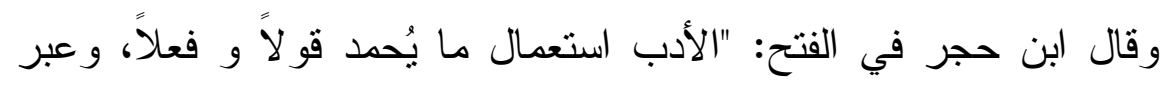
بعضهم عنه بأنه أخذ بمكارم الأخلاق، وقيل الوقوف مع المستحسنات أو أو الوبال

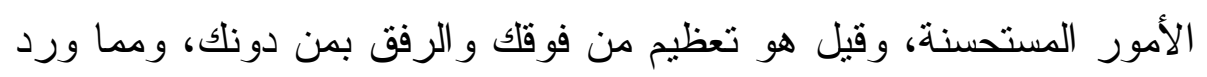

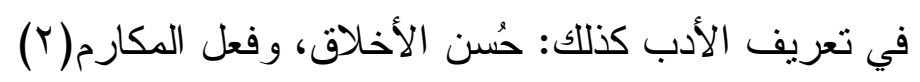

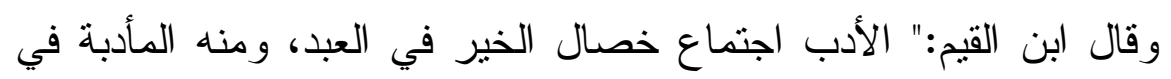

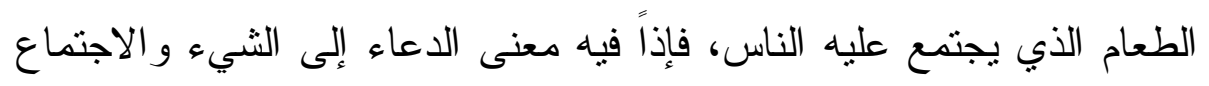

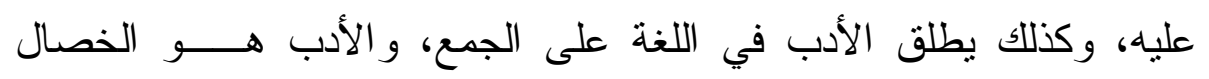

$$
\text { الحميدة" (r). }
$$

و علم الأدب عنده يعني: "علم إصلاح اللسان و الخطاب، و إصابة مو اقعه،

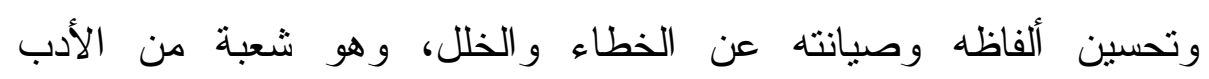

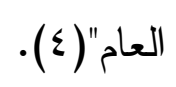

والأدب: على ضربين، أدب النفس وأدب الدرس، والأول: احتراز

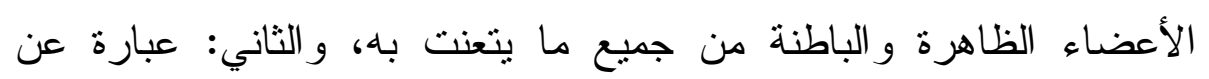
معرفة ما يحترز به عن جميع أنواع الخطابات في المناظرة خطاباً ظنياً و استدلالاً يقينياً (0).

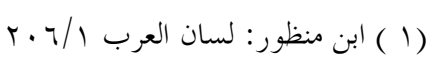

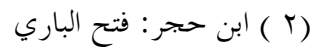

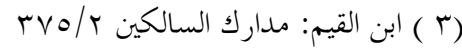

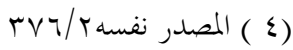

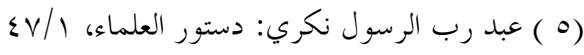


وللأدب أهمية قصوى في حياة المسلم، وقد حث الإسلام على العناية به

في كل ميادينه، قال تعالى: في بيان أهمية الأدب في تقويم الأهل وتربيتهم

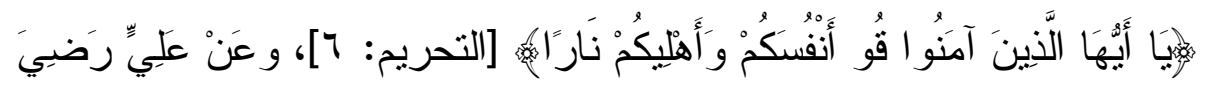

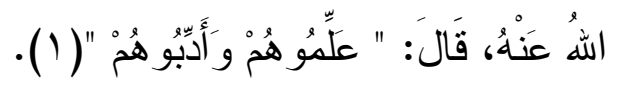

وفي الحديث: عَنِ النَّبِيِ

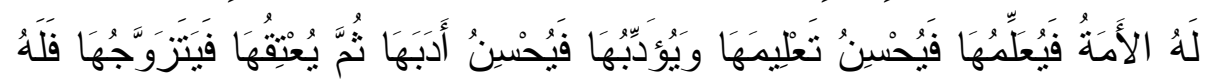

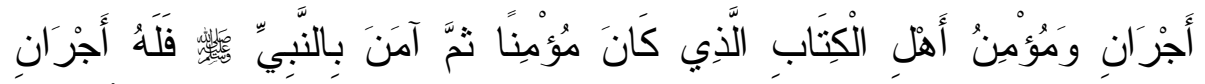

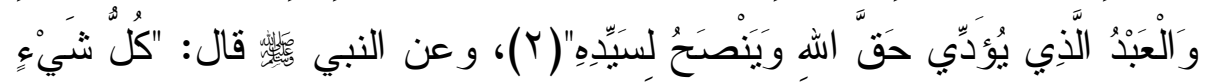

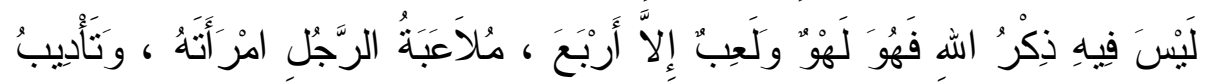

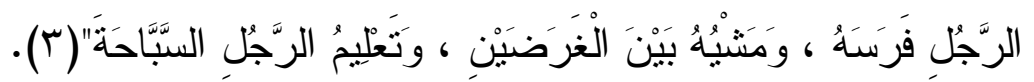

و قالت الحكماء: فضل الأدب في غير الدين مهلكة، وفضل الر أي إذا لم يكن يستعمل في رضوان الله ومنفعة الناس قائد إلى الذنوب، و الحفظ الز اكي الواعي بغير العقل مضر بالعمل الصالح ،والعمل غير الورع عن الذنوب خاز الثيطان، و إفر اط العقل مضر بالجد(ع) .

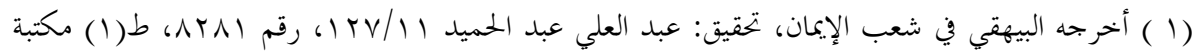

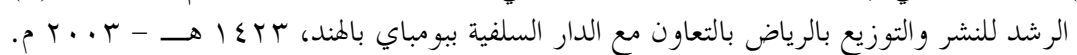

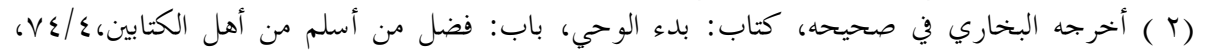

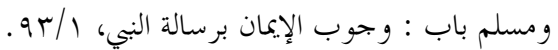

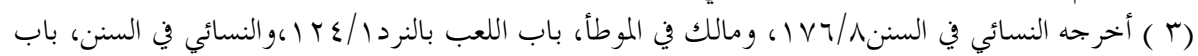

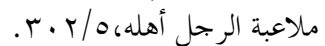

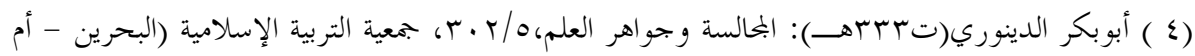

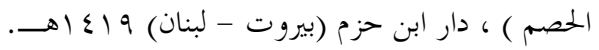




\section{المطلب الثاتي: الأدب مع الله تعالى ورسوله}

الأدب مع الله تعالى، قربة إليه سبحانه، و امتثال لأمره ونهيه، لم يقف عند

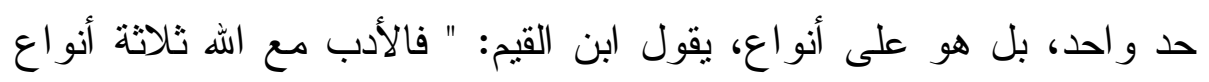

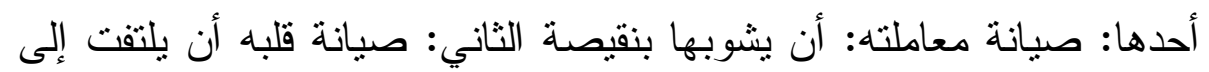
غيره الثالث: صيانة إر ادته أن تتعلق بما بمقتلك عليه" (1 ).

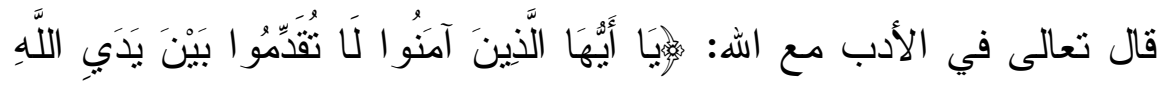

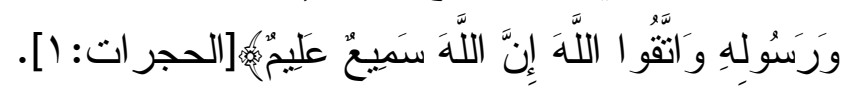
ورد في سبب نزول الآية:(r) كانت عادة العرب وهي إلى الآن الاشتر الك

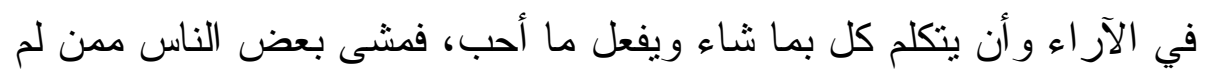
تتمرن نفسه مع النبي أبط

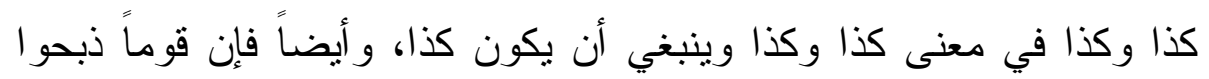

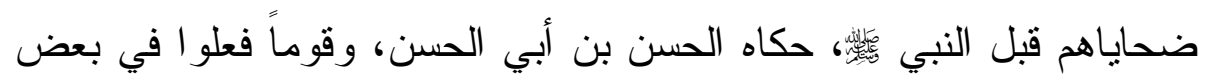
حروبه وغزواته أثثياء بآرائهم، فنزلت هذه الآية ناهية عن جميع ذلك، وحكى الثعلبي عن مسروق أنه قال: دخلت على عائشة في يوم الثك فقالت

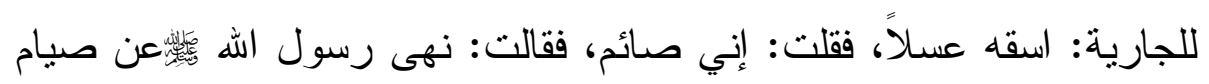

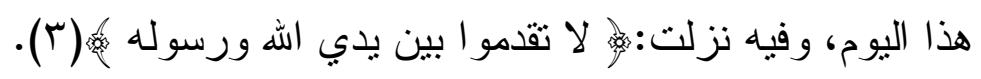
يقول الفخر الرازي في تبيان مقصود الآيات الأول من هذه السورة

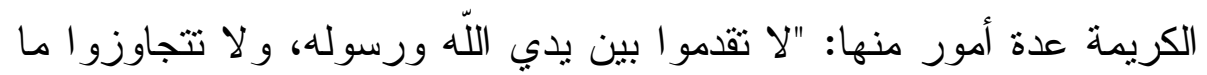

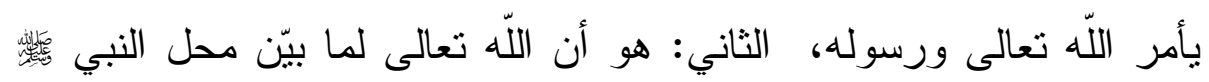

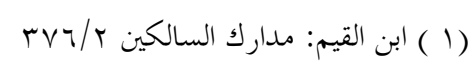

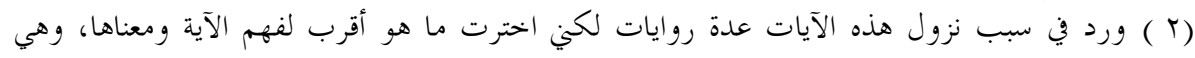

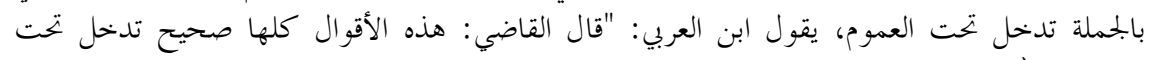

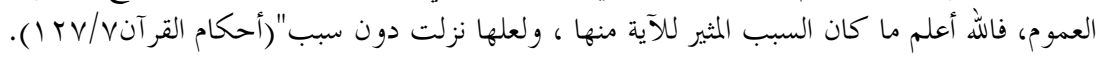

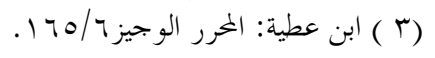

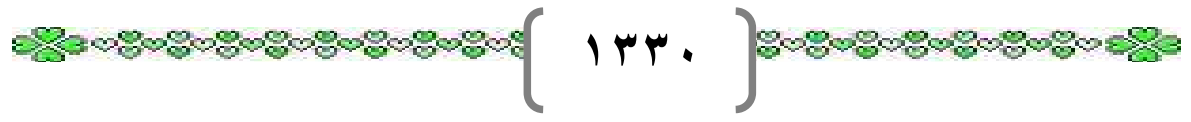


و علو درجته بكونه رسوله الذي يظهر دينه وذكره بأنه رحيم بالمؤمنين بقوله .

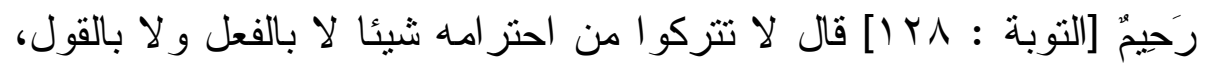

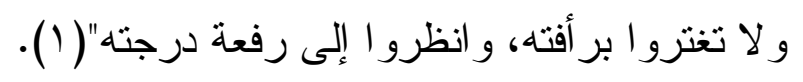

و يعطي الثوكاني معنى آخر للآية فيقول :" لا تقطعو ا أمراً دون الله ورسوله، و لا تعجلو ا به، وقيل: المر اد معنى بين يدي فلان: بحضرته؛ لأن ما يحضره الإنسان، فهو بين يديه"(r) وقال الثنقيطي: "و المعنى لا تتقدموا أمام الهه ورسوله: فتقولوا في شيء بغير علم ولا إذن من الله، وهذه الآية الكريمة فيها التصريح بالنهي عن التقديم بين يدي الله ورسوله، ويدخل في ذللك دخو لا أوليا تشريع ما لم يأذن وند

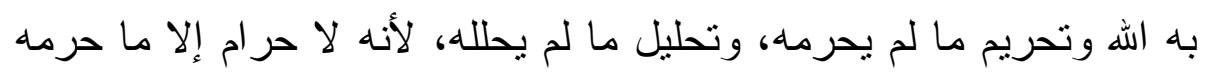
الله و لا حلال إلا ما أحله الله، و لا دين إلا ما شر عهده والله(ب) . وقال ابن كثير: يدخل في عموم هذا الأدب الثرعي حديث معاذ، عن أناسٍ

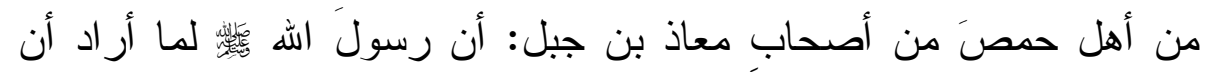

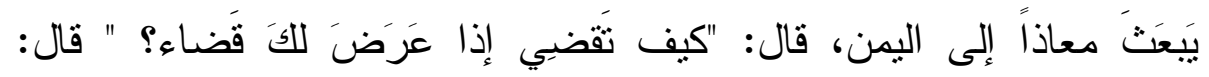

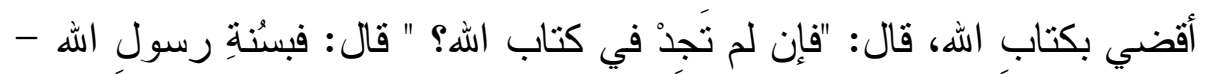

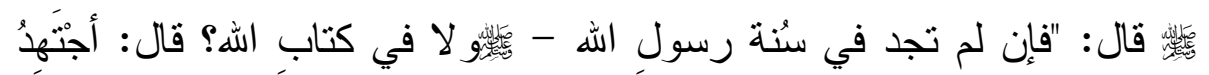

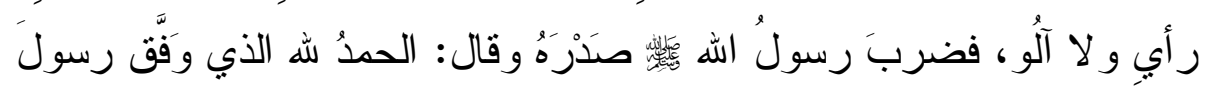

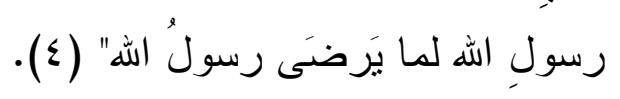

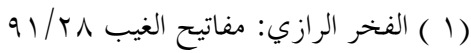

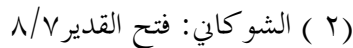

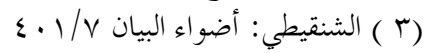

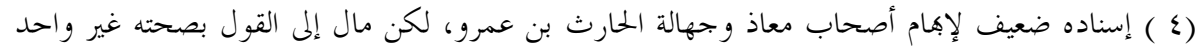

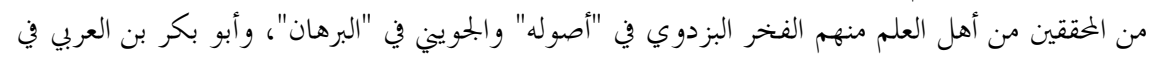

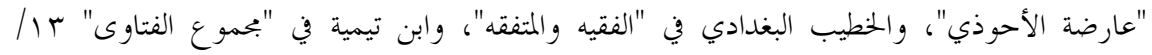


و الغرض منه أنه أخر رأيه ونظره و اجتهاده إلى ما بعد الكتاب و السنة، ولو قدمه قبل البحث عنهما لكان من باب التقديم بين يدي الله ورسوله، وعن

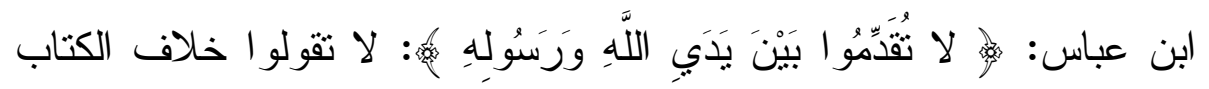
و السنة (1) (1). (1).

إن مقصود الأدب مع الله القيام بدينه و التأدب بآدابه ظاهر ا وباطنا، ولا يستقيم لأحد قط الأدب مع الله إلا بثلاثة أثنياء : معرفته بأسمائه وصفاته ومعرفته بدينه وشر عه وما يحب وما يكره ونفس مستعدة قابلة لينة متهيئة لقبول الحق علما و عملا وحالا.

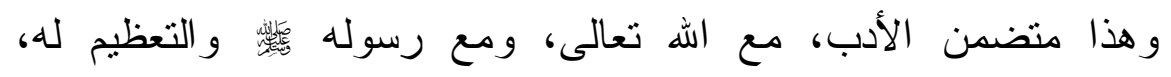

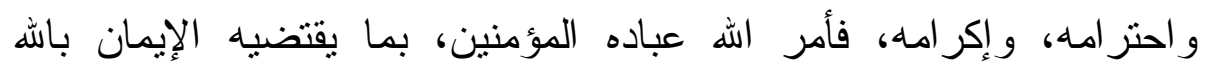

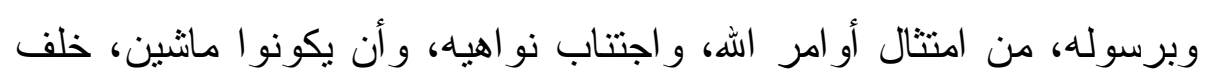

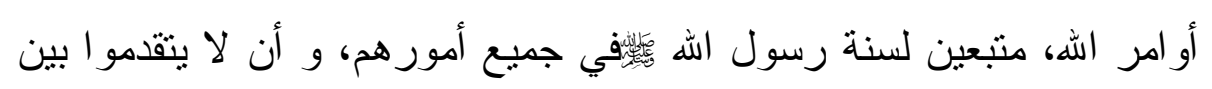

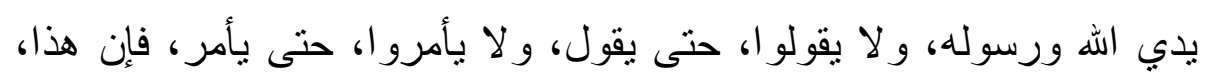
حقيقة الأدب الو اجب، مع الله ورسوله.

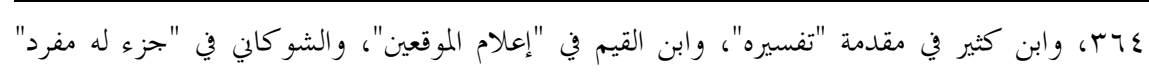

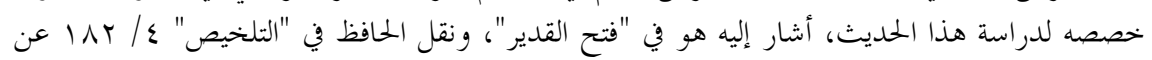

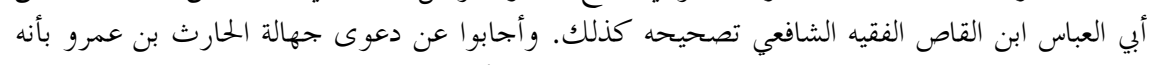

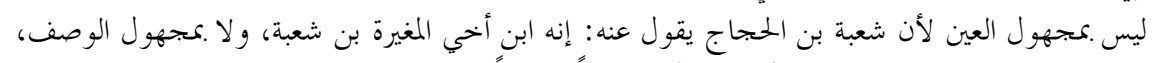

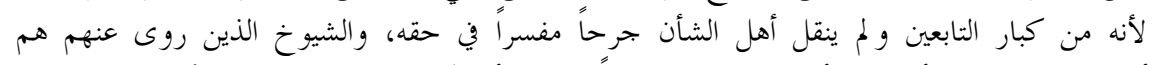

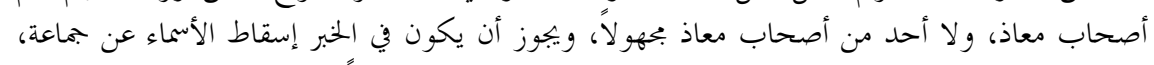

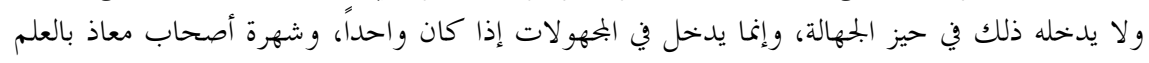

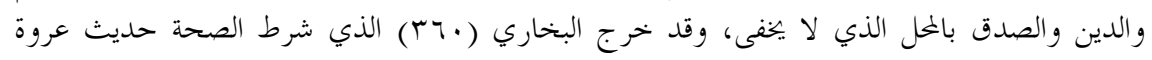

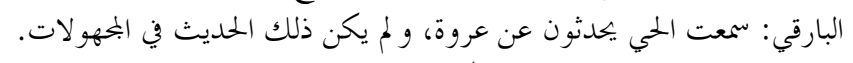

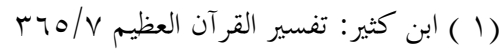

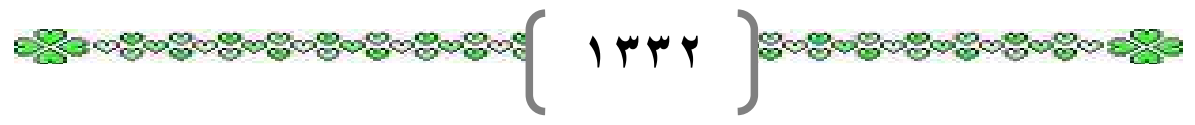


و هو عنوان سعادة العبد وفلاحه، وبفواته، تفوته السعادة الأبدية، و النعيم السرمدي، وفي هذا، النهي الشديد عن تقديم قول غير الرسول ونئ

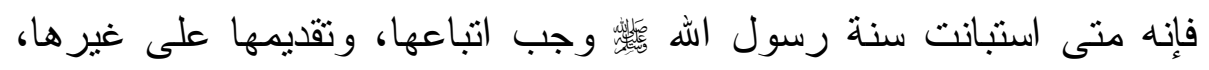

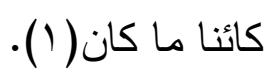
يقول ابن العربي بشأن هذه الآية: نهو ا أن يتكلمو ا بين بدي كلامه ؛ قاله

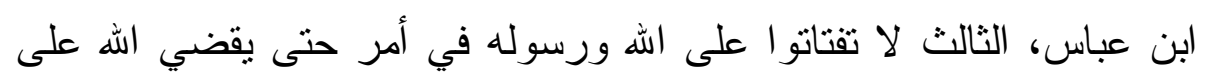
لسان رسول الله لئسئما يشاء؛ قاله مجاهد (Y).

وصور التقدم بين يدي الله عديدة ومتتوعة من أهمها ما يأتي:

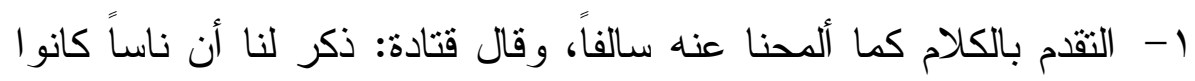
يقولون: لو أنزل في كذا لو وضع كذا وكذا وهذا من القول وهو باللسان .

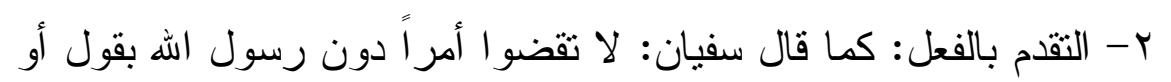
فعل .

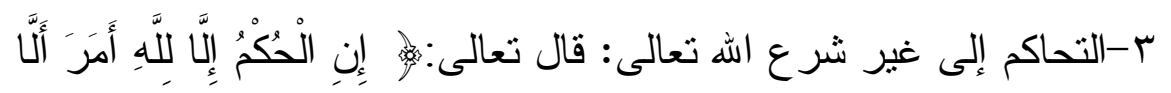

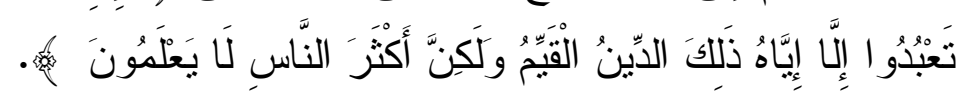
قال ابن تيمية: " فالحكم لله وحده ورسلُه بيلغون عنه، فحكمه حكمه،

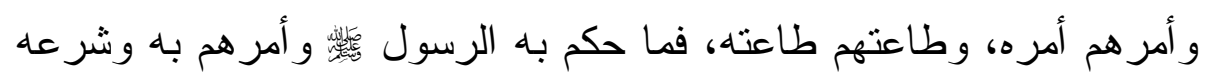
من الدين وجب على جميع الخلائق اتباعه وطاعته؛ فإن ذلك هو حكم الله

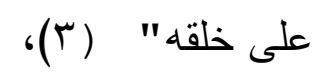

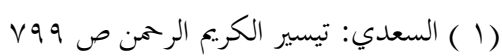

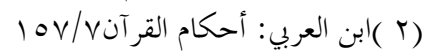

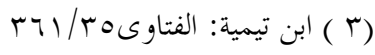

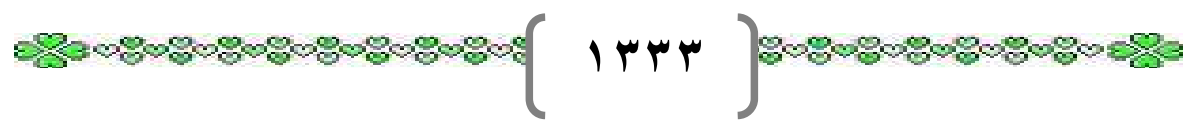


وقال الشنقيطي: " و المعنى لا تتقدمو أمام الله ورسوله فتقولو ا في شيء بغير علم ولا إذن من الله، وهذه الآية الكريمة فيها التصريح بالنهي عن

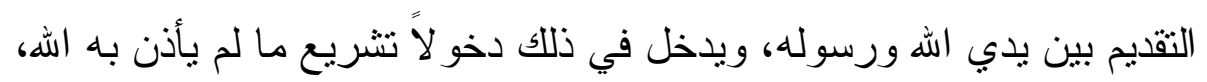

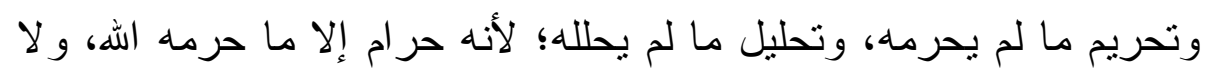
حلا إلا ما أحله الله، و لا دين إلا ما شرعه ونه الله"( (). ومفهوم الآية يدل على وجوب تقديم أمر الله وأمر رسوله، و إنما يكون ذلك بالتمسك بكتاب الله وسنة رسوله، وهذا من الأصول التي اتقق سلف هذه الأمة، وهي أعظم نعمة أنعم الله بها عليهم، يقول شيخ الإسلام ابن تيمية: "

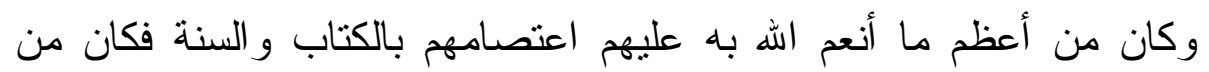

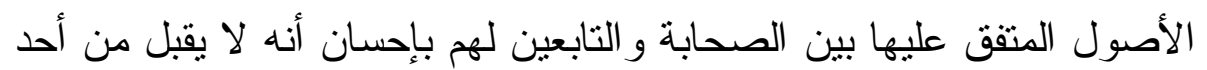

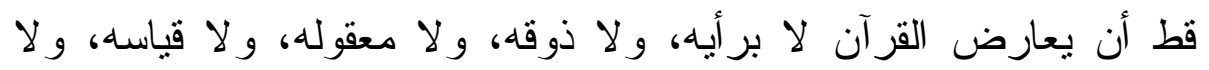
وجده؛ فإنهم ثبت عنهم بالبر اهين القطعيات والآيات البينات أن الرسول جاء بالهدى ودين الحق و أن القرآن يهدي للتي هي أقوم" (ب).

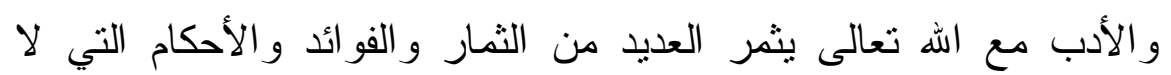

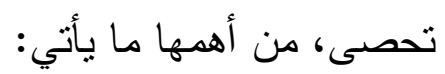
1- أن المطبقين لهذا الأدب هم أهل التقوى، فضلاً عن أنها أصل عظيم من الأصول التي يجب العمل بها، قال ابن العربي: (ب) "هذه الآية أصل في

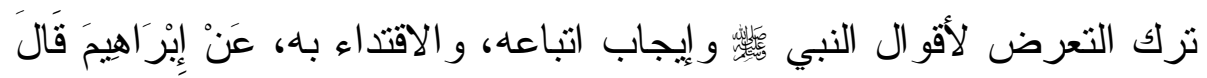

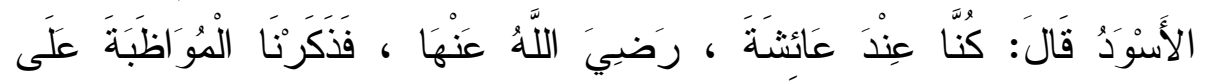

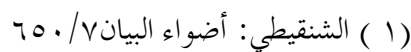

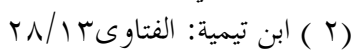

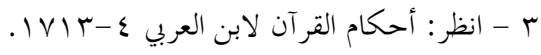




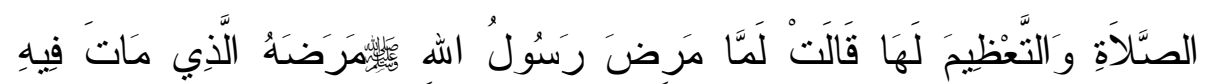

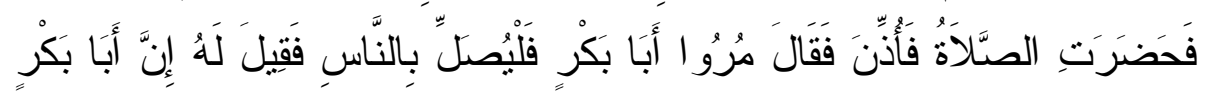

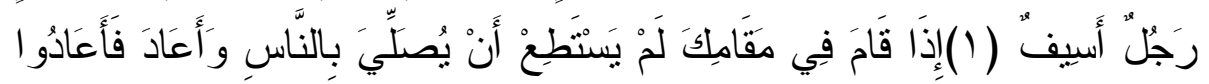

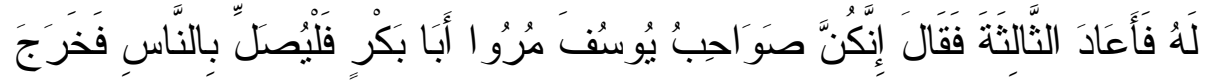

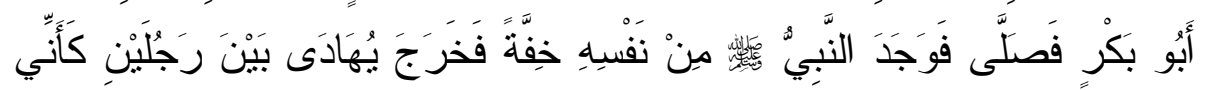

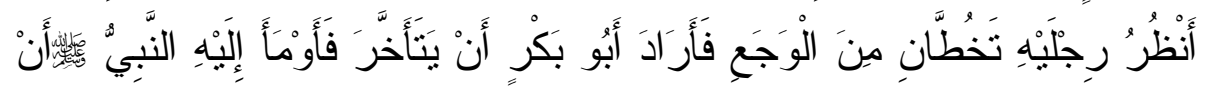

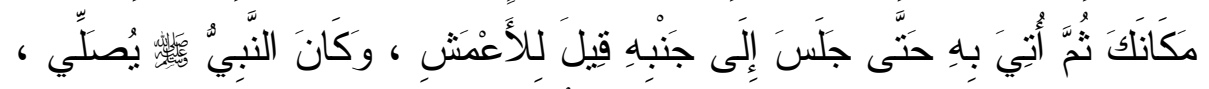

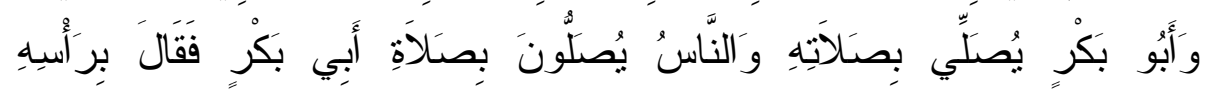

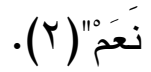

ץ-الإلتز ام الكامل بما أمر به الله تعالى ورسوله.ب-التشريع حق لله تعالى ورسوله. ؟-لا بجوز تقديم الآر اء على شرع الله تعالى، يقول الثيخ عطية سالم عن جملة هذه الفوائد و الثمار : "هذه الآية الكريمة في مستهل هذه السورة الكريمة فيها تأديب للأمة، وتعريف لهم بالحق الو اجب عليهم، من حيث

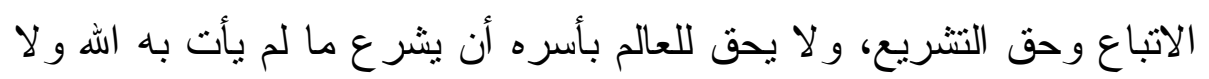
رسوله، ويكفي ذلك تتبيهاً على كل نتريع من شرق أو غرب، ونى من حضارة

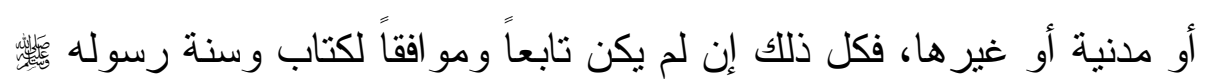

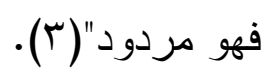

ه-الأخذ الثديد على يد كل من خرق ضود ابط الأدب مع الله، وذلـــــــن مـن

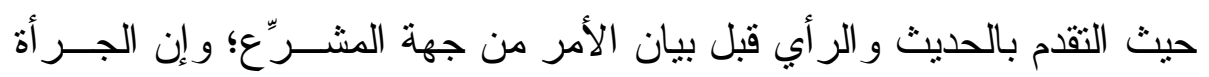

$$
\text { (1) (1) (1) حزين، وقيل: سريع البكاء. }
$$

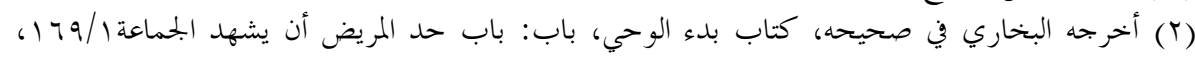

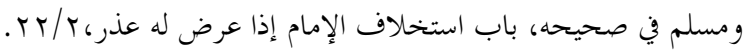

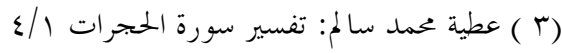




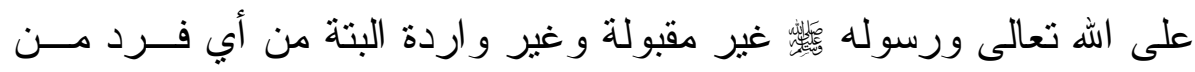

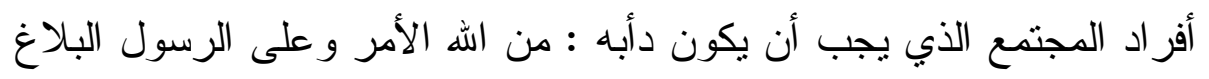

$$
\text { و علينا السمع و الطاعة( (1). }
$$

و الأدب الثاني من الآداب المتعلقة بحق الله تعالى ورسوله، الأدب مع

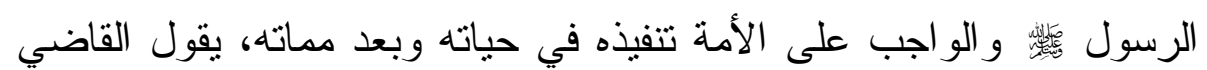
عياض في الثفا: "في وجوب تصديقه و اتباعه في سنته وطاعته ومحبته ومناصحته وتوقيره وبره وحكم الصلاة عليه و التسليم وزيارة قبره  جميع ما جاء به وما قاله ومطابقة تصديق القلب بذلك شهادة اللسان بأنه رسول الله

وقال ابن القيم: "فر أس الأدب معه: كمال التسليم له والانقياد لأمره وتلقي خبره بالقبول و التصديق دون أن يحمله معارضة خيال باطل يسميه معقو لا أو

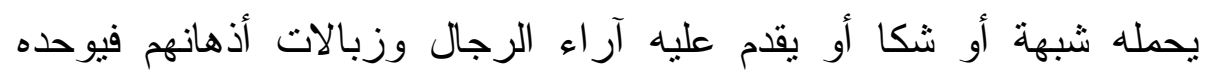
بالتحكيم و التسليم و الانقياد و الإذعان كما وحد المرسل سبحانه وتعالى بالعبادة

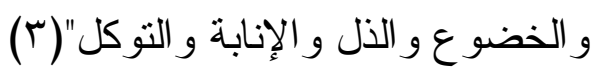

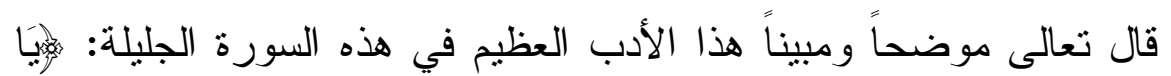

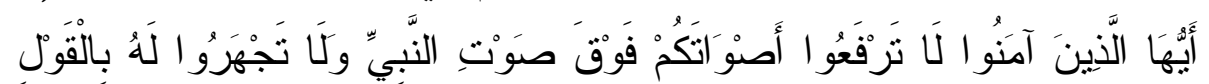

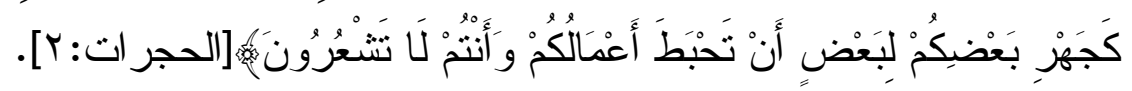

$$
\begin{aligned}
& \text { (1 ) وسيم فتح الله: أخلاق و آداب البحتمع الإسلامي من خلال سورة الحجرات صب الفاض }
\end{aligned}
$$

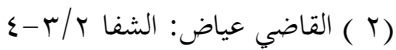

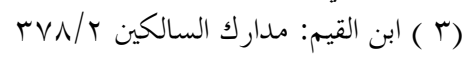


وحق أن نقول إن السورة الكريمة في مجملها سورة الآداب، آداب مع الله، آداب مع رسول الله، آداب في حضرته، آداب في غييته، آداب معه كربِّ أسرة في حجراته، ثم بعد ذلك آداب مع الجماعة الإسلامية، وطوائف رئه المسلمين، ثم آداب الأفر اد في حد ذاتهم( (1). يقول الإمام القرطبي في سبب نزول هذه الآية أنها نزلت في الأقرع ابن

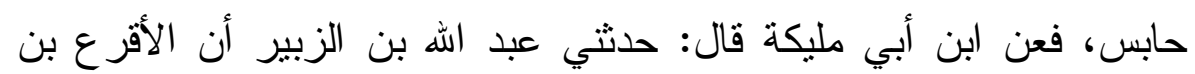
حابس قدم على النبي

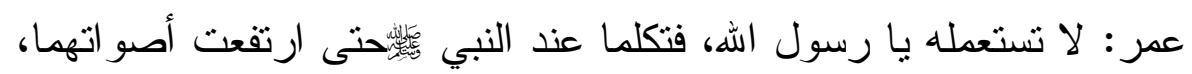
فقال أبو بكر لعمر : ما أردت إلا خلافي. فقال عمر : ما أردت خلافك، قال:

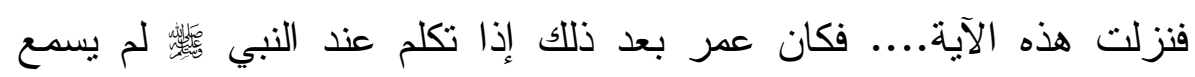
كلامه حتى يستفهمه (r). (r).

ومعنى الآية: الأمر بتعظيم رسول الله بحضرته و عند مخاطبته، أي إذا نطق ونطقتم فعليكم ألا تبلغو البأصو اتكم

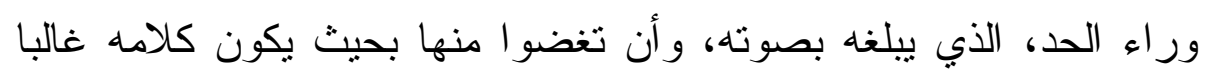
لكلامكم، وجهره باهر ا لجهركم، حتى تكون مزيته عليكم لائحة، وسابقته

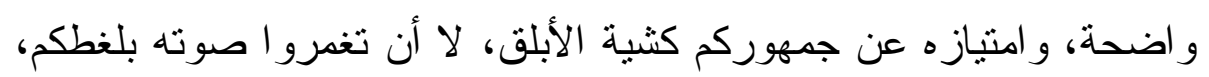

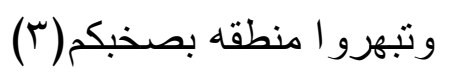

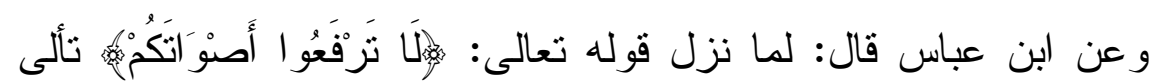
(أي: حلف) أبو بكر ألا يكلم رسول الله إلا كأخي السرار فأنزل الله في أبى نيى

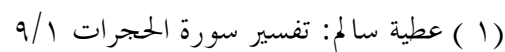

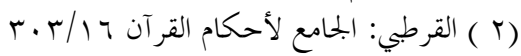

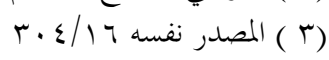




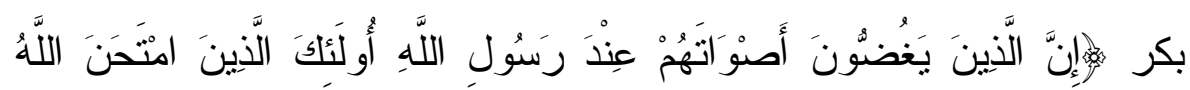

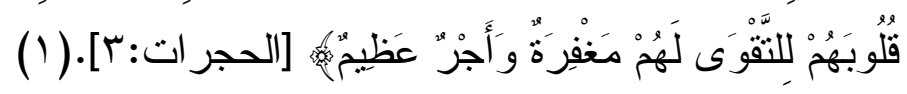

قال القاضي أبو بكر بن العربي مبينا العديد من الأحكام الثرعبة التي

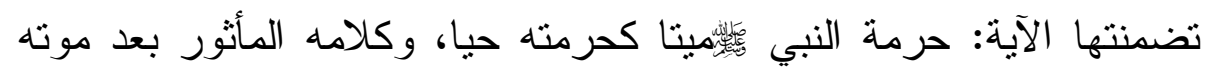

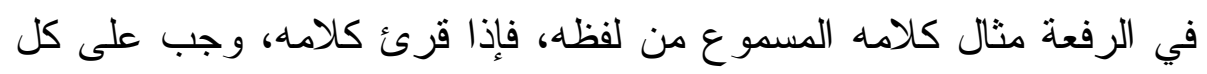

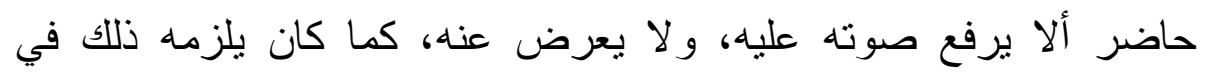
مجلسه عند تلفظه به، وقد نبه الله سبحانه على دوام الحرمة المذكورة على لعلى

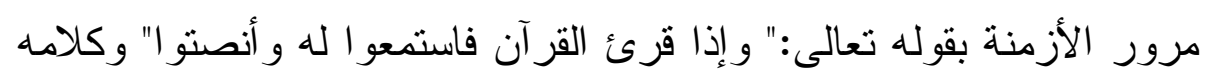

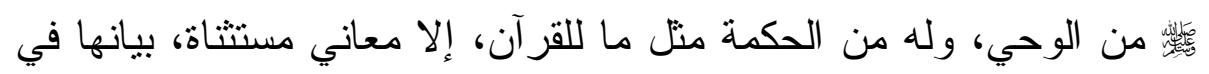

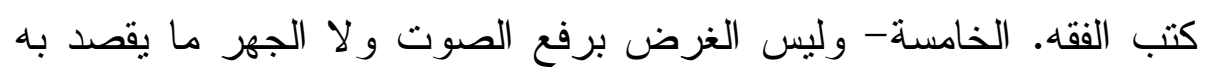

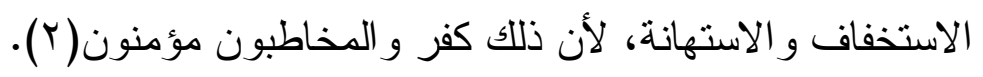

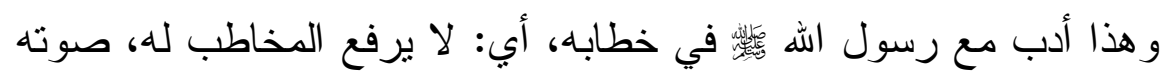
معه، فوق صوته، و لا يجهر له بالقول، بل يغض الصوت، ويخاطبه بأدب

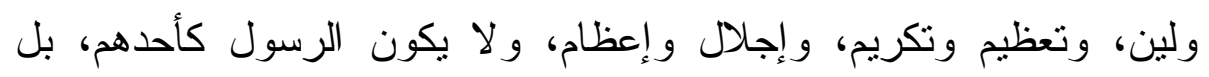

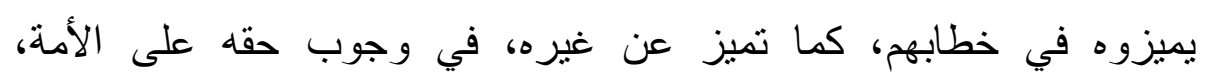

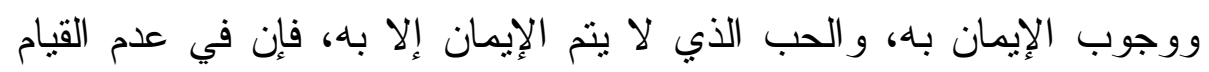

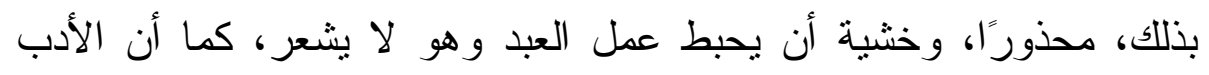

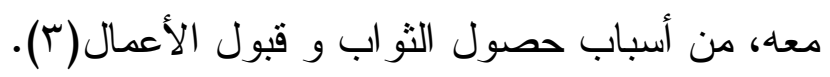

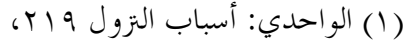

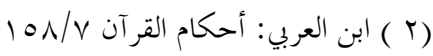

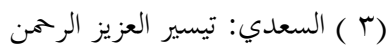


و هذا يستلزم عدم رفع الصوت فوق صوت النبي

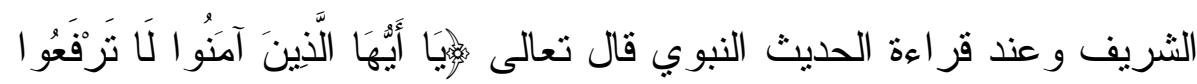

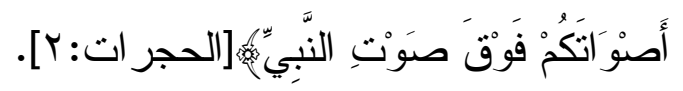

وقال العلماء: يكره رفع الصوت عند قبره الصلاة و السلام؛ لأنه محترم حياً وفي قبره عليه أفضل الصلاة و السلام دائماًا (1) (1) (1)

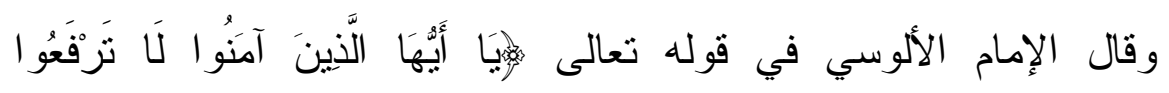

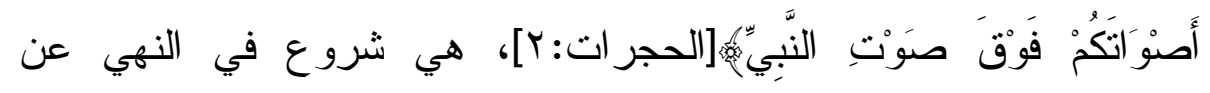
التجاوز في كيفية القول عند النبي ئسئ بعد النهي عن التجاوز في نفس القول و الفعل و إعادة النداء مع قرب العهد به للمبالغة في الإيقاظ و التتبيه و الإشعار باستقلال كل من الكلامين باستدعاء الاعتتاء بشأنه أي لا تبلغو أبأصو اتكم

$$
\text { ور اء حد ييلغه عليه الصداة و السلام(r). }
$$

يذكر الآلوسي عدة أمور مستوحاة من الآية الكريمة منها: الأول نهي عن رفع الصوت فوق صوته عليه الصلاة والسلام، وهذا نهي عن مساواة

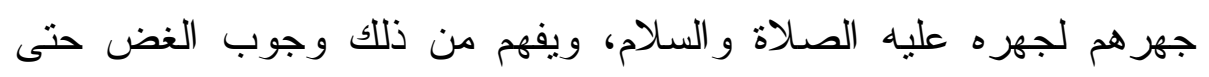

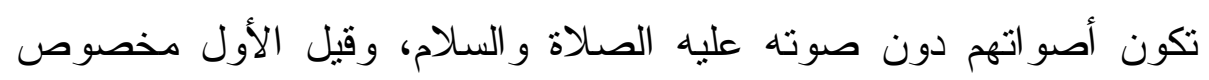

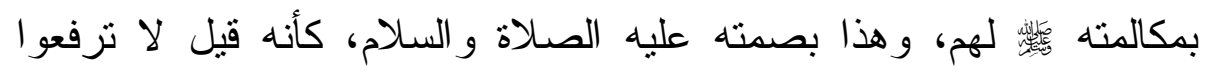

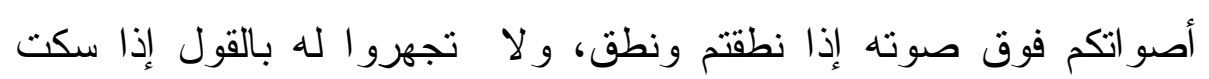

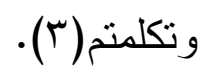

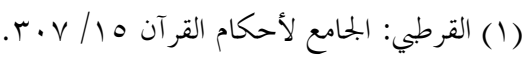

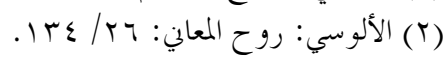

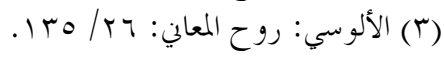


ولقد فهم أصحاب رسول الله

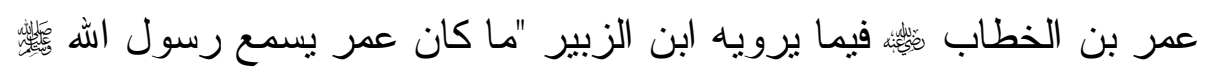

$$
\text { حتى يستقهمه"( (1). }
$$

ونهي عن رفع الصوت عنده عليه الصلاة والسلام خشية أن يغضب من ذلك؛ فيغضب الله تعالى لغضبه فيحبط عمل من أغضبه وهو لا يدري، روي

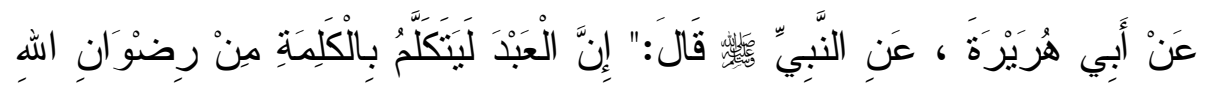

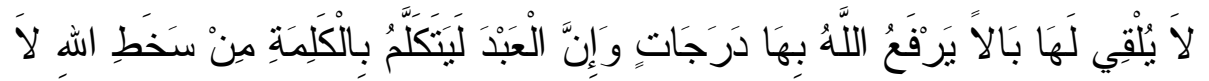

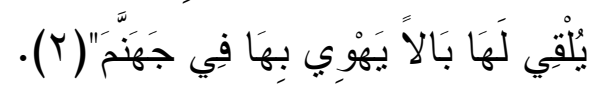

و إحباط العمل جاء في القرآن الكريم في ثثلاثة مو اضع وذكر في اثتني عشرة سورة من القرآن الكريم وتحدثت عنه ست عشرة آية في القرآن

$$
\text { الكريم(ب). }
$$

ومن المواطن التي يحبط العمل من أجلها، رفع الصوت فوق صوت النبي

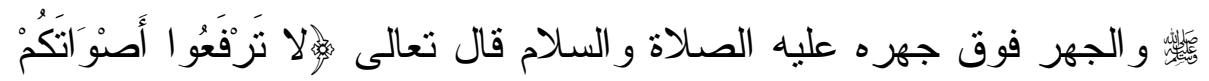

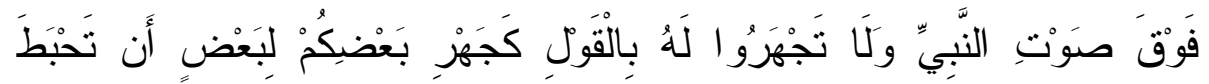

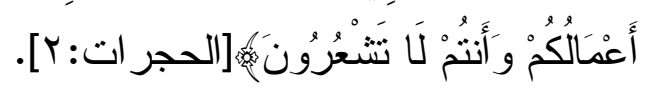

و عليه فقد وجب الإيمان برسول الله

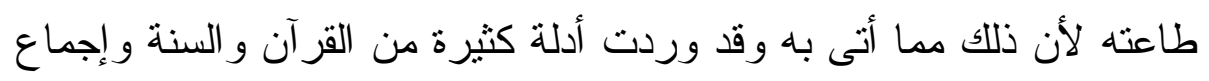

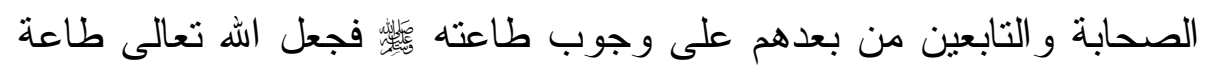
رسوله طاعته وقرن طاعته بطاعته قال الإمام أحمد: "نظرت في المصحف وند

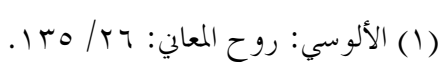

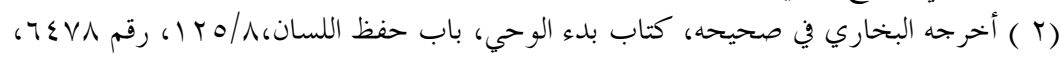

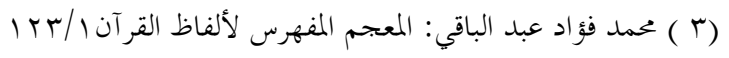




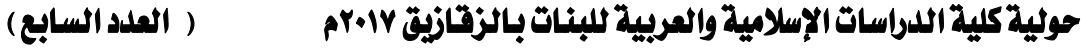

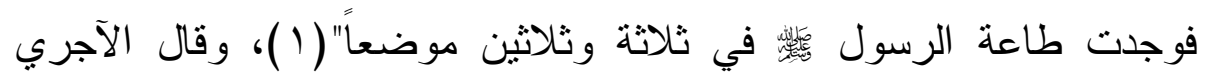

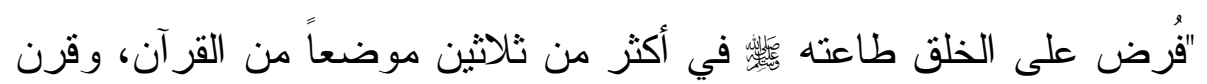
طاعته بطاعته، وقرن بين مخالفته ومخالفته، كما قرن بين اسمه و اسمه فلا

$$
\text { يذكر الله سبحانه إلا ويذكر معه)(r). }
$$

إن الأدب مع الله سبحانه وتعالى ومع رسوله له كما ورد في السورة الكريمة، أعطانا العديد من الفوائد و الأحكام العديدة التي ألمحنا إلى بعضعها سالفاً، وهنا نريد إضافة بعض الأمور المهمة التي تكمن في الآتي: ا-النداء في قوله تعالى: يا أيها الذين آمنوا لا ترفعو ا...." يتطلب في نفس

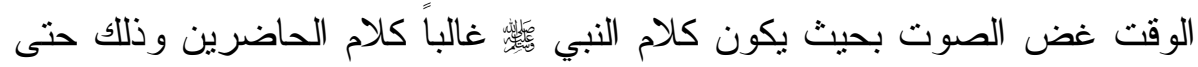

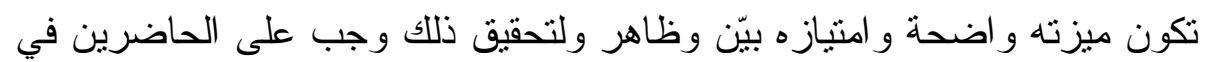
مجلس النبي وقياساً على ذلك كره العلماء رفع الصوت في مجالس العلماء ومجالس الذكر و العلم و القضاء(r).

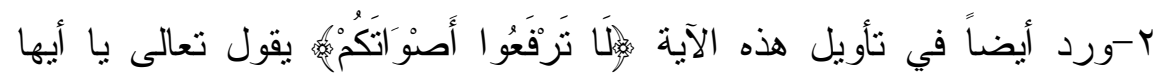

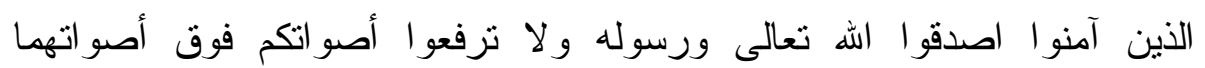
فتجهموه بالكلام وتغلظون له في الخطاب وكذلك لا تتادوه كما ينادي بعضهم بعضاً

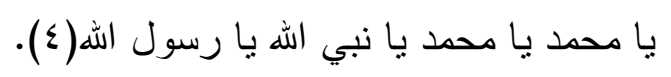

r- لا يحق للمسلمين جميعاً ولو اجتمعوا أن يتقدموا على رسول الله بآرائهم

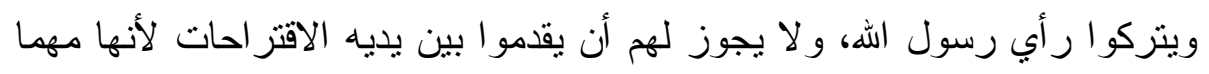

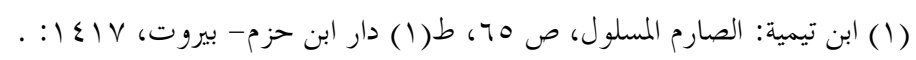

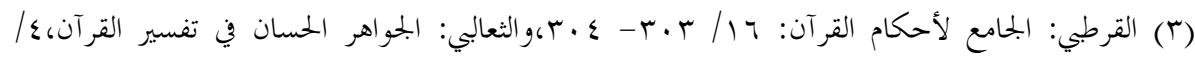

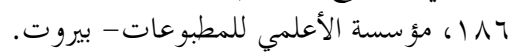

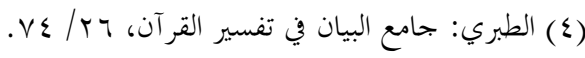

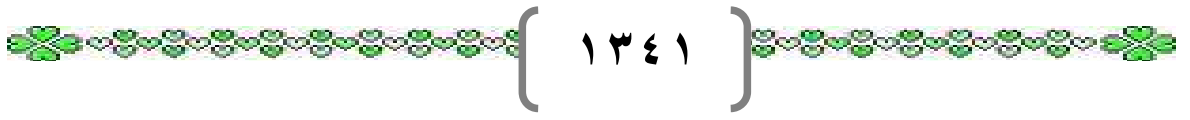




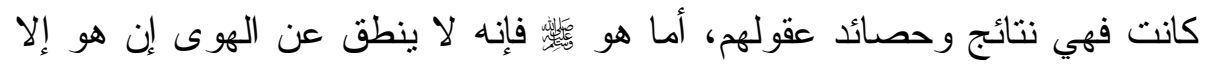

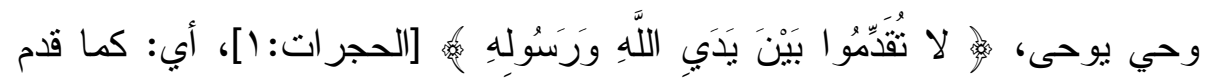

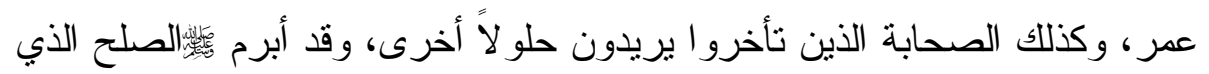
هو فتح مبين.

ع- يظن بعض الناس أنهما شيءٌ واحد، ولكن الحقيقة أنهما أمران مختلفان، فالأول: في رفع الصوت من حيث هو، ولو كان بتلاوة القرآن، و الثاني: نوعية

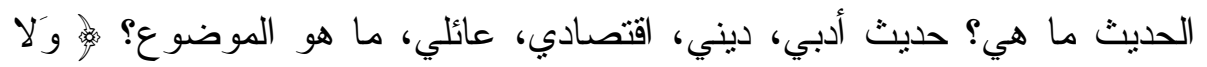

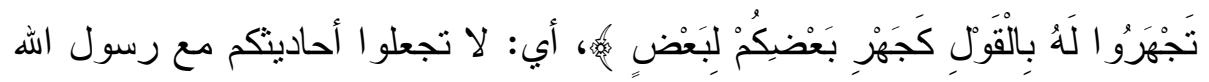
في الأمور التي تجعلونها بين أنفسكم في خلواتكم؛ لأن الإنسان مع صديقه وزئه لتهيله

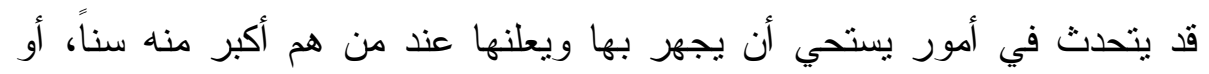
منزلة.

ه- كما أن هناك أدب مع الله ورسوله فهناك أدب مع الخلق، يقول ابن القيم عن

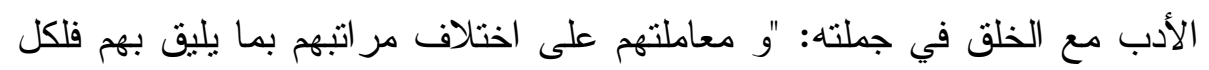

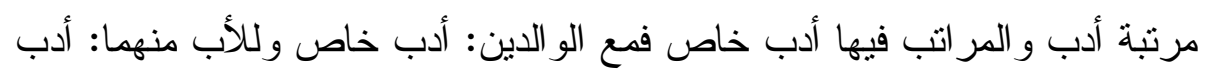

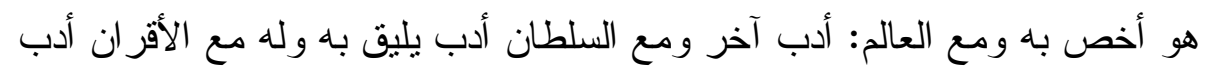

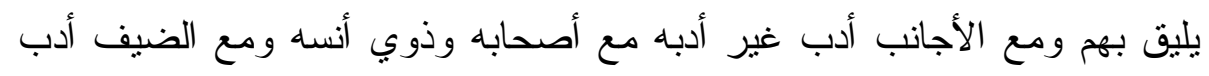

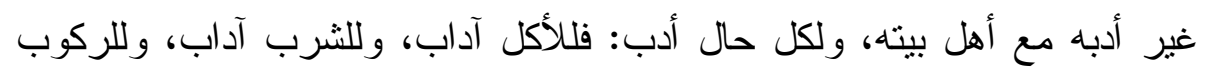

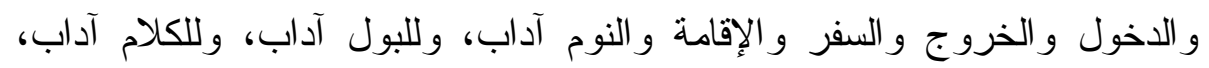

$$
\text { وللسكوت و الاستماع آداب (1). }
$$




\section{الميحث الثاني: التثيت في الأخيار ودوره في يناء الأمة. المطلب الأول: حقيقة التثيت(1) وأهميته}

التثبت في الأخبار فضيلة تدل على الرجولة وضبط النفس، ولكنها ليست كثيرة عند الناس، فقد يكون الرجل عدلا ولكنه ذو غفلة؛ فتس إليه الأخبار فيأخذها بمحمل الصدق، أو ينقلها إلى غيره عن صفاء نية فيقع في أسر الكاذبين، لذا نجد أكثر الناس يقعون في تصديق الأخبار من حيث لاء لاء لإهن

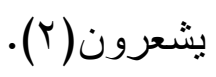

والتثبت في اللغة: ثبت الثيء ثباتا وثبوثا؛ و أثنته غيره وثثته، بمعنى،

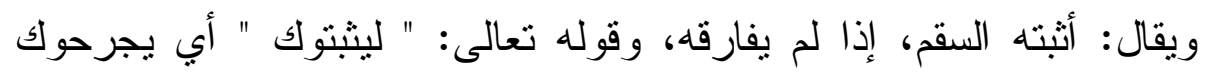

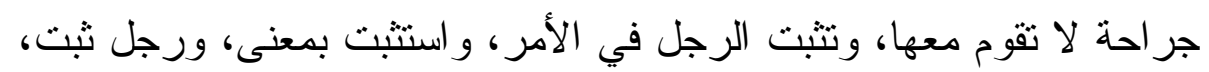

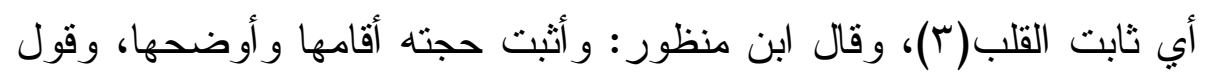
ثابت صحيح وفي التنزيل العزيز "يثبت اله الذين آمنوا بالقول الثابت"[إير اهيم: ]، وكله من الثبات(ع)، وقال ابن فارس: الثاء و الباء و التاء كلمة و احدة، وهي دو ام الشيء، يقال: ثبت ثباتا وثثوتا(ه).

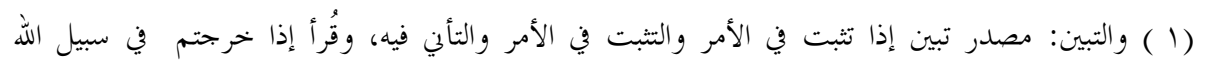

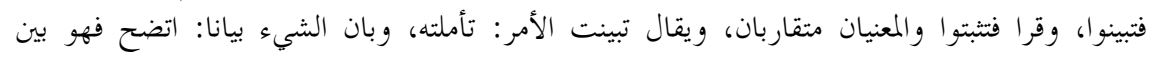

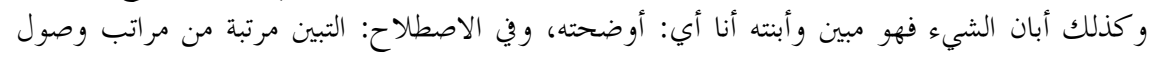

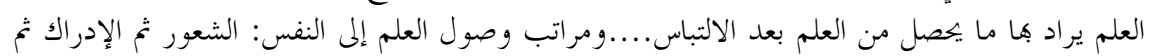

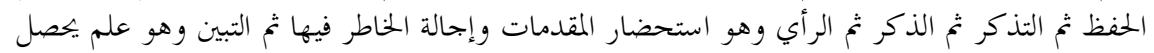

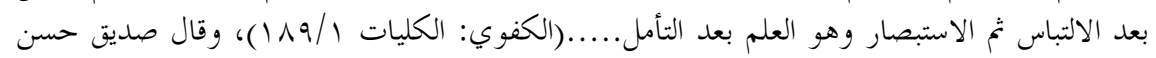

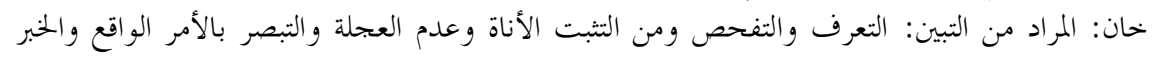

$$
\begin{aligned}
& \text { الوارد حتى يتضح ويظهر. }
\end{aligned}
$$

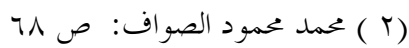

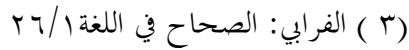

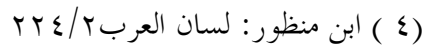

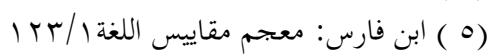




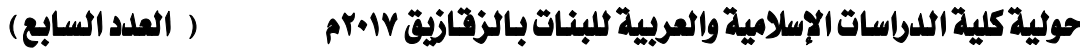

و على هذا فمادة الكلمة تدور حول دو ام الثيء، و الثبات في الأمر و الر أي و الخبر وكذلك المعرفة.

وفي الاصطلاح: يرى جمهور العلماء أن التبين والتثبت متقاربان، و علـىى هذا فيكون المعنى يشتمل المعنيين، وقال بعض أهل العلم بينهما تبــاين مــن (1) بعض الوجوه. (1) وقال الشوكاني: و المر اد من التبين: التعرّف والتفحص، ومن التثبت: الأناة و عدم العجلة و التبصر في الأمسـر الو اقــع و الخبــر الــوارد حتــى يتضـــح

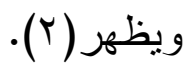

وقيل: التثبت: تبين الأمور فيه لمعنى التبصر والاستيضاح و التأكــد مــن الأمر قبل الحكم له أو عليه. وقيل: التبيّن : طلب البيان و التعرّق ، وقريب من التثبت ، و المر اد به هنا التحقق والتببت من الخبر حتى يكون الإنسان على بصيرة من أمره (ب)، وقيل التبتب: نرك العجلة و التدبر و التأني في الأمر(ع). أهمية التثبت: عندما نتأمل خطاب القرآن نجده صريحًا في الأمر بوجوب التتبت و التبين في الأخبار عند رواية الفاسق لها كما في الآية الموجودة فـي

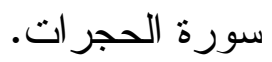

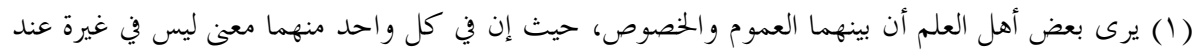

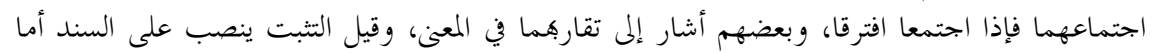

$$
\begin{aligned}
& \text { التبين فيدور حول معني الخبر. }
\end{aligned}
$$

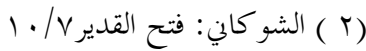

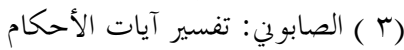

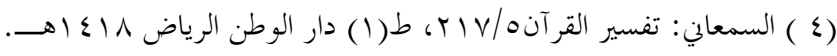


لذلك يقول الإمام الحسن البصري: "المؤمن وقاف حتى يتبين" ( ()، وقـال

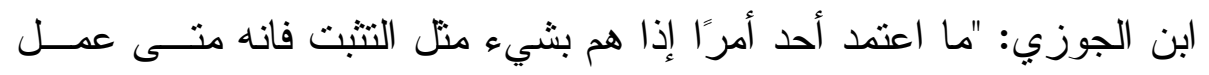

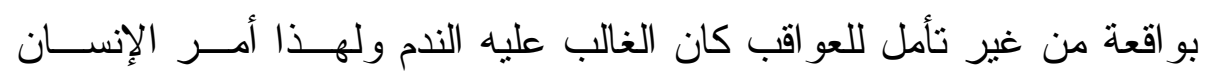

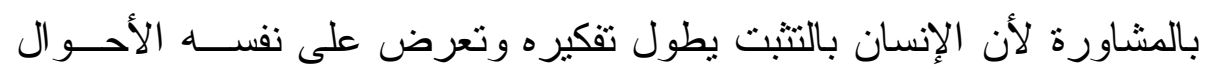
وكأنه شاور وقد قيل: خمير الر أي خير من فطيره.

و أثند الناس تفريطًا من عمل مبادرة في و اقعة من غير تثبت و لا استثــارة خصوصًا فيما يوجب الغضب فإنه ينزفه طلب الهلاك و استتبع الندم العظــيم

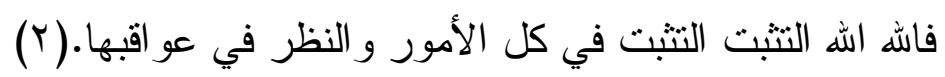
فالتثبت يعد أحد السمات البارزة للمنهج الثرعي و النضـــج العقلــي الــذي يو افق الثوابت الإسلامية الأصيلة، يقول ابن المقفع " أصل العقل التثبت ".(r) ومن ميزات الأمة المنوطة بها و التي لم توجد في غيرها وجــود المــنهج

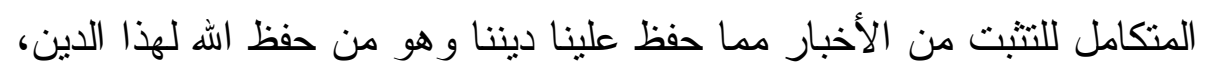

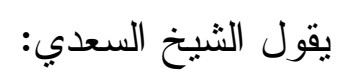
"و التثبت في سماع الأخبار وتمحيصها ونقلها و إذاعتها و البناء عليها، أصل

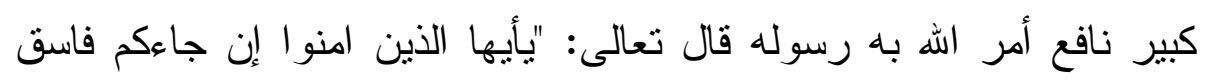

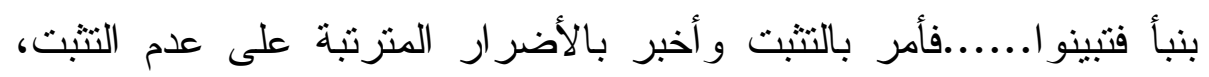

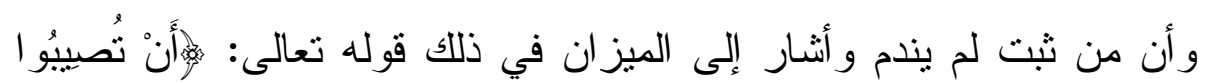

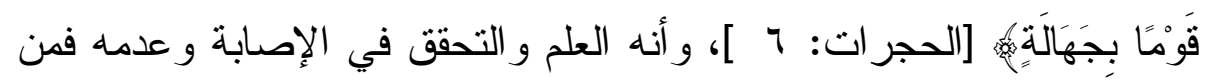

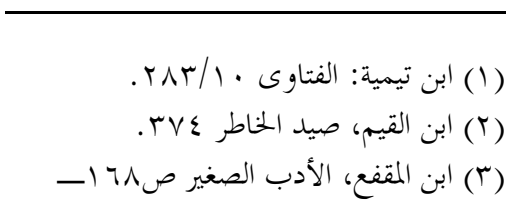

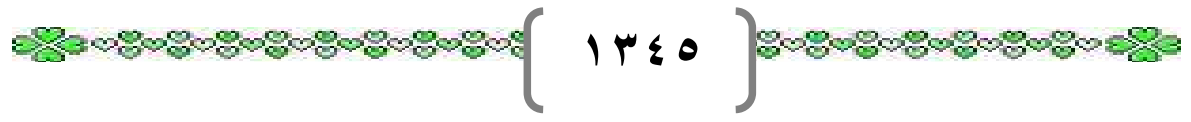


تحقق وعلم كيف يسمع وكيف ينقل وكيف يعمل فهو الحازم المصيب ومن كان غير ذلك فهو الأحمق الطائش الذي مآله الندامة...(1) وبالنظر في هذا المنهج الديني الثرعي، و غيره من المناهج الوضعية يتبين تميز هذا الدين وسموه و عظمته في كل مناهجه لاسيما وهذا المنهج الثرعي في تلقى الخبر يقول سيد قطب: "التثبت من كل خبر ومن كل ظــاهرة ومــن كل حركة قبل الحكم عليها هو دعوة القرآن الكريم ومنهج الإســـام الــدقيق، ومنى استقام القلب و العقل على هذا المنهج لم ييق مجال للوهم و الخر افة فــي عالم العقيدة ولم ييق مجال للظن و الثبهة في عالم الحكم و القضـاء و التعامـلـلـ

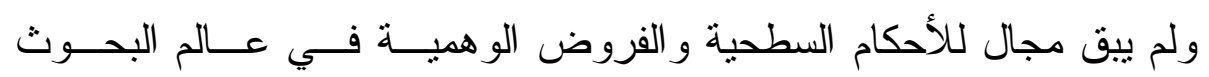

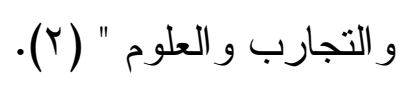

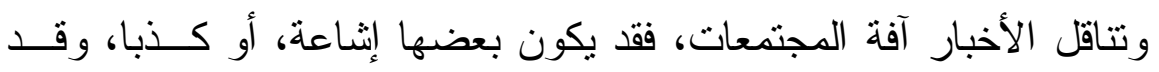
يكون هنالك كثير من المبالغة في الخبر وتضخيمه، و غالبا ما يكون نقل الخبر

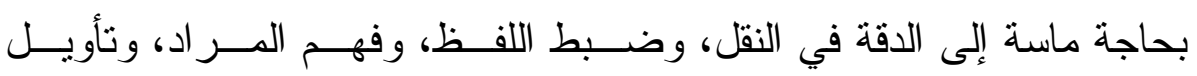

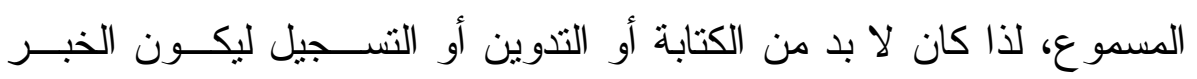

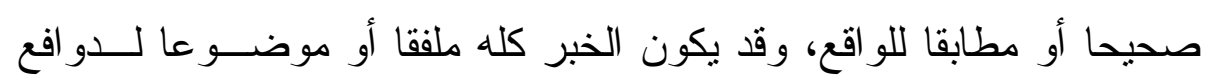
سياسية أو مناصرة اتجاه معين أو لبذر بذور الفرقة، وتأجيج نار الخلاف بين

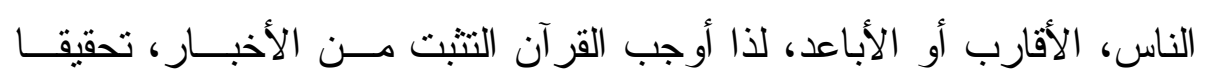
للمصلحة العامة أو الخاصة، ومنعا من إيقاع الفتنة، وزر الاع الفرقة. وللتتبت أنو اع كثيرة، وفى كل نوع نجد من خلاله عناية الإسلام الأكيــدة بالمنهج الثرعي للخبر ، وما يجب على المسلم فعله من خلال تلقى خبر سليم 
خال من الأخطاء، وكذللك حتى تشتقر الأمة في كل ميادين حياتها، من أهـــ

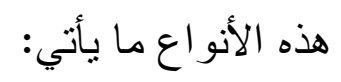

أولا: التثبت في القول على الله: إن هذا النوع في التثبـــت مــن أخطــر

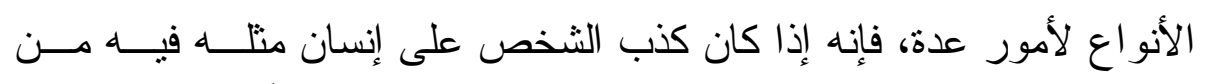

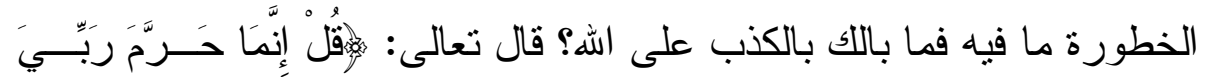

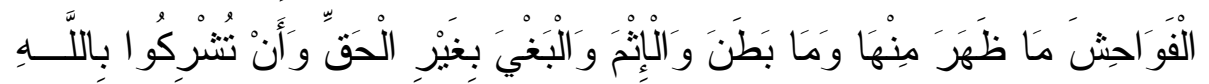

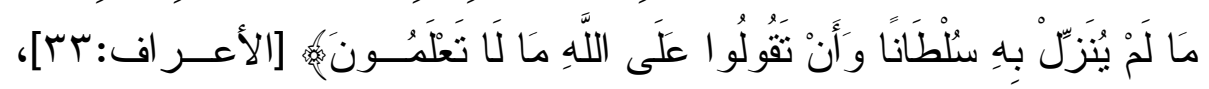
فجعل القول على اله قريباً للشرك باله؛ لأن الذي يقول على الله جعل نفســـهـ

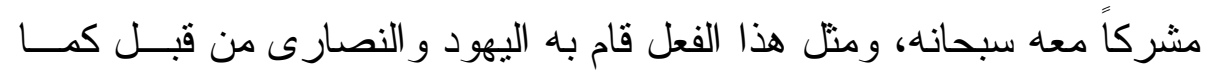

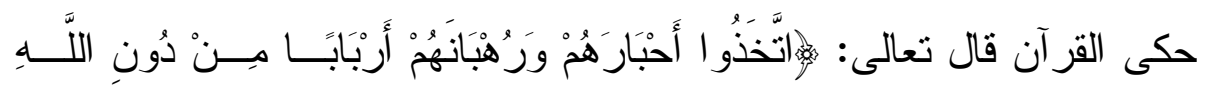

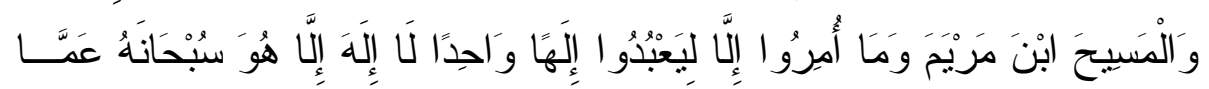

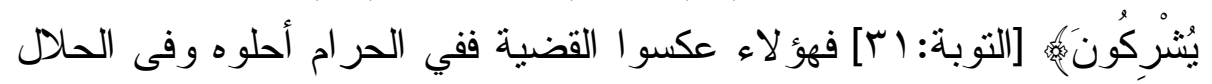
حرموه. إذن القول على الله بغير علم بتحليل الحرام أو تحريم الحـــله هـــ مــن أخطر الأمور وهو من الكذب إذا كان الإنسان غير منتبت ولهذا قال تعـالى:

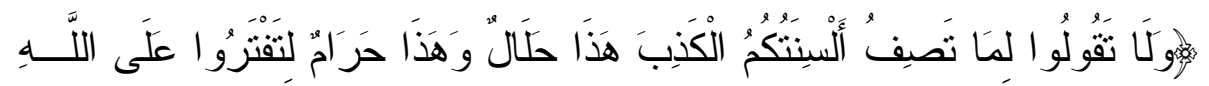
الْكَذِبَ [ النساء: (V)]

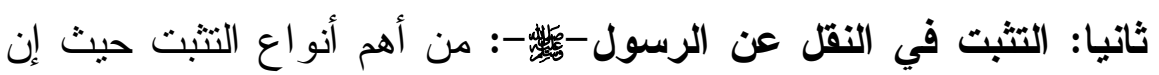
من كذب عليه فإنه منوعد بنار جهنم - لذلك حرص السلف الصالح على

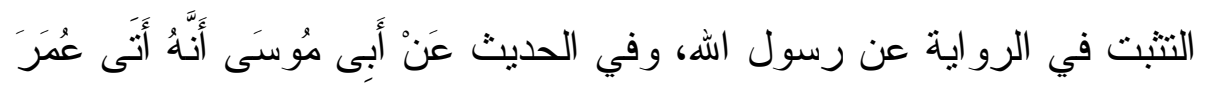

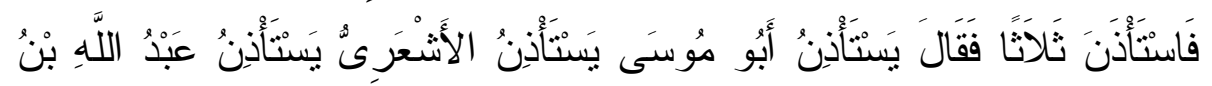




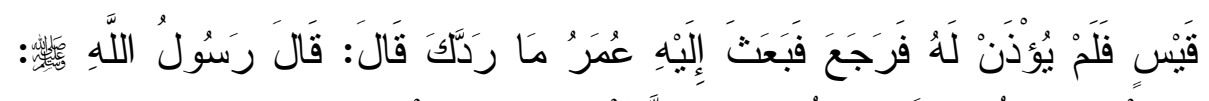

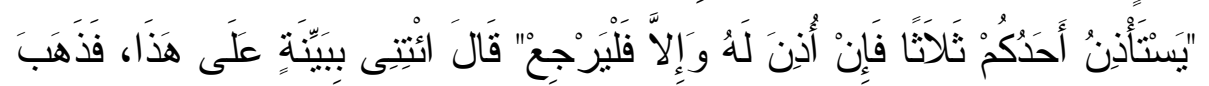

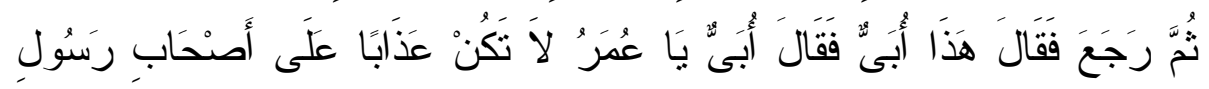
* اللَّهُ

وفعل الصحابة رضي الله تعالى عنهم في التثبت، من باب التثبت في النقل

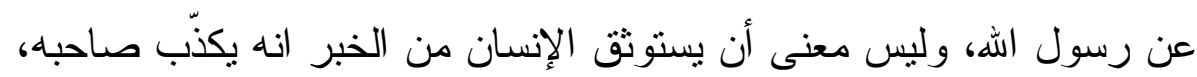
أبدا فهذا من باب التثبت و التنيين.

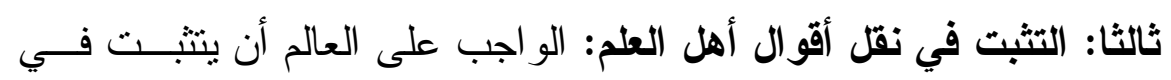

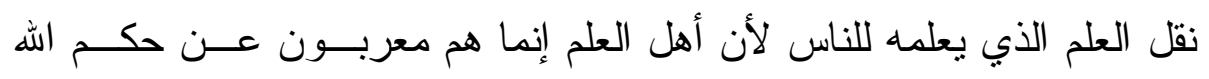

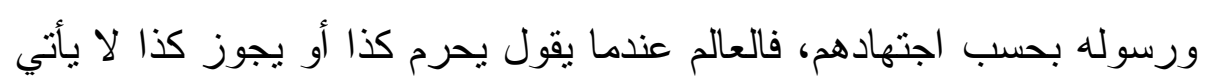

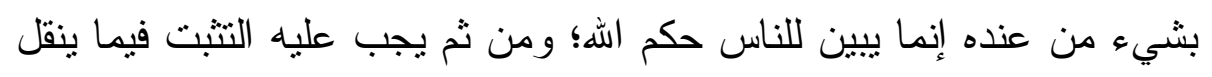

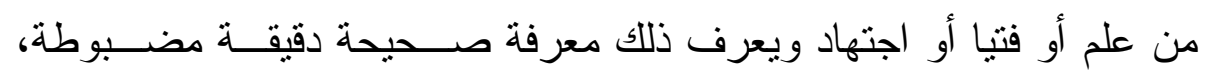

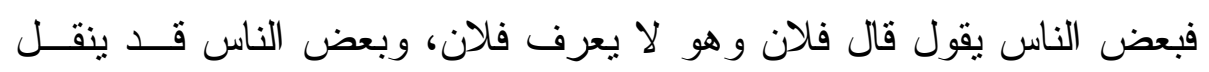
بالو اسطة فيقع الخطأ والخلط و الظلم و الجور على على أهل العلم.

رابعاً: التثبت في نقل أقوال الناس: ورد في الصحيحين من حديث حذيفة:

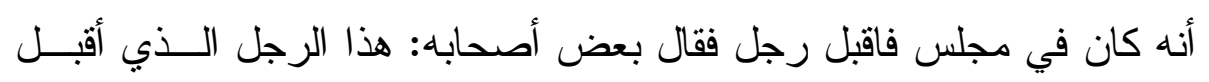

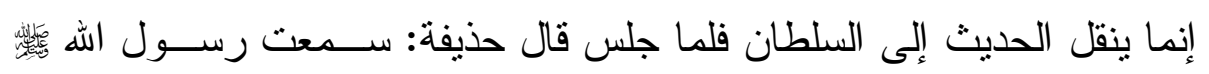

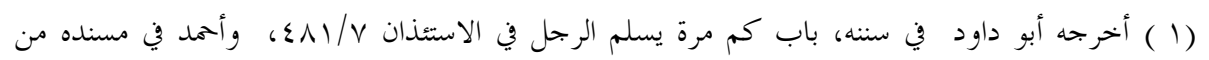

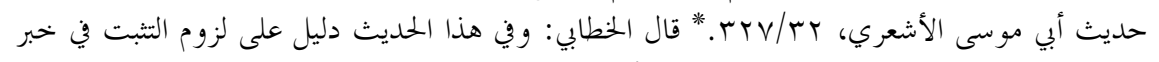

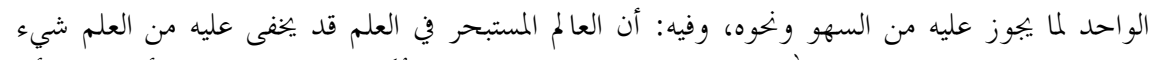

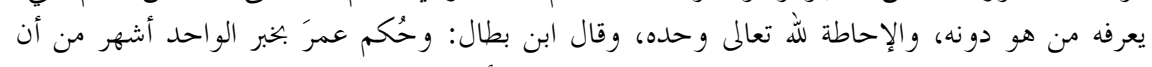

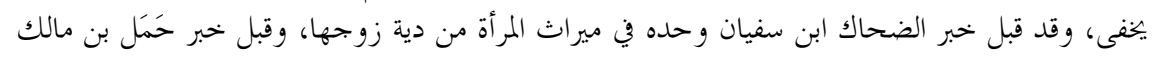

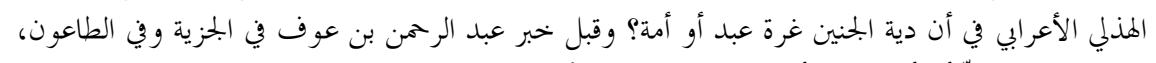

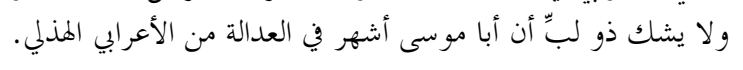

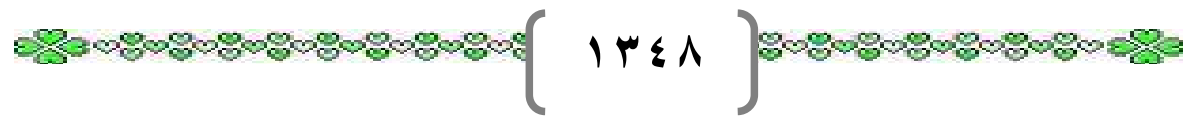




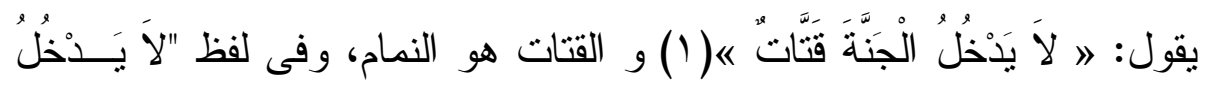

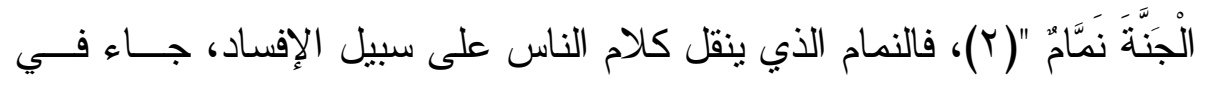

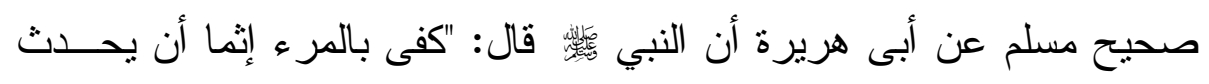

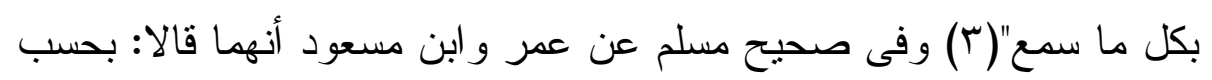
المر ء من الكذب أن يحدث بكل ما سمع "( ع). و إذا ما تدبرنا آيات القرآن الكريم وجدنا اهتمامًا بالغًا بمسألة التثبت لما لها

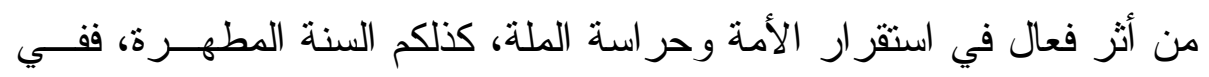

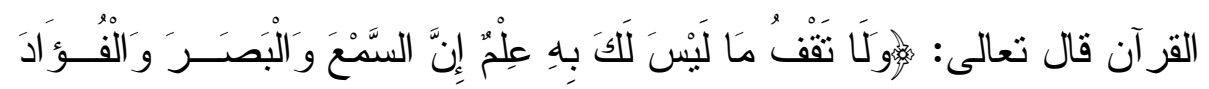

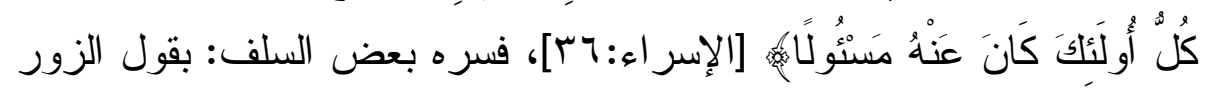
وشهادة الزور ، وفسره آخرون بغير ذلك، وكل هذه لا تعدو أن تكون أمتلــــة

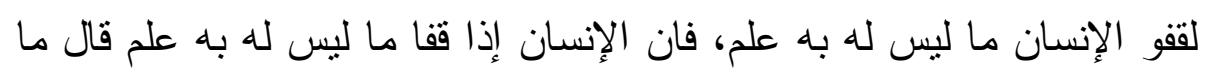

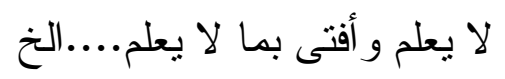

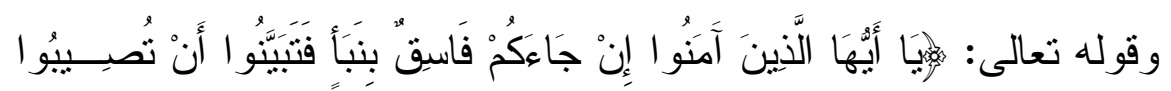

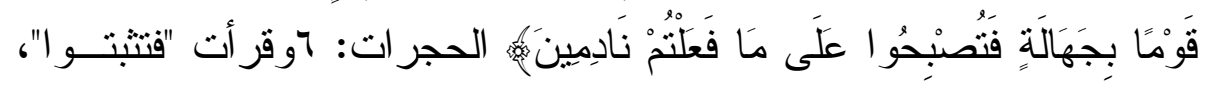
و التتبت و التبين هما بمعنى و احد، و هذا أمسـر مــن الله للإنســـان أن يتبــين

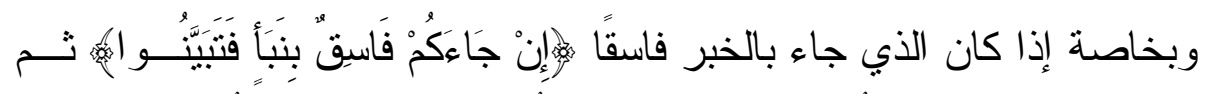

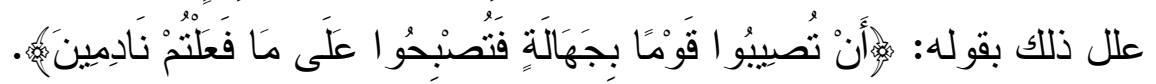

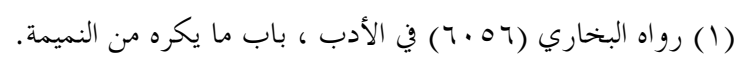

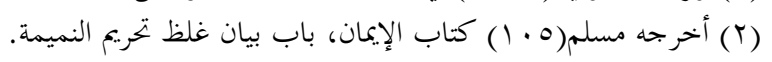

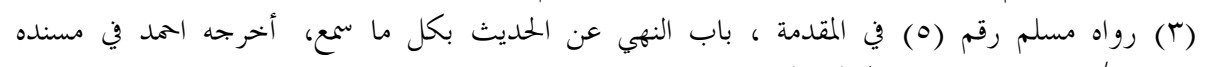

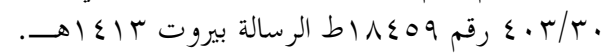

$$
\begin{aligned}
& \text { (ع) رواه مسلم رقم (0) في المقدمة ، باب النهي عن الحديث بكل ما سمع المع. }
\end{aligned}
$$




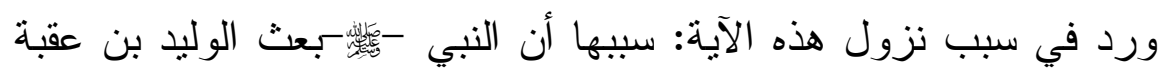

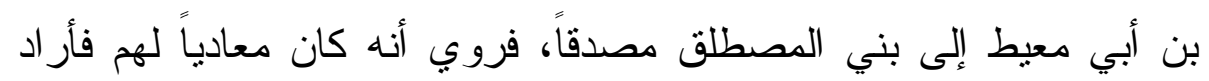

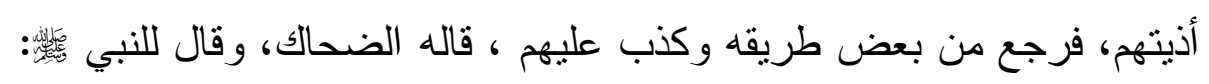

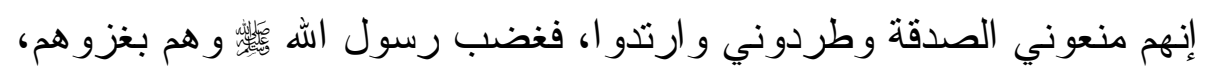
ونظر في ذلك ، وبعث خالد بن الوليد إليهم، فورده وفدهم منكرين لذلك، وروي عن أم سلمة وابن عباس أن الوليد بن عقبة لما قرب منهم خرجو ا إليه

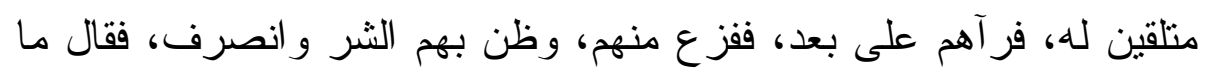

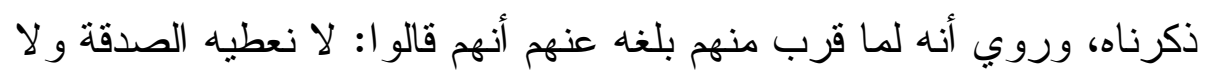
نعطيه، فعمل على صحة هذا الخبر و انصرف، فقال ما ذكرناه فنزلت الآية بهذا السبب، والوليد على ما ذكر مجاهد هو المشار إليه بالفاسق وحكى الزهر اوي قالت أم سلمة: هو الوليد بن عقبة (1).

و المعنى العام للآية أن من الآداب التي على أولي الألباب، التأدب بها و استعمالها، وهو أنه إذا أخبر هم فاسق بخبر أن يتتبتو ا في خبره، و ولا يأخذوه مجردًا، فإن في ذلك خطرًا كبيرًا، ووقوعًا في الإثم، فإن خبره إذا جعل إنل بمنزلة خبر الصادق العدل، حكم بموجب ذلك ومقتضاه، فحصل من تلف

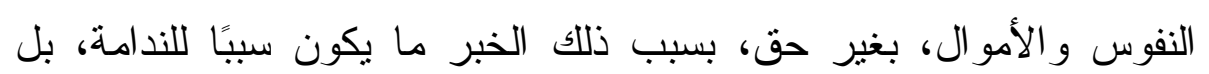

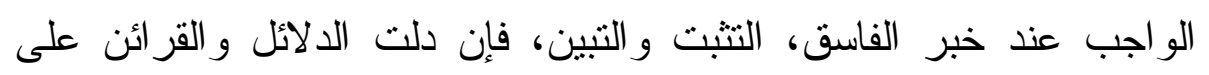
صدقه، عمل به وصدق، و إن دلت على كذبه، كذب، ولم يعمل به، ففيه دليل،

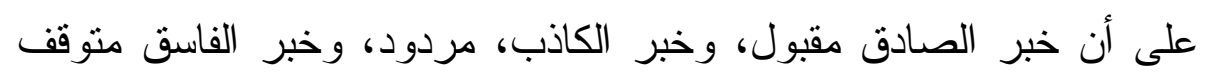


فيه كما ذكرنا، ولهذا كان السلف يقبلون روايات كثير من الخوارج،

$$
\text { المعروفين بالصدق، ولو كانو ا فساقًا (1). }
$$

ومن هنا امتتع طو ائف من العلماء من قبول رواية مجهول الحال لاحتمال

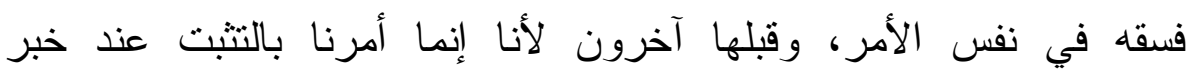
الفاسق(Y)، وهذا ليس بمحقق الفسق لأنه مجهول الحال.(r).

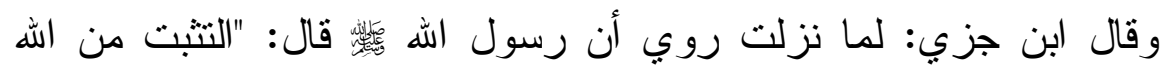

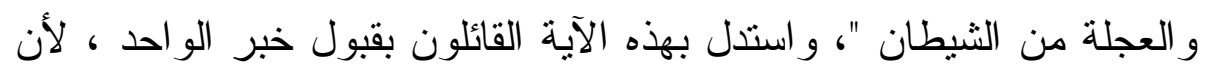
دليل الخطاب يقتضي أن خبر غير الفاسق مقبول، قال المنذر بن سعيد البلوطي: وهذه الآية نردّ على من قال: إن المسلمين كلهم عدول، لأن اله أمر

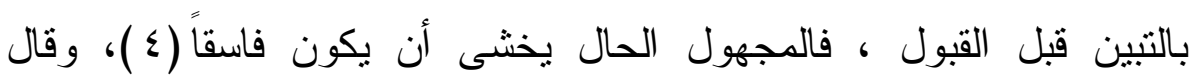
الثنقيطي: وهذه الآية تدل على عدم تصديق الفاسق في خبره (0).

وللمنهج الثرعي في التثبت دور مهم في حر اسة الملة ومقدساتها وتز اثتهــا من كل تغيير أو تبديل أو تحريف، و التثبت في الرواية عن النبـي فئس

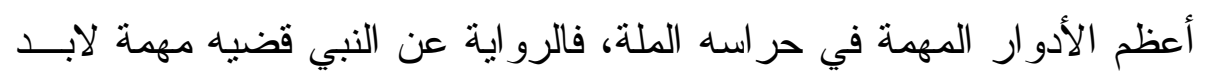

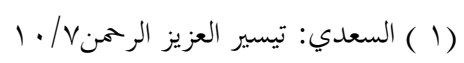

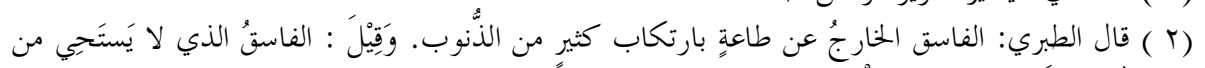

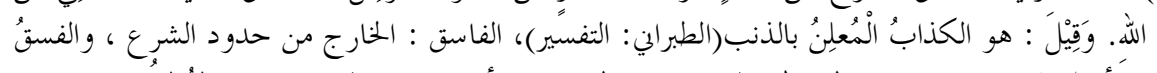

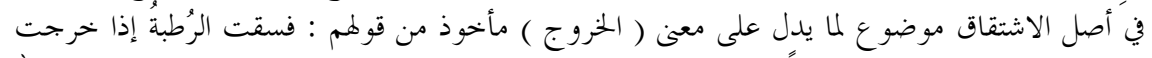

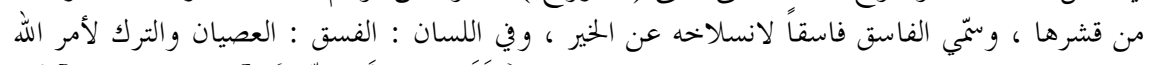

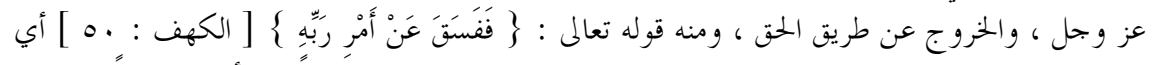

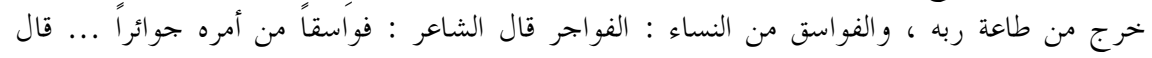

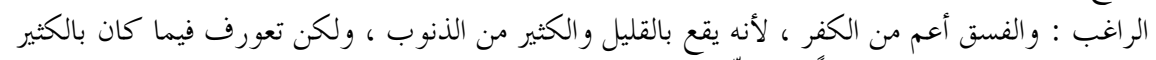

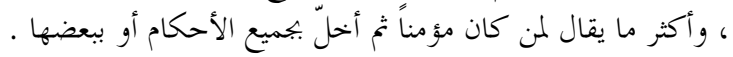

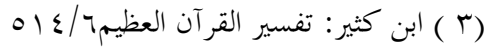

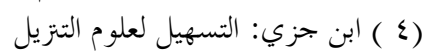

$$
\begin{aligned}
& \text { (0) ( ) الشنقيطي: أضواء البيان }
\end{aligned}
$$


من النتبت فيها لأن كلام النبي وحى وتشريع من الله عز وجل لقوله تعـالى:

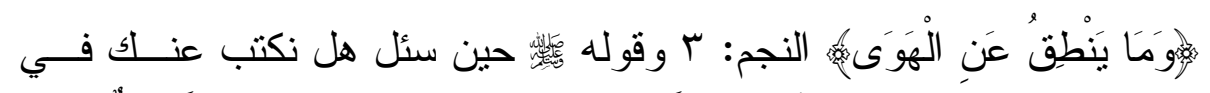

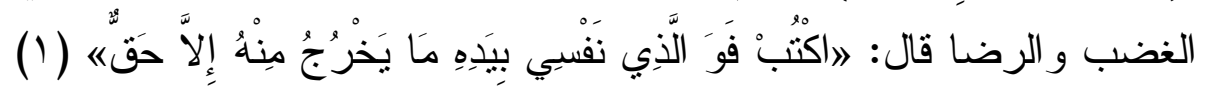

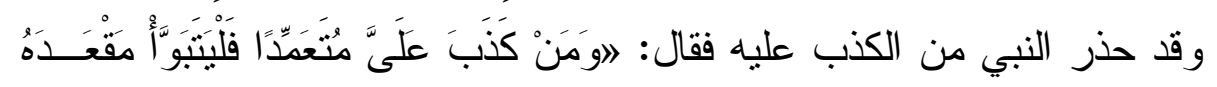

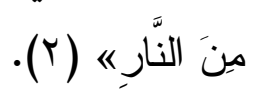

وقد دلت هذه الآية من سورة الحجر ات على أمرين :

الأول: أن الفاسق إن جاء بنبأ ممكن معرفة حقيقته ، وهل ما قاله فيه فيه الفاسق حق أو كذب - فإنه يجب فيه التثبت . الثاني: هو ما استدل عليه بها أهل الأصول من قبول خبر العدل لأن قوله تعالى: "إن جاءكم فاسق بنبإ" فتبينو البدل بدليل خطابه، أعني مفهوم مخالفته أن الجائي بنبأ إن كان غير فاسق بل عدلا لا يلزم التبين في نبئه على قر اءة: فتبينو ا و لا التتبت على قر اءة: فنتبتو ا، وهو كذللك، و أما شهادة الفاسق فهي مردودة كما دلت عليه آية النور المذكورة آنفا.

ويقول القرطبي: في هذه الآية دليل على قبول خبر الواحد إذا كان عدلا، لأنه إنما أمر فيها بالتثبت عند نقل خبر الفاسق، ومن ثبت فسقه بطل قوله في

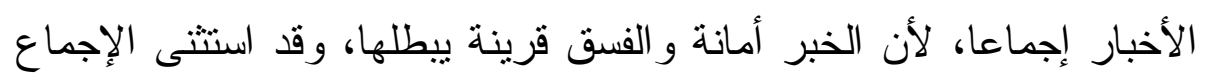

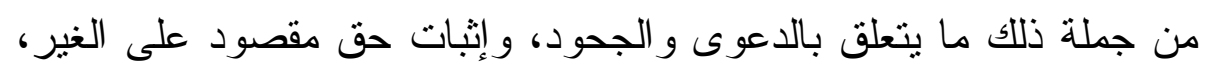
منل أن يقول: هذا عبدي، فإنه يقبل قوله (ب).

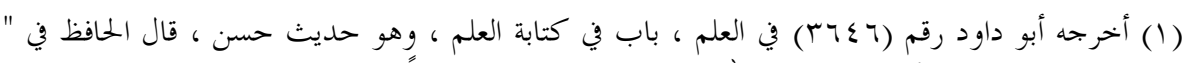

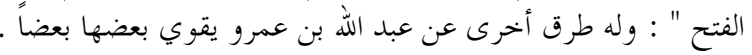

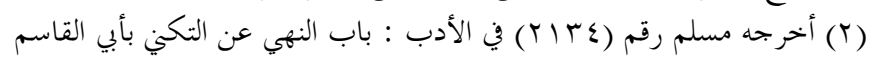

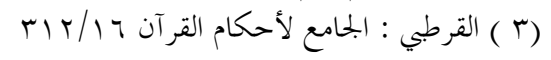

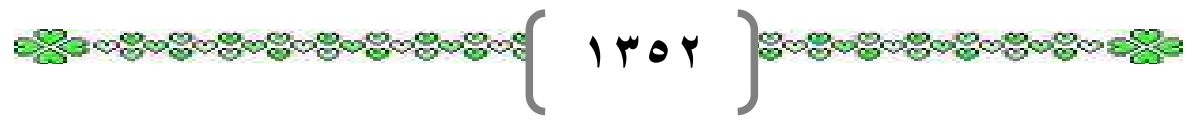


وفي الآية دليل على فساد من قال: إن المسلمين كلهم عدول حتى تتبت الجرحة، لأن اله تعالى أمر بالتتبت قبل القبول، و لا معنى للتتبت بعد إنفاذ الحكم، فإن حكم الحاكم قبل التتبت فقد أصاب المحكوم عليه بجهالة( (1). المطلب الثاني: الشائعات وأثرها في هدم بنيان الأمة

تعد الثائعات من أخطر الحروب المعنوية والنفسية؛ بل من أثند الأسلحة فتكًا و أعظمها وقعا وتأثثير ا، وليس من المبالغة إذا قلنا أنها ظاهرة اجتماعية عالمية لها خطورتها البالغة على المجتمعات. وللثائعات تاريخ عميق الجذور حيث إنها وجدت مع وجود الإنسان بل عاثت وتكاثرت في أحضان كل الحضار ات ومنذ فجر التاريخ و الثائعة تمثل مصدر قلق في البناء الاجتماعي و الاتتماء الحضاري لكل الثعوب و البيئات. ولقد تكفل الإسلام بحياة كريمة طاهرة فوقف من الثائعات ومروجيها موقف الحازم الفطن لما في ذلك من آثار جد خطيرة على تماسك المجتمع المسلم وتلاحم أبنائه وسلامة لحمته و الحفاظ على بيضته.

وحذر الإسلام من هذا السلوك وعدّه من الرذائل المنافية للأخلاق العالية، و السجايا الكريمة التي حثت عليها شريعتا الغراء من الاجتماع و المحبة

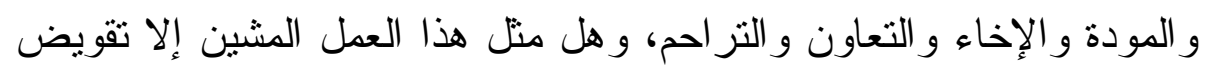
لتلك القيم؟ ومعول هدم لهذه المثل....؟؟ وحسبك الوعيد و التهديد الموجود في ولي

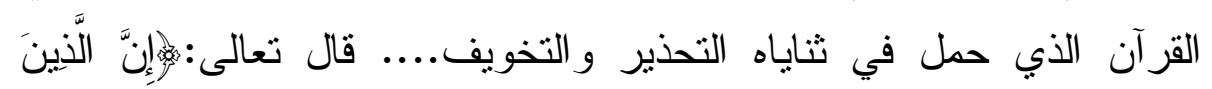

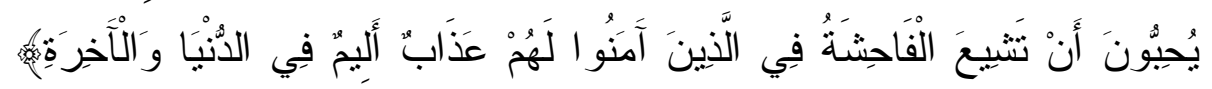

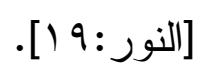

(1)

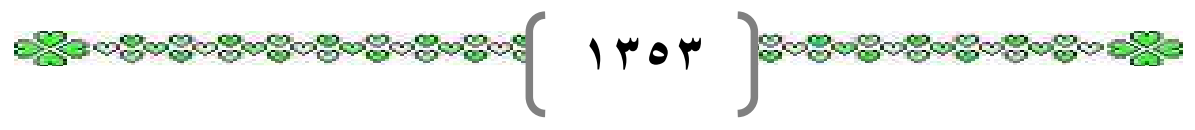




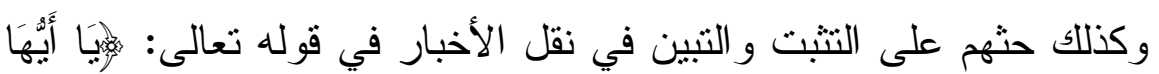

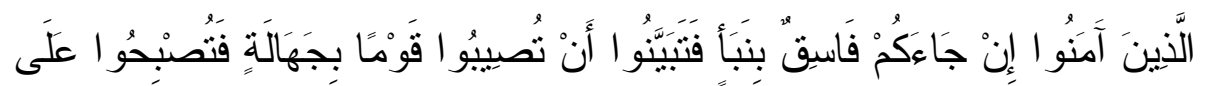

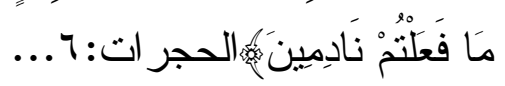

و أخبر الحق أن الإنسان مسئول أمام الهه ومحاسب عن كل صغير وجليل،

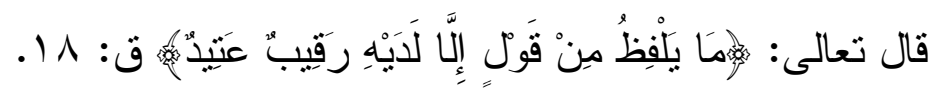

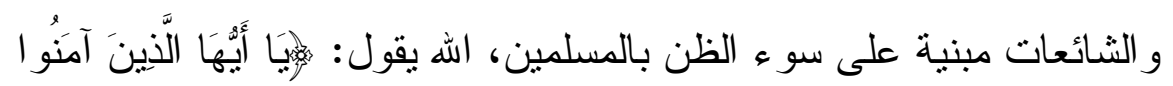

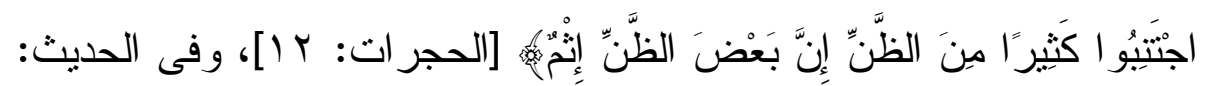

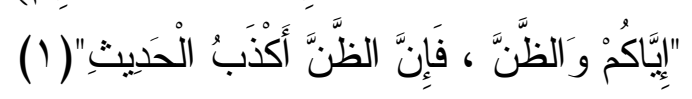

كما نهى الإسلام أنباعه أن يطلقو ا الكلام على عو اهنه ويُلغو ا عقولهم عند

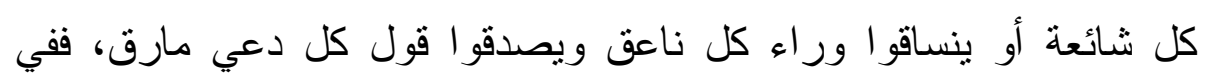

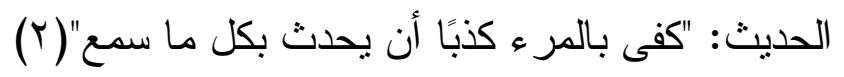
وسدًا للباب أمام الوشاة المرجفين ونقلة الثائعات ومنعًا لرواج الثائعة و البلاغات المجهولة الكيدية المغرضة والأخبار المكذوبة، صرح البناة الرسول:

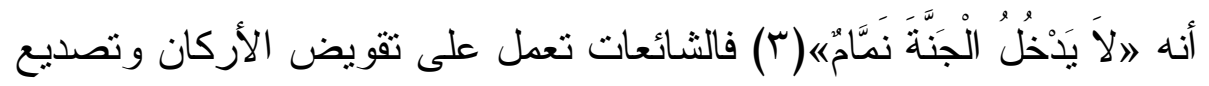

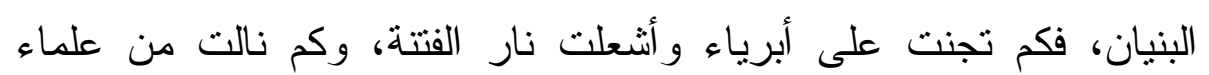
و عظماء... وكم حطمت من أمجاد وحضار ات وكم دمرت من أسر وبيوتات.

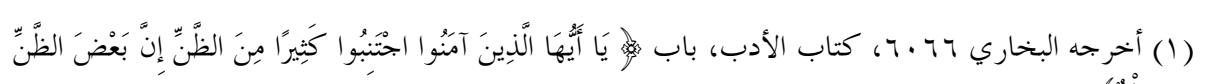

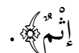

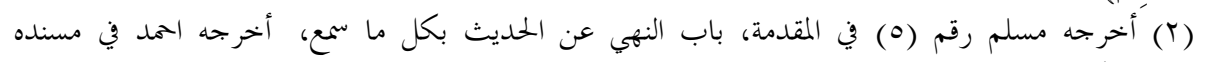

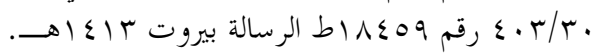

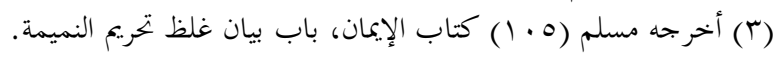

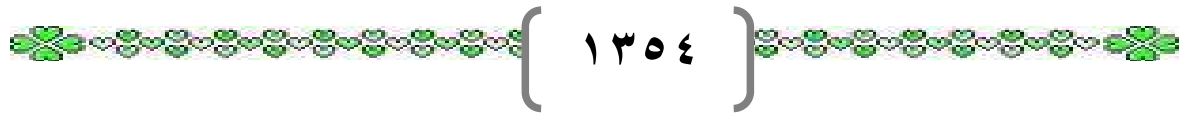


و الثائعات قديمة المنشأ وبخاصة إذا تولاها أعداء الإسلام لا سيما اليهود قتلة الأنبياء.. فالمسيح تشكك الثائعات المغرضة فيه وفى أمه الصديقة كما

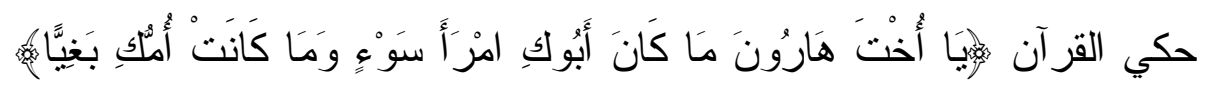

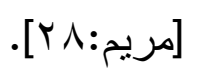

و يوسف عليه السلام نموذج من نماذج الطهر و النقاء، حفظه الله تعالى من

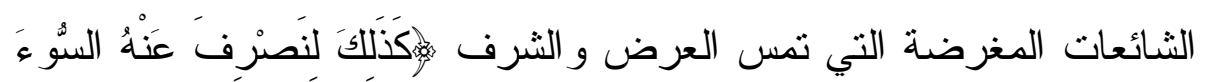

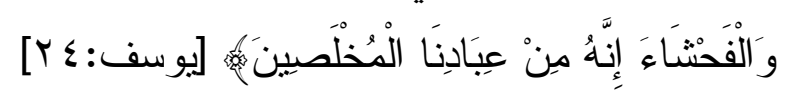

و الرسول نموذج يحمل في طياته نماذج حية لتاريخ الثائعة و الموقف السليم منها فقد رميت دعوته المباركة بالثائعات منذ بزوغها فَرُمى بالسحر و الجنون و الكذب و الكهانة وتفنن الكفار و المنافقين في صنع الأر اجيف الكاذبة و الاتهامات الباطلة - ولعل من أثنهر ها حادثة الإفكاك.

وتتطور الثائعات بتطور العصر ويمنل العصر الحاضر عصرًا ذهبيًا لرواج الثائعات فآلاف الوسائل الإعلامية و القنوات الفضائية والشبكات المعلوماتية تتولى كبر نشر الثائعات المغرضة ضد عقيدة الأمة ومثلها؛ وذلك لتخلى الأمة عن حراسة هذه العقيدة، ومن هنا ندرك خطورة هذه

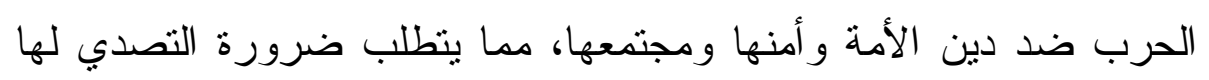
و أهمية مكافحتها و التخطيط لاستئصالها.

فالو اجب على العلماء و الدعاة وطلاب العلم إدر الك أبعاد مثنل هذه

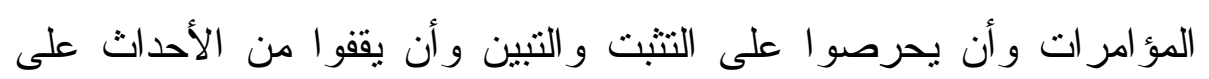
علم وبصيرة معتصمين بالكتاب و السنة. 
أضف إلى الثائعات الكذب، و الخيانة، و الغيبة و النميمة وسوء الظن...الخ وما في ذلك كله من آثار مدمرة تهدم بنيان الأمة.

\section{الميحث الثالث: آداب التعاملات الأخلاقية بين أفراد المجتمع}

لقد وضع الإسلام العديد من الضوابط الأخلاقية العظيمة للعلاقات الاجتماعية؛ التي تحفظ الفرد والمجتمع، وتخلق جواً من الإخوة و الوحدة الإنة و المحبة و الصلة الوثثقة بين المسلمين بعضهم البعض، ولقد أقام الإسلام العلاقة بين أبناء مجتمعة على دعامتين: الأولى: رعاية الإخوة التي هي الرباط الوثيق بين المسلمين. الثاتية: صيانة الحقوق و الحرمات التي حماها الإسلام لكل فرد من أفر اد الأمة، من دم وعرض ومال.. وكل قول أو عمل أو سلوك فيه عدوان على الألى

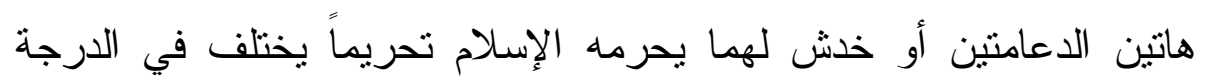
على حسب ما ينجم عنه من ضرر مادى أو أدبي.

ولقد حوى القرآن الكريم الكثير من الآيات التي تفصل هذه المحرمات

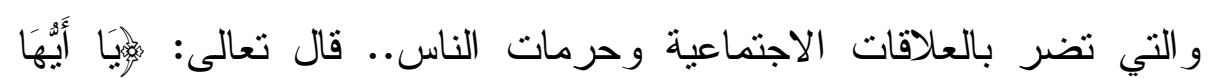

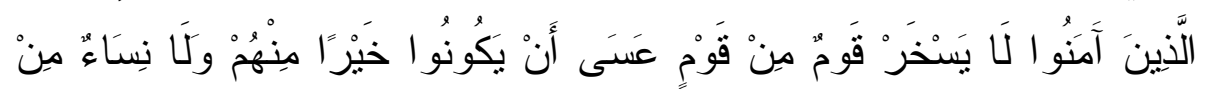

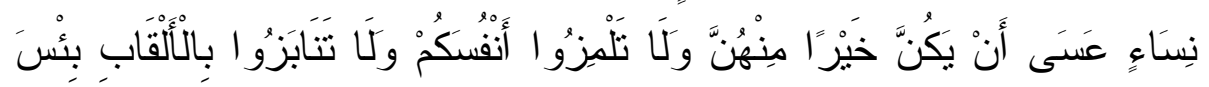

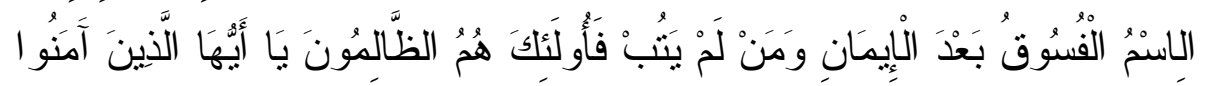

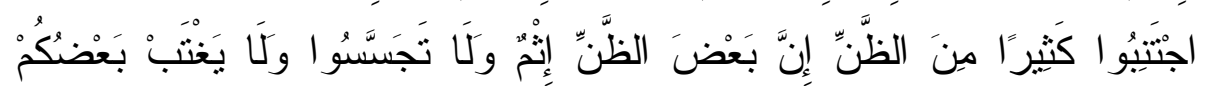

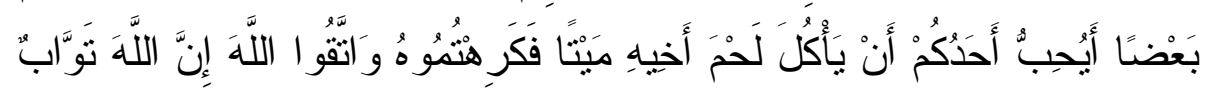

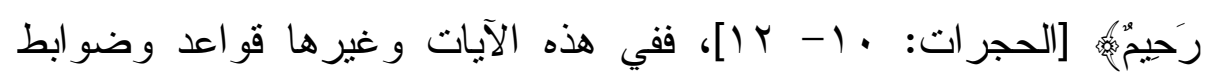

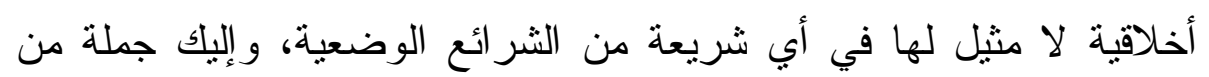
هذه التعاملات الأخلاقية التي بين أفر اد المجتمع في المطالب الآتية:

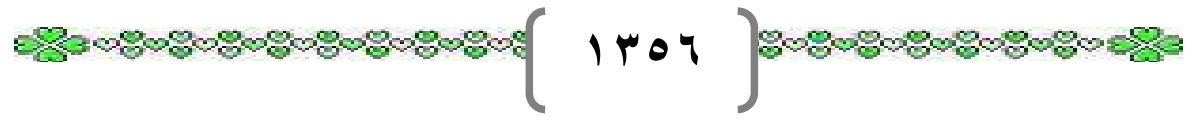




\section{المطلب الأول: نهي الإسلام عنَ السخرية}

النهي عن السخرية هي الدعامة الأولى لصيانة الحرمات، ولقد نهي

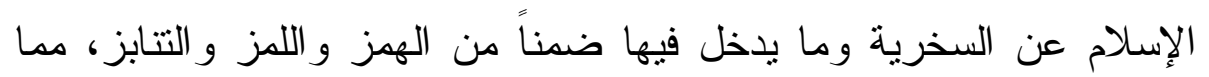
يُعد من قبيل حماية المجتمع من التفتت و التشقق، وفي هذا النص القر آني المتعلق بهذه الآداب وما اتنتمل عليه من أدب التكامل، ينهى الله عز وجل الذين آمنو ا عن عدة قبائح اجتماعية، من شأنها بذر بزور الفرقة و العداوة و البغضاء بين المسلمين، لما فيها من إيذاء أو إضرار من بعضهم لبعض، لهنه

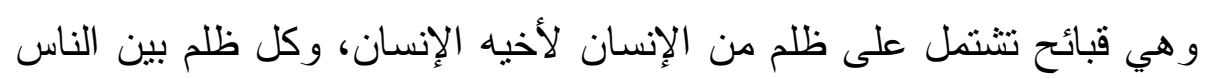

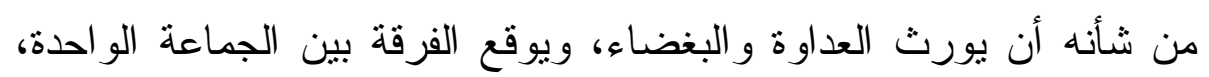
و هذه القبائح الست هي:

"السخرية - اتهام المؤمنين بالظنون الضعيفة التي لا تقوى على الاتهام -

التجسس على المؤمنين - غيبة المؤمنين المتقين". أولاً: مفهوم السخرية لغة و اصطلاحاً:

السخرية في اللغةة: سَخِرَ منه من باب طرب و سُخرُ اً بضمنين و مَسْخَرَاً بوزن مذهب، وحكى أبو زيد سَخِرَ به وهو أردأ اللغتين، وقال الأخفش سخر منه وباه، وضحك منه وبه، وهزئ منه وبه، كل يقال، والاسم

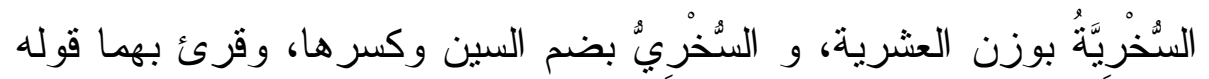

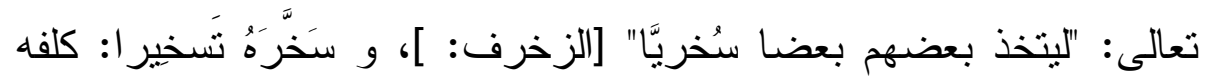

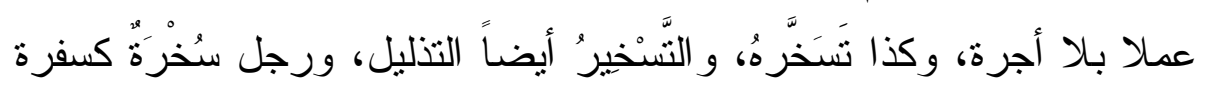

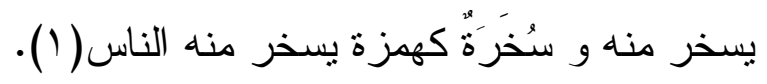

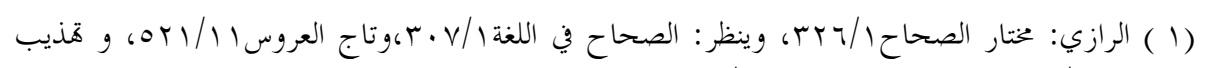

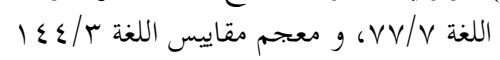

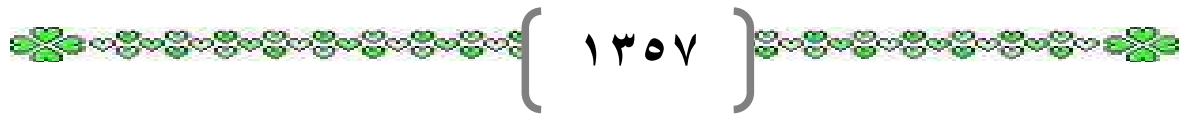


و السخرية: بضم أوله وسكون ثانيه وكسر ثالثه مصدر سخر، من سخر

$$
\text { الاستهز اء و التحقير (1). }
$$

وكلّ ذلك مأخوذ من مادّة "س خ ر" التّي تدلّ على "احتقار و استذلال" ومن ذلك أيضا قولهم: سخرّ اللّه- عزّ وجلّ- الثّيء، وذللك إذا ذلّه للأمره

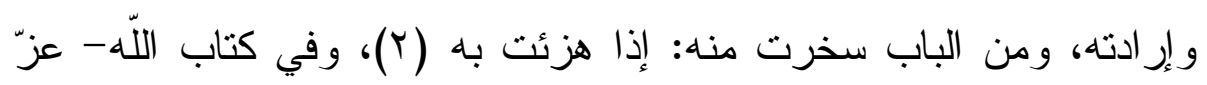

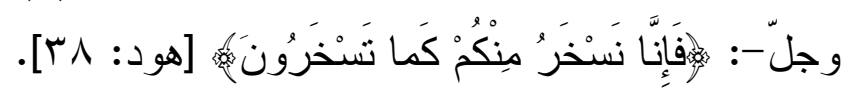

و عليه فمادة سخر في اللغة تدور حول أربعة معاني: الاستهز اء و التحقير ، و التذليل، و التكليف بالعمل، و التسليط.

والسخرية اصطلاحاً: قال المناويّ: السّخرية هي استزر اء العقل معنى، بمنزلة التّشخير في الفعل حسّا، ونقل عن ابن الكمال قوله: السّخرية تكون من شيء يحق" عند صاحبه و لا يحقّ عند السّاخر (r). وقال الفيروز آبادي: سياقة إلىى الغَرَض المختصّ بهـ قهرًا، قال تعالى

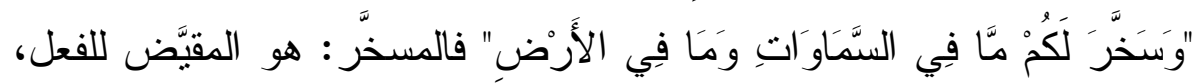

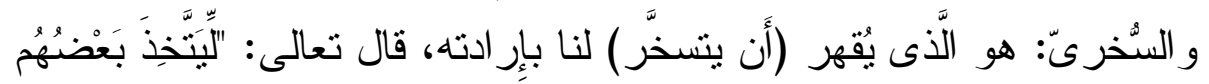

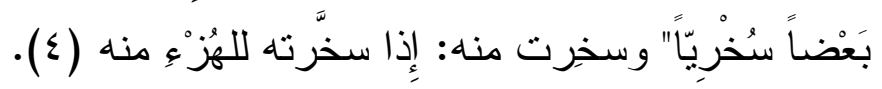

وقال القرطبي : السخرية الاستحقار والاستهانة و التتبيه على العيوب

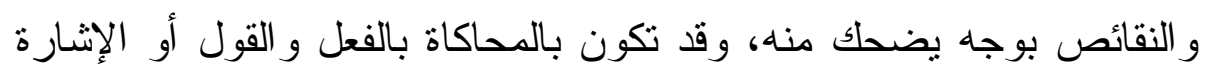

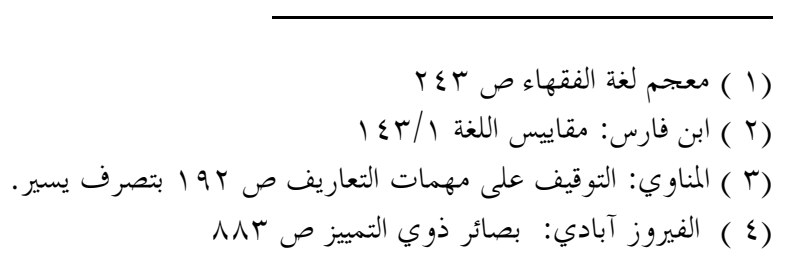

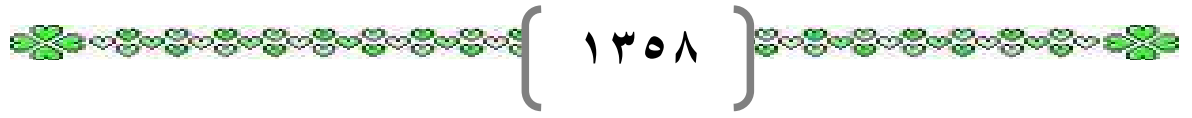


أو الإيماء أو الضحك على كلام المسخور منه إذا تخبط فيه أو غلط، أو على

$$
\text { صنعته، أو قبح صورتهاء (1) }
$$

وقيل: هو ذكر الثخص بما يكره على وجه مضحك بحضرته، و اختير أنه

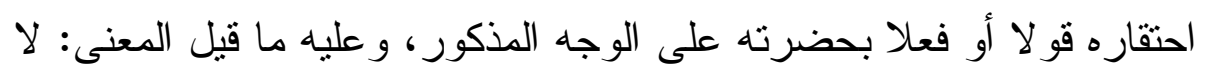
يحتقر بعض المؤمنين بعضا(r).

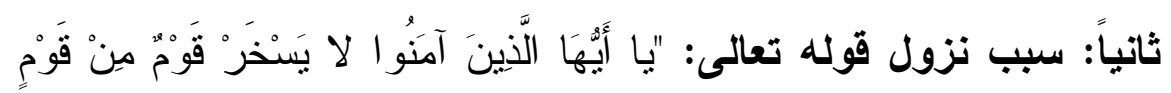
..."[الحجرات: (1]، قال ابن عطية في سبب نزول هذه الآيات: هذه الآيات

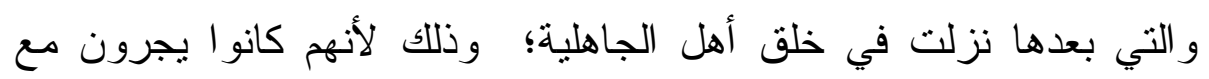
الثهو ات نفوسهم لم يقومهم أمر من الله ولا نهي، فكان الرجل يسطو ويهمز ويلمز وينبز بالألقاب ويظن الظنون؛ فيتكلم بها ويغتاب ويفتخر بنسبه إلى هلى

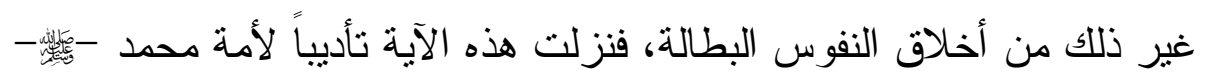

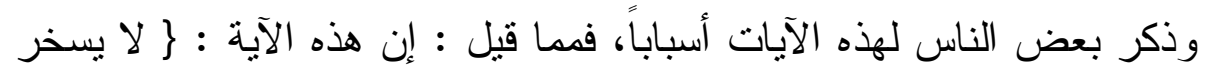
قوم \{ نزلت بسبب عكرمة بن أبي جهل، وذلك أنه كان يمشي بالمدينة مسلماً،

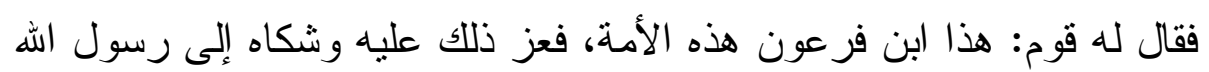
كسائر أمر الثرع ولو نتبعت الأسباب لكانت أكثر من أن تحصى(ب).

وقال القرطبي: اختلف في سبب نزولها ، فقال ابن عباس : نزلت في ثابت بن قيس بن شماس كان في أذنه وقر، فإذا سبقوه الى مجلس النبي - أوسعو اله إذا أتى حتى يجلس إلى جنبه لبسمع ما يقول، فأقبل ذات يوم وقد

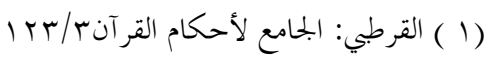

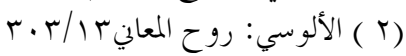

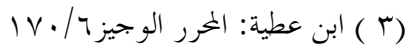

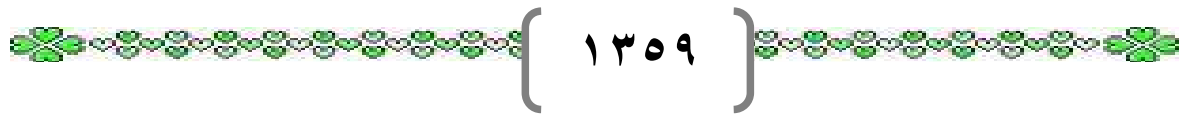




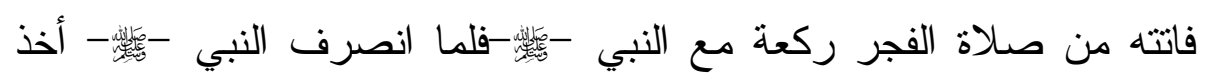
أصحابه مجالسهم منه، فرفض كل رجل منهم بمجلسه، و عضو ا فيه فلا يكاد يوسع أحد لأحد حتى يظل الرجل لا يجد مجلسا فيظل قائما، فلما انصرف وفه ونه ثابت من الصلاة تخطي رقاب الناس ويقول: تفسحوا تفسحوا، ففسحو الله

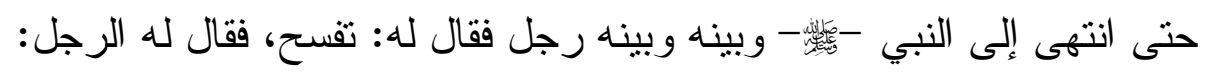
قد وجدت مجلسا فأجلس، فجلس ثابت من خلفه مغضبا، ثم قال: من هذا ؟ قالو ا فلان، فقال ثابت: ابن فلانة يعيره بها، يعني أما له في الجاهلية، فاستحيا الرجل، فنزلت، وقال الضحاك: نزلت في وفد بني تميم الذي تقدم ذكرهم في

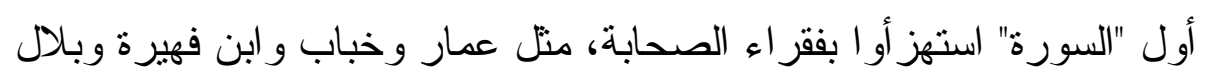

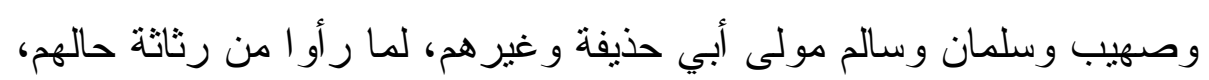
فنزلت في الذين آمنو ا منهم، وقال مجاهد: هو سخرية الغني من الفقير ، وقال ابن زيد: لا يسخر من ستر الله عليه ذنوبه ممن كثفه الله، فلعل إظهار ذنوبه

$$
\text { في الدنيا خير له في الآخرة( (1). }
$$

ثالثاً: التحذير من مغبة السخرية وأضر ارها: ينهى الله تعالى عن السخرية بالناس، و هو احتقار هم و الاستهز اء بهم، كما ثبت في الصحيح عن رسول الله - ذأنها ذلك: احتقار هم واستصغار هم، وهذا حر ام، فإنه قد يكون المحتقر أعظم قدراً

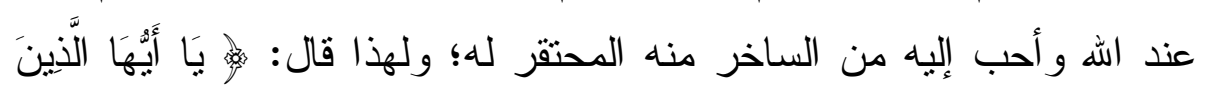

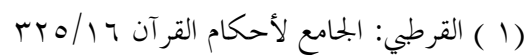

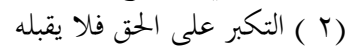

$$
\begin{aligned}
& \text { ( ) الاحتقار والاستهانة }
\end{aligned}
$$

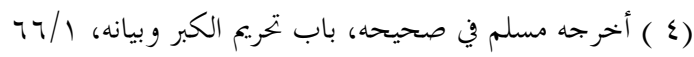




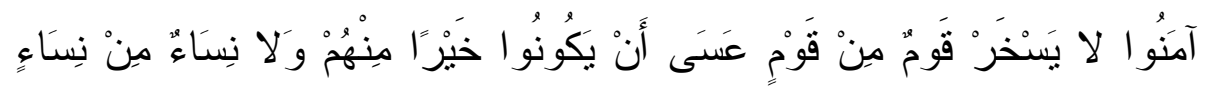

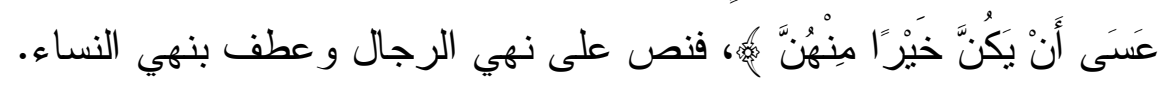

ومن حق المؤمنين على بعضهم البعض أن" لا بَسْخَرْ قَوْم مِن قَوْمِ" بكل

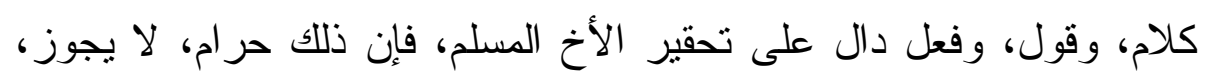

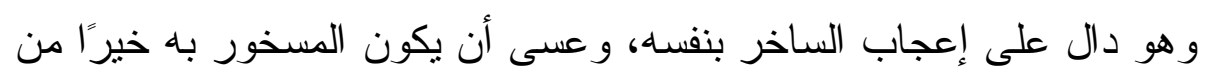
الساخر، كما هو الغالب و الو اقع، فإن السخرية، لا تقع إلا من قلب ممتلـئ من

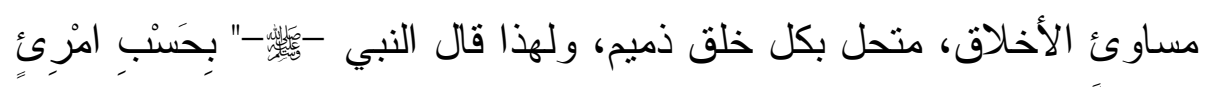

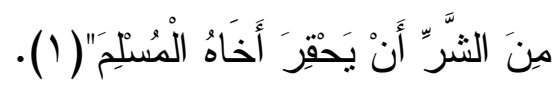

ولقد حذر الإسـام من السخرية وبين أضرارها في الكتاب(Y) و السنة، فعَنْ

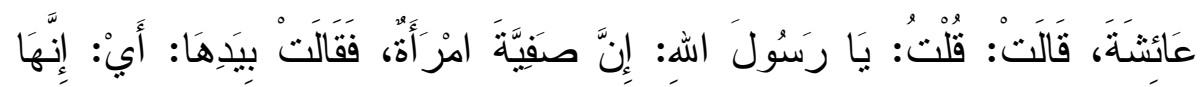

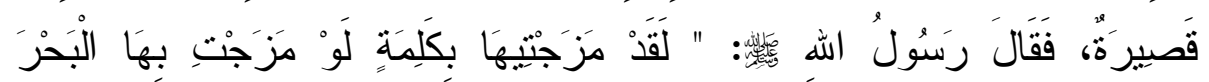

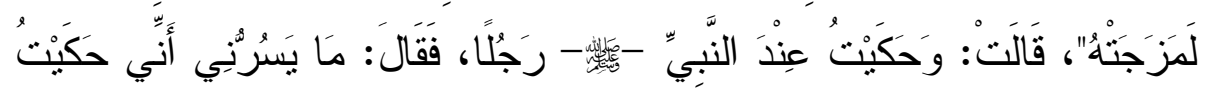

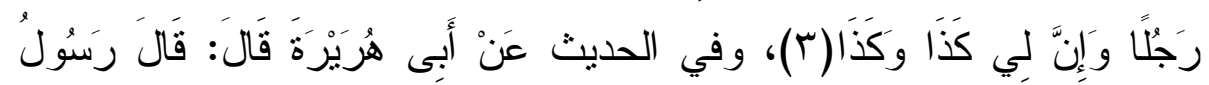

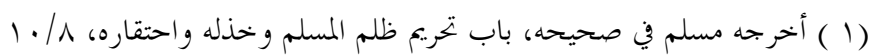

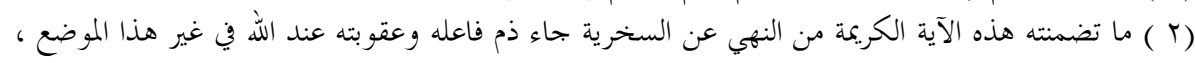

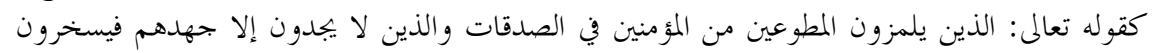

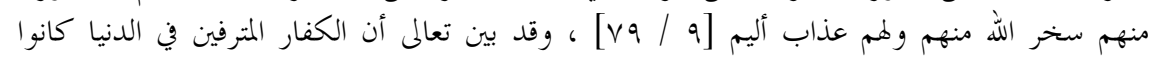

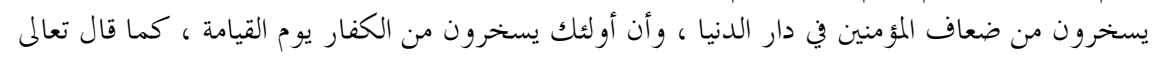

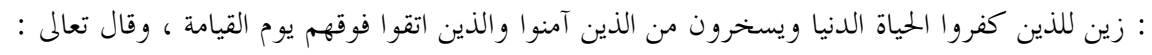

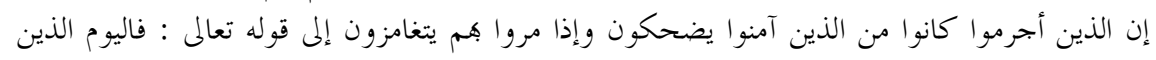

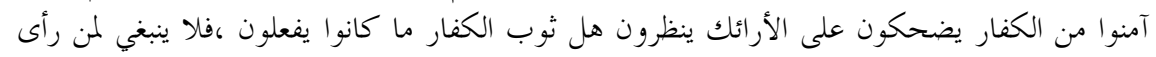

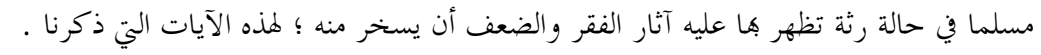

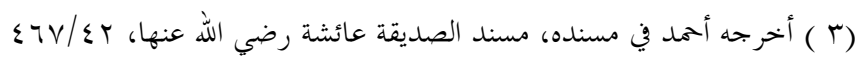

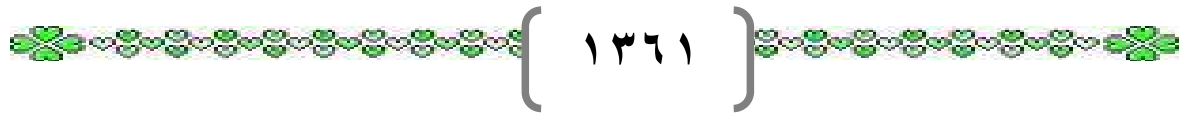




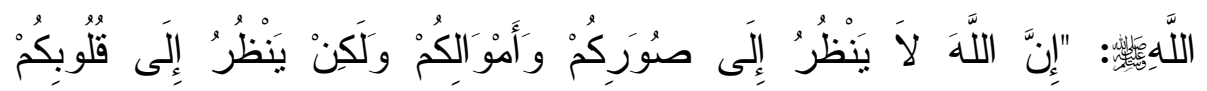

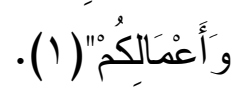

قال العلماء: إنه لما كانت القلوب هي المصححة للأعمال الظاهرة، وأعمال القلب غيب عنا، فلا يقطع بمغيب أحد؛ لما برى عليه من صور ألفاء أعمال

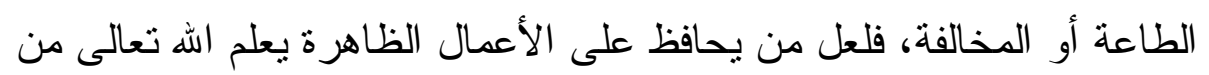

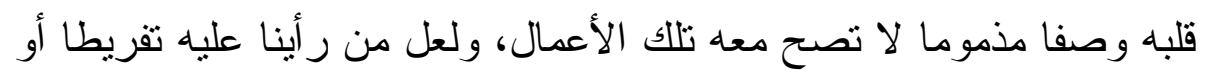

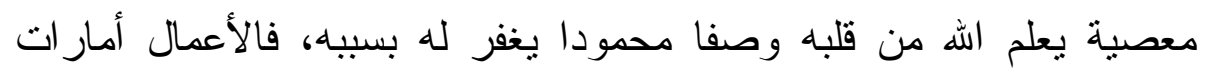
ظنبة لا أدلة قطعية، ويترتب عليها عدم الغلو في تعظيم من ر أينا عليه أفعالا

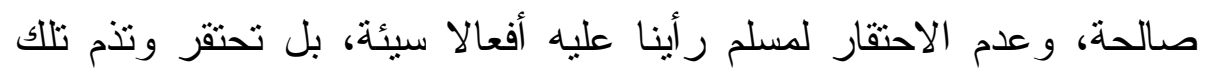

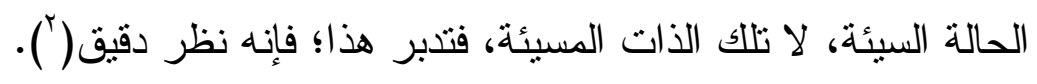

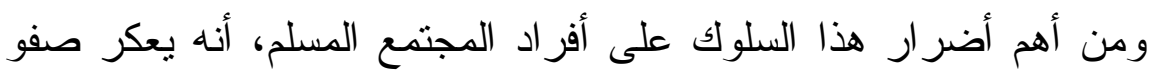

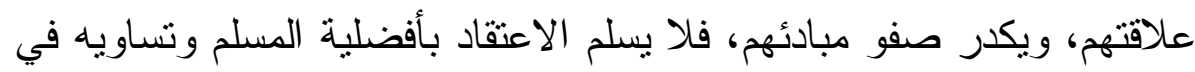

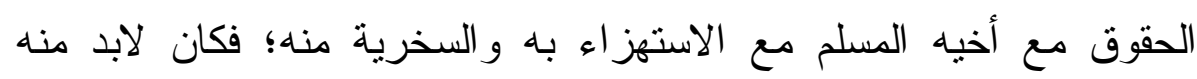

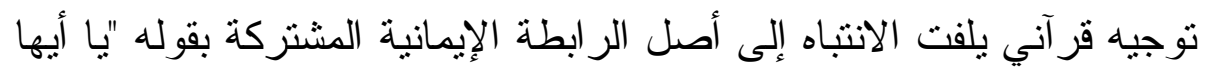

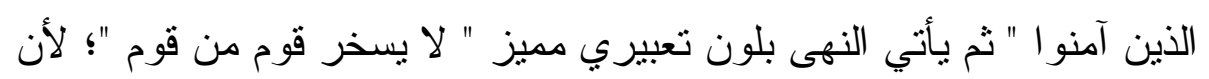
السخرية تغلب فيها المشاركة فناسب أن يأتي النهى بهذا اللون.(ए). و السخرية منافية لخلق المسلم؛ لأن فيها استعلاء بغير الحق؛ ولذلك نبهت

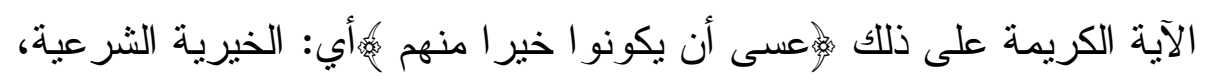

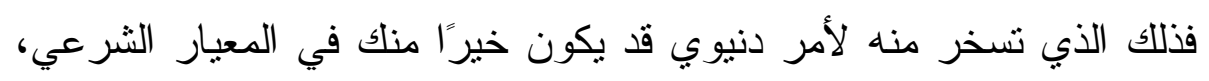

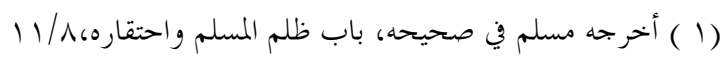

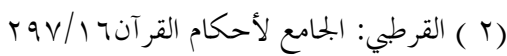

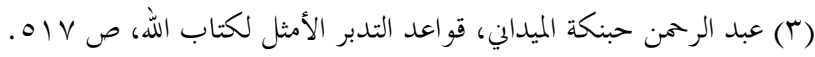


هذا بالإضـافة إلى ما تحدثه هذه السخرية من غل في النفوس وشــر بين

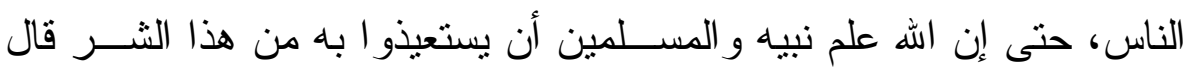

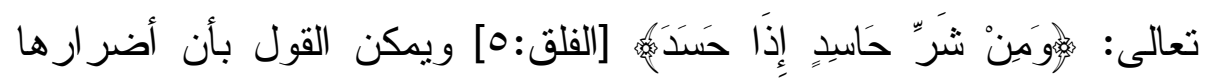
على الفرد و المجتمع خطيرة منمثلة في الآتي:

فى السخرية مخالفة صريحة لأمر الله كما جاء في الآية الكريمة هابلا يسخر قوم من قوم مهر ثم هي جالبة لسخطه مستوجبة لعذابه، وهي تفكلك عرى المجتمع وتجعل المستسخر به ناقما على الساخر منربصنًا به يحاول الانتقام Sid

و هي تميت القلب وتورثه الغفلة حتى إذا كان يوم القبــامة ندم الساخر

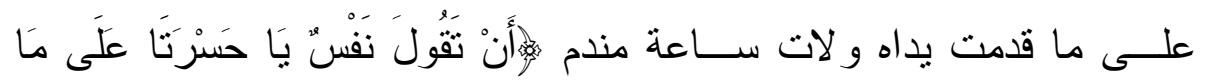

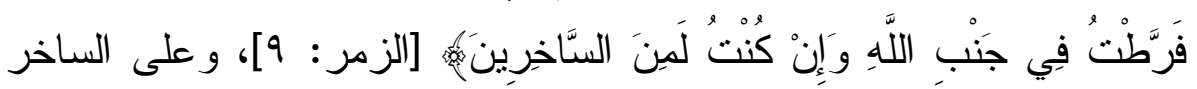
أن يتوقع عقوبته في الدار العاجلة بأن بحدث له منل ما حدث للمسخور منه.(1) (1)

خامساً: السر في إفراد النساء بالأكر: و السر في أفرد النساء بالذكر لأن

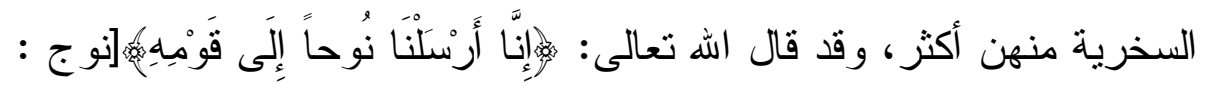

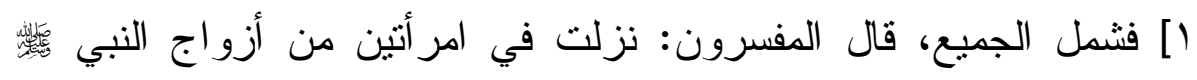
سخرتا من أم سلمة، وذلك أنها ربطت خصريها بسبيبة - وهو ثوب أبيض، ومتلها السب- وسدلت طرفيها خلفها فكانت تجرها، فقالت عائنة لحفصة رضي الله عنهما: انظري ما تجر خلفها كأنه لسان كلب، فهذه كانت

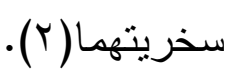

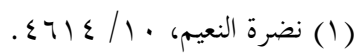

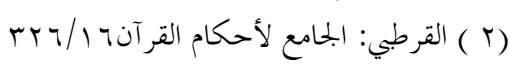

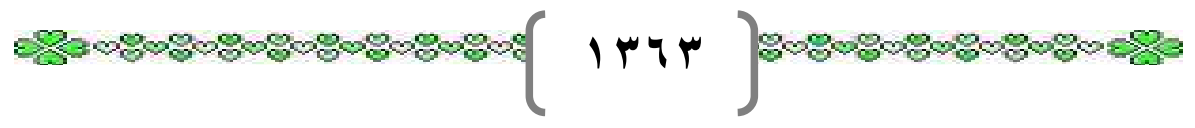


سادساً: الهمز (') و(اللمز)(") من الستخرية: قال القرطبيّ: قال سفيان

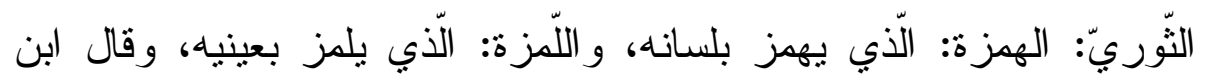

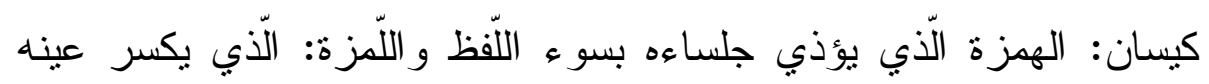

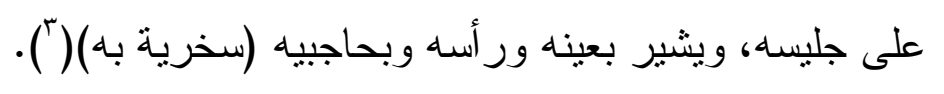

ويقول يحيى المعلّميّ: الهمز : هو الستخرية من التّاس بالإثشارة كتحريك

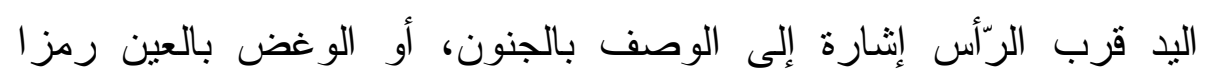

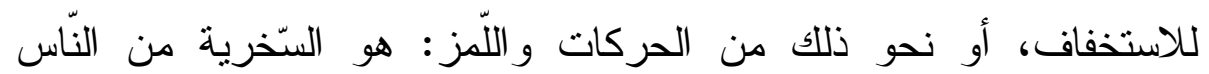
بالقول، كتسمية الثخّص باسم يدلّ على عاهة فيه أو مرض، أو اتِّامه بخليقة

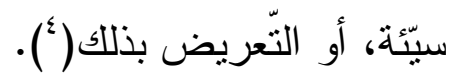

سابعاً: التنابز بالألقاب من الستخرية: قال الطَّريّ: التّابز بالألقاب هو

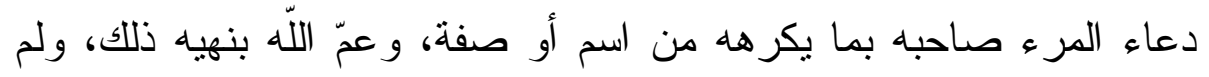

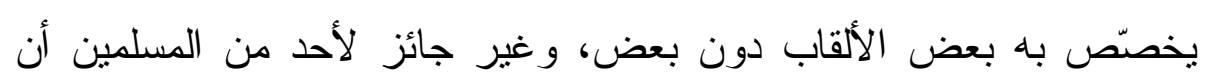
ينبز أخاه باسم يكر هله أو صفة يكر هها (ال) دون بعض، وعير

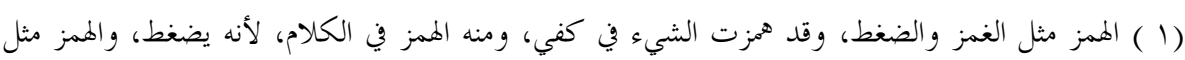

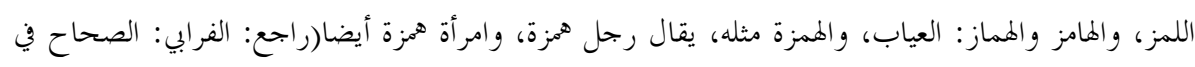
اللغة/r/r T) .

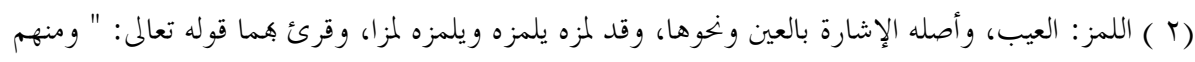

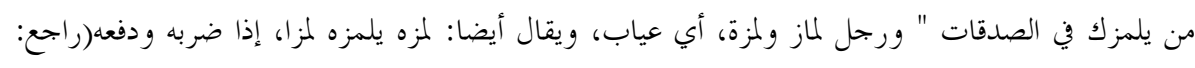

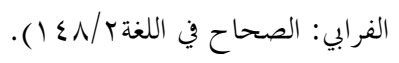

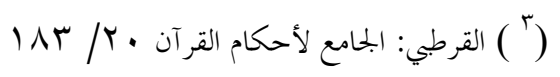

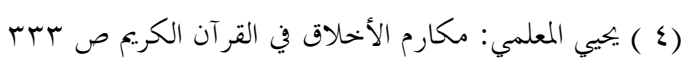

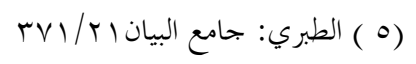

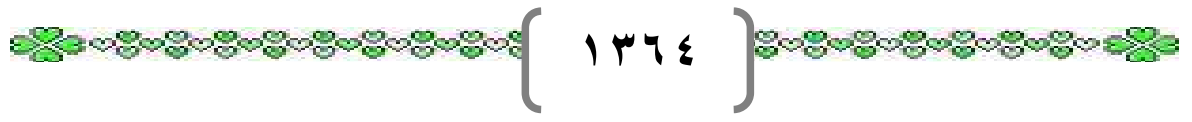


و النهي عن التنابز بالألقاب: مناداة رجل أخاه بما يكره من الأسماء و الكني

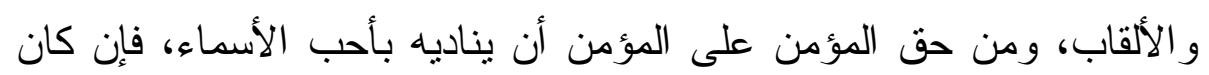

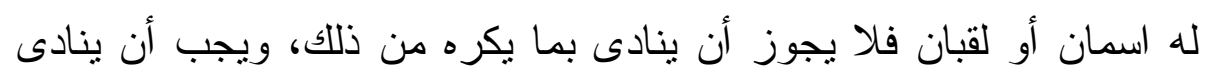
بأحبها إليه، ولما نهى الحق عن السخرية وما يتعلق بها من آفات قال:

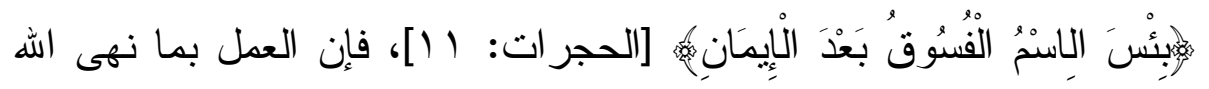

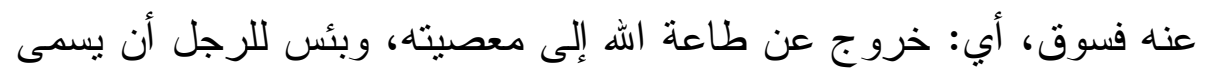
فاسقا بعد إيمان " ولم يتب" بعد أن نهاه الله " فأولئك هم الظالمون".

ويلحق بما سبق التّهكم: وهو ما كان ظاهره جدّا وباطنه هز لا، يقول

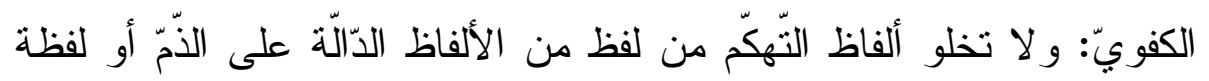

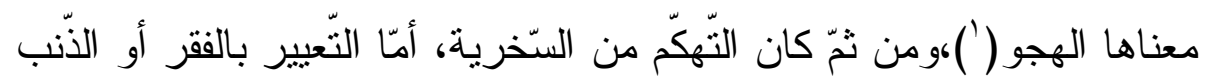
أو العلّة أو ما شابه ذلك فقد نصّو الهُ على أنّه من السّخرية، يقول الإمام الطّبريّ: "عمّ اللّه بنهيه المؤمنين عن أن بسخر بعضهم من بعض جميع

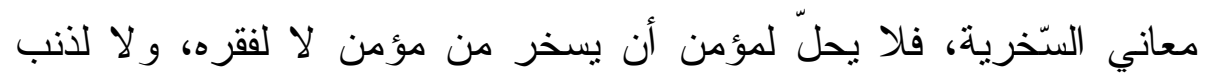

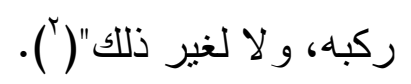

ويفهم من نهي المولى عزّ وجلّ عن السّخرية بأنو اعها المختلفة أنها حر ام،

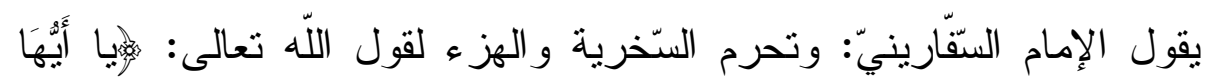

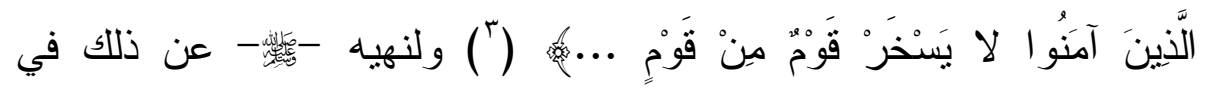
مو اضع عديدة.

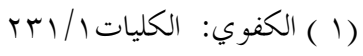

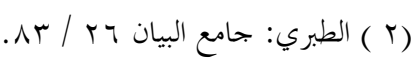

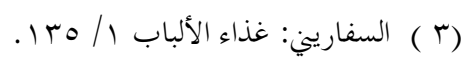

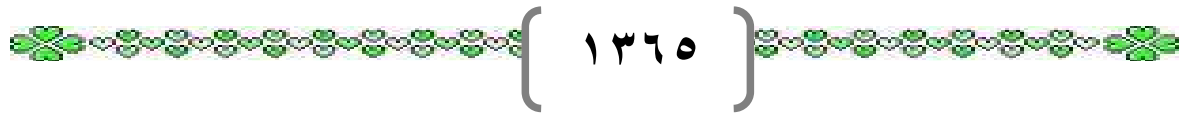




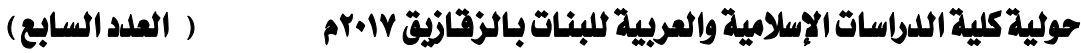

\section{المطلب الثاني: نهي الإسلام عن الظن}

\section{أولاً: مفهوم الظن لغة واصطلاحاً:}

الظن في اللغة: قال ابن فارس: الظاء و النون أصيل صحيح يدل على معنين مختلفين: يقين وشك، فأما اليقين فقول القائل: ظننت ظنا، أي أيقنت.

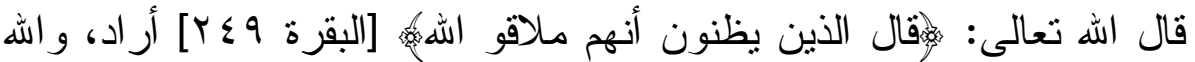
أعلم، يوقنون، أراد: أيقنوا، وهو في القرآن كثثر، و الأصل الآخر: الثكك، يقال ظننت الثيء، إذا لم تتيقنه، ومن ذلك الظنة: التهمة. و الظنين: المتهم، و الظنون: السيئ الظن، و النظني: إعمال الظن، و أصل النظني النظنن، ويقولون: سؤت به ظنا وأسأت به الظن، يدخلون الألف إذا جاؤو ا بالألف

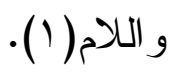

والظن اصطلاحاً: الاعتقاد الراجع مع احتمال النقيض ويستعمل في اليقين و الثك، وقيل الظن أحد طرفي الثك بصفة الرجحان(r)**. وقال الرّاغب: الظّّّ: اسم لما يحصل عن أمارة ومتى قويت أدّت إلى العلم

$$
\text { ومنتى ضعفت جدّا لم تتجاوز حدّ التّوهّم(ب). }
$$

وقال ابن منظور : الظنّ شكّ ويقين، إلّا أنّه ليس بيقين عيان إنّما هو يقين

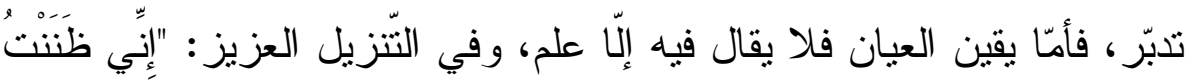

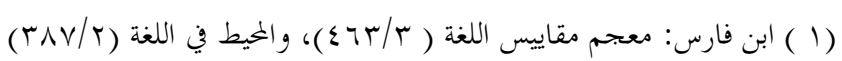

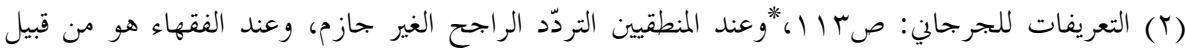

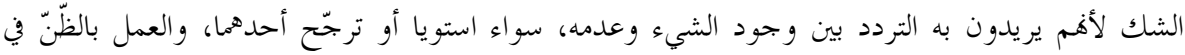

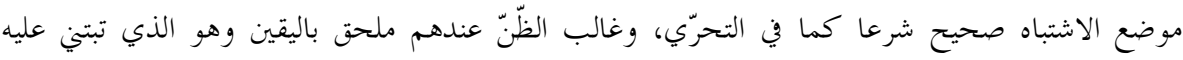

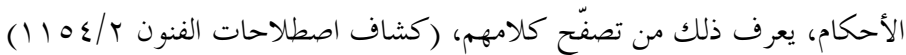

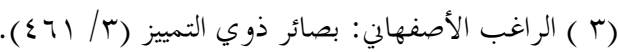




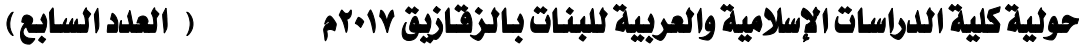

أَنَيّي مُلاقِ حِسابيَهة" [الحاقة: . ب] أبي علمت، وقال الجوهريّ: الظّنّ معروف،

$$
\text { وقد يوضع موضع العلم (1). }
$$

$$
\text { وقال الشوكاني: الظن هو مجرد التهمة التي لا سبب لها(r). }
$$

وقال ابن العربي: قال علمائنا: إن حقيقة الظن، تجويز أمرين في النفس لأحدها نرجيح على الآخر ، و الثك: عبارة عن استو ائهما، و العلم: هو حذف لهن

$$
\text { أحدهما وتعيين الآخر (r). }
$$

ثالثاً: أنواع الظن: الظن على أربعة أوجه: محظور ، ومأمور به، ومندوب

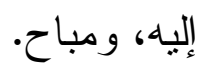

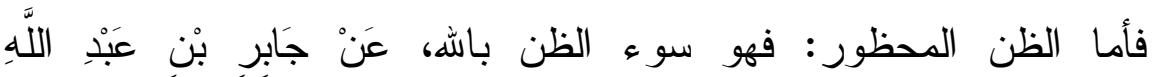

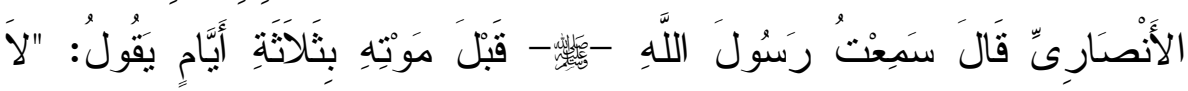

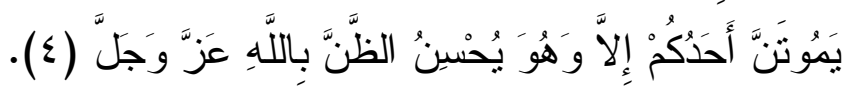

ولقد ورد الظّّن في القرآن مجملاً بمعنى اليقين، وبمعنى الثّلّهّ، وبمعنى

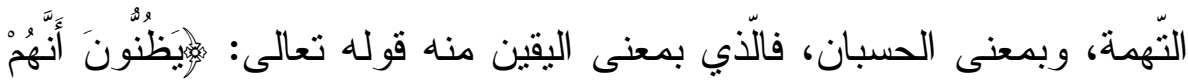

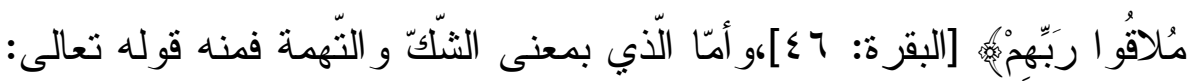


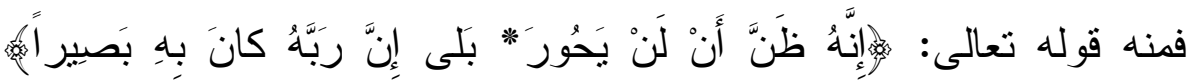

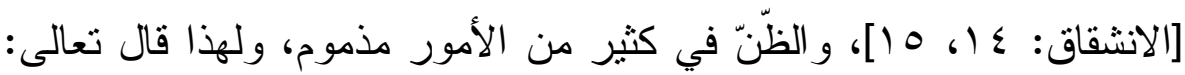

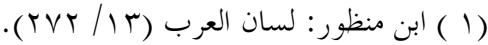

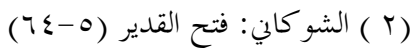

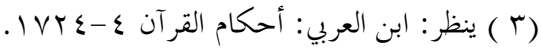

$$
\begin{aligned}
& \text { (ع) أخرجه مسلم في صحيحه باب: الأمر بحسن الظن بالله تعالى،1/10/ } 1 \text {. }
\end{aligned}
$$




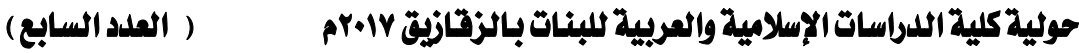

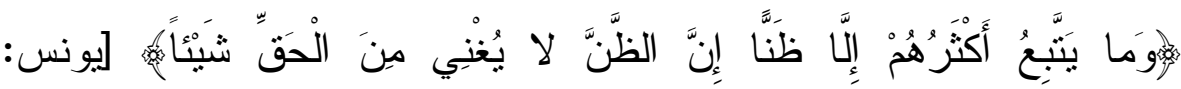
(1) $[$ ru

قال الكفويّ: عن مجاهد قال: كلّ ظنّ في القرآن فهو يقين وهذا يشكل في

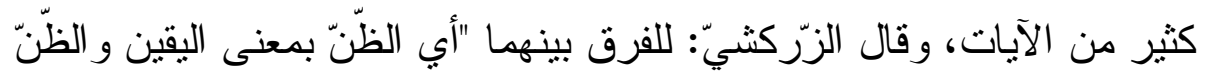
بمعنى الثنّكّ" ضابطان في القر آن الكريم:

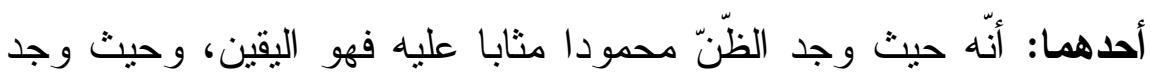
مذموما منت عَّا عليه بالعذاب فهو الثّكّ.

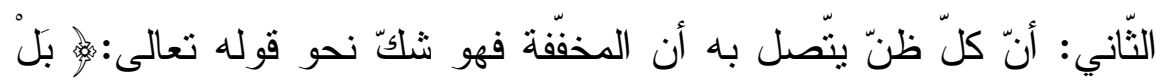

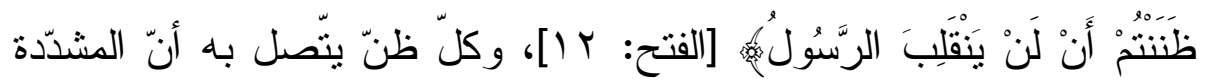

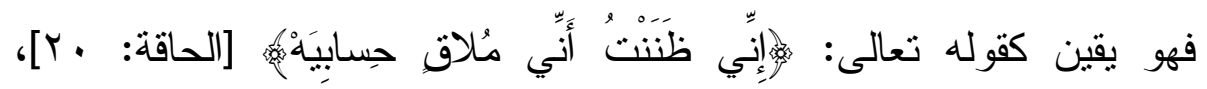
و المعنى في ذلك أنّ: (أنّ) المشدّدة للتّأكيد فذخلت في اليقين و المخفّة بخلافها

$$
\text { فرخلت في الثَّكّ (r) }
$$

ويضع الجصاص العديد من الضوابط للظن المحظور فيقول: "وكل ظن فيما له سبيل إلى معرفته، مما تعبد بعلمه فهو محظور، لأنه لما كان متعبداً تعبد بعلمه ونصب له الاليل عليه فلم يتبع الدليل وحصل على الظن كان

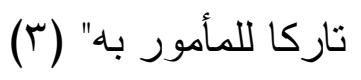

و أما المأمور به: هو ما لم ينصب له عليه دليل يوصله إلى العلم اليقيني به، وقد تعبد بتتفيذ الحكم فيه، فالاقتصار على غالب الظن وإجراء الحكم عليه واجب، وذللك نحو ما تعبدنا به من قبول شهادة العدول، وتحري القبلة،

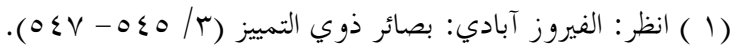

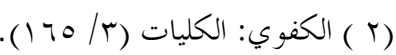

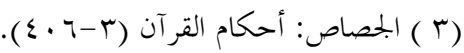


و تقويم المستهكات، و أرش الجنايات التي لم يرد بمقادير ها توقيف، فهذه وما كان من نظائر ها قد تعبدنا فيها بتتفيذ أحكام غالب الظن. ( (1). و أما الظن المندوب إليه: فهو حسن الظن بالأخ المسلم، فإن قيل: إذا كان سوء الظن محظورا فواجب أن يكون حسن الظن واجبا، قيل له: لا يجب

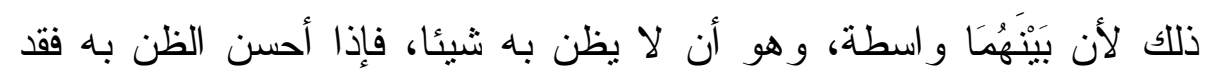
فعل مندوبا إليه. (r) (ب). و أما الظن المباح فالثكاك في الصلاة يجوز له أن يعمل بما غلب على ظنه، ويجوز له أن يبني على اليقين. (r). ونقل أبو البقاء (ع) أن الزركثي أورد ضابطين للفرق بين الظن الوارد في القرآن بمعنى اليقين و الظن الو ارد بمعنى الثنك: أحدهما: أنه حيث وجد الظن محموداً مثنابًا عليه فهو اليقين وحيث وجد

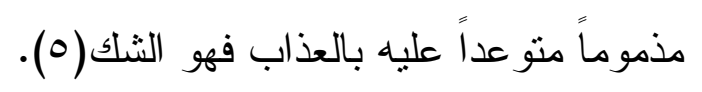

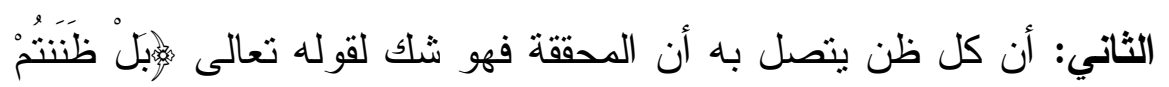

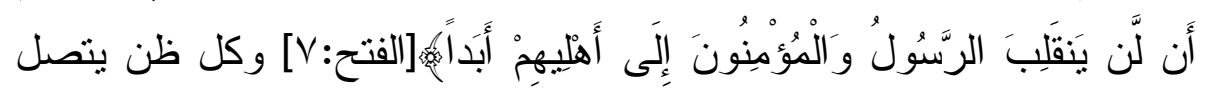

$$
\begin{aligned}
& \text { (1) ينظر : المصدر نفسه (r-T • • ع). }
\end{aligned}
$$

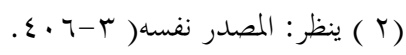

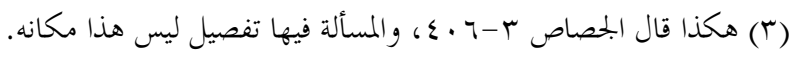

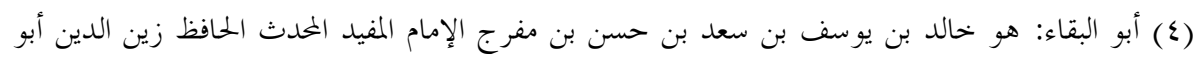

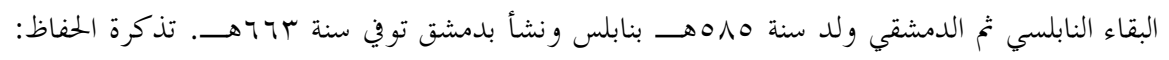
. I $\leqslant \leqslant \vee / \varepsilon$

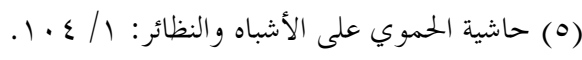

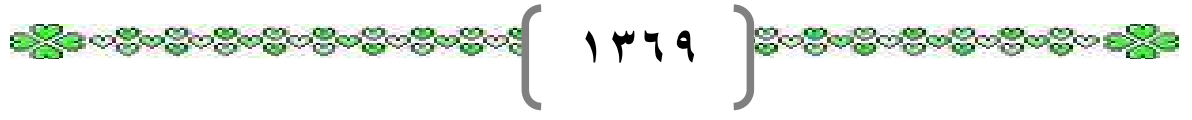




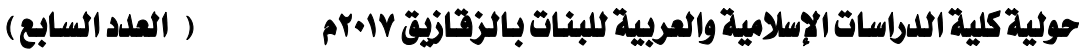

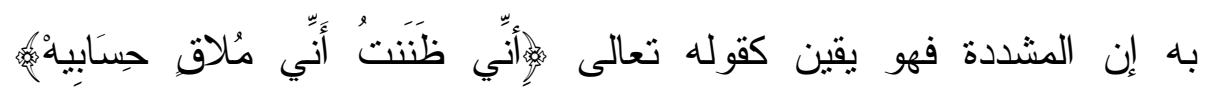

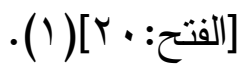

وللظن حالتان: حالة تعرف وتقوى بوجه من وجوه الأدلة فيجوز الحكم بها، و أكثر أحكام الثريعة مبنية على غلبة الظن، كالقياس وخبر الو احد وغير ونه ونه ذلك من قيم المتلفات وأروش الجنايات. و الحالة الثانية: أن يقع في النفس وله شيء من غير دلالة فلا يكون ذلك أولى من ضده، فهذا هو الثك، فلا يجوز الحكم بها، وهو المنهي عنه على ما قررناه آنفا، وقد أنكرت جماعة من هون المبتدعة تعبد الله بالظن وجواز العمل به، تحكما في الدين ودعوى في

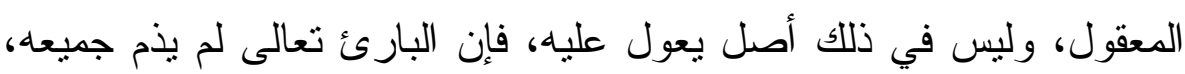

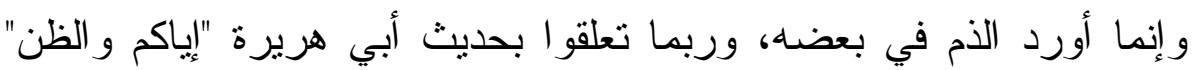
فإن هذا لا حجة فيه، لأن الظن في الثريعة قسمان: محمود ومذموم، فالمحمود منه ما سلم معه دين الظان و المظنون به عند بلوغه، و المذموم

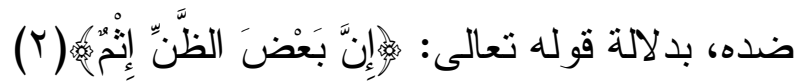
رابعا: نهي القرآن عن الظن السيء وعاقبته الوخيمة: لقد ورد النهي عن

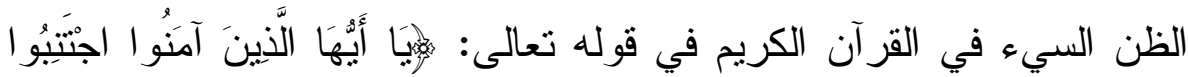

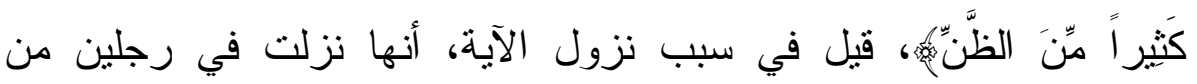

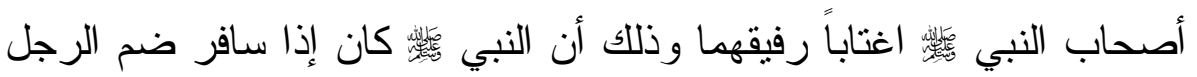
المحتاج إلى الرجلين الميسورين فضم سلمان إلى رجلين يخدمها فجاء فلم يجدا طعاماً فقالا له أذهب فاطلب لنا طعاماً فذهب فلم يجد فقالا لو بعثنا

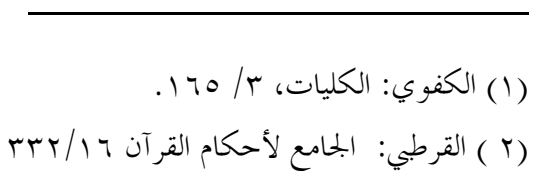

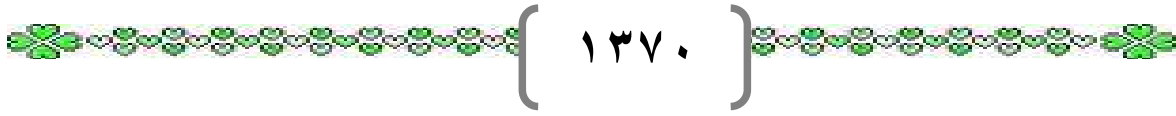


سلمان إلى بئر سُميحة( (1) لغار ماؤها ثم انطلقا يتجسسان هل عند أسامة

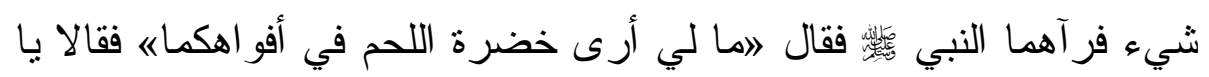
نبي الهه واله ما أكلنا في يومنا هذا لحماً ولا غيره فقال لاولكنكما ظلتما تأكلان لحم سلمان و أسامةه فنزلت (r).

ولقد نهى الله تعالى عباده المؤمنين عن كثير من الظن، وهو التهمة و التخون للأهل والأقارب و الناس في غير محله؛ لأن بعض ذلك يكون إثما محضا، فليجتتب كثير منه احتياطا، وروينا عن أمير المؤمنين عمر بن الخطاب، رضي الله عنه، أنه قال: و لا تظنن بكلمة خرجت من أخيك المسلم إلا خير ا، و أنت تجد لها في الخير محملا، ولقد وردت العديد من الآيات القر آنية في هذا الصدد.

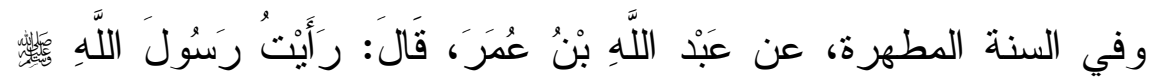

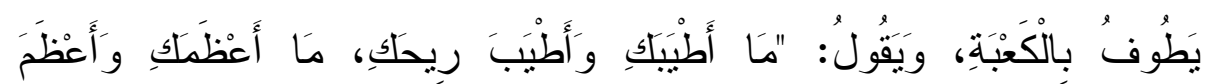

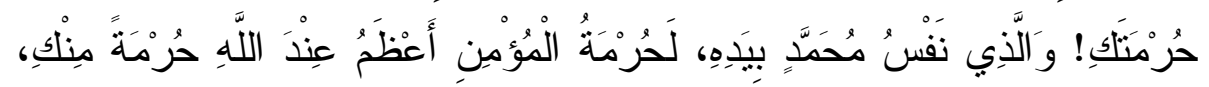

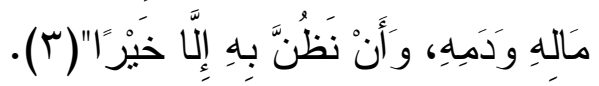

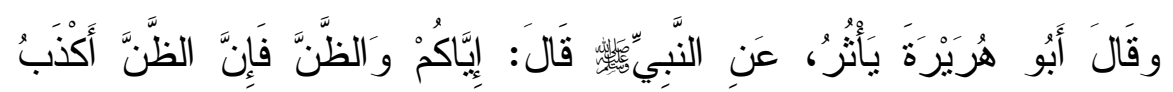

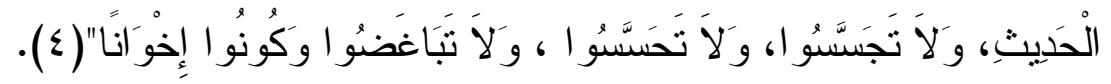

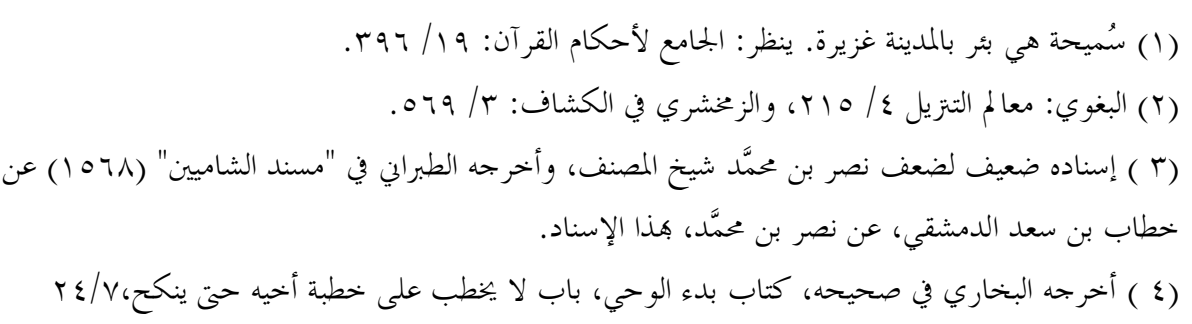

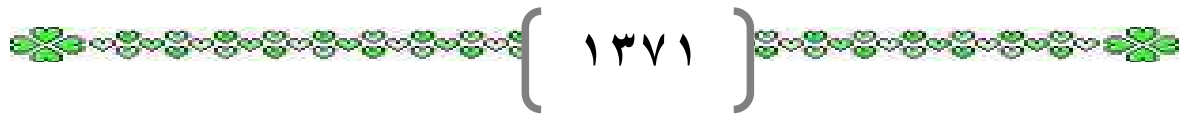


يقول الثيخ السعدي في تبيان الظن وحقيقته و أنواعه الغير مشروعة، كما وضح القرآن في السورة الجليلة: نهى الله تعالى عن كثير من الظن السوء

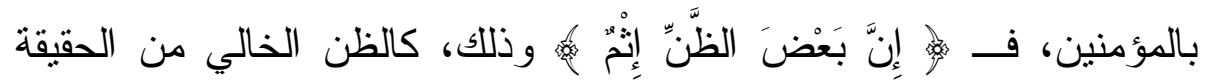
و القرينة، وكظن السوء، الذي يقترن به كثير من الأقو ال، و الأفعال المحرمة، فإن بقاء ظن السوء بالقلب، لا يقتصر صاحبه على مجرد ذللك، بل لا يز ال بها، حتى يقول ما لا ينبغي، ويفعل ما لا ينبغي، وفي ذلك أيضًا، إساءة الظن بالمسلم، وبغضه، و عداوته المأمور بخلاف ذلك منه( (1).

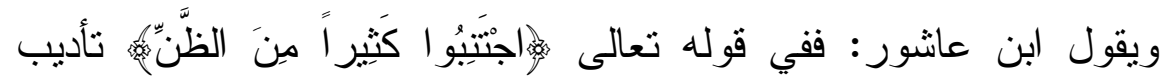
عظيم يبطل ما كان فاثيا في الجاهلية من الظنون السيئة و التهم الباطلة وأن الظنون السيئة تتشأ عنها الغيرة المفرطة و المكائد، و الاغتيالات، و الطعن في الأنساب، و المبادأة بالقتال حذر ا من اعتداء مظنون ظنا باطلا، كما قالو ا خذ

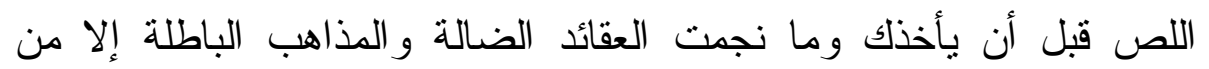

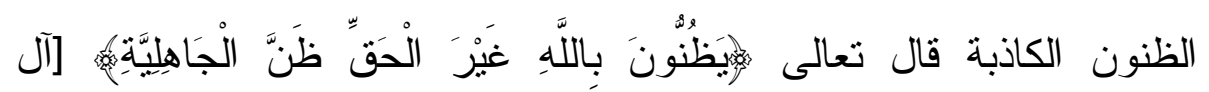

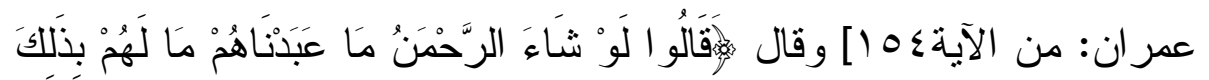

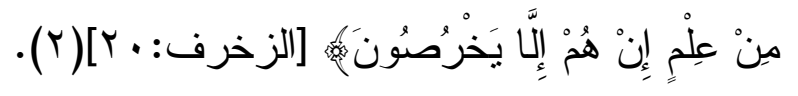

وليس كل ظن إثم، إذ بعضه ليس بإثم، و لا يلزم اجتنابه وهو ظن الخير بالناس وحسنه بالله تعالى، و المظنون من شهادات الثهود و المظنون به من أهل الثر، فإن ذلك سقوط عدالته وغير ذلك هي من حكم الظن به، وظن الخير بالمؤمن محمود و الظن المنهي عنه: هو أن نظن سوءاً برجل ظاهره الصلاح؛ بل الو اجب تنزيل الظن وحكمه وتتأول الخير، وقال بعض الناس: "

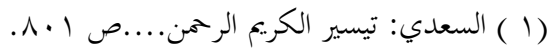

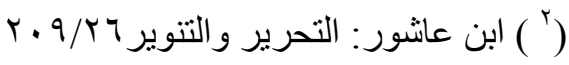




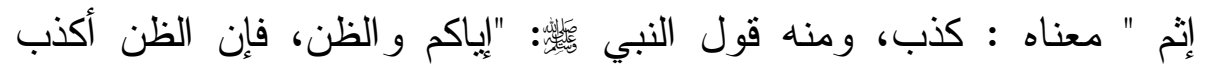
الحديث" (1) وقال بعض الناس، معنى: "إن بعض الظن إثم " أي إذا تكلم

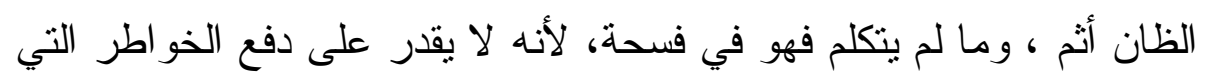
بييحها ما ورد في الخبر: " الحزم سوء الظن "(r).

قال القاضي أبو محمد : وما زال أولو العلم يحترسون من سوء الظن ويسدون ذر ائعه، قال سلمان الفارسي : إني لأعد غر اف قِدرِي مخافة الظن ،وكان أبو العالية يختم على بقية طعامه مخافة سوء الظن بخادمه، وقال ابن

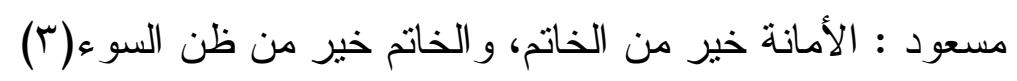

قال الغز الي في (الإحياء): اعلم أن سوء الظن حرام، منل سوء القول؛ فكما يحرم عليك أن تحدث غيرك بلسانك بمساوئ الغير، فليس للك أن تحدث

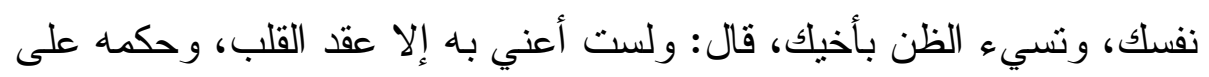
غيره بسوء الظن، فأما الخواطر وحديث النفس، فهو معفو عنه، بل الثك ولك وله أيضاً معفو عنه، ولكن المنهي عنه أن يظن، و الظن عبارة عما نزكن إليه

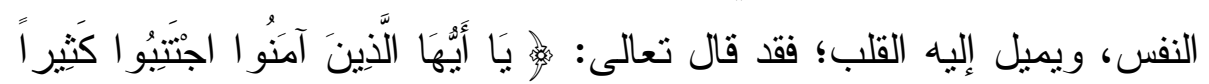

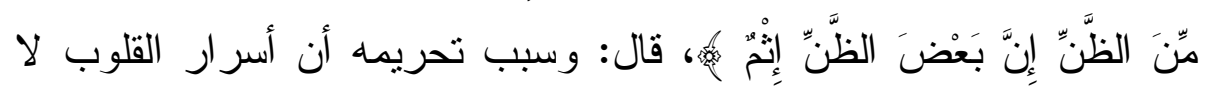
يعلمها إلا علام الغيوب، فليس للك أن تعتقد في غيرك سوءاً إلا إذا انكشفت

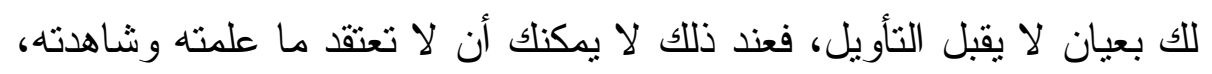

$$
\text { (1)) }
$$

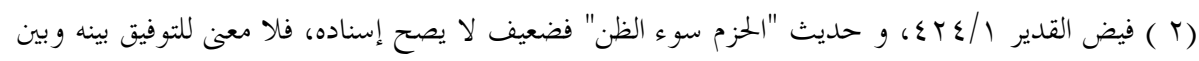

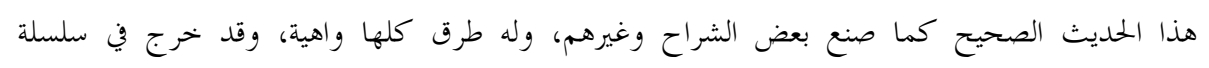

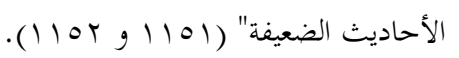

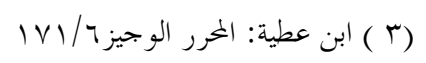

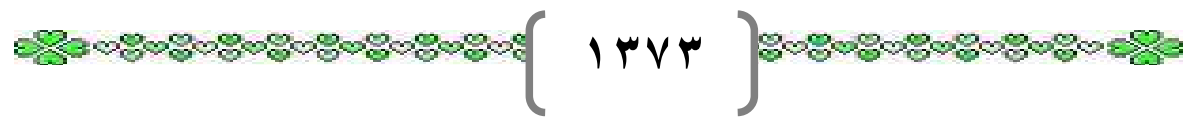


وما لم تشاهده بعينيك، ولم تسمعه بأذنك، ثم وقع في قلبك، فإنما الثيطان

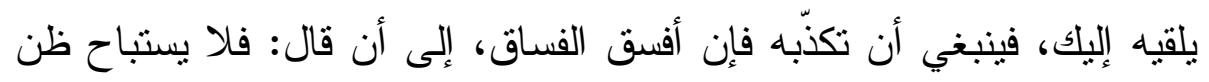
السوء إلا بما يستباح به المال، وهو بعين مشاهدة، أو بينة عادلة (1)

\section{المطلب الثالث: نهي الإسلام عن التجسس}

الأدب الثالث من آداب التعامل الواردة في السورة الجليلة و الذي يتضمن النهي عن نتبع عورات المسلمين ومعاييهم والاستكثاف عما ستروه، وقد ورد النهي في الكتاب و السنة عن التجسس وبخاصة أن عو اقبه وخيمة بين أفراد المجتمع فضلا عن عقاب الله تعالى في الآخرة، و القرآن يقاوم هذا العمل الدنيء من الناحية الأخلاقية، لتطهير القلب من منل هذا الاتجاه اللئيم لتتبع عور ات الآخرين وكثف سو آتهم. وتمشيا مع أهدافه في نظافة الأخلاق

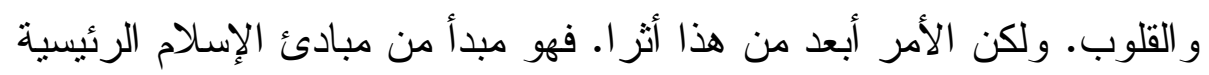
في نظامه الاجتماعي، وفي إجر اءاته التشريعية و التنفيذية.

\section{أولاً: مفهوم التجسس لغة و اصطلاحا:}

التجسس في اللغة: قال ابن منظور : و الجس جس الخبر ، ومنه التجسس، وجس الخبر وتجسسه بحث عنه وفحص، فال اللحياني تجسست فلانا ومن فلان بحتت عنه كتحست ... و المجس والمجسة ممسة ما جستنه بيدك وكس وتجست الخبر وتحسته بمعنى واحد وفي الحديث: "لا تجسسو ا" التجسس بالجيم التفتيش عن بواطن الأمور وأكثر ما يقال في الثر، و والجاسوس ولتش صاحب سر الثر، و الناموس صاحب سر الخير، وقيل التجسس بالجيم أن

( ' ( ) الغز الي: إحياء علوم الدين

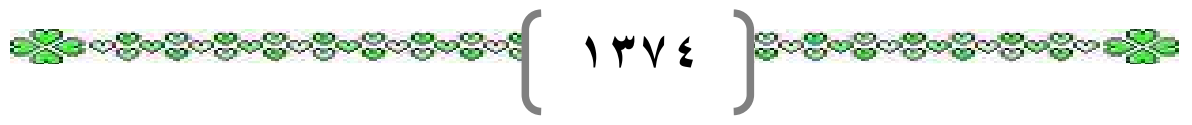




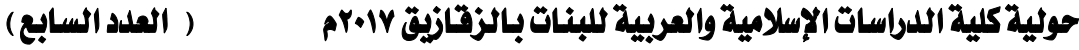

بطلبه لغيره وبالحاء أن بطلبه لنفسه، وقيل بالجيم البحث عن العورات وبالحاء الاستماع، وقيل معناهما و احد في تطلب معرفة الأخبار ..(1)

وفي الاصطلاح: التجسس: التََّحُّص عن بواطِن الأمور، و أكثر ما يقال

$$
\text { ذللك في الثر، وقيل: التجسُّ: البحث عن العورات(ب). }
$$

وقال الكفوي: التجسس: السؤال عن العورات من غيرهو التحسس بالحاء

$$
\text { المغفلة استكثاف ذلك بنفساه(ب) }
$$

وقال ابن الأثثر: التّجسّس: التّقتيش عن بو اطن الأمور و أكثر ما يقال في

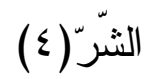

وقال القرطبي: و اختلف هل هما بمعنى واحد أو بمعنيين؟ فقال الأخفش: ليس تبعد إحداهما عن الأخرى، لأنّ التحسّس البحث عمّا بكتم عنك، ولك،

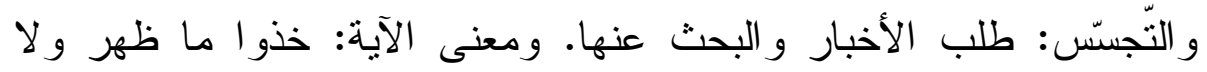
تتبّعو ا عور ات المسلمين، أي لا يبحث أحدكم عن غيب أخيه حتى يطلّع عليه بعد أن ستره اللّه (0)

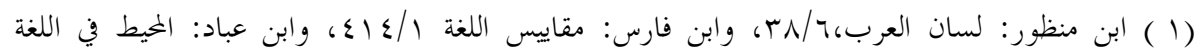
، rNV/T

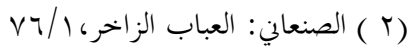

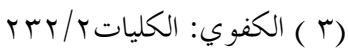

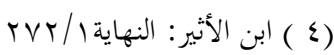

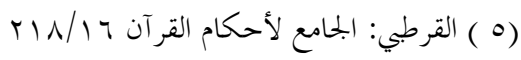




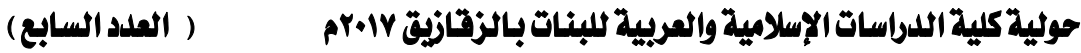

وقال الطبّريّ: لا تَجَسَُّو أبي لا يتتبّع بعضكم عورة أخيه ولا يبحث عن

سرائره، يبتغي بذلك الظّهور على عيوبه (1)

وقد فرّق بين التجسس و التحس يحيى بن أبي كثير، فقال التجس البحث عن عورات الناس، و التحس الاستماع لأحاديث الناس، وقيل: التجسس ولني

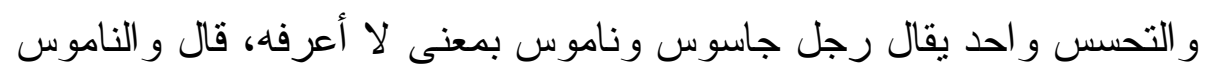
عندي صاحب سر الملك (r)* و وجن

ويروى أن ابن عباس سئل عن الفرق بينهما فقال: لا يبعد أحدهما عن

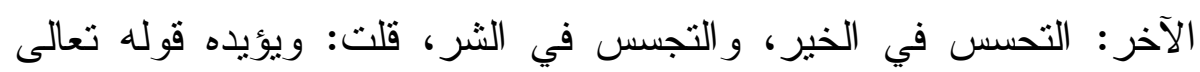
حكاية عن يعقوب: "يا بني اذهبو ا فتحسسو ا من يوسف" بالحاء على القر اءة

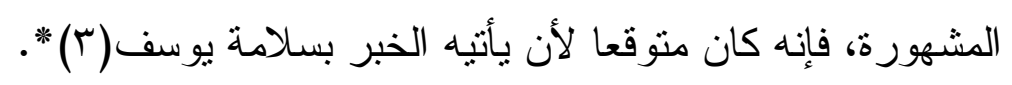

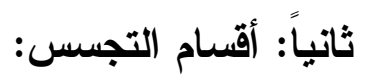

قسم بعض العلماء التجسس إلى قسمين: الأول: التجسـس بهــدف تتبـع ع العور ات وكثف الأسر ار : في التجسس تتبع لعــور ات المســـلمين ومعــايبهر

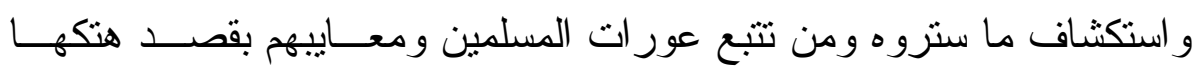

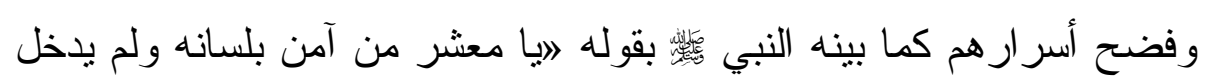

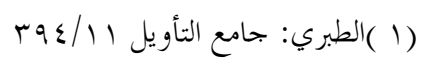

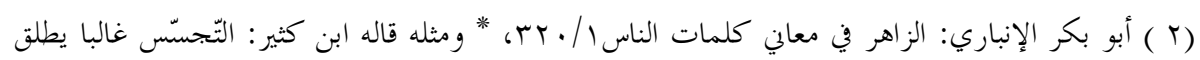

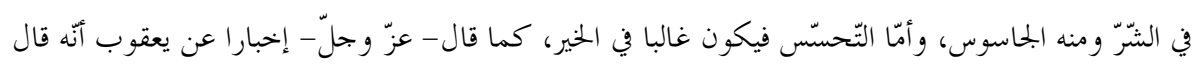

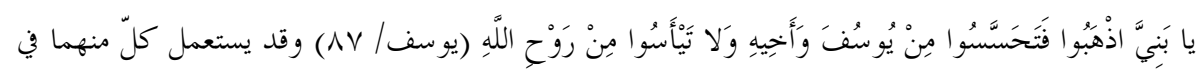

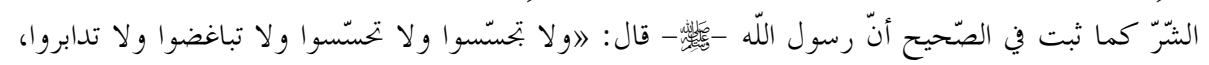

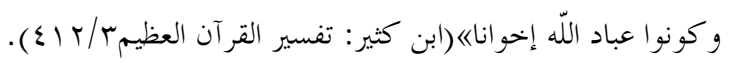

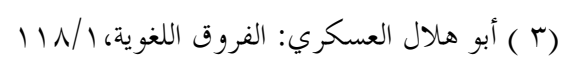

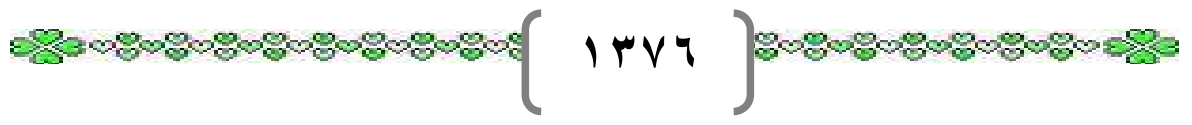


الأيمان في قلبه لا تؤذو ا المسلمين و لا تعيروهم و لا تتبعو ا عور اتهم فإن مسن

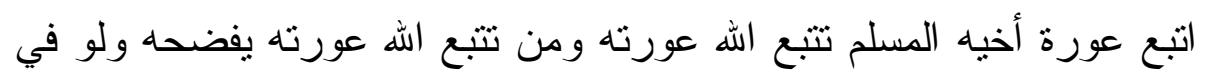

$$
\text { جوف رحله (1). }
$$

الثاني: التجسس للمصلحة: وهو التجسس الذي لا يفضي إلى ضرر وهـــ

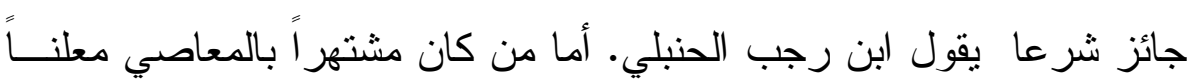

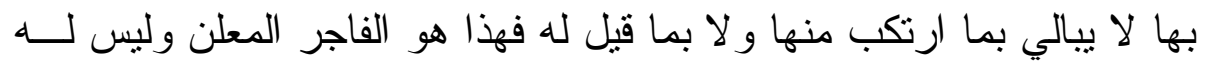

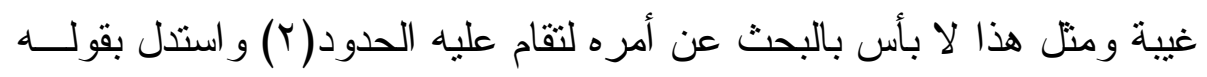

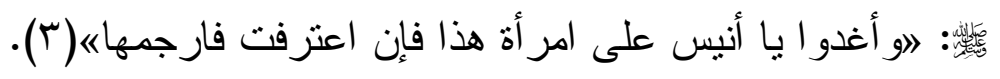
ومن هذا القبيل يجوز التجسس على المسلمين لمعرفة حـــوائجهم ولتقــديم

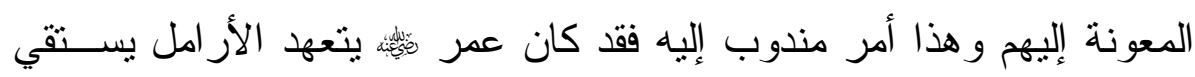

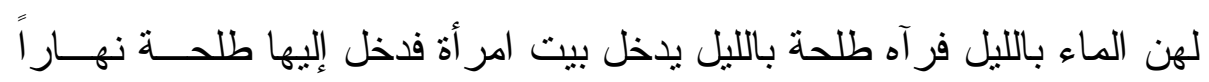

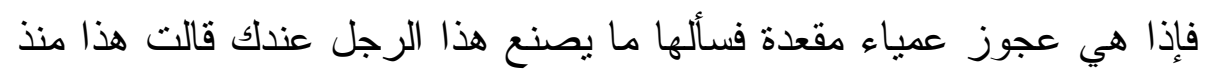
كذا وكذا يتعهني ويأتيني بما يصلحني ويخرج عني الأذى فقال طلحة ثكلتك أمك يا طلحة أعور ات عمر تتبع(ع).

ويدخل في هذا الحكم مسألة التجسس لغرض الزو اج و المصاهرة وهو أمر لا تخفى أهميته على أحد ذلك لأن عقد النكاح من العقـود المعقــدة و الــذي هـي يترنب عليه حقوق وو اجبات كثيرة فإذا تجسس المسلم وتتبع وتفحص عن كل

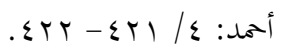

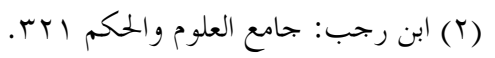

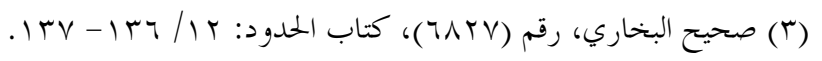

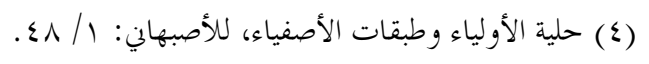


ما يخص الزوجة و أهلها من حيث الجمال و النسب و الدين و الصـــة وكـــلك

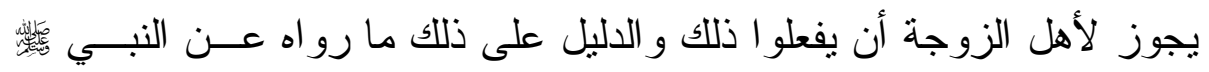
"إذا خطب أحدكم المر أة فإن استطاع أن ينظر منها إلى ما يدعوه إلى نكاحها فليفعله( (1).

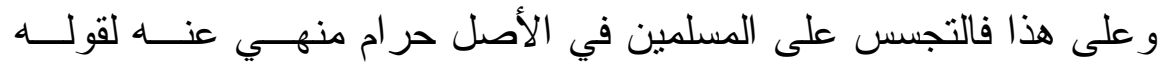

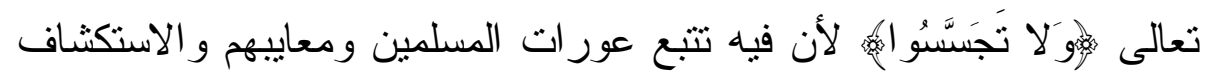

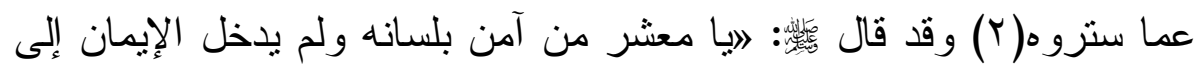
قلبه لا تتبعو ا عور ات المسلمين فإن من تتبع عـور ات المســلمين تتبـع الله عورته حتى يفضحه ولو في جوف بيتها(r).

وقال ابن وهب(ع) و الستر و اجب إلا عن الإمام و الو الي و أحــــ الثـــهود

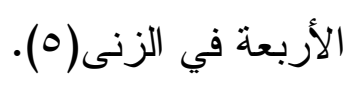

وقد يكون التجسس واجباً فقد نقل ابن الماجشون(؟) أنـه قــال اللصــوص وقطاع الطريق أرى أن بطلبو ا في مظانهم ويعان عليهم حتى يقتلو أو ينفـــوا

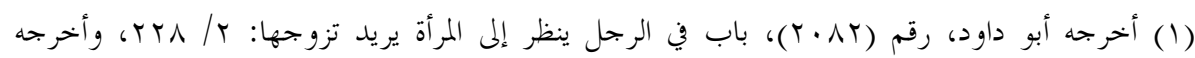

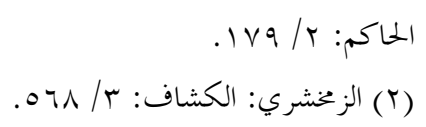

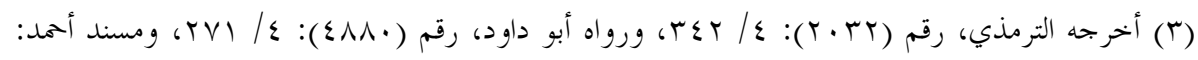

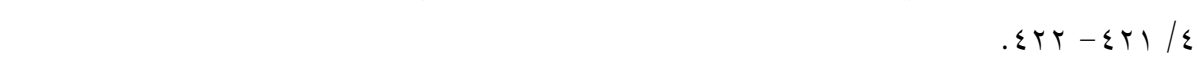

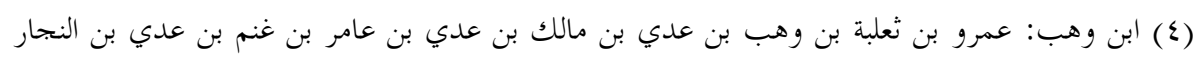

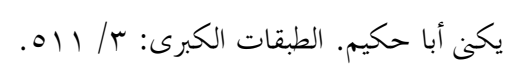

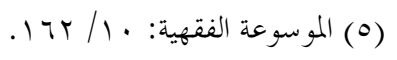

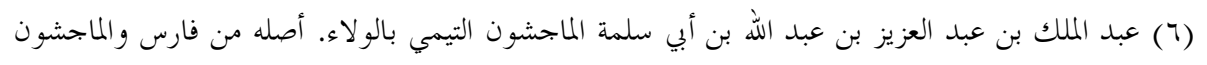

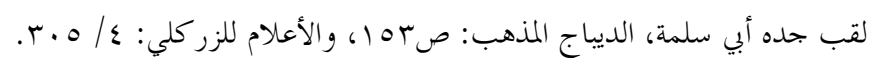

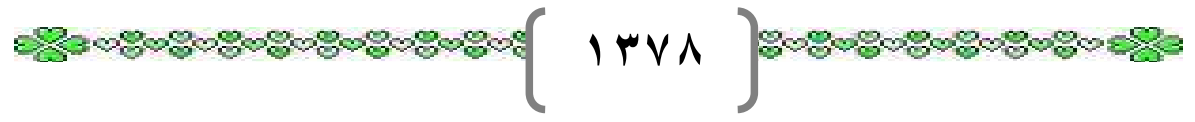


من الأرض بالهرب( (1)، وطلبهم لا يكون إلا بالتجسس عليهم وتتبع أخبار هم. ويباح في الحرب بين المسلمين وغيرهم بعث الجواسيس لتعـرف أخبــار جيش الكفار من عدد و عتاد وأين يقيمون وما إلى ذلك. وكذلك يباح التجسس إذا رفع إلى الحاكم أن في بيت فلان خمراً (ب). ثالثاً: النهي عن التجسس وتبيان عاقبته الوخيمة:

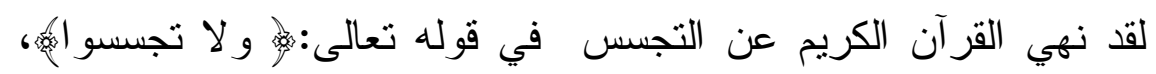
يقول الإمام البغوي: التجسس: هو البحث عن عيوب الناس، وقد نهى الله تعالى عن البحث عن المستور من أمور الناس وتتبع عور اتهم حتى لا يظهر على ما ستره الله منها(ب).

ويقول ابن عاشور في وجه النهي عن التجسس: ووجه النهي عنه أنه ضرب من الكيد و التطلع على العورات، وقد يرى المتجسس من المتجسس

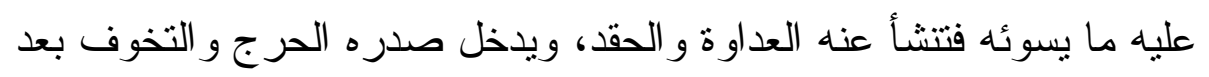
أن كانت ضمائره خالصة طيبة وذلك من نكد العيش، وذللك ثلم للأخوة الإسلامية لأنه يبعث على إظهار التتكر ثم إن اطلع المتجسس عليه على تجسس الآخر ساءه فنشأ في نفسه كره له و انتلمت الأخوة ثلمة أخرى كما لإنها وصفنا في حال المتجسس، ثم يبعث ذلك على انتقام كليهما من أخيه(؟).

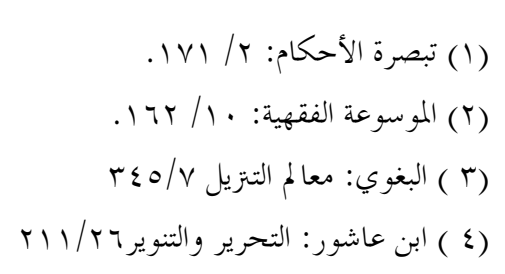

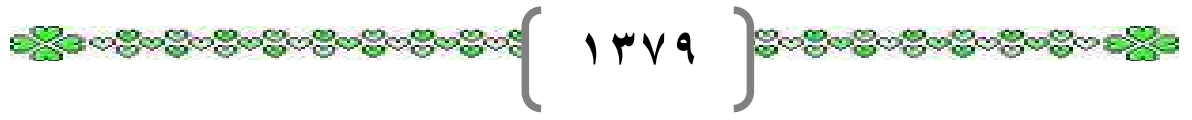


و التجسس المنهي عنه هو التجسس الذي لا ينجر منه نفع للمسلمين أو دفع ضر عنهم فلا يشمل التجسس على الأعداء ولا تجسس الثرط على الجناة

$$
\text { و اللصوص(1) (1) (1) (1) }
$$

وقال زيد بن وهب: قيل لابن مسعود: هل للك في الوليد بن عقبــة تقطــــر

لحيته خمرًا، فقال: إنا قد نهينا عن التجسس، فإن بظهر لناشيء شنأخذه به(ب)

وقال الإمام القرطبي في معنى الآية: خذو ا ما ظهر ولا تتبعوا عور ات

المسلمين، أي لا يبحث أحدكم عن عيب أخيه حتى بطلع عليه بعد أن ستره

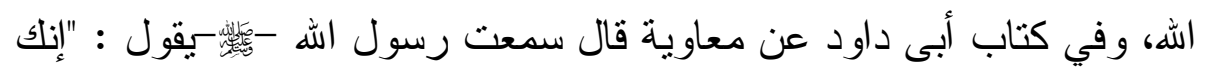
إن اتبعت عورات الناس أفسدتهم أو كدت تفسدهم"؛ فقال أبو الدرداء : كلمة

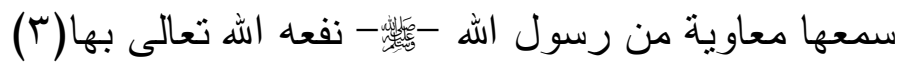

وقال ابن جرير: أي: لا يتبع بعضكم عورة بعض، ولا يبحث عن سرائره، يبتغي بذلك الظهور على عيوبه، ولكن اقنعوا بما ظهر لكم من

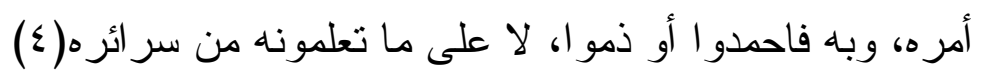

وقال الغز الي: ومعنى التجسس أن لا يترك عَبَّد الله تحت ستر الله، فيتوصل إلى الاطلاع ، وهتلك السنر، حتى ينكشف له ما هو كان مستوراً عنه، كان أسلم لقلبه ودينه.

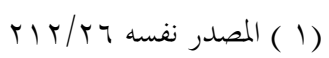

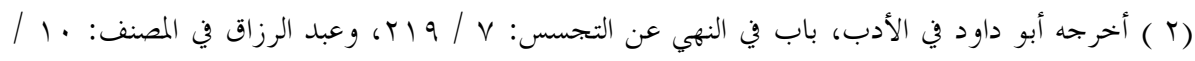

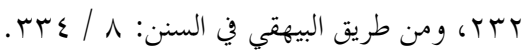

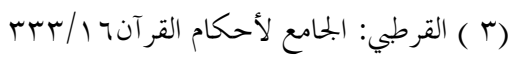

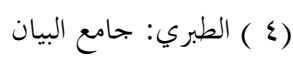

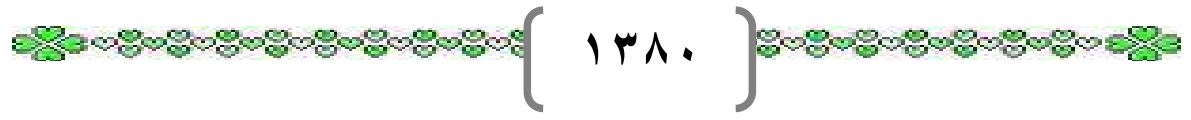


وفي السنة المطهرة ما يشير إلى ذلك كثير ا، ففي الحديث عن أبي هريرة

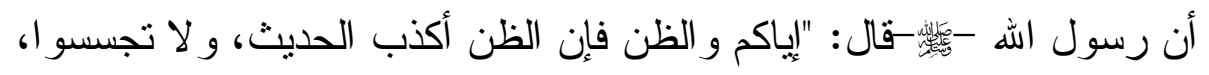
ولا تتافسوا، و لا تحاسدوا، و لا تباغضوا، و لا تدابروا، وكونو الهباد اله

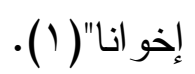

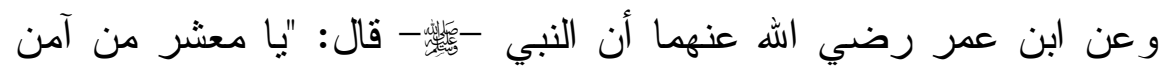
بلسانه ولم يفضِ الإيمان إلى قلبه، لا تغتابو ا المسلمين ولا تتبعوا عور اتهم، فإنه من تتبع عورات المسلمين، يتتبع الله عورته، ومن يتتبع الله عورته يفضحه ولو في جوف رحله"، قال: ونظر ابن عمر يومًا إلى الكعبة فقال: ما أعظمك و أعظم حرمتلك، و المؤمن أعظم عند الله حرمة منك (r) و أخرج الخر ائطي في مكارم الأخلاق عن ثور الكندي أن عمر رضي اللّه تعالى عنه كان يعس بالمدينة فسمع صوت رجل في بيت بتغنى فتسور عليه

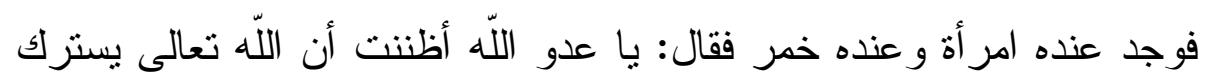
و أنت على معصية؟ فقال: وأنت يا أمير المؤمنين لا تعجل علي إن كنت

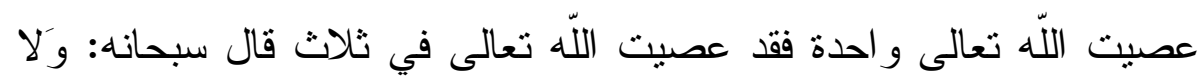

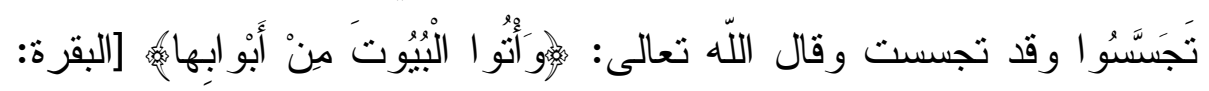

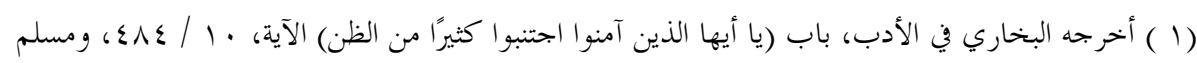

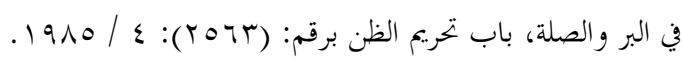

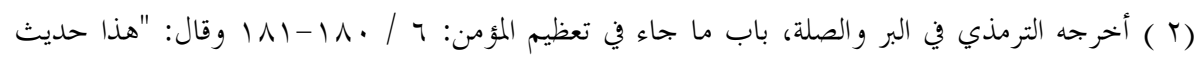

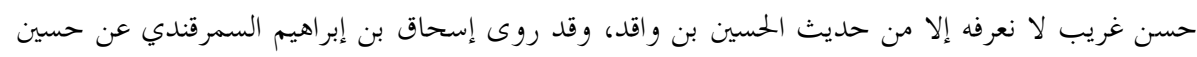

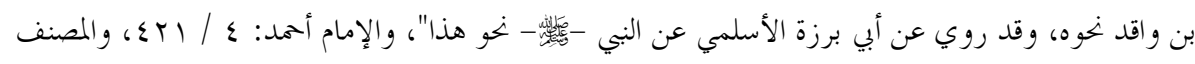

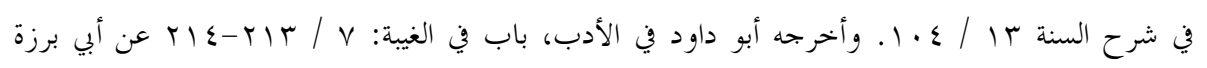
الأسلمي رضي الله عنه. - ماح.

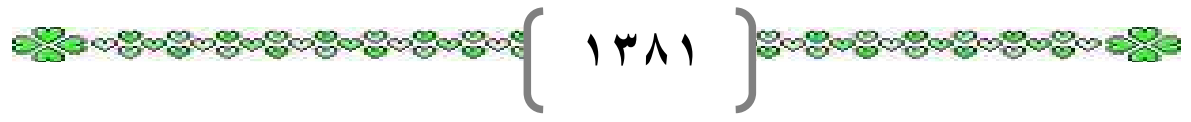




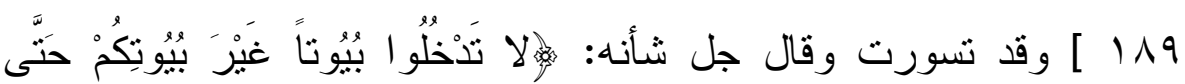

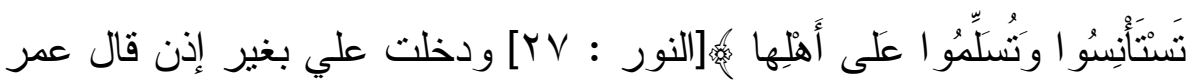
رضي اللّه تعالى عنه: فهل عندكم من خير إن عفوت عنك؟ فئ فال: نعم فعفا

$$
\text { عنه وخرج وثركه (1) }
$$

ومن ثم ففيه تحريم التحسس، وهو البحث عن معايب الناس كما تقدم ولا فرق في ذلك بين الماضين و العصريين، قال ابن عبد البر: وذلك حرام كالغيبة أو أثند من الغيبة قال الله تعالى:

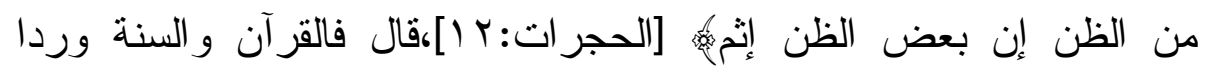
جميعا بأحكام هذا المعنى، وهو قد اشتهر في زماننا فإنا لله، و إنا إليه راجعون(r)

رابعا: ثر ات سوء الظن: إن من ثمر ات سوء الظن التجسس، فالقلب عند ما يبنلى بسوء الظن فإنه لا يقتنع بهو اجسه الظنية، بل يمتد به الظن إلى كلى طلب التحقيق تجسسا وتحسسا، ولما كان هذا غاية دن غايات ظن السوء تتاوله النهي. أما التجسس بعد الظن، وكلاهما يستلزم الآخر فالظن عندما يحقق لا مفر من التجسس، وكل تجسس الباعث و الداعي إليه هو الظن"(r) ويلحق بهذه الثمرات الأضرار الناتجة عن التجسس، والتي تتمثل في الآتي:

( (1) دليل ضعف الإيمان وفساد الخلق. (r) (Y) دليل دناءة النفس وخستها.

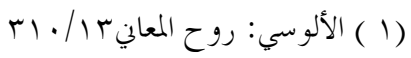

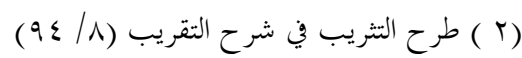

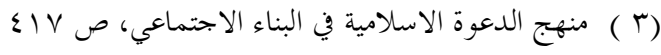




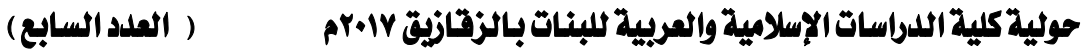

$$
\begin{aligned}
& \text { (r) يوغر الصدور ويورث الفجور • } \\
& \text { (ع) يورد صاحبه مو ارد الهلاك. } \\
& \text { (0) يؤدي إلى فساد الحياة وكثف العور ات. }
\end{aligned}
$$

(7) يستحق صاحبه غضب الله ورسوله و المؤمنين(1)

\section{المطلب الرايع: نهي الإسلام عن الغيية}

\section{أولاً: مفهوم الغيبة في اللغة والاصطلاح}

الغيبة في اللغة: الغيب: كل ما غاب عنلك. تقول: غاب عنه غيبة و غيبا و غيوبا ومغيبا. وجمع الغائب غيب وغياب و غيب أيضا. و غييته أنا. و غيابة الجب: قعره... اغتابه اغتيابا، إذا وقع فيه، و الاسم الغيبة، وهو أن يتكلم خلف إنسان مستور بما يغمه لو سمعه. فإن كان صدقا سمي غيية، و إن كان

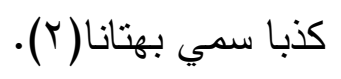

و الغيبة هي الاسم من الاغتياب وهو مأخوذ من مادّة (غ ي ب) التّي تدلّ

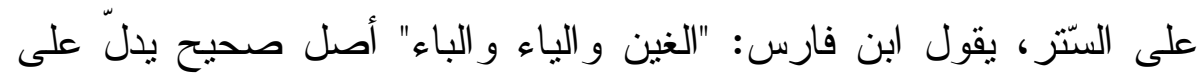
تستّر الثّيء عن العيون ثمّ يقاس من ذلك الغيب: ما غاب مدّا لا يعلمه إلّا

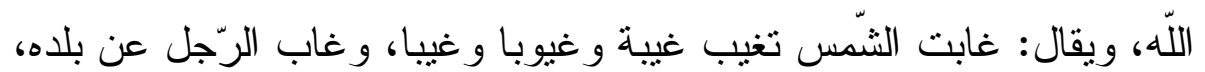

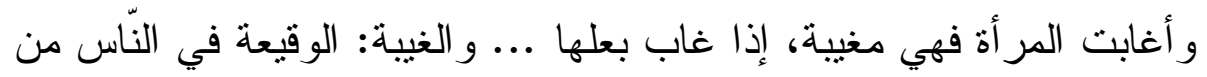
هذا، لأنها لا تقال إلّا في غيبة، وتغيّب مثل غاب، ويتعدّى بالتّنعيف فيقال

$$
\begin{aligned}
& \text { (1) }
\end{aligned}
$$

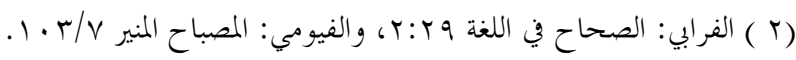


غيّيته، وهو التّواري في المغيب، و اغتابه اغتيابا إذا ذكره بما يكره من العيوب، والاسم الغيبة، فإن كان باطلا فهو الغيبة في بهت ولئ (1).

وقال ابن منظور : والغيبة من الغيبوبة و الغيبة من الاغتياب و اغتاب الرجل

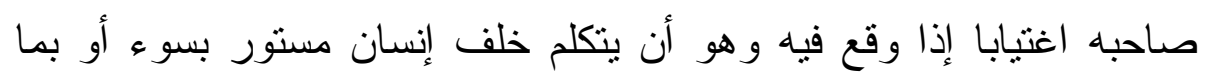
يغمه لو سمعه وإن كان فيه فإن كان صدقا فهو غيبة وإن كان كذبا فهو

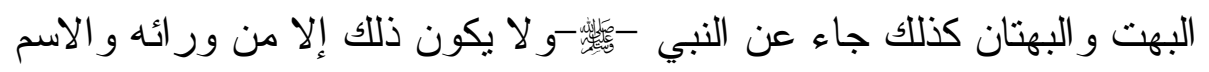
الغيبة وفي التتزيل العزيز و لا يغتب بعضكم بعضا أي لا يتتاول رجلا بظهر الاهن ونه

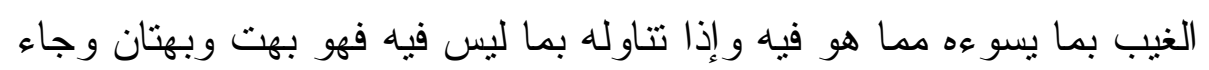

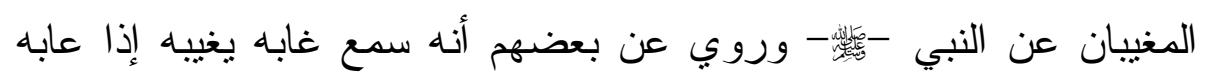
وذكر منه ما يسو ابه ابن الأعر ابي غاب إذا اغتاب وغاب إذا ذكر بعر إنسانا

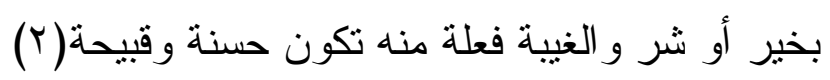

وفي الاصطلاح: قال الجرجاني: الغيبة بكسر الغين أن تذكر أخالك بما يكر هه فإن كان فيه فقد اغتبته و إن لم يكن فيه فقد بهته أب قلت عليه ما لم الم يفعله وذكر مساوئ الإنسان في غيبته وهي فيه و إن لم تكن فيه فهي بهنان و إن و اجهه فهو شتم (r)

$$
\begin{aligned}
& \text { (1 ) ابن فارس : مقاييس اللغة }
\end{aligned}
$$

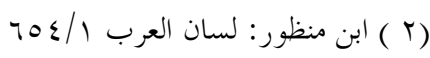

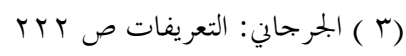


وقال المناوي: الغيبة بالكسر أن تذكر أخاك بما يكر هه فإن كان فيه فقد اغتبته و إلا فقد بهته أي قلت عليه ما لم يفعله ومن أحسن تعاريفها ذكر العيب ليبه

$$
\text { بظهر الغيب(1) (1) }
$$

وقال الكفويّ: أن يتكلّم خلف إنسان مستور بكلام هو فيه(ب)

وقال التّهانويّ: الغيبة: أن تذكر أخاك بما يكرهه لو بلغه، سواء ذكرت نقصانا في بدنه أو في لبسه، أو في خلقه، أو في فعله، أو في قوله، أو في دينه، أو في دنياه، أو في ولده، أو في ثوبه، أو في داره، أو في دابّته(ب). ثانياً: دوافع الغيبة وبو اعثها وبم تكون:

فال الغز اليّ: للغيبة أسباب وبو اعث، وفيما يلي خلاصتها: 1 - شفاء المغتاب غيظه بذكر مساوئ من يغتابه.

r- مجاملة الأقر ان و الرّفاق ومشاركتهم فيما يخوضون لئه فيه من الغيبة. r- ظنّ المغتاب في غيره ظنّا سيّيّا مدعاة إلى الغيبة. ع - أن يبرئ المغتاب نفسه من شيء وينسبه إلى غيره أو يذكر غيره بأنه مشارك له.

0- رفع النّفس وتزكيتها بتتقيص الغير 7- حسد من يثتي عليه النّاس ويذكرونه بخير . V - الاستهز اء و السيّخرية وتحقير الآخرين(ع)

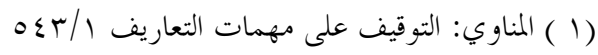

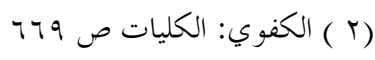

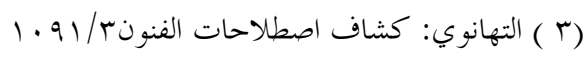

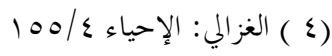


الغيية تكون بالقول وتكون بغيره قال الإمام الغزالي الذكر باللسان إنما

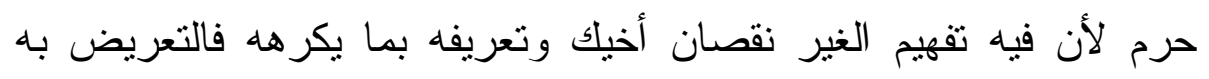
كالتصريح و الفعل فيه كالقول والإشارة و الإيماء و الغمز و الهمز و الكتابة

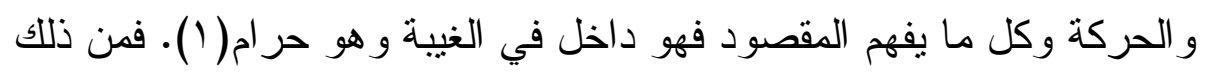
قول عائشة- رضي اله عنها- دخلت علينا امر أة فلما ولت أومأت بيدي أنها قصيرة فقال عليه الصلاة و السلام 》اغنتبيهاهي وقال الحسن الغيبة ثلاثة أوجه كلها في كتاب الله تعالى الغيبة والإفلك و البهتان. فأما الغيية فهي تقول في أخيك ما هو فيه و أما الإقك فأن تقول فيه ما بلغك عنه و أما البهتان فأن تقول فيه ما لبس فيه فيه (Y).

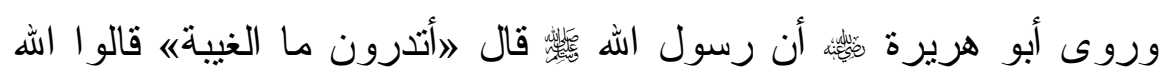
ورسوله أعلم قال 》ذكرك أخاك بما يكرهه قال أفرأيت إن كان في أخي ما أقول قال 》اإن كان فيه ما تقول فقد اغتبته و إن لم يكن فيه فقد بهتهش(ب). و إن الهه سبحانه وتعالى منل الغيبة بأكل الميتة لأن الميت لا يعلم بأكل

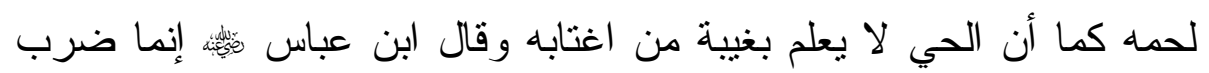

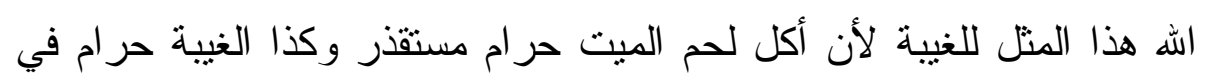

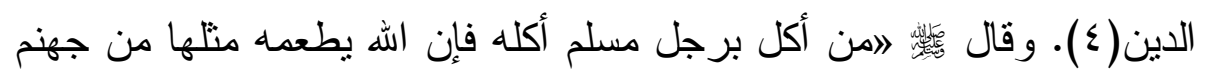
ومن كسي ثوباً برجل مسلم فإن الله يكسوه مثلكه من جهنم ومن قام برجل مقام

$$
\text { سمعه ورياء فإن الله يقوم به مقام سمعة ورياء يوم القيامةه(0). }
$$

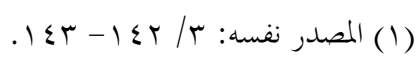

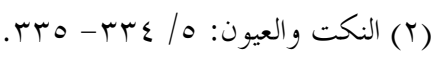

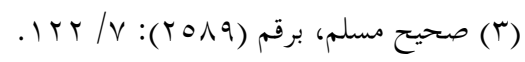

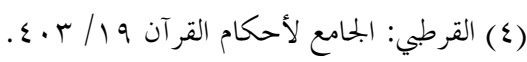

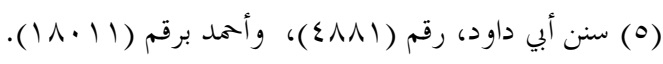

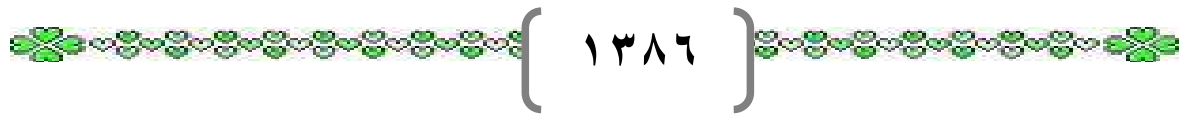


وذهب قوم إلى أن الغيبة لا تكون إلا في الدين ولا تكون في الخلقة و الحسب ذلك فعل اله به وذهب آخرون إلى أن الغيبة لا تكون إلا في الخلق

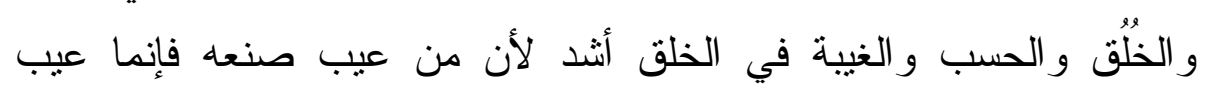

$$
\text { صانعها (1) (1) (1) (1) }
$$

و هذا كله مردود أما الأول فيرده حديث عائشة- رضي الله عنها- حين

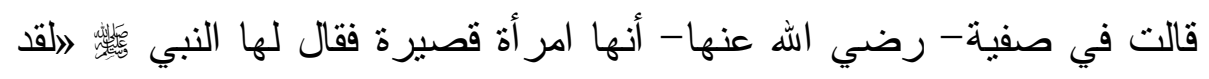
قلت كلمة لو مزج بها البحر لمزجته《(r). وما كان في معناه حسب ما تقدم. و أما الثاني فمردود أيضاً عند جميع العلماء لأن العلماء منذ أصحاب

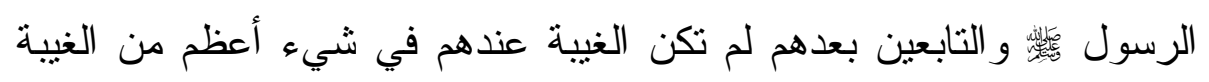
في الدين لأن عيب الدين أعظم العيب فكل مؤمن يكره أن يذكر في دينه أثند

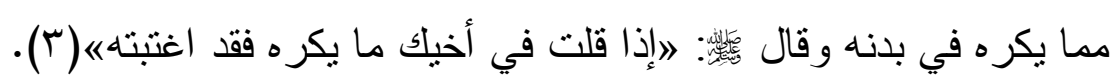

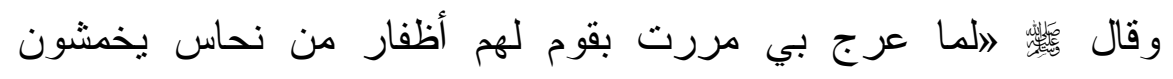

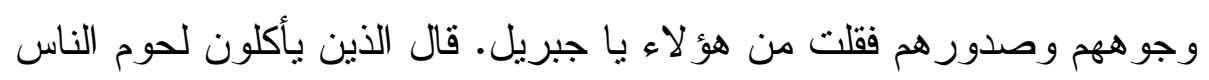

$$
\text { ويقعون في أعر اضهمه(ع). }
$$

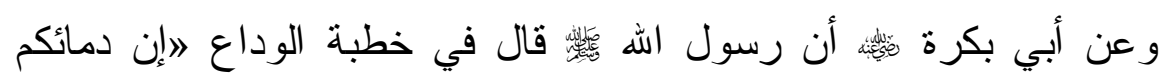
و أمو الكم و أعر اضكم حر ام عليكم كحرة يومكم هذا في شهركم هذا في بلدكم هذا ألا هل بلغتش(0).

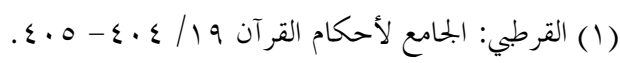

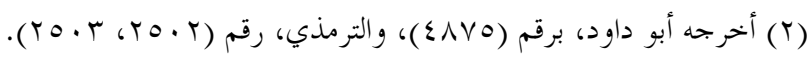

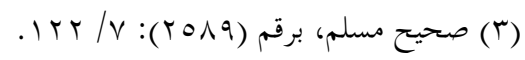

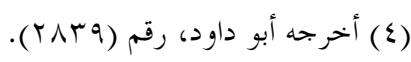

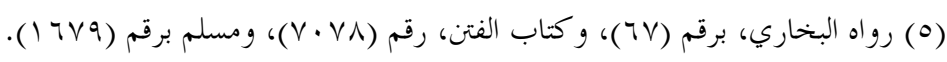




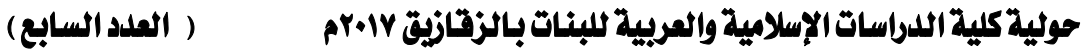

ثالثاً: نهي القرآن عن الغيبة وتبيان عاقبتها الوخيمة:

قال تعالى: "ولا يغتب بعضكم بعضا"، في هذه الآية دليل على التحذير

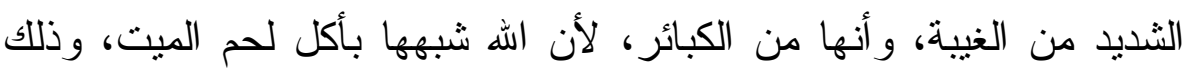

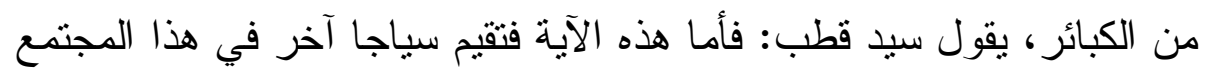
الفاضل الكريم، حول حرمات الأشخاص به وكر اماتهم وحرياتهم، بينما هي تعلم الناس كيف ينظفون مشـــــــاعرهم وضمائر هم، في أسلوب مؤثر

$$
\text { (1)... عجيب }
$$

قال الزجاج : وبيانه أن ذِكرك بسوءٍ مَنْ لم يَحْضُر ، بمنزلة أكل لحمه وهو ميت لا يُحِسٌ بذلك، قال القاضي أبو يعلى: وهذا نأكيد لتحريم الغيبة، لأن

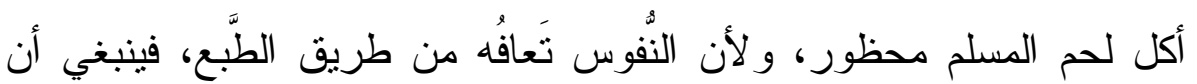
تكون الغيبة بمنزلته في الكر اهة(ب) • و العلة في بيان النهي عن الغيبة كما بين الألوسي قائلاً: علة النهي عن الغيبة الإيذاء بتفهيم الغير نقصان المغتاب وهو موجود حيث أفهمت الغير ما يكر هه المغتاب بأي وجه كان من طرق الإفهام، وهي بالفعل كان تمشي

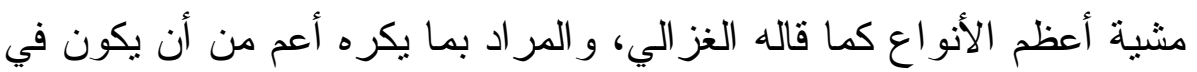
دينه أو دنياه أو خلقه أو ماله أو ولده أو زوجته أو مملوكه أو خادمه أو لباسه

$$
\text { أو غير ذلك مما يتعلق به(ب) }
$$

و الغيبة مشروعة في بعض الأحيان، قال النّوويّ: اعلم أنّ الغيبة تباح لغرض صحيح شرعيّ لا يمكن الوصول إليه إلّا بها، وهو ستّة أسباب:

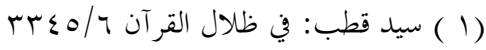

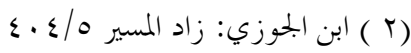

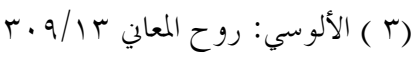


الأوّل: المتظلّم، فيجوز للمظلوم أن يتظلّم إلى السّلطان و القاضي وغيرهما ممّن له و لاية، أو قدرة على إنصافه من ظالمه، فيقول: ظلمني فلان بكذا.

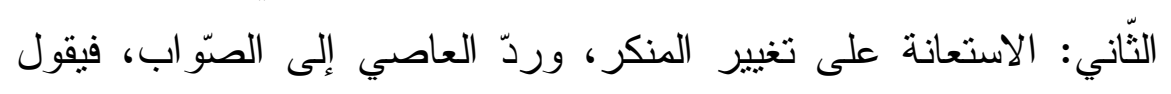

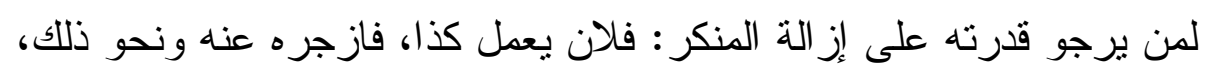
ويكون مقصوده التّوصيّ إلى إز الة المنكر، فإن لم يقصد ذلك كان حر اما.

الثّالث: الاستفتاء، فيقول للمفتي: ظلمني أبي، أو أخي، أو زوجي، أو فلان بكذا، فهل له ذلك؟ وما طريقي في الخلاص منه، وتحصيل حقّي، ودفع الظلّم؟ ونحو ذلك، فهذا جائز للحاجة.

\section{الرّ"ابع: تحذير المسلمين من الثّرّ ونصيحتهم.}

الخامس: أن يكون مجاهر ا بفسقه أو بدعته كالمجاهر بشرب الخمر، ومصادرة النّاس، و غير ذلك. لكون.

السّادس: التّعريف، فإذا كان الإنسان معروفا بلقب؛ كالأعمش والأعرج و الأصمّ، و الأعمى؛ و الأحول، و غيرهم جاز تعريفهم بذلك؛ ويحرم إطلاقه على جهة النقص؛ ولو أمكن تعريفه بغير ذلك كان أولى، فهذه ستّة أسباب

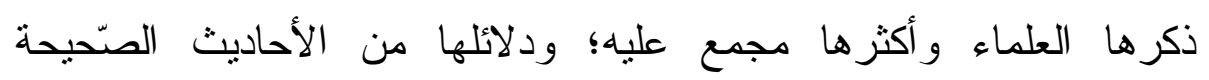

مشهورة) (1) مجرها

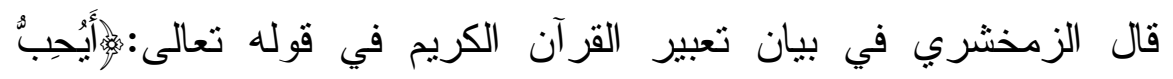

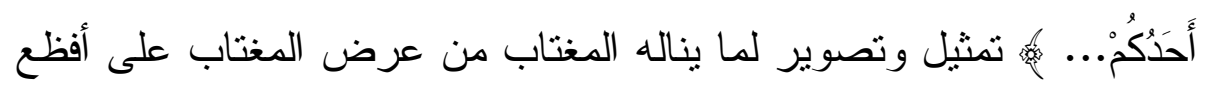
وجه و أفحشه، وفيه مبالغات شتى: منها الاستقهام الذي معناه التقرير ، وهو 
يفيد المبالغة من حيث إنه لا يقع في كلام مسلم عند كل سامع، حقيقة أو

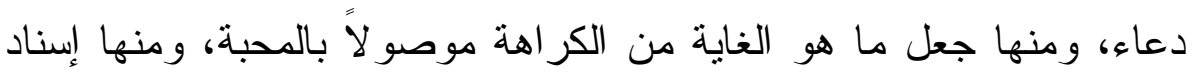

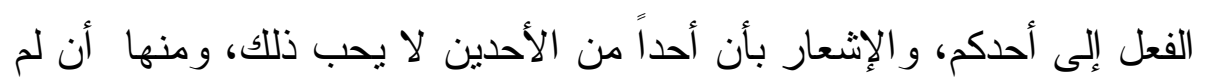

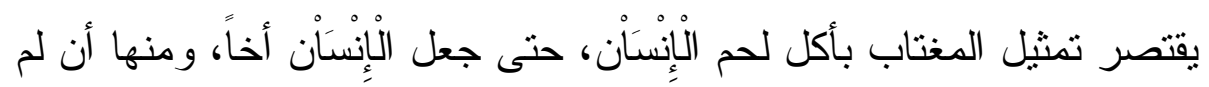

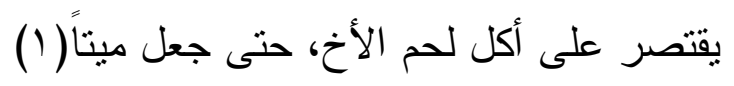
وقال ابن الأثثر في " المثل السائر " في بحث الكناية: فمن ذلك قوله

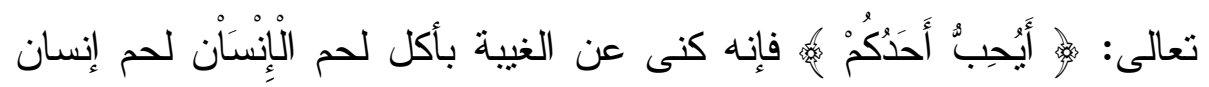

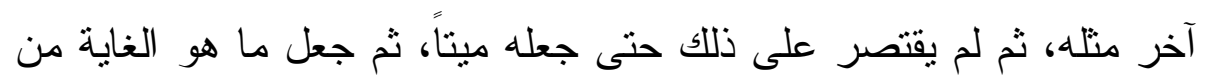

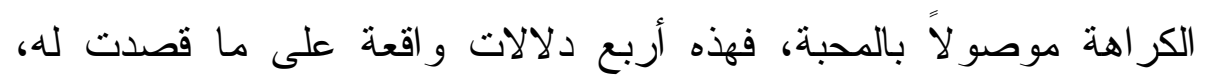
مطابقة للمعنى الذي وردت من أجله (ب). وفي السنة المطهرة العديد من ألوان وصنوف التوجيهات التي تتعلق بالمسألة وتبيان عو اقبها، عن أبي هريرة قال: قيل: يا رسول اللّه، ما الغيبة؟

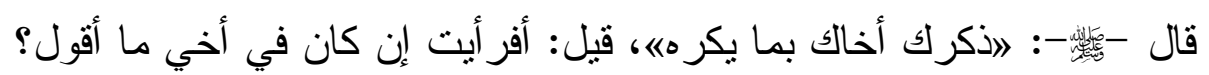

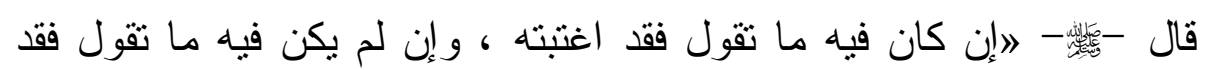

بهته «(r)

و عن أبي حذيفة، عن عائشة - رضي اللّه عنها - قالت : قلت للنبي  》لقد قلت كلمة لو مزجت بماء البحر لمزجته)(ع).

$$
\begin{aligned}
& \text { (1 ) الزخشري: الكشاف } \\
& \text { (r) القاسمي: محاسن التأويل غير مرقم }
\end{aligned}
$$

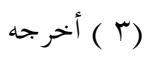

$$
\begin{aligned}
& \text { (ع ) الحديث سبق تخريجه }
\end{aligned}
$$

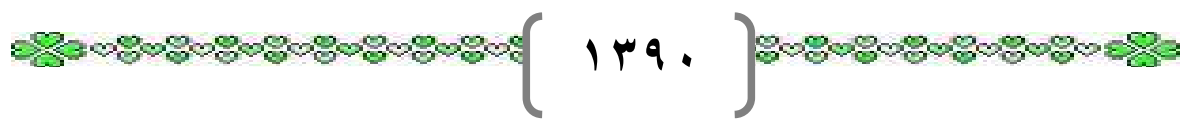


ولقد عدّ الإمام ابن حجر الغيبة من الكبائر وقال: الّذي دلّت عليه الدّلائل

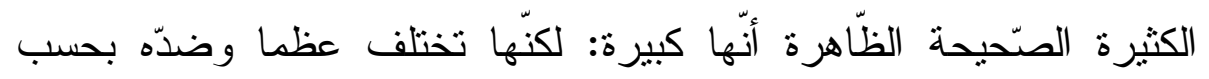
اختلاف مفسدتها. وقد جعلها من أوتي جو امع الكلم عديلة غصب المال، وقتل

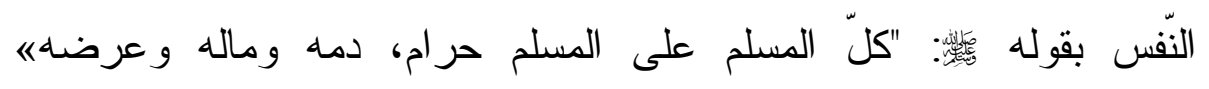
و الغصب و القتل كبيرتان إجماعا، فكذا ثلم العرض( (1)

ويجب على المسلم رد غيية صاحبه، قال النّوويّ: "اعلم أنّه ينبخي لمن سمع غيبة مسلم أن يردّها ويزجر قائلها، فإن لم ينزجر بالكلام زجره بيده،

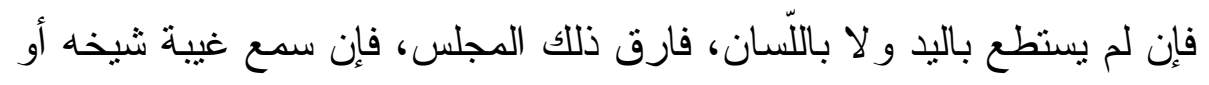

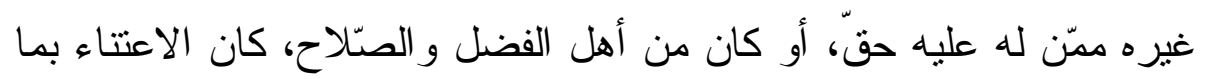

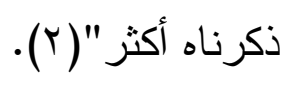

خامساً: أضرار الغيبة على الفرد والمجتمع: (1) (1) صاحب الغيبة يعذّب في النّار بأكل النّن القذر . (Y) ينال عقاب اللّه في قبره (Y) (r) تذهب أنو ار إيمانه و آثنار إسلامه.

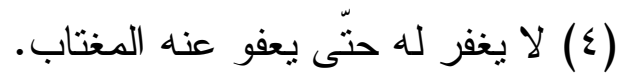

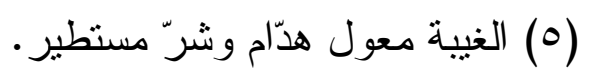

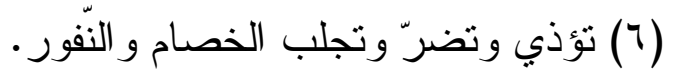
(V) مرض اجتماعيّ يقطع أو اصر المحبّة بين المسلمين.

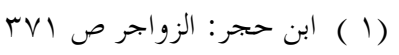

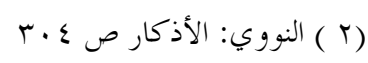




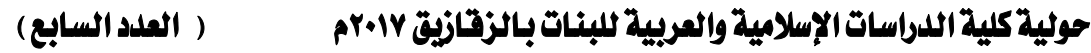

( ) دليل على خسّة المغتاب ودناءة نفسه ( ).

و علاج الغيبة كما ذكر الغزالي أن مساوئ الأخلاق كلها إنما تعالج بالعلم و العمل وأن علاج كل علة بمضاده سببها ثم ذكر أن علاج كف اللسان عن الغيبة يكون على وجهين أحدهما على الجملة و الآخر على التفصيل. أما علاجه على الجملة فهو أن يعلم تعرضه لسخط اله تعالى لغييته وأن

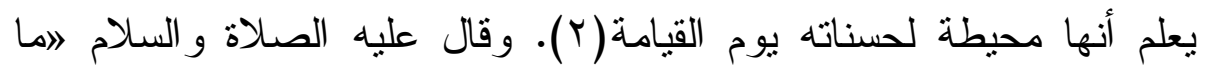
النار في البيت بأسر ع من الغيبة في حسنات العبده(ب). و أما علاجه على التفصبل فهو أن ينظر إلى السبب الباعث له على الغيبة فيقطعه فإن علاج كل علة إنما يكون بقطع سببها (ع).

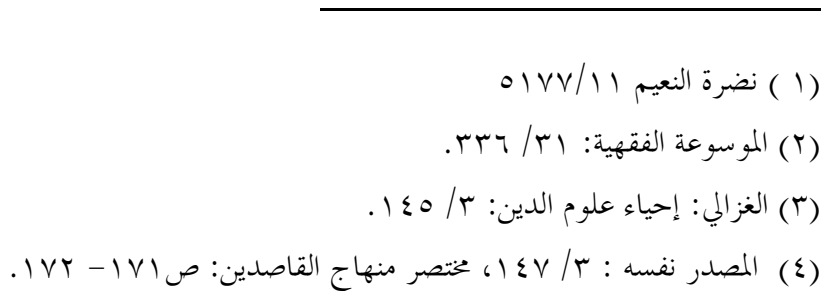




\section{الذاتمة}

الحمد لله الذي بنعمته تتم الصالحات، وبنوره تتشرق الأرض و الســماو ات، وبعد: فقد انتهيت بفضل الله تعالى ومنته من هذه الدر اسة المباركــة، و التــي

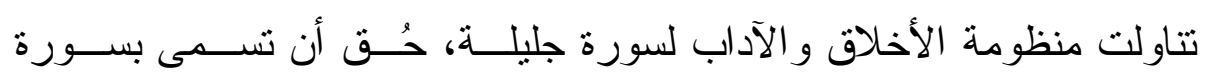

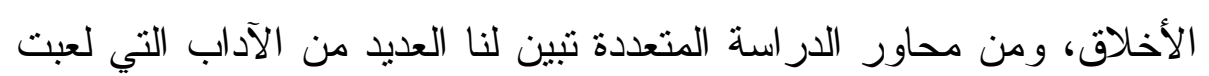
دورًا فاعلاً في ضبط مسيرة المجتمع المسلم، ويمكن الإشارة إلى أهم نتــائج هذا البحث في النقاط الآتية: 1- آداب التعامل في الإسلام لا تتفك بأي حال عن العقيدة، وليست الأخلاق

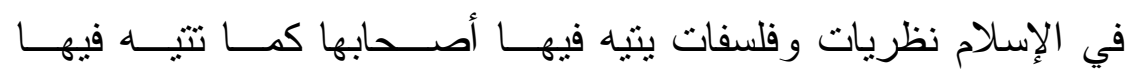
المجتمعات التي تقع فريسة الافتتان بها.

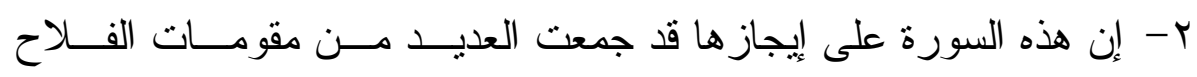
و الثبات في ضبط المجتمع الإسلامي بما لا يمكن تحقيقه البتـــة بشـتـى هـ النظم الوضعية مجتمعة، و هذا يدل على شمولية المنظومة الأخلاقية. r- ضرورة الالتز ام بعدم التقدم بين يدي الله ورسوله، وأن صور هذا التقدم

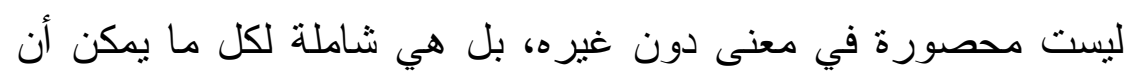

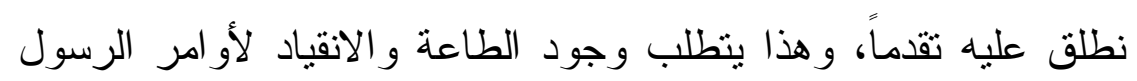
ئس

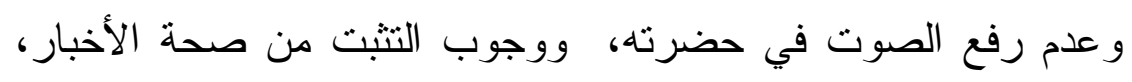
وعدم الاعتماد على أقو ال الفسقة المفسدين، وكذلك النهي عن السخرية، ودوبة و التجسس و الغيبة وسوء الظن وعن سائر الأخلاق الذميمة. و إنني آمل بعد هذه الدراسة عدة أمور من أهمها ما يأتي: 


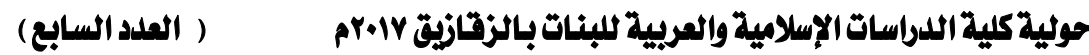

1- تحصين الأجيال من مخاطر العدوان على كتاب الله تعالى وترجمته المتعددة، وذلك بالكثف عن مقاصد الكاتبين وعن حقيقة انتماءاتهم الفكرية. ع- ضرورة تمحيص كتب التفسير وتدقيق ما فيها من أخبار ، وذلك خدمة

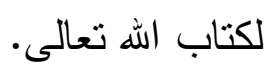

0- القرآن الكريم مصدر الأحكام، وهو الذي لا تتضضي عجائبه، فينبغي

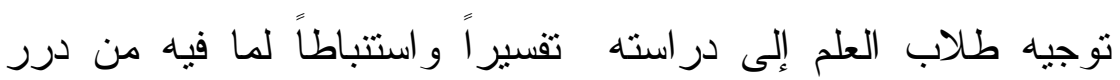

$$
\text { وعجائب لا تتقضي. }
$$

وصل اللهم على سيدنا محمد و على آله وصحبه وسلم 


\section{ثيت المصاصر والمراجع}

1- أبو داود: سليمان بن الأشعث بن إسحاق بن بشير بن شداد بن عمرو

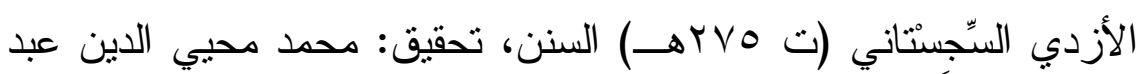
الحميد، المكتبة العصرية، صيدا بيروت.

r- أبو نصر الفر ابي: الصحاح في اللغة، بدون تاريخ.

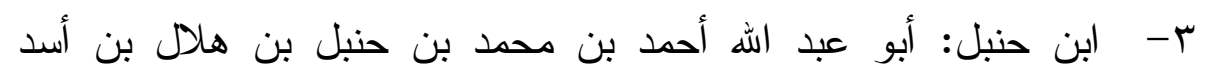
الثبياني (ت إكاهـ)، المسند، تحقيق: شعيب الأرنؤوط - عادل مرشد ، و وآخرون، بدون تاريخ.

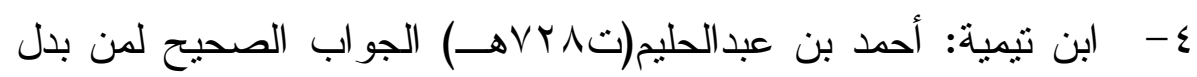

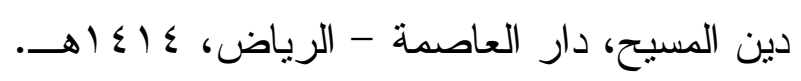

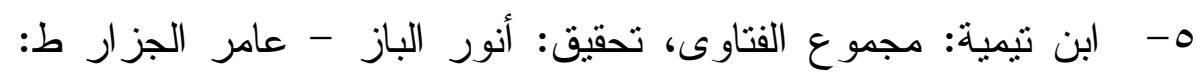

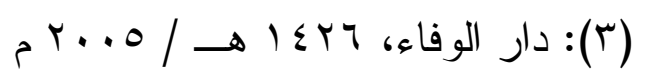

צ- ابن تيمية: الصارم المسلول، ط(1) دار ابن حزم- بيروت،

$$
\rightarrow 15
$$

- ابن جزي: محمد بن أحمد بن محمد(ت اء لهـ) التسهيل لعلوم التنزيل، بدون تاريخ.

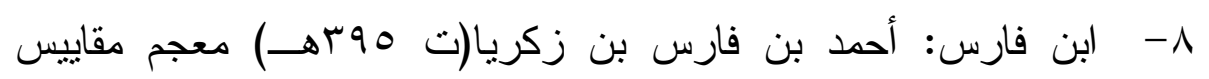

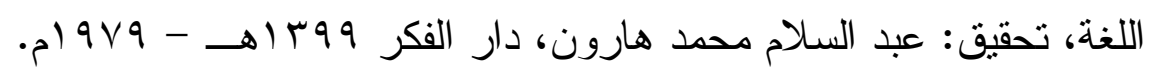

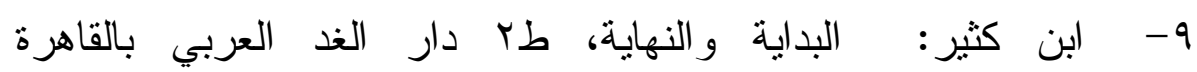
$\rightarrow 1511 / 399$. 
. القر آن العظيم، تحقيق : سامي بن محمد سلامة ط: (Y) : دار طيبة للنشر

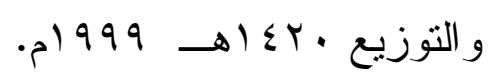

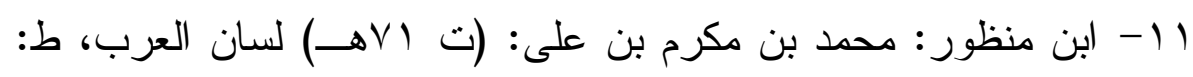

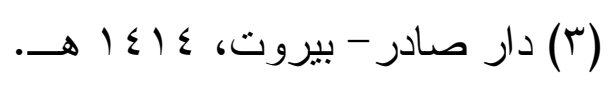

rا - ابنِ عبادٍ: الصاحب، المحيطَ في اللغةِ، تحقيق: محمد حسن آل ياسين،

$$
\text { بدون تاريخ. }
$$

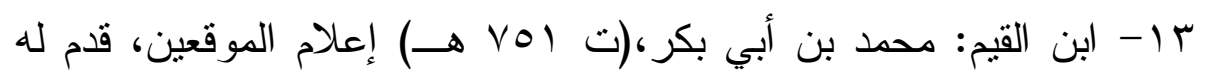

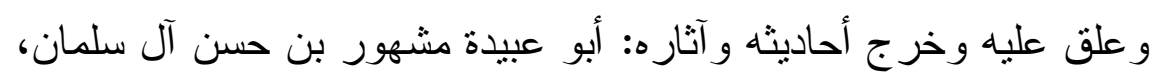
ط: (1) دار ابن الجوزي للنشر و التوزيع، المملكة العربية السعودية،

$$
\rightarrow 1 \leqslant r r
$$

ع ا - ابن القيم، صيد الخاطر ، بدون تاريخ.

1 - ابن القيم: مدارج السالكين ط(Y) دار الكتاب العربي ، بيروت،

$$
\text { . أ }
$$

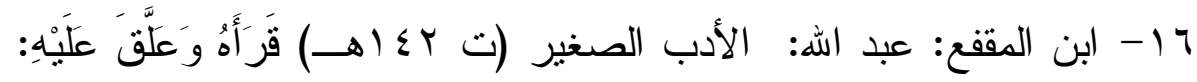
و ائلُ بْنُ حَفَفِ بْنِ خَلَفِ، دار ابن القيم بالإسكندرية.

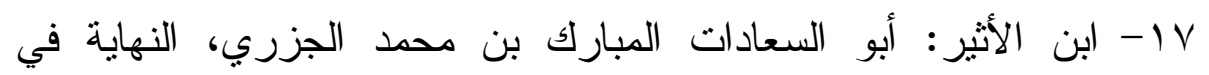
غريب الحديث و الأثر، تحقيق: طاهر أحمد الزاوي - محمود محمد بن

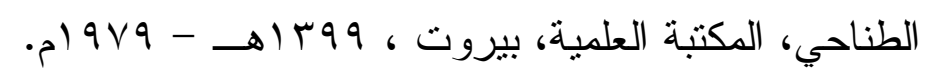

11- ابن الجوزي: جمال الدين عبد الرحمن بن علي بن محمد (ت:

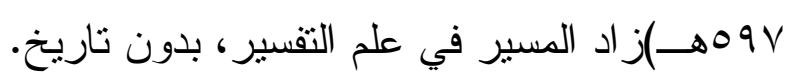

9 1 - ابن رجب: زين الدين أبي الفرج عبد الرحمن بن شهاب الدين (ت

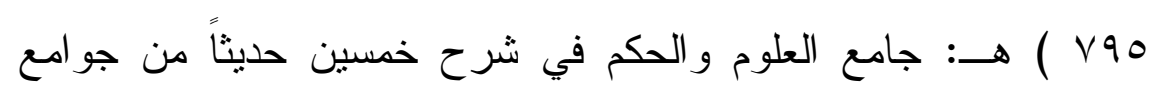


الكلم، حقق نصوصه وخرّج أحاديثه و علّق عليه: الدكتور ماهر ياسين الفحل، بدون تاريخ.

• r- ابن عاشور: محمد الطاهر بن محمد بن محمد الطاهر،(ت : بوץ اهــ) التحرير و التتوير(تحرير المعنى السديد وتتوير العقل الجديد

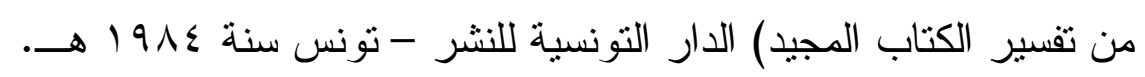

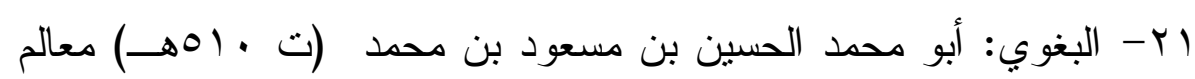
التنزيل في تقسير القرآن، تحقيق: عبد الرزاق المهدي، ط: ( () دار إحياء

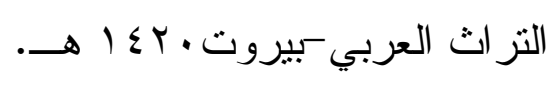

r r- البقاعي: برهان الدين أبي الحسن إبراهيم بن عمر:نظم الدرر في تتاسب الآيات و السور، تحقيق: عبد الرازق المهدي ،دار الكتب العلمية

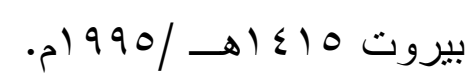

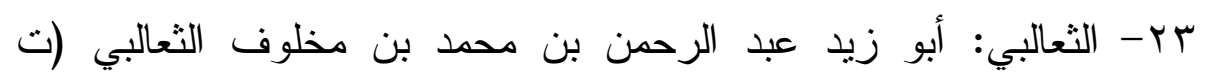
Av

$$
\text { لألمطبو عات - بيروت. }
$$

צ ץ- التهانوي: محمد على(ت1/101) كثاف اصطلاحات الفنون و العلوم،

$$
\text { مكتبة لبنان ناشرون بيروت } 997 \text { 19 م. }
$$

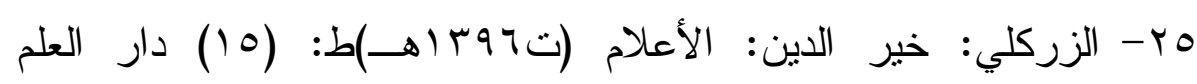

$$
\text { للماليين r r. . ب م). }
$$

דr- ابن منظور : جمال الدين محمد بن مكرم (ت I/ Iهـ) ،لسان العرب، ط: (ب)، عني بتصحيحها أمين محمد عبد الوهاب وزميله، دار إحياء

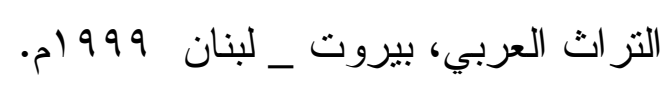

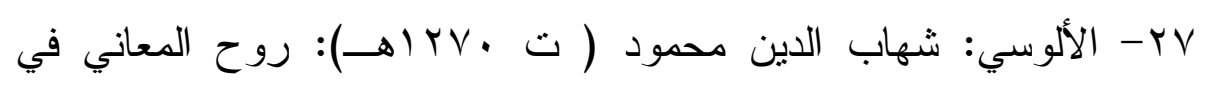

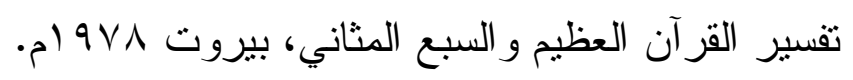




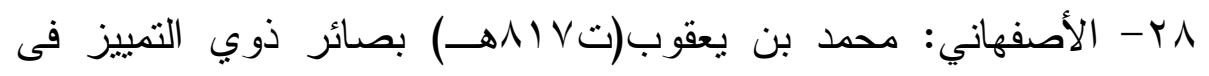

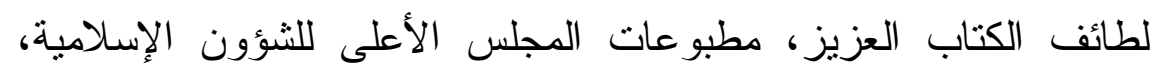

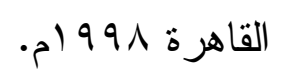

و المحيط: ، دار الكتب العلمية، بيروت .

•r- الأنصاري: يوسف: أساليب الأمر و النهي في القرآن و أسرارها

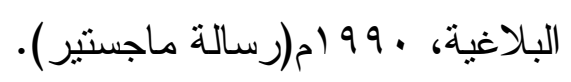

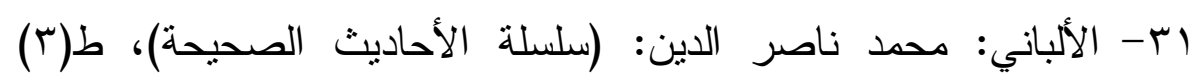
المكتب الإسلامي بيروت. المبان.

rس- الأنباري: أبو بكر محمد بن القاسم، الزاهر في معاني كلمات الناس،

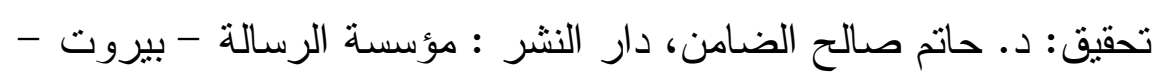

$$
\text { . 199r- } \rightarrow 1 \leq 1 r
$$

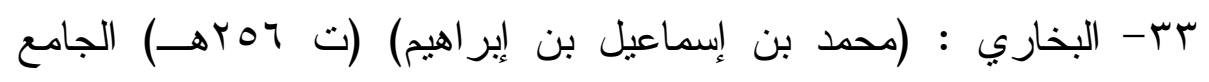
الصحيح، دار الشعب القاهرة ،بدون تاريخ. ع - البيهقي: شعب الإيمان، تحقيق: عبد العلي عبد الحميد، ط: (1) مكتبة الرشد للنشر و التوزيع بالرياض بالتعاون مع الدار السلفية ببومباي بالهند،

$$
\text { . ب r - ד }
$$

هץ- الجصاص: أبو إسحاق إسماعيل بن إسحاق المالكي ،أحكام القر آن،

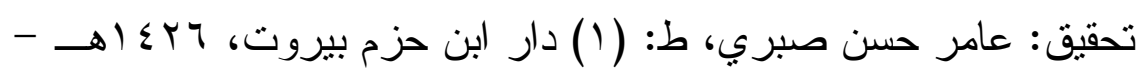

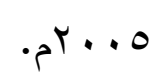

דب- الجرجاني: علي بن محمد بن علي، التعريفات، تحقيق وتعليق: عبد

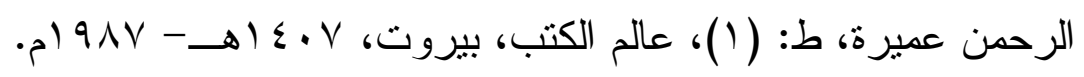


VV الجويني: عبد الملك بن عبد الله بن يوسف: الكافية في الجدل، تحقيق:

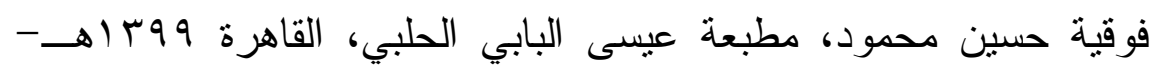
. $) 9 \vee 9$

^ץ- الحاكم: محمد بن عبداله أبو عبداله، المستدرك على الصحيحين، تحقيق: مصطفى عبد القادر عطا، ط: (ץ) دار الكتب العلمية - بيروت

$$
.199 \cdot-1 \leq 11
$$

q ب- الدارمي: عبداله بن عبدالرحمن أبو محمد، السنن، تحقيق: فواز أحمد زمرلي، خالد السبع العلمي، حسين سليم أسد، ط: ( () دار الكتاب العربي

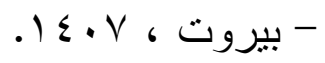

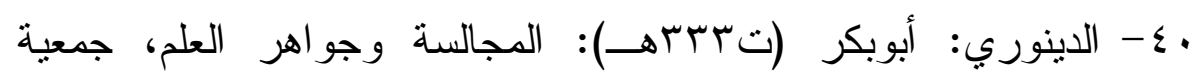
التربية الإسلامية (البحرين - أم الحصم )، دار ابن حزم (بيروت لبنان)

إ- ابن العربي: أحمد بن عبد الله أبو بكر (ت آـهــ): أحكام القرآن، بدون تاريخ.

r - الأصفهاني: حسين بن محمد بن المفضل: المفردات في غريب القرآن،

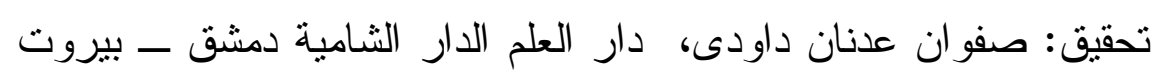
$\rightarrow 1 \leqslant 1\}$

rع- الأصبهاني: أحمد بن عبد الله(ت.عاب) حلية الأولياء وطبقات

$$
\text { الأصفياء، ط: (ع) دار الكتاب العربي - بيروت. }
$$

؟ - الألوسي: شهاب الدين محمود ابن عبد الله الحسيني: روح المعاني في تفسير القرآن و السبع المثاني، تحقيق: على عبد الباري عطية ، دار الكتب

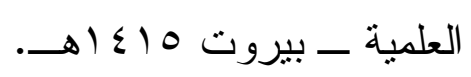


0ـ- الزمخشري: جار اله أبو القاسم محمود، الكثاف عن حقائق غوامض التنزيل و عيون الأقاويل فى وجوه التأويل، دار الكتاب العربي - بيروت $\rightarrow 1 \varepsilon \cdot V$

7؟ - الزمخشري: جار الله أبو القاسم محمود ،أساس البلاغة، بدون تاريخ. V V - الزرقاني: محمد عبد الباقي، شرح المو اهب اللانية للعلامة القسطلاني، بدون ناريخ.

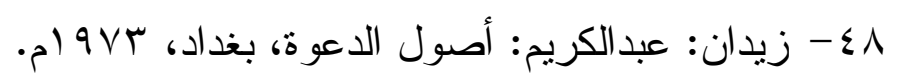

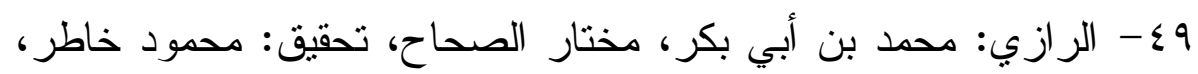

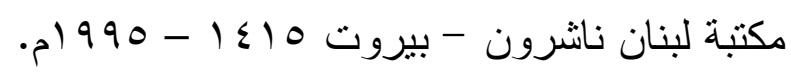
•- السفاريني: محمد بن أحمد بن سالم، غذاء الألباب شرح منظومة الآداب، تحقيق: محمد عبد العزيز الخالدي ط: (Y) دار الكتب العلمية

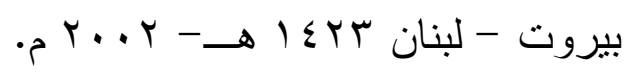

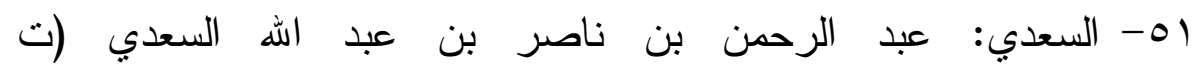

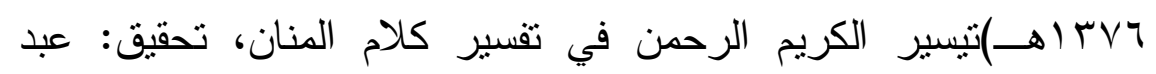

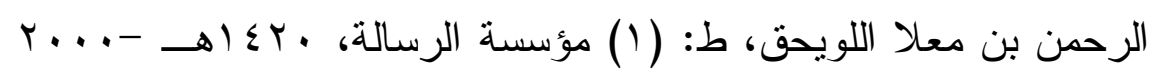

ror السمعاني: أبو المظفر منصور بن محمد بن عبد الجبار (تص^^هـ)

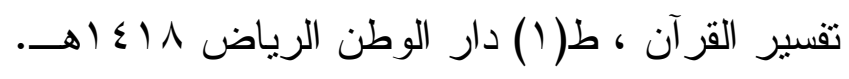
ror- الشوكاني: محمد بن علي بن محمد (ت . ب أهـ)، فتح القدير الجامع بين فني الرواية و الدراية من علم التفسير، بدون تاريخ.

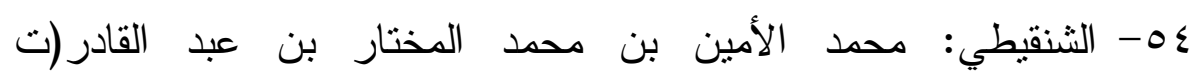
بq إهـ) أضو اء البيان في إيضاح القرآن بالقرآن، دار الفكر للطباعة و النشر و التوزيع بيروت - لبنان 10؛ 1990 هـ 190 مـ 


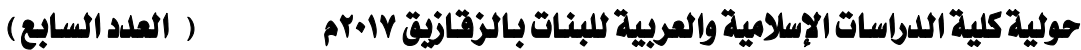

00- الصابوني: صفوة التفاسير ، دار الصابوني، بذون تاريخ.

4ه- الصو اف: محمد محمود، نظر ات في سورة الحجر ات، بدون تاريخ. - الصنعاني: الحسن بن محمد بن الحسن (ت .07 و اللباب الفاخر ، بدون تاريخ.

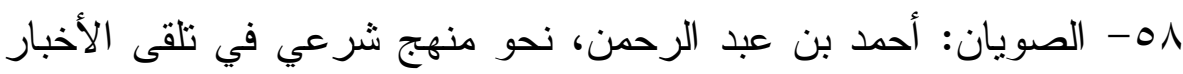

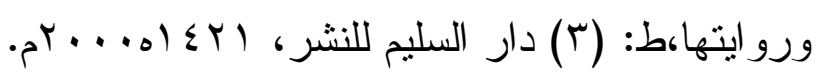

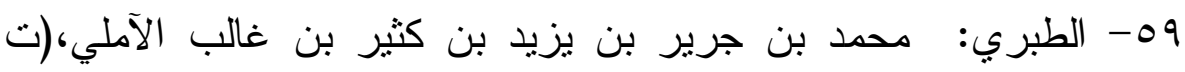

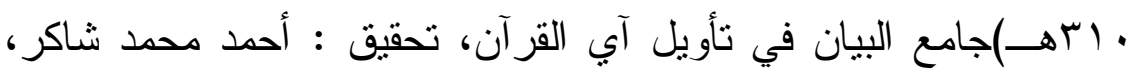

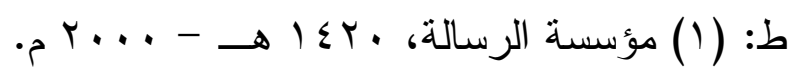
• آ- العسقلاني: ابن حجر : فتح الباري شرح صحيح البخاري، دار المعرفة

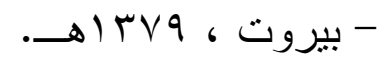
r r- عطية: محمد سالم(ت •rی (اهـ): تفسير سورة الحجر ات، بدون تاريخ rا7- عياض: أبو الفضل عياض بن موسى، الثفا، بدون تاريخ. ـ ا- العمر : ناصر بن سليمان: سورة الحجر ات در اسة تحليلية وموضو عية، بدون تاريخ

10 - الغز الي: محمد بن محمد، إحياء علوم الدين، دار المعرفة بيروت

7 - الفيروز آبادي: بصائر ذوى التمبيز في لطائف الكتاب العزيز ، تحقيق

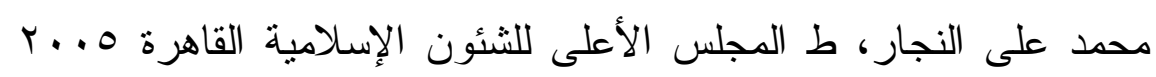

$$
\rightarrow \leq r 0 / 2
$$

VIT- القطان: مناع، مباحث في علوم القرآن، ط: (r) مكنبة المعارف للنشر

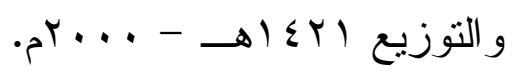


1 - القاسمي: محمد جمال الدين،حاسن التأويل، ط دار الفكر بيروت

$$
\text { . } 9 \vee \wedge-\rightarrow 1 \% 9 \Lambda
$$

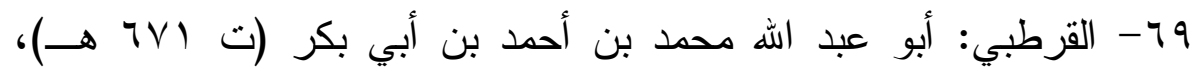

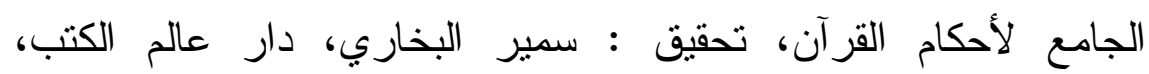

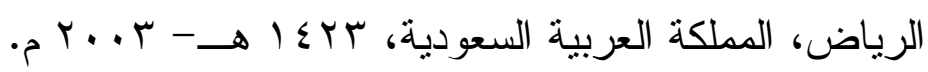
• . الكا - الكفوي: بو البقاء أيوب بن موسى الحسيني الكفومي، الكليات، تحقيق: عدنان درويش، محمد المصري، دار النشر : مؤسسة الرسالة - بيروت -

$$
\text { . } 1991-\$ 1 \leqslant 19
$$

r وسيم فتح الله: أخلاق و آداب المجتمع الإسلامي من خلال سورة

$$
\text { الحجر ات، بدون تاريخ. }
$$

نكري: القاضي عبد رب النبي بن عبد رب الرسول الأحمدي: دستور العلماء أو جامع العلوم في اصطلاحات الفنون، تحقيق : عرب عبار اته الفارسية: حسن هاني فحص، دار الكتب العلمية - لبنان - بيروت - ابr|

$$
\text { r... }
$$

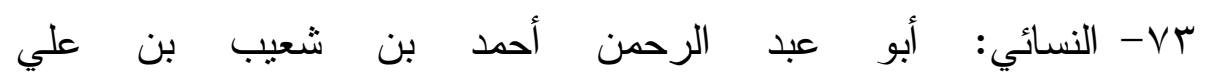
الخر اساني(تr +rهـ)، السنن، تحقيق: عبد الفتاح أبو غدة، ط: (r)

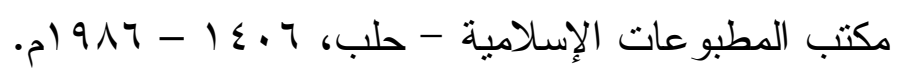

乏 - الواحدي: أبو الحسن علي بن أحمد النيسابوري، أسباب النزول،

مؤسسة الحلبي وشركاه للنشر و النوزيع.

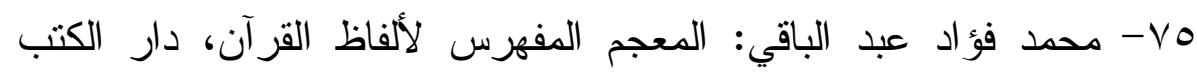

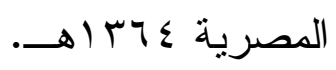


TVI النووي: بو زكريا محيي الدين يحيى بن شرف (ت TV7هـ)، رياض الصالحين، تحقيق: تحقيق: محمد ناصر الدين الألباني المكتب الإسلامي،

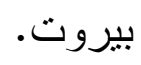

-VV النيسابوري: نظام الدين الحسن بن محمد، تفسير غرائب القرآن، بدون

تاريخ.

- V^ تحقيق: الثيخ زكريا عمير ان، ط:(1) دار الكتب العلمية - بيروت -

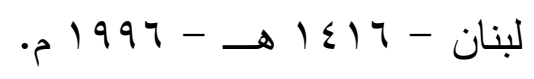

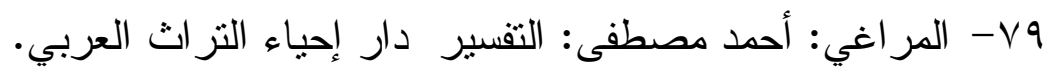

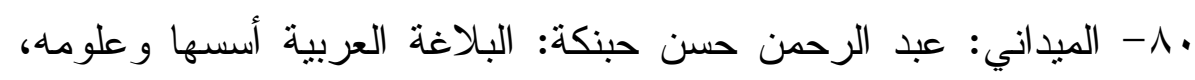

$$
\text { بدون تاريخ. }
$$

1 - الميداني: عبد الرحمن حسن حبنكة: قو اعد التدبر الأمتل لكتاب الله،

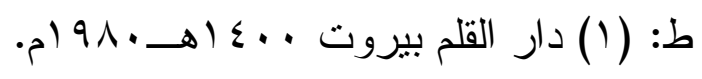

r - مالك: بن أنس، الموطأ، محمد مصطفى الأعظمي ط: (1) مؤسسة

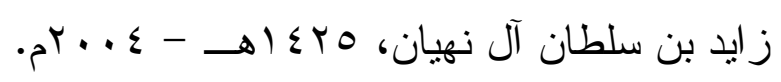

rی - المناوي: محمد عبد الرؤف ، التوقيف على مهمات التعاريف، تحقيق :

د. محمد رضوان الداية ط: (1) دار الفكر المعاصر ، دار الفكر -

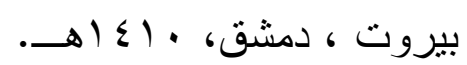

ع ^- المعلمي: يحي بن عبد اله: مكارم الأخلاق في القرآن الكريم، بدون

تناريخ. 


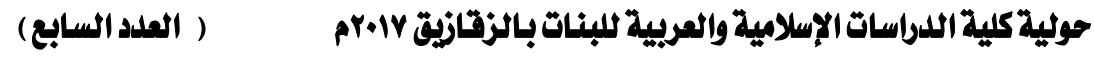

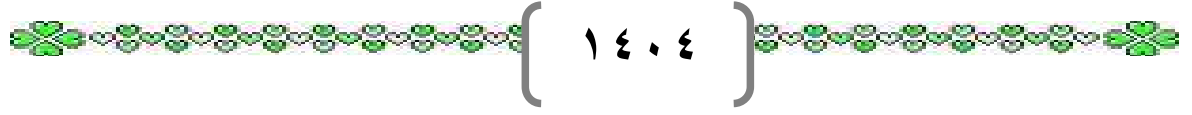




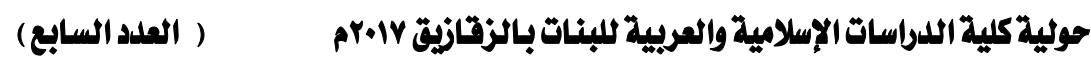

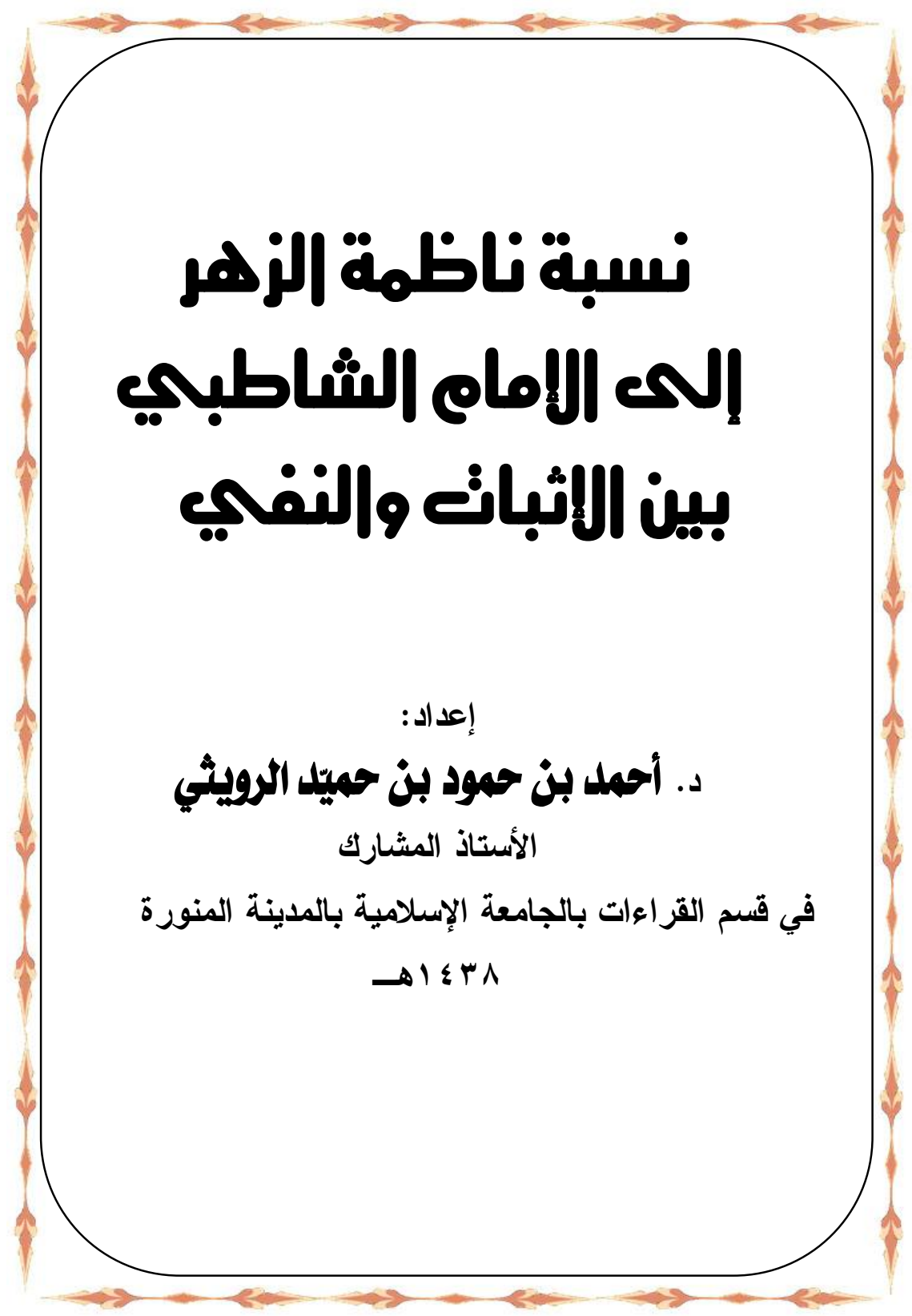

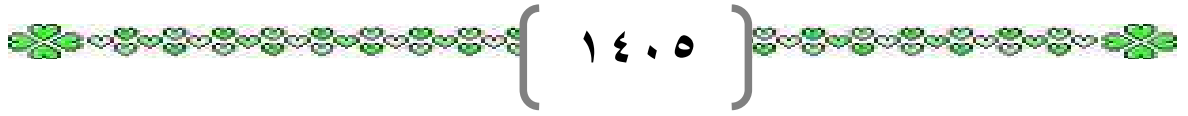




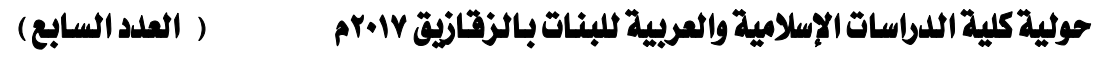

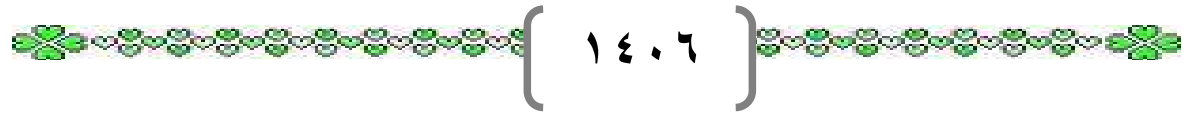




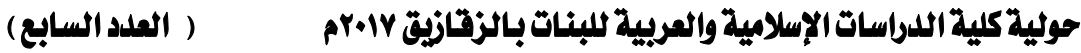

\section{بسم الله الرحمن الرحيم}

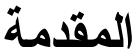

الحمد لله و الصلاة و السلام على رسول الله و على آله وصحبه أجمعين.

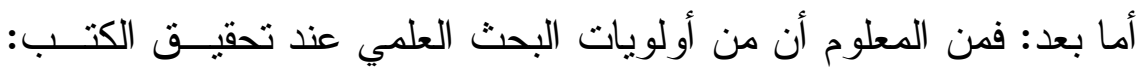
الاعتتاء بإنبات نسبة الكتاب إلى المؤلف، وبيان الأدلة إلى ذلك.

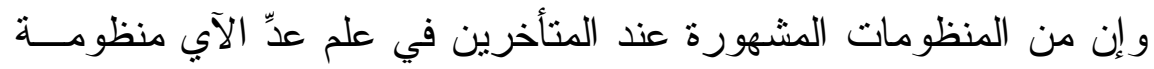
(ناظمة الزهر)، وهذا البحث يتعلق بقضية نسبة هذه المنظومة إلـى الإمــام القاسم بن فِيرهُه الثاطبي، هل نثبت نسبتها إليه أو أنها نُببت إليه. أهمية الموضوع و أسباب اختياره: - أن هذا الموضوع يبحث في جزئية من ترجمة الإمــام القاســـم بـن فِــرهّه

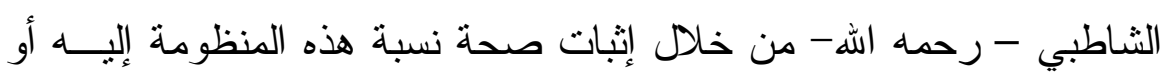
عدم صحة نسبتها إليه.

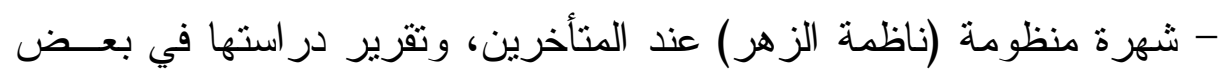

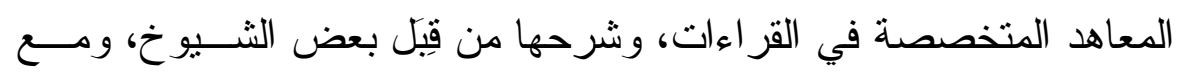
هذا فلم تُحث قضية: إثبات نسبتها إلى الإمام الثاطبي حسب قو اعد البحث العلمي. - وقوفي على نصوص لبعض الأئمة المعتبرين تتحدث عن نسبتها إلى الإمام الثاطبي.

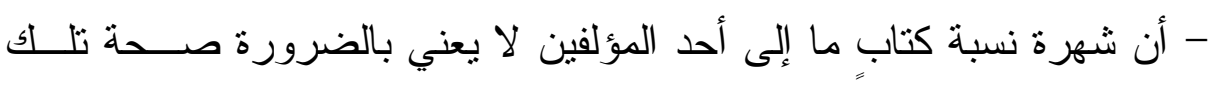
النسبة، فقد تُطبقُ الثهرة ذللك، وخير مثال لذلك : شر ح الدرة المنسوب للإمام النويري، حيـــث ثبــــ

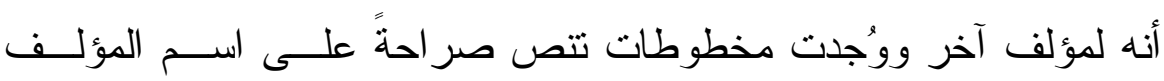




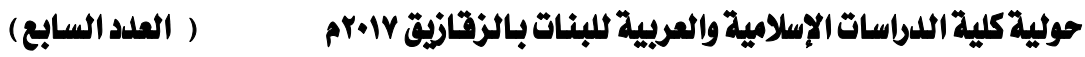

الحقيقي، مع أن نسبة هذا الكتاب اثتتهرت - خطأَ- إلى النويري منــذ مـــا

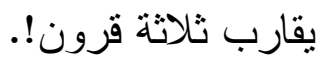

- ما بلغني عن بعض الثيوخ من نزددهم في نسبة هذه المنظومة إلى الإمــام

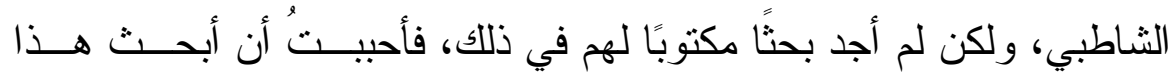
الموضو ع بحثًا علميًا.

لذلك عزمت مستعينًا بالله على بحث هذا الموضوع، على علمًا بأن هذا البحــثـ

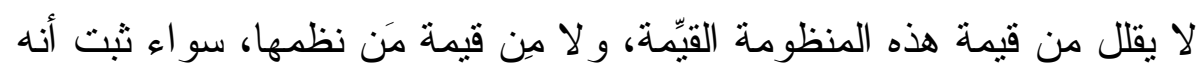
الإمام الثاطبي (ناظم الحرز) أو غيره، ولكنه يهدف إلى تحقيق صحة النسبة إلى الإمام الثاطبي مين عدمه فحسب. خطة البحث:

قسمت البحث إلى مقدمة وخمسة مباحث وخاتمة. المقدمة: وفيها أهمية الموضوع و أسباب اختياره وخطة البحث و المنهج. المبحث الأول: في ترجمة الإمام الثاطبي - رحمه الله تعالى -. المبحث الثاني: في التعريف بمنظومة (ناظمة الزهر).

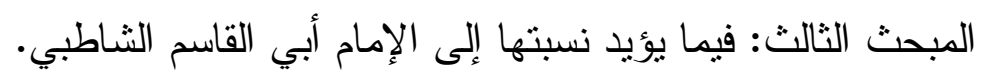

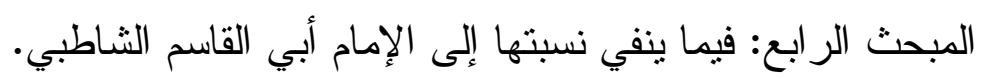
المبحث الخامس: في مناقشة القولين وبيان الراجح. ثم الخاتمة: وفيها أهم النتائج و التوصيات. منهج البحث:

- استقر اء نزجمة الإمام الثاطبي، وحصر مؤلفاته. - تَتَّبع نسبة الكتاب عبر القرون.

- البحث في كتب التراجم التي تلت عصر الإمام الثشاطبي، حيث لا تخلو من ذكر محفوظات ومرويات الأعلام المترجم لهم. 


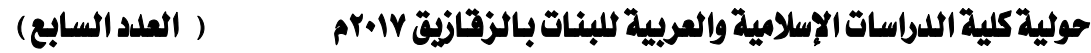

- البحث في الكتب المتخصصة في أسماء الكتب ورو ايتها بالأسانيد إلـى مؤلفيها.

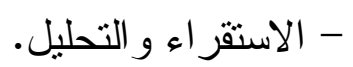

- نوثيق النقول من مصادر ها.

- عرض كل قول و أدلته.

- مناقشة الأدلة و القر ائن.

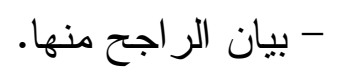




\section{الميحث الأول: ترحمة الإمام الشاطلي|"(1):

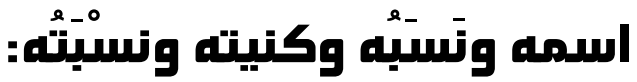

اسمه ونسبه : القاسم بن فِيرهُه(r) بن خلف بن أحمد الرُّعَينـي الثــاطبي

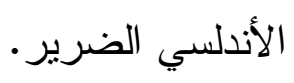

كنيته : لله كُنيتان، أبو محمد ، و أبو القاسم ، كنَّاه بأبي محمد شيخُه النَّزْي

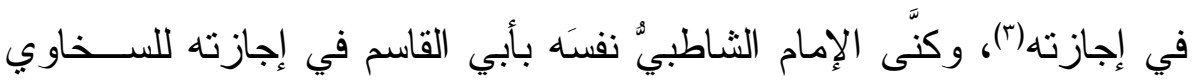

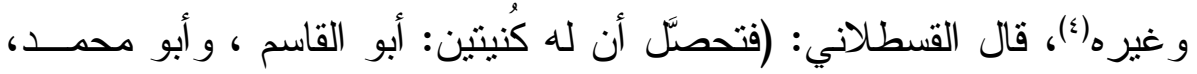

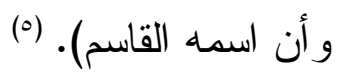

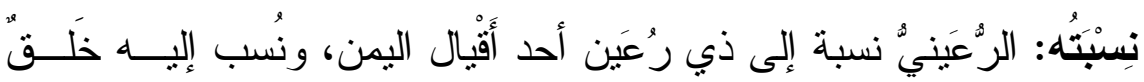

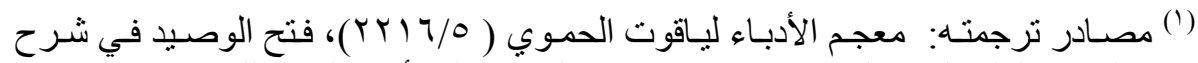

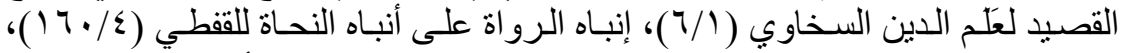

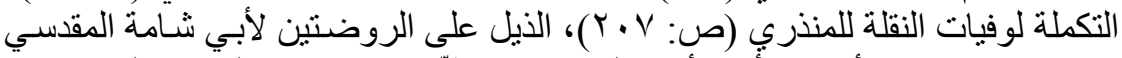

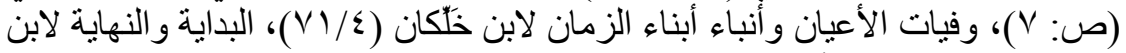

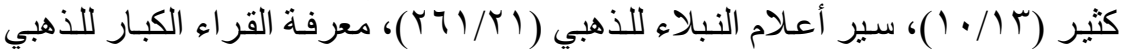

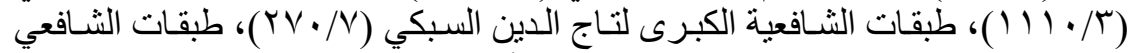

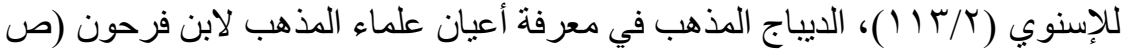
(Y

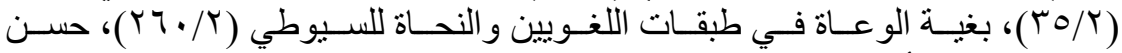

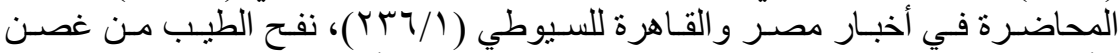

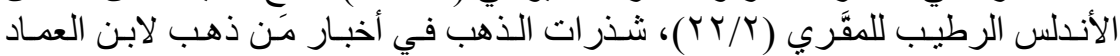

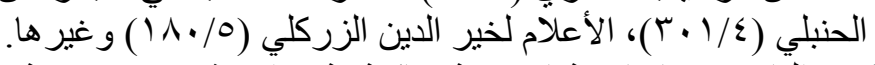

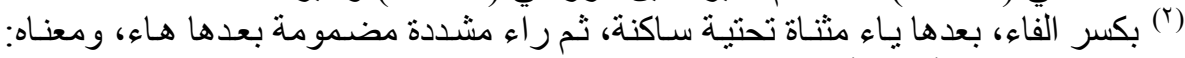

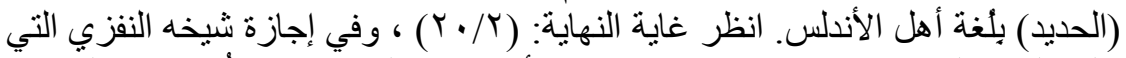

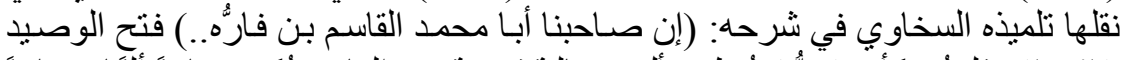

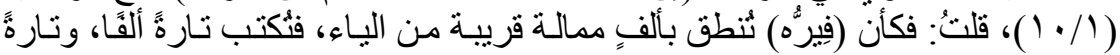

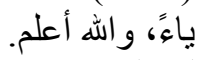

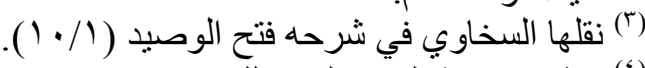

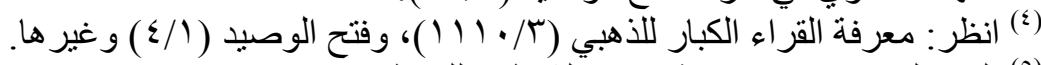

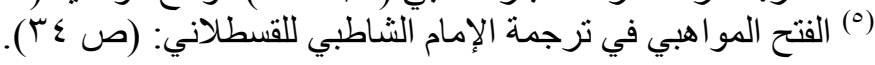


كثيرون. (1) - (1)

و الثاطبيٌٌ نسبة إلى شاطبة : مدينة في شرق الأندلس، وهي مدينة كبيــرة

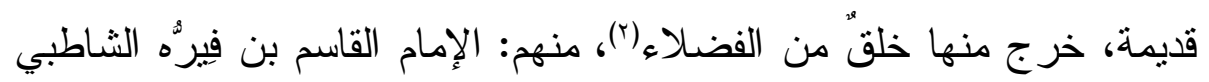

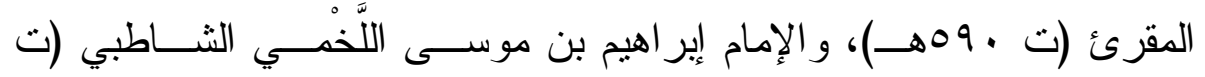
• .

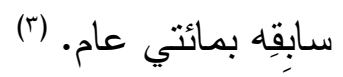

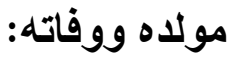

مولده: اتفقو اعلى أن مولده كان في أو اخر سنة ثمان وثثلاثين وخمســمائة

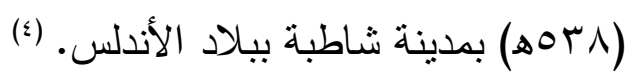

وفاته: بعد رحلته من الأندلس و استقر اره بمصر ، بقي بها إلى أن تــوفي

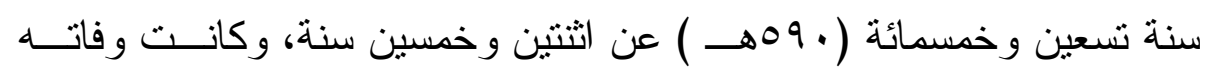

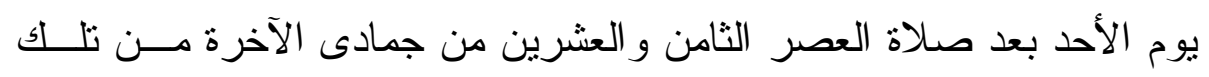

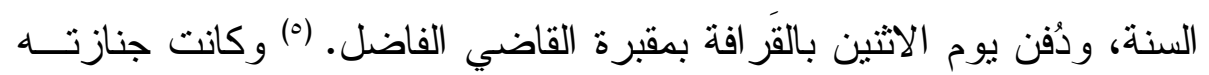

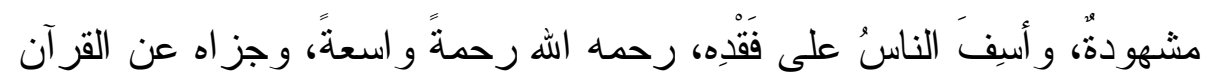

$$
\text { و أهله خير الجز اء. }
$$

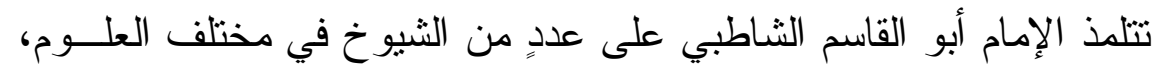
أقتصر هنا على ذِكر شيوخه في القر اءات، ممن قرأ عليهم القراءات عَرْضِّا،

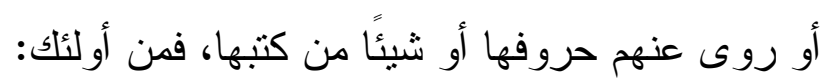

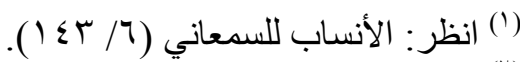

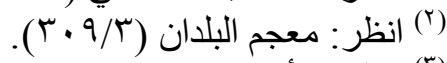

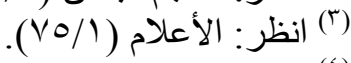

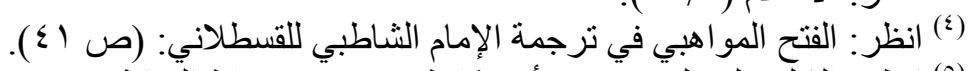

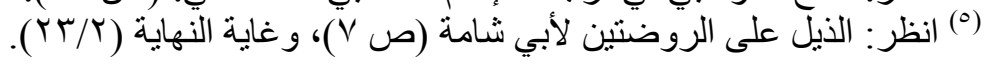


1 - محمد بن علي بن محمد بن أبي العاص النَّزْي الشاطبي، أبو عبد الله بن اللائهُ الثاطبي الضرير ، أحد أئمة الإقر اء المتصدرين في بلدة شاطبة، قر أ عليه الإمام أبو القاسم الثاطبي القر اءاتِ السبع بمضمَّنِ التيســير و وغيـره

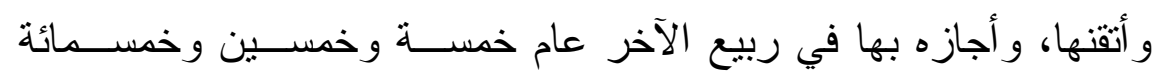

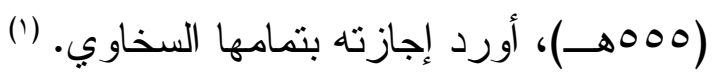

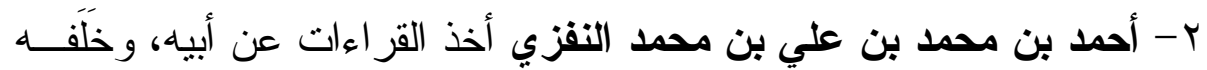

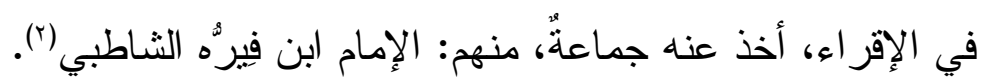

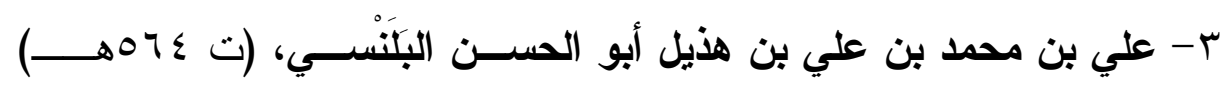
صاحب أبي داود سليمان بن نجاح، وربييُه، انتهت إلبه رئاسة الإقر اء في

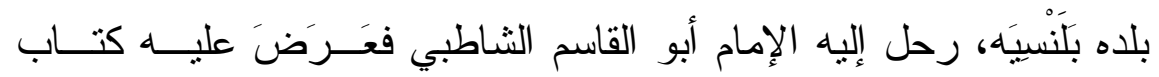

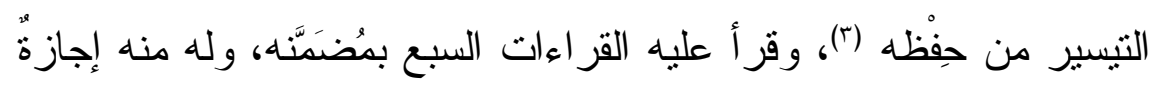
أوردها بتمامها السخاوي. (๕) ، وقد علا سندُ الإمام الثاطبي بقر اعته على إنى

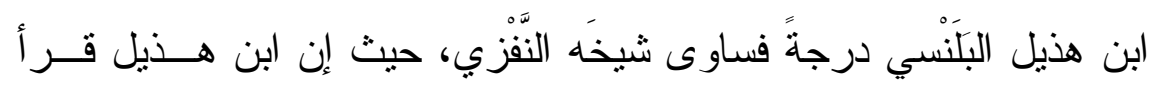

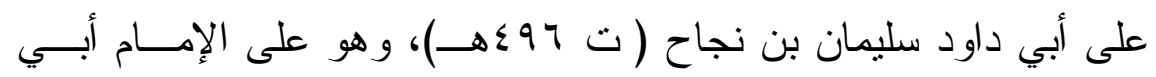

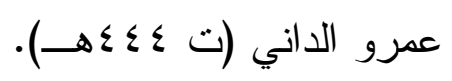

ع - علي بن عبد الله بن خلف بن النعمة أبو الحسن الأنصاري البلنســي (ت:

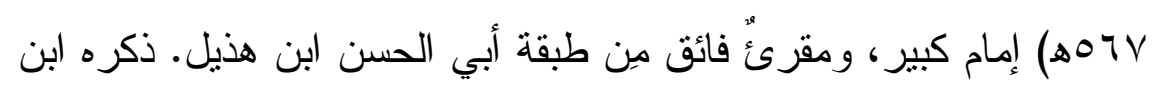

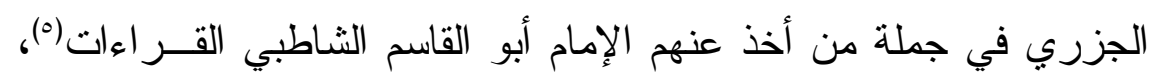

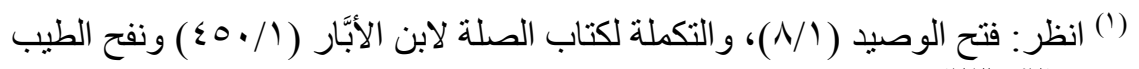

$$
\begin{aligned}
& \text { ( (YT./T) }
\end{aligned}
$$

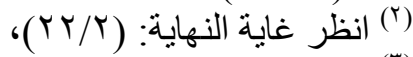

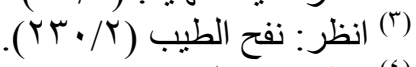

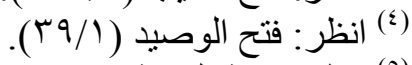

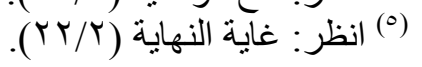

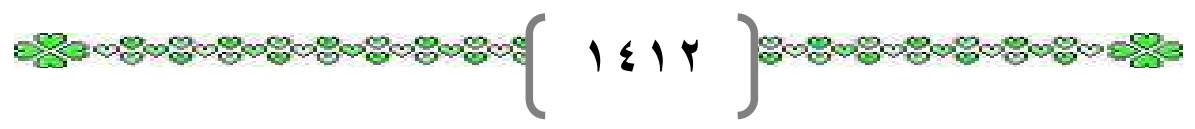




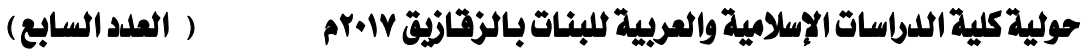

وقال ابن الجزري في تزجمته: لاوروى عنه الثــاطبي شــرح الهدايــة

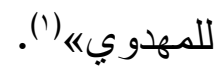

0- محمد بن يوسف بن مفرج بن سعادة أبو بكر الإشبيلي نزيل تلمســان (ت

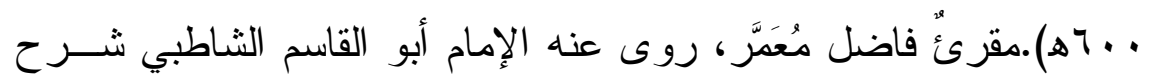

$$
\text { الاية للمهدوي. (r) }
$$

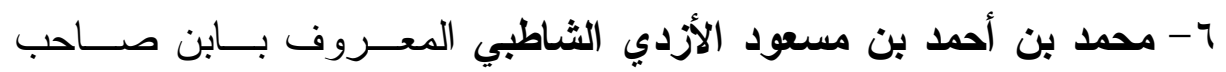

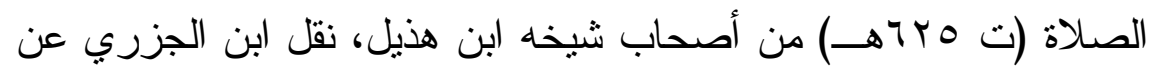
أبي بكر بن مسدي أن ابن صاحب الصلاة هو الذي لقَّن ابن فِيرهّ الثاطبي

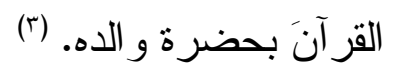

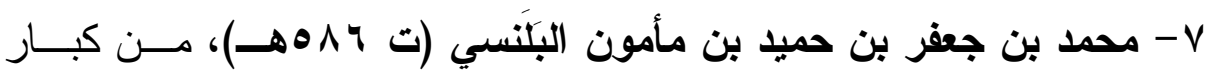

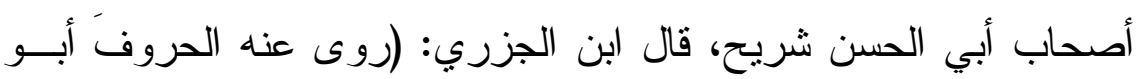

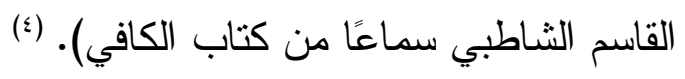

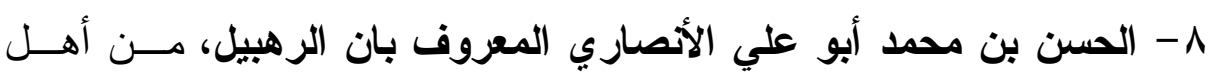

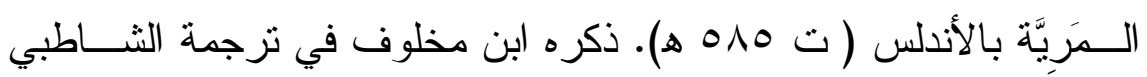

$$
\text { وقال: أخذ عنه القر اءات(ه). }
$$

هؤلاء الثيوخ الذين أخذ عنهم الإمام الثشاطبي القراءات، أو ورى عـنهم

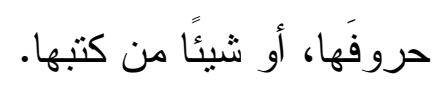

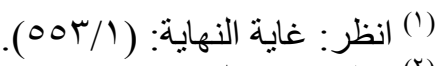

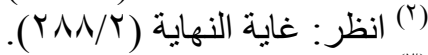

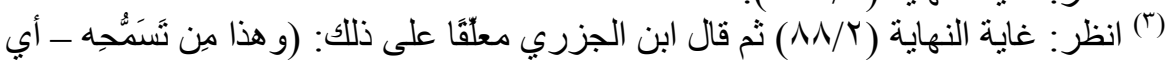

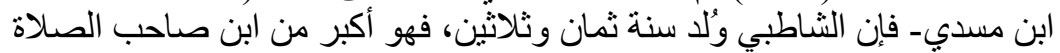

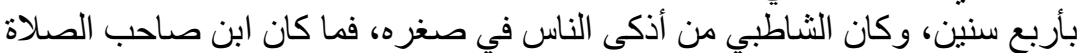

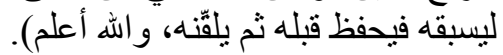

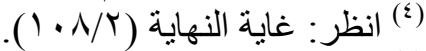

$$
\begin{aligned}
& \text { (') انظر: شجرة النور الزكية (ص: (1) 101 109). }
\end{aligned}
$$


وقد أخذ عن بعض هؤلاء الثيوخ، وعن غيرهم علومًا أخرى كالحــديث

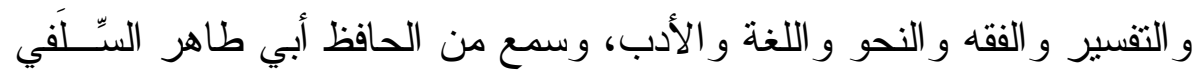

بالإسكندرية. (')

\section{تلامبذه}

أخذ عن الإمام الثاطبي و انتفع به خلقّ كثير ، منهم:

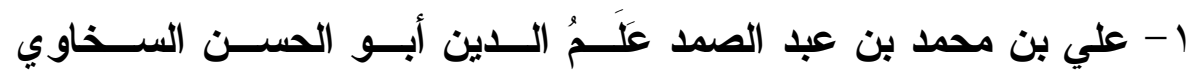

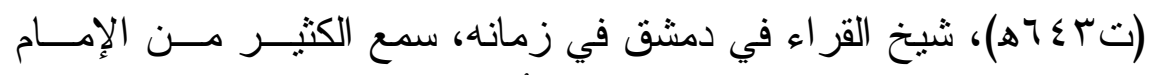

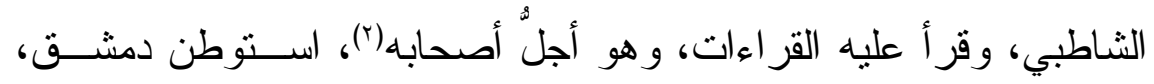
وتصدَّر بجامعها للإقر اء، قال عنه الحافظ الذهبي في تاريخ الإسلام: الرّأ

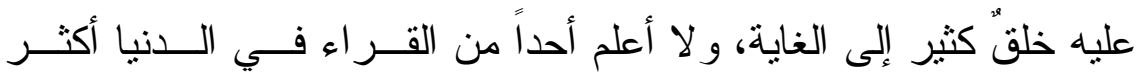

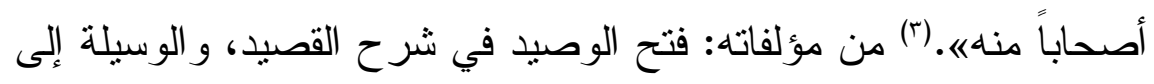
كشف العقيلة، شرح فيهما قصيدتَي شيخه الثاطبي في القر اءات و الرسم. r- علي بن شجاع بن سالم العباسي الهاشي، كمال الاين، صهر الإمــام الثاطبي، المعروف بالكمال الضرير (ت (ا77هـ) كان شيخ القر اء بالــديار

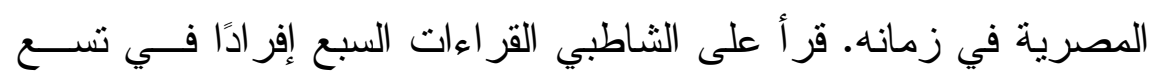

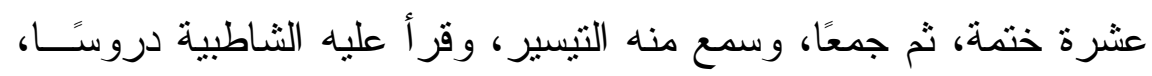

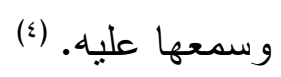

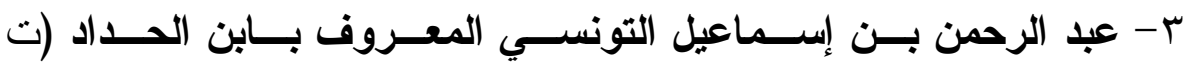

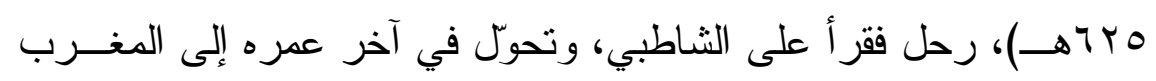

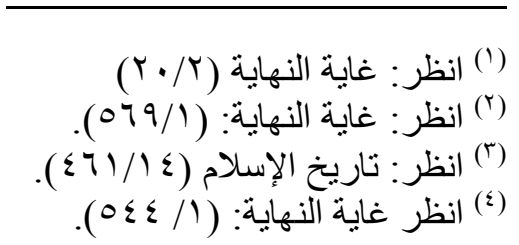

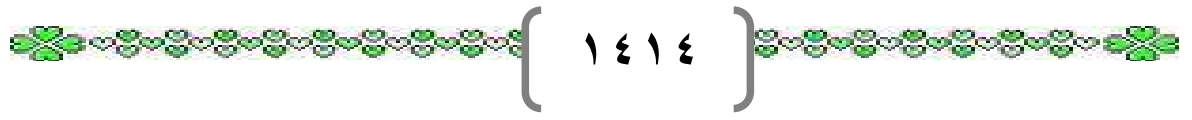




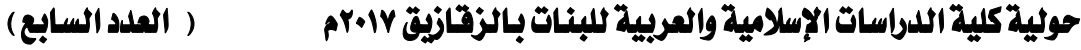

فسكن مر اكش، و عمل شرحًا للشاطبية، قال ابن الجـزري: (ويحتــلـ أن

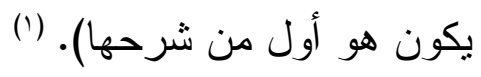

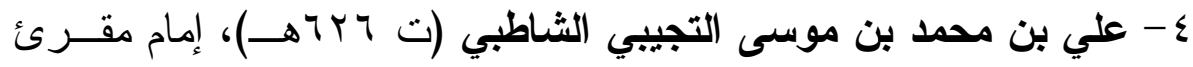

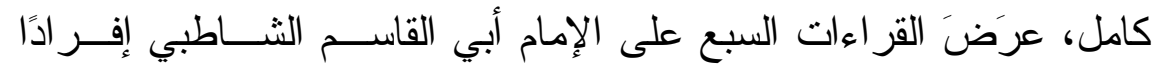

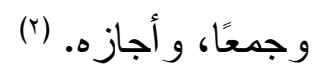

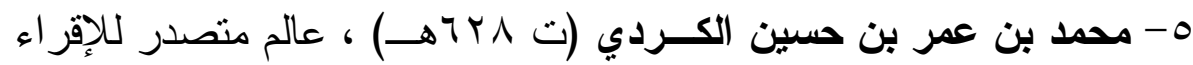

بجامع دمشق، قر أ القر اءات و القصيد على الإمام أبي القاسم الثاطبي. (r) 7- محمد بن عمر بن يوسف الأنصاري القرطبي (ابTهــ) إمام عالم فقيه مقرئ، قر أ القر اءات و القصيدتين اللامية و الر ائية على الإمام أبي القاســم ئح

الثاطبي، وجلس للإقر اء بالفاضلية بعد وفاة الإمام الثاطبي. (ء)

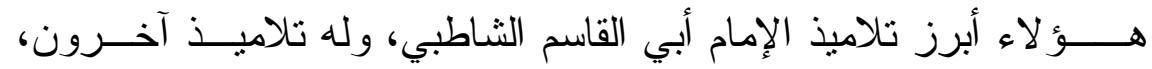

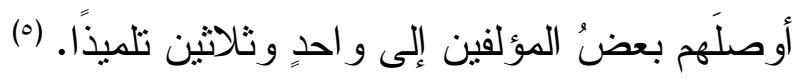
مؤلفاته و آثار ه: كان الإمام أبو القاسم الثشاطبي متصدِّرًا لإقر اء القر آن الكريم و القــر اءات،

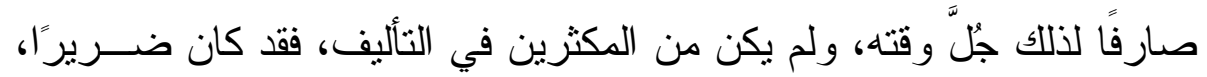

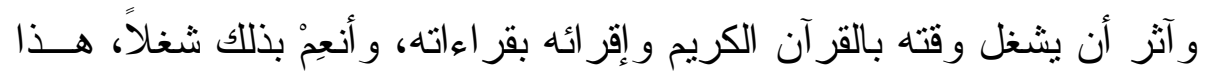

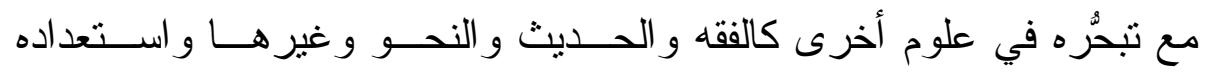

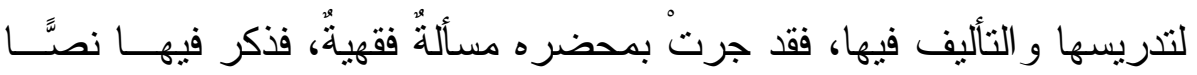
و استحضر كتابًا، فقال لهم: اطلبوها منه في مقدار كذا وكذا، وما زال يعـيِّنُ

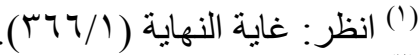

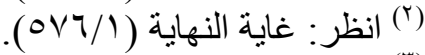

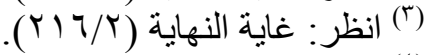

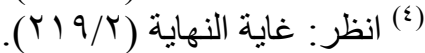

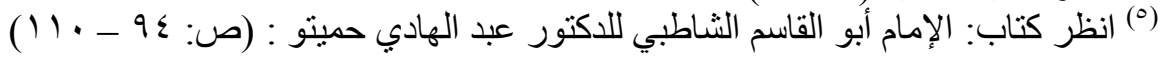

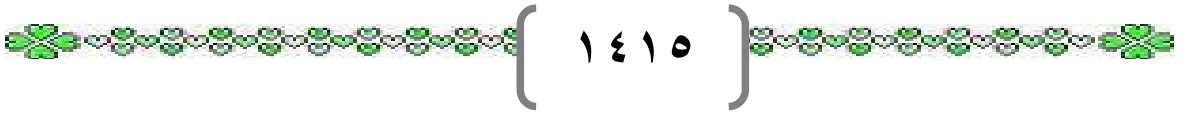


لهم موضعها حتى وجدوها حيثُ ذَكر ! فقالو اله: أتحفظظ الفقهَب! ، قـــال لهــــ

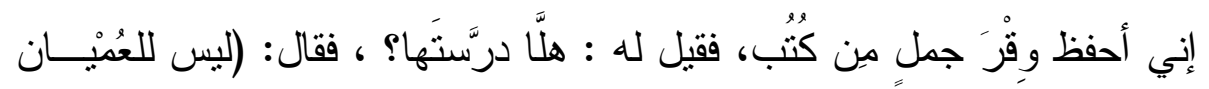
إلا القر آن). (')

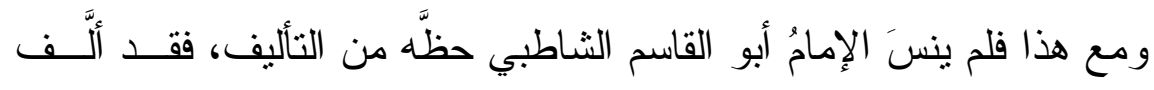

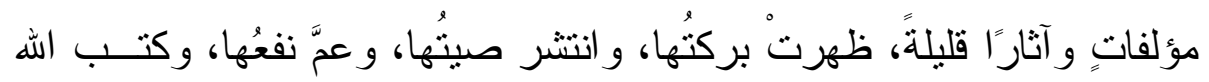
لها القبول بسبب إخلاص مؤلفها - رحمه الله تعالى -، وتكاد تلك الآثار تكون

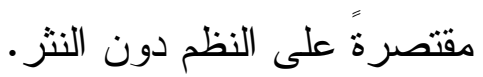
فمن ذلك:

1- حرز الأماني ووجه التهاني، المنظومة اللامية الثهيرة بالثــاطبية،

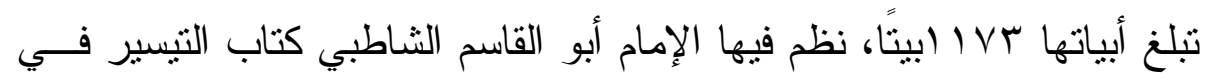

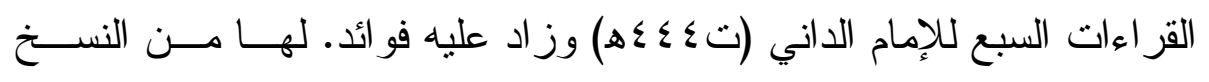
المخطوطة و المطبو عة و عليها من الثروح و الحو اثني ما لا يُحصى كتهـرةً

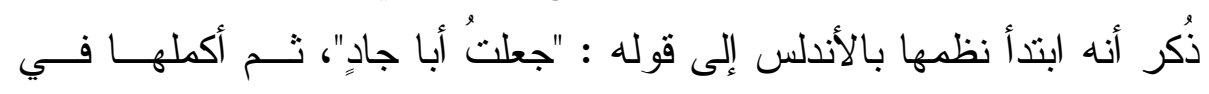
القاهرة. نقل عنه تلميذهُ السخاوي قولَه: ( لا يقر أُ أحدُ قصيدتي هذه إلا وينفعــه الله بها؛ لأني نظمتُها لله سبحانه) (r). وقال ابن خَِّّان: (ولقد أبدع فيها كُلَّ الإبداع، وهي عمدة قر اء هذا الزمان

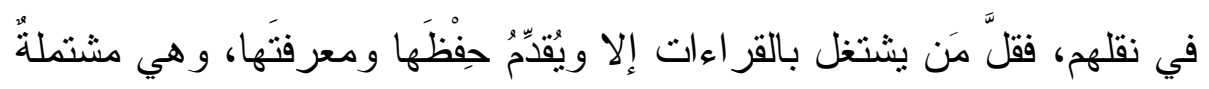

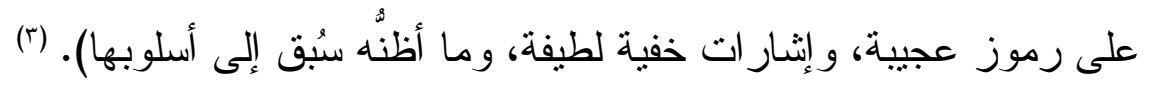

(') انظر : الذيل و التكملة لكتابي الموصول والصلة لأبي عبد الله محمد بن عبد الملك

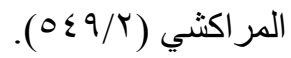

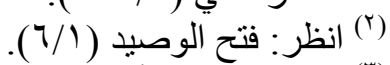

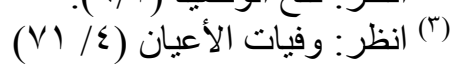

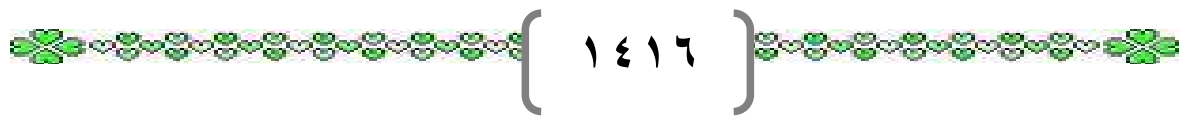


وقال الحافظ الذهبي: (وقصيدناه في القراءات و الرسم مدــا بــدل علــى

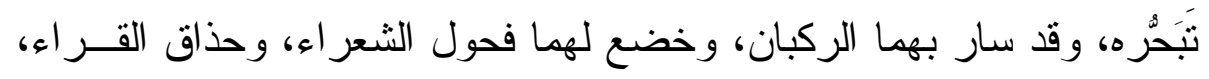

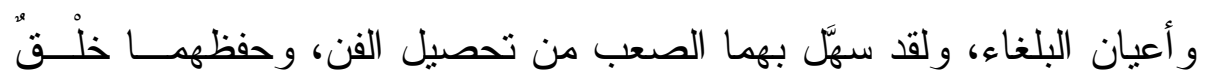

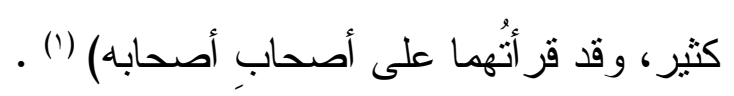
وقال الإمام ابن الجزري: (ومَن وقفتَ على قصيدتيه؛ عَلمَ مقدار ما آتـاه

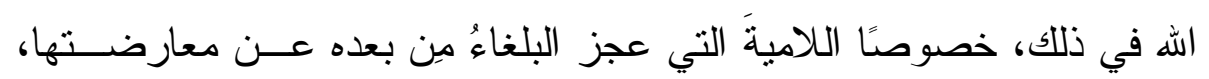

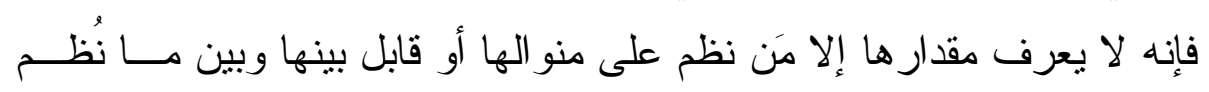

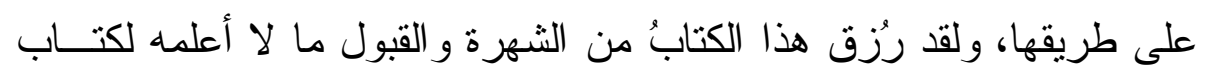
غيره في هذا الفنّ، بل أكاد أن أقول: و لا في غير هذا الفنّ؛، فإنني لا أحسب

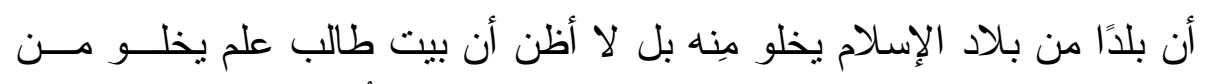

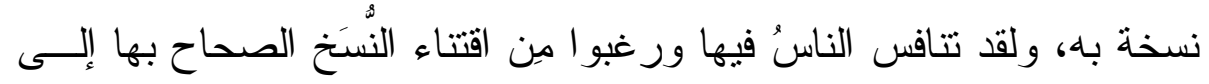

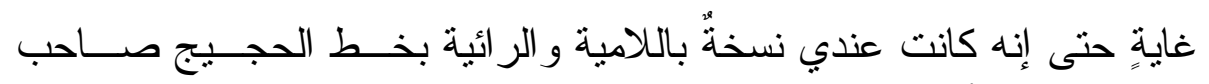

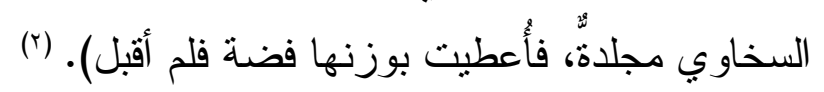
ومين أثنهر شروح القصيدة الثاطبية اللامية و أقدمِها - إن لم يكن أقدمَها:

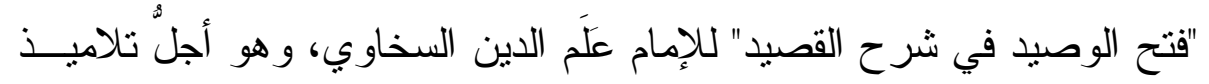
الإمام أبي القاسم الثاطبي - كما تقدمت الإشارةٌ إليه-. r - عقيلة أتز اب القصائد في أسنى المقاصــد، المنظومة الر ائية الثهيرة،

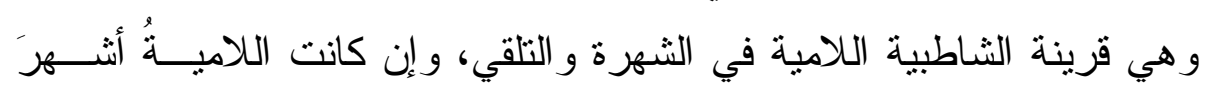
منها. قال تلميذه السخاوي: (وله قصيدته المعروفة بعقيلة أتز اب القصائد فــي

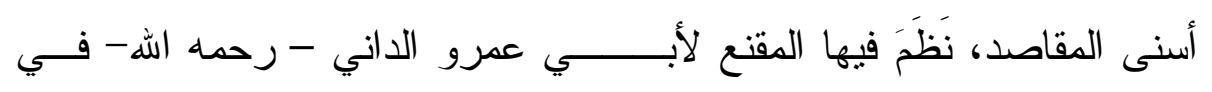




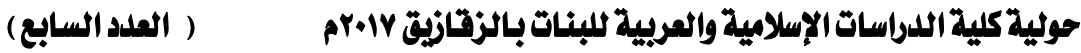

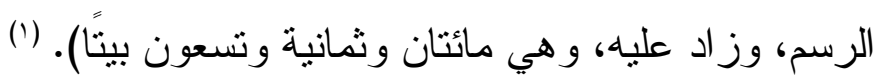

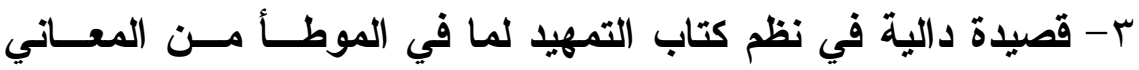

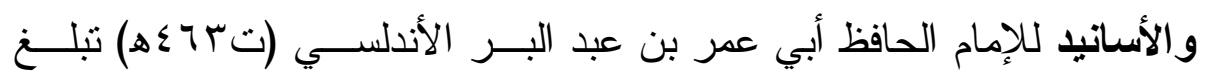
خمسمائة بيت، قال السخاوي عن شيخه أبي القاسم الثاطبي: 》ا و أخبرني أنه

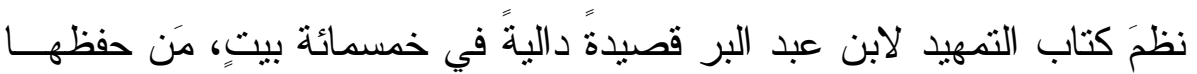

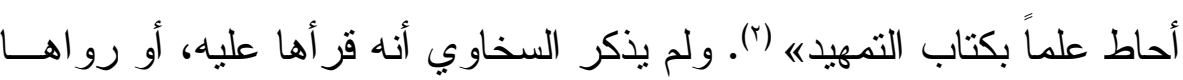

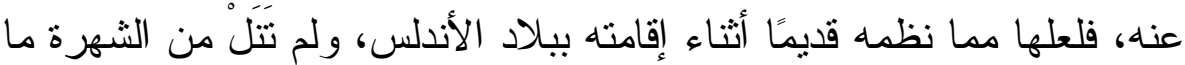

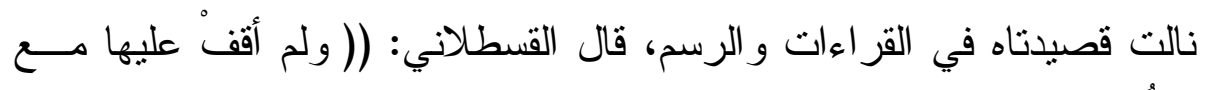

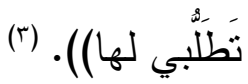

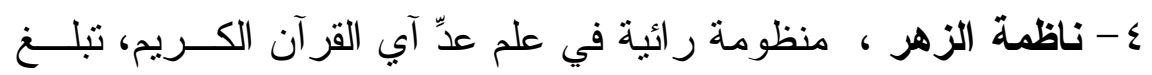

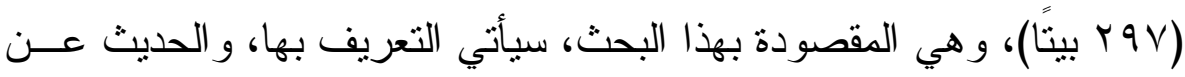
نسبتها إلى الإمام أبي القاسم الثناطبي فيما يأتي - إن شاء الله تعالى -.

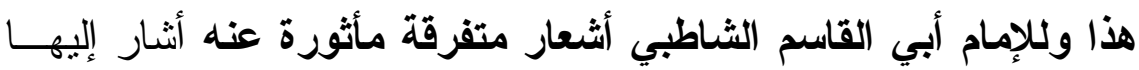

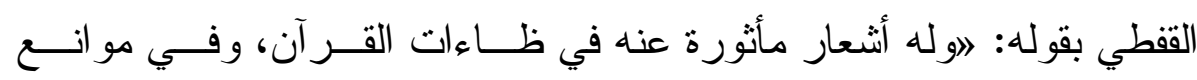

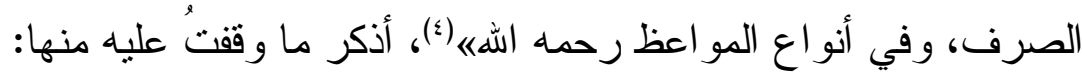

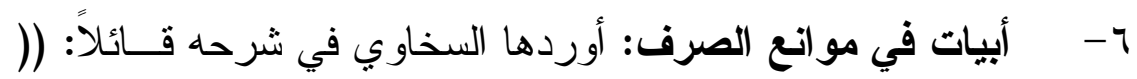

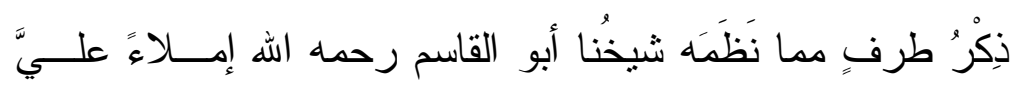
لنفسه في مو انع الصرف )( (0) ثم ذكر هذه الأبيات الأربعة:

$$
\begin{aligned}
& \text { (1) انظر : فتح الوصيد (1/( • (1)). }
\end{aligned}
$$

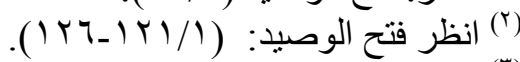

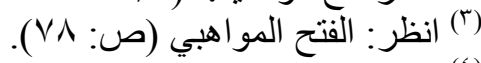

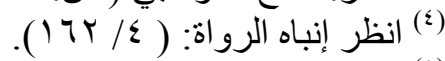

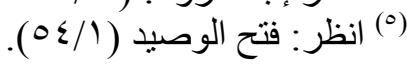




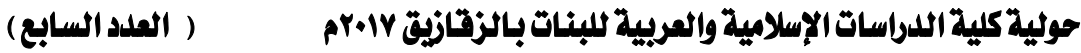

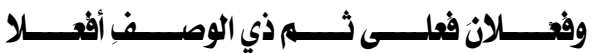

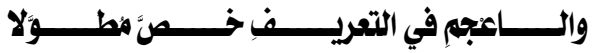

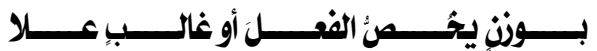

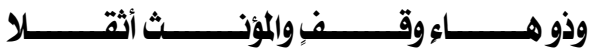

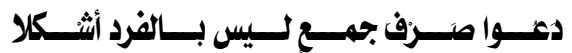

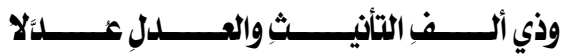

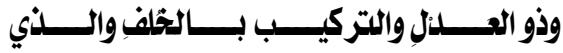

צ- أبيات في ظاءات القرآن ، قال السخاوي في شرحه: (وله في ظاءات

$$
\text { القر آن) (') ثُ ذكر هذه الأبيات الأربعة: }
$$

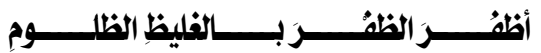

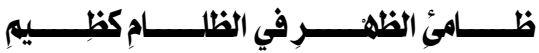

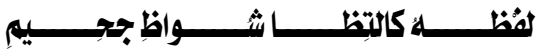

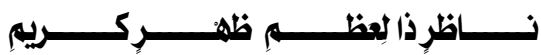
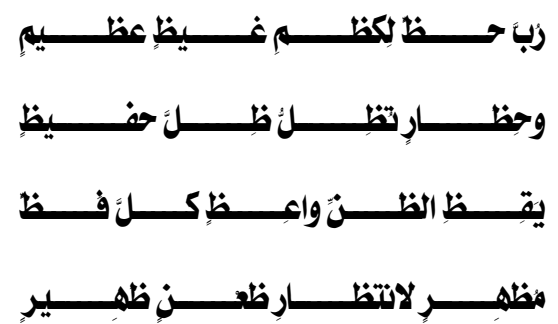

V- قصيدة بائيَّة، عدد أبياتها ثمانية عشر بيتًا، أوردها السخاوي بتمامها في مقدمة شرحه للثاطبية ، ومطلعُها:

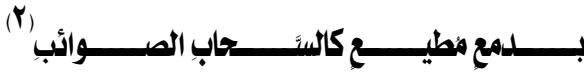

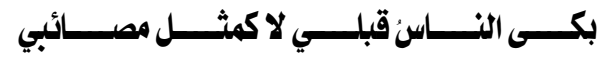
وقد استشهد الإمام أبو شامة المقدي ببعض أبياتِها في شرحه للبيت التاسع من الثاطبية، وبيَّن بعض معانيهاب(). ^- قصيدة ميمية، عدد أبياتها ستة وثثلاثون بيتًا، أوردها السخاوي في وهي مقدمة شرحه للشاطبية قائلاً: (وله أيضًا - رحمه الهـ - ثم ذكر هذه القصيدة بتمامها، ومطلتعُها:

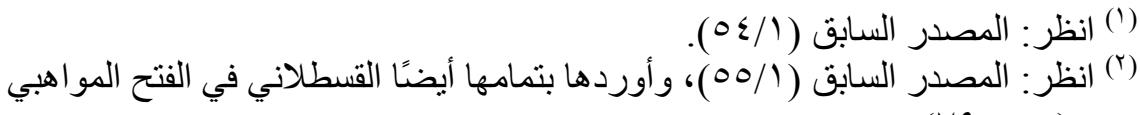

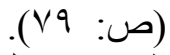
(־) انظر : إبراز المعاني لأبي شامة (10/1)، 17 (1). 
وما لي مليمتا هين سئت الأكارما

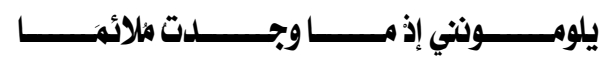

9- ومن منظوماته - رحمه الله- - أبياتُ أجاب فيها عن لغز أبي الحسن

$$
\text { الحُصني(r) عن كلمة (سوءات) التي يقول فيها : }
$$

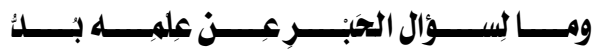

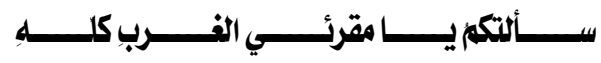

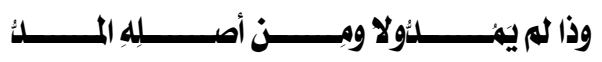

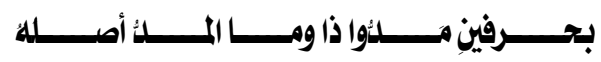

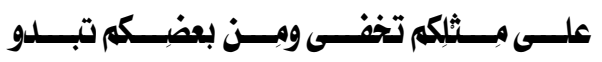

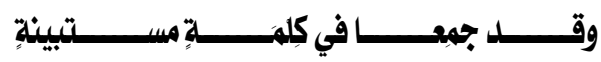

فأجابه عددٌ من القر اء، منهم الإمام أبو القاسم الثاطبي في عشرة أبياتٍ

يقول فيها:

لاى قَصز "سوعاتٍٍ" وفي همزها مَدُوا

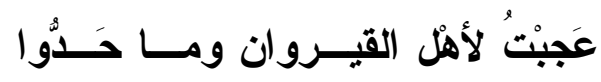

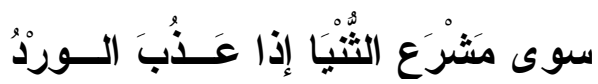

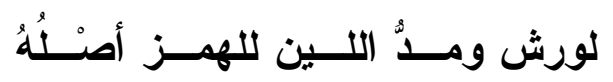

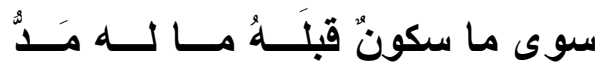

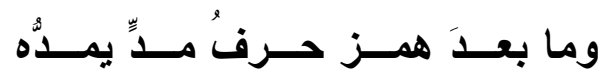

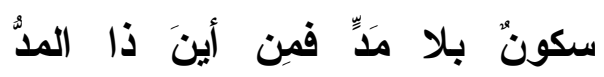

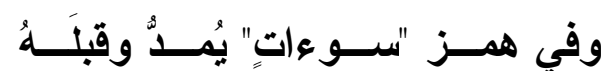

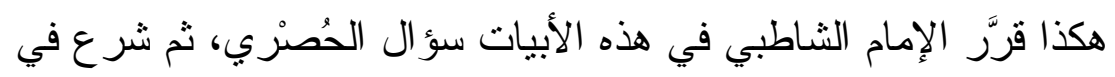

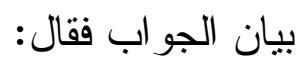

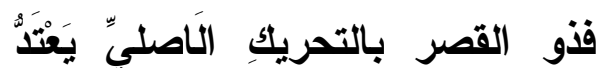

يقولون عينُ الجمع فــرعُ ســونهـا

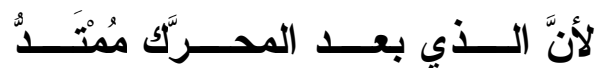

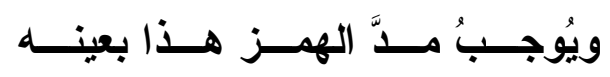

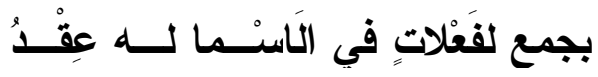

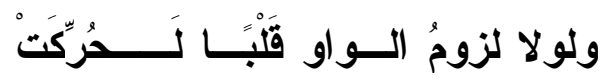

(1) انظر: فتح الوصيد ( OV/I)، وأوردها بتمامها أيضًا القسطلاني في الفتح المواهبي (ص: . ( 1 .

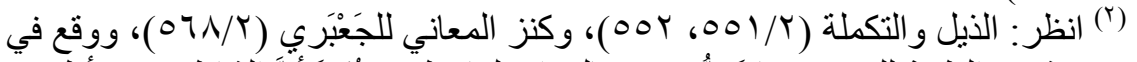

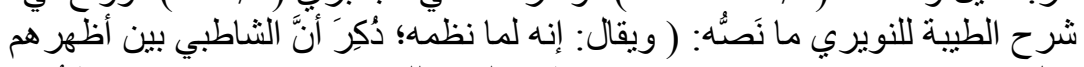

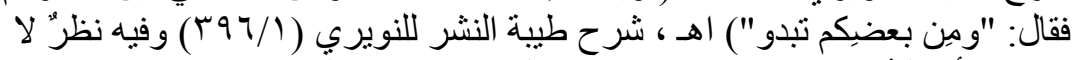

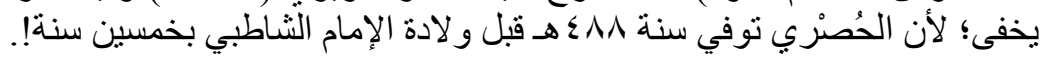

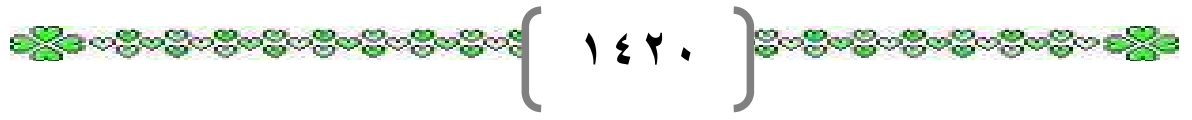




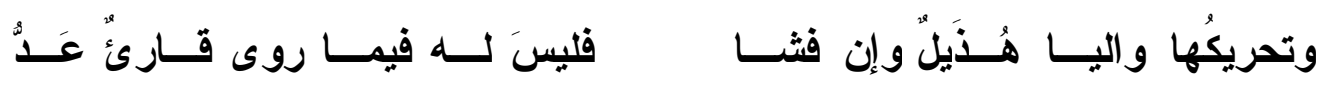

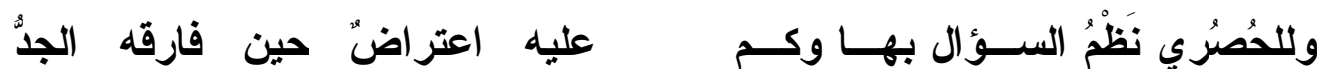

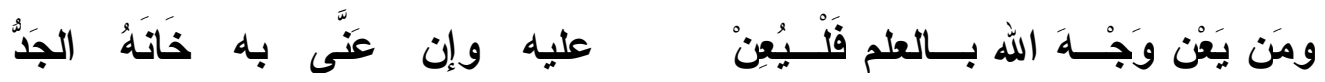
• 1 - ومِن نَظمِهِ - رحمه الله - : هذان البيتان:

$\stackrel{2}{2}$ فَ

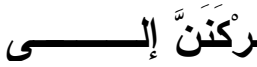

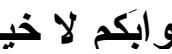
ע

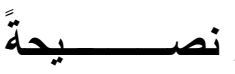

أذإ

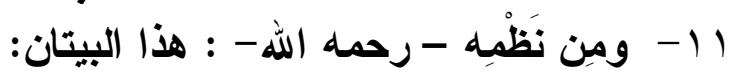

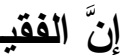

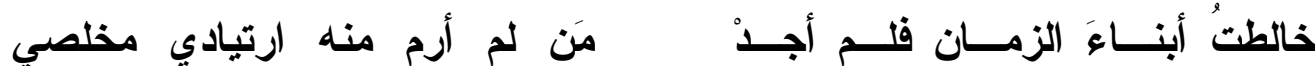

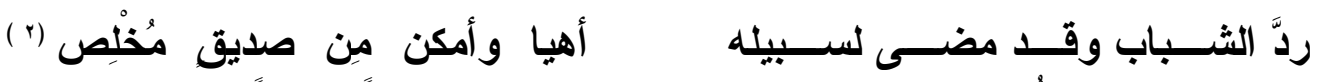
هذا ما وققت عليه من مؤلفاته و آثار ه - رحمه الله رحمةً و اسعةً

\section{مكانته العلمية وثناء العلماء عليه:}

قال عنه تلميذه أبو الحسن السخاوي في مقدمة شرحه للثـــاطبية: لاكـــان

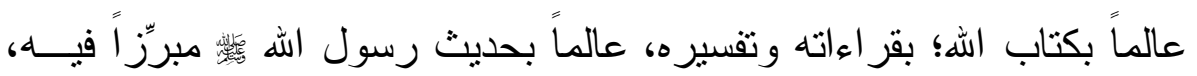

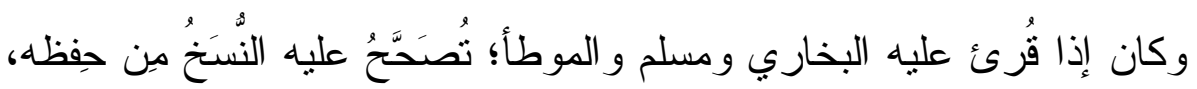

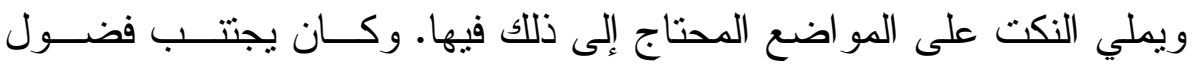
القول، و لا يتكلم في سائر أوقاته إلا بما تدعو إليـــه ضــرورة، و لا يجلـس للإقر اء إلا على طهارة، في هيئة حسنة وخضوع و استكانة، ويمنع جلســاءه

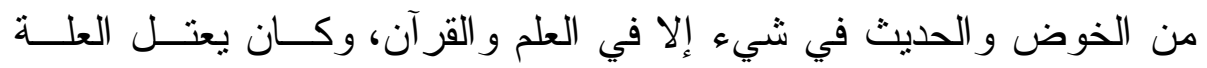

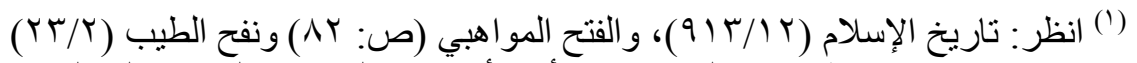

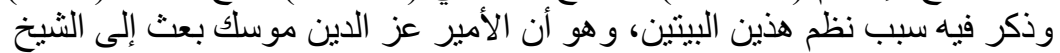

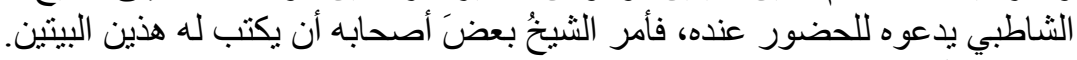
(r) (r) انظر : نفح الطيب (r/T). 
الثديدة فلا يشتكي و لا يتأوه، و إذا سئل عن حاله فال: "العافية" و لا يزيد على

ذللكه. (1)

- وقال السخاوي - أيضـا" - في كتابه جمال القر اء، بعد أن ساق كثـــراً مــن

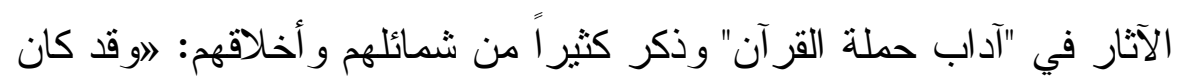
شيخنا أبو القاسم الثاطبي - رحمه اله - صاحبِ هذه الأوصساف جميعِهــا،

$$
\text { وربما زاد عليهاه.) (r) }
$$

- وقال عنه الحافظ الذهبي: 》الثنيخ، الإمام، العالم، العامـلـ، القــدوة، ســيد

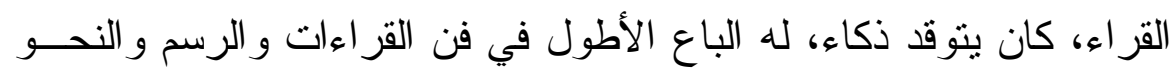

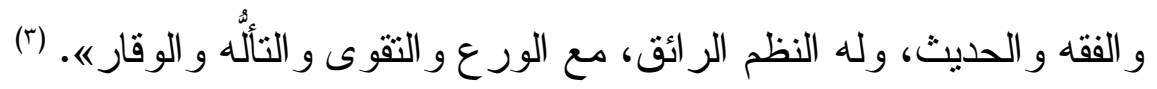

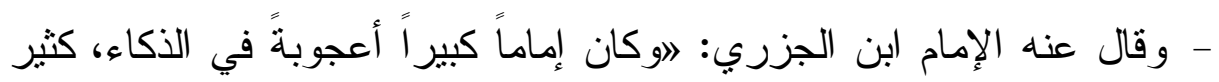

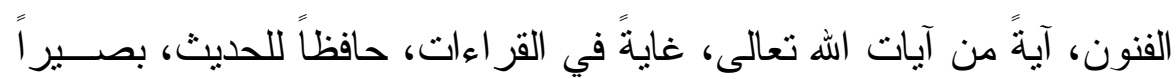

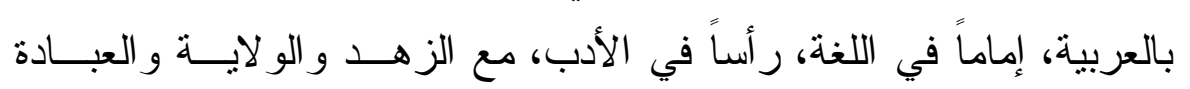

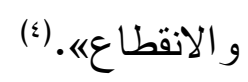

- وقال عنه ياقوت الحموي: اكان فاضلاً في النحو و القر اعة و علم التفسـير، ،

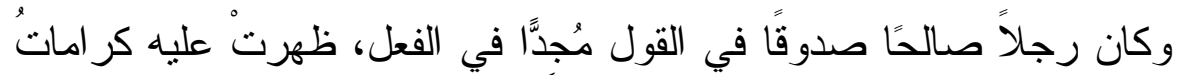

$$
\text { (الصالحينه }
$$

- وقال عنه ابن عبد الملك: لاوكان مِن جلة أئمة المقرئين، كثيرَ المحفوظات،

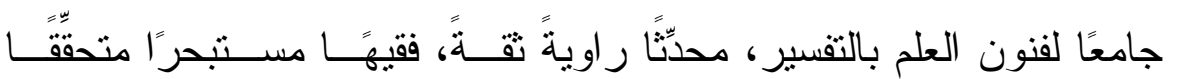

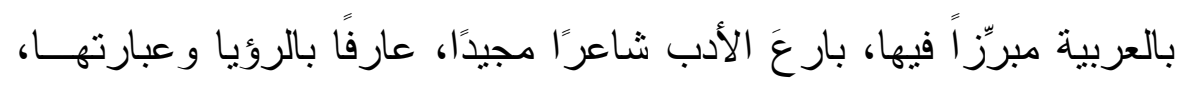

$$
\begin{aligned}
& \text { (1) (1) انظر: فتح الوصيد: (1/1) (1). }
\end{aligned}
$$

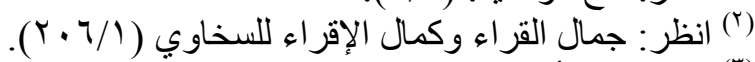

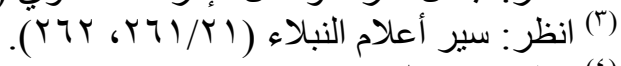

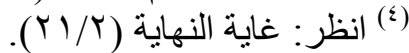

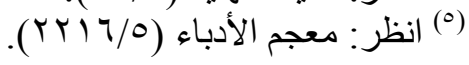




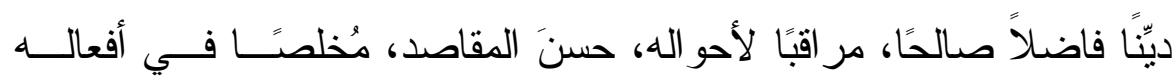

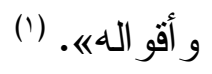

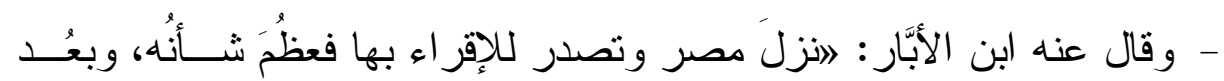

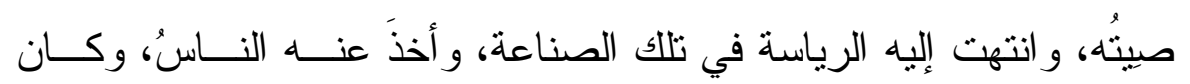

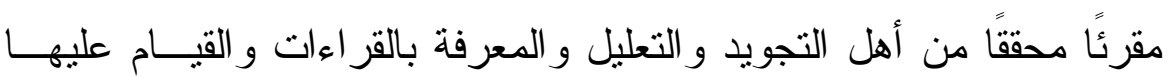

$$
\text { و الحفظ لهاه. (ن) }
$$

- ـ وقال عنه ابن الصـلاح: 》كَانَ أحد القراء المجودين، و العلماء المشهورين،

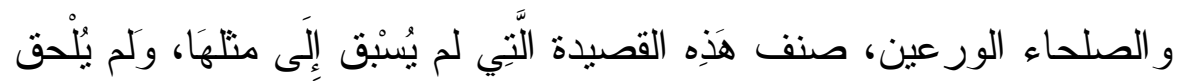

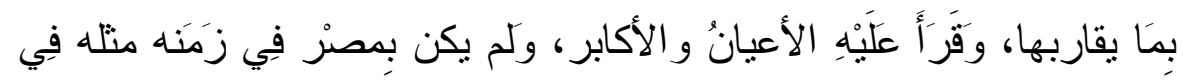
تعدد فنونه وكَتَرْة محفوظهه هذه مقتطفات من ثتاء العلماء عليه - رحمه الله تعالى -.

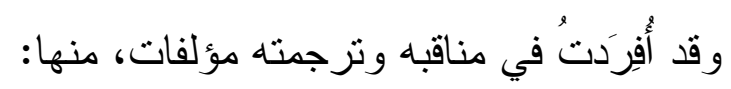

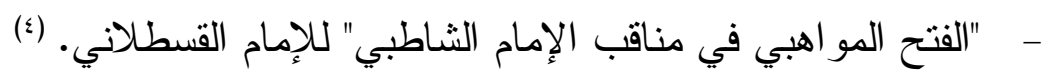

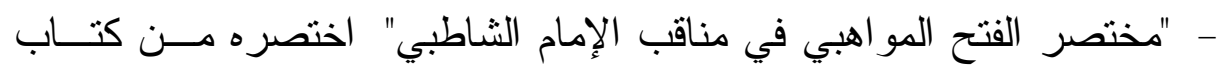

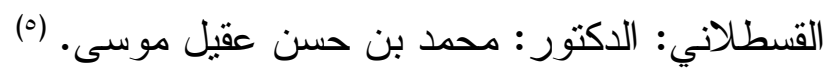
- " بغية الطالبي في ترجمة أبي القاسم الثاطبي" لفضيلة الأســتاذ الــدكتور :

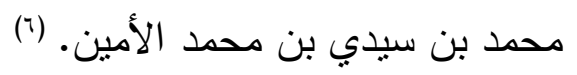

- الإمام أبو القاسم الثاطبي" للاكتور : عبد الهادي بن عبد اله حميتو. (v)

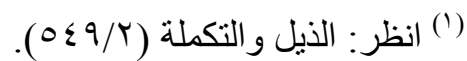

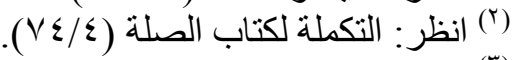

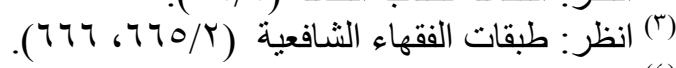

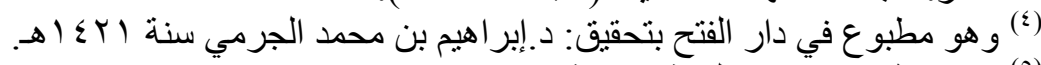

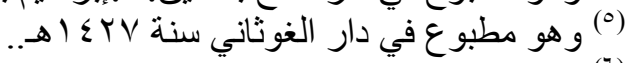

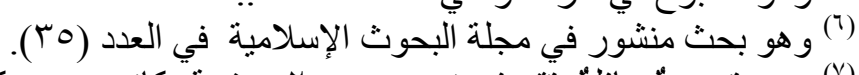

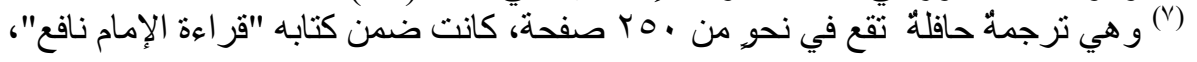




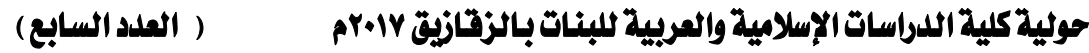

هذا بالإضافة إلى كثيرٍ من البحوث و الرسائل العلمية التي تتناولت شيئًا من

تحقيق أو در اسة شروح منظوماته، حيث لا تخلو غالبًا من نرجمةٍ له -

رحمه الله تعالى -

نافع"، ثم أفردت في هذا الكتاب الذي طبع في دار أضواء السلف سنة هبـ أهـ. 


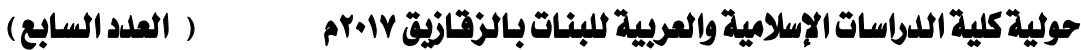

\section{الميحث الثاني: التعريف بمنظومة (ناظمة الزهر):}

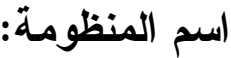

لا خلاف في أن اسمها: (ناظمة الزُّهُر) فقد نصَّ عليه ناظمها في مطلعها|(') ميث قال:

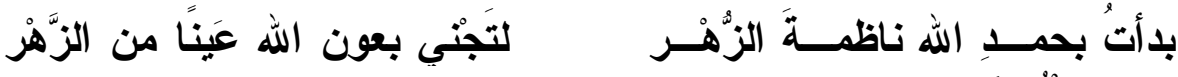

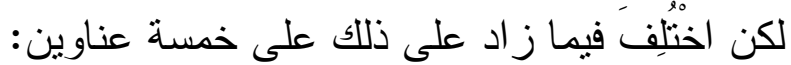

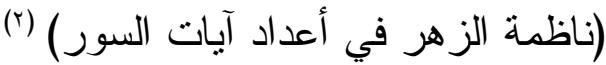

(ناظمة الزهر في عدِّ آي السور ) (ن) (ن)

(ناظمة الزهر في علم الفو اصل) (ن) (ن) (ن)

(ناظمة الزهر في عد الآي) (ن)

(ㄴ) (ناظمة الزُهْر في الأعداد، و اختلافِ أهل البلاد)

و المتأمّل لهذه العناوين يرى هذه الاختلافات ليست داخلةً في عنو ان

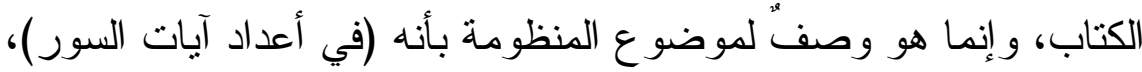
أو (في عددّ آي السُّرَ) أو (في علم الفو اصل) أو (في عدِّ الآي) وكلُّها ألفاظٌ مختلفة تؤدي إلى معنى مُتَّقِق. إلا أن العنوان الأخير - وهو إنى (ناظمة الزهُهز في الأعداد، و اختلافِ أهل البلاد)- - ربما يوحي بما فيه من السجع إلى أنه ضمن عنوان الكتاب، و الله

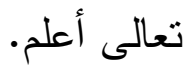

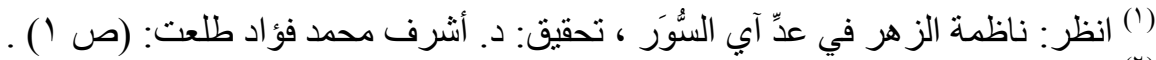

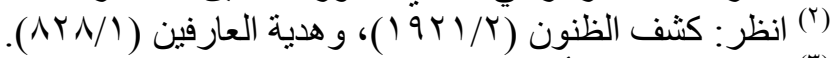

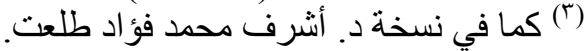

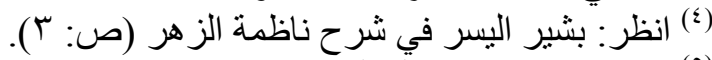

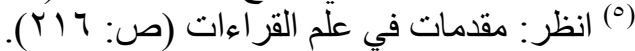

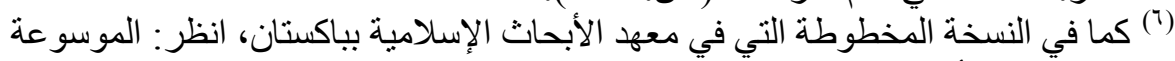

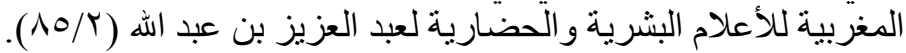


و هناك مِن العلماء مَن اكتقى بوصفها بالر ائية، كما فعل الجَبْبري في

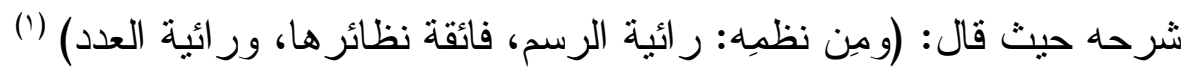

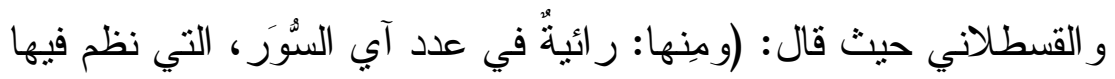

تأليف الفضل بن شاذان و ابن عمار و أبي عمرو الداني).(؟)

هذا فيما يتعلق بعنو ان المنظومة، أما مسألة ثثوت نسبتها أو نفي نسبتها

إلى الإمام أبي القاسم الثاطبي - رحمه الله تعالى - فسيأني في المباحث القادمة.

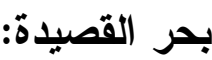

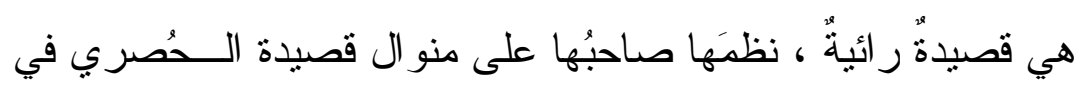

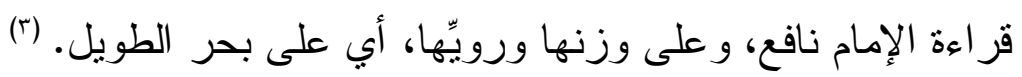

وهي بهذا تختلف عن القصيدة الر ائية المسماة (عقيلة أتر اب القصائد)

حيث إنها على بحر البسيط.

عدد أبياتها:

تبلغ أبياتُ ناظمة الزهر : مائتين وسبعةً وتسعين بيتًا. قال الناظم في آخر هاء():

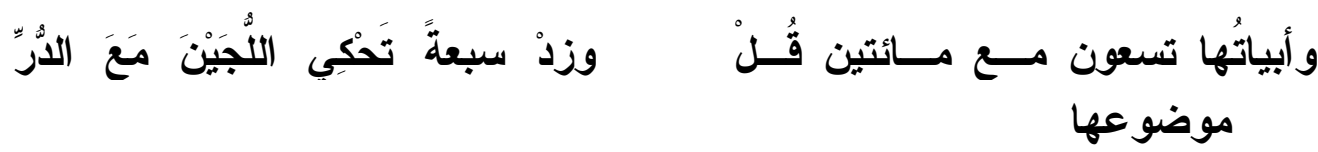

تتتاول المنظومة علم عدِّ الآي، ببيان المواضع المختلف في عدِّها، وذِكر العدد الإجمالي لعدد آيات كل سورةٍ متفق على عددها أو مختلفٍ فيه.

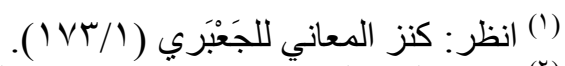

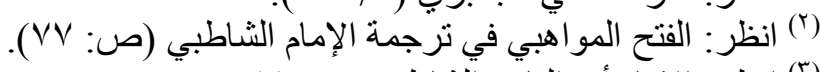

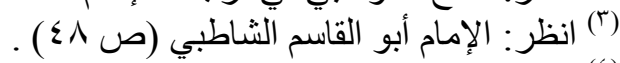

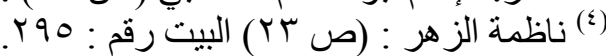




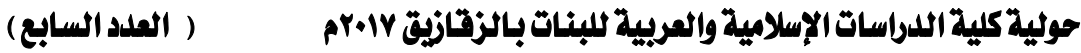

وقد نظمَ فيها صـاحبُها: الكتابَ الذي ألَّفه الفضل بن شاذان في عدد آي القرآن، مع استعانته بما جمعه ابن عمَّار وأبو عمرو الداني.

حيث قال:

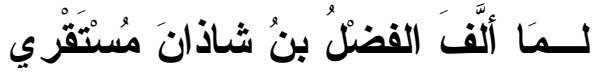

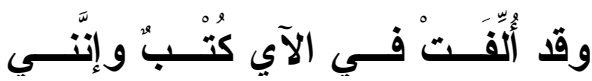

مَعَ ابن يسار ما احتَبَوْهُ على يُسنر

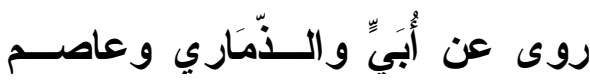

وعنه روى الكوفي، وفي الكلٍ

وما لابن عيسى ســاقَهُ فـــي كِتَابِــهِ

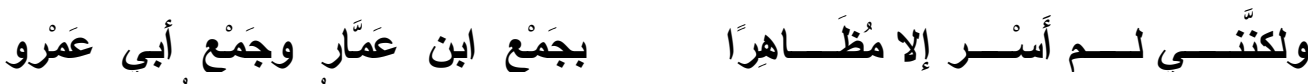

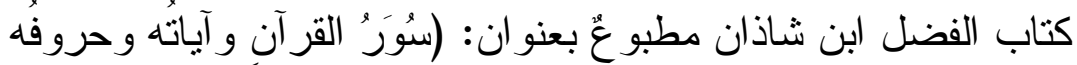

ونزولُه) (')، وفي أوله ما يوضح كلام الناظم، حيث فال: (فاتحة الكتاب:

عدَّها عطاء بن بسار ، و عاصم الجحدري، ويحيى بن الحارث الذماري، وفيما

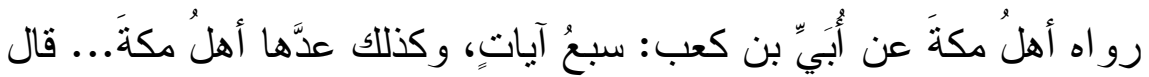

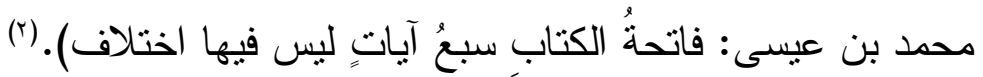
وبهذا يُعلم أنَّ ابن عيسى المذكور في ناظمة الزهر ليس هو سُّلَيم بن

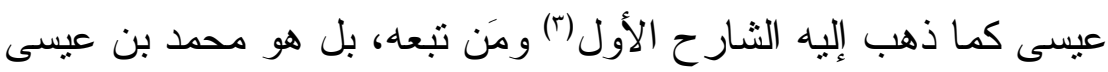
الأصبهاني كما في كتاب ابن شاذان.

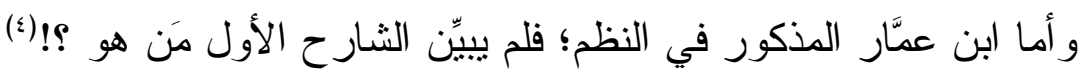
ولذلك اختلِفَ فيه فقيل: هو ( هشام بن عمار السُّلمي) يعني الراوي لقر اءة

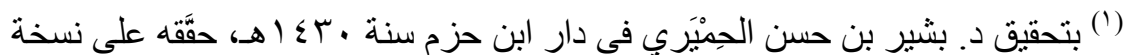

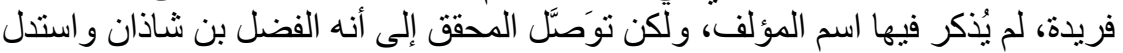

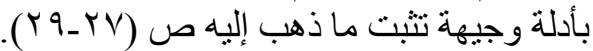

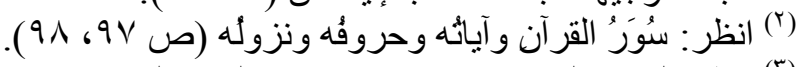

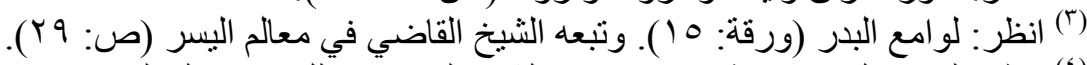

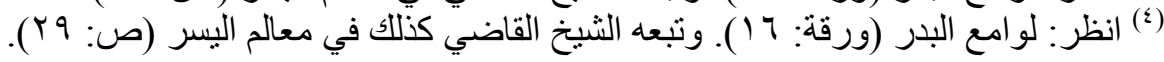

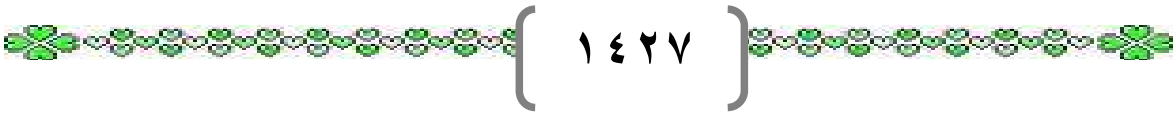




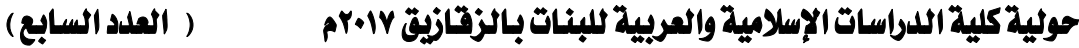

ابن عامر (')، وقيل: بل هو (أحمد بن عمار المهْدَوي). (r) ولم يتبيَّن لي على وجه القطع المقصود بابن عمَّار ، وإن كنتُ أميل إلى أنه المهُخَوبي لأنه من أقران أبي عمرو الداني ومعاصريه، بخلاف هشام بن عمَّار فهو قديم الوفاة، فيُستبعد أن يقرنه الناظم بأبي عمرو الداني، - و الله تعالى أعلم-.

\section{منهجه و اصطلاحه:}

سلك الناظم - رحمه الله- في ناظمة الز هر مسلك الاختصـار باستعمال الرموز، حيث استعملها لبيان عدد آي كل سُورة، كما استعملها أيضًا للالالة على علماء العدد.

وهذه الرموز التي استعملها الناظم، منها رموز” كلمية، ورموز” حرفية. أما الرموز الكلمية فذكرها الناظم في قوله(؟):

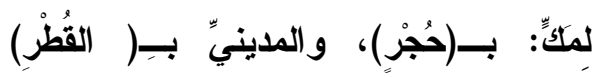

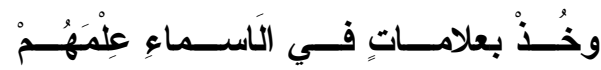
وخُذْ فيهها مَعْ صُحْبَةِ الثَامِ بــــ(الكُثْر)

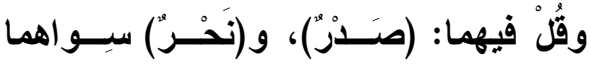
جَرَيْنَ فهُنَّ القصدُ عن عُرْفِ اوْ نُكْرِ

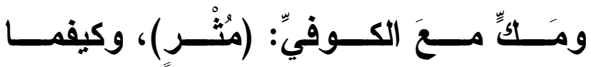
وهاكََ بيانَ هذه الرموز الكلمية: حجز : رمز به إلى العدد المكي. قظر : رمز به إلى العدد المدني، ولم يعيِّن الأول أو الأخير ، فيشمل ردل العددين. صدْز : رمز به إلى العدد المدني، و العدد المكي. نحرْ : رمز به إلى العدد الكوفي و العدد الثامي و العدد البصري. كُشْر: رمز به إلى العدد المدني و العدد المكي و العدد الثامي. 


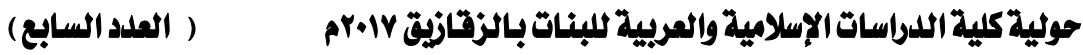

مُثْرِ: رمز به إلى العدد المكي و العدد الكوفي. (')

وأما الرموز الحرفية التي رمز بها الناظم إلى علماء العدد فهي الحروف الستة الأولى من حروف (أبجد هوز) كما نصَّ عليها بقوله(r):

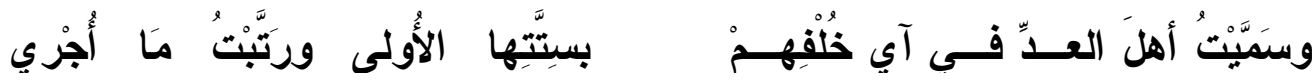

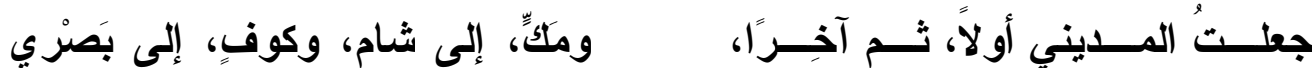

$$
\begin{aligned}
& \text { فتكون الرموز الحرفية لعلماء العدد كالآتي: } \\
& \text { 1- (أ) : رمز به إلى المدني الأول. } \\
& \text { r- (ب): رمز به إلى المدني الأخير. } \\
& \text { r- (ج) : رمز به إلى المكي. رمز إلى } \\
& \text { ع - (د): رمز بـه إلى الثامي. } \\
& \text { - - (0) : رمز به إلى الكوفي. } \\
& \text { צ- (و): رمز به إلى البصري. (َ) }
\end{aligned}
$$

وأما الرموز التي استعملها الناظم لبيان عدد آيات كل سورة:

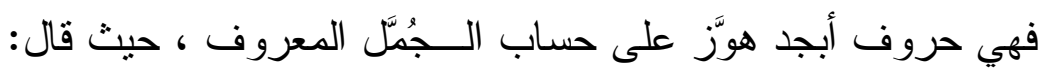

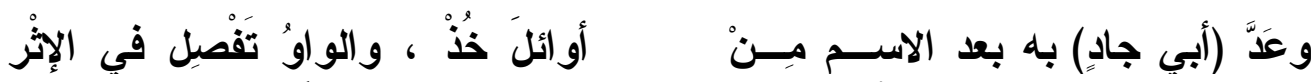

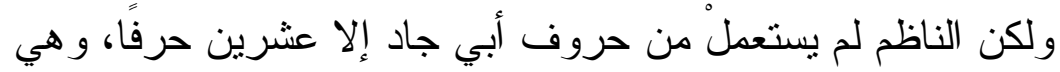

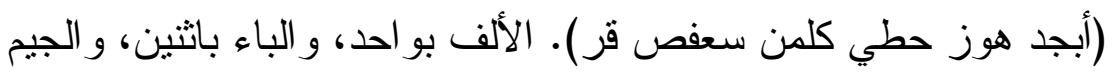

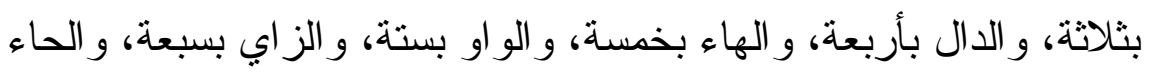
بثمانية، و الطاء بتسعة، و الياء بعشرة، و الكاف بعشرين، و اللام بثلاثين، و الميم بأربعين، و النون بخمسين، و السين بستين، و العين بسبعين، و الفاء

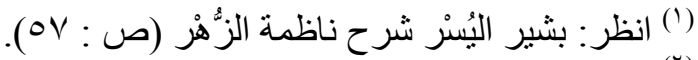

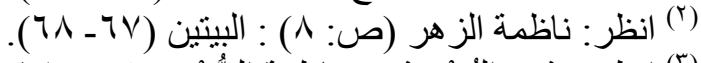

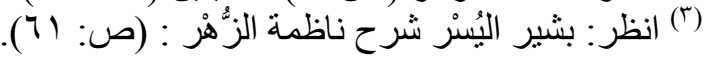




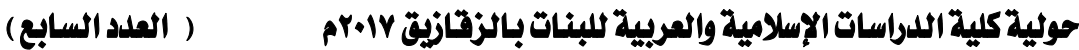

بثمانين، و الصاد بتسعين، و القاف بمائة، و الر اء بمائتين. ولم يَزْْ على هذا؛

لأنه لم يَصِيل عددُ سورةٍ من سور القرآن إلى ثلاثثائة آية. (')

تقسيمات المنظومة

تتقسم ناظمة الزهر إلى أربعة أقسام:

القسم الأول: مقدمة المنظومة.

وتقع في (ع ب) بيتًا، بدأها الناظم بقوله:

لتَجْنِي بعون الله عينًا من الزَّهز

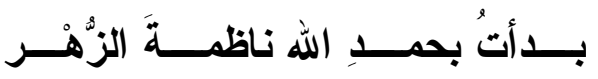

وختمها بقوله: - 2 - ولهم

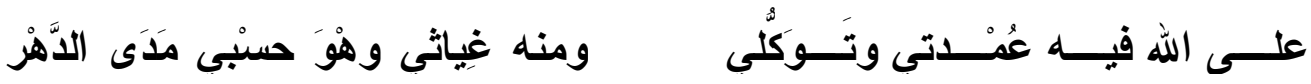

القسم الثاني: بابٌّ في عِلم الفو اصل والاصطلاحات والأسماء وغيرها.

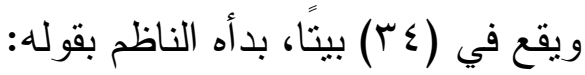

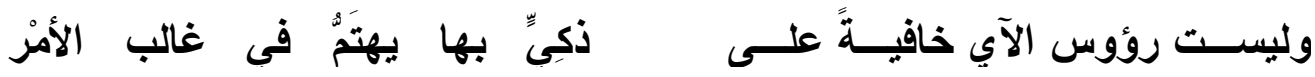

وختمها بالرموز الحرفية لعلماء العدد فقال:

ومكَّة، إلى شـام، وكوفِ، إلى بَصنزي

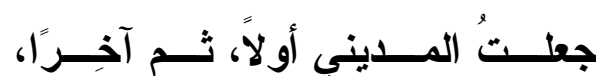

القسم الثالث: سُوَر القرَآن الكريم

بدأ فيه الناظم بسورة الفاتحة فسورة البقرة ، وهكذا إلى آخر القرآن

العظيم، يذكر في كل سورةٍ عددَها، وما فيها من اختلاف علماء العدد. ويقع

هذا القسم في (Y Y م بيتًا.

القسم الرابع - والأخير - : خاتمة المنظومة.

وتقع في أربعة أبياتٍ ختم بها الناظم قصيدته فقال:

$$
\text { (1) (انظر : المرجع السابق : (ص: O1). }
$$




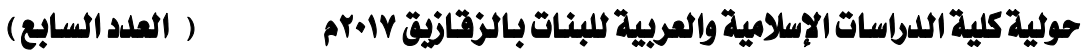

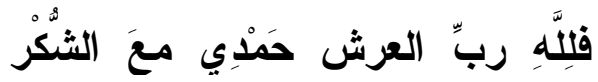

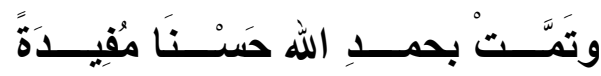

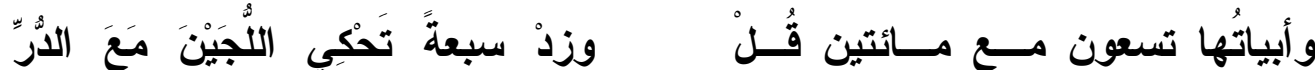

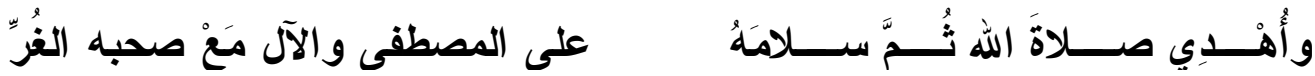

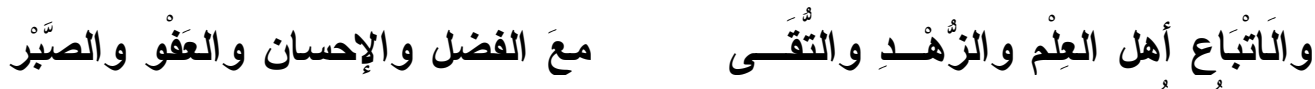

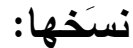

أولاً النُسَخْ المخطوطة: وقفتُ في الفهرس الثامل على بيانات سبع نُسخ مخطوطة من (ناظمة

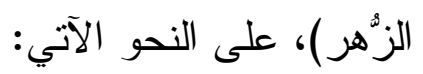

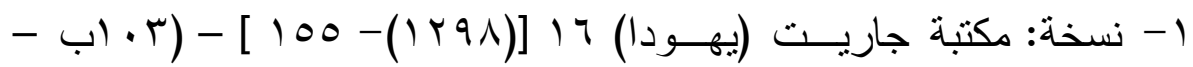

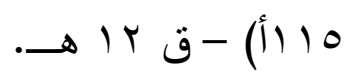

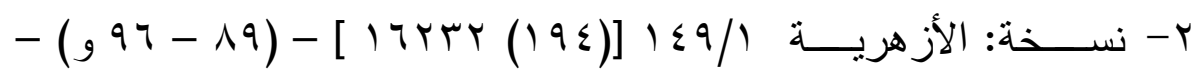

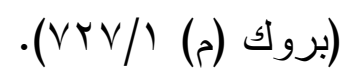

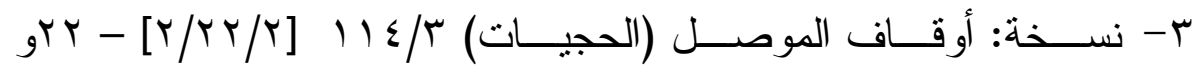

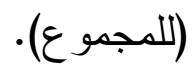

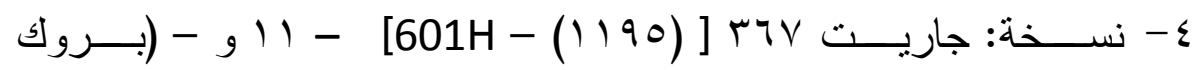
$\left.\cdot(\circ)^{\prime} /\right)$

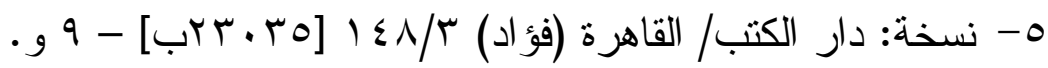

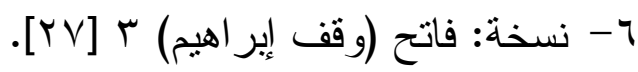

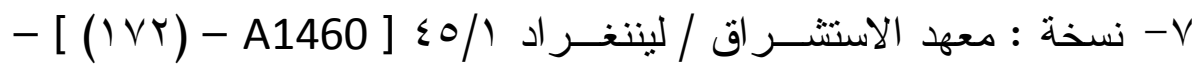
(). $(\varphi \wedge r-19)$

(1) الفهرس الثامل للتراث العربي الإسلامي المخطوط (مخطوطات التفسبر و علومه) : (r) $(r \cdot 9 / r)$ 


$$
\text { وقد وقفتُ على نسخة ثامنة غير ما ذُكرَ، وهي: }
$$

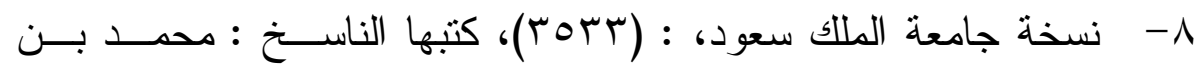
يوسف الدفر اوي الدسوقي، وقال في آخرها: (وكان الفراغ من كتابة هــذه

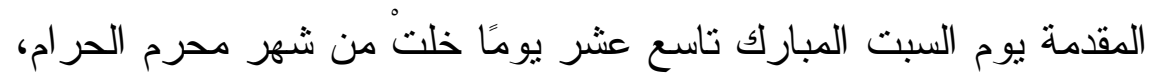

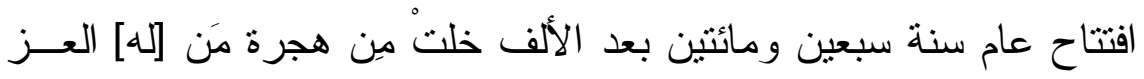
و الثرف: محمدٍ صلى الله علي وسلم، على يد كاتبها الفقير إلى اله تعالى:

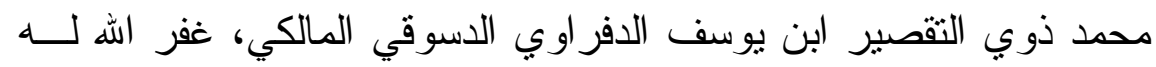

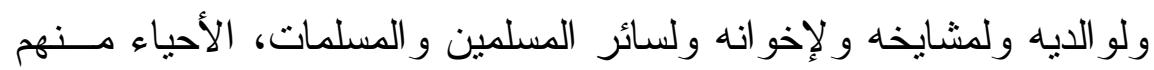

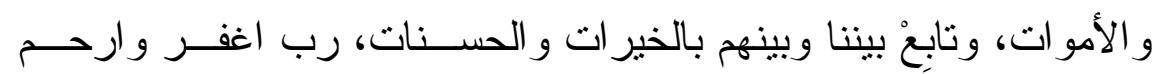

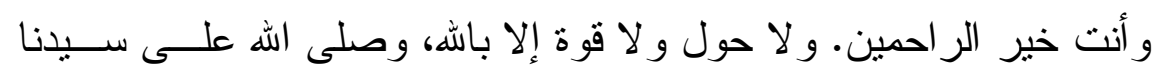
محمد و على آله وصحبه وسلم تسليمًا كثيرًا، و الحمد لله رب إلا العالمين). ثانيًا: النستخ المطبوعة:

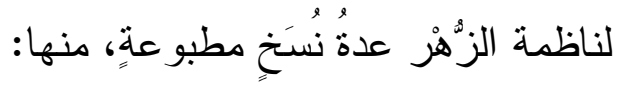
- نسخة ضمن (إتحاف البررة بالمتون العشرة) جمــع ونزتيــب وتصـــيح

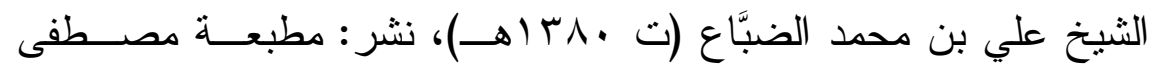

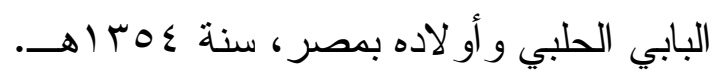
- نسخة، بتحقيق وضبط الثيخ محمد صادق قمحاوي، نشر : مكتبة ومطبعة

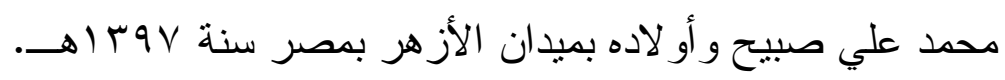
- نسخة، بتحقيق: د. أثرف محمد فؤاد طلعت، نشر : مكتبة الإمام البخاري

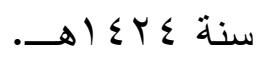
- نسخة : بتحقيق د. بشير بن حسن الحِمِيْري. (') -

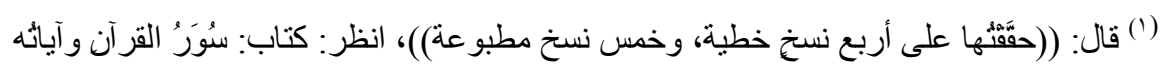

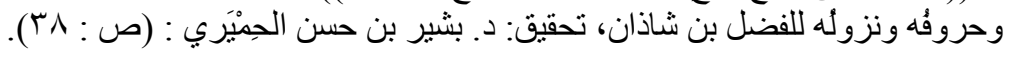




\section{شروحها:}

1- (لوامع البدر في بستان ناظمة الزُهُ ) للثيخ عبد الله بـن صــالح بــن

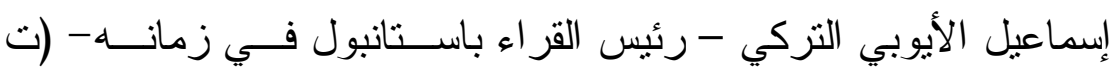

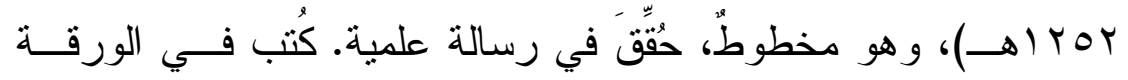

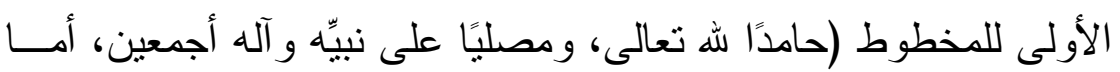

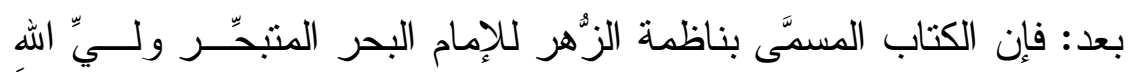

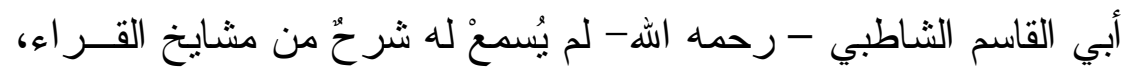

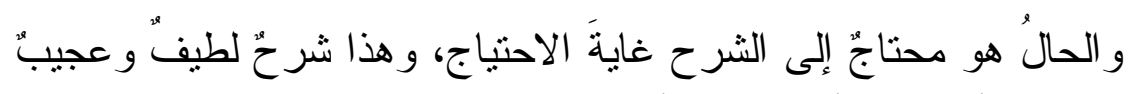

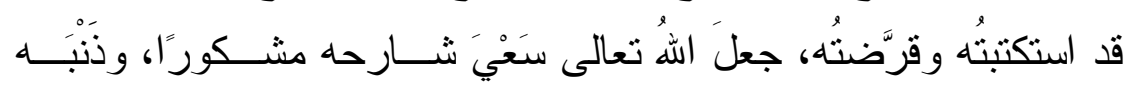

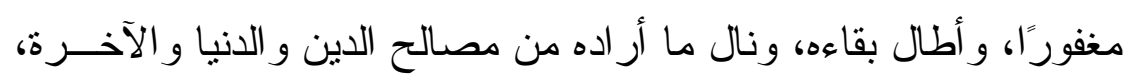
و غفرَ لآبائه و أجداده و أساتيذه من القر اء و غير هم أجمعين آمين. الحقيــر

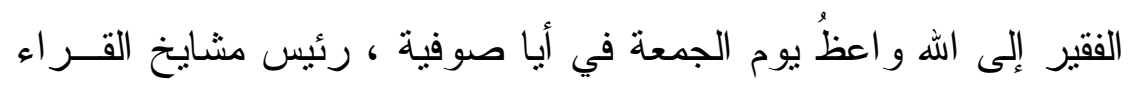
في وقته: شيخ فيض الله، سنة r T I ). و وقال المؤلف في مقدمة شرحه

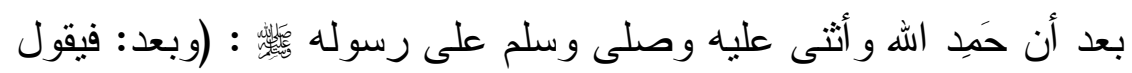

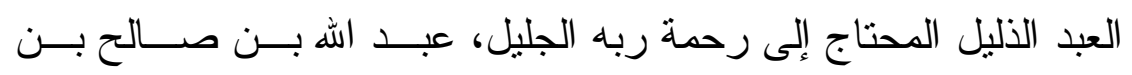
إسماعيل، المفتخر بخدمة الإمام في الجامع العالي، المنسوب إلى جَنَّابِ

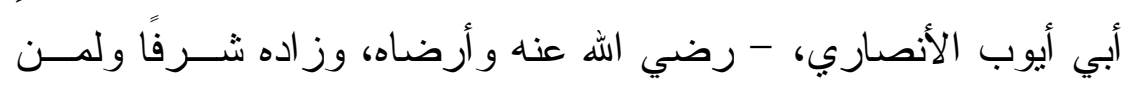

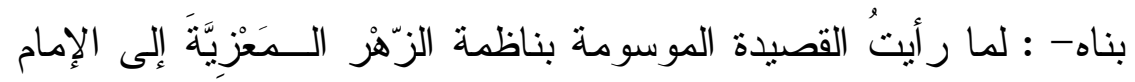

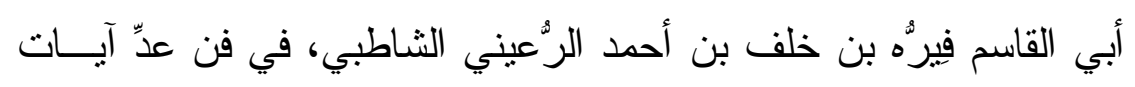

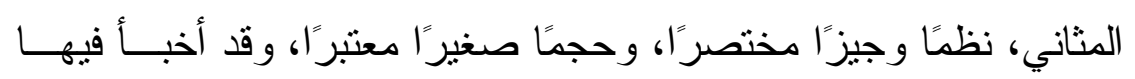

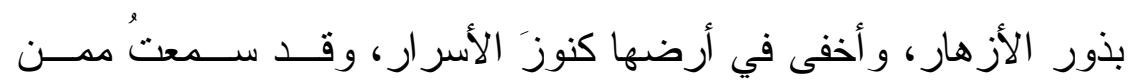

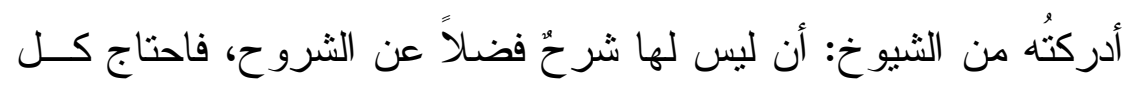

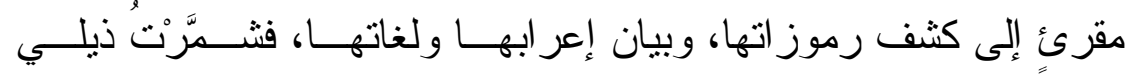


لاجتناء عيونها، وبذلتُ جُهدي لفتح كنوزها...)) إلى أن فال: ((وسمَّيتهُ:

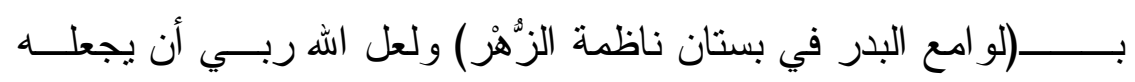

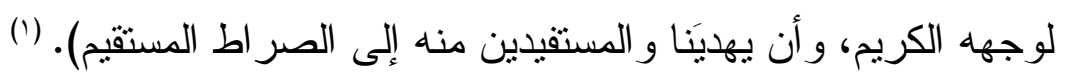

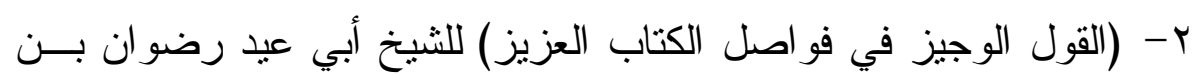

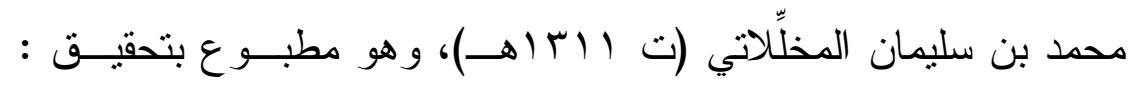

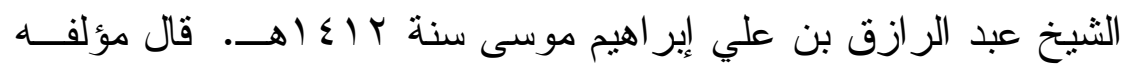

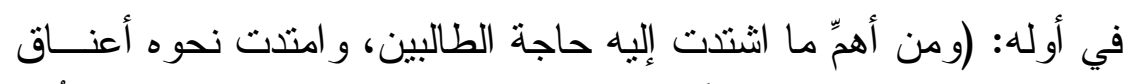
المهرة من الر اغبين: ما تعلَّقَ بمعرفة فو اصل الآيات ومبادئها، وما اتُّقِقَ

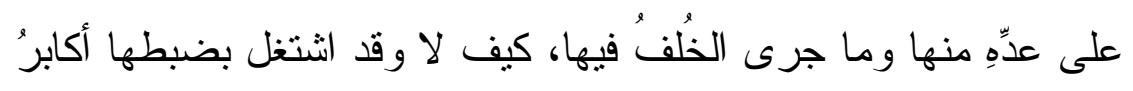

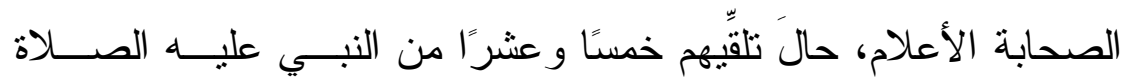

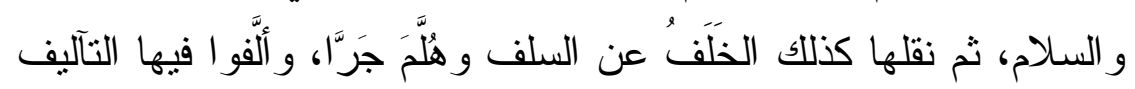

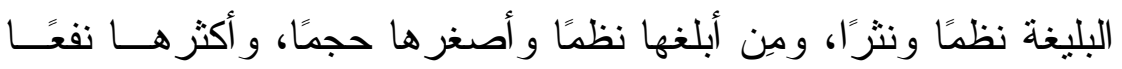

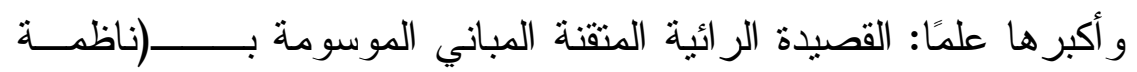

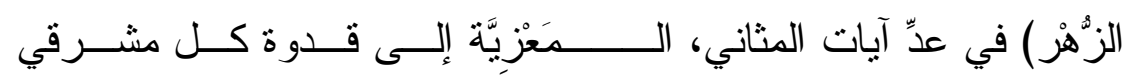

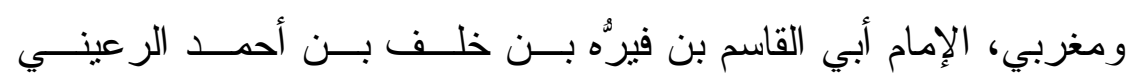
الثاطبي) ... إلى أن قال: (حيث لم أقف على شرحٍ لها يزيل الإثـــال،

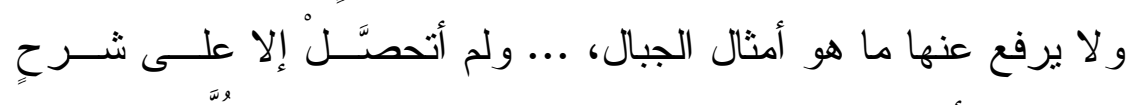

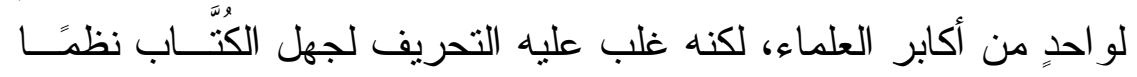

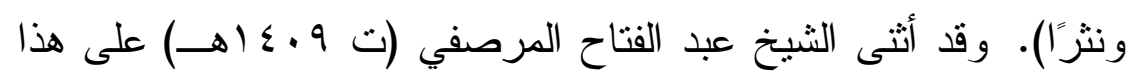

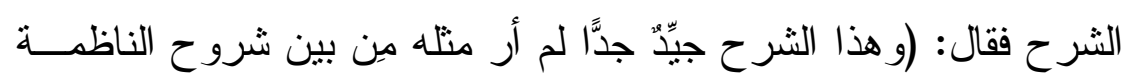

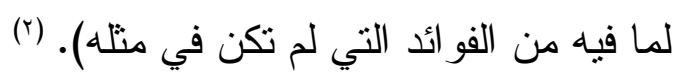




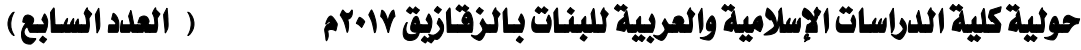

r- (شرح ناظمة الزُّهُ ) للثيخ موسى جار الله الروسي (ت 97 (هــــ، وهو مخطوط.

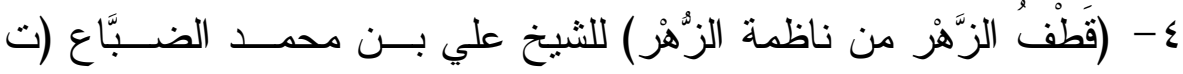

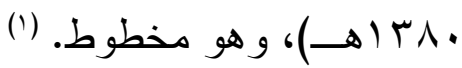

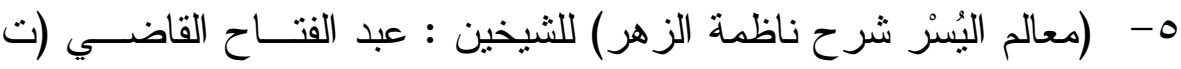

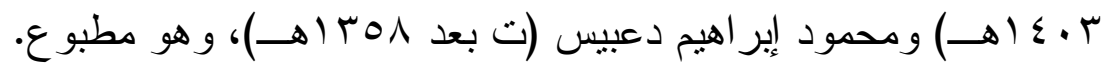

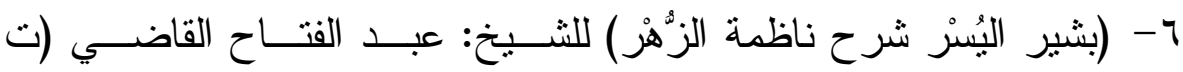
r +ـ (اهـ)، وهو مطبوع قديمًا في المكتبة المحمودية(r)، ذكر مؤلفه في

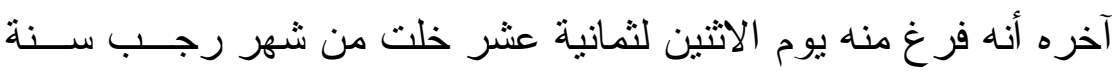

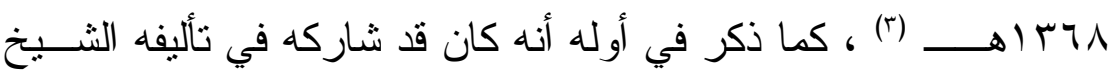

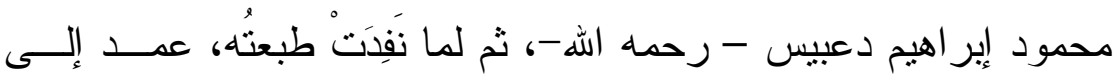

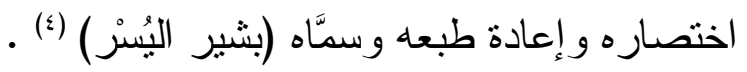
-V (شرح ناظمة الزهر) تأليف: محمد بن أحمد بن حسن بن أحمد سعيد بن زيد الصنعاني (ولد سنة I IVV

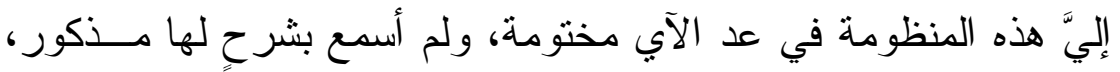

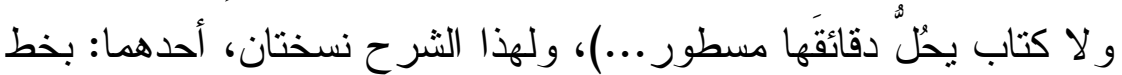
المؤلِّف و عليها تقريظ شيخه علي بن أحمد الثرفي شيخ الإقــر اء فـــي ولي اليمن في عصره، و الأخرى: بخط أحد تلاميذه.

(1) ذكره الثيخ عبد الفتاح المرصفي في هداية القاري (T/ (T) (T).

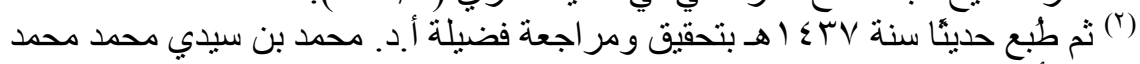

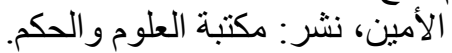

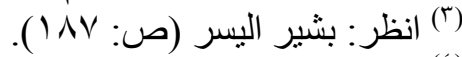

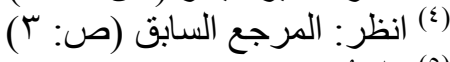

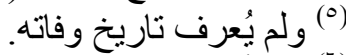

(?) كما أفاد بذلك الثيخ محمد سعيد بكران (أبو إسحاق الحضرمي) في ملتقى أهل التفسير.

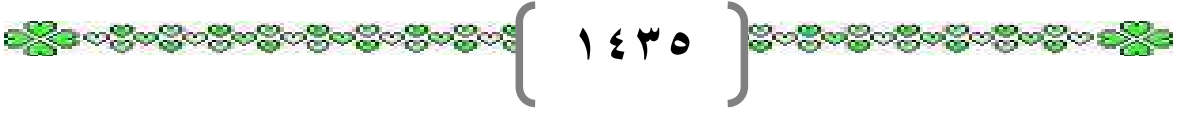




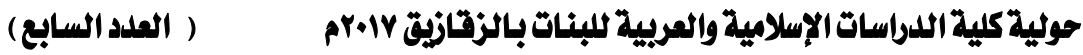

و أما كتاب (أفضل الدرر شرح القصيدة الر ائية) للشيخ: قارئ حفظ الرحمن بن عبدالثكور (ت ری ب اهــ) (') فيحتمل أن يكون شرحًا لر ائية

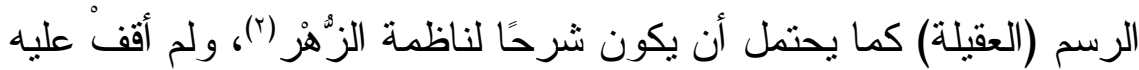
لأذكر ذلك على وجه القطع و التعيين.

\section{الميحث الثالث: فيما يؤيد نسيتها إلى الإمام أيي القاسم الشاصلي}

ا ـقال الجعبري (ت r r TMـ) في ترجمة الإمام أبي القاسم الثاطبي: (ومين

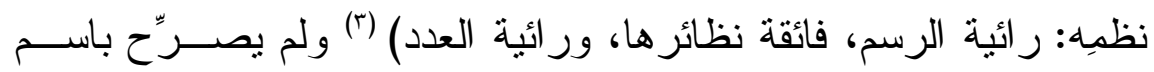
المنظومة.

r.وردت منسوبةً إلى الإمام الثاطبي - رحمه الله- ضمن الأسئلة التبريزية

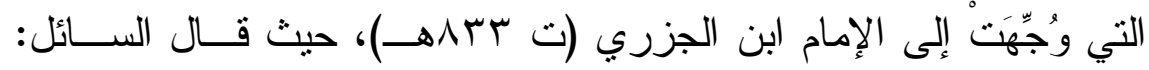

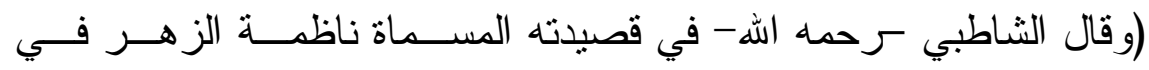

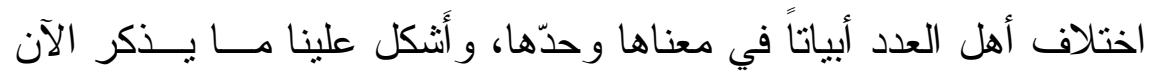

$$
\text { (๕) • منها... (إلخ) }
$$

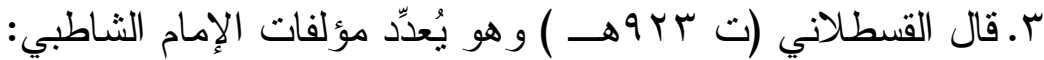
(ومنها: رائيةٌ في عدد آي السور، التي نظم فيها تأليف الفضل بن شاذان، و ابن عمَّار ، و أبي عمرو الدَّاني، و وأوُّكها:

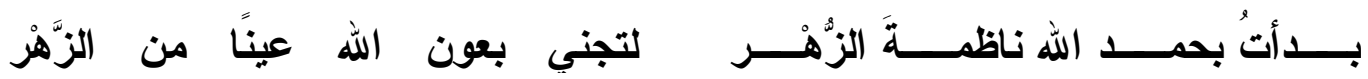

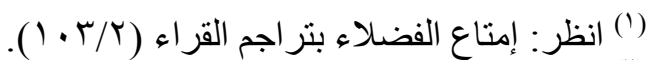

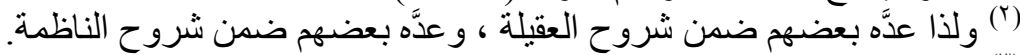

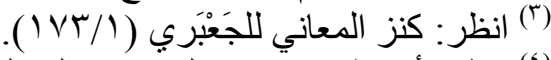

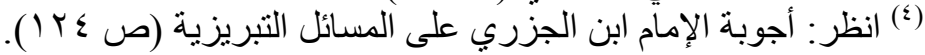




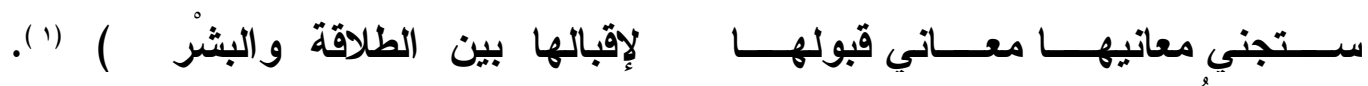

ذُكرت هذه المنظومة في فهارس الكتب ضمن تآليف الإمام الثاطبي.

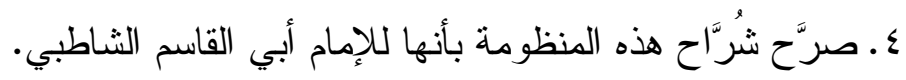

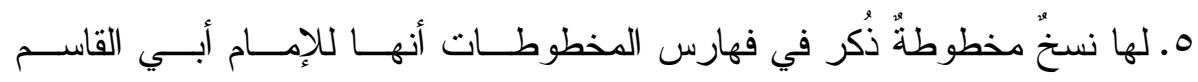
الثاطبي.

7. تشبه صنيع الثشاطبي في الحرز و العقبلة، كمـــا فـي اســتعمال رمــوز كلميــة

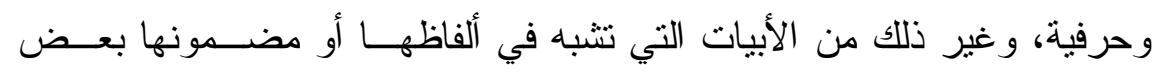

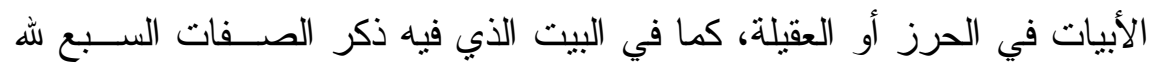

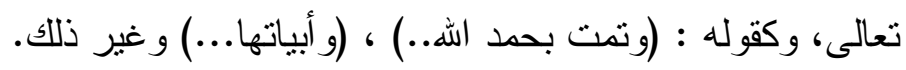

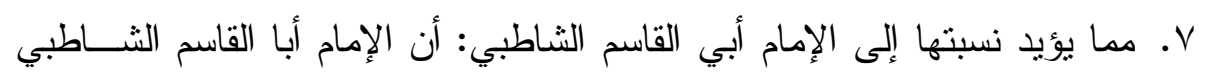

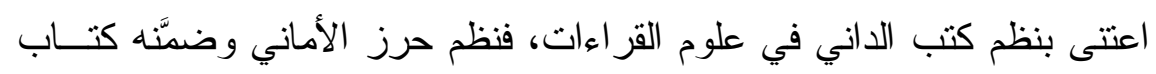

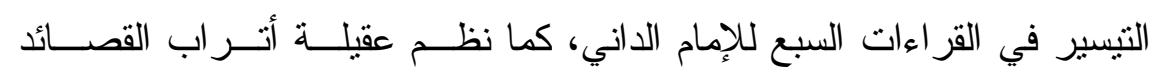

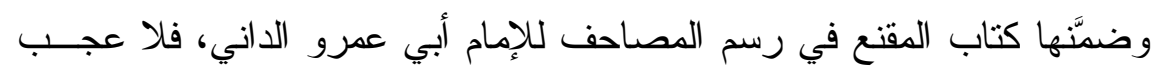
أن ينظم ناظمة الزهر ويضدنها كتاب البيان في عد آي القرآن للداني!.

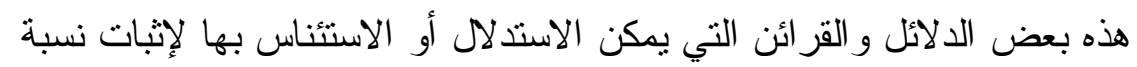
(ناظمة الزهر) إلى الإمام أبي القاسم الثاطبي.

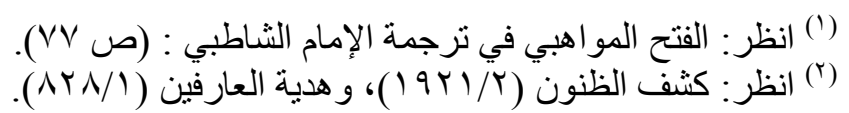

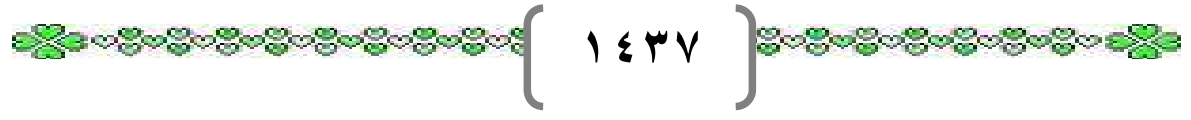




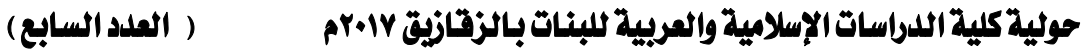

\section{الميحث الرايع: ما يُستحل يه على عدم ثيوت تسيتها إلى الإمام الشاطيي}

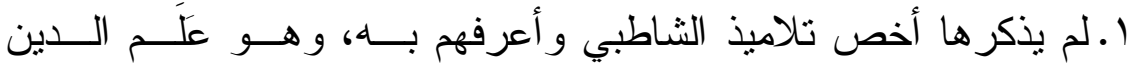

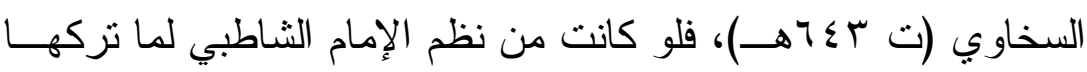
تلميذه البارِ" السخاوي الذي لم يُخفل ذِكر البيتين و الثنلاثة من نظم شيخه، فكيف يُهمل ذِكر ناظمة الزهر التي تبلغ زهاء ثلاثمائة بيت!، و المقــام مقام استقصاء و إطناب في إظهار فضائل الإمام الثاطبي و آثاره.

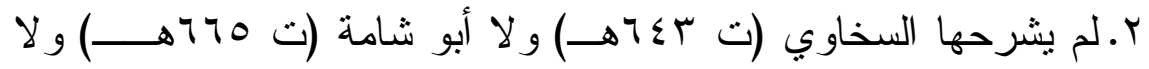

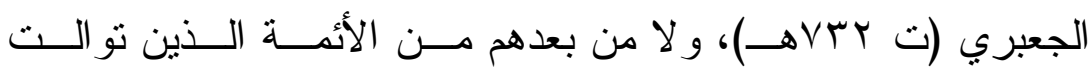

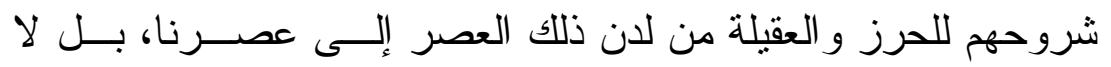

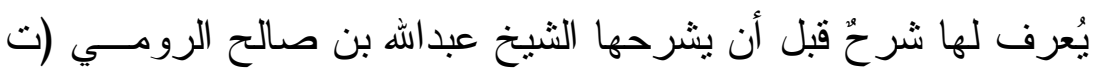

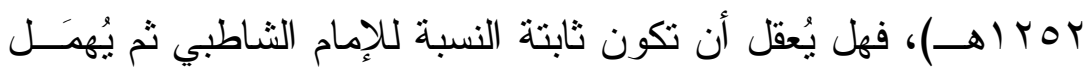
شرحها طو ال تلك القرون!.

r.لم يذكر ها الإمام ابن الجزري في كتابه غاية النهاية، مع عنايته بــذكر

منظومات في عدد الآي لمؤلفين أقل شهرة من الإمام الثاطبي. (')

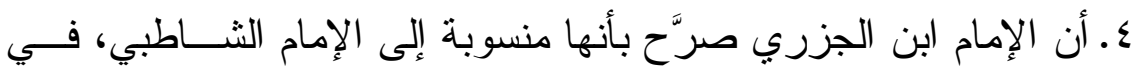
أجوبته عن المسائل التبريزية، حين أجاب عن قــول الســائل: (وقــال الثاطبي كرحمه الله - في قصيدته المسماة ناظمة الزهر ... إلخ)، فقال الإمام ابن الجزري: (وأما السؤال عن أبيات ناظمة الزهر التي نُســبت

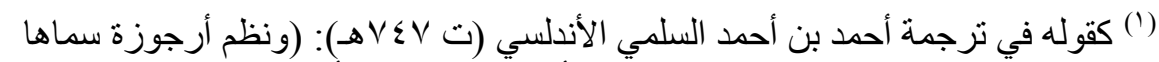

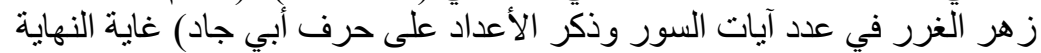

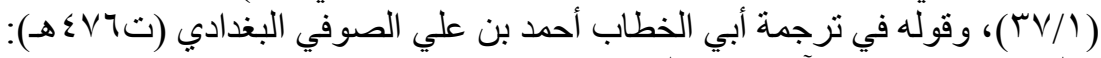

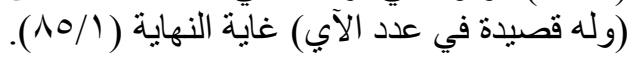




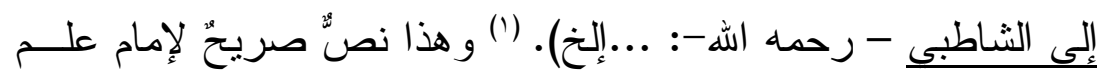
القر اءات الإمام ابن الجزري في أن هذه المنظومة منسوبة إلى الإمــام الثاطبي، وليست ثابتة النسبة إليه. و هذا - كما نزى - دليل قوي.

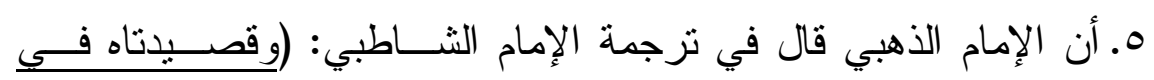

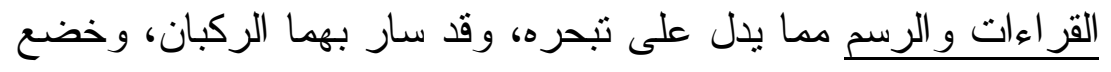

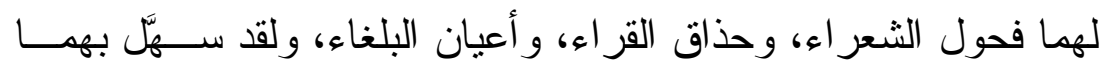

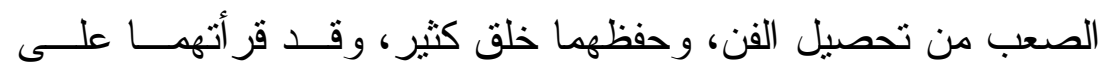

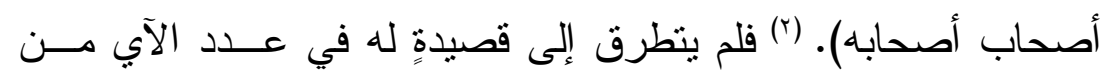

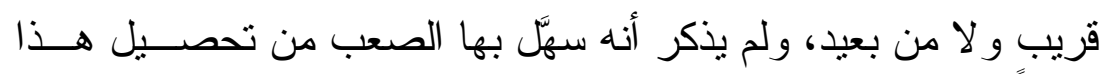
العلم، ولم يُشِير إلى أن أحدًا قر أها عليه و أقر أها مَن بعده.

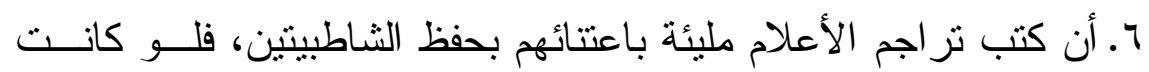

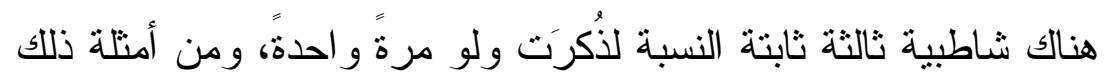
أن شمس الدين السخاوي ذكر في الضوء اللامع أكثر من تسعين عَمًَا حفظوا الثاطبيتين، يعني اللامية في القراءات و الر ائية في الرسم، ولم

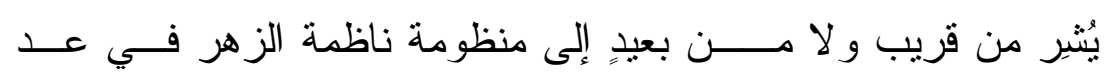

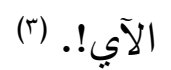
V. أن الثاطبيتين (الحرز و العقيلة) ذُكرت لهما أسانيد متصلة إلى الإمــام

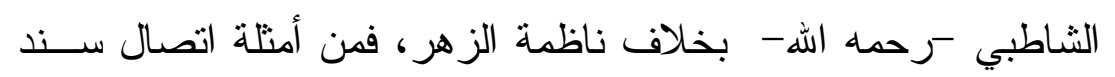
الثاطبيتين بالإمام الثاطبي: ما ورد في ترجمة الحسن بن عبد الكريم

(1) (انظر : أجوبة الإمام ابن الجزري على المسائل التبريزية (ص ب آ (1).

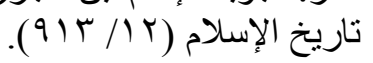

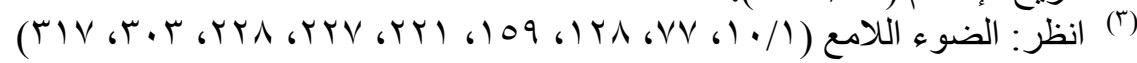
و غير ها كثير. 
الغماري المعروف بسبط زيادة (وسمع الشاطبيتين من أبــي عبــــ الله القرطبي تلميذ الثاطبي) (')، ومنله ما ورد في ترجمة علي بن أبي بكر بن سبع المكناسي: (و أخذ أيضًا عن بدر الدين ابن جماعة الثــاطبيتين

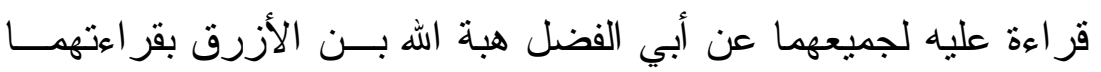
عليه عن المؤلف كذلك).(r) وقال الحافظ ابن حجر: (القصيدة الثاطبية الشاطبية وهي حرز الأماني لأبي القاسم الثاطبي، قر أتها على الثــيخ أبي إسحاق التتوخي بسماعه لجميعها على القاضي بدر الدين محمد بن

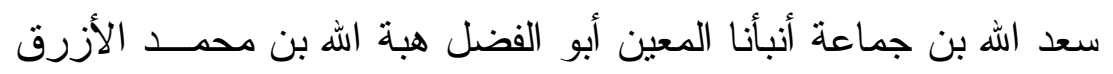

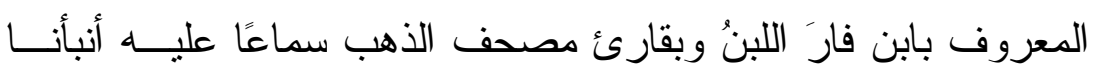

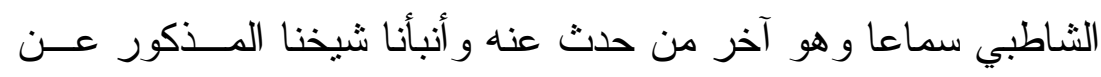

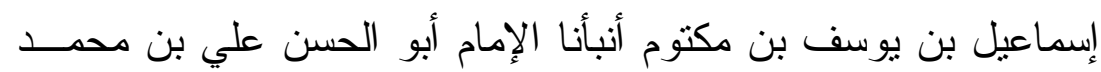

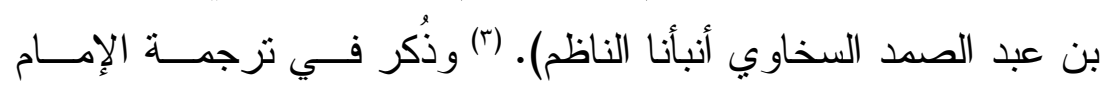

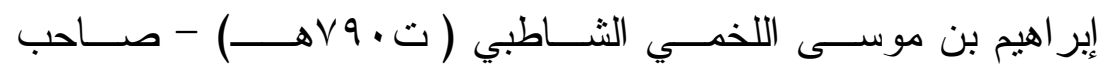
المو افقات- (و أما الثاطبية فحدثه بها عن الثيخ ابن مز احم المـذذكور قر اعة بحق قر اعته على بدر الدين ابن جماعة بقر اعته لها على هبة الله

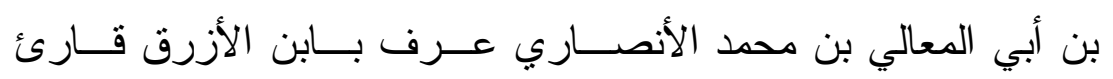

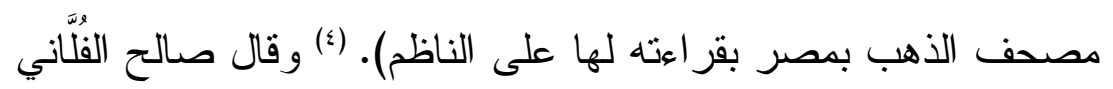
في ثبته قطف الثمر : (الثشاطبيتان: أرويهما قر اءة بسند الموطأ الى ابن مرزوق الحفيد عن جده الخطيب عن أحمد بن محمد الحنبلي عن أبـي

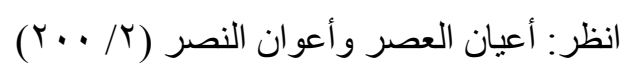

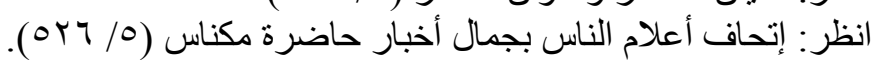

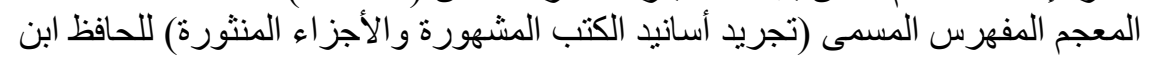


الحسن بن شجاع صهر الثشاطبي عن المؤلف أبي القاســـــــن فيـرة

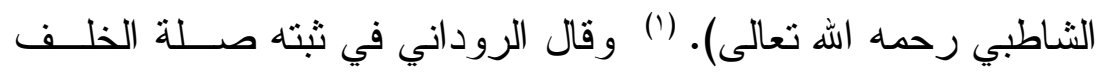

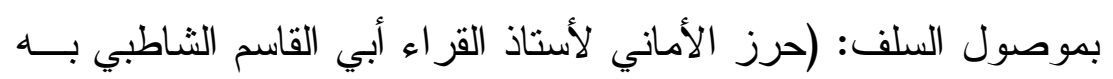

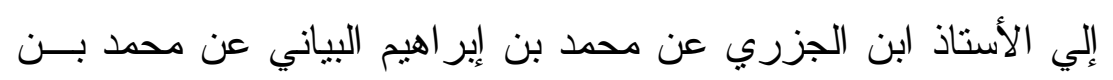
إبر اهيم بن سعد الله الحموي عن أبي الفضل محمد بــن هبـــة الله بـن الهن

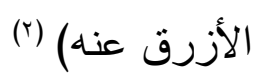

فهل لناظمة الزهر أسانيد إلى الإمام الثاطبي منل هذه الأسانيد؟!.

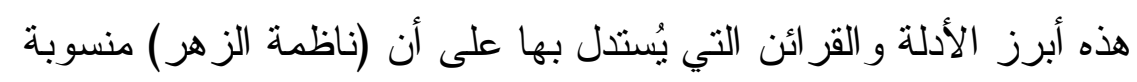
إلى الإمام الثاطبي - رحمه الله-، وليست ثابتة النسبة إليه

\section{الميحث الخامس: الراجح من القولين}

بالنظر إلى أدلة الفريقين يتبين أن أعدل القولين و أقربهها للصواب القول بأن (ناظمة الزهر) منسوبةٌ إلى الإمام الشاطبي، وليست ثابتة النسبة. وذلك لما يلي:

- أن (ناظمة الزهر) لم تُذكر -فيما اطلعتُ عليه- في شيء من الكتب و المر اجع إلى عصر الجعبري (ت بrVهـ)، حيث أثنار إليها إثشارةً فقال: (رائية العدد) ولم يُسَمِهِا.

- أن السائل في المسائل التبريزية لما نقل منها أبياتًا سأل عنها الإمام ابن الجزري (ت بr/هــ) وقال في مسألته: (وقال الشاطبي رحمه الله) ،

$$
\begin{aligned}
& \text { (1) قطف الثمر في رفع أسانيد المصنفات (ص: ع ؟Y) (Y). } \\
& \text { (T) صلة الخلف بموصول السلف (ص: (Y) (Y) (Y). }
\end{aligned}
$$




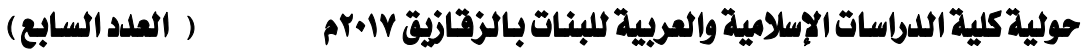

\section{أجاب عنه الإمام ابن الجزري قائلاً : (ناظمة الزهر التى نُسبت إلى}

الثشاطبي). فإذا لم تثبت نسبتها لدى إمام علم القر اءات بلا مناز ع فكيف

$$
\text { نثتبها بناءً على قول غيره! }
$$

- أن القسطلاني (ت بrوهــ) عندما ذكرها ضمن مؤلفات الإمام الثاطبي فقال: (ر ائية في العدد)، إنما تبع في ذلك الجعبري. - أن هذه المنظومة لا يُعرف لها إسناد إلى المؤلف - فيما اطلعتُ عليهبخلاف الثاطبيتين (الحرز و العقيلة)، التي سارت بهما الركبان. - أن هذه المنظومة لا يُعرف لها شرحُ من لان عصر الإمام الثناطبي الذي نُبت إليه إلى أثثاء القرن الثالث عشر حين شرَحَها الثارح الأول الثيخ عبد الله بن صالح الأيوبي (ت ror I اهـ) وكان مما قال في مقدمة شرحه

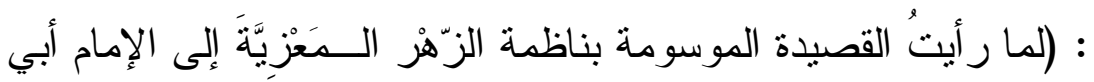
القاسم فِيرهّ بن خلف بن أحمد الرُّعيني الثناطبي) وقد تقدم قوله هذا عند ذكر شروح ناظمة الز هر ، و الذي يعنينا هنا قوله (الــــعْيَّةَ ) وكذا قال الثيخ المخلاتي (ت الاس اهــ) ، و لا يخفى أن معنى (الـــعْزِيَّة): المنسوبة، فهي منسوبة إلى الإمام الثاطبي رحمه الله، فاستدلال المثتنين لنسبتها إلى الإمام الثاطبي بشرح الثيخ الأيوبي هو في الحقبقة دليل عليهم لا لهم.

و لا شك أن عدم ذكر هذه القصيدة التي هي نظير عقبلة أتر اب القصائد في الحجم، وتقوم مقامها في علم عد الآي كما قامت تللك في علم الرسم؛ يُتئير في النفس الثكك، فكيف يُهمِلُ ذِكْرَها ويدعُ مجردَ الإشارة إليها الإمامُ عَلَم 
الدين السخاوي (التلميذ البارّ للإمام الثاطبي) الذي ما ترك من آثار شيخه شيئًا إلا ذكره، حتى إنه ذكر البيتين و الثناثة ونحو ذلك في نرجمة شيخه في أول شرحه فتح الوصيد، و اعتنى بالثاطبيتين فشر ح القصيدة اللامية (الحرز) في القر اءات في كتابه (فتح الوصيد)، وشرح القصيدة الرائية (العقيلة) في كتابه (الوسيلة)، بينما لم يشر ح ناظمة الزهر ، بل لم يعرِّج عليها، بل لم يُشِرْ

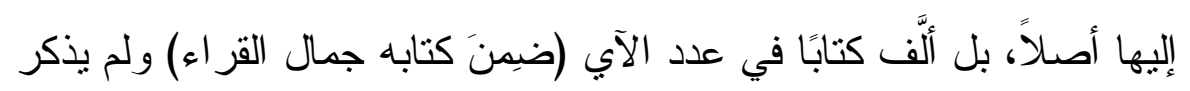
شيئًا عن ناظمة الزهر، فلو كانت ناظمة الزهر من نظم شيخه الثاطبي فهل يُعقل أن يُعرض عنها كل هذا الإعر اض، ويتجاهلها هذا التجاهل! إن إهمال ذكر ناظمة الزهر ونقلها ورو ايتها وشرحها من قِيَل المقرَّبن

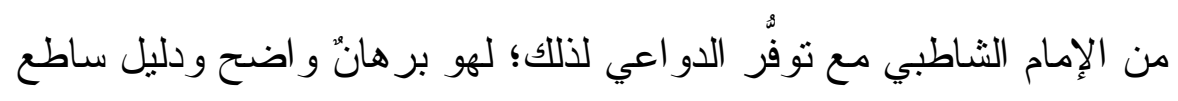
على أنها ليست للإمام الثاطبي، فالإمام الشاطبي لـ يكن من القر اء

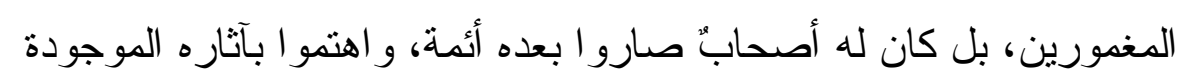
و المفقودة مثل القصيدة الدالية في نظم التمهيد، بل لم يُغفلو البيتين و الأربعة من الأبيات التي نظمها الإمام أبو القاسم الثاطبي. إنه الإمام الثاطبي الذي سارت بقصيدتيه الركبان كما قال الإمام الذهبي: (وقصيدتاه في القر اءات و الرسم مما يدل على تََحَرُه، وقد سار بهما الركبان، وخضع لهما فحول الشعر اء، وحذاق القراء، و أعيان البلغاء، ولقد 


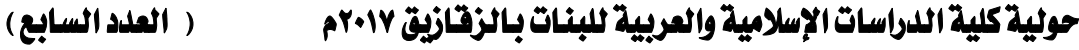

سهُّل بهما الصعب من تحصيل الفن، وحفظهما خلْقُ كثير ، وقد قر أتُهما على

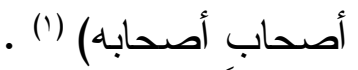

وقال عنه الإمام ابن الجزري: (ومَن وقفَ على قصيدتيه؛ عَلَِّ مقدار ما آتاه الله في ذللك، خصوصنًا اللاميةً التي عجز البلغاءُ مين بعده عن معارضتها، فإنه لا يعرف مقدارها إلا مَن نظم على منو الها أو قابل بينها

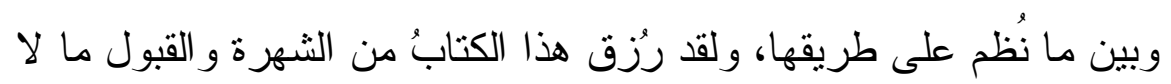
أعلمه لكتاب غيره في هذا الفنّ، بل أكاد أن أقول: و لا في غير هذا الفنّ!، فإنني لا أحسب أن بلدًا من بلاد الإسلام يخلو مِنه بل لا أظن أن بيت طالب علم يخلو من نسخة به، ولقد تتافس الناسُ فيها ور غبو ا مِن اقتتاء النُّنَخ الصحاح بها إلى غايةٍ حتى إنه كانت عندي نسخةٌ باللامية و الر ائية بخط

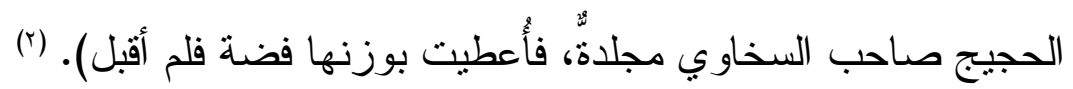
فلم يذكر الإمام الذهبي و لا الإمام ابن الجزري أن ناظمة الزهر مما سارت بها الركبان، ولم يُشير إليها من قريبٍ ولا من بعيد، وبهذا تعلم أن قول بعض الأساتذة المعاصرين في أثناء حديثه عن (ناظمة الزهر): (وهي

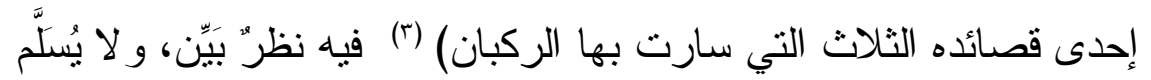
لقائله إلا إن قصد أنها سارت بها الركبان واثتهرت بعد شرحها في القرن الثالث عشر !. 


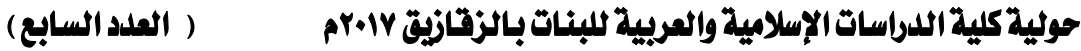

و لا تتعجَّبْ من عدم ثثوت نسبة (ناظمة الزهر) إلى الإمام الثناطبي (ت • 9هـ)، فهذا شرح الدرة للإِمام النويري (ت 10Vهـ)، على الرغم من كثرة تداوله و النقل عنه من قِيَل العلماء منذ القرن الثاني عشر حيث ذكر الثيخ علي بن محسن الرميلي الصعيدي (ت بعد • با ا(هـ) في شرحه للارة أنه اختصره من شرح العلامة النويري المالكي و الزَّبيدي و غيرهما(')؛ تنيَّن في السنو ات الأخيرة بالدليل القاطع أنه منسوبٌ إلى الإمام النويري وليس من تأليفه قطعًا، بل هو لمؤلفٍ آخر من تلاميذ تلاميذ ابن الجزري، و هو شمس الدين محمد السمرقندي الثهير بحافظ جرَ اغ - ومعناها بالفارسية: السر اج- ، و اسم هذا الثر ح: (عقد الدرر المضية في شرح القر اءات الثناث المروية) كما سماه بذلك مؤلفه، ووجد في نُسَخٍ خطية من

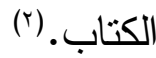

إذن فليس وجود اسم مؤلفٍ ما على كتاب مخطوط دليلاً قطعيًا على صحة نسبته إليه، لا سيما إذا عارضته أدلة أقوى - كما هو الحال هنا-، حيث صرَّح ابن الجزري بأن هذه المنظومة نُسبت إلى الإمام الثاطبي، ومعلومٌ أن الإمام ابن الجزري هو الإمام المحقق المعتتي بهذا الثأن، العارف بأسانيده ورواياته، فمن عنايته ببيان رو ايات مؤلفات الإمام الثاطبي قوله في ترجمة

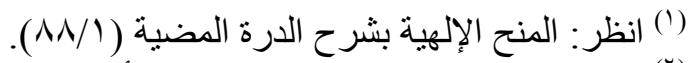

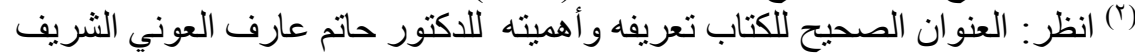

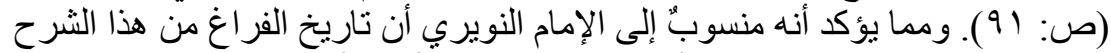

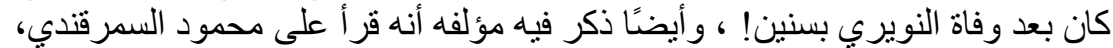
وهو على ابن الجزري، والمعروف أن النويري قر أ على ابن الجزري النى بلا واسطة. 


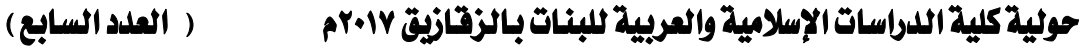

محمد بن عمر القرطبي -تلميذ الثاطبي-: (ولم يسمع أحدٌ من الشاطبي الر ائيةَ كاملةً فيما نعلم سو اهوسوى التجيبي، وله فيها أبيات انفرد برو ايتها

عنه وكذلك في الثاطبية بيتان أحدهما في البقرة والآخر في الرعد). (') وكم من كُتب نُسبت خطاً إلى غير مؤلفيها بسبب أخطاء النُسَّاخ ومفهرسي الكتب و العاملين في خز ائن المخطوطات، أو لأسبابٍ أخرى.

فإن قيل: إذا لم تثبت نسبة (ناظمة الزهر) إلى الإمام الثاطبي (صاحب الحرز و العقيلة)؛ فمن مؤلفها الحقيقي؟! ؛ فالجو اب أن هذا السؤ ال خارجٌ عن موضوع هذا البحث، حيث إن هذا البحث يدور حول ثبوت نسبة "ناظمة الزهر" إلى الإمام الثاطبي أو عدم ثبوتها. أما تحقيق نسبتها إلى مؤلفها الحقيقي؛ فهذا يقع على عاتق من يريد تحقيق المنظومة تحقيقًا علميًا، فهذا من أولويات تحقيق الكتب، قال الأستاذ المحقق عبد السلام هارون (ت 1 • ؛ اهــ): (الكتابُ المحقَّق هو الذي: صـح عنوانه، و اسم مؤلفه، ونسبة الكتاب إليه، وكان متتُهُ أقربَ ما يكون إلى الصورة التي (r) تركها المؤلف). ومن باب الفائدة : هنالك كثثرٌ من القر اء يُنسبون إلى بلدة شاطبة في بلاد الأندلس، فيحتمل أن تكون (ناظمة الزهر) من نظم شاطبيٍ آخر غير الإمام الثاطبي (صاحب الحرز)، فلما وقعت في يد من لا يعلم؛ نسبَها خطاً إلى الإمام الثاطبي (صاحب الحرز).

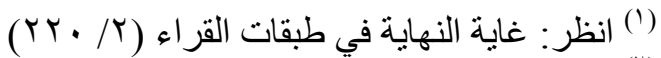

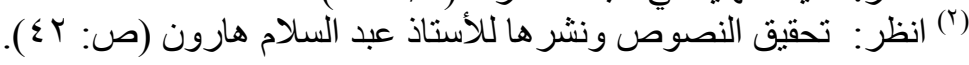


وقد ترجم الإمام ابن الجزري لأكثر من عشرين قارئًا يُنسبون إلى شاطبة، وهم:

ا ـ أحمد بن فرحون بن عبد الله أبو العباس النفزي الثاطبي. (')

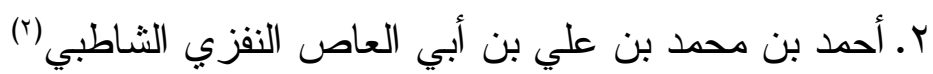
r.شاكر بن خيرة، أبو أحمد العامري مو لاهم الثاطبي ب(")

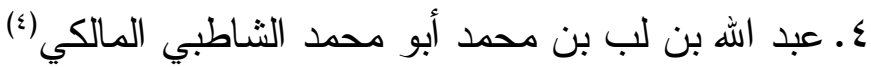

ه. عبد الله بن محمد بن عبد الله أبو محمد الخو لاني الشاطبي(ه) 7. عبيد الله بن نجاح بن يسار أبو مروان الثاطبي(؟) V. علي بن عبد الرحمن بن أحمد بن الدُّش أبو الحسن الشاطبي (v). ^. علي بن محمد بن موسى التجيبي الثاطبي (^) (تلميذ الإمام الثاطبي).

9. محمد بن أحمد بن عبد العزيز بن سعادة أبو عبد الله الثاطبي (9)

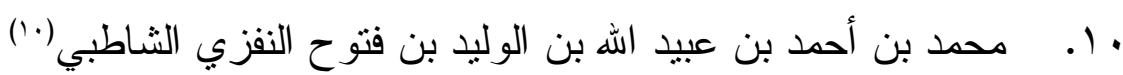

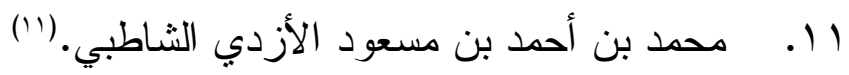
r ا. محمد بن سليمان بن محمد بن سليمان المعافري الثاطبي(r) rا ا. محمد بن صالح بن أحمد الكتاني الثاطبي، المعروف بابن رحيمة(1)

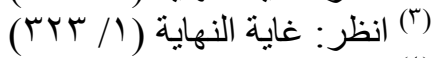

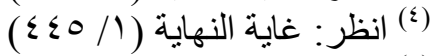

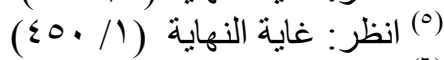

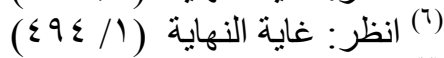

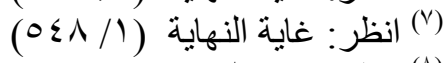

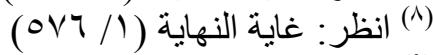

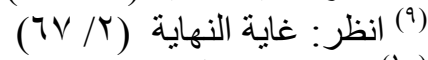

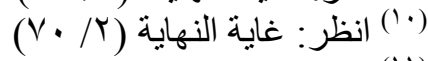

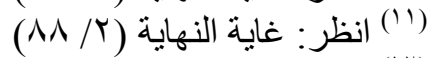

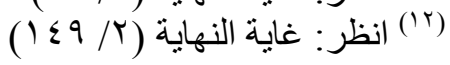




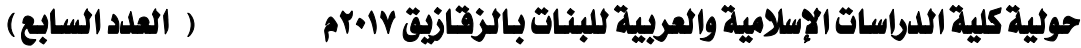

ع (. محمد بن عبد العزيز بن سعادة أبو عبد الله الشاطبي (r) 10 ـ محمد بن علي بن أبي العاص النفزي الثاطبي (َ) (شيخ الإمام الثاطبي). 17 ـ ـ محمد بن علي بن يوسف الأنصاري الثاطبي المعروف برضي الدين(؛) I V . محمد بن قاسم بن فيره الجمال الثاطبي(0) (ابن الإمام الثاطبي).

1 ا ـ محمد بن محمد بن عبد الملك أبو عبد الله الكتاني الثاطبي الضرير (†) 9 ا ـمفوز بن طاهر بن حيدرة بن مفوز أبو بكر المعافري الثاطبي(v) •r.r. هارون بن أحمد بن جعفر بن عات، أبو محمد النفزي الثاطبي (^)

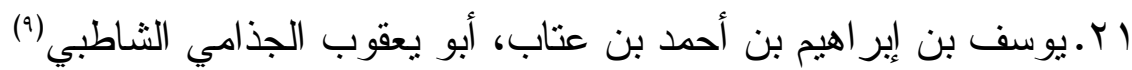
فكل و احد من هؤلاء القر اء يصحُ أن يطلق عليه نسبة (الثاطبي)؛ فقد تكون (ناظمة الزهر) لو احدٍ منهم أو من غير هم ممن يُنسب إلى شاطبة و الله أعلم--.

وقد نكون لأحد تلاميذ الثاطبي كما نُل عن الثيخ عبد الفتاح القاضي (ت ب • (اهـ) أنه قال ما معناه: "أنا أثنك في نسبتها إلى الإمام الثاطبي، ولعلها لأحد تلاميذه".(·) - (1)

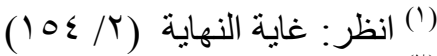

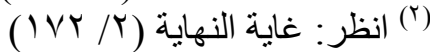

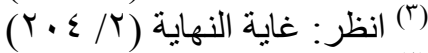

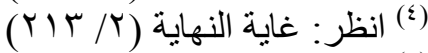

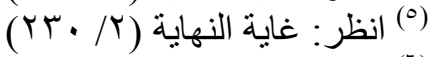

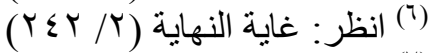

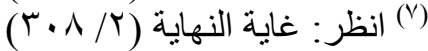

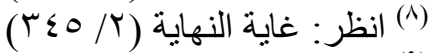

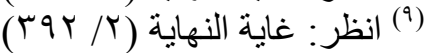

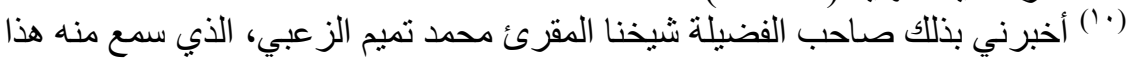
القول بحضرة عددٍ من الثيوخ، منهم الثيخ عبد الفتاح المرصفي - رحمه اللهـ. 


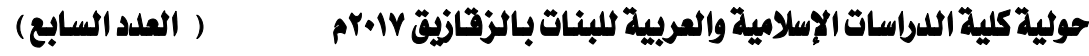

ويحتمل أن يكون هذا التلميذ شاطبيًا أيضًا منل (علي بن موسى التجيبي الثاطبي) أو (محمد ابن الإمام القاسم بن فيره الثاطبي)، أو غير هما. كل هذه مجرد احتمالات، قد تقود من يُعنى بتحقيق (ناظمة الزهر) إلى معرفة مؤلفها الحقيقي، فإن وصل إلى ما يُتبت النسبة إلى مؤلفها الحقيقي قطع بذلك، و إلا فأعدل الأقو ال أن يُقال: (المنسوبة إلى الإمام الثاطبي)، وقد أحسن مَن انتهى إلىى ما عَلِمَ، وفوق كل ذي علمٍ عليمه، و الله بكل شيءٍ عليم.

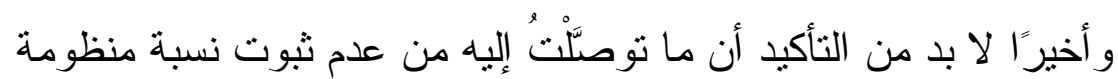
(ناظمة الزهر) إلى الإمام الثاطبي (صاحب الحرز) لا يُقلِّل من قيمتها العلمية، بل تبقى أحد المراجع المعتمدة عند العلماء في علم عدد الآي، ولا يسعنا إلا أن ندعو الله عز وجل أن يتغمَّد ناظمها برحمته، وأن يجعلها في موازين حسناته وينفع بها. و آخر دعو انا أن الحمد لله رب العالمين، و الصلاة و السلام على رسوله الصادق الوعيد الأمين، و على آله وصحبه أجمعين. 


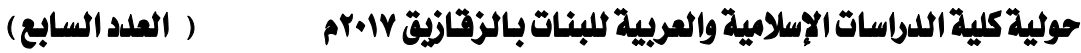

\section{الذاتهة}

الحمد لله الذي بنعمته تتم الصالحات، و الصلاة و السلام على أثنرف

المخلوقات و أزكى البريات، سيدنا محمدٍ و على آله وصحبه أجمعين.

وبعد: فهذه أهم النتائج التي نوصلتُ إليها في هذا البحث، ولثيات وأهم التوصيات

$$
\text { ألتي أوصي بها. }
$$

- لم تتبت نسبة (ناظمة الزهر) إلى الإمام الشاطبي (صاحب حرز الأماني)

$$
\text { - رحمه الله - }
$$

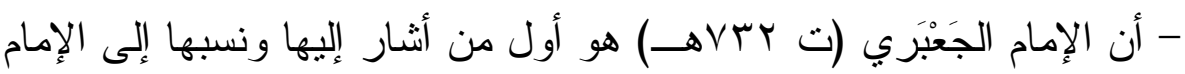
الثاطبي (صاحب الحرز)، وسمَّاها (ر ائيّة العدد)، وذلك في شرحه للشاطبية الذي فرغ منه (سنة 79 79هـ) أي بعد وفاة الثاطبي بأكثر من مائة عام!، وتبعه على ذللك القسطلاني (ت بrوهـ) ونقل منها بيتين من

$$
\text { أولها. }
$$

- أن أول مَن شرحها : الشيخ عبد الهه بن صالح الأيوبي (ت ror roهـ).

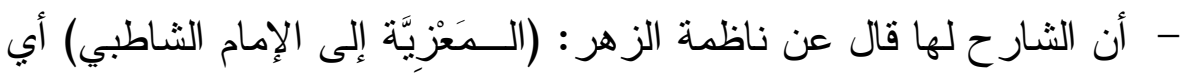
المنسوبة إلبه!. - أن الإمام ابن الجزري (ت سبرهــ) هو أول من صرَّح بأنها منسوبة إلى الإمام الثاطبي في أجوبته على المسائل التبريزية. - أن الثاطبينين: (حرز الأماني) في القراءات، و و(عقيلة أنز اب القصائد) في

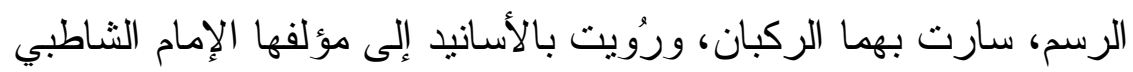

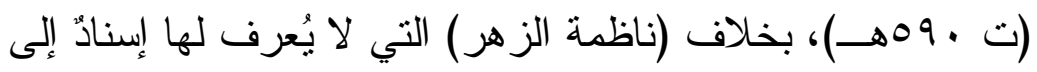
مؤلفها!. 
- أن عََم الدين السخاوي حين ترجم لثيخه الثشاطبي ذكر آثاره ومنظوماته، حتى أنه ذكر البيتين و الثناثة من نظمه، فكيف يُغفل هذه القصيدة الطويلة

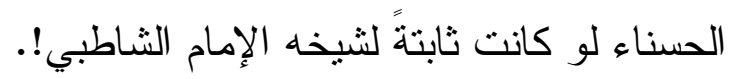
- كثرة القر اء الذين يُنسبون إلى (شاطبة) فيقال في تر اجمه (الثشاطبي)، حيث بلغ عددهم في غاية النهاية أكثر من عشرين قارئًا، فربما تكون

$$
\text { (ناظمة الزهر) لأحدهم أو لغيرهم. }
$$

- أن عدم ثبوت نسبة (ناظمة الزهر) إلى الإمام الثاطبي لا يُقلل من قيمتها وما تضمنته من تسهيل لهذا العلم الجليل علم عدد الآي.

$$
\begin{aligned}
& \text { أهم التوصيات: } \\
& \text { أوصي الباحثين بما يأتي: }
\end{aligned}
$$

- أهمية التأكد من صحة نسبة الكتاب إلى مؤلفه عند تحقيقه، فهذا من

$$
\text { أولويات التحقيق. }
$$

- جمع جميع النسخ الخطية لمنظومة (ناظمة الزهر)، ودر استها ومحاولة الوصول إلى مؤلفها الحقيقي أو معرفة عصره على وجه التحديد أو من

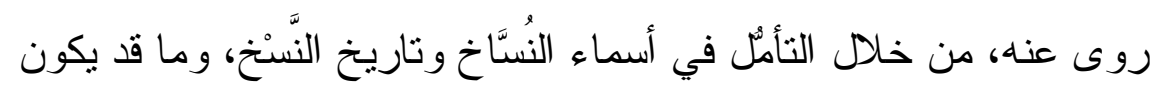
مكتوبًا على النسخ من سماعات أو أسانيد تهدي إلى المؤلف الحقبقي أو تذكر بعض من روى عنه أو سمع منه هذه المنظومة.

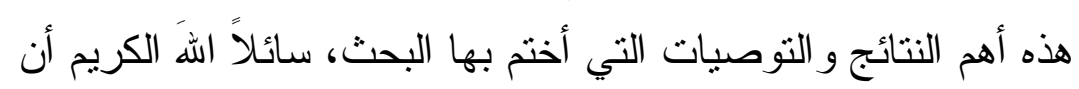
يوفقنا جميعًا للعلم النافع و العمل الصالح وأن يرزقنا حسن الخاتمة، إنه سميعٌ قريب، وصلى الله وبارك على نبينا محمد و على آله وصحبه وسلم تسليمًا كثيرًا. 


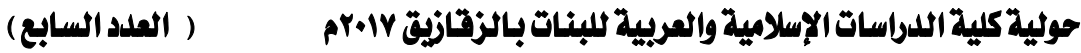

\section{فهرس المصاحر والمراجع}

1-إيراز المعاني من حرز الأماني في القراءات السبع،لأبي شامة عبدالرحمن بن إسماعيل المقدسي (ت 700ه)، تحقيق وتعليق: الثــيخ محمــود بــن

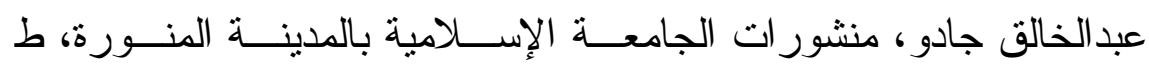
ه

r-إتحاف أعلام الناس بجمال أخبار حاضرة مكناس، تأليف: عبد الرحمن بن محمد السجلماسي، تحقيق: د. علي عمر، نشر : مكتبـــة الثقافــة الدينيــة،

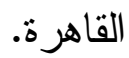
r-أجوبة الإمام ابن الجزري على المسائل التبريزية في القراءات، تحقبـقـ: عبد العزيز محمد تميم الزعبي، نشر : مؤسسة الضحى - بيروت، لبنــان،

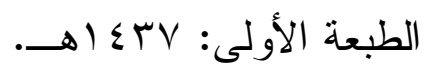

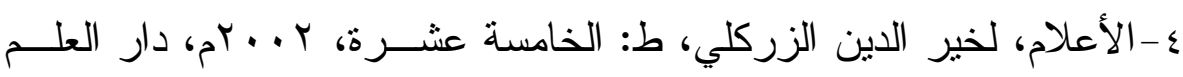

\section{للماليين.}

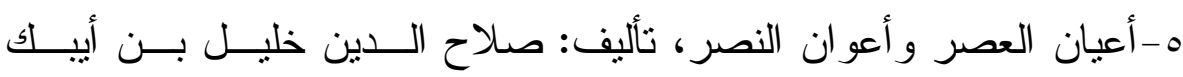

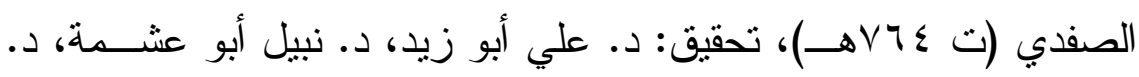

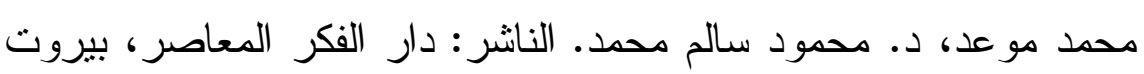

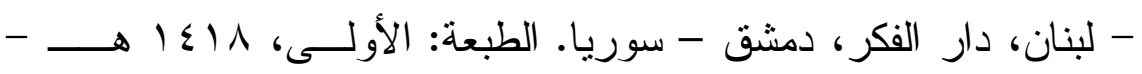
. 1991

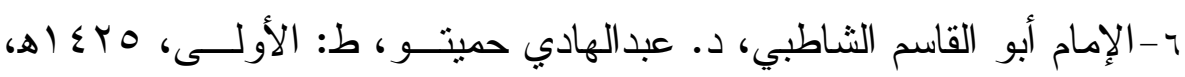
دار أضو اء السلف، الرياض.

V- إمتاع الفضلاء بتر اجم القر اء فيما بعد القرن الثــامن الهجــري، تــأليف:

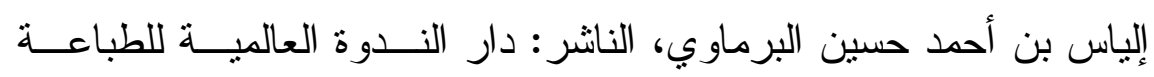

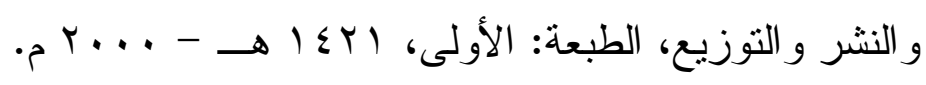


^-إنباه الرواة على أنباه النحاة، للوزير علي بن يوسف القِقْطــي (ت7 ؟7هـ)،

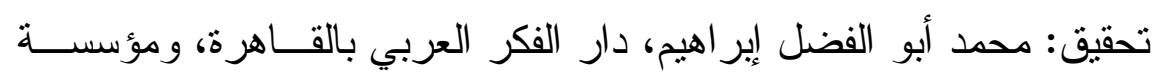

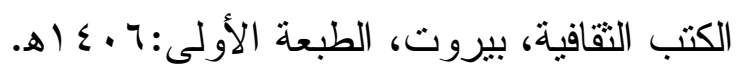

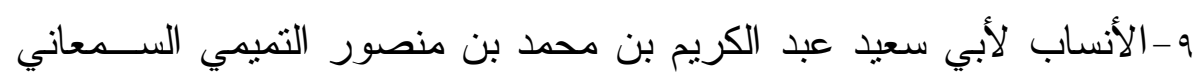

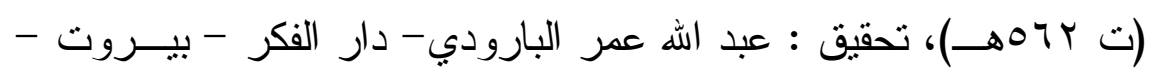

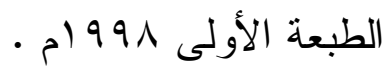
• - برنامج المجاري، تأليف: أبي عبد الله محمد بن محمد بن علــي بـن

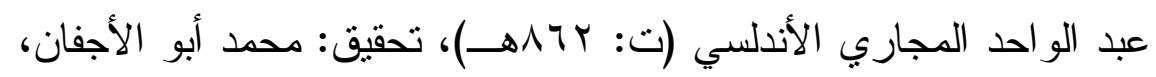
الناشر: دار الغرب الاسلامي - بيروت/ لبنان. 11- بشير اليسر شرح ناظمة الزهر، تأليف: عبد الفتاح القاضــي، نشــر المكتبة المحمودية.

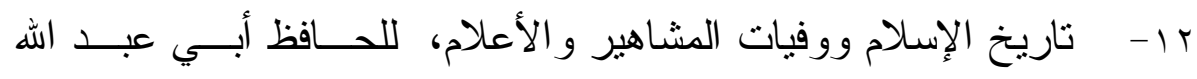

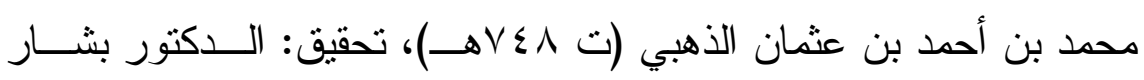

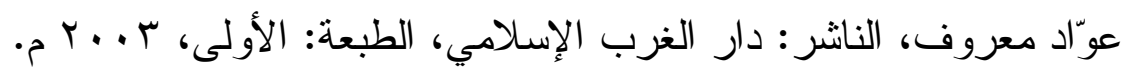

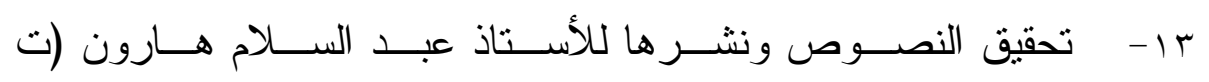
1 • ـ (اهـ)، الناشر : مؤسسة الحلبي وشركاه للنشر و التوزيــع، الطبعــة:

$$
\text { الثانية 140 إهـ }
$$

ع - - التكملة لكتاب الصلة، لأبي بكر محمد بن عبد الله القضاعي البَلَنسـي

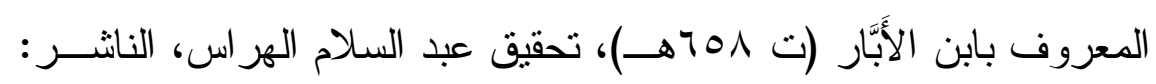

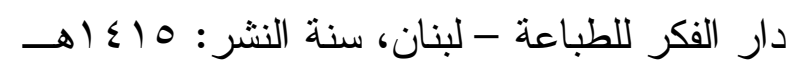

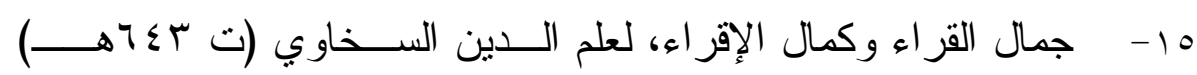

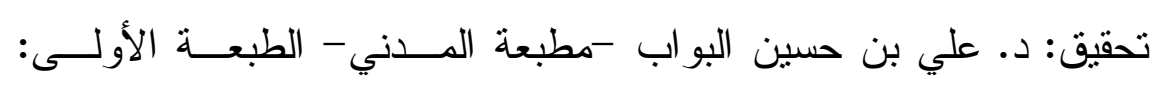
. $\ \varepsilon \cdot \Lambda$

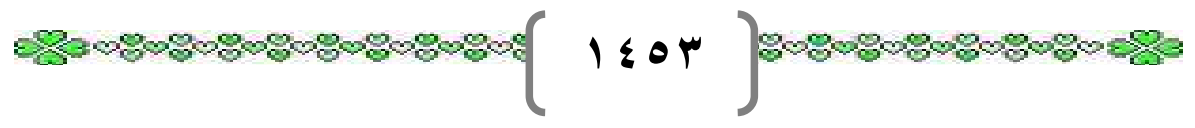


17- الذيل على الروضنتين، لأبي شامة (ت 770هـ)، عُني بنشره: السيد عزت العطار، دار الجيل - بيروت ، الطبعة الأولى: Vـ 9 ام.

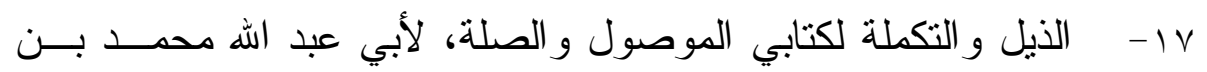
محمد بن عبد الملك الأنصاري الأوسي المر اكثي (المتوفى: r. . هــ)، تحقيق: الدكتور إحسان عباس، الدكتور محمد بن شريفة، الدكتور بثـــار

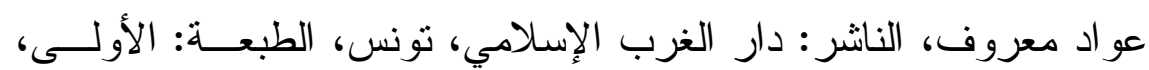
$\cdot r+1 T$

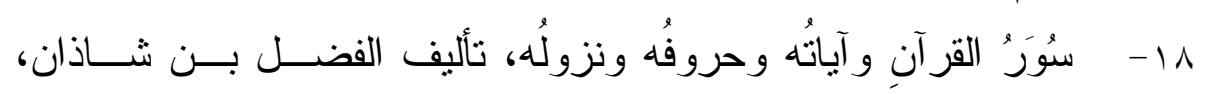

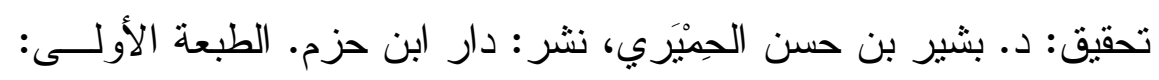
$\rightarrow \leqslant r$.

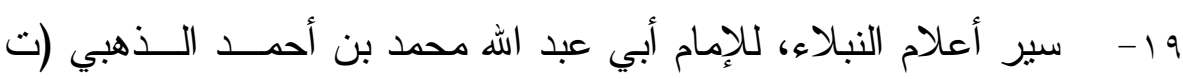
V ه هـ

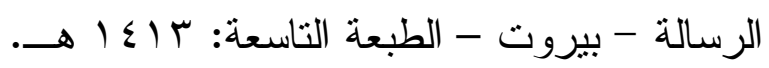
•r- ش شجرة النور الزكية في طبقات السادة المالكية، لمحمد بن مخلـــوف، دار الكتاب العربي، بيروت، لبنان.

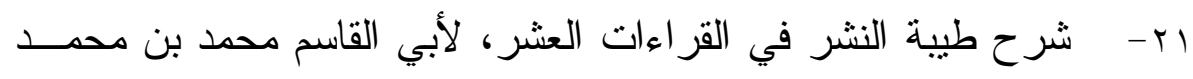
بن محمد بن علي النويري العَقيلي المالكي (ت 10Vهـ). تقديم وتحقيق: د. مجدي محمد سرور سعد باسلوم- دار الكتب العلمية. الطبعة الأولـى بـى . $\rightarrow \leqslant Y \leqslant$

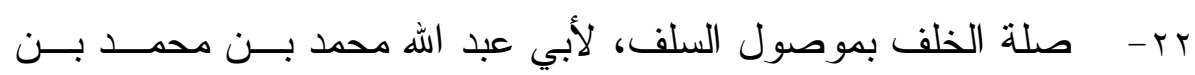
سليمان الرُّوداني السوسي المكيّ المالكي (ت ع9 ـ ـ (هـ)، تحقيق: محمــد

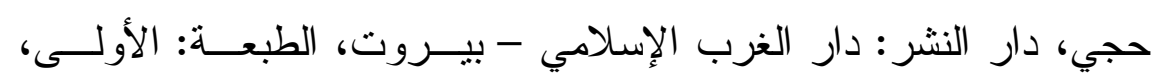
. 1 ا اهـ.

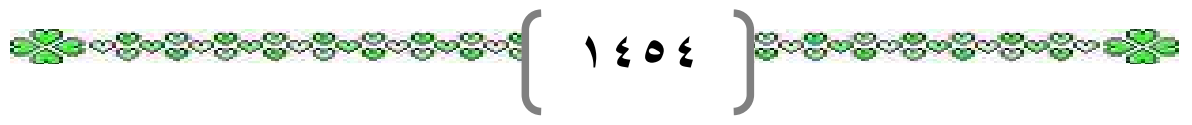




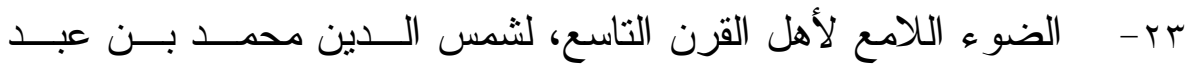
الرحمن السخاوي (ت Y • 9هـ)- دار مكتبة الحياة - بيروت.

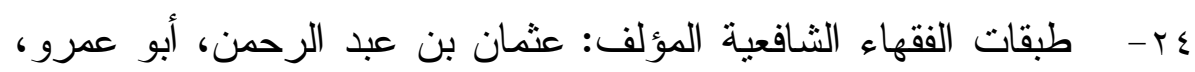

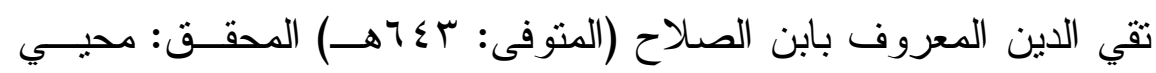

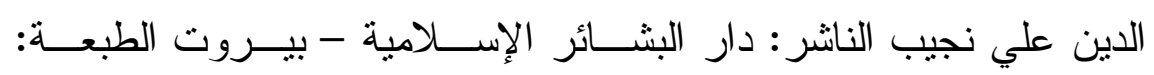

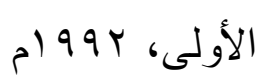

•r - العنو ان الصحيح للكتاب تعريفه و أهميته، وسائل معرفة أحكامه، أمنتلةٌ للأخطاء فيه، تأليف: د. الثريف حاتم بن عارف العــوني - نشــر : دار

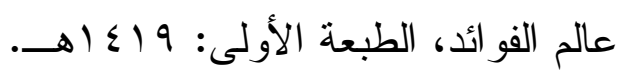

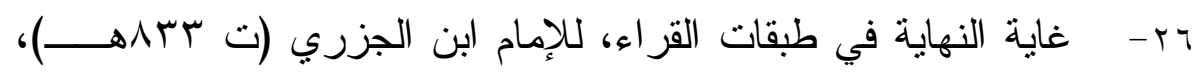

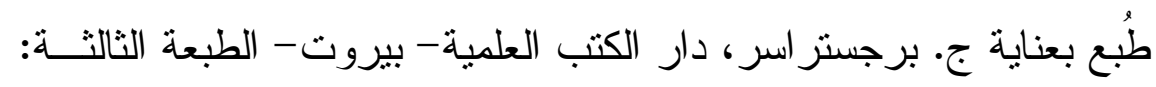
. $) \leqslant \cdot r$

rV - الفتح المو اهبي في ترجمة الإمام الثاطبي للقسطلاني (ت بrوهـ)، تحقيق: إير اهيم بن محمد الجرمي، نشـــر : دار الفـتـح ، عمــان - الأردن

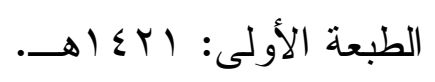

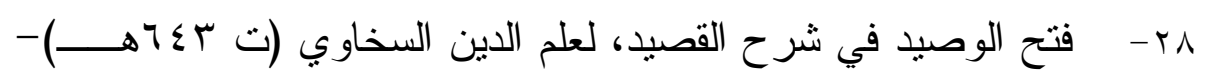
تحقيق: د. مو لاي محمد الإدريسي الطاهري- مكتبة الرشد - الريــاض-

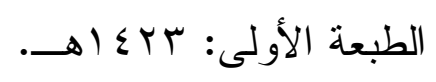

وץ- الفهرس الثامل للتراث العربي و الإسلامي المخطوط ( مخطوطــات التقسير وعلومه)- المجمع الملكي لبحوث الحضارة الإسلامية -مؤسســة

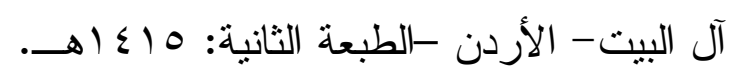


•r- - تطف الثمر في رفع أسانيد المصنفات في الفنــون و الأثــر، تــأليف:

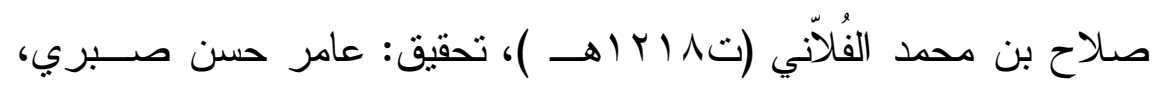

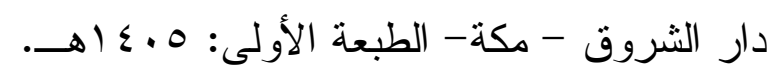

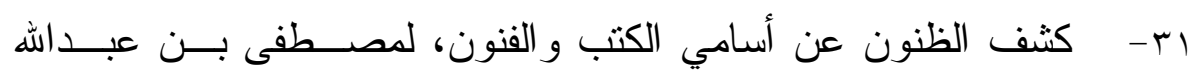

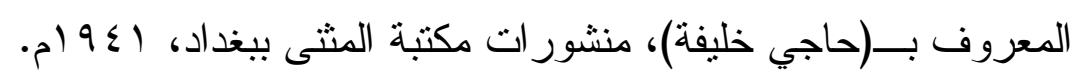

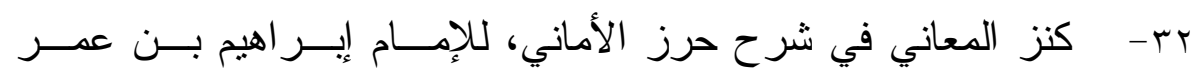
الجعبري (Y (VTهـ) تحقيق: أ. فر غلي سيد عرباوي، نشر : مكتبــة أولاد

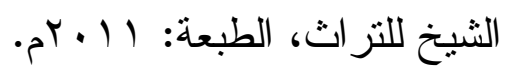

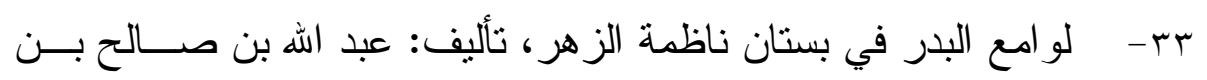

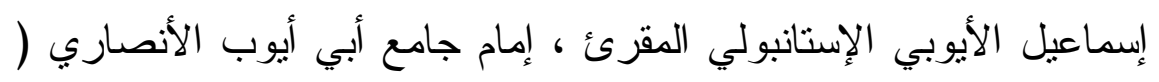
ت ت I TOY هـ )، مخطوط في المكتبة العامة بالدوحة.

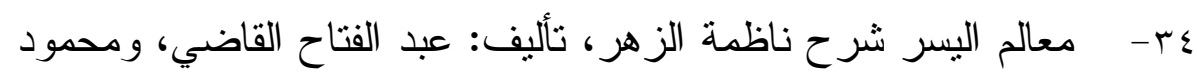
إير اهيم دعبيس، نشر مطبعة الأزهر . الطبعة الأولى 9 ـ 9 (م.

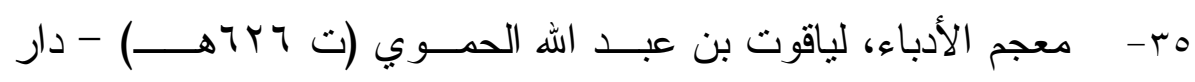

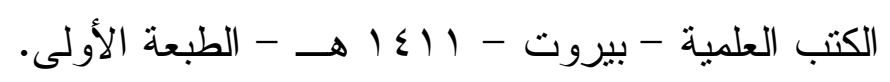

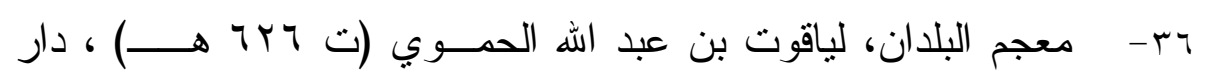

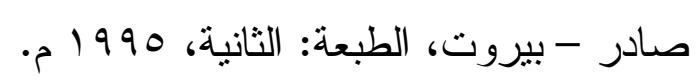

rv - المعجم المفهرس (تجريد أسانيد الكتب المشهورة و الأجزاء المنثورة)،

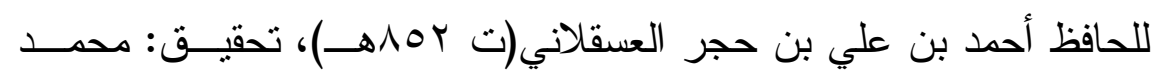

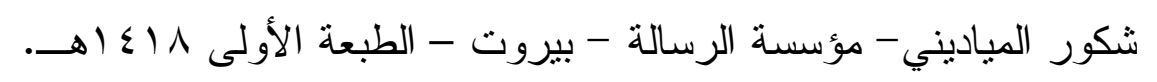
^ז- معجم علوم القرآن، تأليف: إبر اهيم محمد الجرمي، الناشر : دار القلم

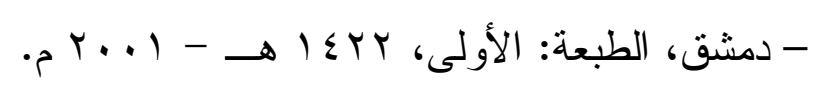


9r- - معرفة القر اء الكبار على الطبقات و الأعصدار، للحافظ أبي عبــــ الله

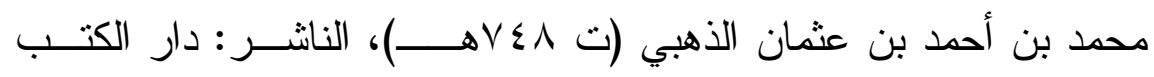

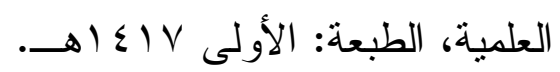

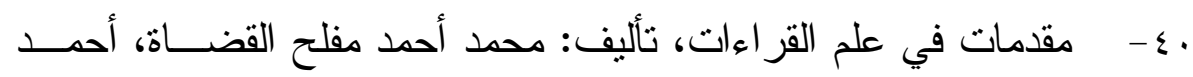
خالد شكرى، محمد خالد منصور، الناشر: دار عمار - عمــان (الأردن)،

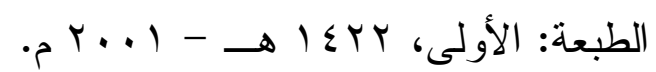

اء- - المنح الإلهية بشرح الدرة المضية، تأليف: علي بن محسن الرميلـي الصعيدي (ت بعد . با (اهــ). تحقيق: مجموعة من الباحثات في جامعسـة

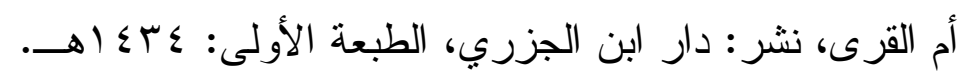

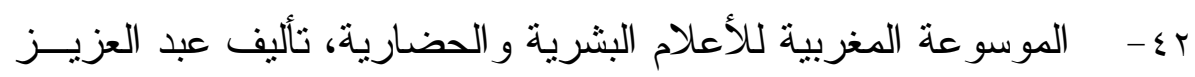

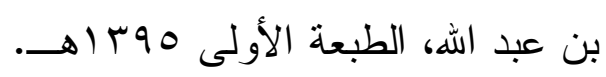

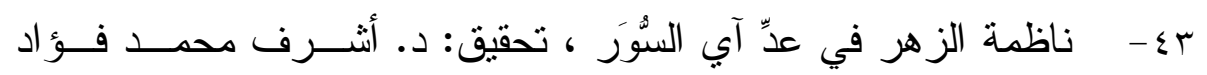
طلعت، نشر : مكتبة الإمام البخاري للنشر و التوزيــع، مصــر - الطبعــة الثانية: الث

عـ - نفح الطيب من غصن الأندلس الرطيب، لأحمد بن محمـــــ المقَّـري

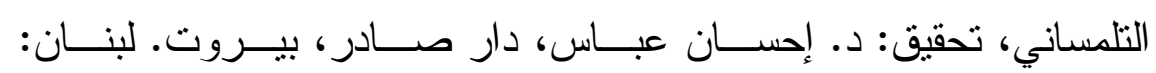
. TAN هـ - هداية القاري إلى تجويد كلام الباري، للشيخ عبــــالفتاح المرصــي،

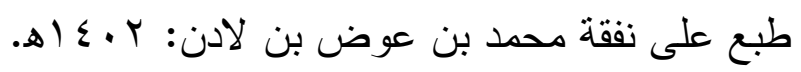

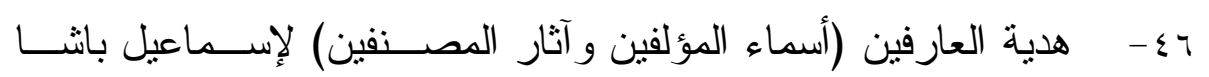
البغدادي، طبع بإستانبول: 901 (م.

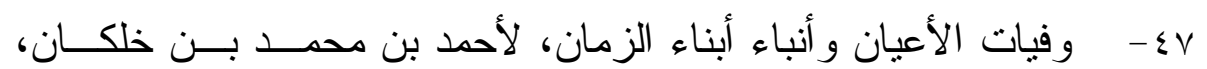
تحقيق: د.إحسان عباس، دار صادر ، بيروت، لبنان. 


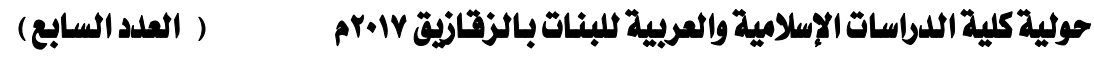

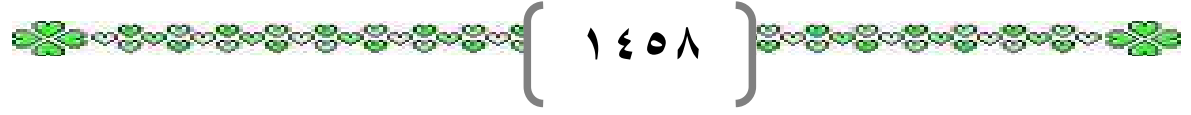

